\title{
Eksperimentalno ispitivanje i numeričko modeliranje betonskih i čeličnih okvira sa zidanom ispunom pod statičkim i dinamičkim opterećenjem
}

\section{Baloević, Goran}

Doctoral thesis / Disertacija

2015

Degree Grantor / Ustanova koja je dodijelila akademski / stručni stupanj:

University of Split, Faculty of Civil Engineering, Architecture and Geodesy / Sveučilište u Splitu, Fakultet građevinarstva, arhitekture i geodezije

https://doi.org/10.31534/DocT.036.BalG

Permanent link / Trajna poveznica: https:/urn.nsk.hr/urn:nbn:hr:123:854678

Rights / Prava: In copyright/Zaštićeno autorskim pravom.

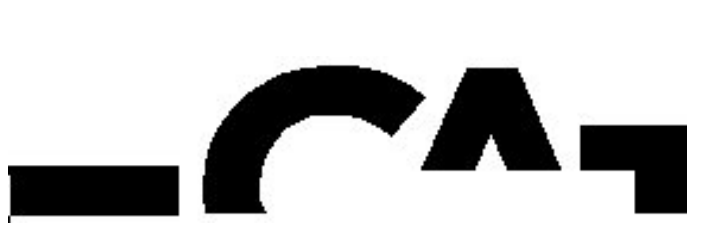

Repository / Repozitorij:

FCEAG Repository - Repository of the Faculty of Civil Engineering, Architecture and Geodesy, University of Split

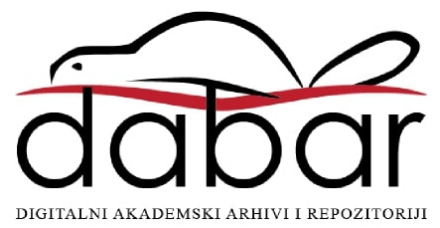




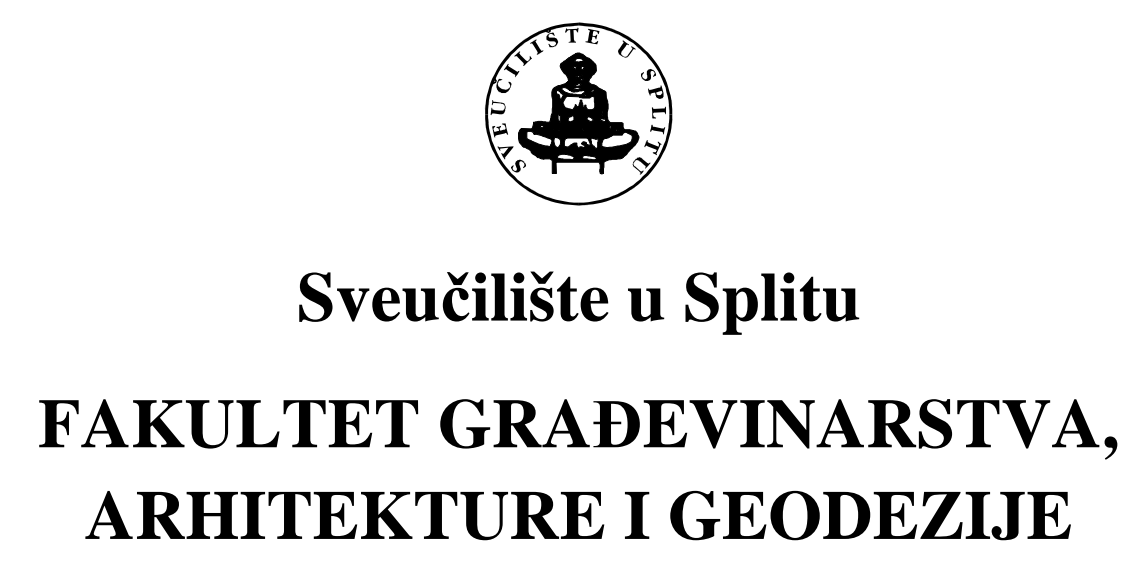

Goran Baloević, dipl.ing.građ.

\section{EKSPERIMENTALNO ISPITIVANJE I NUMERIČKO MODELIRANJE BETONSKIH I ČELIČNIH OKVIRA SA ZIDANOM ISPUNOM POD STATIČKIM I DINAMIČKIM OPTEREĆENJEM}

D i s e r t a c i j a

Split, 2015. 
Goran Baloević

Redni broj: 036

Ova disertacija predana je na ocjenu

Fakultetu građevinarstva, arhitekture i geodezije,

Sveučilišta u Splitu u svrhu stjecanja

akademskog stupnja doktora tehničkih

znanosti u znanstvenom polju građevinarstvo.

Mentor: prof.dr.sc. Jure Radnić

Komentor: izv.prof.dr.sc. Sandra Juradin

Povjerenstvo za ocjenu:

prof.dr.sc. Jure Radnić

izv.prof.dr.sc. Sandra Juradin

prof.dr.sc. Mladen Glibić 


\section{Povjerenstvo za obranu}

prof.dr.sc. Jure Radnić

izv.prof.dr.sc. Sandra Juradin

prof.dr.sc. Mladen Glibić

Rad je obranjen 26. veljače, 2015.

Tajnica:

Saša Delić, dipl.iur. 
Rad sadrži:

200 stranica teksta

169 slika

11 tablica

147 citiranih referenci 
Posvećeno mojoj obitelii, onima kaji to jesu i onima kaji će to postati 
Ovim putem najiskreniju zahvalnost izražavam:

mentoru prof.dr.sc Juri Radniću za voditeljstvo i ukazano povjerenje, kao i za svu pomoć i savjete koje mi je pružio pri izradi disertacije,

komentorici izv.prof.dr.sc. Sandri Juradin na pomoći i korisnim savjetima pri izradi rada,

članu povjerenstva prof.dr.sc. Mladenu Glibiću na sugestijama pri pregledu rada,

mojim radnim kolegama, naročito kolegama dr.sc. Nikoli Grgiću $i$ Goranu Vlastelici, dipl.ing.građ. na pomoći, korisnim savjetima $i$ diskusijama tijekom izrade ovog rada.

I na kraju, najveću zahvalnost izražavam svojoj obitelji i zaručnici Sari. Njihova pomoć, potpora i razumijevanje tijekom cijelog istraživačkog procesa bila mi je od velike pomoći. Ovaj rad je i njihov uspjeh. 
Goran Baloević, dipl. ing. građ.

\title{
Eksperimentalno ispitivanje i numeričko modeliranje betonskih i čeličnih okvira sa zidanom ispunom pod statičkim i dinamičkim opterećenjem
}

\section{Sažetak:}

U ovom su radu prikazani rezultati eksperimentalnih ispitivanja čeličnih i armiranobetonskih okvira sa zidanom ispunom. Eksperimentalni rad obuhvaća statička ispitivanja čeličnih okvira te dinamička ispitivanja čeličnih i betonskih okvira na potresnoj platformi. Aplicirana su dva umjetna akcelerograma i akcelerogram realnog potresa. Pobude su nanošene sukcesivno, s postepenim povećanjem amplituda akcelerograma za $0.1 \mathrm{~g}$. Nadalje, u radu je prikazan razvijeni 2D numerički model za statičku i dinamičku analizu armiranobetonskih i čeličnih okvira sa zidanom ispunom koji može simulirati njihove najvažnije nelinearne efekte. U ovom je radu numerički model poboljšan s adekvatnom simulacijom faznog nastajanja okvira s ispunom, te simulacijom nearmirane i armirane žbuke na vanjskim plohama ziđa. Razvijeni numerički model verificiran je pomoću rezultata prethodno provedenih eksperimenata. Primjenom ovog numeričkog modela, istražen je utjecaj više parametara na ponašanje okvira s ispunom. Na kraju su prikazani najvažniji zaključci o ponašanju ovakvih konstrukcija pod statičkim i potresnim opterećenjem, te dani praktični savjeti i preporuke za njihov pouzdani proračun.

Ključne riječi: okvir sa zidanom ispunom, potresna platforma, umjetni akcelorogrami, numerički model

UDC [624.012.45.04.072.33:519.87](043.3)

[624.014.2.04.072.33:519.87](043.3)

Goran Baloević, M.Civ.Eng.

\section{Experimental testing and numerical modeling of masonry-infilled concrete and steel frames under static and dynamic loads}

\begin{abstract}
:
This thesis presents the results of experimental tests of masonry-infilled concrete and steel frames. The experimental work concerns static tests of masonry-infilled steel frames and dynamic tests of masonry-infilled steel and concrete frames on a shake-table. Two artificial accelerograms and one real accelerogram were applied. The accelerograms were applied successively, by gradually increasing acceleration amplitudes for $0.1 \mathrm{~g}$. Further, the thesis presents a developed 2D numerical model for static and dynamic analysis of masonry-infilled concrete and steel frames that can simulate their main nonlinear effects. In this paper, the numerical model was improved with adequate simulation of structural formation and with simulation of reinforced and unreinforced plaster on exterior sides of a wall. The developed numerical model was verified using the results of the previous performed tests. The influence of several parameters on the behavior of masonryinfilled frames was investigated with the numerical model. Finally, main conclusions regarding behavior of these structures under static and dynamic loads are stated, followed by practical advises and recommendations for their reliable design.
\end{abstract}

Keywords: masonry-infilled frame, shake table, artificial accelerograms, numerical model 


\section{Sadržaj:}

1. UVOD

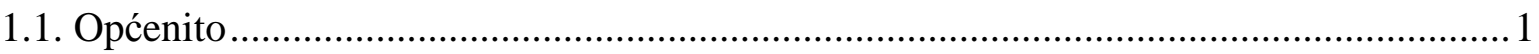

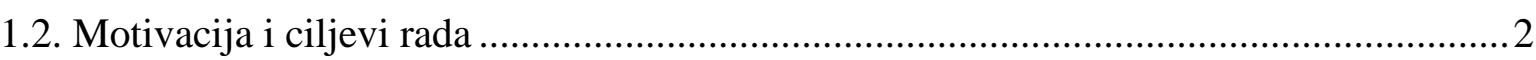

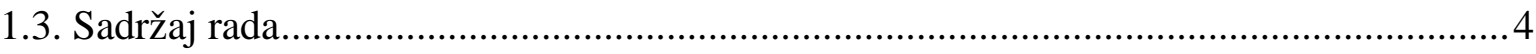

2. DOSADAŠNJE SPOZNAJE PONAŠANJA I MODELIRANJA OKVIRA SA

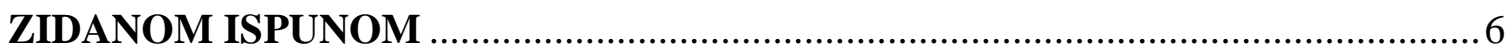

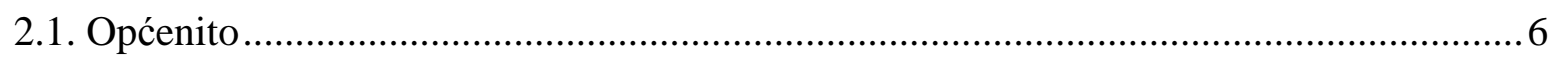

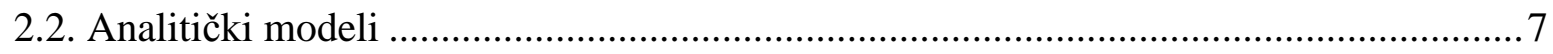

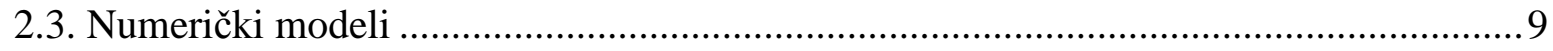

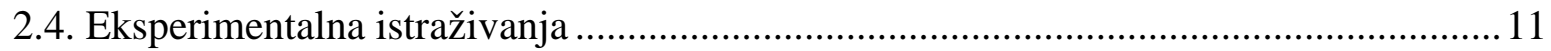

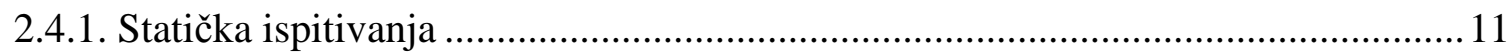

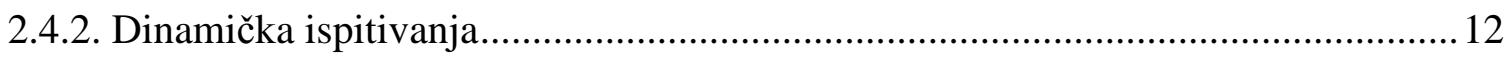

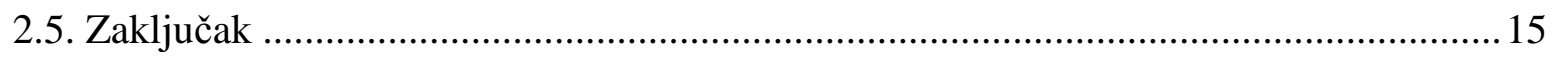

3. EKSPERIMENTALNA ISPITIVANJA PONAŠANJA ČELIČNIH I BETONSKIH

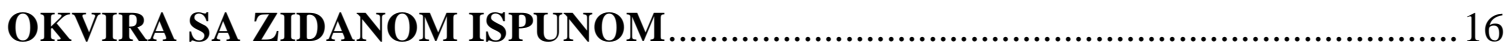

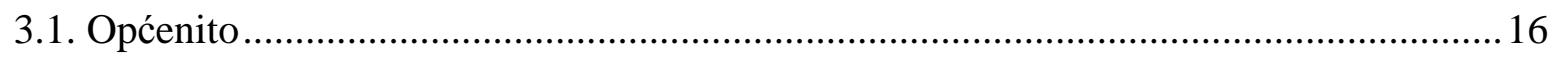

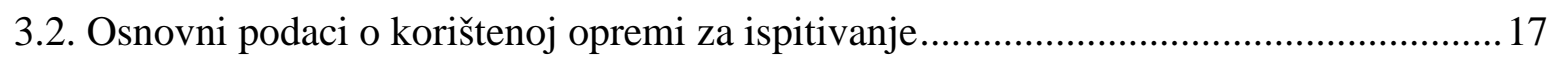

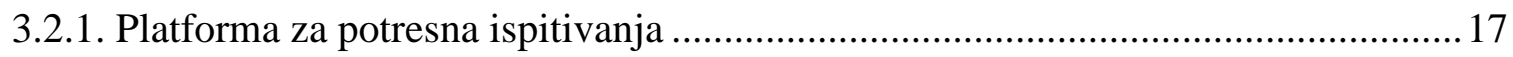

3.2.1. Oprema za mjerenje mehaničkih veličina ....................................................... 19

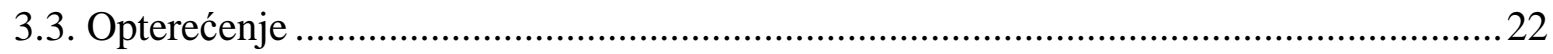

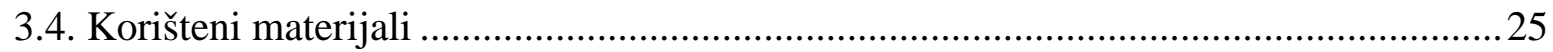

3.3. Statička ispitivanja čeličnih okvira sa zidanom ispunom .......................................2

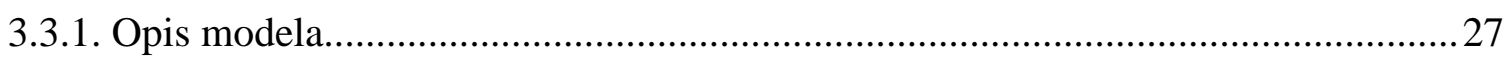

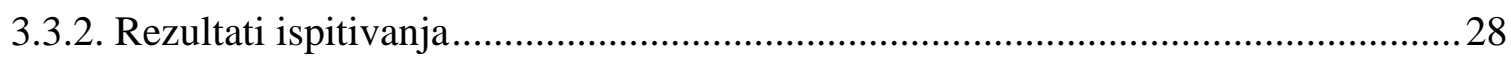

3.4. Dinamička ispitivanja čeličnih okvira sa zidanom ispunom.........................................32

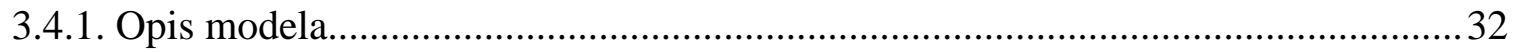

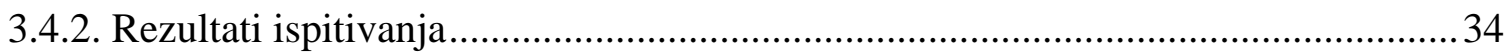

3.4.2.1. Rezultati za umjetni akcelerogram AA1 …............................................... 34

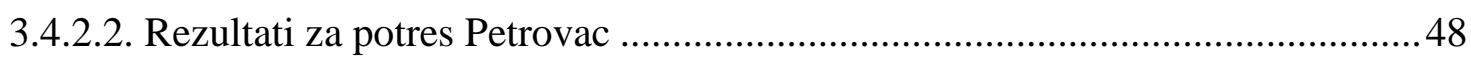

3.5. Dinamička ispitivanja betonskih okvira sa zidanom ispunom.....................................57

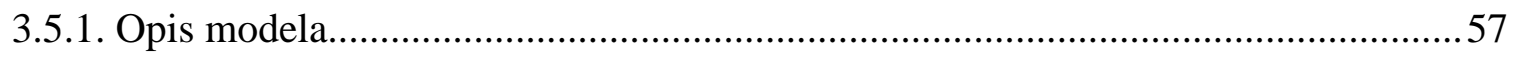




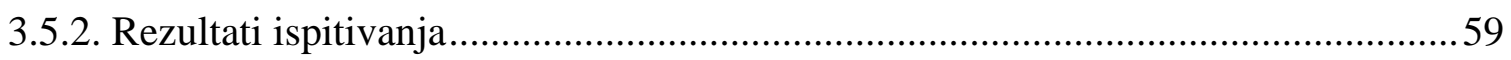

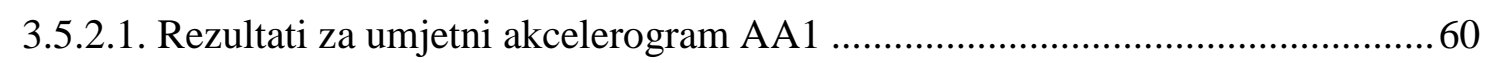

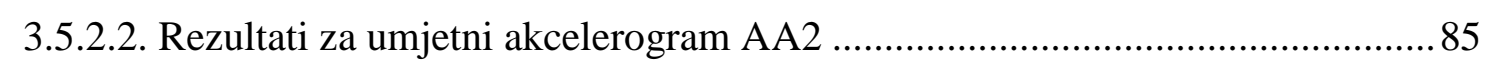

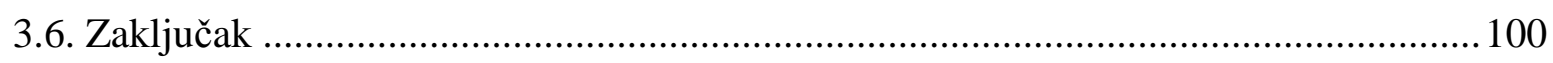

4. NUMERIČKI MODEL ZA STATIČKU I DINAMIČKU ANALIZU OKVIRA SA

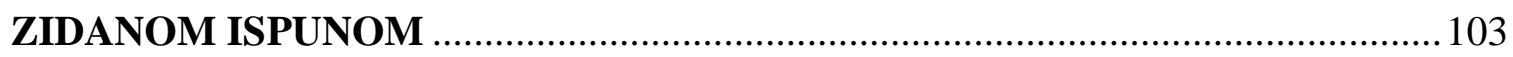

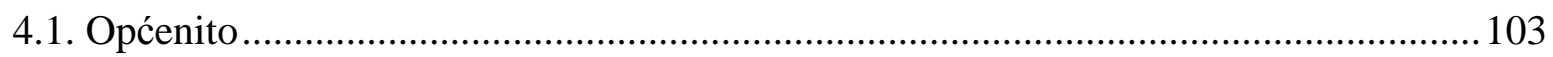

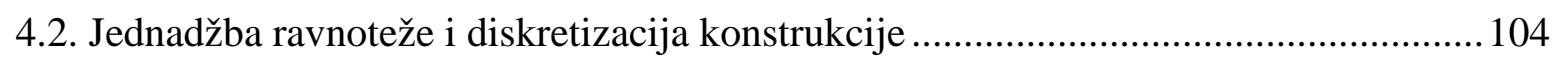

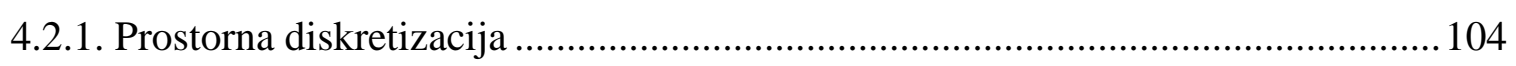

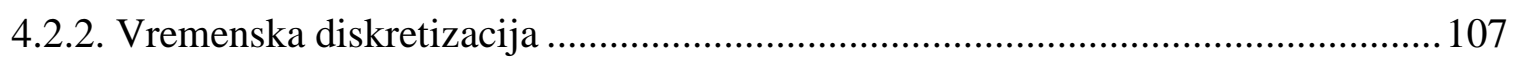

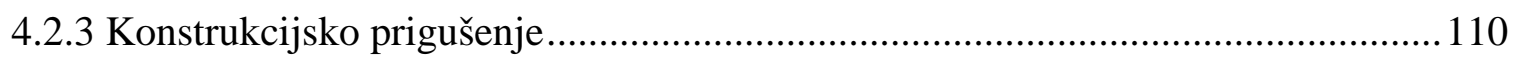

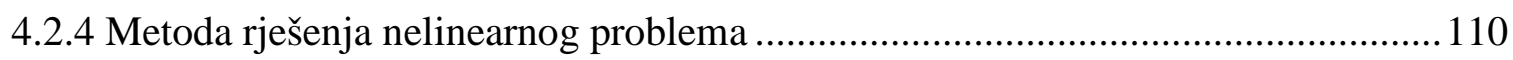

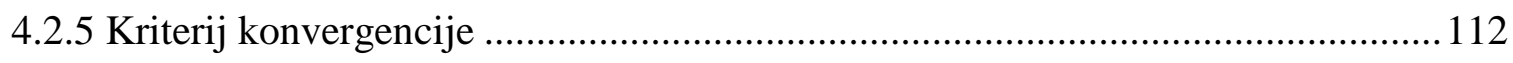

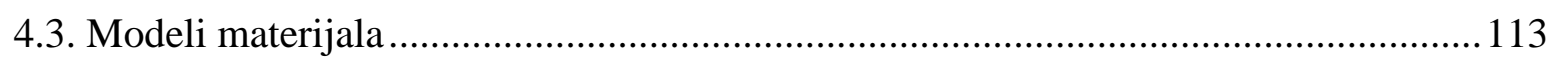

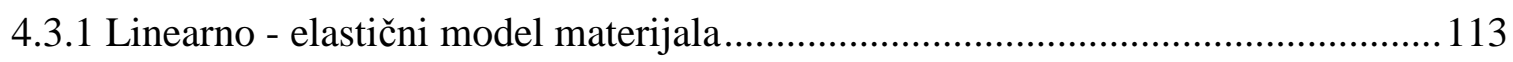

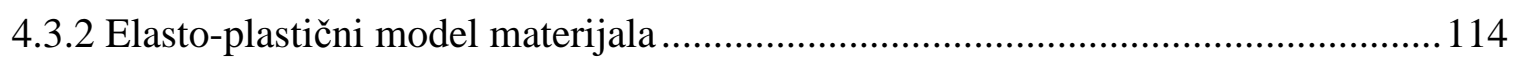

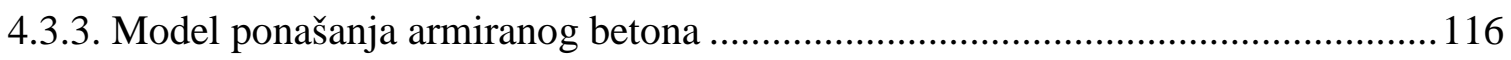

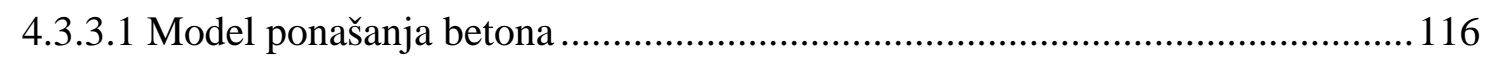

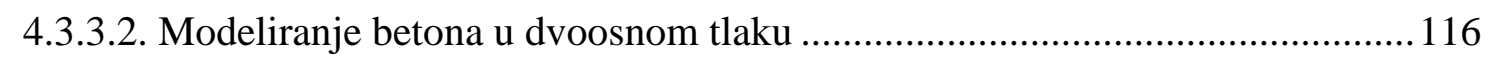

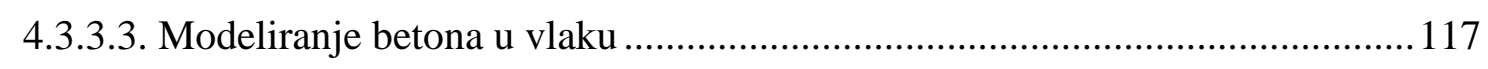

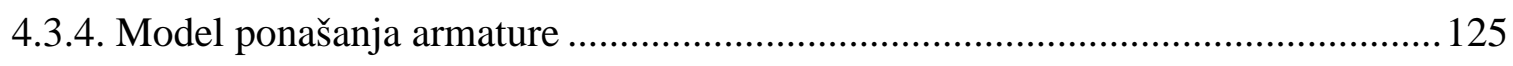

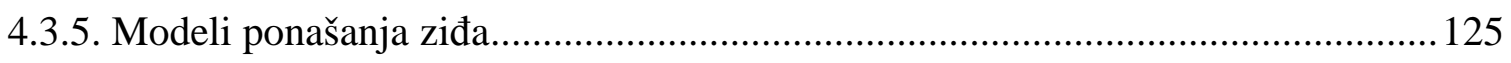

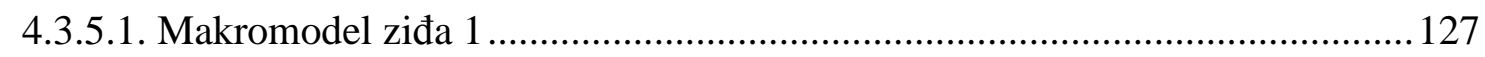

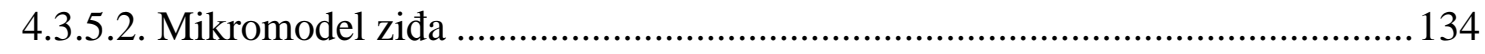

4.3.6. Model ponašanja konstrukcijskog čelika ........................................................ 135

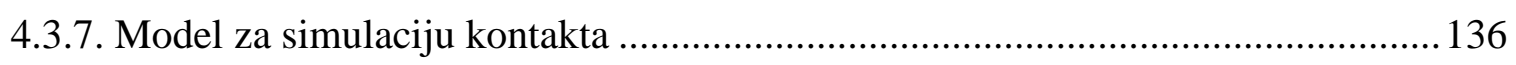

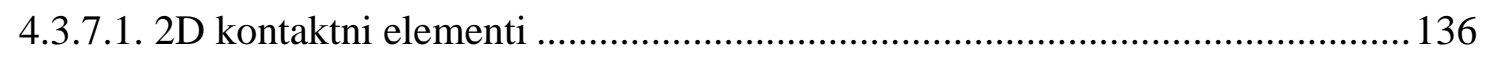

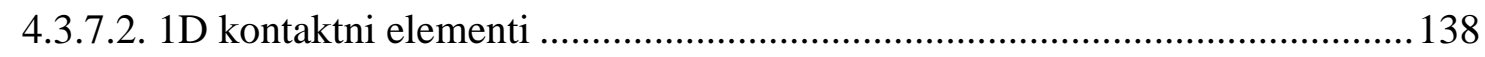

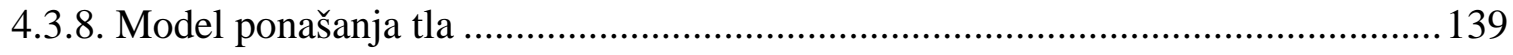

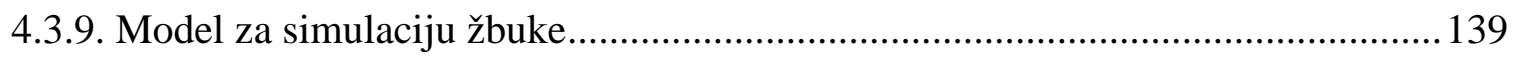

4.3.10. Model za simulaciju faznog nastajanja ........................................................ 141

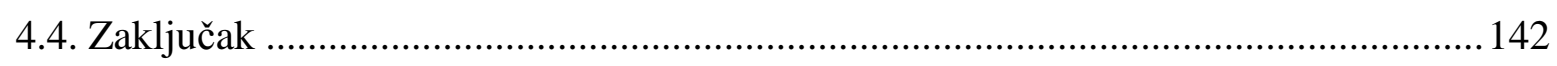

5. VERIFIKACIJA RAZVIJENOG NUMERIČKOG MODELA .............................. 143

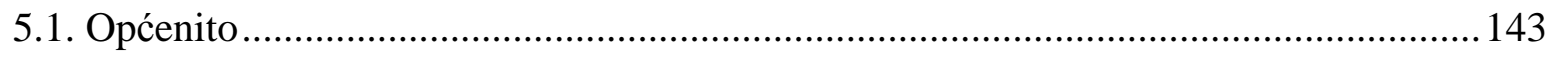




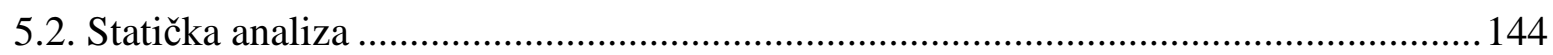

5.2.1. Simulacija statičkih ispitivanja čeličnih okvira sa zidanom ispunom.................... 144

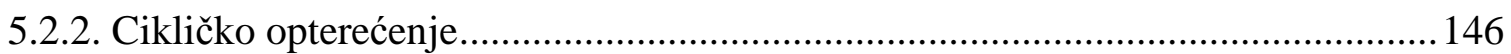

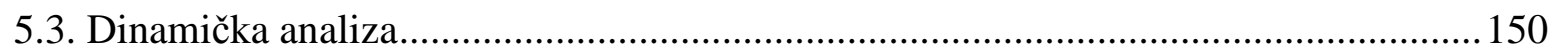

5.3.1. Simulacija dinamičkih ispitivanja čeličnih okvira sa zidanom ispunom ..............150

5.3.2. Simulacija dinamičkih ispitivanja betonskih okvira sa zidanom ispunom ........... 160

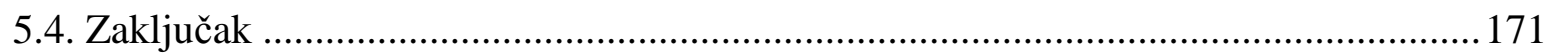

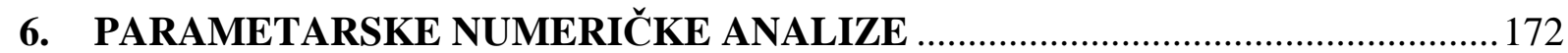

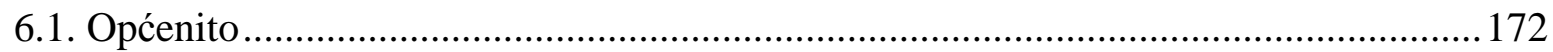

6.2. Primjer numeričke analize troetažnog okvira ..................................................... 173

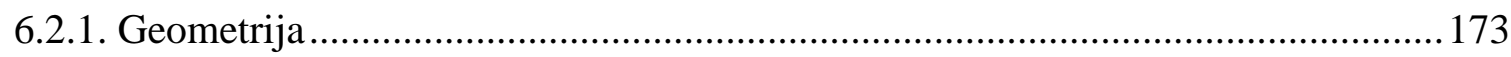

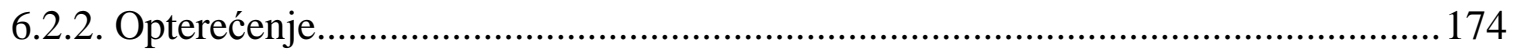

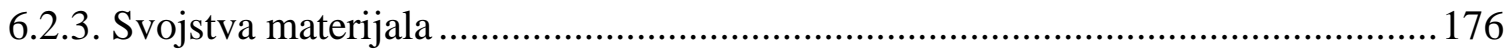

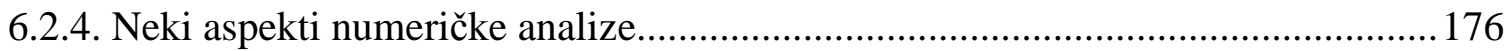

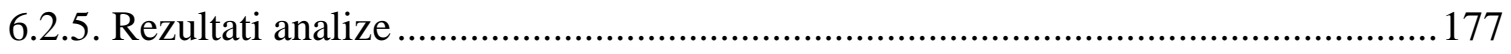

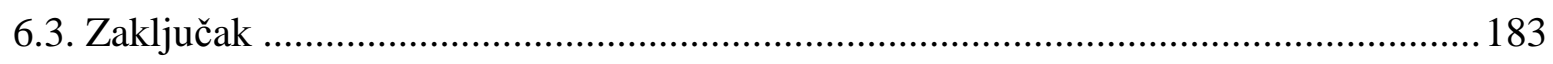

7. ZAKLJUČAK I PRAVCI DALJNJIH ISTRAŽIVANJA ...................................... 185

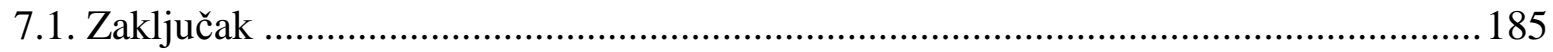

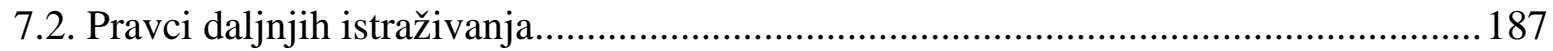

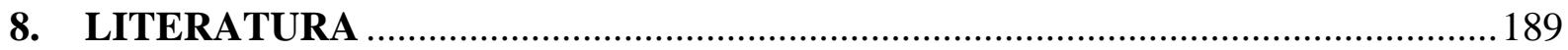




\subsection{Općenito}

Okviri sa zidanom ispunom jedne su od učestalih konstrukcija u svakodnevnoj građevinskoj praksi. Termin okvir sa zidanom ispunom odnosi se na kompozitnu konstrukciju nastalu od okvira koji se naknadno ispunjava ziđem. Pri tome se okviri najčešće izrađuju od armiranog betona i čelika, a rjeđe od drugih gradiva. Ziđe je kompozitni materijal koji nastaje zidanjem s pomoću zidnih elemenata (kamen, opeka, beton i sl.) povezanih vezivnim materijalom (mort, ljepilo, i sl.). Ponašanje takvih konstrukcija je vrlo složeno, osobito pri potresu, ovisno o ponašanju individualnog sustava (okvir, ziđe), interakciji između okvira i ziđa, te lokalnim efektima koji se javljaju u ziđu i gradivima okvira.

$U$ dosadašnjim inženjerskim proračunima okvira s ispunom, ispuna se u pravilu nije uzimala kao konstrukcijski (nosivi) element, već je čitavo seizmičko opterećenje preuzimao sam okvir. Naime, ispuna nije uključivana u ukupnu otpornost kompozitnog sustava (što je redovito na strani veće sigurnosti za nosivost) i njegovu krutost (što je redovito na strani manje sigurnosti za veličinu potresnih sila). Dakle, cjelokupna krutost i otpornost takvih sustava računski je povjeravana samo okviru. Takvim pristupom nije moguće utvrditi stanje naprezanja i razinu oštećenja $\mathrm{u}$ ispuni. Isto tako, iako je takav pristup pretežito na strani veće 
sigurnosti za dimenzioniranje okvira, u nekim slučajevima stvarno ponašanje sustava okvirispuna pri potresu može biti nepovoljnije od proračunskog (primjerice okviri s fleksibilnim etažama). Suvremeni propisi (primjerice Eurocode 8, FEMA 356) predviđaju uključivanje ispune pri seizmičkom proračunu okvira s ispunom. Nažalost, takvi pristupi još uvijek nisu dostatno pouzdani i sveobuhvatni. Pri tome su prilično složeni i nedovoljno precizni za široku projektantsku primjenu.

Ispuna unutar okvira može bitno promijeniti odgovor kompozitne konstrukcije pri potresnom djelovanju. Naime, umetanjem ispune u okvir stvara se značajno krući sustav u odnosu na sustav samog (čistog) okvira. Zbog povećanja krutosti sustava, pri potresu dolazi do povećanja seizmičkih sila na konstrukciju. Okvir sa zidanom ispunom mora imati dostatnu otpornost, kako bi pouzdano preuzeo seizmičke sile i spriječio pojavu lokalnog oštećenja konstrukcije. Varijabilnost u materijalnim karakteristikama, odnosima krutosti, geometrijskoj konfiguraciji, položaju ispune unutar okvira i načinu izvedbe konstrukcije, čini ovaj problem još kompleksnijim. U slučajevima okvira s ispunom koji imaju fleksibilne etaže (bez ispune), kao i slučajevima značajno perforirane ispune, približne inženjerske proračune treba izbjegavati.

Iz prethodnog navedenog slijedi da je ponašanje okvirnih konstrukcija sa zidanom ispunom pri statičkom i naročito potresnom opterećenju vrlo složeno i zahtjeva veliku pozornost pri njihovom projektiranju. Stoga su potrebna daljnja eksperimentalna i numerička istraživanja kako bi se moglo preciznije predvidjeti ponašanje takvih konstrukcija pri potresu, te dati praktični savjeti i preporuke za njihov pouzdani proračun.

\subsection{Motivacija i ciljevi rada}

Posljednjih godina došlo je do značajnog napretka u nelinearnom numeričkom modeliranju betonskih, čeličnih i zidanih konstrukcija. Zahvaljujući većoj količini memorije i brzini računanja, novija računala pružaju sve veću mogućnost za korištenje složenih numeričkih modela. Kompleksni modeli često koriste velik broj parametara, koji mogu imati velik utjecaj na rezultate numeričke analize, te ih je često potrebno kalibrirati s pomoću eksperimentalnih podataka. Eksperimentalnim ispitivanjem postiže se najbolji uvid u stvarno ponašanje konstrukcija, naročito uz suvremene i precizne instrumente za mjerenje i pohranu podataka. Ispitivanja na realnim modelima su relativno složena i skupa, a često i nemoguća. Mnogi istraživači stoga provode testiranja na umanjenim modelima, čime se mogu utvrditi 
relativni odnosi između pojedinih ispitnih uzoraka i testirati neka varijantna rješenja. Kombinacija numeričkog i eksperimentalnog ispitivanja stvara optimalnu podlogu za kvalitetan znanstveni rad. Uz pomoć eksperimentalnih istraživanja može se bolje spoznati stvarno ponašanje konstrukcija do sloma, te uz pomoć dobivenih rezultata kalibrirati i verificirati numeričke modele koji mogu poslužiti za pouzdanu analizu konstrukcija u praksi.

Utjecaj ispune u okvirnim konstrukcijama pri djelovanju potresa veoma je značajan. Ispuna u pravilu ima pozitivne, ali ponekad i negativne utjecaje na globalnu nosivost $\mathrm{i}$ sigurnost konstrukcije. Umetanje zidne ispune u okvir najčešće uzrokuje povećanje globalne krutosti i granične nosivosti novonastalog sustava. Može se očekivati da će takva konstrukcija imati značajno manje pomake pri djelovanju horizontalnih seizmičkih sila, u odnosu na čiste okvirne konstrukcije ili zidane konstrukcije bez okvira. Međutim, zbog povećanja krutosti, kod okvira s ispunom dolazi do povećanja seizmičkih sila. U nekim slučajevima to može voditi nepovoljnijem stanju u odnosu na čiste okvire. Naime, u praksi su brojni slučajevi okvirnih konstrukcija $\mathrm{s}$ ispunom u kojima na pojedinim etažama postoje otvori $\mathrm{u}$ ispuni (perforirana ispuna), odnosno na pojedinim etažama uopće nema ispune. Takav sustav nema jednoliku krutost po visini, što može imati pogubne posljedice za sigurnost konstrukcije pri potresu.

Dakle, kao što je prethodno navedeno, još uvijek nema takvog numeričkog modela za simulaciju betonskih i čeličnih okvira sa zidanom ispunom koji bi pouzdano simulirao sve najvažnije nelinearne efekte njihova ponašanja u uvjetima statičkog i osobito potresnog opterećenja. Zato su još uvijek dragocjena istraživanja u tom području, koja bi vodila razvoju pouzdanog numeričkog modela za analizu realnih praktičnih konstrukcija. U cilju testiranja relevantnih numeričkih modela za statičku i dinamičku analizu okvira sa zidanom ispunom, ali prije svega i radi dobivanja pravog uvida u njihovo stvarno ponašanje pri statičkom opterećenju i potresu, nužna je provedba kvalitetnih eksperimentalnih istraživanja ponašanja ovih konstrukcija do sloma. Pri tome su od neprocjenjive važnosti dobro planirana i uspješno provedena ispitivanja ovih sustava na potresnoj platformi. Od velike važnosti su eksperimentalna istraživanja utjecaja brojnih faktora na ponašanje modela konstrukcije u manjem mjerilu (na potresnoj platformi ili pri statičkom opterećenju).

Osnovna svrha ovog rada je dvojaka:

(1) Provedba eksperimentalnih istraživanja betonskih i čeličnih okvira s ispunom pod statičkim opterećenjem do sloma, te ispitivanja ovih sustava na potresnoj platformi. Eksperimentalno je ispitan utjecaj više faktora na ponašanje okvira s ispunom kako bi se stekle spoznaje o stvarnom ponašanju ovih sustava pri statičkom i potresnom opterećenju. 
(2) Poboljšanje postojećeg numeričkog modela za statičku i dinamičku analizu ravninskih konstrukcija od betona (okviri, zidovi), čelika (okviri) i ziđa [1-5] pomoću prethodno provedenih eksperimenata. Pri tome ove konstrukcije mogu biti samostalne ili povezane (primjerice betonski ili čelični okviri sa zidanom ispunom). Poboljšanje postojećeg modela odnosi se na modeliranje efekta faznog nastajanja okvira s ispunom, te modeliranje utjecaja žbuke (nearmirane i armirane) kod ožbukanog ziđa. Primjenom ovog numeričkog modela, numerički je istražen utjecaj više parametara na ponašanje okvira $s$ ispunom (primjerice $[6,7])$.

\subsection{Sadržaj rada}

Doktorska disertacija sadrži osam poglavlja.

Prvo poglavlje je uvodno, u kojem se ukratko obrazlaže osnovna problematika te iznosi ideja rada.

U drugom poglavlju prikazan je pregled dosadašnjih spoznaja ponašanja i modeliranja okvira sa zidanom ispunom. Odvojeno su razmatrani radovi s analitičkim i numeričkim modelima za simulaciju ponašanja okvira sa zidanom ispunom, te radovi s eksperimentalnim ispitivanjima ovakvih sustava pod statičkim i dinamičkim opterećenjem.

Treće poglavlje prikazuje eksperimentalna ispitivanja modela čeličnih i betonskih okvira sa zidanom ispunom. Ispitivanja su podjeljena u tri grupe. Prva grupa obuhvaća statička ispitivanja čeličnih okvira sa zidanom ispunom. Druga grupa obuhvaća dinamička ispitivanja istih sustava pomoću potresne platforme. Treća grupa obuhvaća dinamička ispitivanja armiranobetonskih okvira sa zidanom ispunom pomoću potresne platforme. U poglavlju su prikazani plan i program eksperimentalnih ispitivanja, opis opreme za ispitivanje i mjerenje, karakteristike uzoraka te rezultati ispitivanja s pripadajućim komentarima. Svi su rezultati prezentirani grafički.

U četvrtom poglavlju prikazan je prethodno razvijeni i provjereni numerički model za statičku i dinamičku analizu ravninskih armiranobetonskih i čeličnih okvira sa zidanom ispunom, koji može simulirati najvažnije nelinearne efekte sustava okvir-ziđe-temelj-tlo. U ovom radu, numerički model je poboljšan s adekvatnom simulacijom faznog nastajanja okvira $\mathrm{s}$ ispunom, te adekvatnom simulacijom nearmirane i armirane žbuke na vanjskim plohama ziđa. 
U petom poglavlju je verifikaciran i provjeren razvijeni numerički model za statičku i dinamičku analizu armiranobetonskih i čeličnih okvira sa zidanom ispunom. Verifikacija modela je vršena pomoću rezultata prethodno provedenih eksperimentalnih istraživanja.

Šesto poglavlje obuhvaća numeričku analizu pomoću koje je istražen utjecaj više parametara na ponašanje armiranobetonskih okvira sa zidanom ispunom pod dinamičkim (potresnim) opterećenjem korištenjem razvijenog numeričkog modela. Svi su rezultati prezentirani grafički.

U sedmom poglavlju izloženi su zaključci rada i preporuke za daljnja istraživanja.

Na kraju rada, u osmom poglavlju, dan je pregled korištene literature. 


\section{DOSADAŠNJE SPOZNAJE PONAŠANJA I MODELIRANJA OKVIRA SA ZIDANOM ISPUNOM}

\subsection{Općenito}

Do sada su izvršena mnogobrojna eksperimentalna i numerička istraživanja ponašanja okvira sa zidanom ispunom pod statičkim, kvazi-statičkim i dinamičkim opterećenjem. Neka od njih mogu se naći u radovima [8-108]. Veći broj dosadašnjih istraživanja odnosio se na betonske okvire sa zidanom ispunom, a manji broj na čelične okvire sa zidanom ispunom. Isto tako, manji je broj eksperimentalnih istraživanja i razvijenih numeričkih modela koji se odnose na ponašanje ovih kompozitnih konstrukcija pri djelovanju potresa, a veći pri statičkom opterećenju. U nastavku su ukratko kronološki navedena neka najvažnija istraživanja, prvo u području numeričkog modeliranja i potom u području eksperimentalnih istraživanja ovih konstrukcija. 


\subsection{Analitički modeli}

Kao jedan od prvih istraživača u predmetnom području, Polyakov [8] je zaključio da ispuna ukrućuje okvire, pri čemu u njoj dolazi do formiranja tlačnih dijagonala pri horizontalnom opterećenju. Holmes [9] je predložio linearni model ekvivalentnog štapa za proračun čvrstoće i krutosti zidane ispune (Slika 2.1). Ispuna je modelirana s ekvivalentnim tlačnim štapom od istog materijala, efektivne širine jednake trećini duljine dijagonale ispune:

$$
\frac{w}{d}=\frac{1}{3}
$$

Stafford-Smith [10] je predložio teorijski izraz za proračun širine pojasa ekvivalentnog štapa uzimajući u obzir relativni odnos krutosti okvira i ispune. Pri tome koristi analitičku formulu za proračun kontaktne duljine između okvira i ispune $\alpha$, kao:

$$
\alpha=\frac{\pi}{2 \lambda_{h}}
$$

Ovdje bezdimenzionalni parametar $\lambda_{\mathrm{h}}$ predstavlja relativnu krutost okvira i ispune, kao:

$$
\lambda_{h}=\sqrt[4]{\frac{E_{w} t_{w} \sin 2 \theta}{4 E I h_{w}}}
$$

pri čemu su $E_{\mathrm{w}}$ modul elastičnosti ispune, $E I$ savojna krutost stupova okvira, $t_{\mathrm{w}}$ debljina ispune i ekvivalentnog štapa, $h$ visina stupova, $h_{\mathrm{w}}$ visina ispune unutar okvira i $\theta$ kut pružanja dijagonale ispune prema horizontalnoj osi.

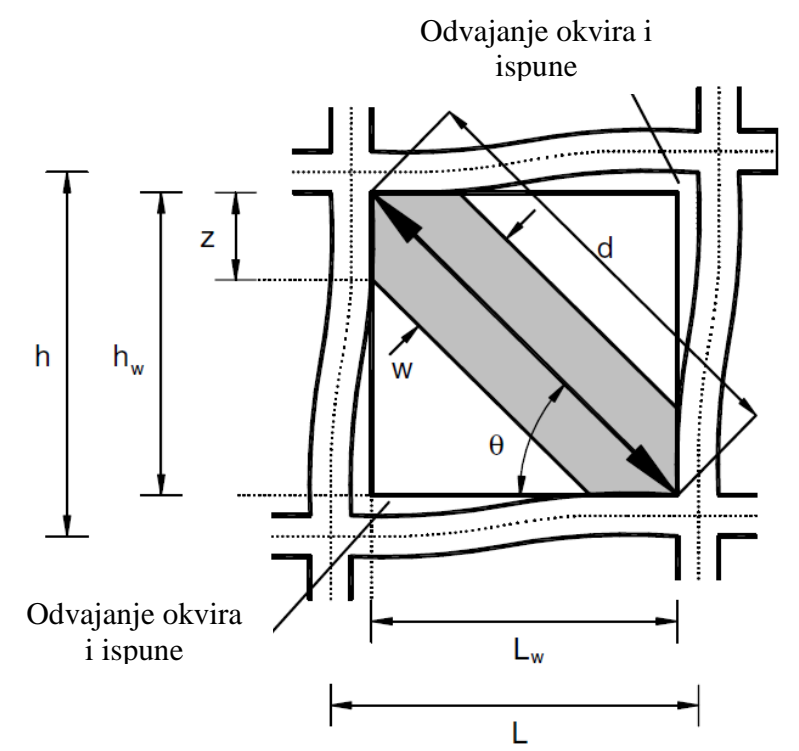

Slika 2.1. Nosivi sklopovi okvira sa zidanom ispunom (preuzeto Asteris [37]) 
Mainstone [11] uvodi alternativni izraz:

$$
\frac{w}{d}=0.16 \lambda_{h}^{-0.3}
$$

Ova formula je uključena u propis FEMA-274 (FEMA 1997) i FEMA-306 (FEMA 1998) za analizu i sanaciju zgrada. Također, veći dio istraživača je koristio formulu za analizu okvira sa zidanom ispunom.

Wood [12] te Liauw i Kawn [13] su razvili metodu plastične analize za procjenu granične nosivosti čeličnih okvira s ispunom. Žarnic [14] je razvio elastični idealno-plastični model ekvivalentnog štapa, s parametrima koji ovise o dimenzijama okvira i ispune, mehaničkim svojstvima individualnog materijala, te interakciji okvira i ispune. Razni autori su predložili svoje modele.

U posljednja dva desetljeća pokazalo se da jednoštapni model nije pogodan za modeliranje kompleksnog ponašanja okvira s ispunom. Predlažu se kompleksniji makromodeli, koji se uglavnom temelje na broju usvojenih ekvivaletnih štapova. Višeštapni model ekvivalentnog štapa predložili su Chrysostomou i suradnici [15], uzimajući u obzir degradaciju krutosti i čvrtoće ispune temeljem prethodnih eksperimentalnih istraživanja (vidjeti Sliku 2.2).

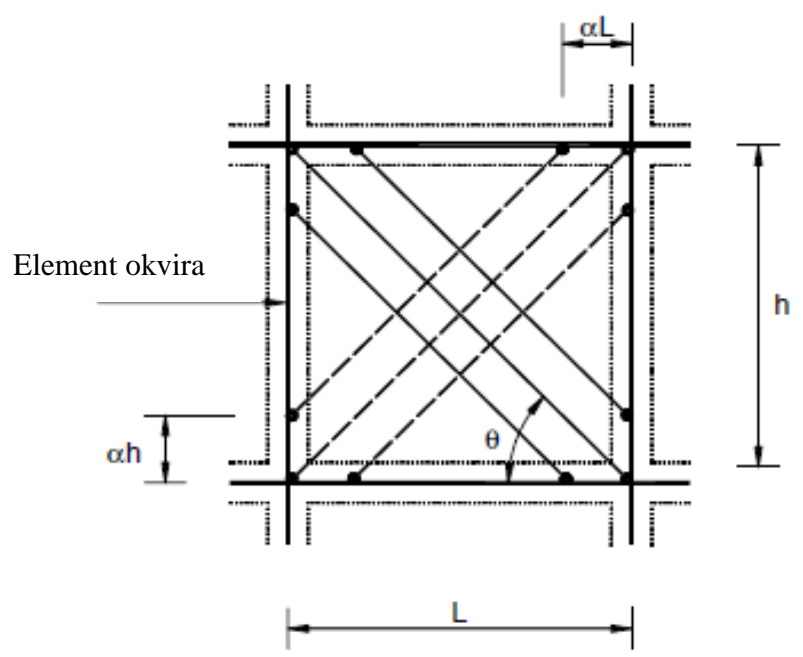

Slika 2.2. Šestero-štapni model ispune unutar okvira (preuzeto Chrysostomou [15])

Saneinejad i Hobbs [16] razvili su elasto-plastičnu metodu za proračun čeličnih i betonskih okvira s ispunom, opterećenih u svojoj ravnini. Predloženi analitički model koristi dva dijagonalna tlačna štapa za simulaciju odgovora ispune unutar okvira. El-Dakhakhni i suradnici $[17,18]$ koriste troštapni model, od kojih je jedan štap smješten u dijagonali ispune, a preostala dva van nje. Crisafulli i Carr [19] su predložili novi makromodel koji koristi 
četveročvorni element ispune, spojen s okvirom u njegovim uglovima. Model odvojeno simulira tlačno i posmično ponašanje ispune, koristeći dva paralelna štapa za simulaciju tlaka i jednu oprugu za simulaciju posmika.

Unatoč brojnim razvijenim analitičkim modelima i njihovim poboljšanjima [20-27], analitičko modeliranje nelinearnog ponašanja okvira s ispunom je relativno teško i neprecizno jer se njime ne mogu obuhvatiti neki tipični mehanizmi sloma.

\subsection{Numerički modeli}

U posljednje vrijeme došlo je do značajnog napretka u nelinearnom modeliranju betonskih i čeličnih okvira sa zidanom ispunom. Razvijeni su različiti numerički modeli, od kojih najveći dio koristi metodu konačnih elemenata.

Mallick i Severn [28] su prvi predložili korištenje metode konačnih elemenata za analizu okvira s ispunom. Koristili su gredne i plošne konačne elemente za simulaciju okvira i ispune, s naglaskom na problem adekvatne simulacije njihova međudjelovanja.

Dhanasekar i Page [29] te Liauw i Lo [30] su koristili linearne i nelinearne gredne elemente za modeliranje čeličnih okvira, plošne elemente za modeliranje ispune te kontaktne elemente za simulaciju interakcije između okvira i ispune. Schmidt [31], Mehrabi i Shing [32] te Ghosh i Amde [33] su simulirali ponašanje betonskih okvira sa zidanom ispunom koristeći model razmazanih pukotina. Chiou i suradnici [34] su modelirali betonske okvire s ispunom diskretizirajući okvir i ispunu na konačne elemente povezane kontaktnim oprugama, za simulaciju vlačnog i posmičnog sloma.

Stavridis i Shing [35] su razvili kompleksni nelinearni model za analizu betonskih okvira s ispunom. Model koristi razmazani i diskretni model pukotina, kako bi se mogli opisati neki tipični oblici sloma. Koutromanos i suradnici [36] su koristili diskretni model pukotina i poboljšani model razmazanih pukotina, kako bi simulirao cikličko ponašanje okvira sa zidanom ispunom.

Asteris [37-40] je predložio novu metodu analize, u kojoj se u svakom koraku računaju kontaktne duljine između okvira $\mathrm{i}$ ispune te odgovarajuća kontaktna naprezanja. Pri tome se okvir i ispuna razmatraju zasebno, uzimajući u obzir sile međudjelovanja (Slika 2.3). 


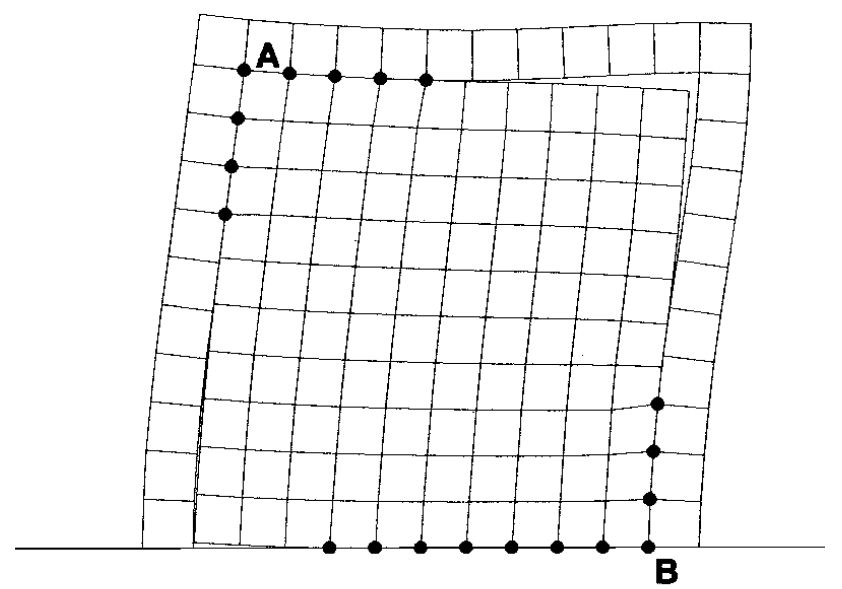

Slika 2.3. Primjer analize okvira s ispunom pomoću metode kontaktnih čvorova (preuzeto Asteris [39])

Mohebkhak i suradnici [41] koriste metodu diskretnih elemenata za nelinearnu analizu okvira s ispunom (Slika 2.4).

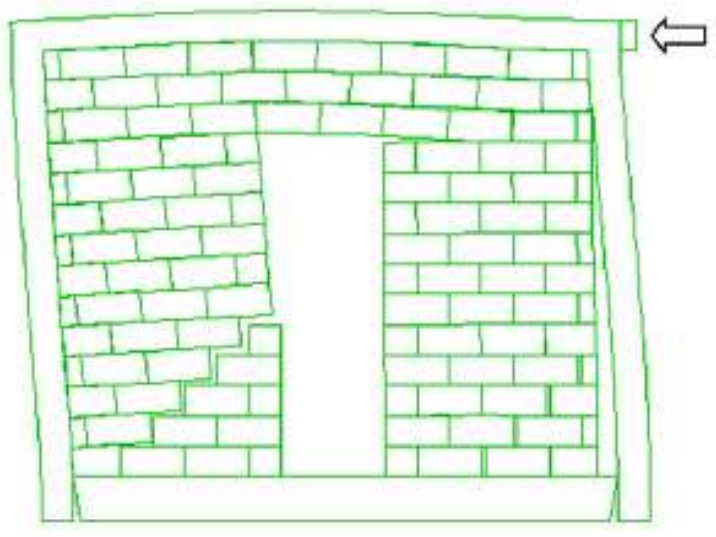

Slika 2.4. Primjer analize okvira s ispunom pomoću metode diskretnih elemenata (preuzeto Mohebkhak [41])

Unatoč brojnim razvijenim numeričkim modelima [42-65], simulacija stvarnog ponašanja okvira $\mathrm{s}$ ispunom može biti neadekvatna ukoliko nisu uključeni najvažniji nelinearni efekti sustava. Kompleksniji modeli često koriste velik broj parametara, koji imaju velik utjecaj na rezultate analize. Njihovi se rezultati ponekad ne poklapaju s rezultatima dobivenim eksperimentalnim testovima. 


\subsection{Eksperimentalna istraživanja}

Provedena su brojna eksperimentalna istraživanja ponašanja okvira sa zidanom ispunom pod statičkim, cikličkim, pseudo-dinamičkim i dinamičkim (potresnim) opterećenjem [66108]. Veći dio radova odnosi se na statička ispitivanja, dok manji dio radova obuhvaća dinamička ispitivanja ovakvih konstrukcija. U nastavku je prikazan pregled najvažnijih eksperimentalnih radova.

\subsubsection{Statička ispitivanja}

Klinger i Bertero [66] ispitali su umanjeni model (1:3) reprezentativne betonske stambene zgrade, sa zaključkom da ispuna smanjuje rizik kolapsa konstrukcije. Bertero i Brokken [67] proveli su niz eksperimentalnih ispitivanja na umanjenim modelima betonskih okvira s ispunom, izloženih monotono rastućem i cikličkom opterećenju (vidjeti Sliku 2.5). Korišteni su različiti materijali ispune, kao i različita količina armature u okviru.

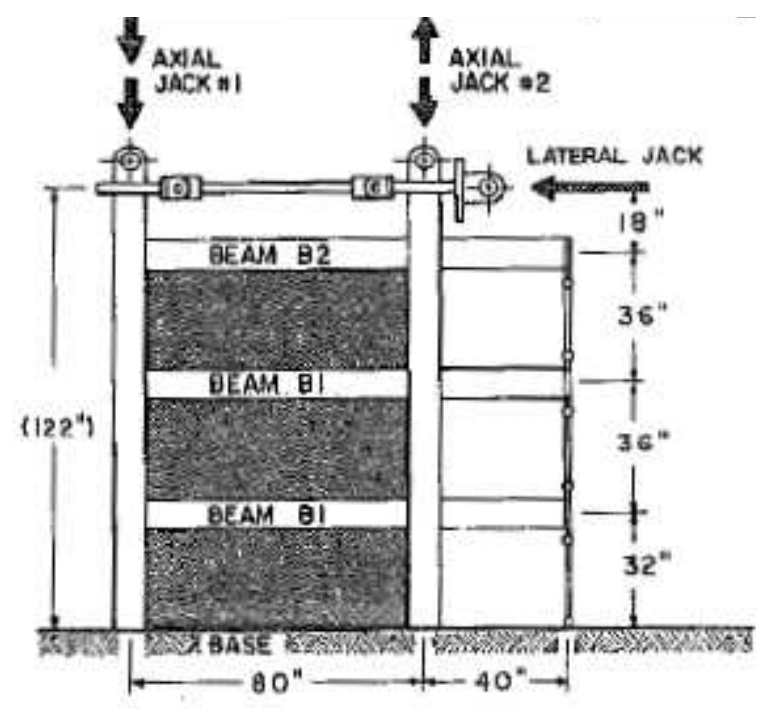

Slika 2.5. Sistem ispitivanja okvira s ispunom koji su proveli Bertero i Brokken (preuzeto Bertero i Brokken [67])

Rezultate intenzivnih eksperimentalnih istraživanja na čeličnim okvirima s ispunom objavili su Dawe i Seah [68-70]. El-Dakhakhni [71] je proveo ispitivanje na čeličnim okvirima s betonskom ispunom, ojačanim GFRP trakama. Mander i suradnici [72] su ispitivali čelične okvire sa zidanom ispunom na umanjenim modelima. Mehrabi i suradnici [73] su ispitali više uzoraka betonskih okvira s ispunom od betonskih blokova, proračunatih u 
skladu s važećim normama. Cilj je bio istražiti utjecaj odnosa krutosti ispune i okvira na ponašanje okvirnih konstrukcija $s$ ispunom. Eksperimentalni rezultati su pokazali da ispuna značajno doprinosi nosivosti i krutosti sustava. Al-Chaar i suradnici [20] su ispitivali 5 umanjenih (1:2) uzoraka jednoetažnih okvira sa zidanom ispunom pod monotonim statičkim opterećenjem. Cilj je bio istražiti utjecaj broja polja okvira i tipa ispune na ponašanje okvirnih konstrukcija s ispunom.

Neki autori bavili su se ispitivanjem utjecaja otvora u ziđu na ponašanje okvira $s$ ispunom. Kakaletsis i Karayannis [74-78] su ispitivali utjecaj otvora u ziđu na ponašanje betonskih okvira s ispunom pri cikličkom opterećenju. Tasnimi i Mohebkhah [79] su ispitivali utjecaj otvora u čeličnim okvirima s ispunom pri cikličkom opterećenju. Mosalam i suradnici [80] su proveli kvazi-statička ispitivanja na umanjenim (1:4), jednoetažnim čeličnim okvirima sa zidanom ispunom. Ispitivali su utjecaj relativne čvrstoće zidnih elemenata i morta, broj polja okvira te konfiguraciju otvora u ispuni. Anil i Altin [81] su proveli ciklička ispitivanja na 9 jednopoljnih, jednoetažnih, umanjenih (1:3) okvira sa zidanom ispunom, s različitom konfiguracijom i položajem otvora unutar ispune. Blackard i suradnici [82] su proveli ciklička ispitivanja na umanjenim (2:3) uzorcima $\mathrm{AB}$ okvira sa zidanom ispunom $\mathrm{s}$ različitom konfiguracijom otvora. Također, kod nekih uzoraka korišteno je ojačanje ziđa pomoću cementnih kompozitnih materijala.

\subsubsection{Dinamička ispitivanja}

Mosalam i suradnici [83] proveli su pseudo-dinamička ispitivanja na umanjenom (1:4), dvoetažnom, dvopoljnom čeličnom okviru sa zidanom ispunom izloženom seriji simuliranih akcelerograma. Buonopane i White [84] ispitali su umanjeni (1:2) dvoetažni, dvopoljni AB okvir sa zidanom ispunom pod pseudo-dinamičkim opterećenjem, simulirajući seriju pobuda realnog potresa. Colangelo [85] je ispitao 13 jednoetažnih, jednopoljnih, umanjenih (1:2) AB okvira s ispunom pod presudo-dinamičkim opterećenjem. Okviri su izloženi ponavljanom djelovanju realnog potresa. Negro i suradnici [86, 87] su proveli niz pseudo-dinamičkih testova na četverokatnoj betonskoj zgradi, u varijantama čistog okvira te okvira s pravilnim i nepravilnim položajem ispune.

Proveden je manji broj eksperimenata koji obuhvaćaju ponašanje okvira s ispunom na potresnom stolu. Klinger i suradnici [88] su ispitali dva umanjena (1:2) modela jednoetažnog okvira s ispunom na potresnoj platformi, proračunatih prema dva različita propisa. Prvo su 
ispitani čisti okviri (bez ispune), nakon čega su naknadno ispunjeni ziđem i izloženi povećavanim amplitudama akcelerograma. Fardis i suradnici [89] su ispitali dvoetažnu, jednopoljnu prostornu $\mathrm{AB}$ okvirnu konstrukciju s različitim položajem ispune, izloženu pobudi s dva okomita horizontalna smjera gibanja. Ispitivanje je vršeno pomoću potresne platfome pri ISMES-u, u Bergamu u Italiji. Žarnić i suradnici [90] su testirali dva umanjena (1:4) modela na potresnom stolu pri Sveučilištu u Bristolu, UK. Modeli su proračunati prema važećim propisima, te izloženi harmonijskim pobudama koje imaju period za $10 \%$ manji od fundamentalnog perioda ispitivanih modela.

Lee i Woo [91] su ispitali umanjeni (1:5), dvopoljni, troetažni prostorni AB okvir pri Hyundai Institute of Construction Technology. Uzorak je izložen djelovanju više potresa, te ispitan metodom naguravanja (eng. pushover test). Dolce i suradnici [92] su ispitali dva umanjena (1:3.3), troetažna, dvopoljna $\mathrm{AB}$ okvira s zidanom ispunom, proračunata za područja manje seizmičnosti. Uzorci su izloženi nizu umjetnih akcelerograma s postupno povećavanom amplitudom.

Hashemi i Mosalam [93] su proveli ispitivanja na umanjenom (3:4), jednoetažnom uzorku, sastavljenom od tri paralelna AB okvira, od kojih je srednji ispunjen ziđem (Slika 2.6). Ispitivanje je vršeno pomoću potresne platforme pri Sveučilitu u Kaliforniji, u Berkleyu. Uzorak je predstavljao prizemlje prototipa peterokatne zgrade, proračunate u skladu $s$ važećim propisima. Uzorak je izložen skaliranim akcelerogramima dvaju realna potresa.

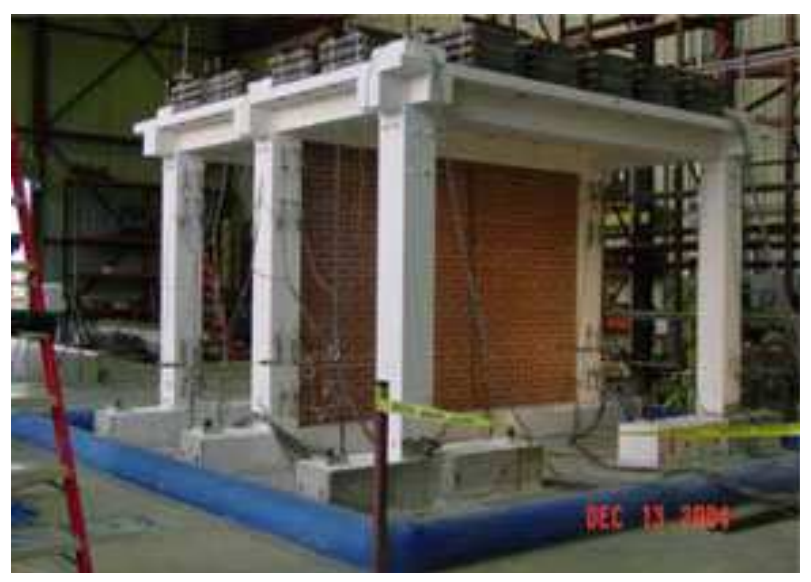

Slika 2.6. Ispitivanje uzorka na potresnoj platformi u Berkleyu (preuzeto Hashemi i Mosalam [93])

Stavridis [94, 95] je ispitao umanjeni (2:3), troetažni, dvopoljni okvir sa zidanom ispunom na vanjskoj platformi pri Sveučilištu u Kaliforniji, u San Diegu (UCSD NEES). Okvir je u jednom polju bio potpuno ispunjen ziđem, dok je u drugom polju imao otvore za 
prozor (Slika 2.7). Cilj ovog ispitivanja je bio istražiti dinamički odgovor višeetažnih višepoljnih okvira sa zidanom ispunom.

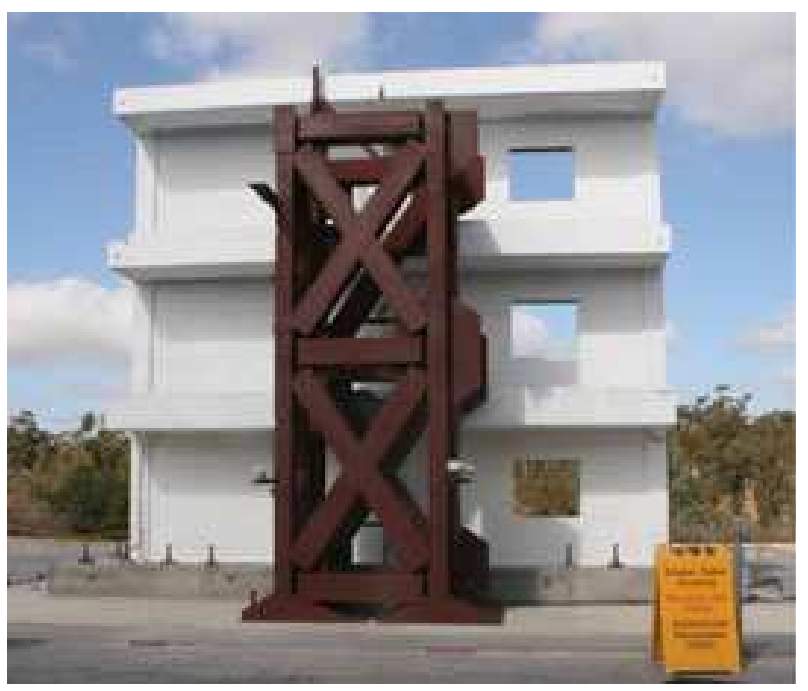

Slika 2.7. Ispitivanje uzorka na potresnoj platformi u San Diegu (preuzeto Stavridis [94])

Ispitivanja ponašanja sustava okvir-ispuna na potresnom stolu su novijeg datuma i još uvijek su rijetka. Kod većine provedenih eksperimenata, ispitan je manji broj uzoraka (do dva uzorka). Pri tome su vršena ispitivanja na uzorcima $u$ realnom i umanjenom mjerilu. Ispitivanja na konstrukcijama u realnom mjerilu su najvjerodostojnija, ali i najskuplja $\mathrm{i}$ ponekad nemoguća, najčešće zbog ograničenih tlocrtnih dimenzija i performansi dostupnih potresnih platformi. Naime, izradom uzoraka u umanjenom mjerilu omogućen je veći broj provedenih eksperimentalnih ispitivanja ovih sustava na platformi. Kod takvog pristupa moguće je istražiti utjecaj pojedinih parametara na njihovo ponašanje pri potresnom opterećenju. 


\subsection{Zaključak}

Iako su razvijeni brojni numerički modeli za statičku i dinamičku analizu čeličnih i betonskih okvira sa zidanom ispunom, koji se značajno razlikuju glede njihove složenosti i točnosti, još uvijek nema takvog numeričkog modela koji bi bio dostatno jednostavan za praktičnu uporabu i koji bi modelirao sve najvažnije nelinearne efekte ponašanja ovih konstrukcija (fazno nastajanje nosivog sustava, interakciju sustava okvir-ziđe-tlo, popuštanje čelika, betona, ziđa i tla u tlaku, razvoj pukotina u betonu, ziđu i tlu, anizotropiju ziđa, utjecaj posmika na slom gradiva, promjenu geometrije sustava i sl.).

Eksperimentalna ispitivanja ponašanja predmetnih konstrukcija s pomoću dinamičke platforme, koja može najtočnije opisati njihovo stvarno ponašanje pri potresu, još uvijek su rijetka. Prvenstveni razlog tome je mali broj ove skupe i sofisticirane opreme u svijetu, te veliki troškovi provedbe takvih ispitivanja. Nužna su daljnja istraživanja ovih nosivih sustava s pomoću dinamičkih platformi. Pri tome su ispitivanja konstrukcija u realnom mjerilu najvjerodostojnija. Međutim, parametarske analize na modelima konstrukcija u manjem mjerilu mogu biti od velike koristi. 


\section{EKSPERIMENTALNA ISPITIVANJA PONAŠANJA ČELIČNIH I BETONSKIH OKVIRA SA ZIDANOM ISPUNOM}

\subsection{Općenito}

U ovom su poglavlju prikazani program i rezultati eksperimentalnih ispitivanja ponašanja čeličnih i betonskih okvira sa zidanom ispunom. Ispitivanja su rađena $u$ Laboratoriju za potresna ispitivanja u Žrnovnici pokraj Splita, pri Fakultetu građevinarstva, arhitekture i geodezije, Sveučilišta u Splitu. Laboratorij raspolaže s opremom za statička, dinamička (potresna platforma) i udarna ispitivanja različitih konstrukcija. Eksperimentalni rad obuhvaća sljedeća ispitivanja:

1. statička ispitivanja čeličnih okvira sa zidanom ispunom

2. dinamička ispitivanja čeličnih okvira sa zidanom ispunom

3. dinamička ispitivanja betonskih okvira sa zidanom ispunom

Eksperimentalna ispitivanja čeličnih okvira sa zidanom ispunom obavljena su na jednoetažnim jednopoljnim okvirima u umanjenom mjerilu (1:3). Okviri su ukliješteni u podlogu. Elementi zidane ispune su iz porastog betona, povezani bijelim tankoslojnim 
mortom. Statička ispitivanja obuhvaćaju praćenje ponašanja okvira do sloma pod horizontalnom statičkom silom u vrhu okvira.

Dinamička ispitivanja na potresnoj platformi obuhvaćaju nosive sustave kao kod statičkog testa. Svaki nosivi sustav je izložen djelovanju umjetnog akcelerograma i realnog potresa (horizontalna komponenta ubrzanja), pri čemu se amplituda potresa sukcesivno povećavala do sloma konstrukcije, odnosno do njenog oštećenja.

Eksperimentalna ispitivanja betonskih okvira sa zidanom ispunom obavljena su na dvoetažnim jednopoljnim okvirima u umanjenom mjerilu (1:4). Okviri su ukliješteni u podlogu. Elementi zidane ispune su također iz porastog betona. Svaki nosivi sustav je izložen djelovanju horizontalne komponente ubrzanja umjetnog akcelerograma, pri čemu se amplituda potresa sukcesivno povećava do sloma konstrukcije, odnosno do njenog oštećenja.

U svakom trenutku vremena, odnosno za svaki inkrement statičke sile, mjerene su karakteristične veličine (pomaci, ubrzanja, deformacije/naprezanja, stanje pukotina). Svi su glavni rezultati grafički prezentirani.

U nastavku su prikazani osnovni podaci o korištenoj opremi, plan i program eksperimentalnih ispitivanja, izmjereni rezultati te zaključci provedenih ispitivanja.

\subsection{Osnovni podaci o korištenoj opremi za ispitivanje}

\subsubsection{Platforma za potresna ispitivanja}

Eksperimentalna ispitivanja uzoraka okvira sa zidanom ispunom provedena su u Laboratoriju za potresna ispitivanja u Žrnovnici pokraj Splita (Slika 3.1). Laboratorij radi kao sastavni dio Fakulteta građevinarstva, arhitekture i geodezije, Sveučilišta u Splitu, te raspolaže opremom za statička, dinamička i udarna ispitivanja različitih konstrukcija.

Eksperimentalno ispitivanje i numeričko modeliranje betonskih i čeličnih okvira sa zidanom ispunom pod statičkim i dinamičkim opterećenjem 


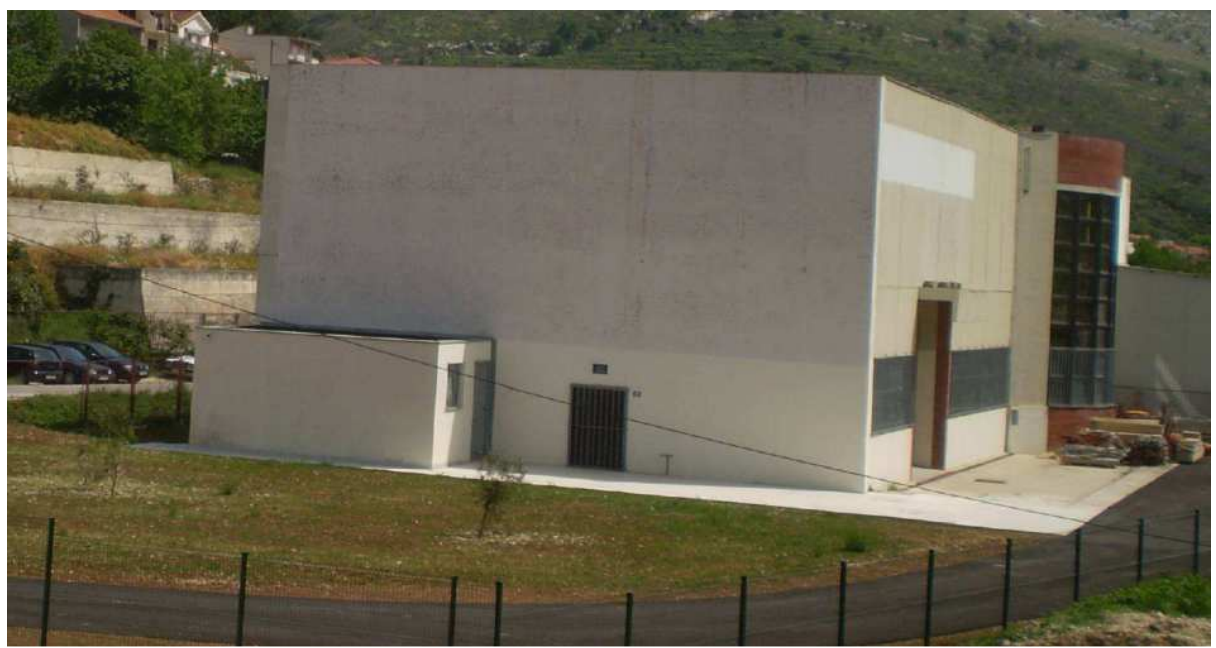

Slika 3.1. Zgrada laboratorija za potresna istraživanja u Žrnovnici

Statička ispitivanja vršena su pomoću hidrauličnog sustava za nanošenje opterećenja.

Dinamička ispitivanja vršena su pomoću potresne platforne (eng. shake-table). Konstrukcija gornje plohe platforme je sandučasta ortotropna čelična ploča, tlocrtnih dimenzija 4.0×4.0 m. Vanjski izgled platforme prikazan je na Slici 3.2.

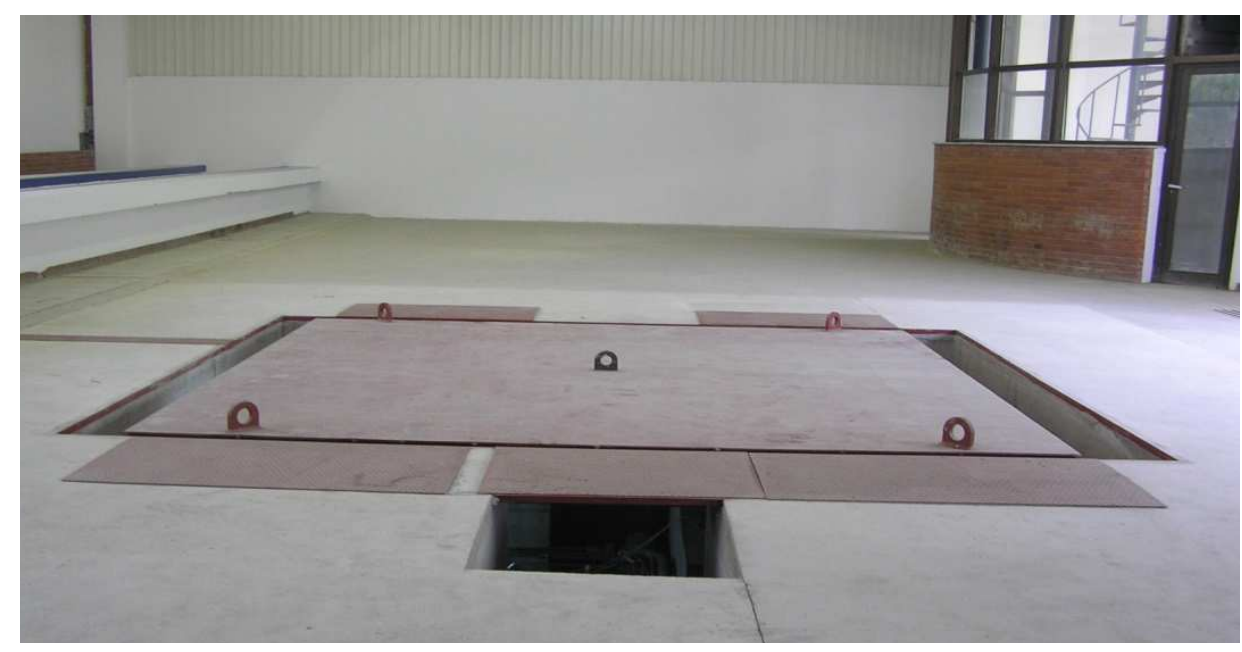

Slika 3.2. Vanjski izgled platforme

Ukupna masa čelične konstrukcije platforme iznosi približno 5 tona, dok je maksimalna masa uzorka za ispitivanje ograničena na 20 tona. Platforma je oslonjena na posebno konstruirane mehaničke ležajeve - njihala, koji omogućuju horizontalne pomake s vrlo niskim koeficijentom trenja na ležajevima. Bočni horizontalni pomaci platforme su spriječeni uzdužnim "vodilicama". Horizontalna sila s pogonskog cilindra prenosi se na platformu u njezinom težištu. Platforma je smještena u masivnoj krutoj armiranobetonskoj školjci, koja 
prenosi dinamičke vibracije (sile) s platforme na okolno tlo. Za pogon platforme koristi se elektro-hidraulički sustav snage $100 \mathrm{~kW}$.

Platforma ima jednokomponentni horizontalni smjer gibanja. Najveći pomaci platforme su $\pm 150 \mathrm{~mm}$, najveće ubrzanje \pm 3 g i najveća frekvencija $30 \mathrm{~Hz}$. Povratna sprega po pomaku, brzini i ubrzanju je osigurana kroz upravljački algoritam. Zadavanje funkcije ubrzanja je moguće u obliku proizvoljne funkcije, sinusne funkcije, funkcije trokuta i pravokutnika. Međusobno su ovisni težina ispitnih uzoraka, pomaci (ubrzanja) i frekvencije platforme. Zadana i ostvarena ubrzanja platforme imaju visoku razinu podudarnosti, što potvrđuje visoku razinu kvalitete platforme.

Platforma ima mogućnost ispitivanja stvarnih građevina i njihovih modela tlocrtnih izmjera do $4 \times 4 \mathrm{~m}$, mase do 20 tona i visine do $9 \mathrm{~m}$.

\subsubsection{Oprema za mjerenje mehaničkih veličina}

Kontinuirano snimanje i prikupljanje podataka sa svih senzora tijekom eksperimenata omogućeno je pomoću sustava Quantum-X MX 840A i računalnog programa Catman Easy, proizvoda tvrtke HBM (Hottinger Baldwin Messtechnik). Sustav Quantum i vizualno sučelje programa Catman prikazani su na Slici 3.3.

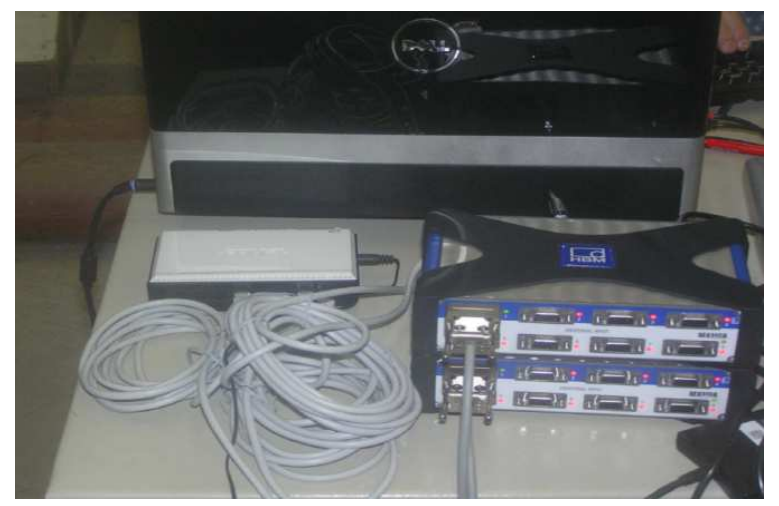

(i) Sustav uređaja Quantum

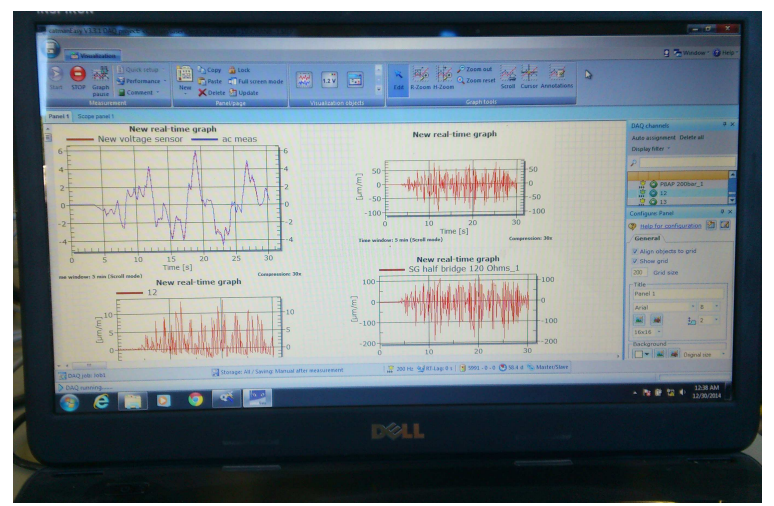

(ii) Sučelje programa Catman

Slika 3.3. Sustav za prikupljanje, obradu i prikaz podataka

Mjerenje pomaka vršeno je pomoću elektroničkih uređaja (inductive displacement transducer) tipa WA/500-L i tipa WA/100-L proizvođača HBM, koji su prikazani na Slici 3.4. Uređaj tipa WA/100-L može mjeriti pomake do $100 \mathrm{~mm}$, dok uređaj tipa WA/500-L mjeri pomake do $500 \mathrm{~mm}$. 


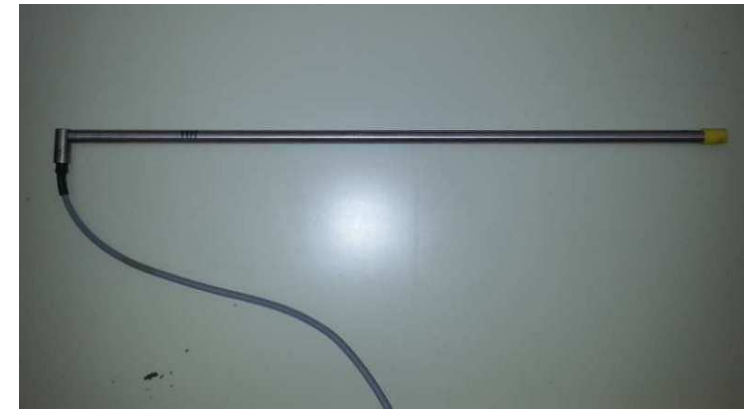

(i) Tip WA/500-L

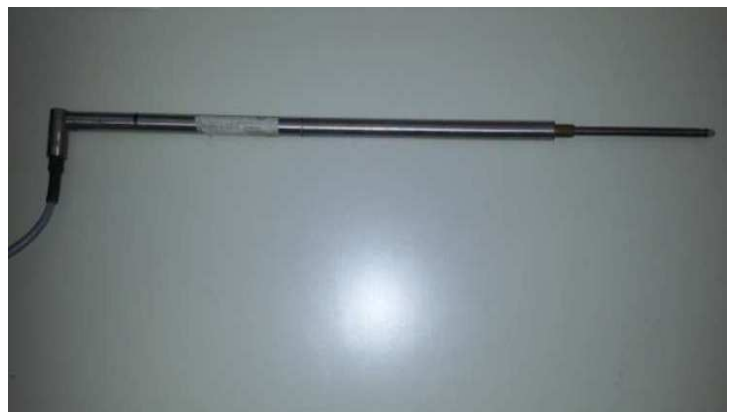

(ii) Tip WA/100-L

Slika 3.4. Uređaji za mjerenje pomaka

Mjerenje deformacija vršeno je pomoću elektro-otpornih mjernih traka (tenzometara), koji su prikazani na Slici 3.5. Kod toga su korištene trake s dužinom mjerne baze $50 \mathrm{~mm}$ tip 50/120 LY11 (HBM) za mjerenje deformacija na betonu, te trake s dužinom baze $6 \mathrm{~mm}$ tip 6/120 LY11 (HBM) za mjerenje deformacija na čeliku (čelični okviri, armatura u betonskim okvirima). Korištene mjerne trake su početnog električnog otpora $120 \Omega$, a maksimalno izduženje im je $\pm 5 \%( \pm 50000 \mu \mathrm{m} / \mathrm{m})$.

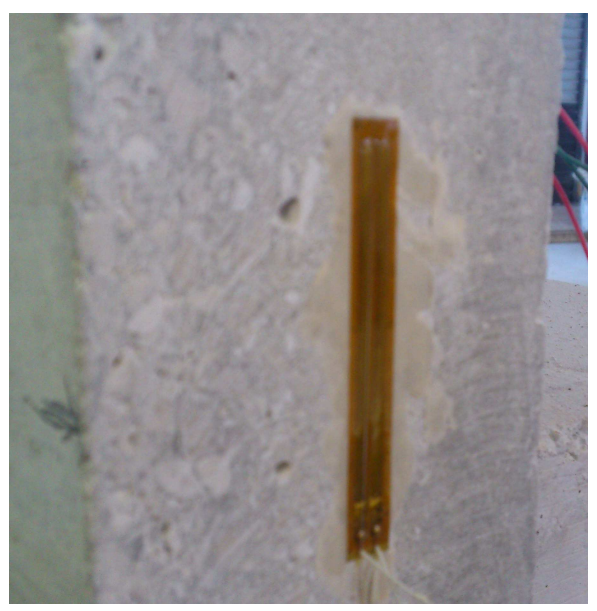

(i) Tenzometri za beton

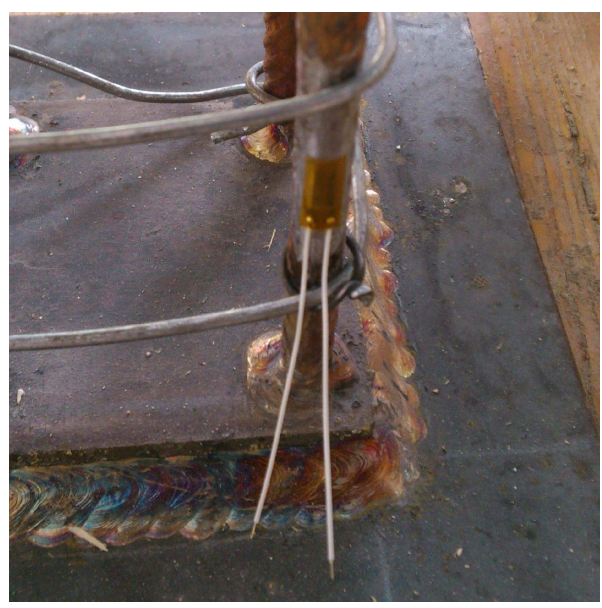

(ii) Tenzometri za čelik

Slika 3.5. Uređaji za mjerenje deformacija (tenzometri)

Mjerne trake na armaturi su zalijepljene u fazi izrade armaturnog koša okvira (prije betoniranja). Mjerne trake na betonu i na čeličnim okvirima su zalijepljene 24 sata prije ispitivanja. Podloga za lijepljenje traka je prethodno brušena i očišćena. Na beton su trake lijepljene pomoću dvo-komponentnog ljepila X60 (HBM), a na čelik pomoću jednokomponentnog ljepila Z70 (HBM). Ljepilo nema ograničenja po pitanju deformacija, već po pitanju temperatura (koristiti se pri temperaturama od $-55^{\circ} \mathrm{C}$ do $100^{\circ} \mathrm{C}$ ). Zaštita zalijepljenih mjernih traka izvedena je uz pomoć zaštitnog sredstva SG250 (HBM). Priprema podloge, lijepljenje i zaštita traka vršena je prema uputama proizvođača. 
Prosječne deformacije u ziđu mjerene su pomoću elektronskog komparatora WA/10-L proizvođača HBM. Komparator može mjeriti pomake do $10 \mathrm{~mm}$. Mjerenje je vršeno pomoću mjernih niti, koje su usidrene u ziđe pomoću sidrenih vijaka (Slika 3.6.). Duljina mjerne baze definirana je razmakom sidrenih vijaka. Prosječna deformacija u ziđu se proračunava kao izmjerena vrijednost pomaka podijeljena s duljinom mjerne baze.

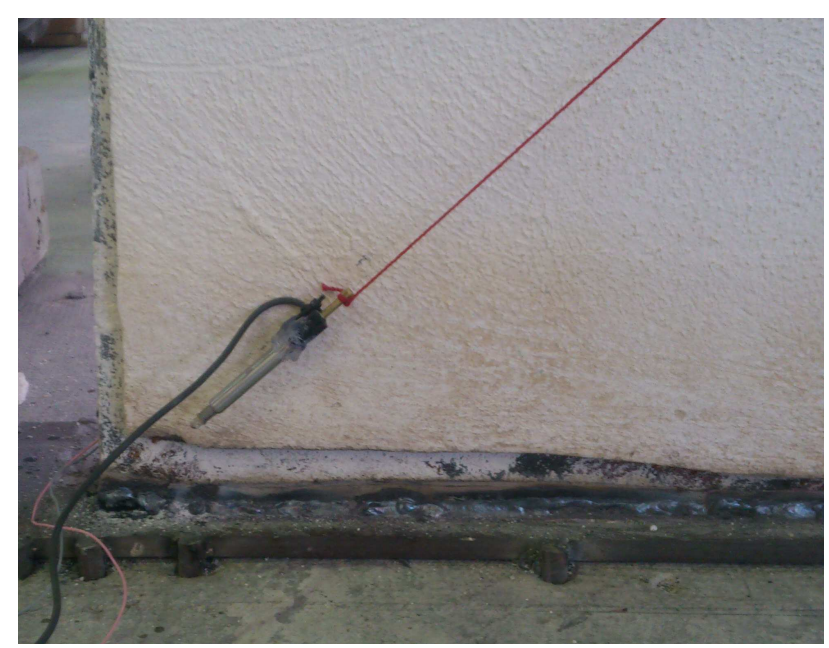

Slika 3.6. Mjerenje prosječnih deformacija ziđa

Za mjerenje ubrzanja korištena su dva tipa piezo-električnih niskofrekventnih akcelerometara. Za mjerenje ubrzanja na konstrukciji korišten je Piezobeam akcelerometar tipa $8640 \mathrm{~A}$ proizvođača Kistler, mjernog opsega $\pm 5 \mathrm{~g}$, uz automatsko kompenziranje gravitacijskog ubrzanja. Mjerenje ubrzanja platforme obavljeno je pomoću akcelerometra tipa 4610 proizvođača Measurment Specialties (MEAS), s izrazito niskom razinom šuma i visokim performansama signala, mjernog područja $\pm 5 \mathrm{~g}$. Oba tipa korištenih akcelerometara prikazana su na Slici 3.7.

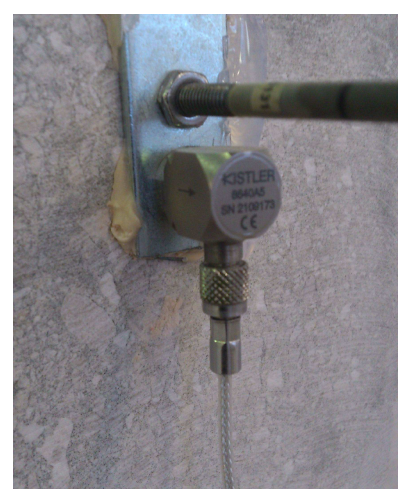

(i) Tip 8640A Kistler

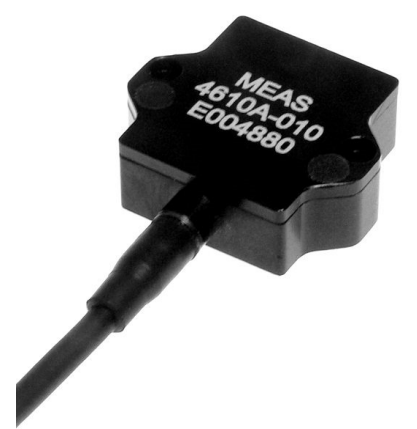

(ii) Tip 4610 MEAS

Slika 3.7. Uređaji za mjerenje ubrzanja (akcelerometri) 


\subsection{Opterećenje}

Jedna od najvažnijih zadaća u potresnom inženjerstvu je istraživanje ponašanja i odgovora konstrukcije pri gibanju tla uslijed djelovanja potresa. Različite konstrukcije imaju i različito ponašanje kada su izložene djelovanju istog potresa. Definiranje najnepovoljnijeg tipa potresa za određenu građevinu je iznimno složena zadaća te je i danas predmet velikog broja istraživanja. S inženjerskog aspekta, najznačajnija svojstva potresnog gibanja su: ubrzanje, brzina i pomak tla zabilježeni za vrijeme potresa. Akcelerogram potresa predstavlja vremenski zapis izmjerenih ubrzanja tla na nekoj lokaciji, koji se najčešće može okarakterizirati s njegova tri osnovna parametra: maksimalno ubrzanje, duljina trajanja i predominantni period.

Tradicionalni pristup u seizmičkim proračunima konstrukcija bazira se na elastičnim spektrima odgovora ubrzanja podloge. Spektar odgovora neke razmatrane mehanike veličine predstavlja dijagram njenih ekstremnih vrijednosti u ovisnosti o periodu jednostupnjevnog sustava, analiziran za neku konkretnu pobudu. U potresnom inženjerstvu najčešće se konstruiraju spektri odgovora u obliku pomaka, brzina i ubrzanja. Svaki takav dijagram može se konstruirati za različite koeficijente prigušenja $\xi$. Većina relevantnih svjetskih propisa usvojila je elastične spektre ubrzanja tla za proračun potresnih sila koje djeluju na konstrukciju [109].

Suvremeni propisi dopuštaju upotrebu zapisa ubrzanja u vremenu (akcelerograma) za provedbu nelinearnog seizmičkog proračuna konstrukcija. Pri tome je moguće koristiti zapisane akcelerograme ili umjetne akcelerograme, takve da se podudare s elastičnim spektrom odgovora. Međutim, iako su ove metode točnije u opisu problema, zbog svoje kompleksnosti često izlaze iz okvira praktične primjene.

Zahvaljujući dostupnim on-line bazama s vremenskim zapisima prethodno realiziranih potresa [110, 111], moguće je koristiti veći broj akcelerograma u seizmičkoj analizi konstrukcija. Nadalje, razvijene su i razne metode pomoću kojih je moguće kreirati umjetne akcelerograme za proizvoljno odabrane spektre odgovora. Među njima se najviše primjenjuju metode $\mathrm{u}$ vremenskom i frekventnom domenu [112, 113], koje su u stalnom razvoju. Korištenjem ovih metoda moguće je za odabrani (projektni) spektar odgovora kreirati reprezentativni akcelerogram, čiji spektar odgovora najbolje odgovara odabranom (projektnom) spektru odgovora. Ovako definirani akcelerogrami imaju široku primjenu u seizmičkoj analizi konstrukcija.

Eksperimentalno ispitivanje i numeričko modeliranje betonskih i čeličnih okvira sa zidanom ispunom pod statičkim i dinamičkim opterećenjem 
U ovom je radu korišten računalni program SIMQKE [114] za generiranje umjetnih akcelerograma. Program koristi metodu superpozicije sinusnih funkcija za prikaz akcelerograma potresa. Pomoću ovog programa, za proizvoljni projektni spektar odgovora moguće je kreirati reprezentativni akcelerogram čiji je pripadajući spektar odgovora kompatibilan s projektnim spektrom odgovora. Umjetni akcelerogrami kreirani prema prethodno opisanoj proceduri su stacionarni u vremenu u pogledu frekventnog sastava, a nestacionarni u pogledu amplituda kretanja.

Generirana su dva različita umjetna akcelerograma, od kojih je jedan „bržeg“ karaktera (oznaka AA1), a drugi „sporijeg karaktera“ (oznaka AA2). Akcelerogram AA2 kreiran je iz je projektnog elastičnog spektra odgovora prema EN 1998 [115], za tip 1 i tip tla A. Akcelerogram AA1 kreiran je iz modificiranog projektnog spektra kako bi obuhvatio niže periode, odnosno kako bi njegovo djelovanje na krućim sustavima bilo izraženije. Umjetni akcelerogrami AA1 i AA2 s pripadajućim elastičnim spektrima odgovora prikazani su na Slikama 3.8. i 3.9.

Pripadajući spektri odgovora prikazani su uz pomoć računalnog programa SeismoSignal za obradu podataka akcelerograma [116]. Pomoću ovog programa moguće je proračunati pripadajući (ostvareni) spektar odgovora za proizvoljno odabrani akcelerogram.

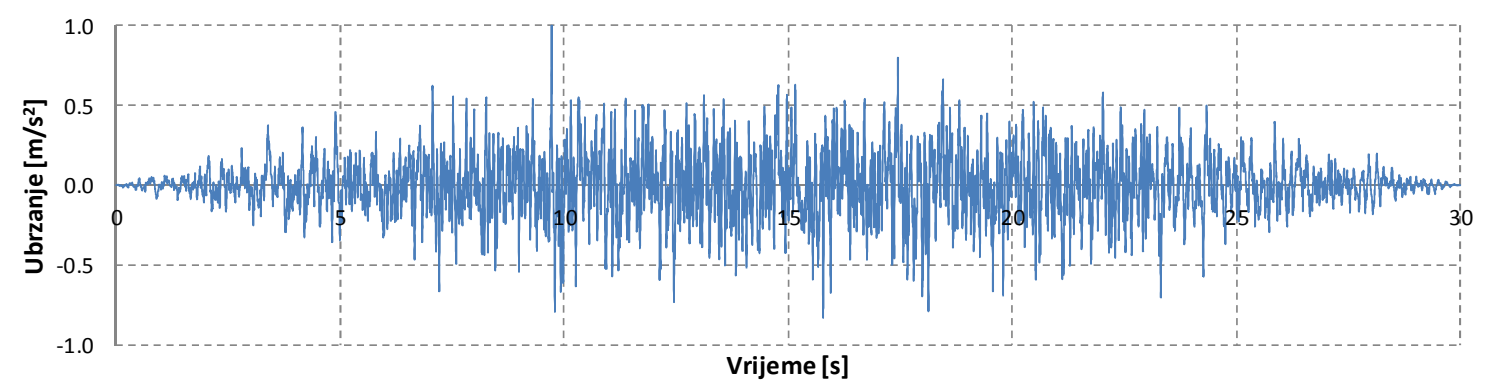

a) Akcelerogram

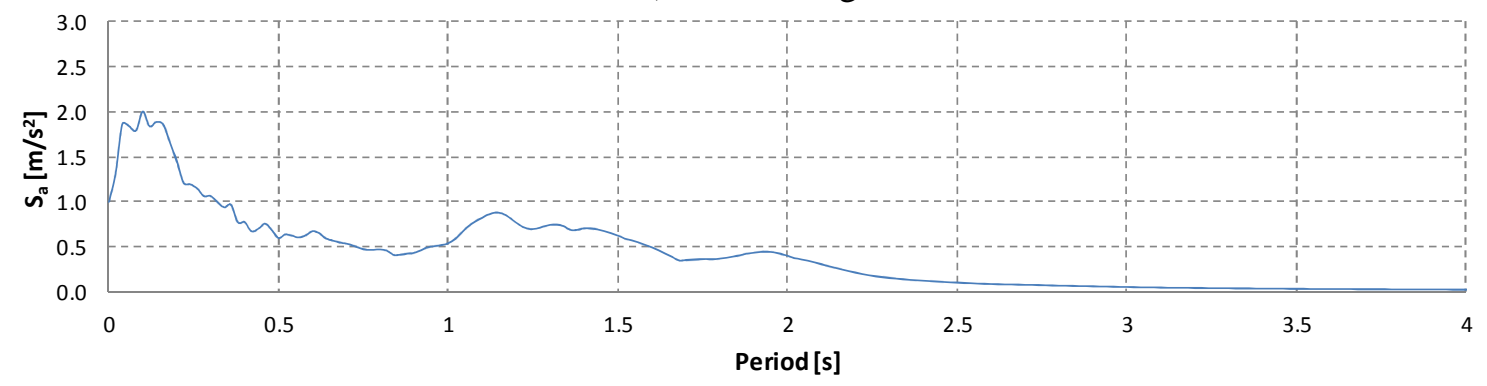

b) Elastični spektar odgovora ( $5 \%$ prigušenje)

Slika 3.8. Vremenski zapis ubrzanja umjetnog akcelerograma AA1 


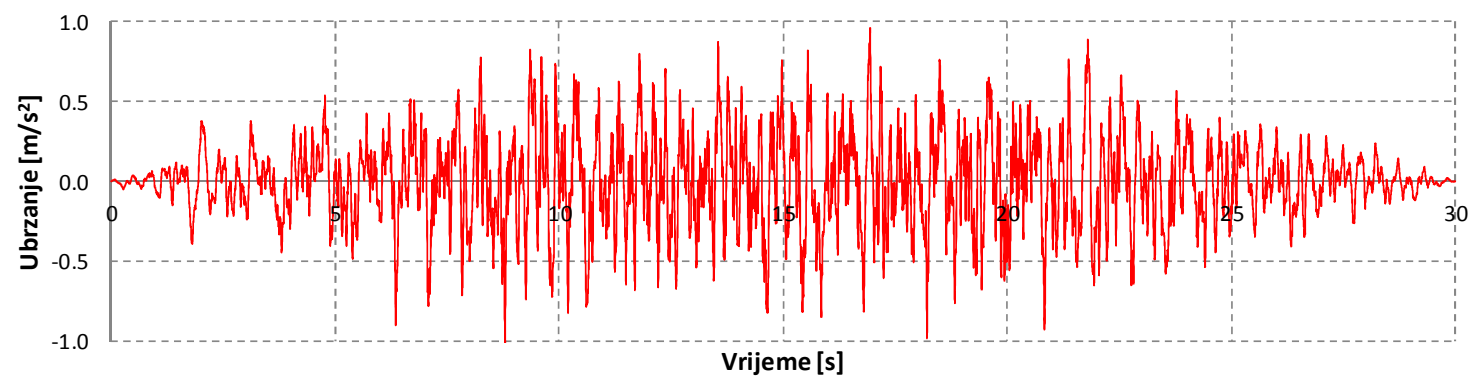

a) Akcelerogram

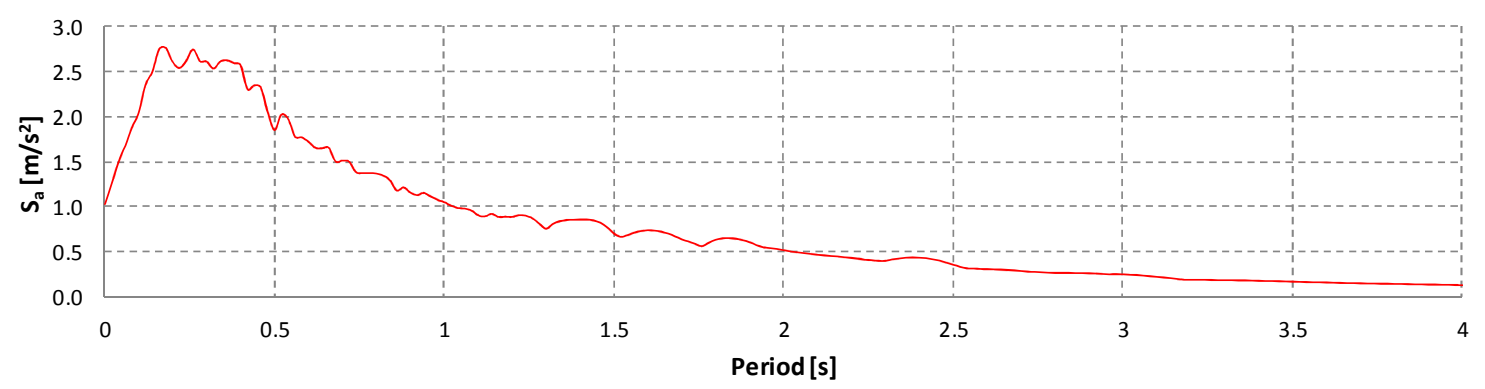

b) Elastični spektar odgovora (5\% prigušenje)

Slika 3.9. Vremenski zapis ubrzanja umjetnog akcelerograma AA2

Uz umjetne akcelerograme, korišten je i vremenski zapis jednog realnog potresa. Odabran je potres Petrovac iz 1979, Crna Gora (orijentacija S-J). Akcelerogram ovog potresa preuzet je iz dostupne baze podataka [110], s prikazom na Slici 3.10.

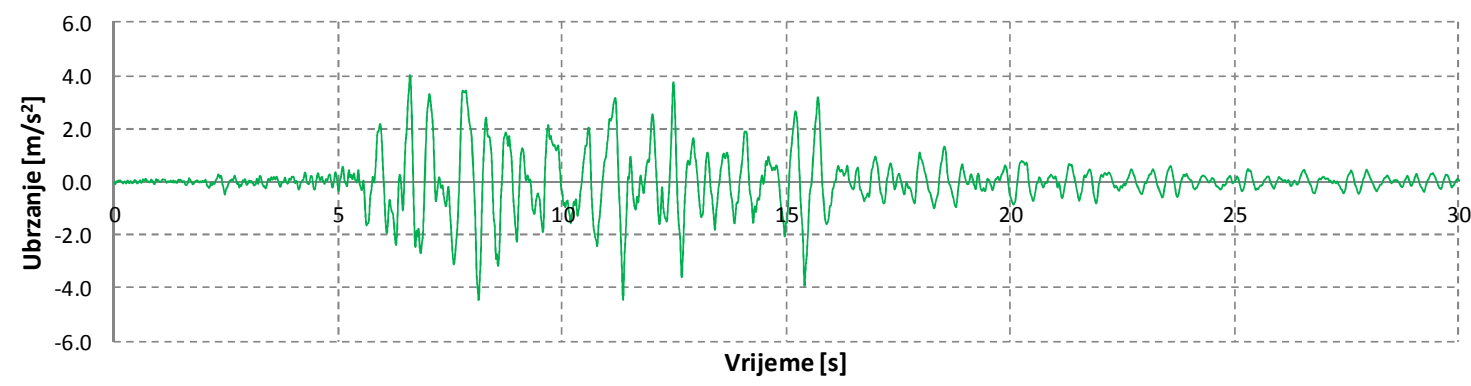

a) Akcelerogram

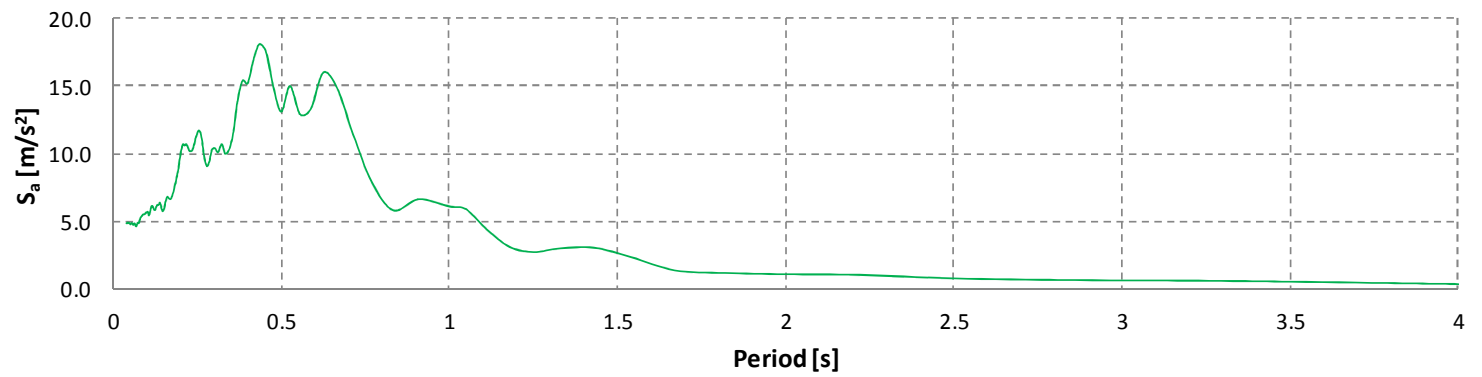

b) Elastični spektar odgovora ( $5 \%$ prigušenje)

Slika 3.10. Vremenski zapis ubrzanja potresa Petrovac

Vremenski zapisi dvaju umjetnih akcelerograma i akcelerograma realnog potresa korišteni su kao ulazno opterećenje pri dinamičkim ispitivanjima na potresnoj platformi. 


\subsection{Korišteni materijali}

Napravljen je opsežan program testnih ispitivanja kako bi se dobila najvažnija fizikalnomehanička svojstva korištenih materijala pri izradi čeličnih i armiranobetonskih okvira sa zidanom ispunom.

Kod oba tipa okvira korištena je zidana ispuna od laganog porastog betona. Zidanje je vršeno upotrebom bijelog tankoslojnog morta. Korišteni su umanjeni zidni elementi, u ovisnosti o mjerilu ispitivanih okvira, koji predstavljaju realni betonski blok dimenzija $625 \times 250 \times 250 \mathrm{~mm}$. Deklarirana tlačna čvrstoća zidnih elemenata od porastog betona iznosila je $3 \mathrm{MPa}$. Deklarirana tlačna čvrstoća morta iznosila je $10 \mathrm{MPa}$, a vlačna čvrstoća $2.5 \mathrm{MPa}$. Ispitana jednoosna tlačna čvrstoća ziđa iznosila je $2.18 \mathrm{MPa}$, vlačna čvrstoća savijanjem iznosila je 0.2 MPa, i ishodišni modul elastičnosti $1.02 \mathrm{GPa}$. Ispitivanje je vršeno u skladu s važećim propisima HRN EN 1052-1:2004 [117] i HRN EN 1052-3:2004 [118].

Ispitana jednoosna tlačna čvrstoća žbuke iznosila je $3 \mathrm{MPa}$, vlačna čvrstoća $1 \mathrm{MPa} \mathrm{i}$ ishodišni modul elastičnosti 3.5 GPa. Ispitivanje je vršeno u skladu s važećom normom HRN EN 1015-11:2000 [119].

Ispitana vlačna čvrstoća staklene mrežice iznosila je $42.8 \mathrm{MPa}, \mathrm{s}$ ishodišnim modulom elastičnosti $1.23 \mathrm{GPa}$. Ispitivanje je vršeno na uzorcima širine $50 \mathrm{~mm}$, prema HRN EN 13496:2004 [120]. Rezultat ispitivanja uzoraka staklene mrežice prikazan je na Slici 3.11.

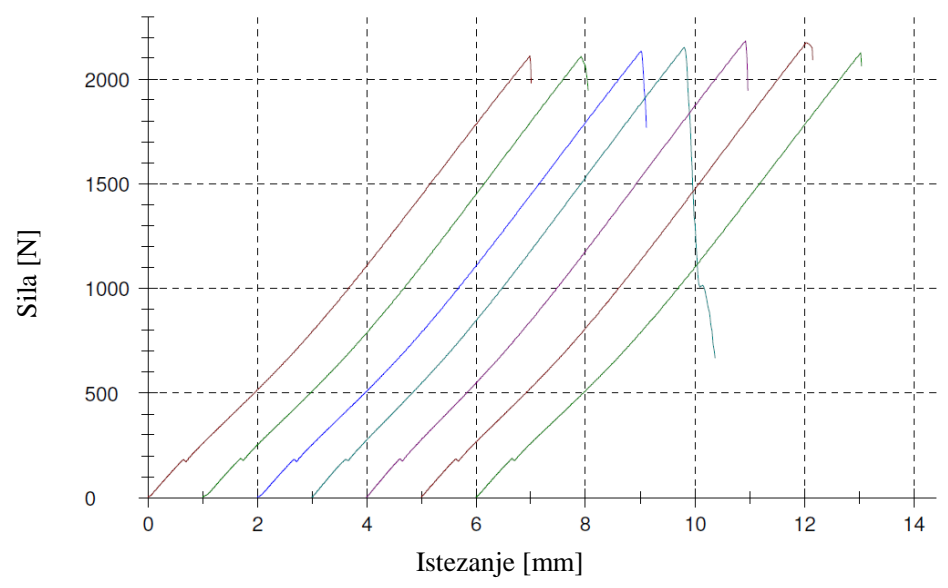

Slika 3.11. Rezultat ispitivanja uzoraka staklene mrežice

Čelični okviri izrađeni su od pravokutnih cijevi i lamela. Deklarirana čvrstoća čelika iznosila je $360 \mathrm{MPa}$, s ishodišnim modulom elastičnosti $200 \mathrm{GPa}$.

Za izradu betonskih okvira korišten je samozbijajući beton, maksimalnog zrna agregata $\mathrm{D}=8 \mathrm{~mm}$. Betonska mješavina sadrži $320 \mathrm{~kg}$ cementa, $150 \mathrm{~kg}$ punila od kamenog brašna, te 
sitnozrni i krupnozrni kameni agregat u omjeru 75:25\%. Vodocementni faktor iznosio je W/C $=0.60$, uz upotrebu superplastifikatora za visoku redukciju vode, poboljšanje obradljivosti i postizanje efekta samozbijanja betona. Ispitana tlačna čvrstoća betona iznosila je $50 \mathrm{MPa}$, vlačna čvrstoća $7 \mathrm{MPa}$ i ishodišni modul elastičnosti $36.1 \mathrm{GPa}$. Ispitivanje je vršeno u skladu s važećim propisima HRN EN 12390-3:2009 [121], HRN EN 12390-6:2010 [122] i HRN EN 12390-13:2013 [123].

Betonski okviri su armirani standardnim rebrastim betonskim čelikom kvalitete B500B. Granična vlačna čvrstoća čelika iznosi $653 \mathrm{MPa}$, a modul elastičnosti $205 \mathrm{GPa}$. Ispitivanje je rađeno prema HRN EN 10002-1 [124]. Veza naprezanje-deformacija utvrđena na uzorcima betona i armature prikazana je na Slici 3.12.

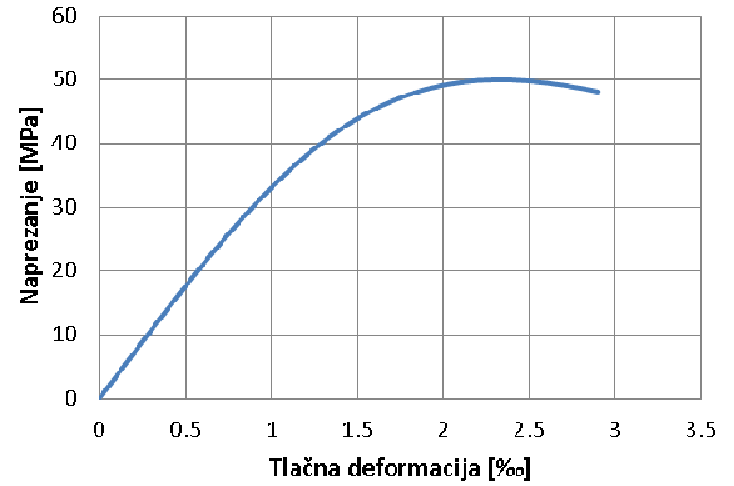

(i) Beton

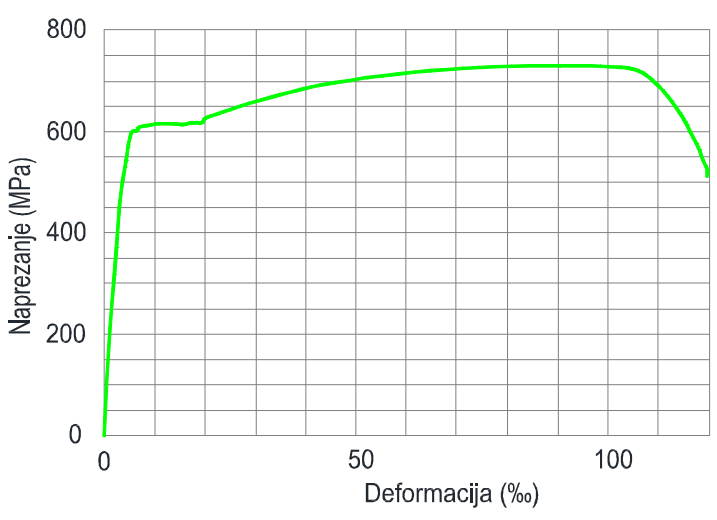

(ii) Armatura

Slika 3.12. Veza naprezanje-deformacija za beton i armaturu 


\subsection{Statička ispitivanja čeličnih okvira sa zidanom ispunom}

\subsubsection{Opis modela}

U ovom je potpoglavlju ispitivan utjecaj žbuke na ponašanje jednoetažnih jednopoljnih čeličnih okvira sa zidanom ispunom pod horizontalnim statičkim opterećenjem [125]. Osnovni geometrijski podaci o ispitanim okvirima dani su na Slici 3.13. Čelični okviri su visine $900 \mathrm{~mm}$, dužine $900 \mathrm{~mm}$, te debljine $80 \mathrm{~mm}$. Ispitani uzorci predstavljaju 1:3 umanjeni model realnog okvira. Uzorci su izrađeni od realnih materijala, s realnim načinom izvedbe.

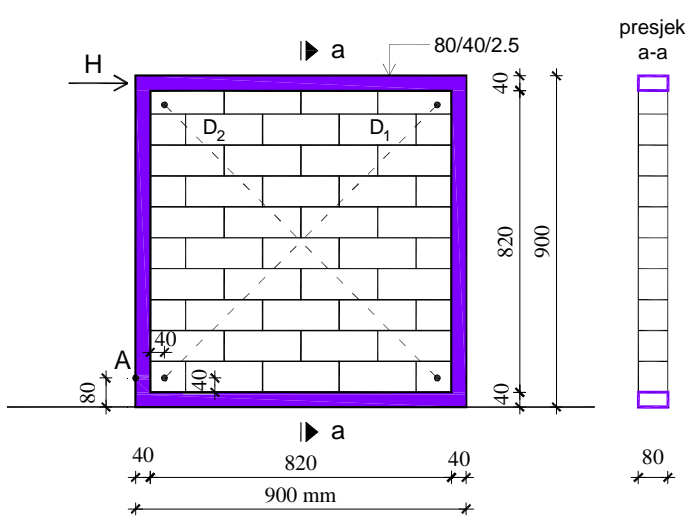

a) Kruti okvir (SF)

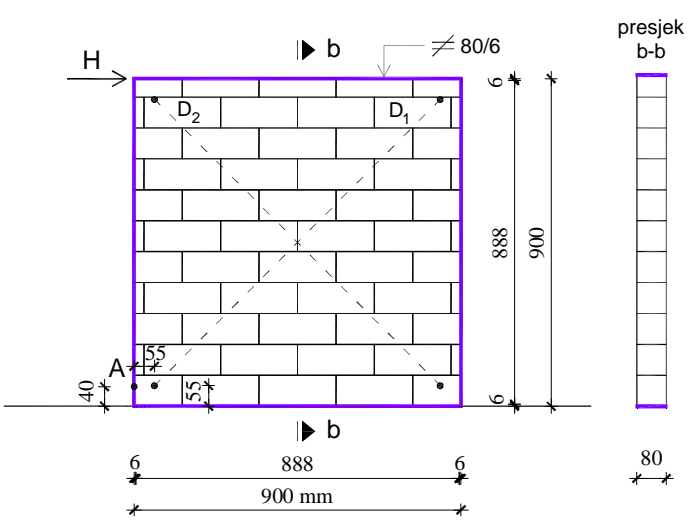

b) Meki okvir (WF)

Slika 3.13. Osnovni geometrijski podaci o ispitanim okvirima

Odvojeno su razmatrani okviri s većom i manjom savojnom krutosti, tj. kruti (SF) i meki (WF) okvir. Kruti okviri izrađeni su od pravokutne čelične cijevi $80 \times 40 \times 2.5 \mathrm{~mm}$, dok su meki okviri izrađeni od čelične lamele $80 \times 6 \mathrm{~mm}$. Pri tome treba napomenuti da je usvojena velika razlika u krutosti čeličnih okvira, koja u praksi nije uobičajena, kako bi utjecaj krutosti okvira pod horizontalnom statičkom silom bio izraženiji. Svi spojevi okvira su zavareni. Okviri su ukliješteni u krutu podlogu.

Svi okviri su ispunjeni ziđem od laganog porastog betona (gustoće oko $450 \mathrm{~kg} / \mathrm{m}^{3}$ ). Zidni elementi su također izrađeni u umanjenoj veličini (1:3). Zidanje je vršeno upotrebom bijelog tankoslojnog morta za zidove od porastog betona. Svaki tip okvira razmatran je s tri varijante ispune: (i) okvir s čistim ziđem (SF-1, WF-1), (ii) okvir s obostrano ožbukanim ziđem (SF-2, WF-2), te (iii) okvir s obostrano ožbukanim ziđem u kombinaciji sa staklenom mrežicom (SF-3, WF-3). Korištena je predgotovljena univerzalna mineralna žbuka. Žbuka je nanešena u sloju debljine $10 \mathrm{~mm}$ sa svake strane ziđa. Staklena mrežica je položena u žbuku u polovini debljine sloja. Nanešena je nešto veća debljina žbuke od one u praksi, kako bi utjecaj 
žbuke pod horizontalnim statičkim opterećenjem bio izraženiji. Okviri su bočno pridržani u razini grede okvira, kako bi se spriječilo bočno savijanje stupova okvira. Prikaz uzorka pripremljenog za ispitivanje dan je na Slici 3.14.

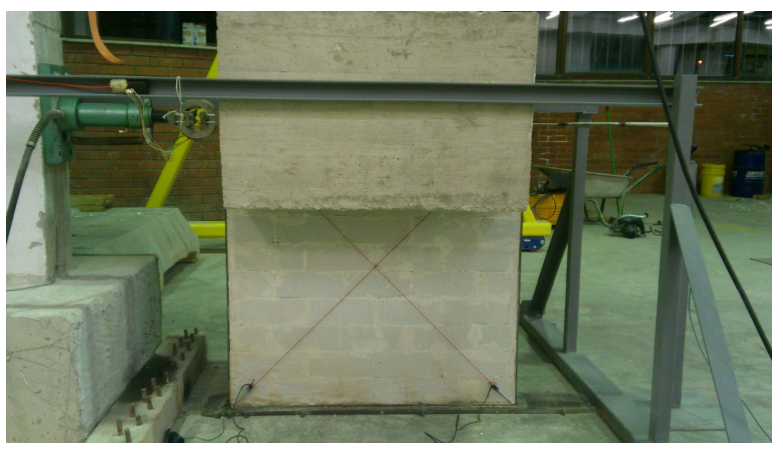

a) Prednji pogled

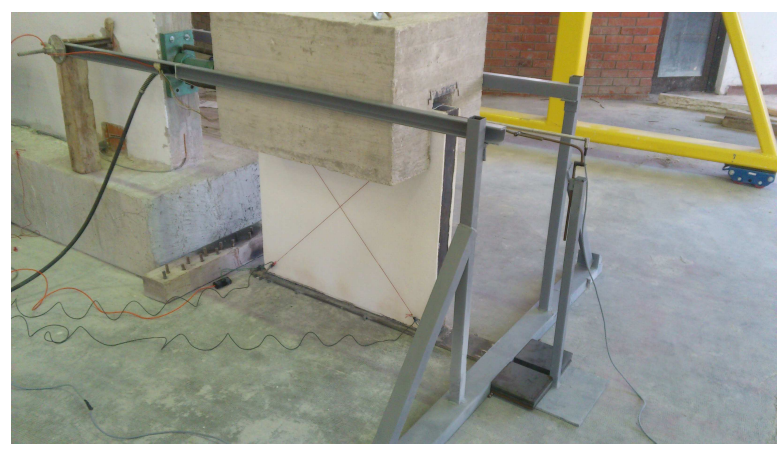

b) Bočni pogled

Slika 3.14. Prikaz uzoraka prije ispitivanja

Svi uzorci su bili opterećeni konstantnim vertikalnim opterećenjem iznosa $5 \mathrm{kN}$ po dužini grede okvira, te horizontalnom silom na vrhu okvira. Za simulaciju vertikalnog opterećenja korišten je betonski blok težine oko 500 kg, konstruiran tako da mu težišna linija prolazi sredinom gornje grede okvira. Horizontalna sila je sukcesivno povećavana do sloma konstrukcije. Pri tome su praćeni horizontalni pomak vrha okvira, deformacija čelika pri dnu stupa, prosječne deformacije ispune u smjeru dijagonala, te stanje pukotina u ispuni za svaki nanešeni inkrement sile.

\subsubsection{Rezultati ispitivanja}

Veza između horizontalne sile $(\mathrm{H})$ i horizontalnog pomaka vrha okvira (u) za kruti okvir (SF) prikazana je na Slici 3.15.a. Vidljivo je da žbuka značajno doprinosi povećanju krutosti, nosivosti i duktilnosti okvira. Naime, okvir SF-2 ima za oko 35\% veću nosivost od okvira SF1. Također je vidljivo da okviri SF-2 i SF-3 imaju podjednaku nosivost, odnosno da armatura u žbuci ne doprinosi značajno povećanju nosivosti ziđa. Ovo se objašnjava s relativno niskim postotkom armiranja žbuke sa staklenom mrežicom. Za očekivati je da bi armiranje žbuke mrežom s većim poprečnim presjekom staklenih niti značajno povećalo njenu učinkovitost. Ovaj se utjecaj nije ispitivao u ovom radu.

Veza između horizontalne sile $(\mathrm{H})$ i horizontalnog pomaka vrha okvira (u) za meki okvir (SF) prikazana je na Slici 3.15.b. Može se primijetiti da meki okvir pokazuje značajno 
manju krutost i nosivost u odnosu na kruti okvir. U odnosu na uzorak SF-1, uzorak WF-1 je preuzeo oko $60 \%$ manju horizontalnu silu H. Uzorak WF-2 ima $20 \%$ veću nosivost od uzorka WF-1, dok uzorak WF-3 ima 6\% veću nosivost od uzorka WF-2.

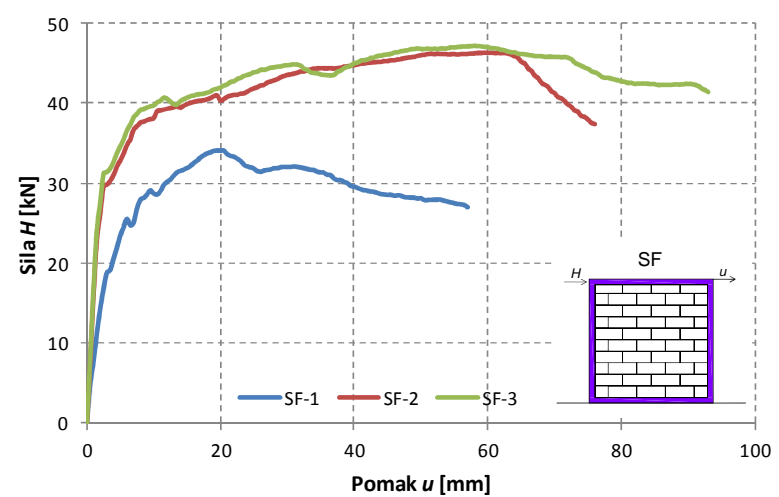

a) Kruti okvir (SF)

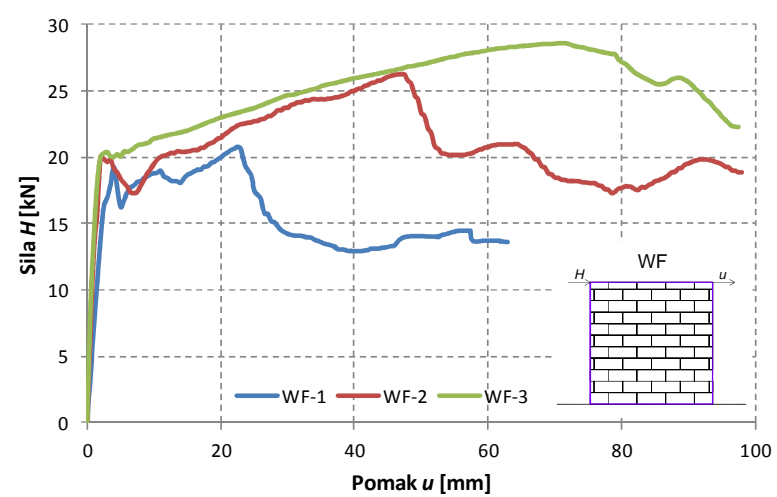

b) Meki okvir (WF)

Slika 3.15. Veza između horizontalne sile $(\mathrm{H})$ i horizontalnog pomaka vrha okvira (u)

Veza između horizontalne sile $(\mathrm{H})$ i vertikalne deformacije $\left(\varepsilon_{\mathrm{s}}\right)$ pri dnu čeličnog stupa $\mathrm{u}$ točki A krutog okvira prikazana je na Slici 3.16.a, a mekog okvira na Slici 3.16.b. Ovi su dijagrami kompatibilni s dijagramima na Slici 3.15.a i 3.15.b. Ovdje treba primijetiti da dolazi do odvajanja okvira i ispune, kao i lokalnog savijanja čeličnog stupa, posebno kod mekih okvira (WF). Iznad deformacije od oko $1.2 \%$, dolazi do tečenja čelika. U odnosu na meki okvir (WF), kruti okvir (SF) ima značajno veće deformacije čelika.

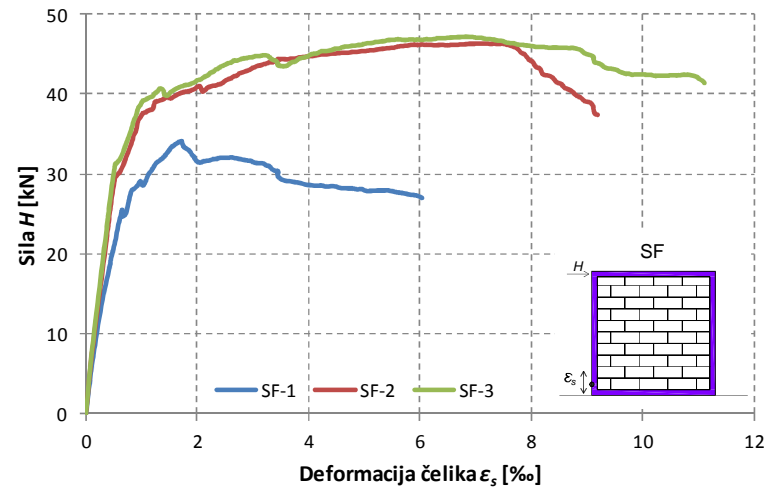

a) Kruti okvir (SF)

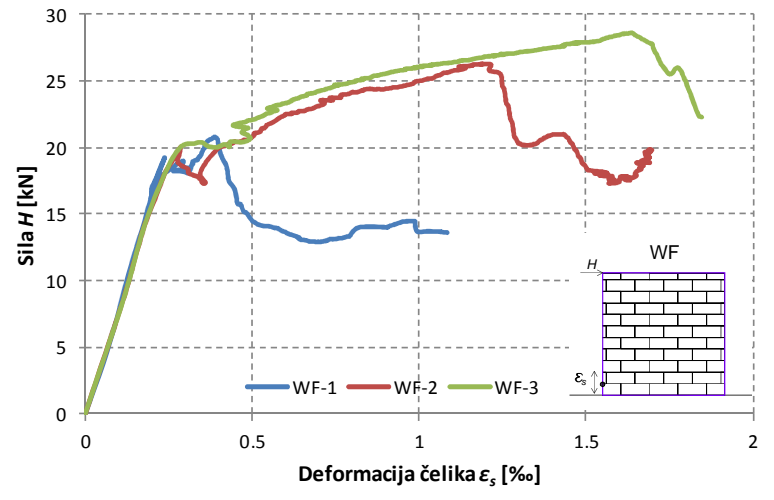

b) Meki okvir (WF)

Slika 3.16. Veza između horizontalne sile $(\mathrm{H})$ i vertikalne deformacije $\left(\varepsilon_{\mathrm{s}}\right)$ pri dnu čeličnog stupa u točki A

Ovisnost prosječne vlačne deformacije ziđa u dijagonali D1 $\left(\varepsilon_{\mathrm{m} 1}\right)$ o horizontalnoj sili (H) za kruti okvir (SF) prikazana je na Slici 3.17.a, a za meki okvir (WF) na Slici 3.17.b. Ovisnost prosječne tlačne deformacije ziđa u dijagonali D2 $\left(\varepsilon_{\mathrm{m} 2}\right)$ o horizontalnoj sili $(\mathrm{H}) \mathrm{za}$ 
kruti okvir (SF) prikazana je na Slici 3.18.a, a za meki okvir (WF) na Slici 3.18.b. Pri valorizaciji ovih rezultata treba imati na umu da su mjerne niti usidrene na krajevima u ziđe u smjeru dijagonala (ne u čelične prečke), te da se u ziđu javljaju široke pukotine i odvajanja ispune od okvira (vidi Sliku 3.19).

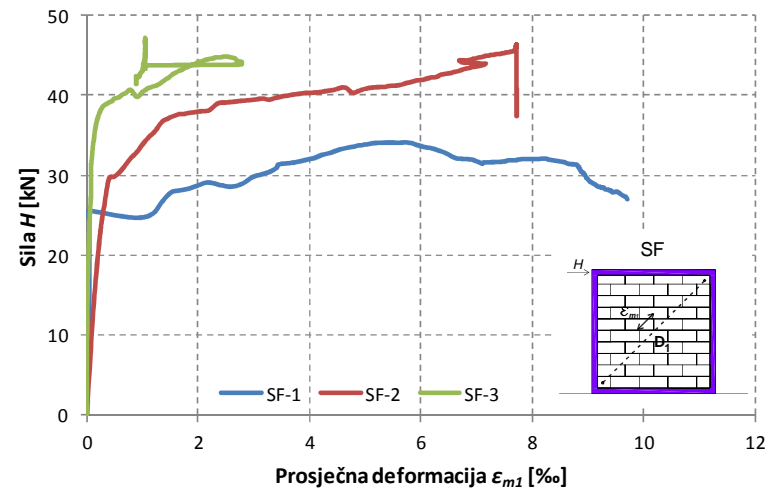

a) Kruti okvir (SF)

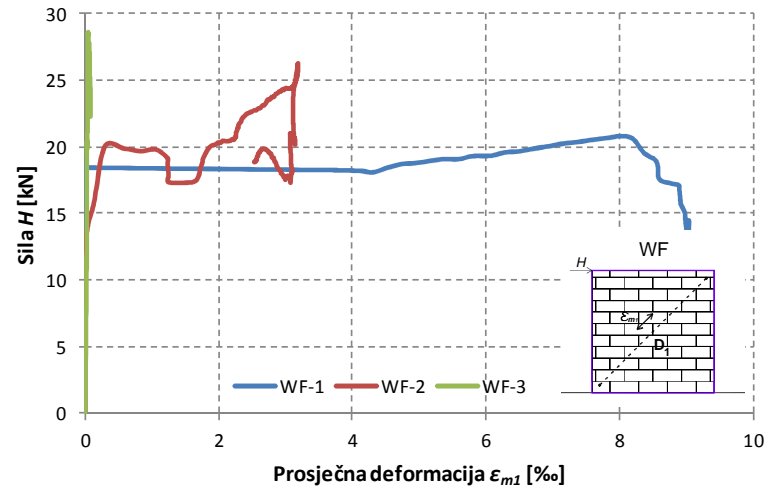

b) Meki okvir (WF)

Slika 3.17. Veza između horizontalne sile $(\mathrm{H})$ i prosječne vlačne deformacije ziđa u dijagonali D1 $\left(\varepsilon_{\mathrm{m} 1}\right)$

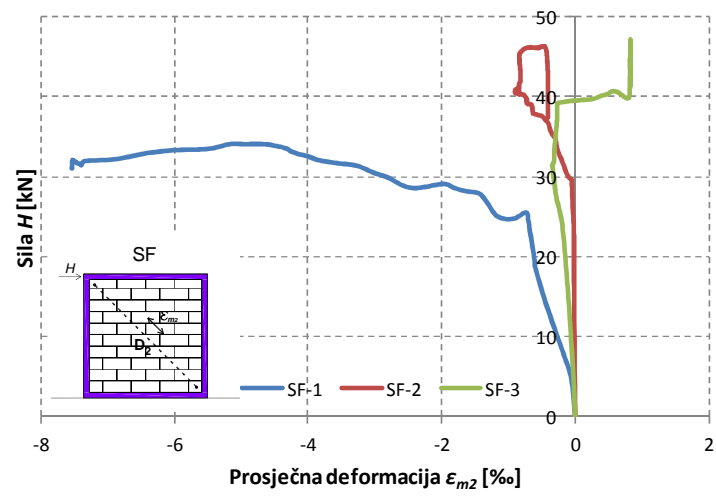

a) Kruti okvir (SF)

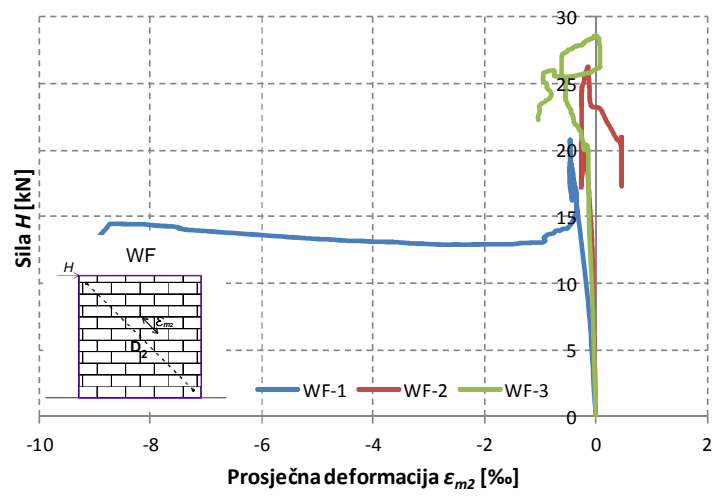

b) Meki okvir (WF)

Slika 3.18. Veza između horizontalne sile $(\mathrm{H})$ i prosječne tlačne deformacije ziđa u dijagonali D2 $\left(\varepsilon_{\mathrm{m} 2}\right)$

Konačno stanje deformacija okvira i ziđa nakon završetka eksperimenta, sa stanjem pukotina u ziđu, prikazano je na Slici 3.19. Može se primijetiti da žbuka smanjuje širinu zona pukotina u ispuni, tj. doprinosi duktilnosti ispune. $\mathrm{U}$ odnosu na kruti okvir (SF), kod mekog okvira (WF) došlo je do značajnog odvajanja okvira i ziđa već pri niskim razinama horizontalne sile $\mathrm{H}$. Pukotine u ziđu se pojavljuju približno okomito na smjer vlačne dijagonale D1. U svim okvirima došlo je do drobljenja ziđa u uglovima tlačne dijagonale D2. 
Kod mekih okvira (WF) došlo je do značajnog lokalnog deformiranja čelične lamele i ziđa na mjestu djelovanja horizontalne sile $\mathrm{H}$.

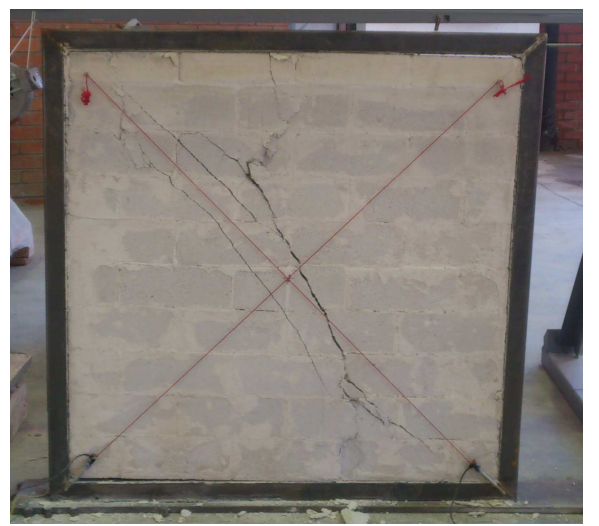

SF-1

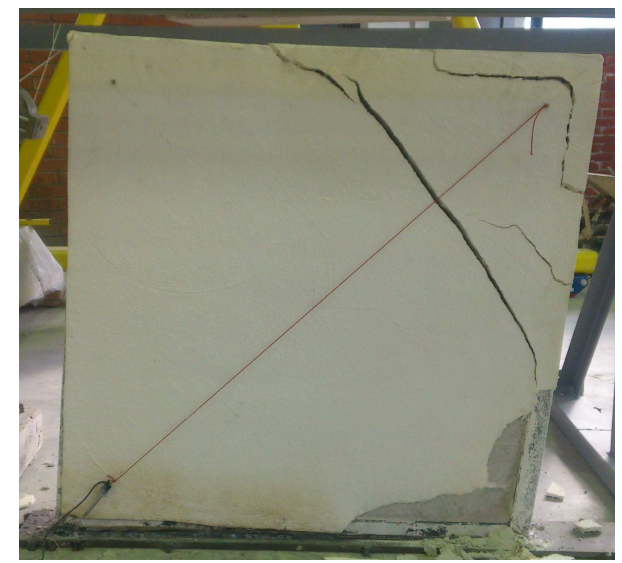

SF-2

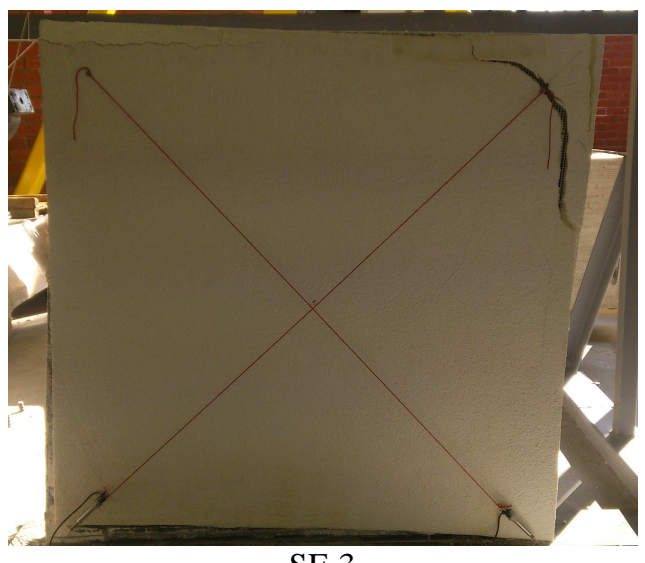

SF-3

a) Kruti okvir (SF)

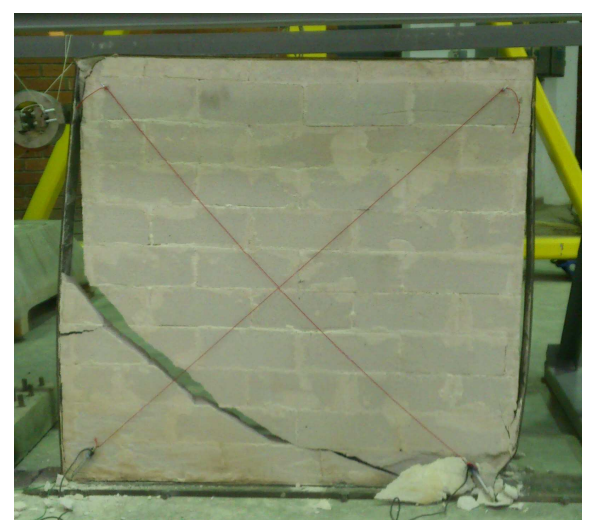

WF-1

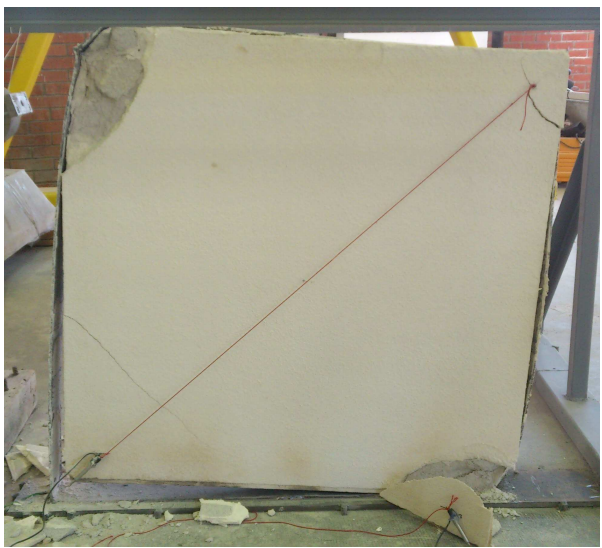

WF-2

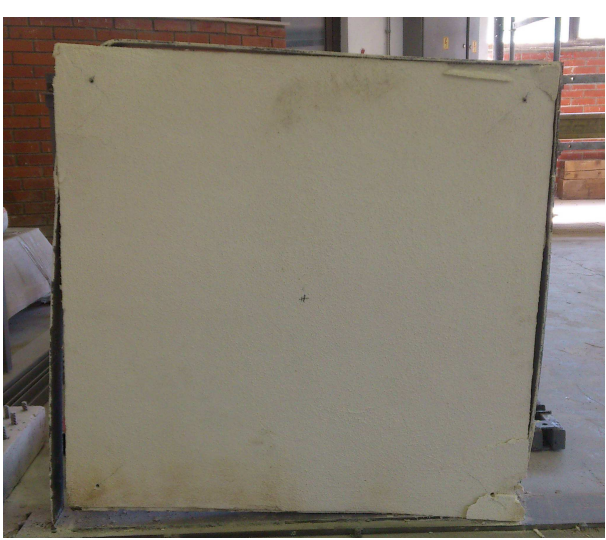

WF-3

b) Meki okvir (WF)

Slika 3.19. Konačno stanje deformacija i pukotina u ziđu za sve uzorke nakon završetka ispitivanja 


\subsection{Dinamička ispitivanja čeličnih okvira sa zidanom ispunom}

\subsubsection{Opis modela}

U ovom je potpoglavlju ispitivan utjecaj žbuke na ponašanje jednoetažnih jednopoljnih čeličnih okvira sa zidanom ispunom na potresnoj platformi [126]. Čelični okviri istovjetni su onima kod statičkog testa (opisano u Točki 3.3.). Osnovni geometrijski podaci o ispitanim okvirima dani su na Slici 3.20.

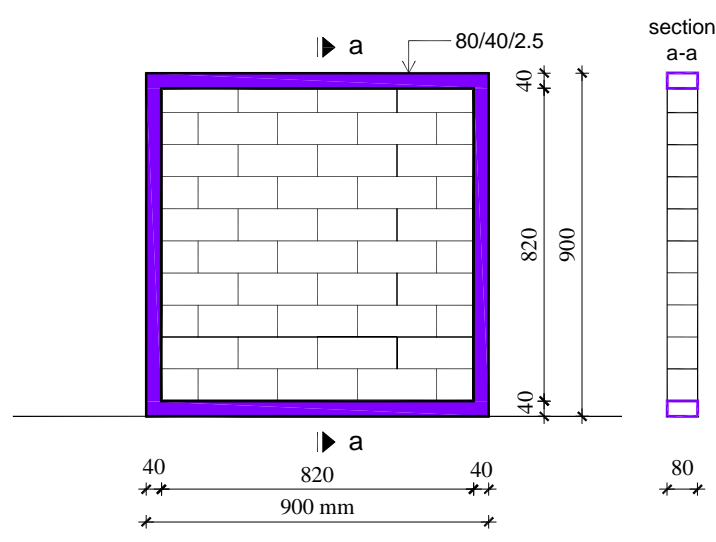

a) Kruti okvir (SF)

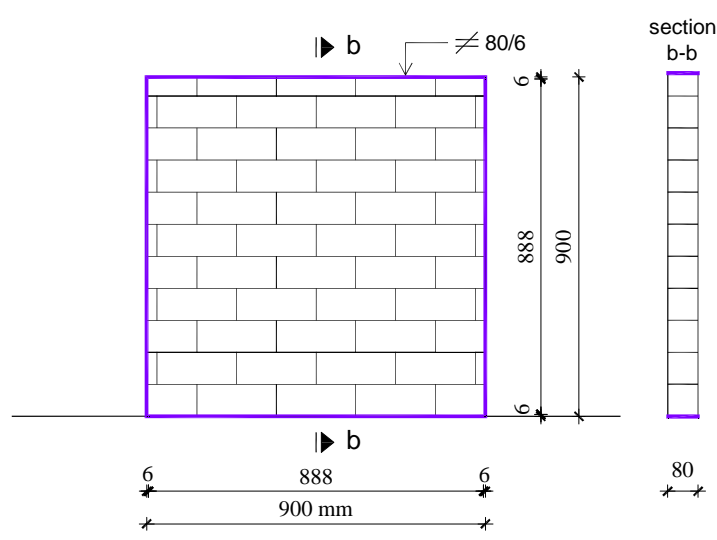

b) Meki okvir (WF)

Slika 3.20. Osnovni geometrijski podaci o ispitanim okvirima

Dakle, odvojeno su razmatrani okviri s većom i manjom savojnom krutosti, tj. kruti (SF) i meki (WF) okvir. Svaki tip okvira razmatran je s tri varijante ispune: (i) okvir s čistim ziđem (SF-1, WF-1), (ii) okvir s obostrano ožbukanim ziđem (SF-2, WF-2), te (iii) okvir s obostrano ožbukanim ziđem u kombinaciji sa staklenom mrežicom (SF-3, WF-3). Okviri su ukliješteni u krutu podlogu (platformu).

Svi uzorci su bili opterećeni konstantnim vertikalnim opterećenjem iznosa $30 \mathrm{kN}$ po dužini grede okvira, te izloženi djelovanju gibanja podloge. Za simulaciju vertikalnog opterećenja korišten je betonski blok dimenzija $1.0 \times 1.0 \times 1.2 \mathrm{~m}$ i mase $3000 \mathrm{~kg}$. Blok je sa svojom donjom stranom zavaren na ispitni uzorak. Okviri su bočno pridržani kako bi se spriječilo bočno izvijanje stupova okvira, te kako ne bi došlo do potencijalnog udara bloka i oštećenja platforme uslijed otkazivanja nosivosti uzorka. Fotografija pripremljenog ispitnog uzorka na platformi prikazana je na Slici 3.21. 


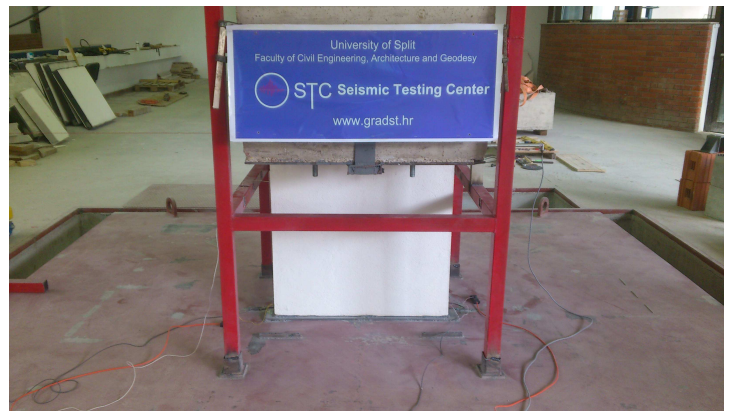

a) Prednji pogled

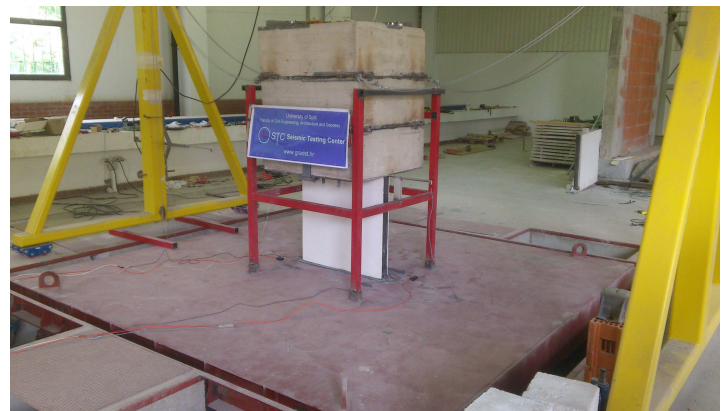

b) Bočni pogled

Slika 3.21. Prikaz uzoraka prije ispitivanja na potresnom stolu

Okviri su najprije izloženi djelovanju umjetnog akcelerograma AA1, opisanog u Točki 3.3. Pomoću ovog akcelerograma proizvedeno je ukupno 8 pobuda, kojima su amplitude ubrzanja postupno povećavane za 0.1 g. Dakle, svi uzorci su izloženi nizu pobuda sa sukcesivnim povećanjem maksimalnog ubrzanja $\mathrm{a}_{\mathrm{g}, \max }=\mathrm{n} \times 0.1 \mathrm{~g} ; \mathrm{n}=1-8$. Nakon toga, svi uzorci su izloženi djelovanju akcelerograma potresa Petrovac, opisanog u Točki 3.3. Kod toga je originalni zapis potresa također skaliran kako bi maksimalne vrijednosti ubrzanja bile $a_{\mathrm{g}, \max }$ $=\mathrm{n} \times 0.1 \mathrm{~g} ; \mathrm{n}=1,2,3$ i 4.5 .

Za svaku apliciranu dinamičku pobudu praćeni su: horizontalni pomak vrha okvira, deformacija čelika pri dnu stupa s vanjskih strana okvira, prosječne deformacije ispune $u$ smjeru dijagonala, te stanje pukotina $u$ ispuni tijekom vremena (vidi Sliku 3.22).
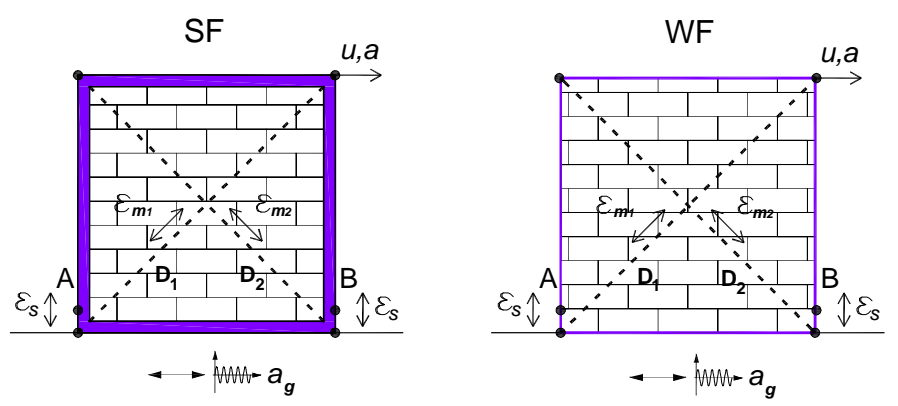
u horizontalni pomak a horizontalno ubrzanje $\varepsilon_{\mathrm{s}} \quad$ deformacija čelika $\varepsilon_{\mathrm{m} 1}, \varepsilon_{\mathrm{m} 2} \quad$ prosječne deformacije ziđa $\mathrm{a}_{\mathrm{g}} \quad$ ubrzanje podloge (platforme)

Slika 3.22. Mjerene veličine na uzorcima 


\subsubsection{Rezultati ispitivanja}

U nastavku su odvojeno prikazani rezultati za umjetni akcelerogram i potres Petrovac. Istovremeno su prikazani rezultati za kruti i meki okvir, kao i za sve tri varijante ispune. Pri valorizaciji ovih rezultata treba imati na umu da je kod nekih uzoraka došlo do trajnih (nepovratnih) pomaka i deformacija uslijed djelovanja prethodno apliciranih pobuda.

\subsubsection{Rezultati za umjetni akcelerogram AA1}

Horizontalni pomaci vrha okvira u vremenu za umjetne akcelerograme prikazani su na Slikama 3.23 i 3.24. Može se primijetiti da kruti okvir ima značajno manje pomake u odnosu na meki okvir. Najveći pomak krutog okvira pri djelovanju umjetnog akcelerograma $\mathrm{s} \mathrm{a}_{\mathrm{g}, \max }=$ $0.8 \mathrm{~g}$ iznosio je $2.6 \mathrm{~mm}$, te mekog okvira $5 \mathrm{~mm}$. Ovo rezultira povoljnijim naponskodeformacijskim stanjem ispune kod krutih okvira nego kod mekih okvira.

U obje varijante krutosti okvira, očit je utjecaj tipa ispune (krutosti ispune) na veličinu pomaka. Najveće pomake imao je čisti okvir. Okvir s nearmiranom žbukom i okvir s armiranom žbukom imali su slične pomake. Naime, veći pomaci kod okvira WF-2 kvare prethodne zaključke. Njegovi veći pomaci su najvjerojatnije rezultat defekata nastalih tijekom zidanja ili u zavarenim spojevima okvira, ili zbog efekta lokalnog savijanja tankih čeličnih stupova. Kod svih ispitanih uzoraka, odvajanje ispune od stupova i greda okvira nastupilo je prije djelovanja posljednjeg umjetnog akcelerograma. Zbog nemogućnosti prijenosa vlačnih i posmičnih naprezanja na spoju okvir-ispuna, ispuna se ponašala kao tlačni štap (u smjeru dijagonala D1 i D2 naizmjenično). Promjenom smjera gibanja, tj. prelaskom vlačnog štapa u tlačni, došlo je do udara okvira $u$ ispunu zbog nastalog razmaka između njih tijekom prethodnog gibanja u suprotnom smjeru. Ovaj fenomen nije bio izražen kod krutih okvira, ali je bio očit kod mekih okvira. Tijekom djelovanja umjetnog potresa, oblik deformiranog okvira vizualno je odgovarao zrcalnom romboidu s promjenjivim dijagonalama.

Deformacije u čeliku pri dnu stupa u točki A (lijevo) prikazane su na Slikama 3.25 i 3.26, a u točki B (desno) na Slikama 3.27 i 3.28. Kruti okvir je imao najveće tlačne deformacije od $-0.55 \%$ o. Obzirom da deformacija tečenja čelika iznosi oko $\pm 1.2 \%$, očito je da su deformacije u čeliku bile u elastičnom području. Za sve tipove ispune (krutosti ispune), deformacije su podjednake, tj. krutost ispune unutar krutog okvira nema značajnog utjecaja. Meki okvir je imao daleko veće deformacije, do oko $\pm 1.6 \%$. Ovo upućuje na pojavu 
nelinearnosti u stupu. Utjecaj krutosti ispune je značajniji kod mekih okvira nego kod krutih okvira. Kod toga, najveće deformacije je imao okvir s najmekšom ispunom (WF-1), a najmanje okvir s najkrućom ispunom (WF-3). Značajne trajne deformacije su nastale u stupu okvira WF-3, a posebno kod okvira WF-2. Kod mekih okvira vjerojatno je prisutan utjecaj lokalnog savijanja stupa zbog njegovog odvajanja od ispune.

Prosječne deformacije u smjeru dijagonala D1 i D2, uvjetno nazvane prosječne deformacije ziđa, prikazane su na Slikama 3.29-3.32. Pri valorizaciji ovih rezultata treba imati na umu da pri pojavi vlaka u smjeru dijagonale dolazi do odvajanja ispune od spoja stupa i grede. Stoga, izmjerene vlačne deformacije ziđa također sadrže nastali razmak. Stvarne vlačne deformacije u ziđu su značajno manje od prikazanih na Slikama 3.29-3.32. Izuzevši okvire SF-1 i WF-1, pukotine u ziđu se nisu pojavile kod umjetnih akcelerograma, već samo odvajanje ispune od okvira (gotovo na svim kontaktnim zonama). Velike deformacije kod okvira WF-2 mogu se objasniti analogno njegovim pomacima. Velike tlačne deformacije štapa su rezultirale oštećenjem ispune u kutovima, pogotovo kod mekih okvira. Treba naglasiti da je ziđe sačinjeno od zidnih elemenata relativno niske čvrstoće. Tip ispune ima mali utjecaj na veličine deformacija u smjeru dijagonala.

Horizontalna ubrzanja pri vrhu okvira u vremenu za umjetni akcelerogram su prikazana na Slikama 3.33-3.34. Prosječne vrijednosti su nešto veće kod krutih okvira, ako se isključe ekstremne vrijednosti kod mekih okvira. Ovi ekstremi su rezultat udara između okvira i ispune kada vrh okvira mijenja smjer gibanja, tj. kada vlačni štap postaje tlačni i obratno.

Usporedbom vrijednosti pomaka na Slikama 3.23 i 3.24, može se primijetiti da povećanjem maksimalnog ubrzanja $a_{\mathrm{g}, \text { max }}$ dolazi do povećanja pomaka vrha okvira. Utjecaj krutosti okvira je također primjetan, pogotovo za meke okvire. Kruća ispuna rezultira manjim pomacima okvira (objašnjenje za WF-2 je dano prethodno). Naime, okviri s ožbukanim ziđem imaju manje pomake u odnosu na okvire s čistim (neožbukanim) ziđem. Korištena staklena mrežica u žbuci je imala vrlo malen utjecaj na vrijednosti pomaka okvira. Usporedbom vrijednosti deformacija čelika na Slikama 3.25-3.28, može se primijetiti da povećanjem maksimalnog ubrzanja $a_{g, m a x}$ dolazi do povećanja deformacija čelika pri dnu stupa. Ovaj efekt je najočitiji za meke okvire WF-1 i WF-2 pri djelovanju pobuda s najvećim ubrzanjima. Povećanjem krutosti ispune, deformacije čelika pri dnu stupova mekih okvira se smanjuju. Ovaj efekt je zanemariv kod krutih okvira. 

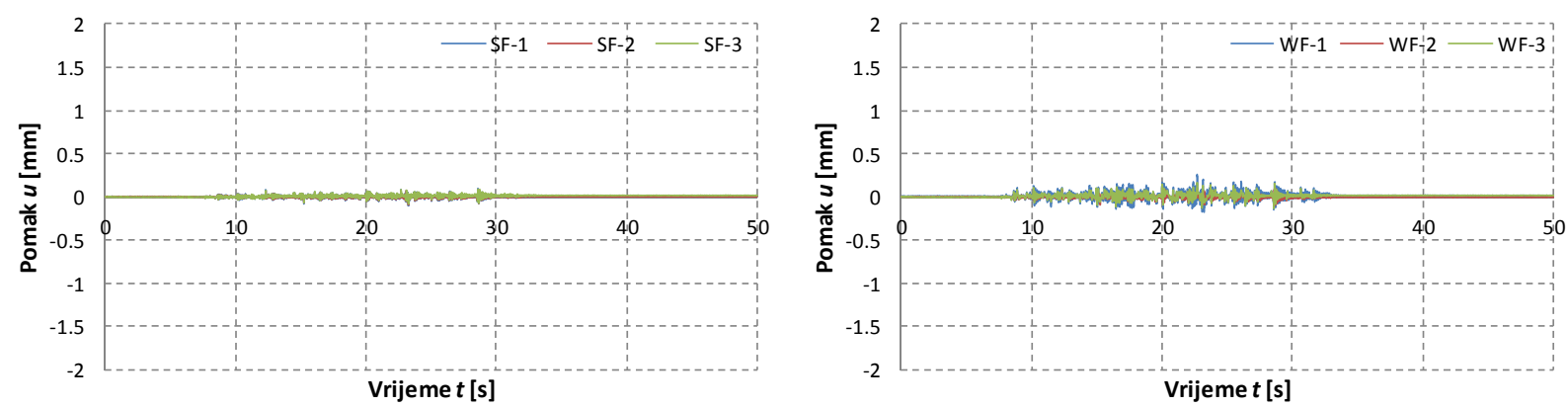

a) $\mathrm{a}_{\mathrm{g}, \max }=0.1 \mathrm{~g}$
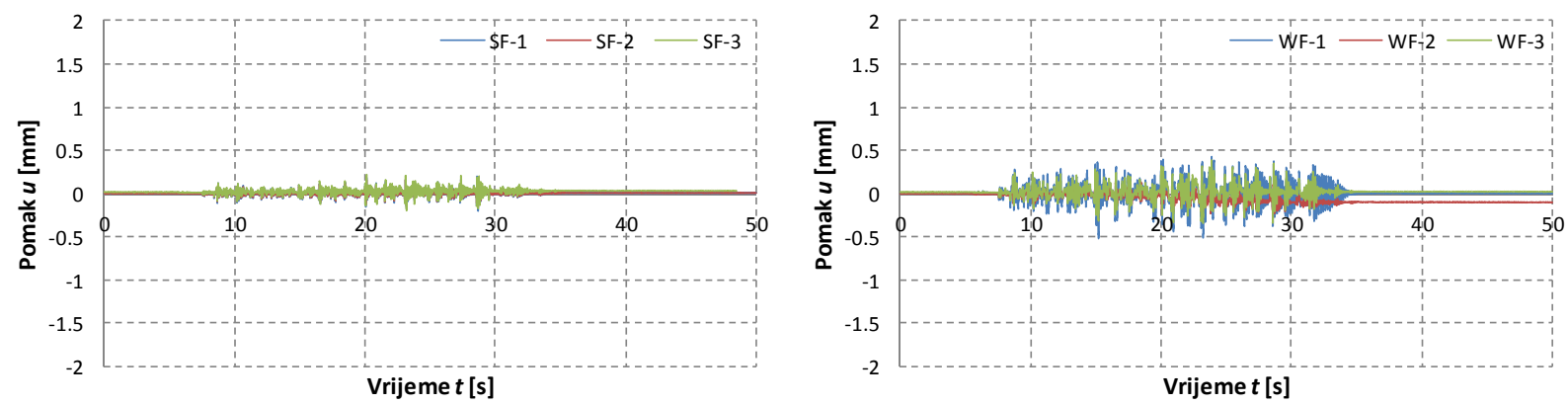

b) $\mathrm{a}_{\mathrm{g}, \max }=0.2 \mathrm{~g}$
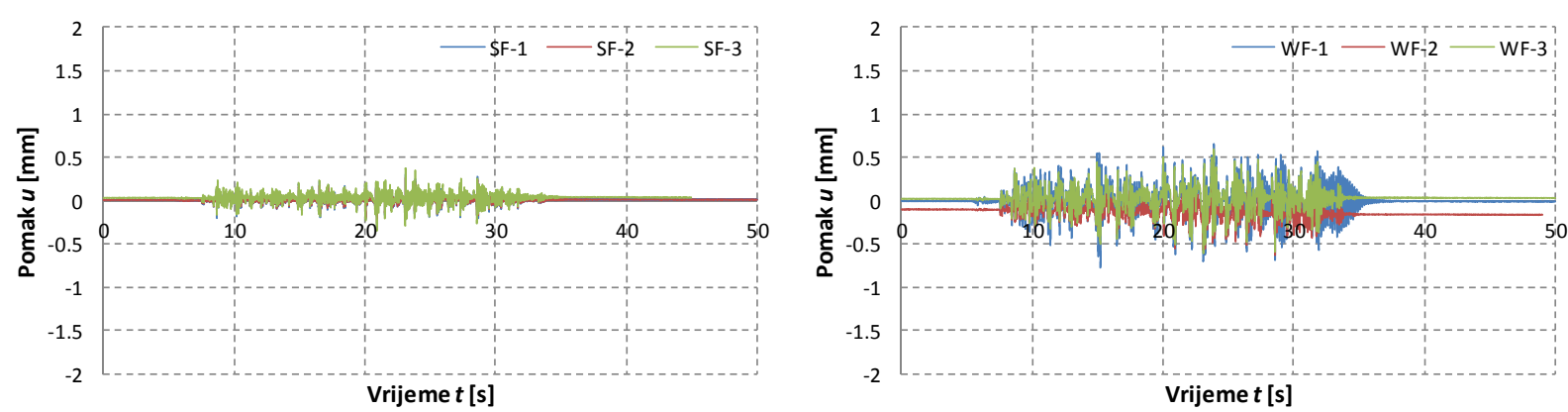

c) $\mathrm{a}_{\mathrm{g}, \max }=0.3 \mathrm{~g}$
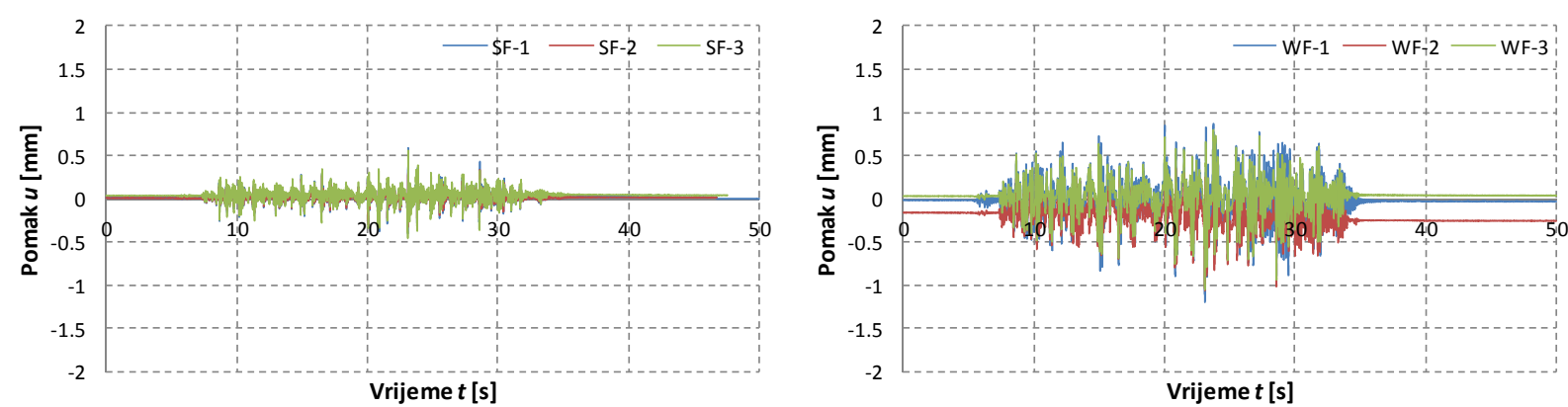

d) $\mathrm{a}_{\mathrm{g}, \max }=0.4 \mathrm{~g}$

Slika 3.23. Pomak vrha okvira $(u)$ u vremenu za umjetni akcelerogram AA1 s maksimalnim ubrzanjem $\mathrm{a}_{\mathrm{g}, \max }=0.1,0.2,0.3$ i $0.4 \mathrm{~g}$ 

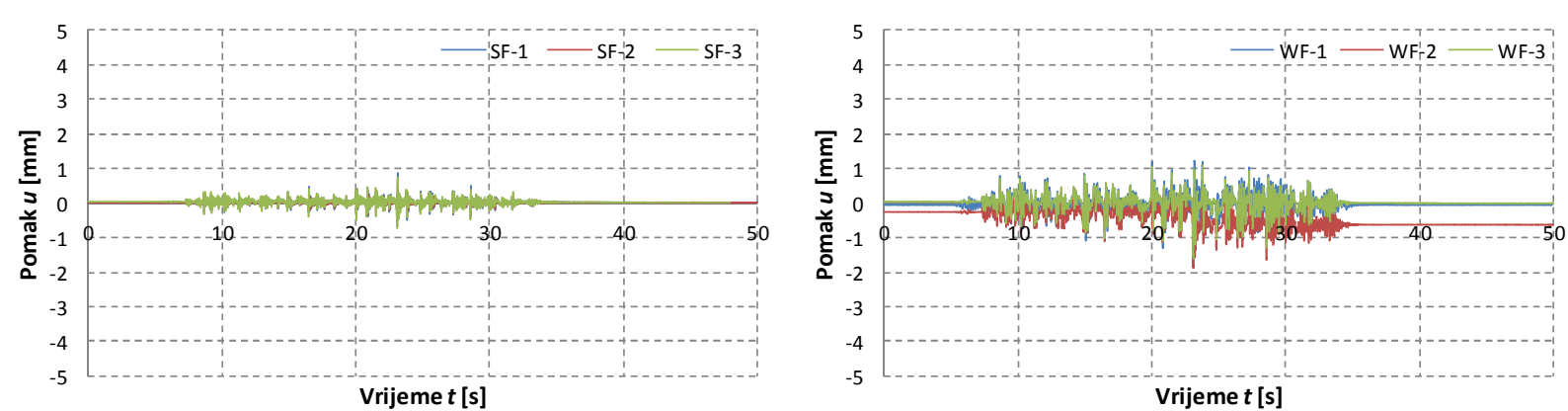

a) $\mathrm{a}_{\mathrm{g}, \max }=0.5 \mathrm{~g}$
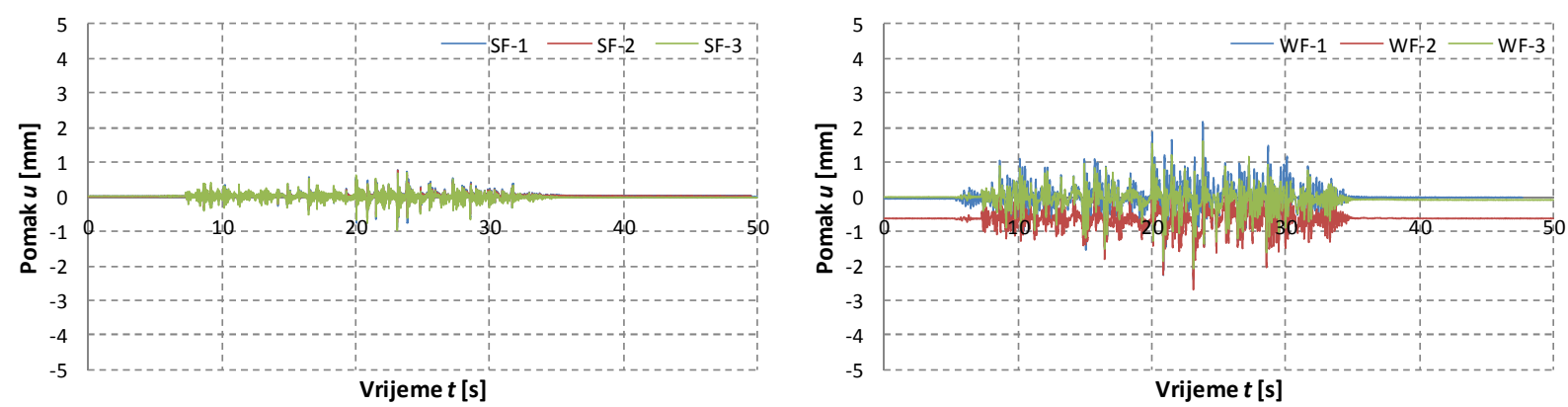

b) $\mathrm{a}_{\mathrm{g}, \max }=0.6 \mathrm{~g}$
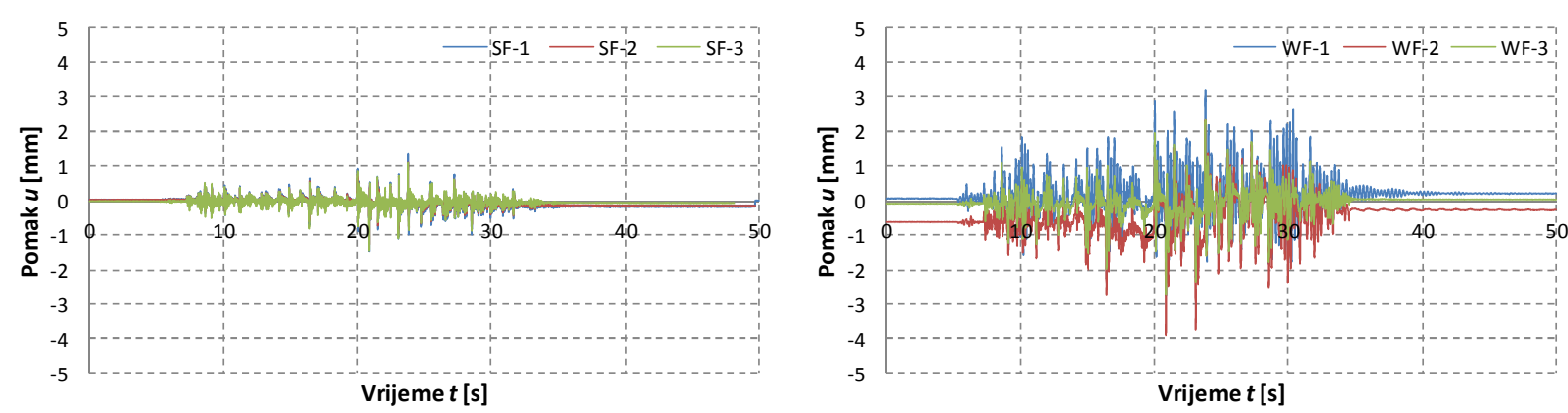

c) $\mathrm{a}_{\mathrm{g}, \max }=0.7 \mathrm{~g}$
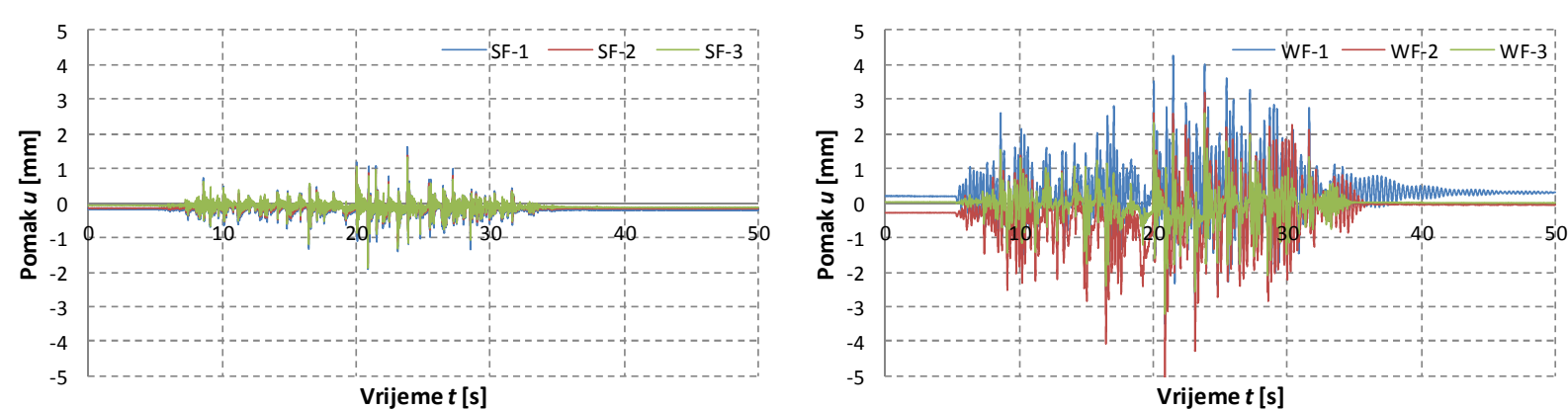

d) $\mathrm{a}_{\mathrm{g}, \max }=0.8 \mathrm{~g}$

Slika 3.24. Pomak vrha okvira $(u)$ u vremenu za umjetni akcelerogram AA1 s maksimalnim ubrzanjem $\mathrm{a}_{\mathrm{g}, \max }=0.5,0.6,0.7 \mathrm{i} 0.8 \mathrm{~g}$ 

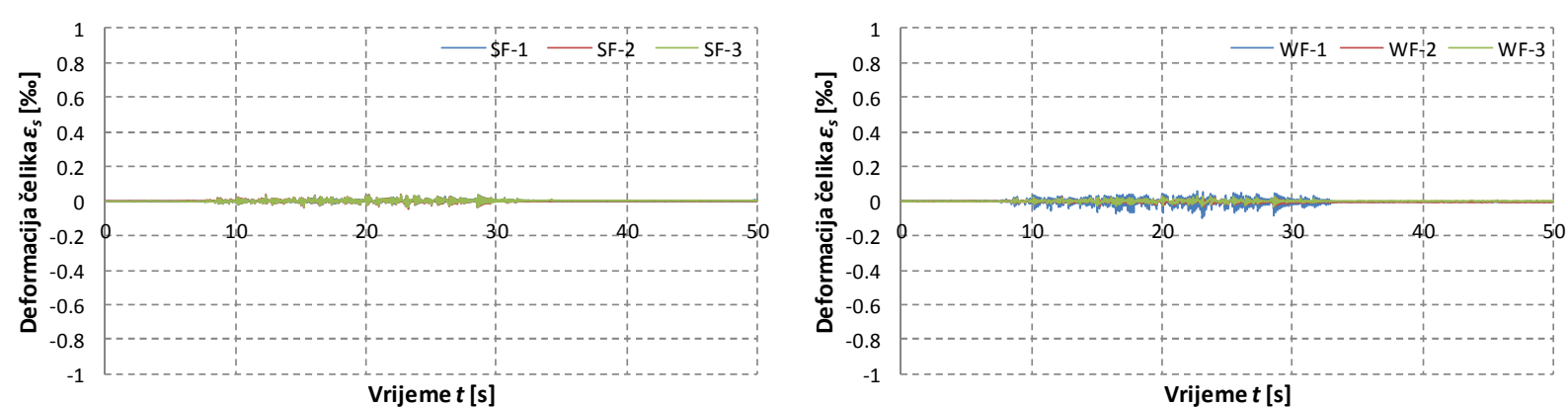

a) $\mathrm{a}_{\mathrm{g}, \max }=0.1 \mathrm{~g}$
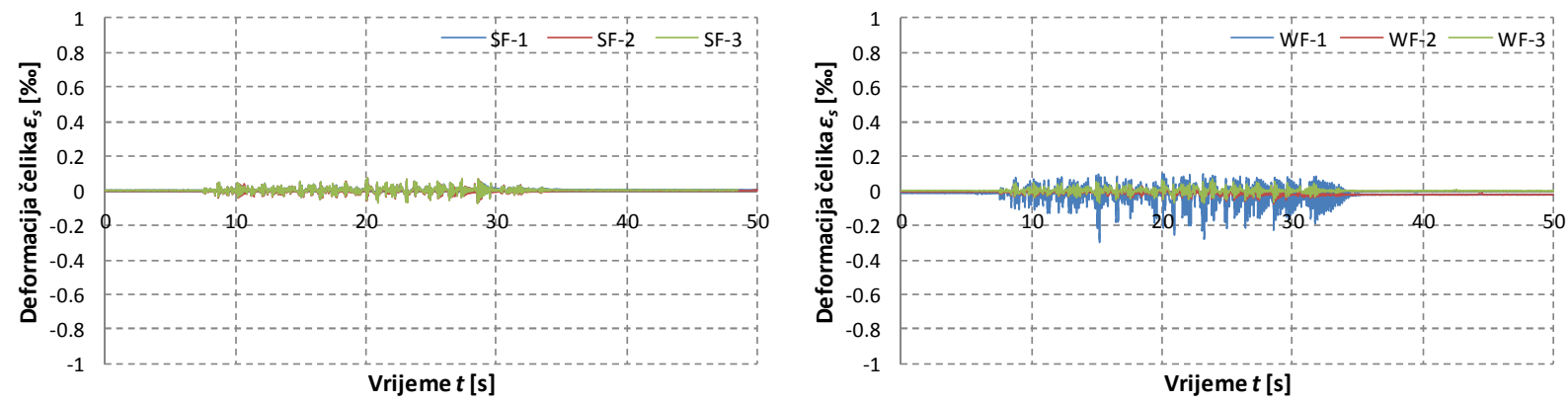

b) $\mathrm{a}_{\mathrm{g}, \max }=0.2 \mathrm{~g}$
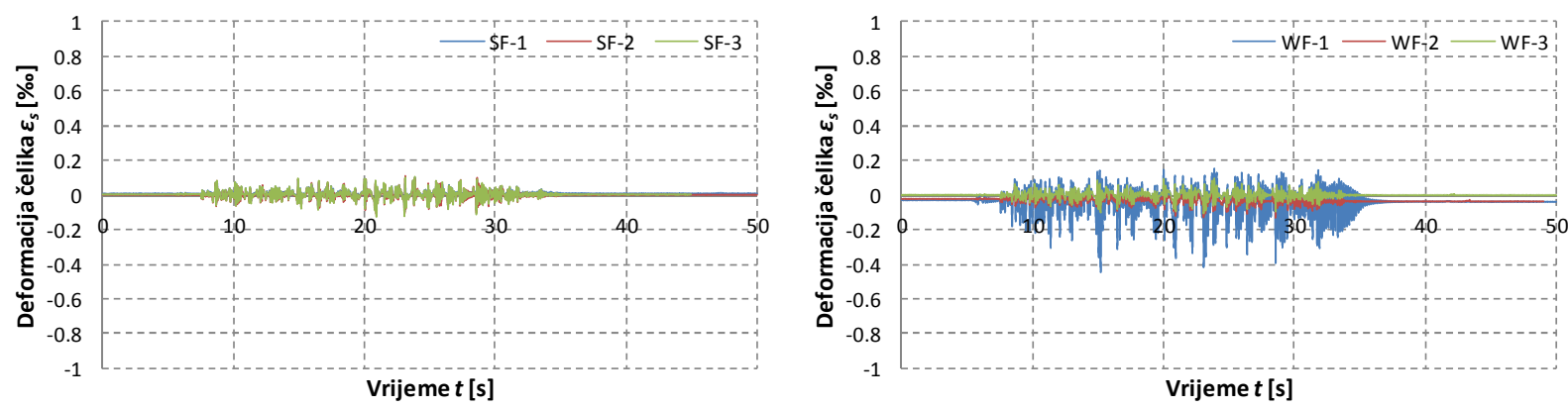

c) $\mathrm{a}_{\mathrm{g}, \max }=0.3 \mathrm{~g}$
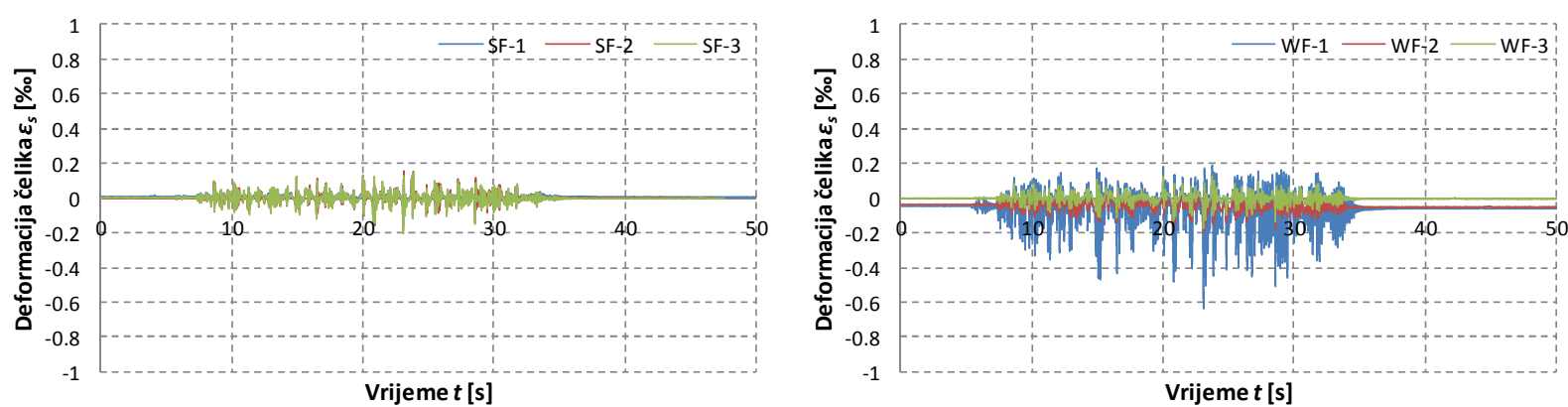

d) $\mathrm{a}_{\mathrm{g}, \max }=0.4 \mathrm{~g}$

Slika 3.25. Deformacija čelika pri dnu stupa u točki A $\left(\varepsilon_{\mathrm{s}}\right)$ u vremenu za umjetni akcelerogram AA1 s maksimalnim ubrzanjem $\mathrm{a}_{\mathrm{g}, \max }=0.1,0.2,0.3 \mathrm{i} 0.4 \mathrm{~g}$ 

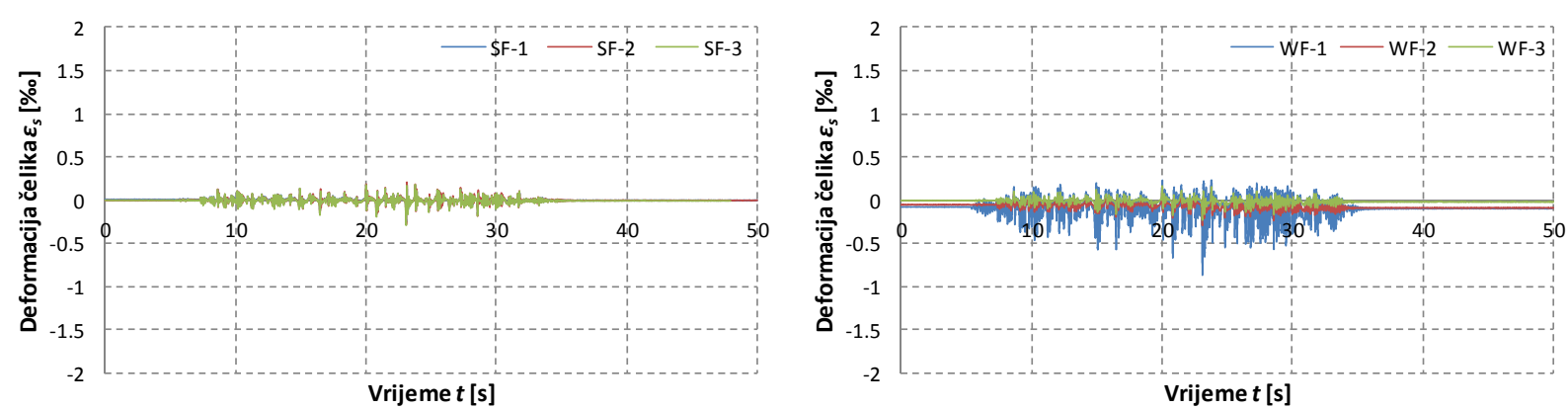

a) $\mathrm{a}_{\mathrm{g}, \max }=0.5 \mathrm{~g}$
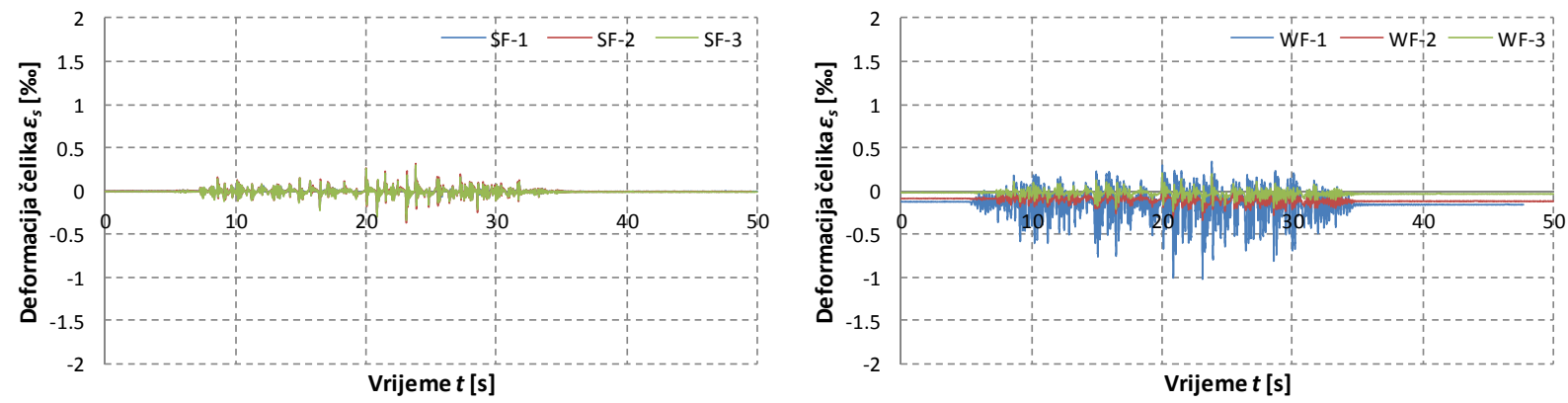

b) $\mathrm{a}_{\mathrm{g}, \max }=0.6 \mathrm{~g}$
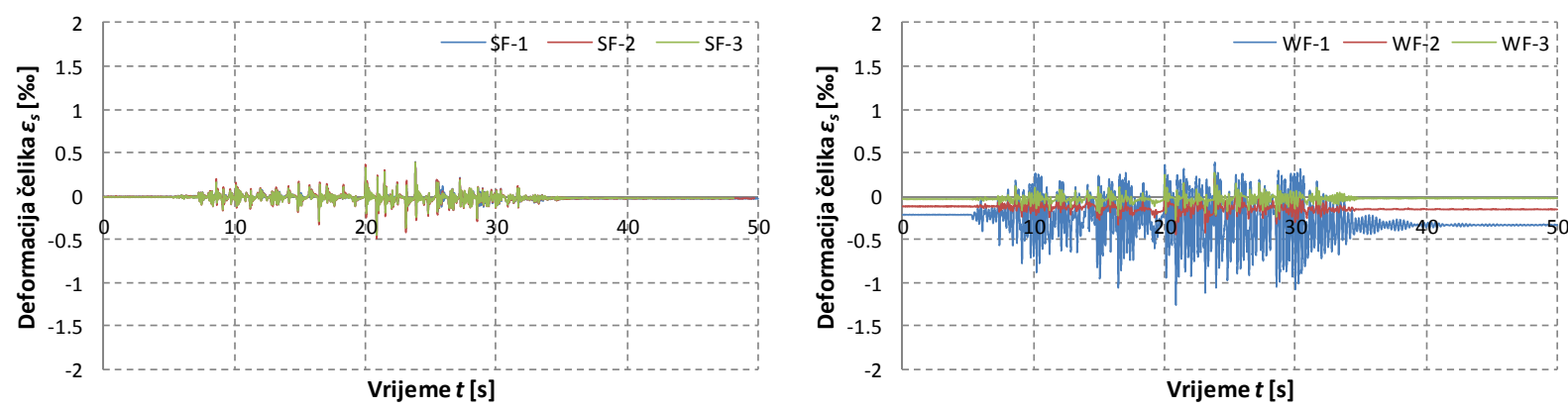

c) $\mathrm{a}_{\mathrm{g}, \max }=0.7 \mathrm{~g}$
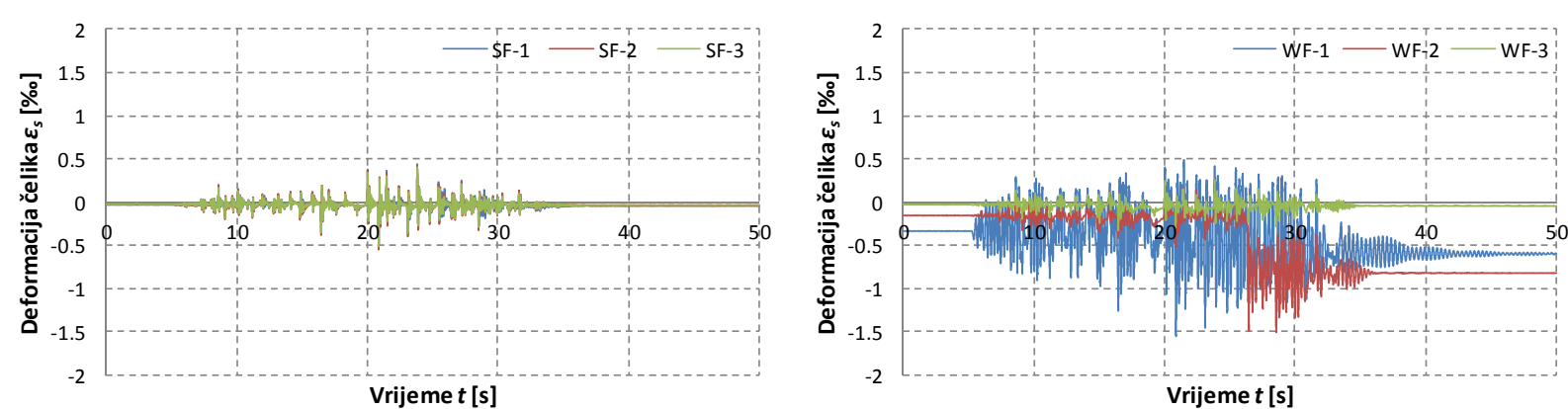

d) $\mathrm{a}_{\mathrm{g}, \max }=0.8 \mathrm{~g}$

Slika 3.26. Deformacija čelika pri dnu stupa u točki A $\left(\varepsilon_{\mathrm{s}}\right)$ u vremenu za umjetni akcelerogram AA1 s maksimalnim ubrzanjem $\mathrm{a}_{\mathrm{g}, \max }=0.5,0.6,0.7 \mathrm{i} 0.8 \mathrm{~g}$ 

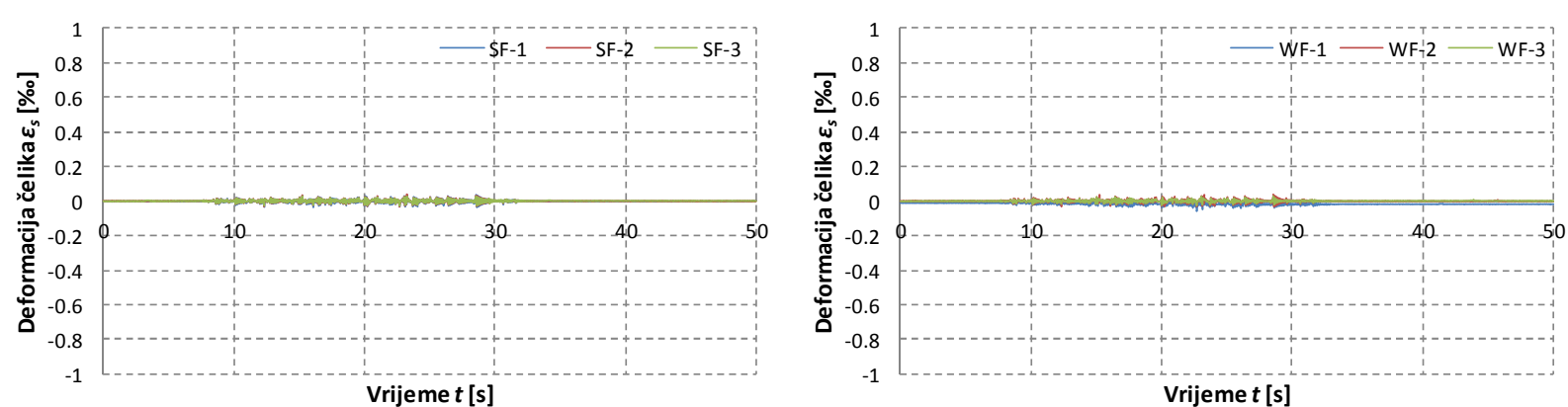

a) $\mathrm{a}_{\mathrm{g}, \max }=0.1 \mathrm{~g}$
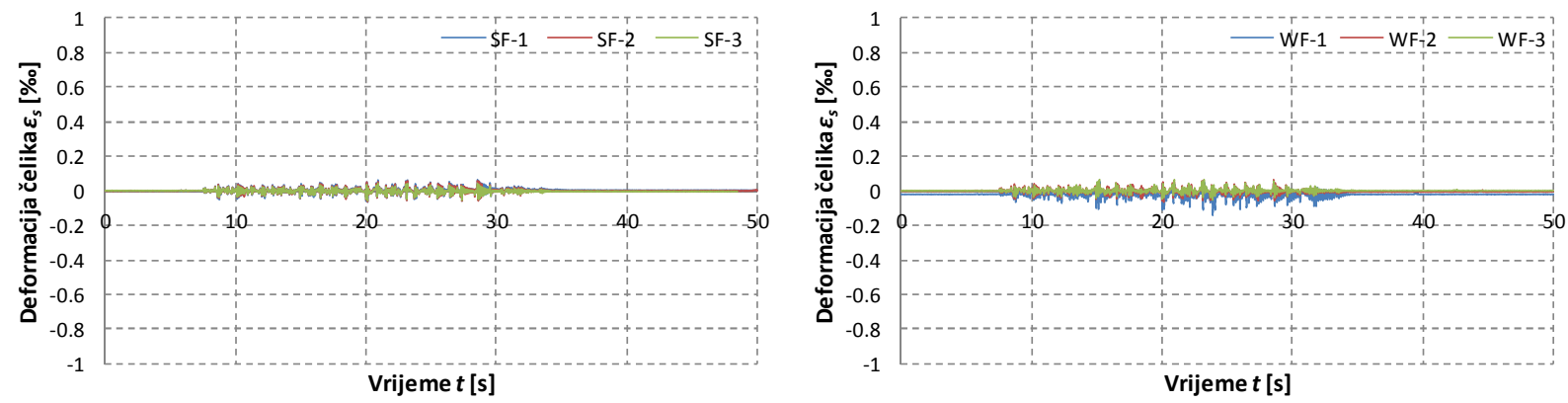

b) $\mathrm{a}_{\mathrm{g}, \max }=0.2 \mathrm{~g}$
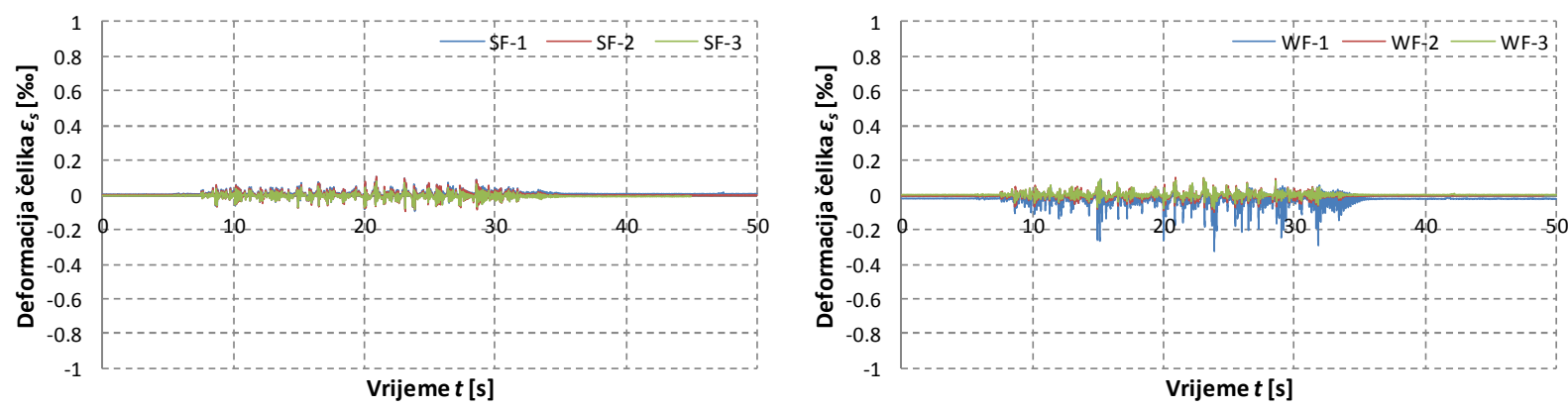

c) $\mathrm{a}_{\mathrm{g}, \max }=0.3 \mathrm{~g}$
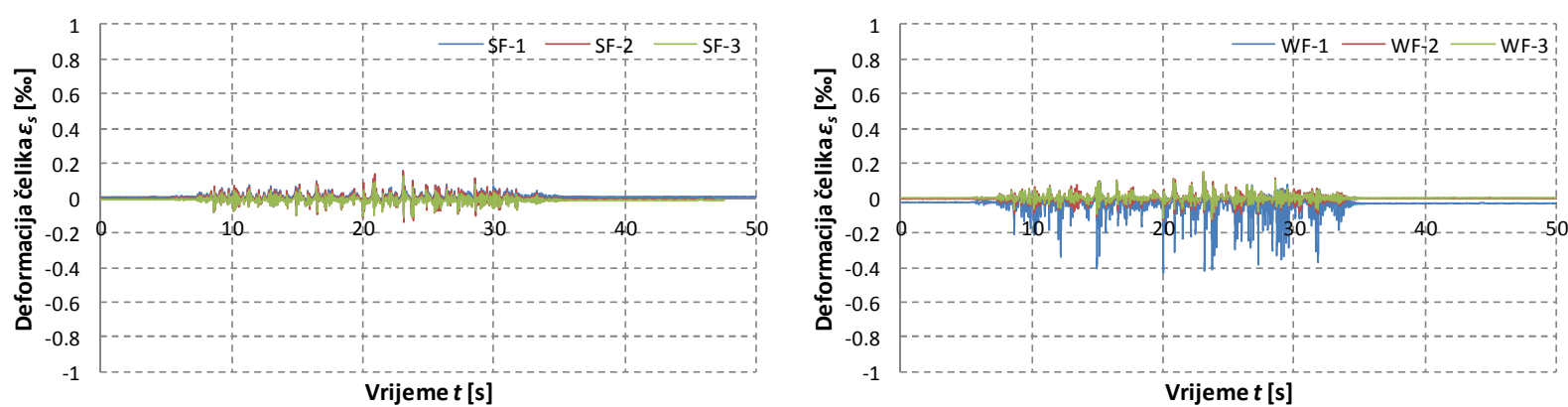

d) $\mathrm{a}_{\mathrm{g}, \max }=0.4 \mathrm{~g}$

Slika 3.27. Deformacija čelika pri dnu stupa u točki B $\left(\varepsilon_{\mathrm{s}}\right)$ u vremenu za umjetni akcelerogram AA1 s maksimalnim ubrzanjem $\mathrm{a}_{\mathrm{g}, \max }=0.1,0.2,0.3 \mathrm{i} 0.4 \mathrm{~g}$ 

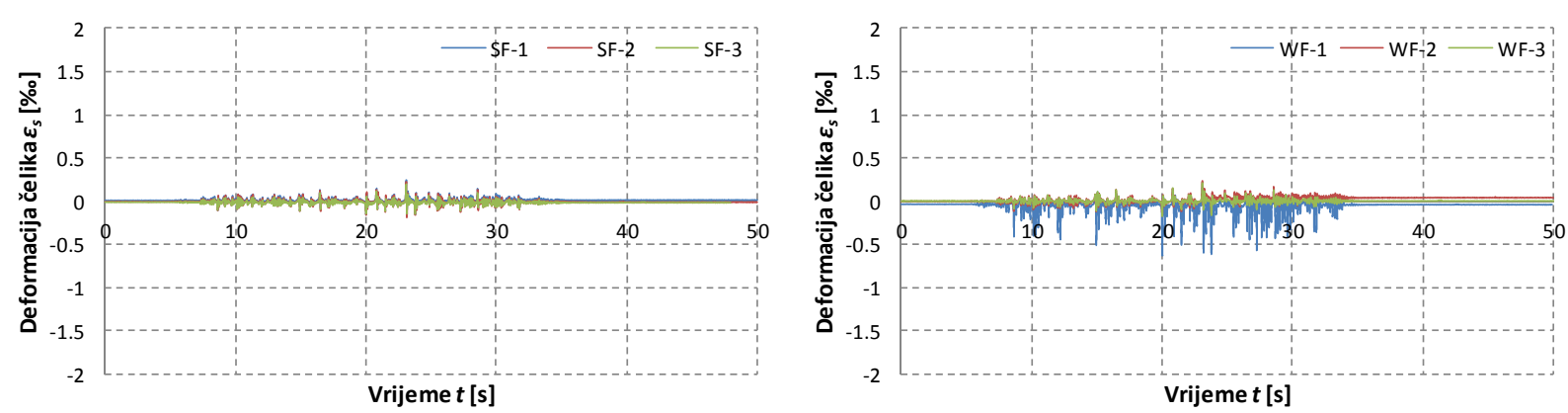

a) $\mathrm{a}_{\mathrm{g}, \max }=0.5 \mathrm{~g}$
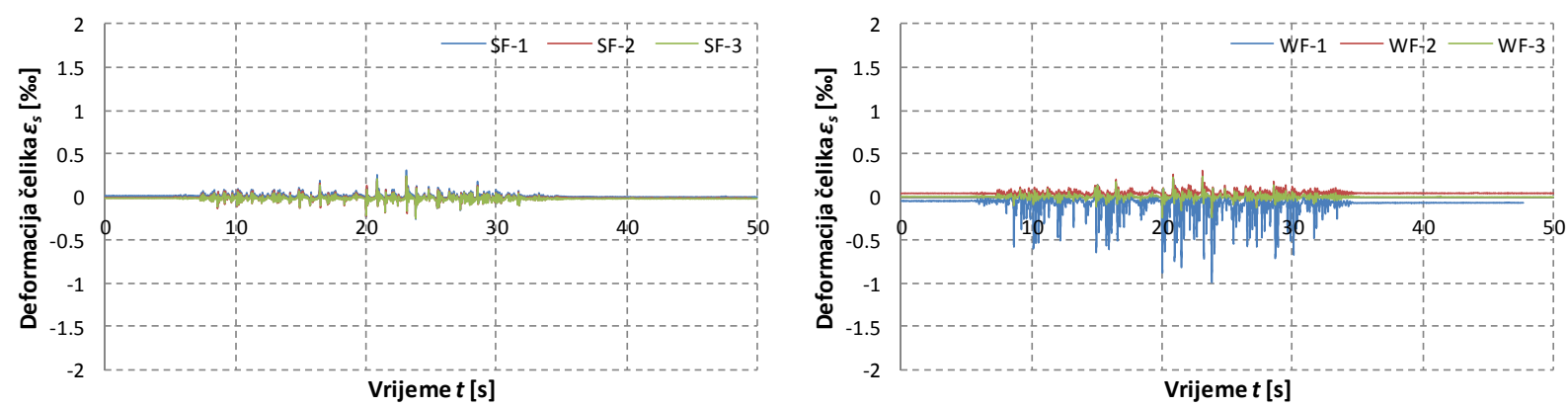

b) $\mathrm{a}_{\mathrm{g}, \max }=0.6 \mathrm{~g}$
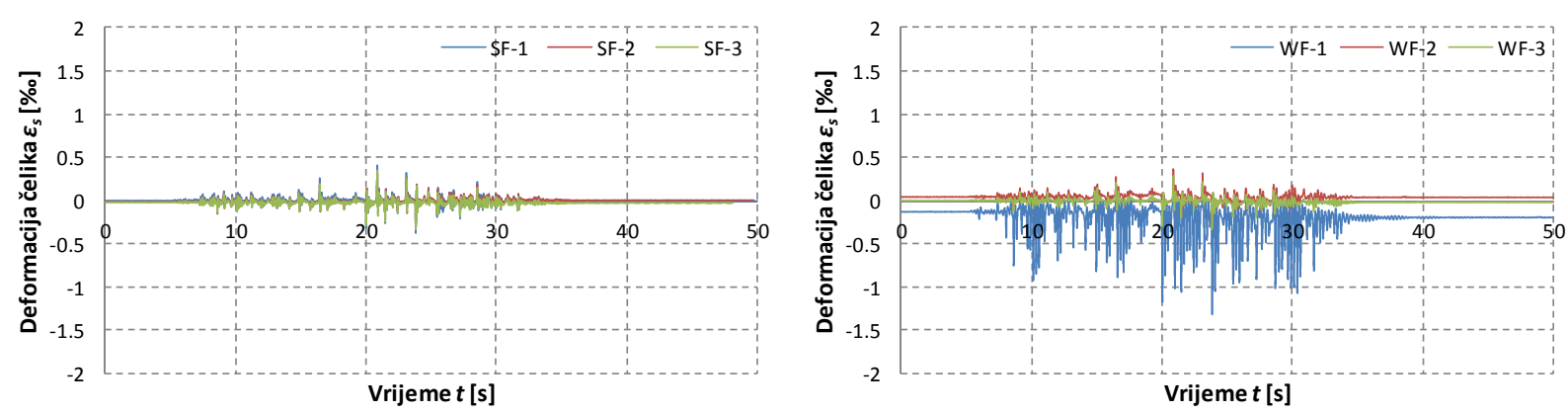

c) $\mathrm{a}_{\mathrm{g}, \max }=0.7 \mathrm{~g}$
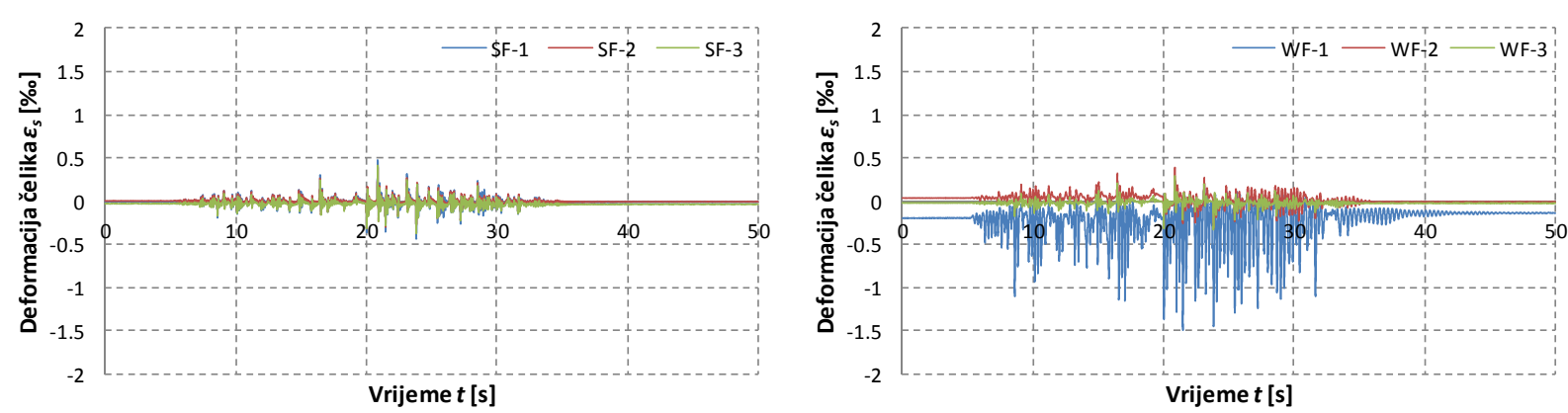

d) $\mathrm{a}_{\mathrm{g}, \max }=0.8 \mathrm{~g}$

Slika 3.28. Deformacija čelika pri dnu stupa u točki B $\left(\varepsilon_{\mathrm{s}}\right)$ u vremenu za umjetni akcelerogram AA1 s maksimalnim ubrzanjem $\mathrm{a}_{\mathrm{g}, \max }=0.5,0.6,0.7 \mathrm{i} 0.8 \mathrm{~g}$ 

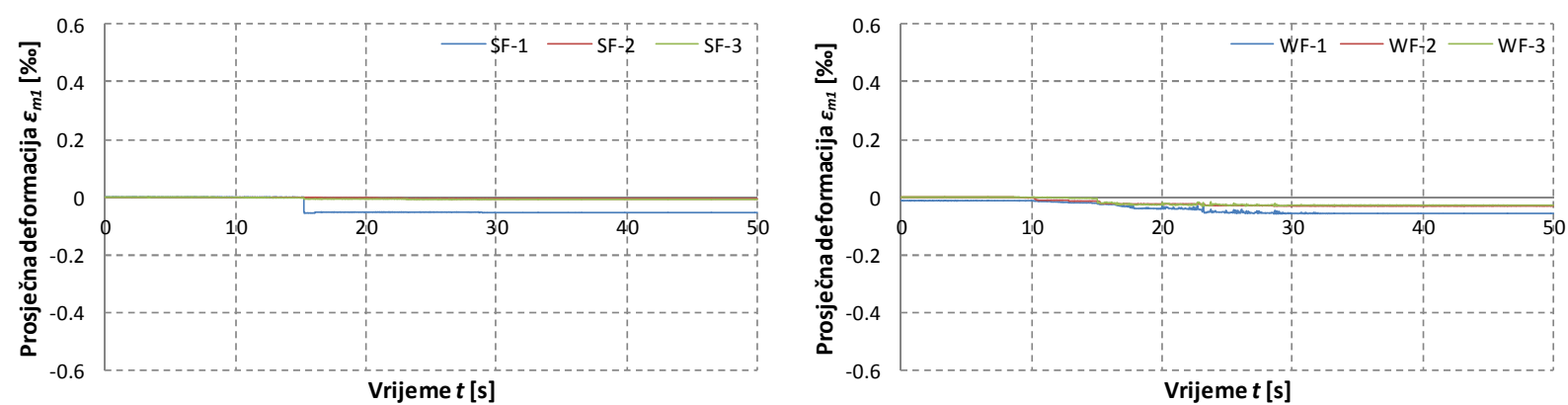

a) $\mathrm{a}_{\mathrm{g}, \max }=0.1 \mathrm{~g}$
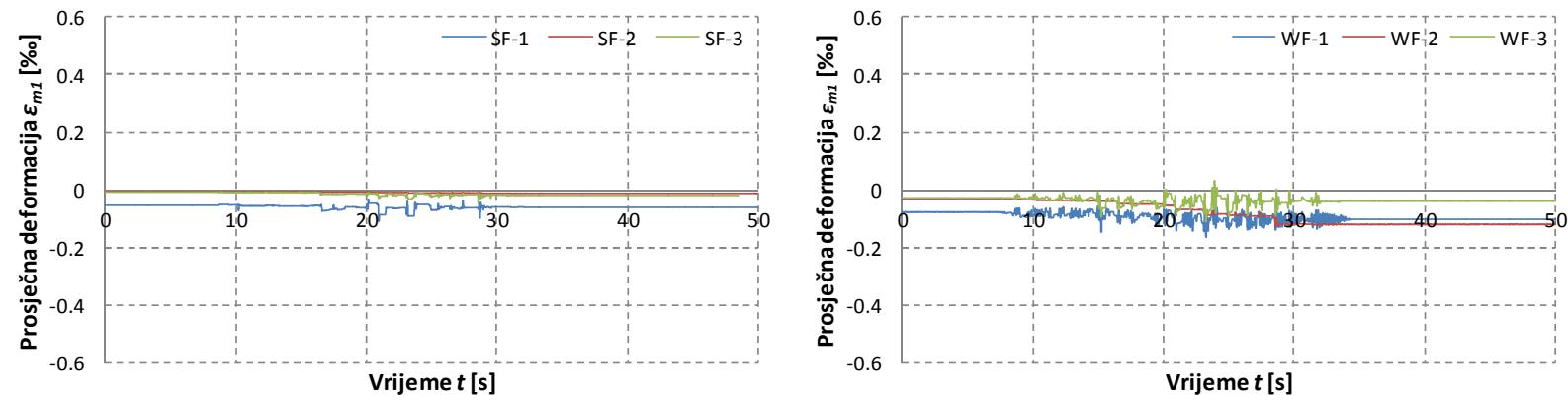

b) $\mathrm{a}_{\mathrm{g}, \max }=0.2 \mathrm{~g}$
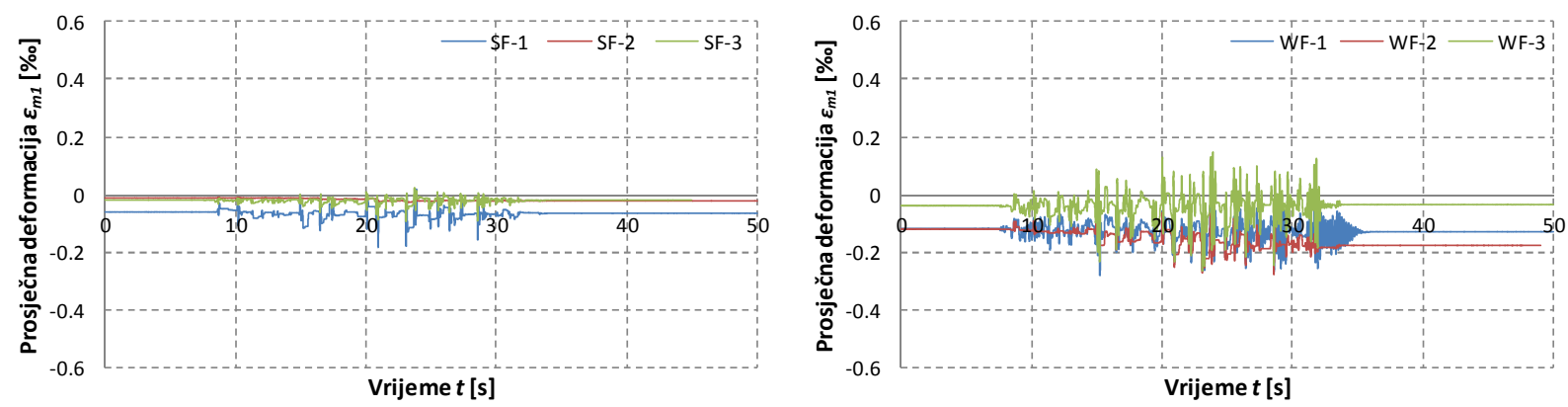

c) $\mathrm{a}_{\mathrm{g}, \max }=0.3 \mathrm{~g}$
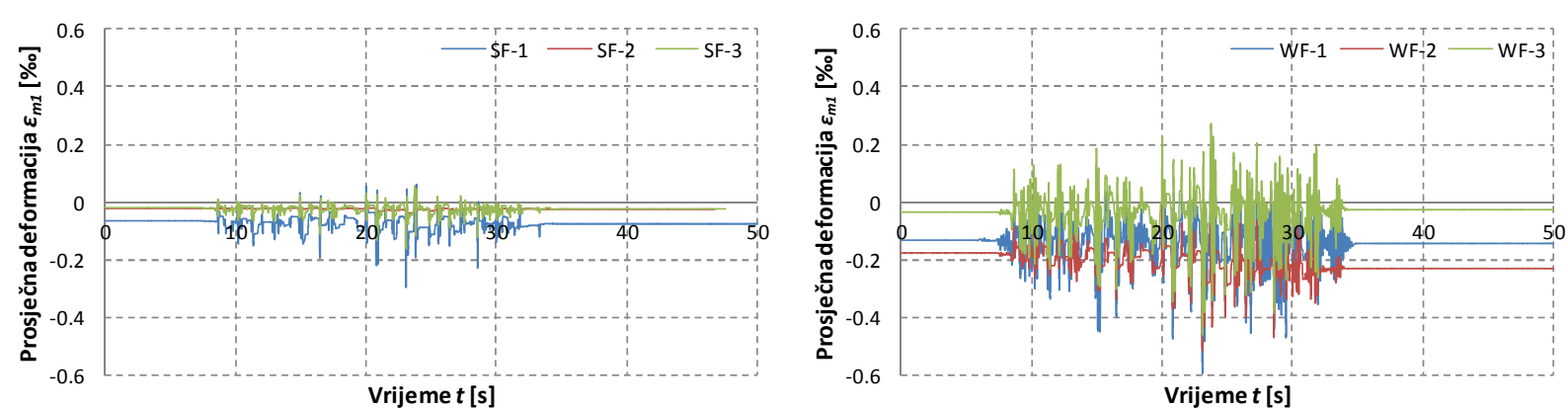

d) $\mathrm{a}_{\mathrm{g}, \max }=0.4 \mathrm{~g}$

Slika 3.29. Prosječna deformacija ziđa u smjeru dijagonale D1 $\left(\varepsilon_{\mathrm{m} 1}\right)$ u vremenu za umjetni akcelerogram AA1 s maksimalnim ubrzanjem $\mathrm{a}_{\mathrm{g}, \max }=0.1,0.2,0.3 \mathrm{i} 0.4 \mathrm{~g}$ 

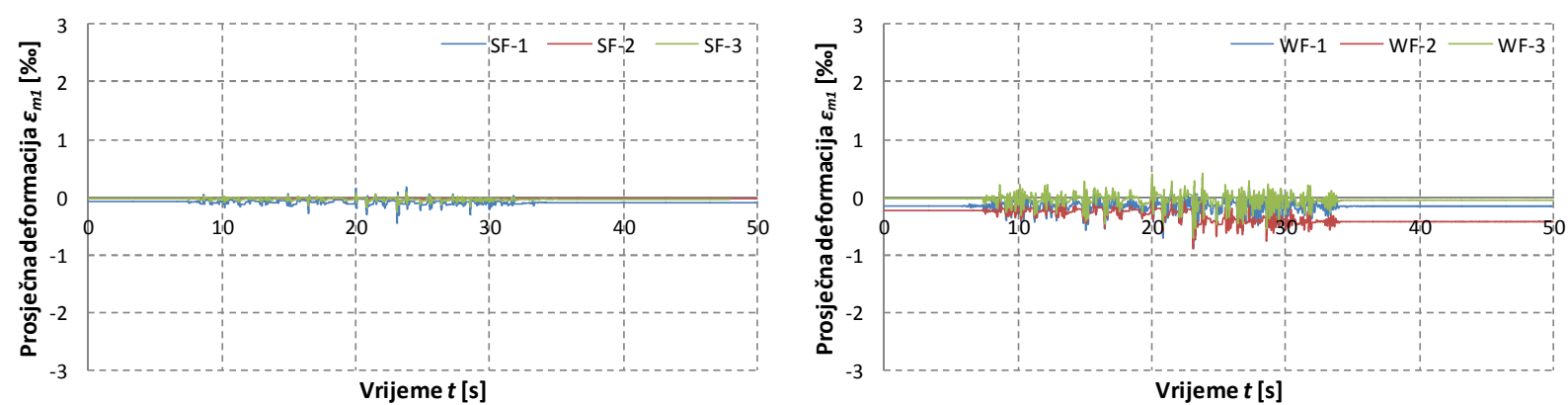

a) $\mathrm{a}_{\mathrm{g}, \max }=0.5 \mathrm{~g}$
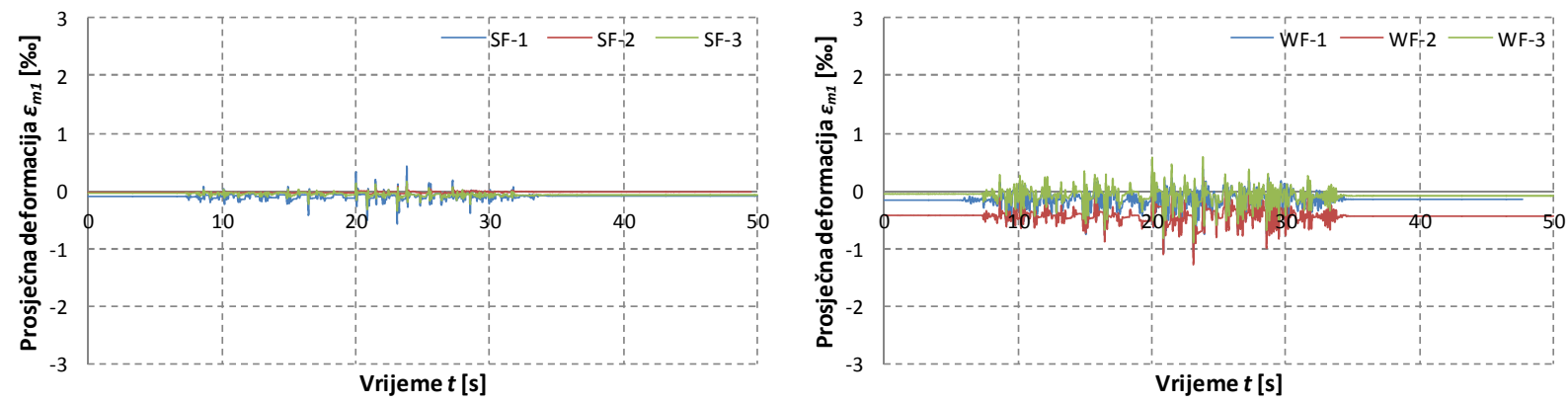

b) $\mathrm{a}_{\mathrm{g}, \max }=0.6 \mathrm{~g}$
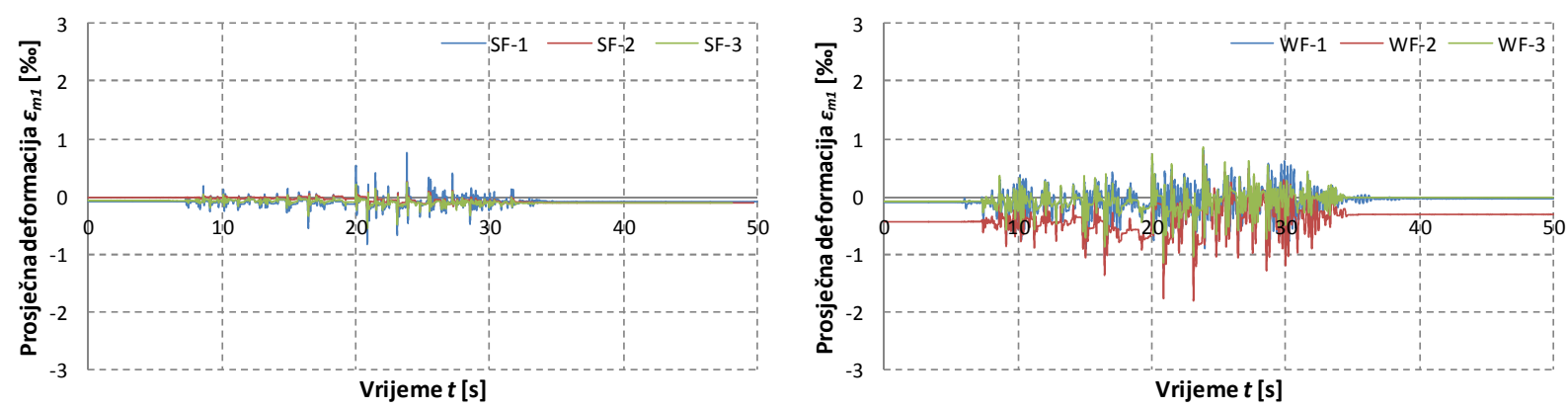

c) $\mathrm{a}_{\mathrm{g}, \max }=0.7 \mathrm{~g}$
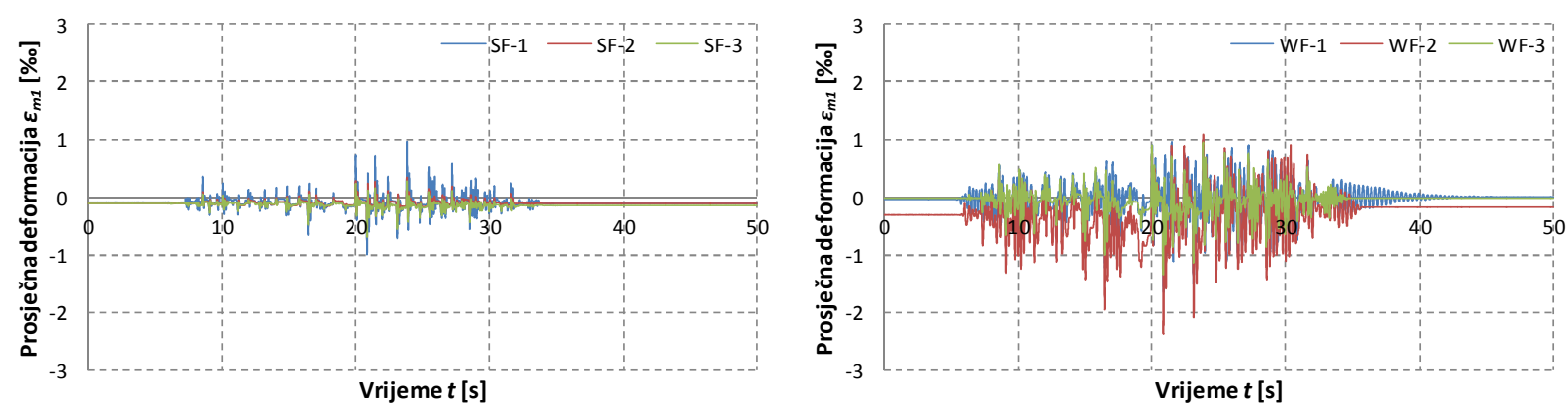

d) $\mathrm{a}_{\mathrm{g}, \max }=0.8 \mathrm{~g}$

Slika 3.30. Prosječna deformacija ziđa u smjeru dijagonale D1 $\left(\varepsilon_{\mathrm{m} 1}\right)$ u vremenu za umjetni akcelerogram AA1 s maksimalnim ubrzanjem $\mathrm{a}_{\mathrm{g}, \max }=0.5,0.6,0.7 \mathrm{i} 0.8 \mathrm{~g}$ 

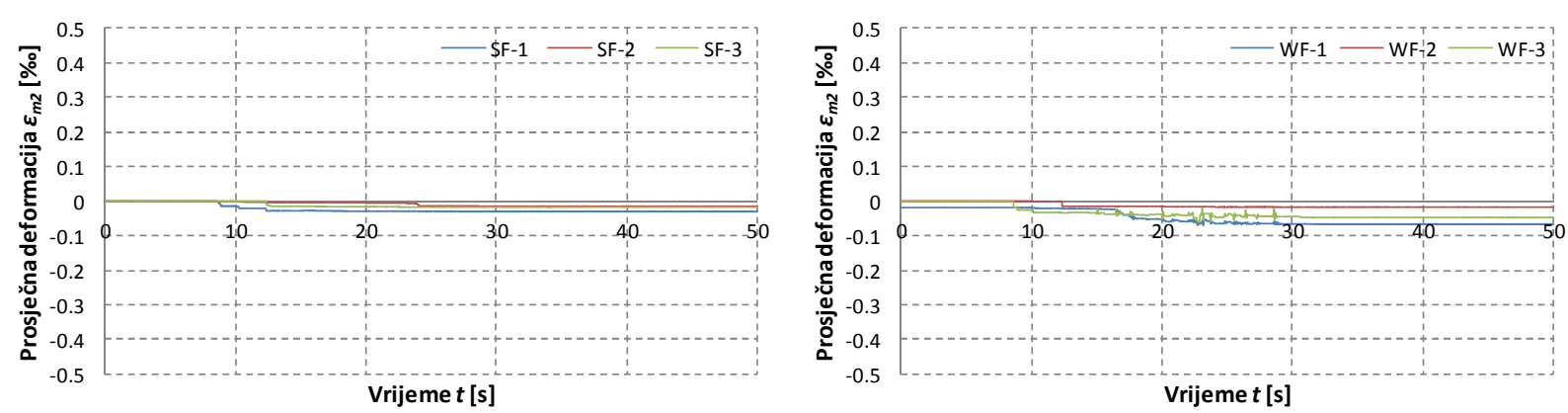

a) $\mathrm{a}_{\mathrm{g}, \max }=0.1 \mathrm{~g}$
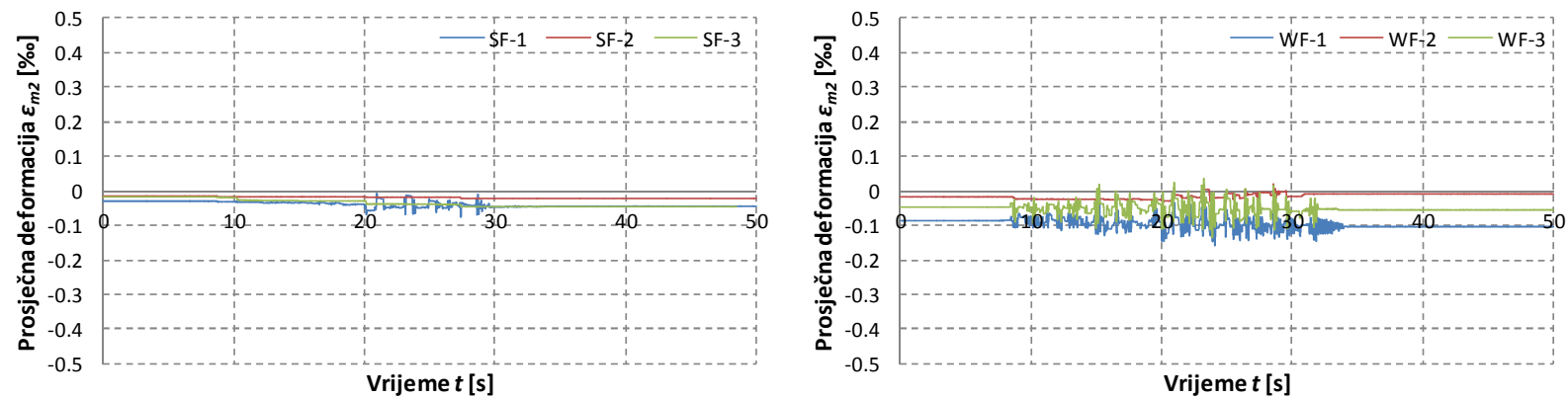

b) $\mathrm{a}_{\mathrm{g}, \max }=0.2 \mathrm{~g}$
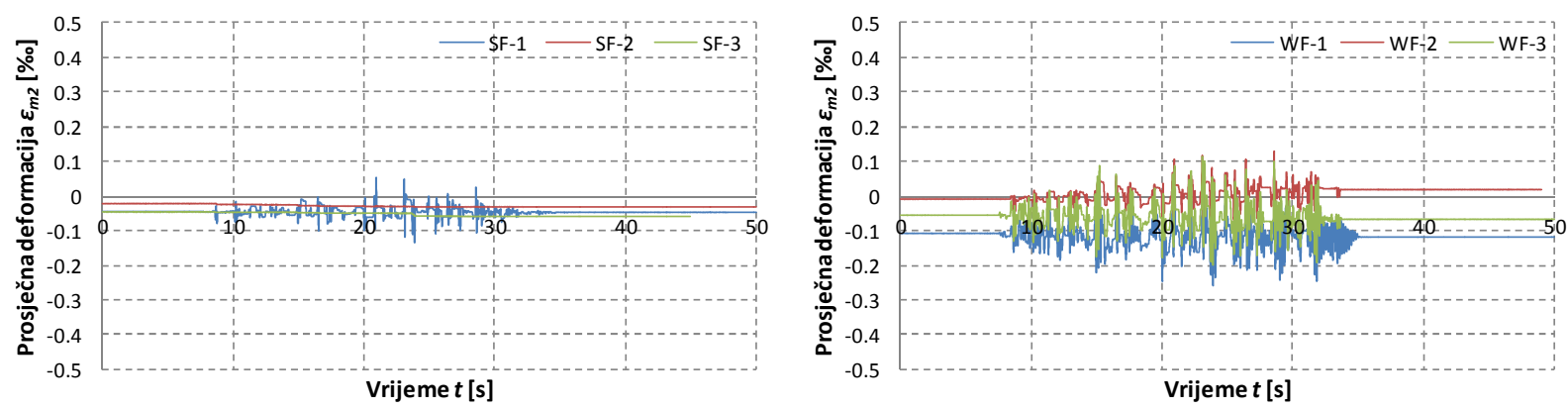

c) $\mathrm{a}_{\mathrm{g}, \max }=0.3 \mathrm{~g}$
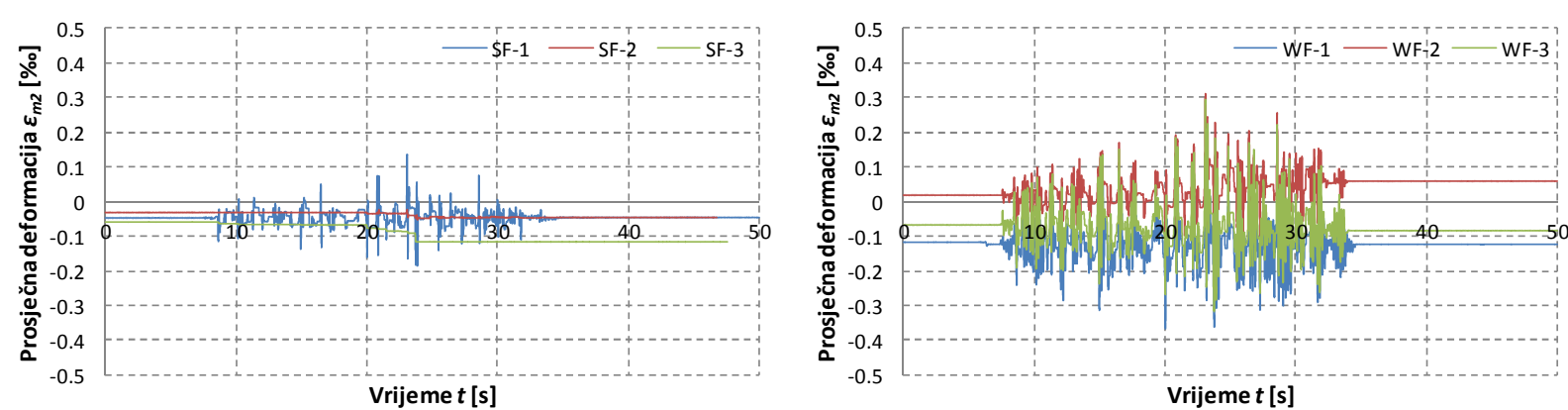

d) $\mathrm{a}_{\mathrm{g}, \max }=0.4 \mathrm{~g}$

Slika 3.31. Prosječna deformacija ziđa u smjeru dijagonale D2 $\left(\varepsilon_{\mathrm{m} 2}\right)$ u vremenu za umjetni akcelerogram AA1 s maksimalnim ubrzanjem $\mathrm{a}_{\mathrm{g}, \max }=0.1,0.2,0.3 \mathrm{i} 0.4 \mathrm{~g}$ 

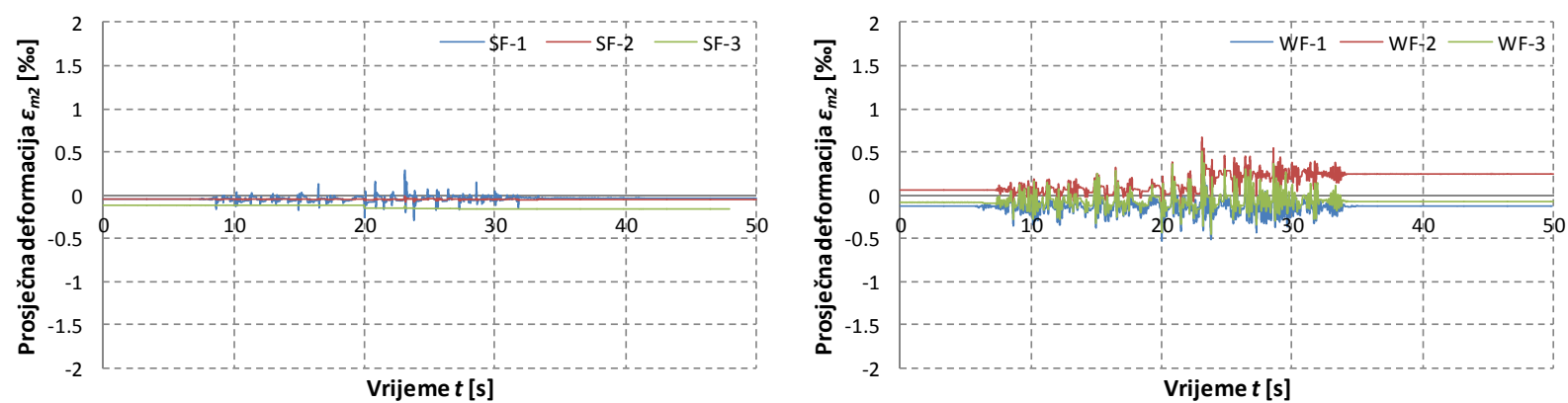

a) $\mathrm{a}_{\mathrm{g}, \max }=0.5 \mathrm{~g}$
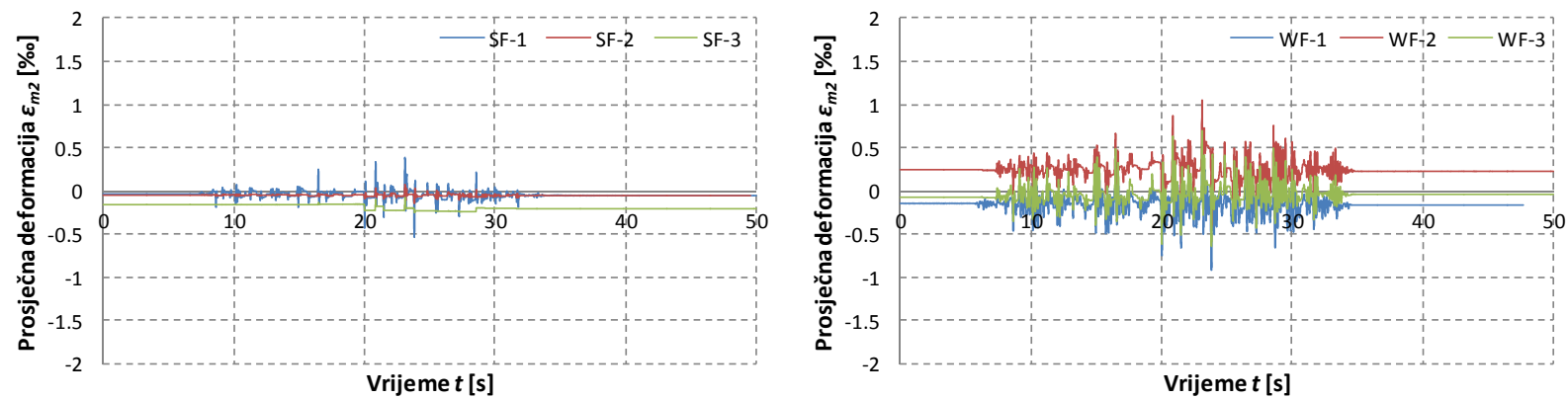

b) $\mathrm{a}_{\mathrm{g}, \max }=0.6 \mathrm{~g}$
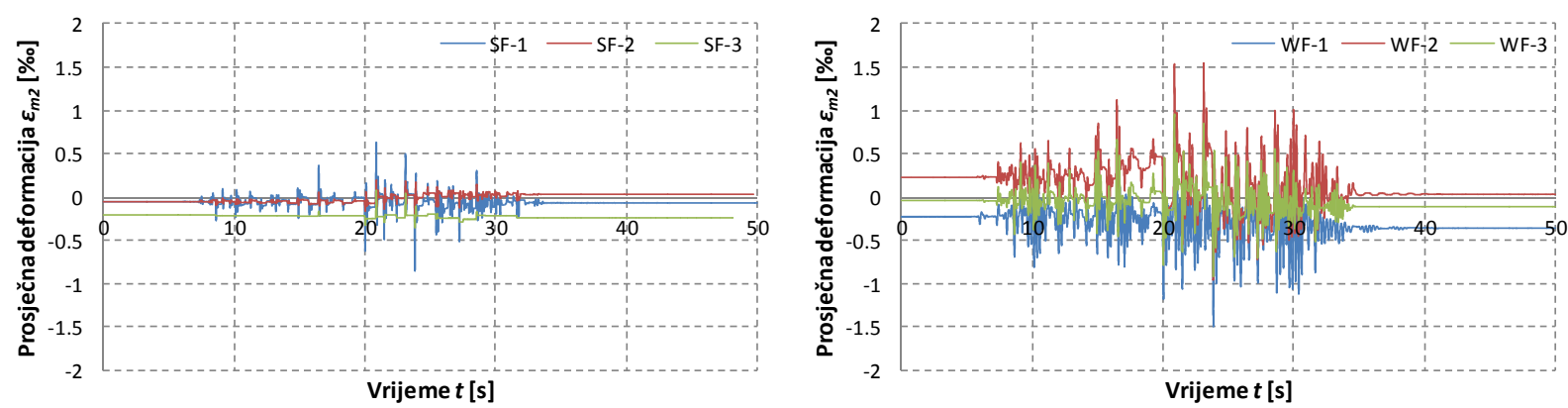

c) $\mathrm{a}_{\mathrm{g}, \max }=0.7 \mathrm{~g}$
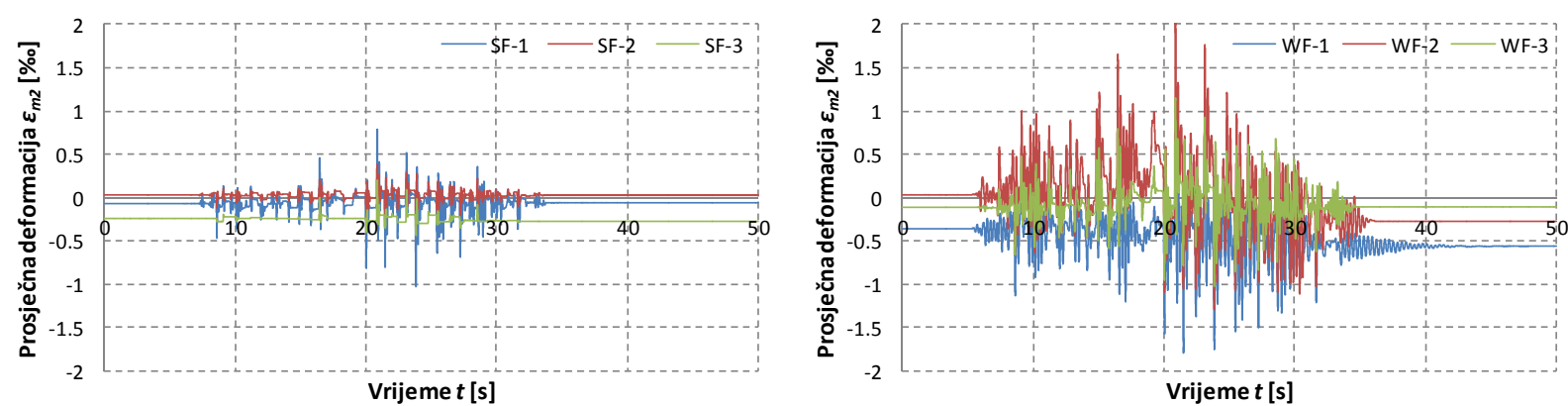

d) $\mathrm{a}_{\mathrm{g}, \max }=0.8 \mathrm{~g}$

Slika 3.32. Prosječna deformacija ziđa u smjeru dijagonale D2 $\left(\varepsilon_{\mathrm{m} 2}\right)$ u vremenu za umjetni akcelerogram AA1 s maksimalnim ubrzanjem $\mathrm{a}_{\mathrm{g}, \max }=0.5,0.6,0.7 \mathrm{i} 0.8 \mathrm{~g}$ 

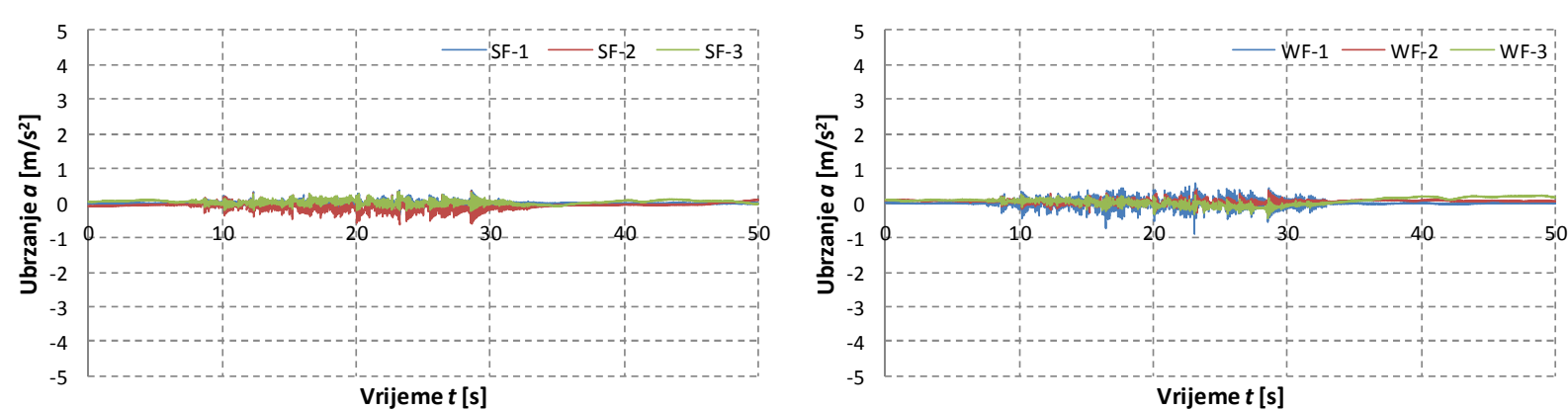

a) $\mathrm{a}_{\mathrm{g}, \max }=0.1 \mathrm{~g}$
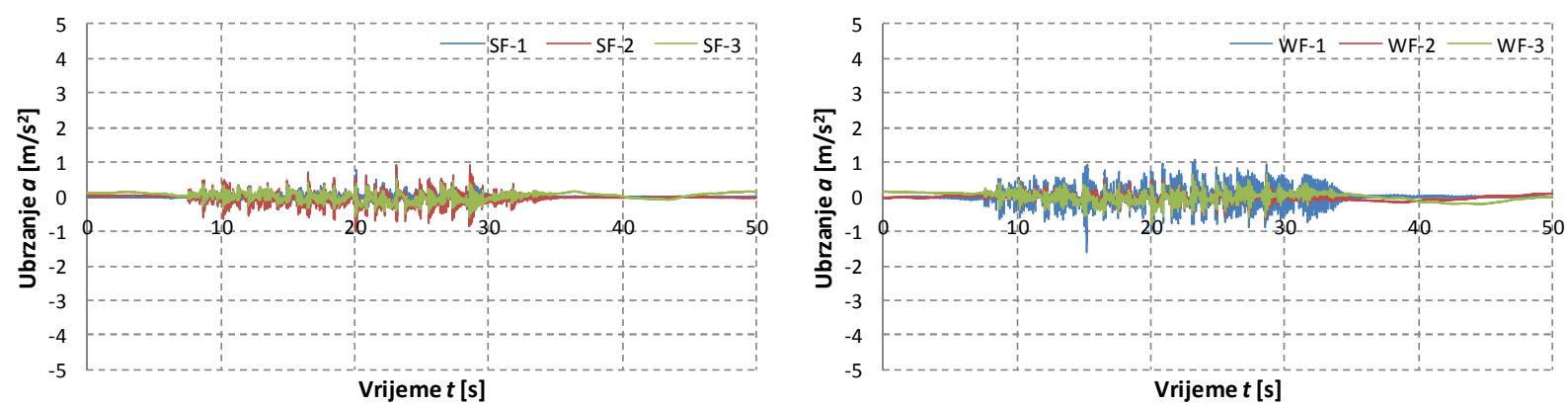

b) $\mathrm{a}_{\mathrm{g}, \max }=0.2 \mathrm{~g}$
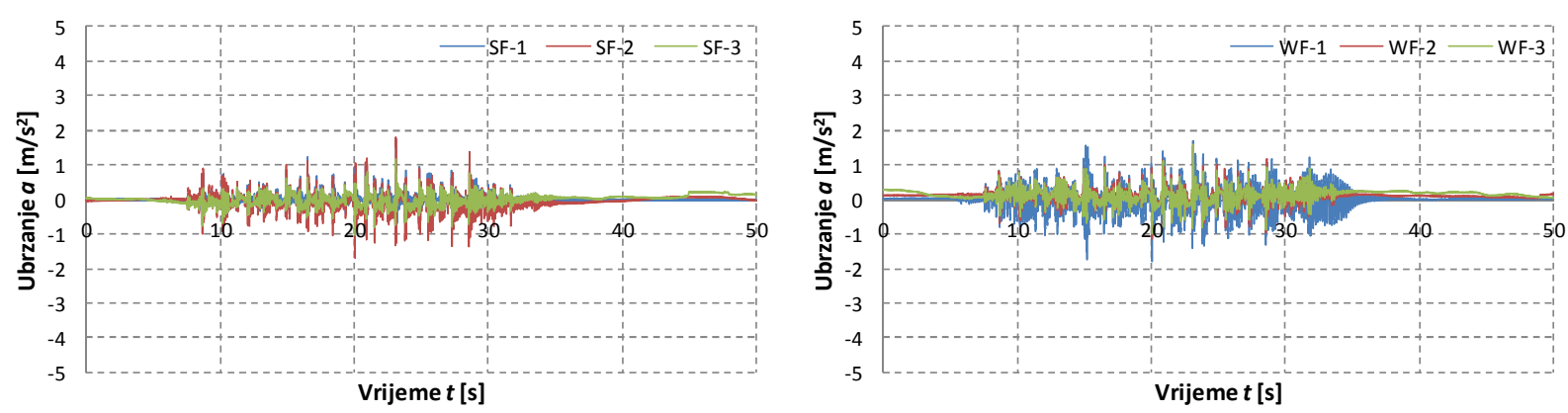

c) $\mathrm{a}_{\mathrm{g}, \max }=0.3 \mathrm{~g}$
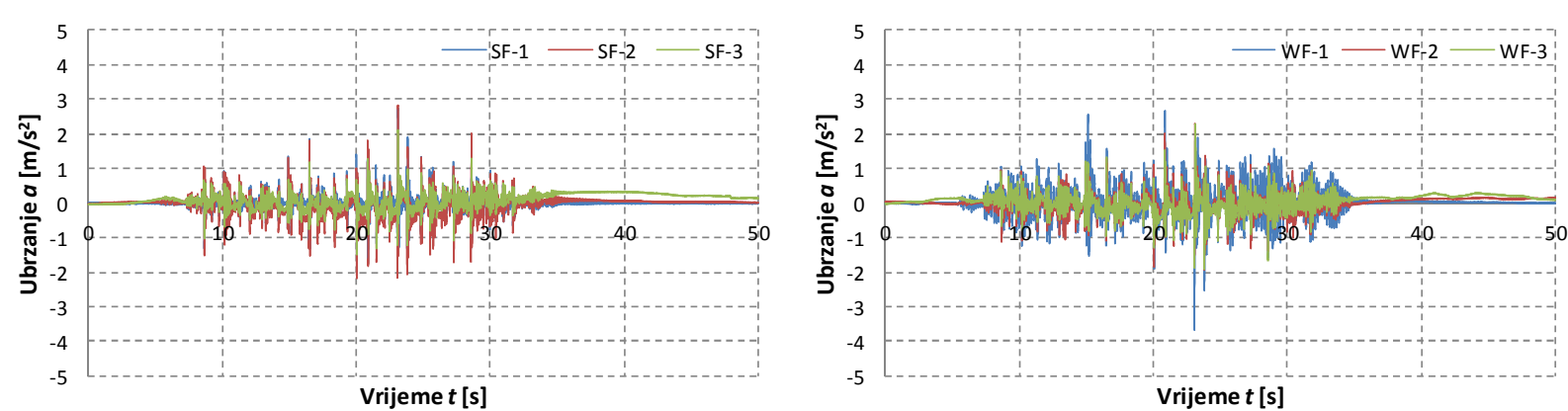

d) $\mathrm{a}_{\mathrm{g}, \max }=0.4 \mathrm{~g}$

Slika 3.33. Ubrzanje vrha okvira (a) u vremenu za umjetni akcelerogram AA1 s maksimalnim ubrzanjem $\mathrm{a}_{\mathrm{g}, \max }=0.1,0.2,0.3$ i $0.4 \mathrm{~g}$ 

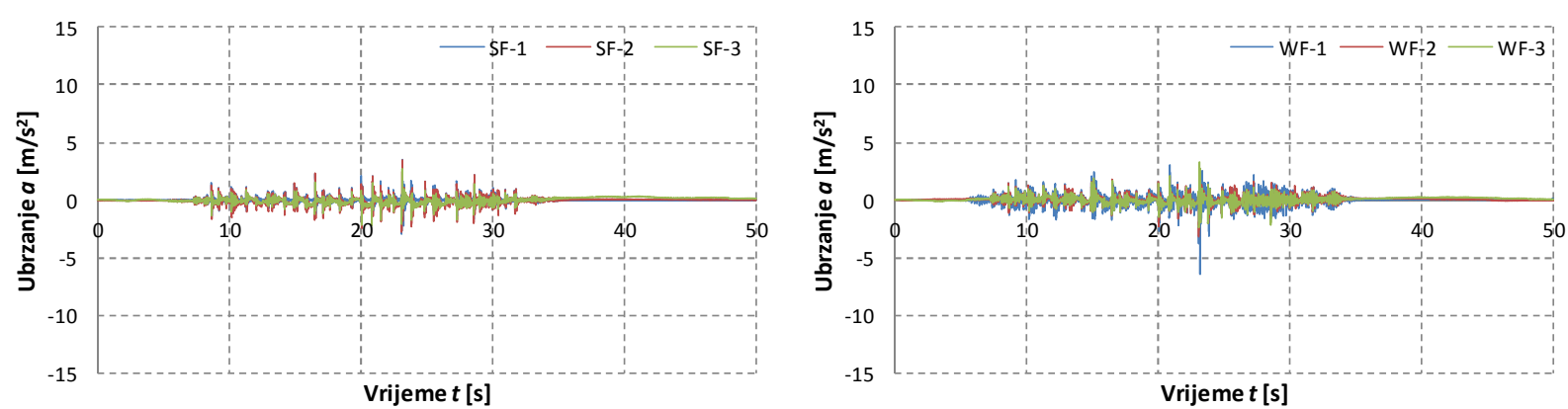

a) $\mathrm{a}_{\mathrm{g}, \max }=0.5 \mathrm{~g}$
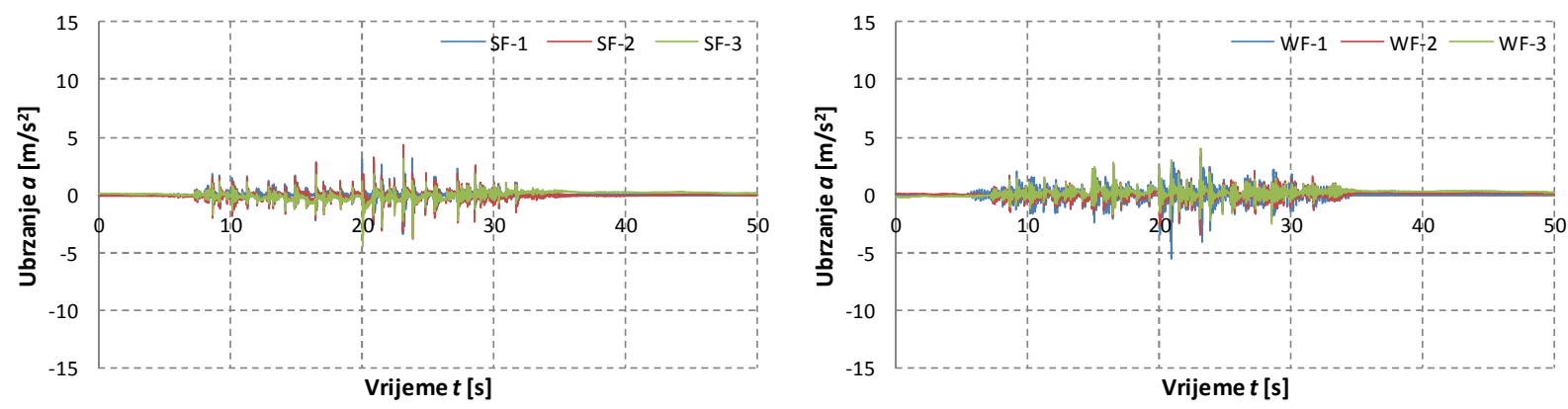

b) $\mathrm{a}_{\mathrm{g}, \max }=0.6 \mathrm{~g}$
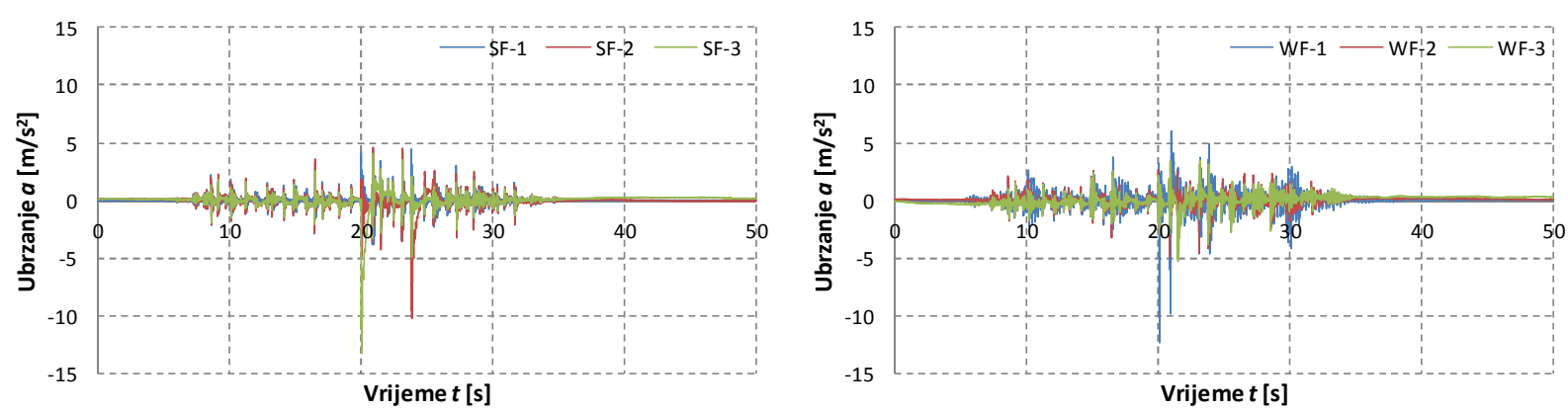

c) $\mathrm{a}_{\mathrm{g}, \max }=0.7 \mathrm{~g}$
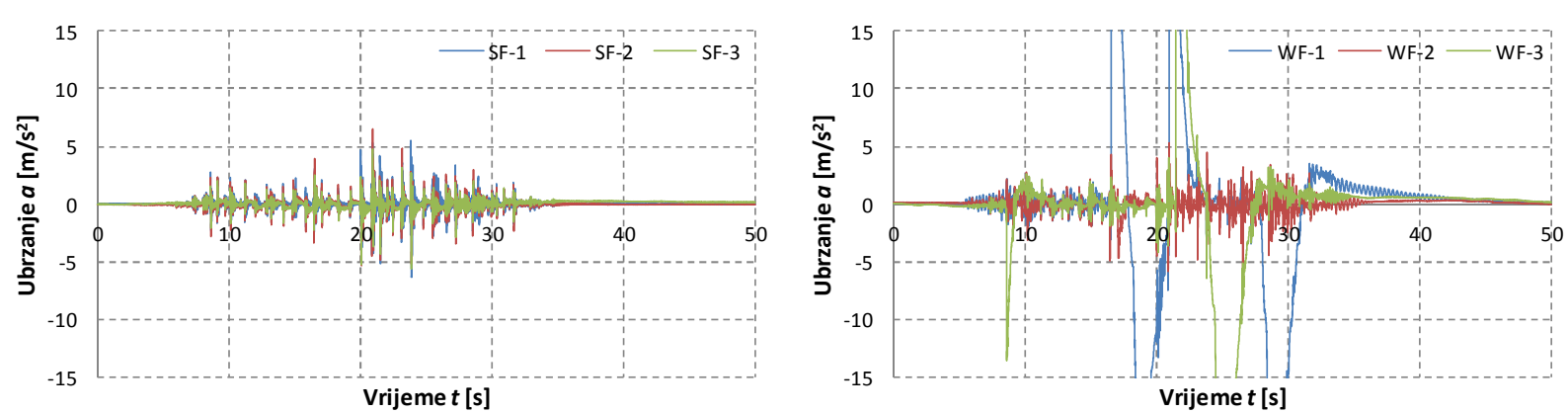

d) $\mathrm{a}_{\mathrm{g}, \max }=0.8 \mathrm{~g}$

Slika 3.34. Ubrzanje vrha okvira (a) u vremenu za umjetni akcelerogram AA1 s maksimalnim ubrzanjem $\mathrm{a}_{\mathrm{g}, \max }=0.5,0.6,0.7 \mathrm{i} 0.8 \mathrm{~g}$ 


\subsubsection{Rezultati za potres Petrovac}

Nakon izlaganja okvira nizu umjetnih akcelerograma, svi okviri su izloženi nizu akcelerograma izvedenih iz zapisa potresa Petrovac. Pri tome su amplitude ubrzanja u svakoj pobudi također postupno povećavane, tako da je maksimalna amplituda u svakoj apliciranoj pobudi $\mathrm{a}_{\mathrm{g}, \max }=0.1 \mathrm{~g}, 0.2 \mathrm{~g}, 0.3 \mathrm{~g}$ i $0.45 \mathrm{~g}$. Horizontalni pomaci vrha okvira u vremenu prikazani su na Slici 3.35. Deformacije u čeliku pri dnu stupa u točki A (lijevo) u vremenu prikazane su na Slici 3.36. Deformacije u čeliku pri dnu stupa u točki B (desno) u vremenu prikazane su na Slici 3.37. Prosječne deformacije u smjeru dijagonala D1 i D2, uvjetno nazvane prosječne deformacije ziđa, u vremenu prikazane su na Slikama 3.38 i 3.39 . Horizontalna ubrzanja pri vrhu okvira u vremenu prikazana su na Slici 3.40.

Usporedbom izmjerenih vrijednosti odgovarajućih veličina, može se zaključiti da su rezultati umjetnog akcelerograma kompatibilni s rezultatima realnog potresa. Pri tome treba imati na umu da su ispitni uzorci već bili prethodno oštećeni uslijed djelovanja umjetnog akcelerograma. Pri interpretaciji rezultata na Slikama 3.35-3.40 treba uzeti u obzir da je uzorak WF-1 doživio velike pomake i deformacije tijekom ispitivanja, te je djelovanje pobude zaustavljeno pri $\mathrm{t}=15.8 \mathrm{~s}$ radi sprječavanja kolapsa konstrukcije i mogućeg oštećenja ispitne opreme.

Eksperimentalno ispitivanje i numeričko modeliranje betonskih i čeličnih okvira sa zidanom ispunom pod statičkim i dinamičkim opterećenjem 

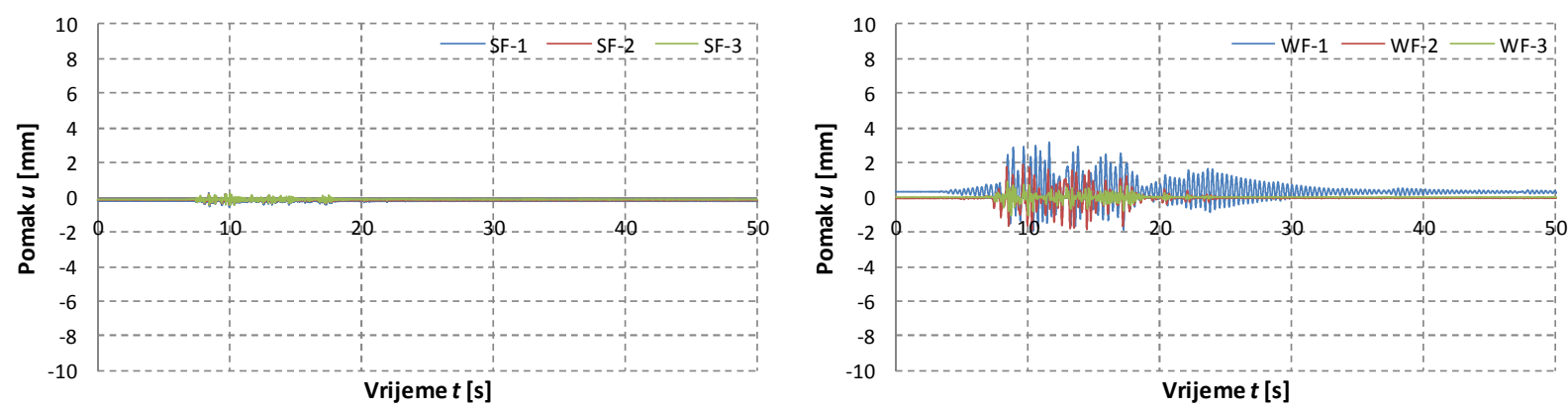

a) $\mathrm{a}_{\mathrm{g}, \max }=0.1 \mathrm{~g}$
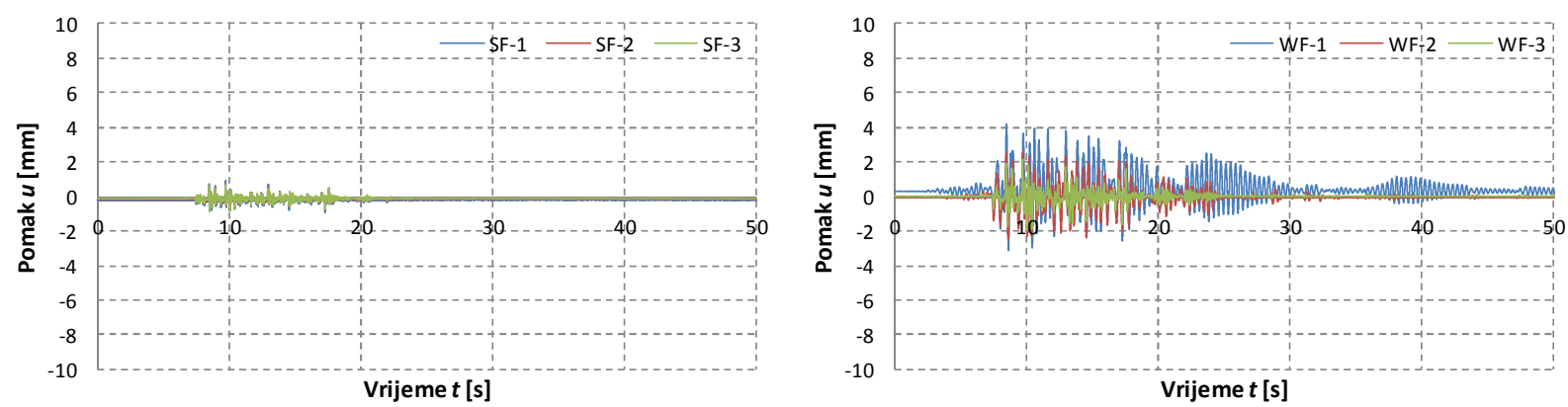

b) $\mathrm{a}_{\mathrm{g}, \max }=0.2 \mathrm{~g}$
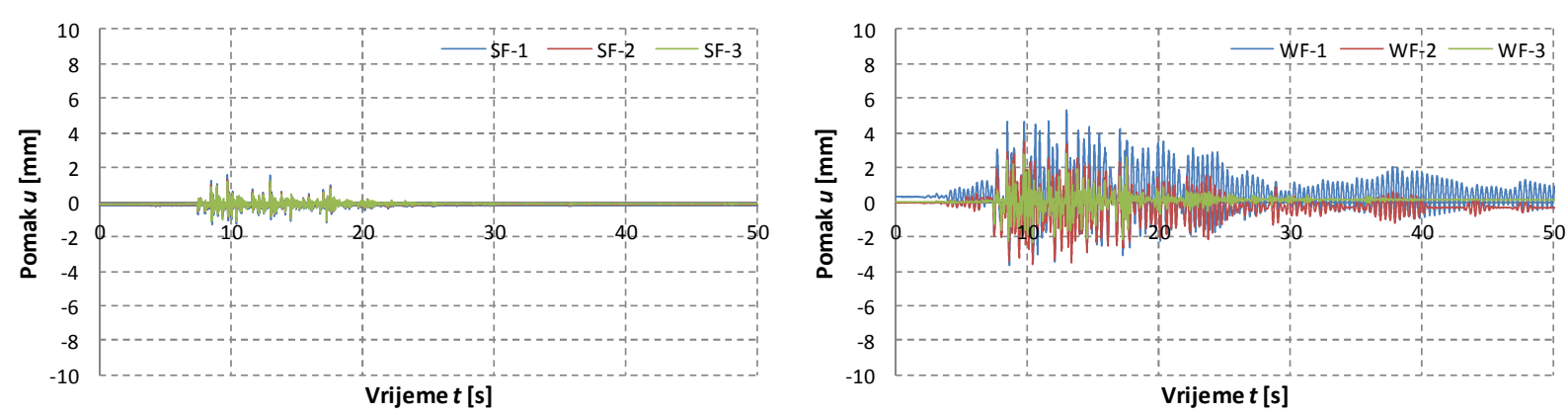

c) $\mathrm{a}_{\mathrm{g}, \max }=0.3 \mathrm{~g}$
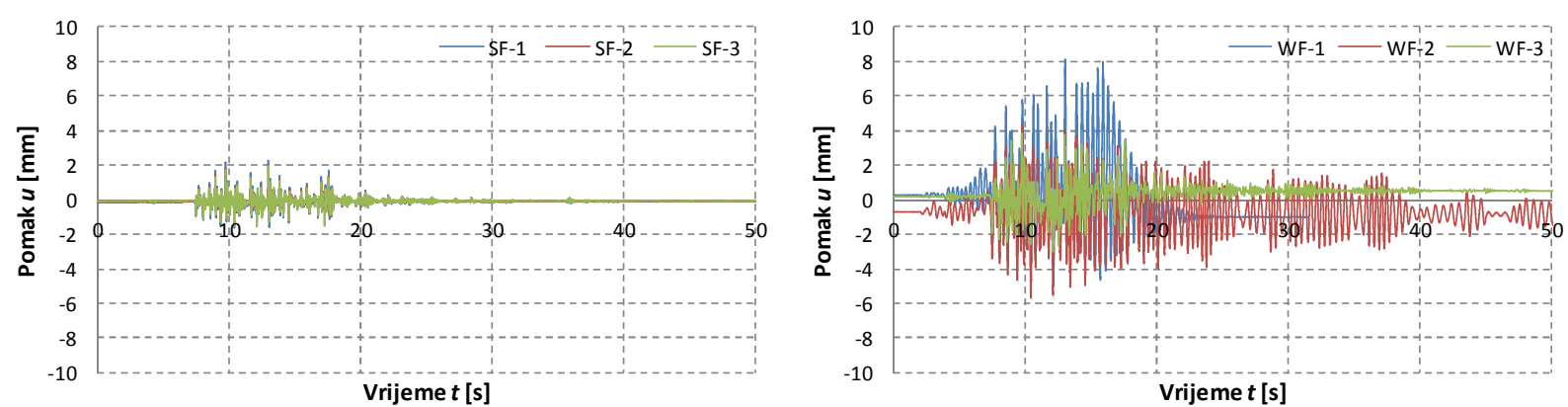

d) $\mathrm{a}_{\mathrm{g}, \max }=0.45 \mathrm{~g}$

Slika 3.35. Pomak vrha okvira $(u)$ u vremenu za potres Petrovac s maksimalnim ubrzanjem $\mathrm{a}_{\mathrm{g}, \max }=0.1,0.2,0.3 \mathrm{i} 0.45 \mathrm{~g}$ 

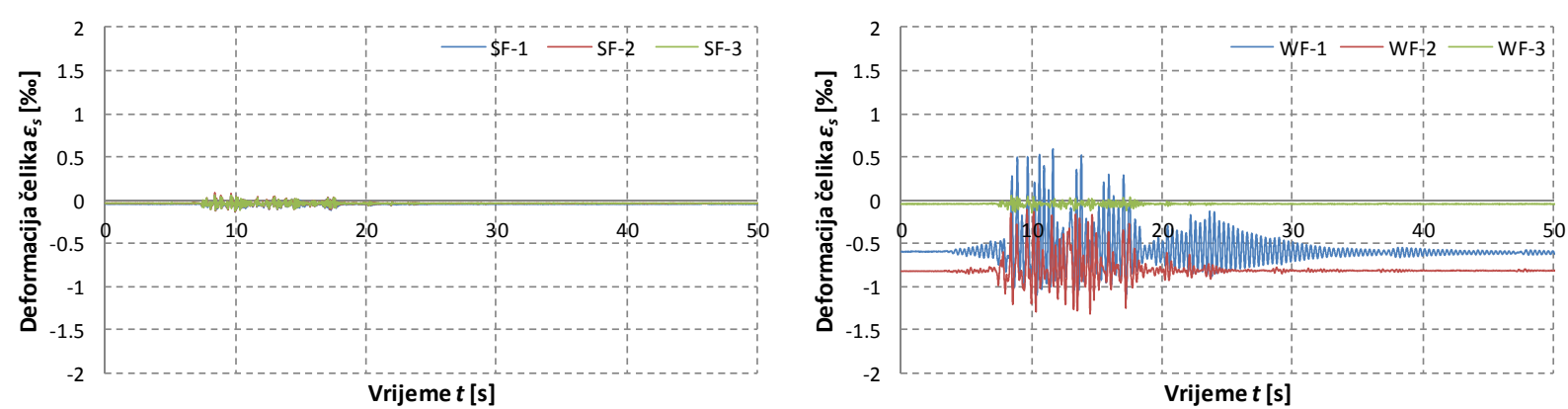

a) $\mathrm{a}_{\mathrm{g}, \max }=0.1 \mathrm{~g}$
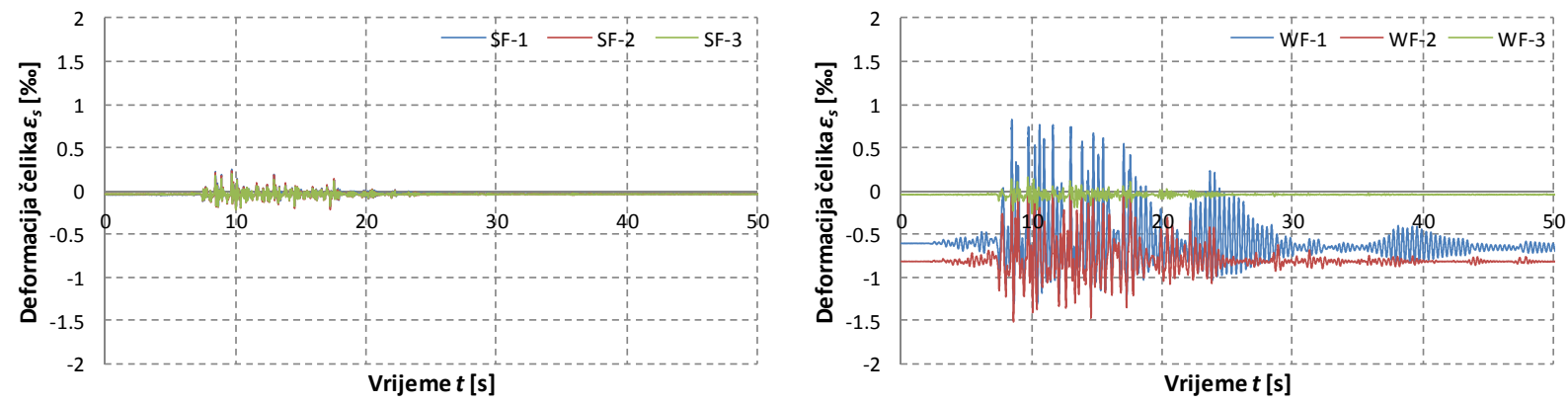

b) $\mathrm{a}_{\mathrm{g}, \max }=0.2 \mathrm{~g}$
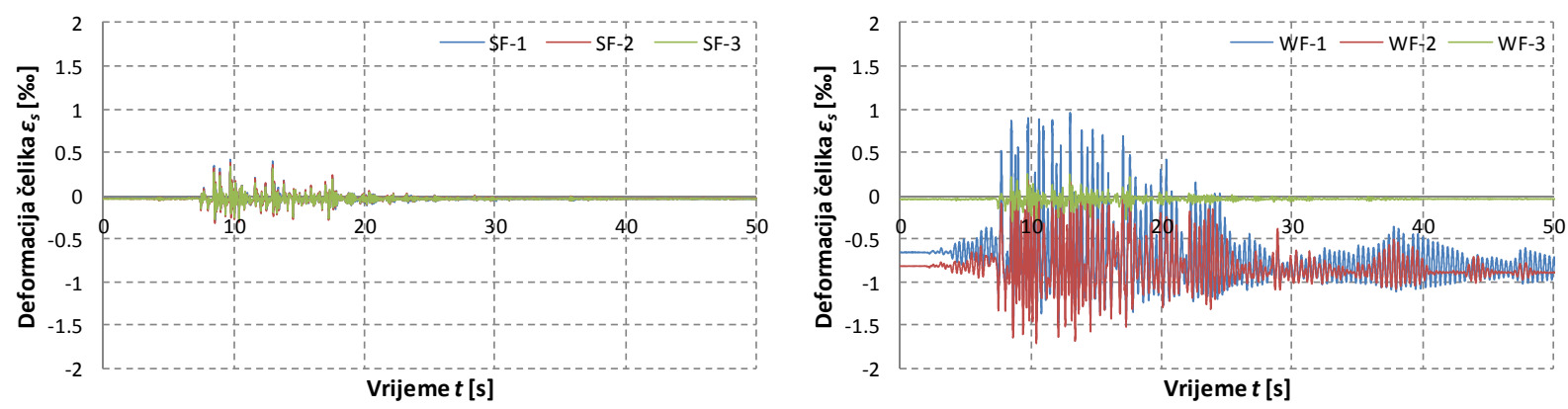

c) $\mathrm{a}_{\mathrm{g}, \max }=0.3 \mathrm{~g}$
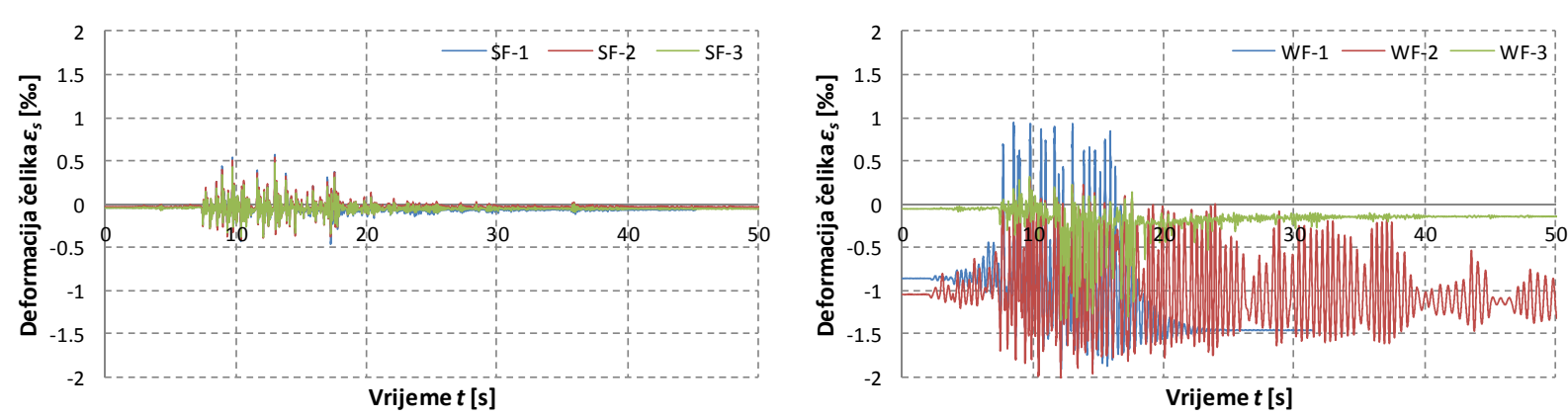

d) $\mathrm{a}_{\mathrm{g}, \max }=0.45 \mathrm{~g}$

Slika 3.36. Deformacija čelika pri dnu stupa u točki A $\left(\varepsilon_{\mathrm{s}}\right) \mathrm{u}$ vremenu za potres Petrovac $\mathrm{s}$ maksimalnim ubrzanjem $\mathrm{a}_{\mathrm{g}, \max }=0.1,0.2,0.3$ i $0.45 \mathrm{~g}$ 

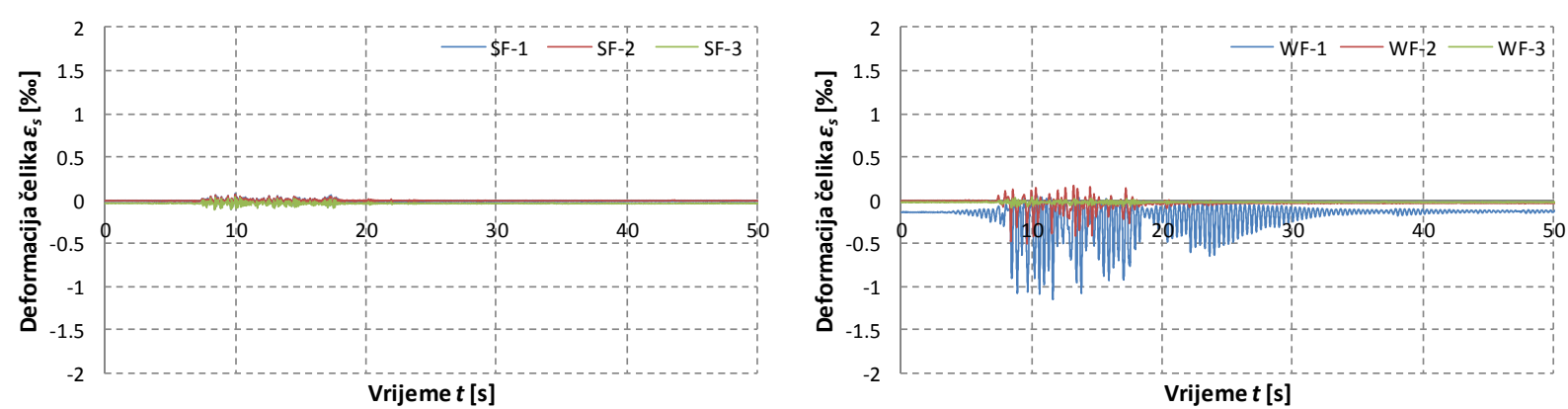

a) $\mathrm{a}_{\mathrm{g}, \max }=0.1 \mathrm{~g}$
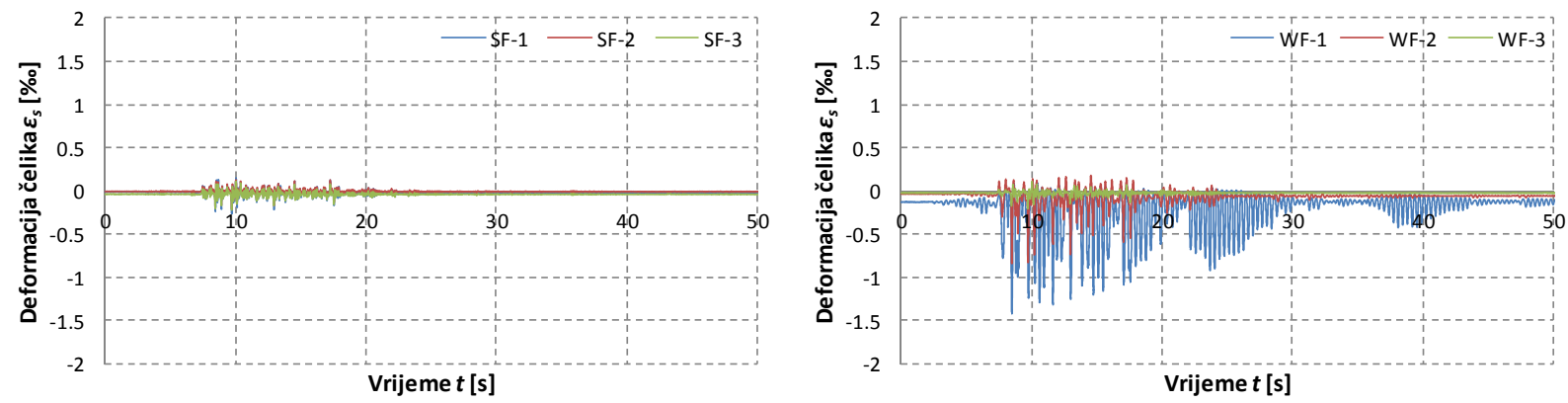

b) $\mathrm{a}_{\mathrm{g}, \max }=0.2 \mathrm{~g}$
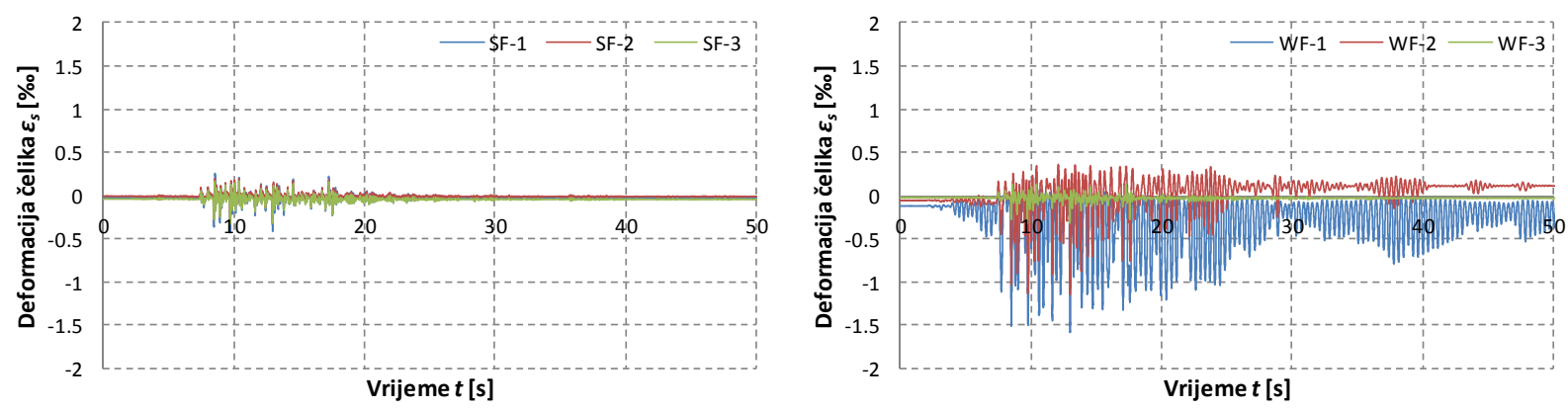

c) $\mathrm{a}_{\mathrm{g}, \max }=0.3 \mathrm{~g}$
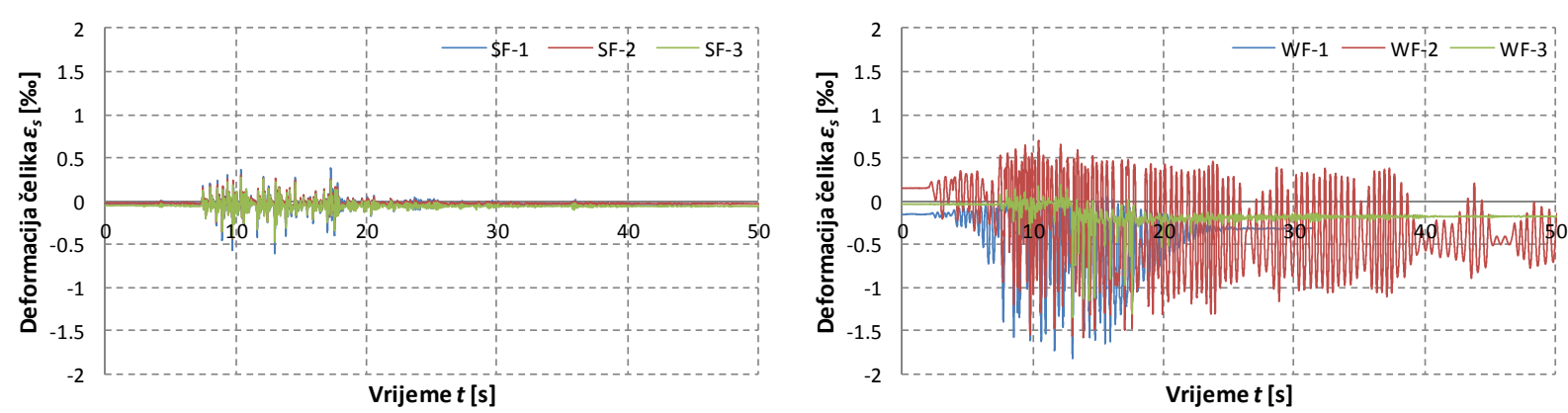

d) $\mathrm{a}_{\mathrm{g}, \max }=0.45 \mathrm{~g}$

Slika 3.37. Deformacija čelika pri dnu stupa u točki B $\left(\varepsilon_{\mathrm{s}}\right) \mathrm{u}$ vremenu za potres Petrovac s maksimalnim ubrzanjem $\mathrm{a}_{\mathrm{g}, \max }=0.1,0.2,0.3$ i $0.45 \mathrm{~g}$ 

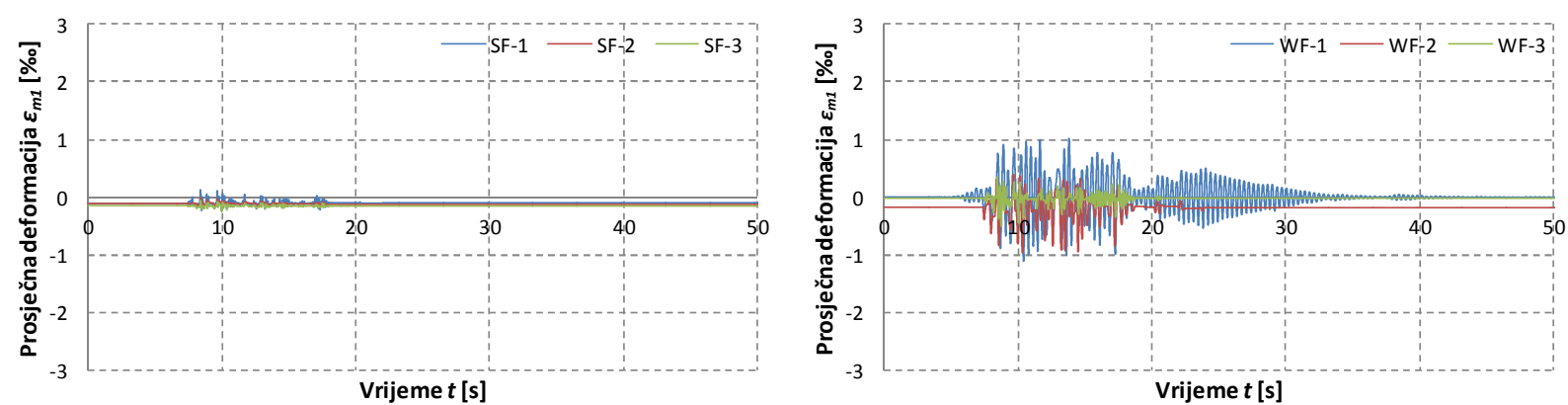

a) $\mathrm{a}_{\mathrm{g}, \max }=0.1 \mathrm{~g}$
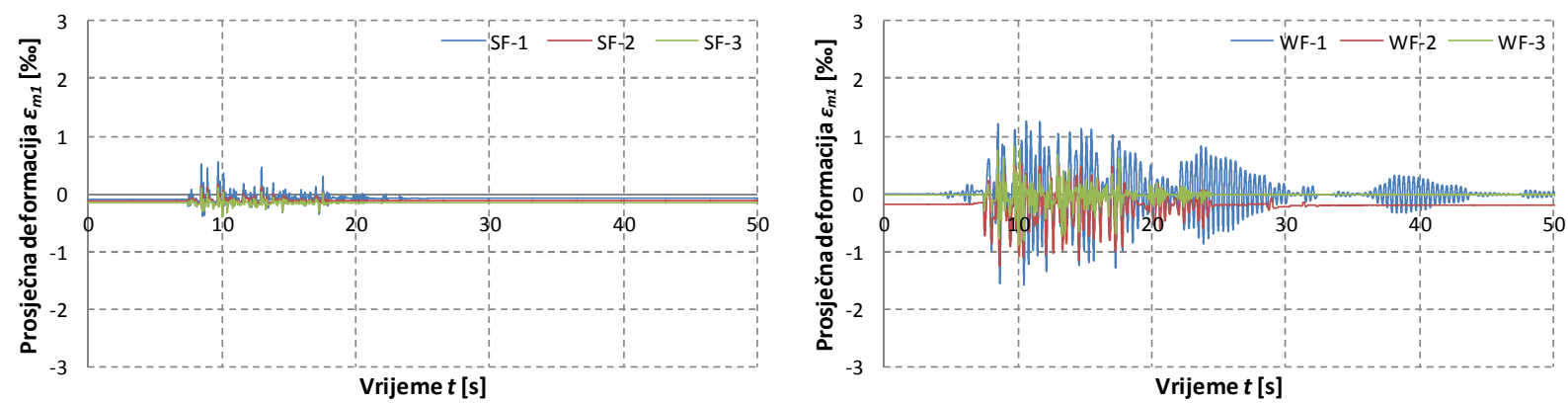

b) $\mathrm{a}_{\mathrm{g}, \max }=0.2 \mathrm{~g}$
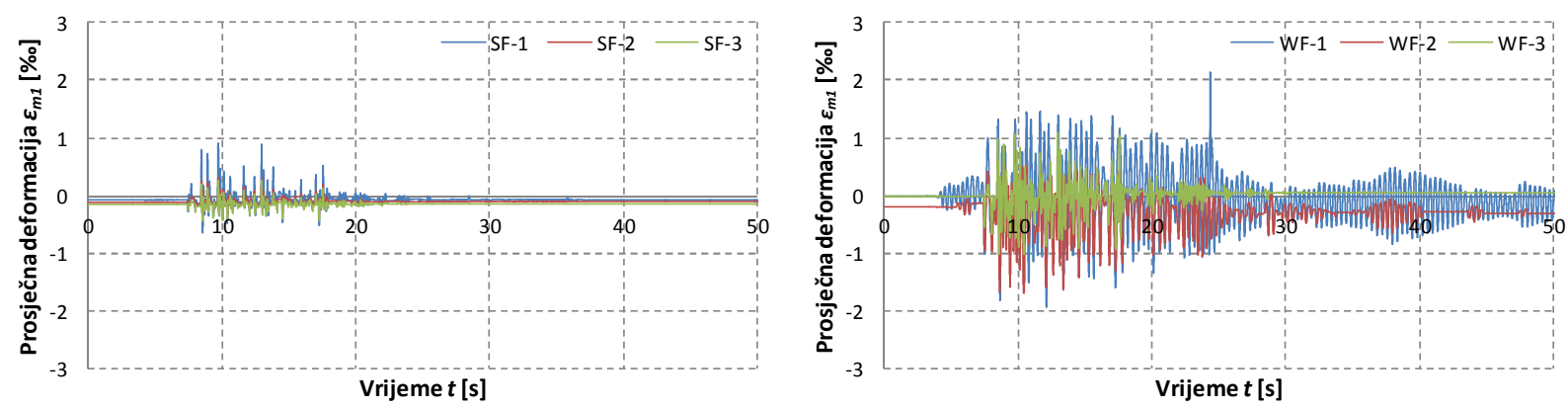

c) $\mathrm{a}_{\mathrm{g}, \max }=0.3 \mathrm{~g}$
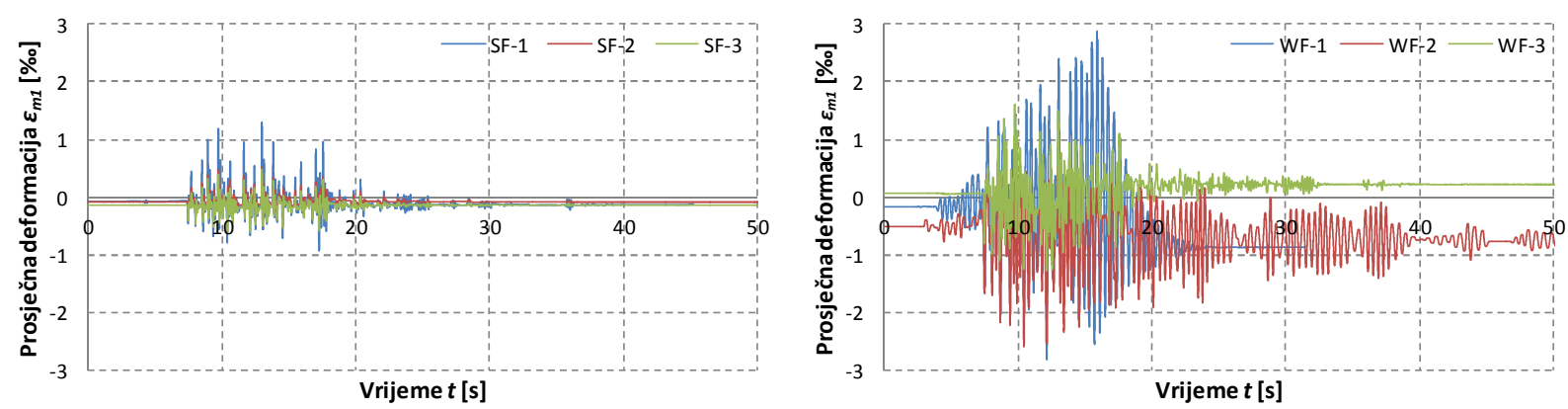

d) $\mathrm{a}_{\mathrm{g}, \max }=0.45 \mathrm{~g}$

Slika 3.38. Prosječna deformacija ziđa u smjeru dijagonale D1 $\left(\varepsilon_{\mathrm{m} 1}\right)$ u vremenu za potres Petrovac s maksimalnim ubrzanjem $\mathrm{a}_{\mathrm{g}, \max }=0.1,0.2,0.3 \mathrm{i} 0.45 \mathrm{~g}$ 

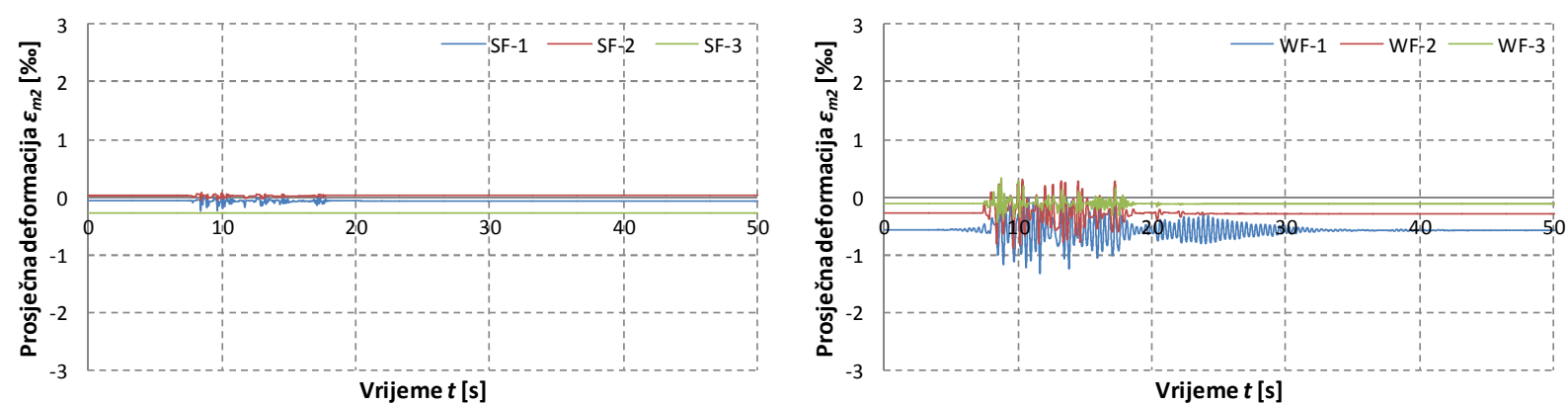

a) $\mathrm{a}_{\mathrm{g}, \max }=0.1 \mathrm{~g}$
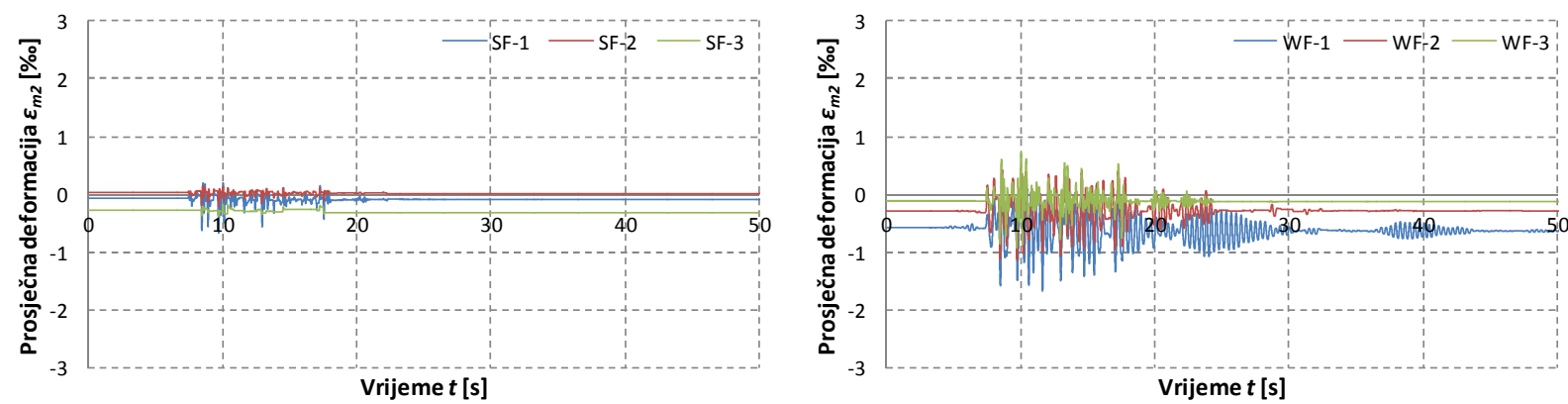

b) $\mathrm{a}_{\mathrm{g}, \max }=0.2 \mathrm{~g}$
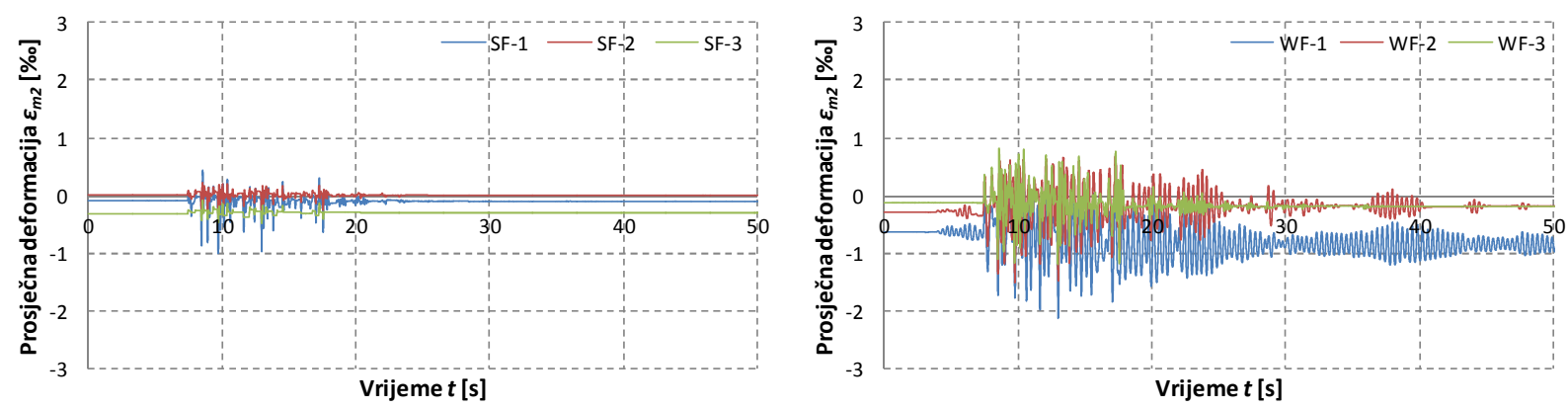

c) $\mathrm{a}_{\mathrm{g}, \max }=0.3 \mathrm{~g}$
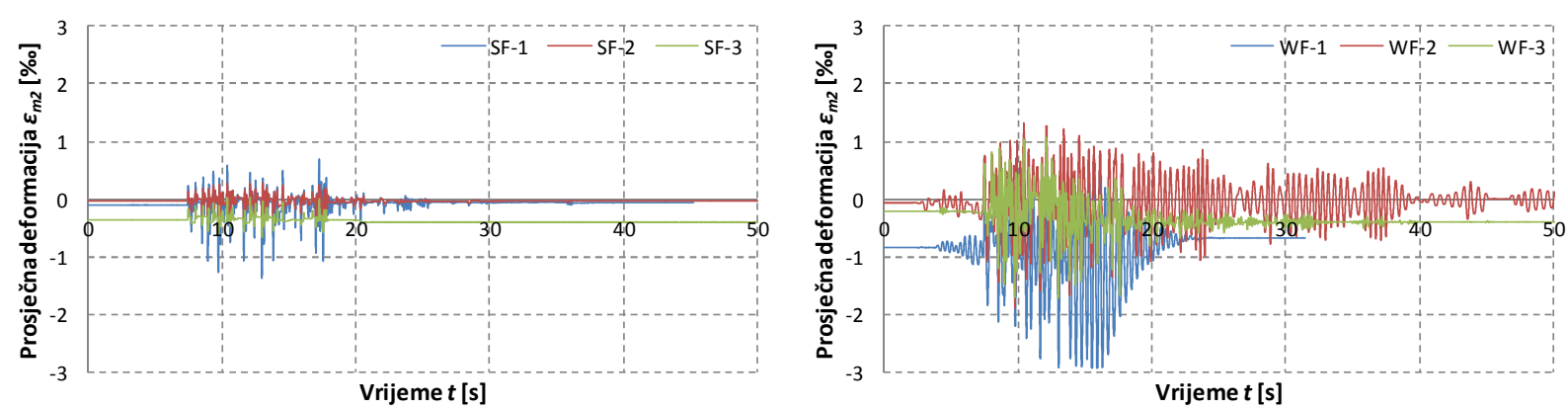

d) $\mathrm{a}_{\mathrm{g}, \max }=0.45 \mathrm{~g}$

Slika 3.39. Prosječna deformacija ziđa u smjeru dijagonale D2 $\left(\varepsilon_{\mathrm{m} 2}\right)$ u vremenu za potres Petrovac s maksimalnim ubrzanjem $\mathrm{a}_{\mathrm{g}, \max }=0.1,0.2,0.3$ i $0.45 \mathrm{~g}$ 

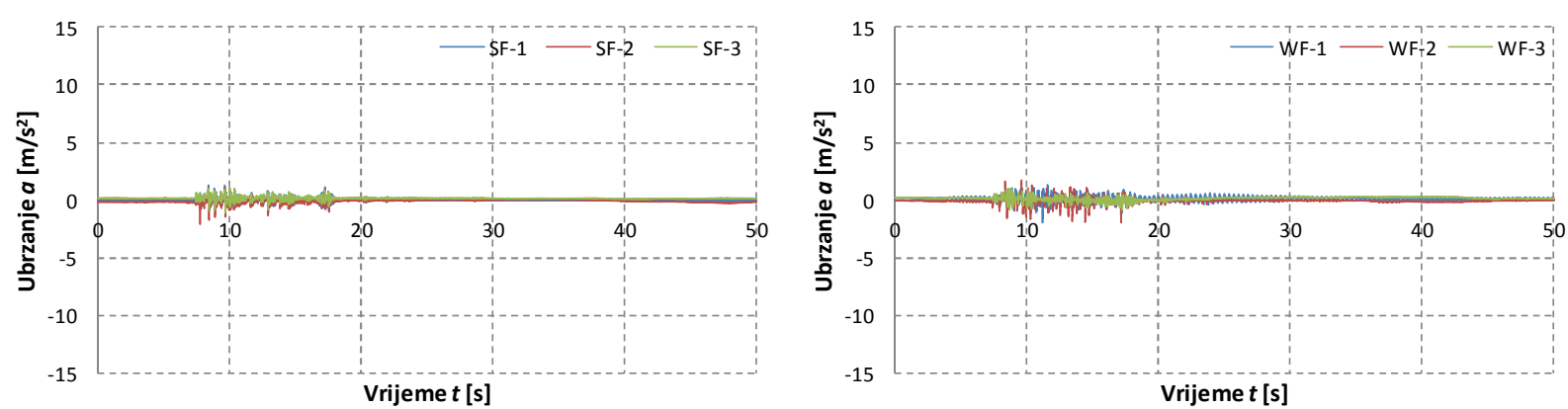

a) $\mathrm{a}_{\mathrm{g}, \max }=0.1 \mathrm{~g}$
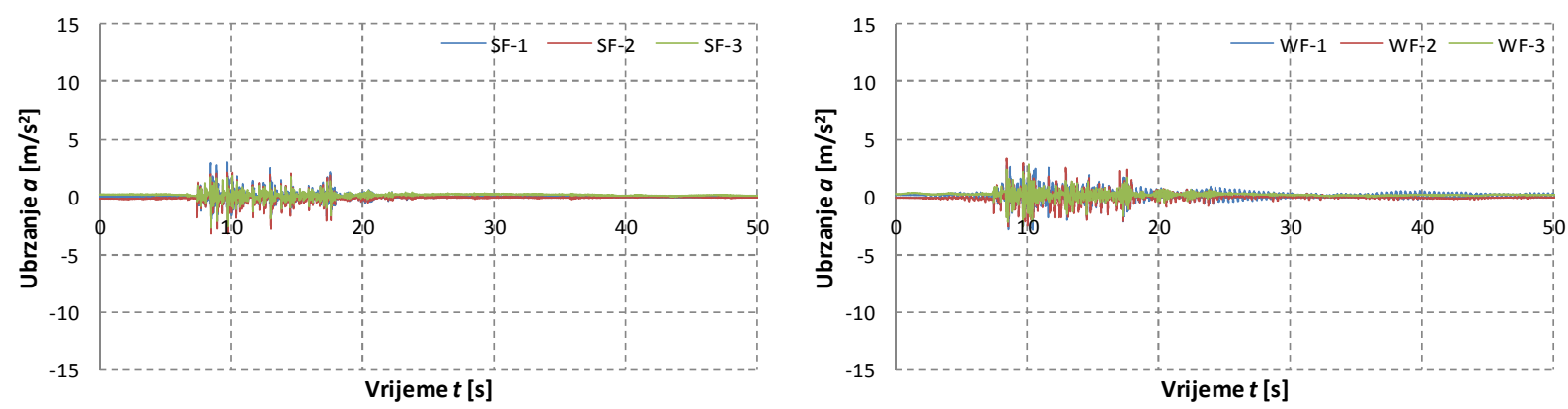

b) $\mathrm{a}_{\mathrm{g}, \max }=0.2 \mathrm{~g}$
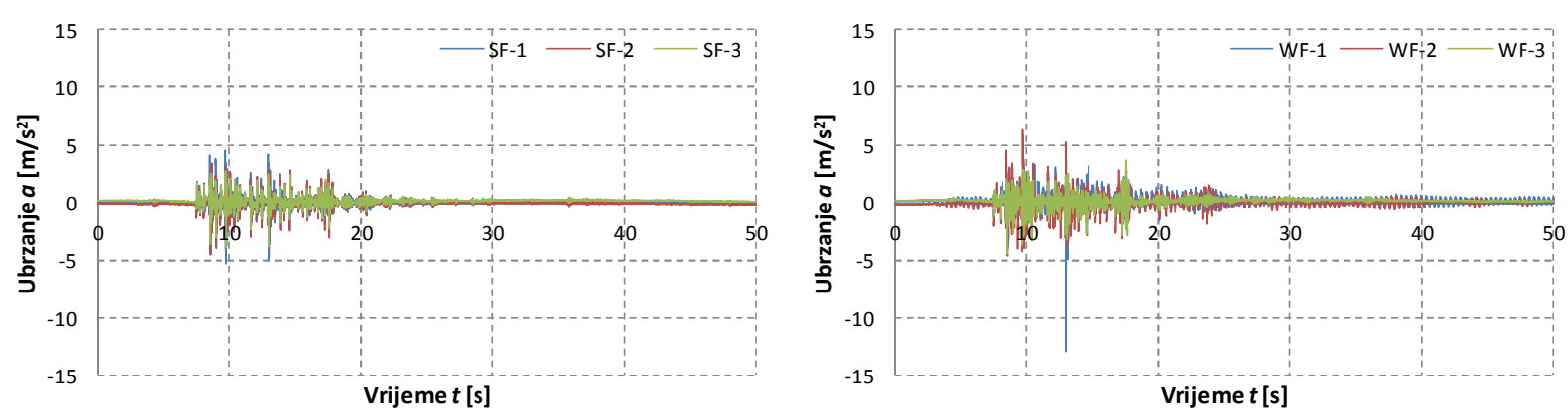

c) $\mathrm{a}_{\mathrm{g}, \max }=0.3 \mathrm{~g}$
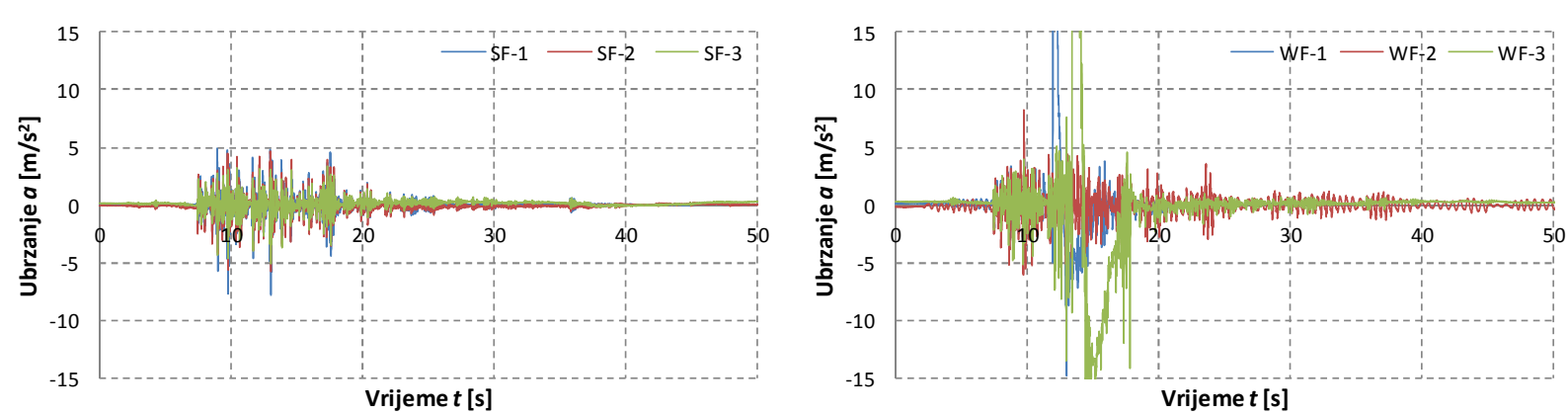

d) $\mathrm{a}_{\mathrm{g}, \max }=0.45 \mathrm{~g}$

Slika 3.40. Ubrzanje vrha okvira (a) u vremenu za potres Petrovac s maksimalnim ubrzanjem $\mathrm{a}_{\mathrm{g}, \max }=0.1,0.2,0.3 \mathrm{i} 0.45 \mathrm{~g}$ 
Konačna stanja pukotina i deformacija ispitivanih okvira $\mathrm{s}$ ispunom nakon svih provedenih testova prikazana su na Slici 3.41. Svi ožbukani okviri (SF-2, SF-3, WF-2, WF-3) nisu imali vidljivih pukotina u ziđu. Okvir WF-1 je imao veće pukotine u ziđu, dok je okvir SF-1 imao manje pukotine u ziđu. Kod svih ispitanih uzoraka došlo je do odvajanja okvira i ispune. Ovaj efekt je bio očitiji kod mekih okvira (WF). Drobljenje ispune u uglovima okvira nastupilo je kod svih ispitanih uzoraka.

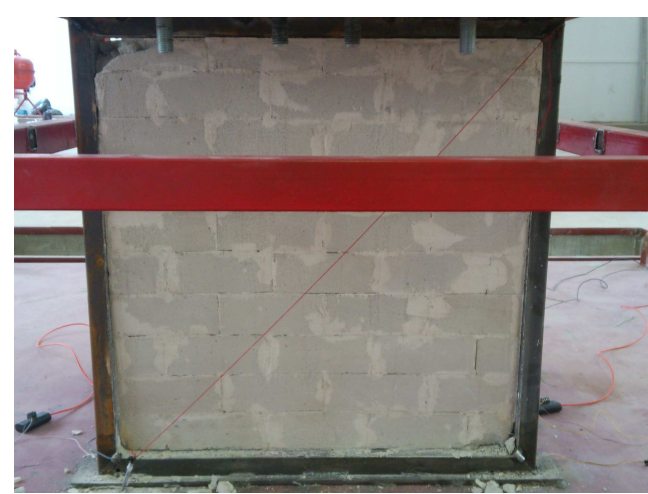

SF-1

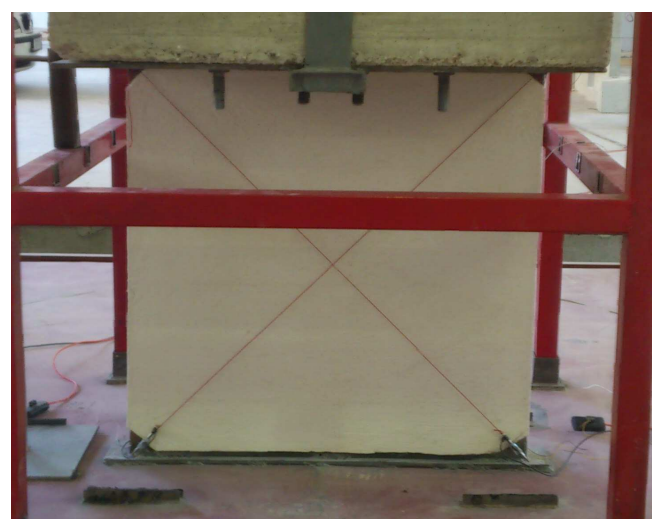

SF-2

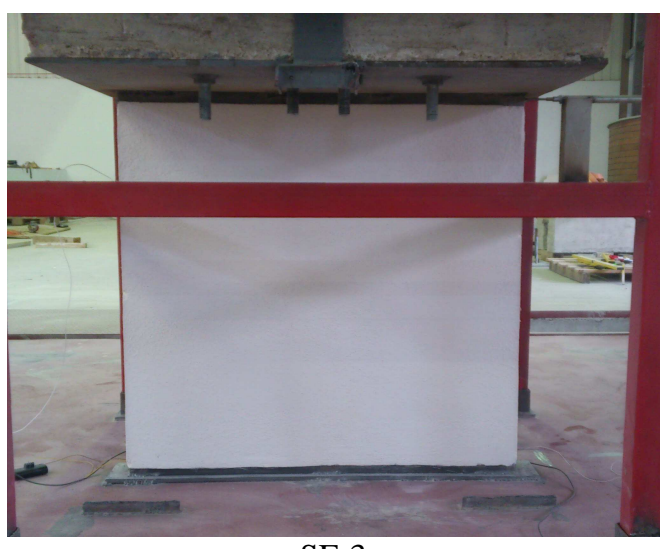

SF-3

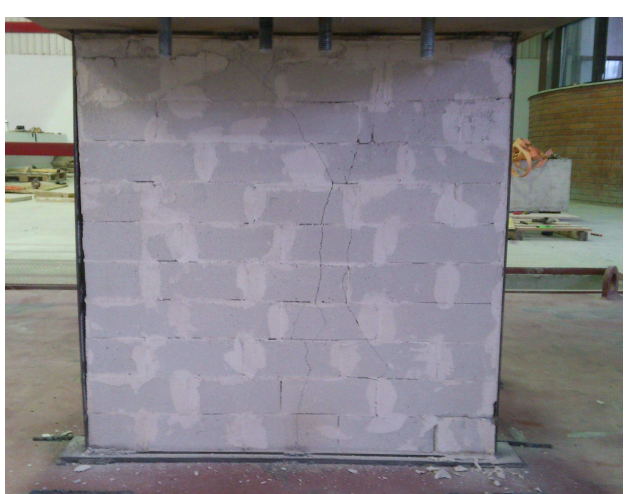

WF-1

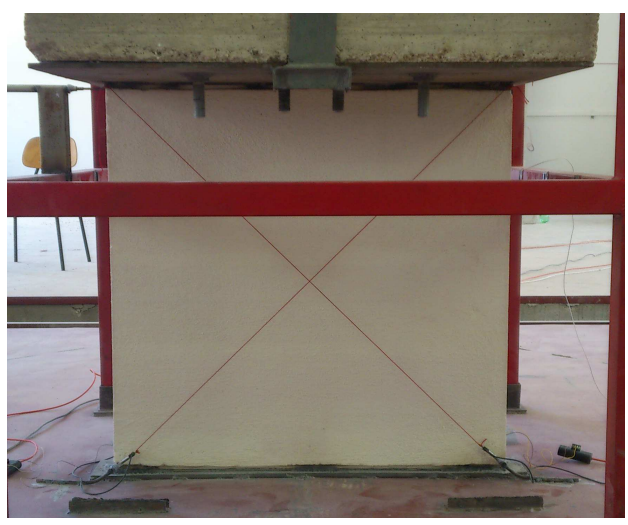

WF-2

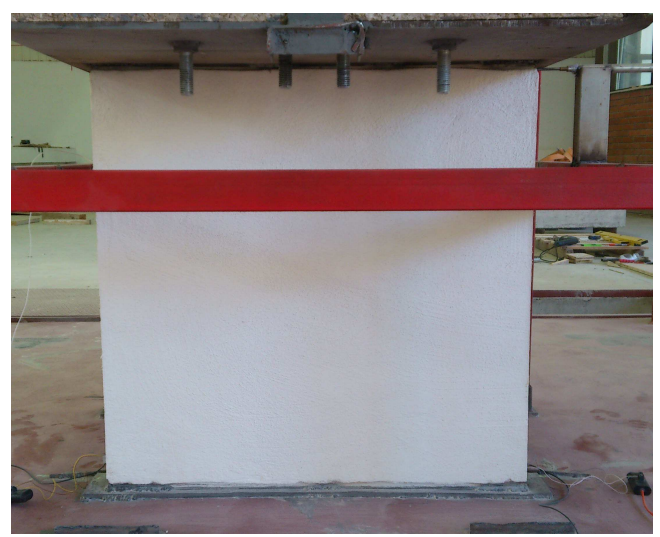

WF-3

(ii) Meki okvir (WF)

Slika 3.41. Konačno stanje deformacija i pukotina u ziđu za sve uzorke nakon završetka ispitivanja na potresnoj platformi 
Izmjerene vrijednosti vlastitih frekvencija i prvih perioda prikazane su u Tablici 3.1.i 3.2. Vlastita frekvencija sustava određena je prije ispitivanja, te nakon izlaganja uzorka setu pobuda AA1 i potresa Petrovac.

Tablica 3.1. Vlastite frekvencije sustava

\begin{tabular}{lllllll}
\hline Frekvencija $(\mathrm{Hz})$ & \multicolumn{7}{l}{ Uzorak } & \multicolumn{7}{l}{} \\
\cline { 2 - 7 } & SF-1 & SF-2 & SF-3 & WF-1 & WF-2 & WF-3 \\
\hline početni & 9.20 & 9.76 & 9.57 & 6.84 & 9.37 & 8.80 \\
nakon "AA1" & 8.79 & 9.40 & 9.18 & 3.70 & 4.88 & 8.00 \\
nakon "Petrovac" & 8.78 & 8.98 & 8.59 & 2.93 & 1.76 & 5.60 \\
\hline
\end{tabular}

Tablica 3.2. Prvi periodi sustava

\begin{tabular}{lllllll}
\hline Period (s) & \multicolumn{7}{l}{ Uzorak } & & & & \\
\cline { 2 - 7 } & SF-1 & SF-2 & SF-3 & WF-1 & WF-2 & WF-3 \\
\hline početni & 0.11 & 0.10 & 0.10 & 0.15 & 0.11 & 0.11 \\
nakon "AA1" & 0.11 & 0.11 & 0.11 & 0.27 & 0.20 & 0.13 \\
nakon "Petrovac" & 0.11 & 0.11 & 0.12 & 0.34 & 0.57 & 0.18 \\
\hline
\end{tabular}

Temeljem uvida u prikazane rezultate može se primijetiti da kruti okvir ne mijenjaju značajno vlastitu frekvenciju sustava, tj. nakon izlaganja krutih okvira umjetnom akcelerogramu AA1 te potresu Petrovac njihova krutost se ne mijenja značajno. Kod mekih okvira dolazi do značajnog pada vlastite frekvencije sustava, što je uzrokovano redukcijom krutosti ispitanih uzoraka. Pri tome najveću redukciju imaju okviri WF-1 i WF-2, dok je kod uzorka WF-3 redukcija manja, što je u skladu s zaključcima iznesenim pomoću dijagrama na Slikama 3.35-3.40. 


\subsection{Dinamička ispitivanja betonskih okvira sa zidanom ispunom}

\subsubsection{Opis modela}

Ispitani su dvoetažni jednopoljni armiranobetonski okviri sa zidanom ispunom na potresnoj platformi. Ispitni uzorci izrađeni su u umanjenom mjerilu (1:4). Razmatrane su sljedeće varijante okvira s ispunom: (i) okvir bez ispune (BF), (ii) okvir s fleksibilnim prizemljem (FF1), (iii) okvir s fleksibilnim katom (FF2), (iv) okvir s manjim otvorom u ispuni na obje etaže (PF1), (v) okvir s većim otvorom u ispuni na obje etaže (PF2), te (vi) potpuno ispunjeni okvir (IF). Shematski prikaz razmatranih okvira s pripadajućim oznakama prikazan je na Slici 3.42.
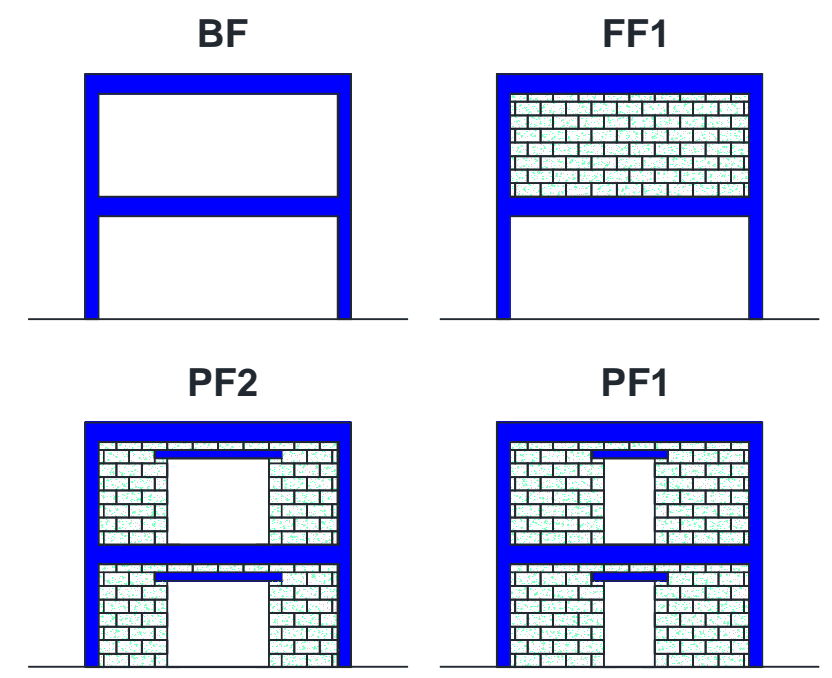

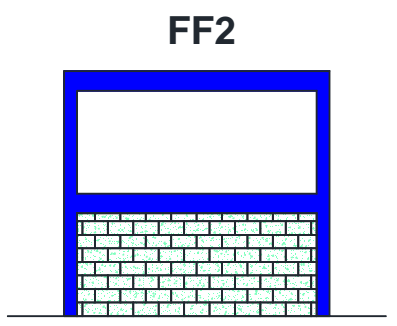

IF
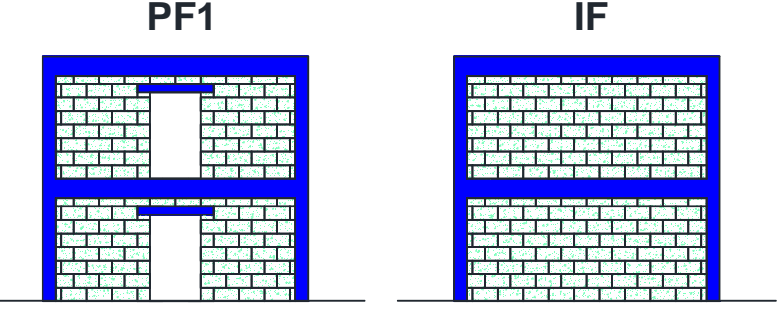

Slika 3.42. Shematski prikaz uzoraka betonskih okvira sa zidanom ispunom

Osnovni geometrijski podaci o ispitanim uzorcima prikazani su na Slici 3.43. Betonski okviri su visine $1500 \mathrm{~mm}$, dužine $1660 \mathrm{~mm}$, te debljine $80 \mathrm{~mm}$. Uzdužnu armaturu u stupovima i gredama okvira čine rebraste čelične šipke promjera $\Phi 8 \mathrm{~mm}$, dok je poprečna armatura izrađena od spiralno namotane čelične žice promjera $\Phi 2 \mathrm{~mm}$ na razmaku od $30 \mathrm{~mm}$. Uzorci su izrađeni od realnih materijala, s realnim načinom izvedbe. Svi okviri su izrađeni od samozbijajućeg betona s maksimalnim zrnom agregata $\mathrm{D}=8 \mathrm{~mm}$. Okviri su ispunjeni ziđem od laganog porastog betona (gustoće oko $450 \mathrm{~kg} / \mathrm{m}^{3}$ ). Zidni elementi su također izrađeni u umanjenoj veličini (1:4). Zidanje je vršeno upotrebom bijelog tankoslojnog morta za zidove od porastog betona. Svi okviri su ukliješteni u podlogu. 


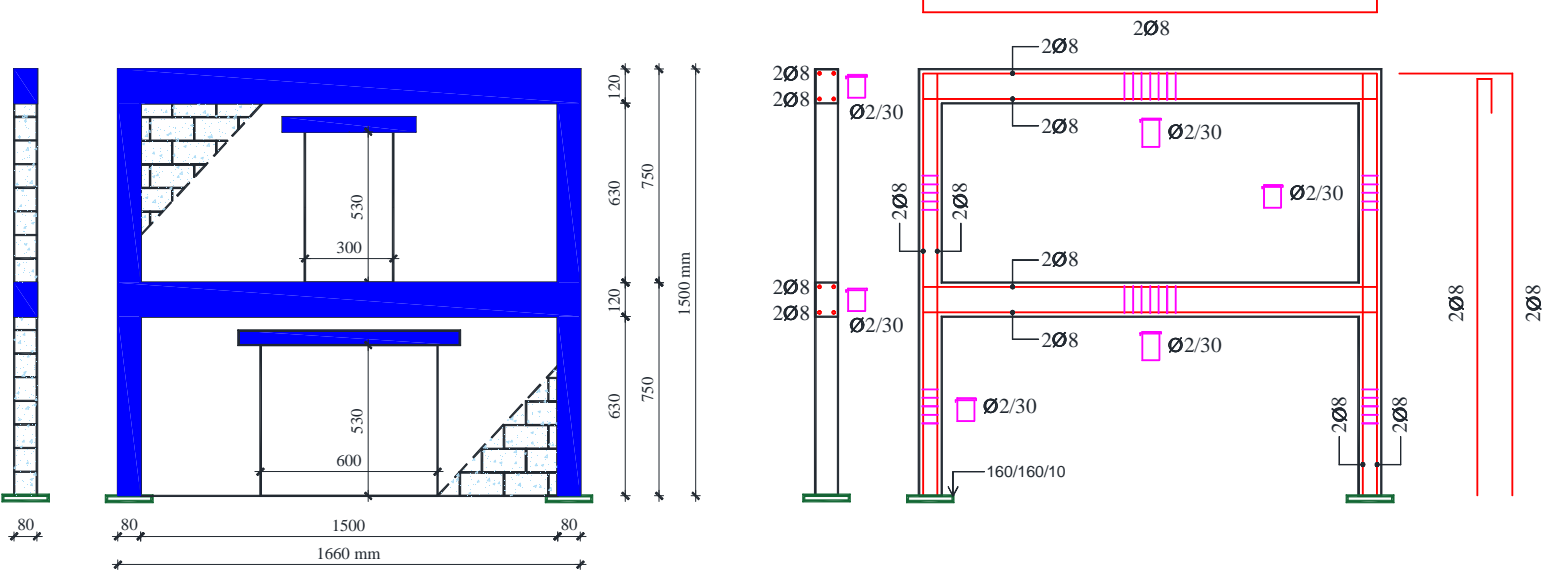

Slika 3.43. Osnovni geometrijski podaci o ispitanim uzorcima

Svi okviri su opterećeni stalnim vertikalnim opterećenjem iznosa $3.0 \mathrm{kN} / \mathrm{m}^{1}$ na svakoj etaži, te izloženi djelovanju horizontalne komponente ubrzanja podloge. Za simulaciju vertikalnog opterećenja korišteni su betonski blokovi dimenzija $25 \times 25 \times 25 \mathrm{~cm}$, postavljeni s obje strane grede okvira. Blokovi su međusobno pritegnuti uz gredu i prenose vertikalnu silu isključivo preko dodirne plohe (trenja). Fotografija uzorka prije ispitivanja prikazana je na Slici 3.44.

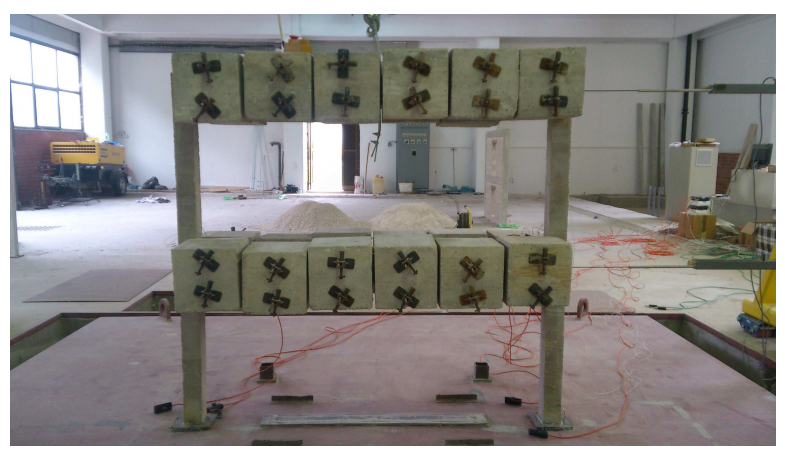

a) Pogled sprijeda

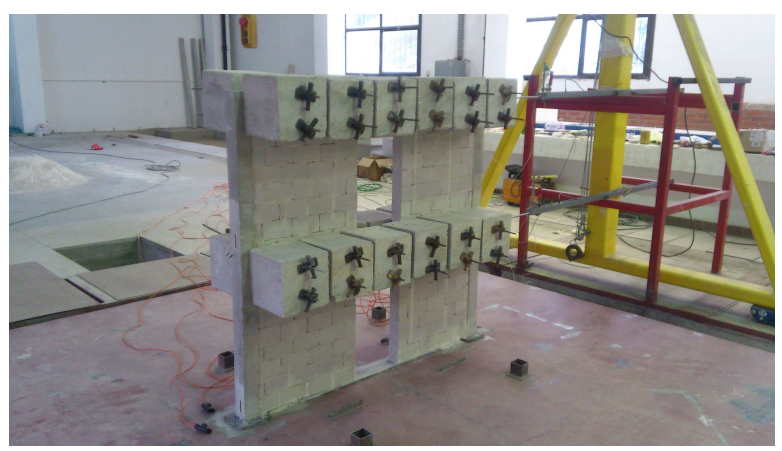

b) Bočni pogled

Slika 3.44. Fotografija pripremljenog uzorka za ispitivanje na potresnoj platformi

Ispitani okviri su izloženi horizontalnoj komponenti ubrzanja dvaju umjetnih akcelerograma AA1 i AA2, opisanih u Točki 3.3. Najprije je apliciran niz od ukupno 8 pobuda izvedenih iz akcelerograma AA1, sa sukcesivno povećavanom maksimalnom amplitudom ubrzanja $\mathrm{a}_{\mathrm{g}, \max }=\mathrm{n} \times 0.1 \mathrm{~g} ; \mathrm{n}=1-8$. Potom je apliciran niz od 4 pobude izvedene iz akcelerograma AA2, kojima je maksimalna amplituda također sukcesivno povećavana $\mathrm{a}_{\mathrm{g}, \max }=$ $\mathrm{n} \times 0.1 \mathrm{~g} ; \mathrm{n}=1-4$. 
Za svaku apliciranu dinamičku pobudu mjerene su mehaničke veličine prikazane na Slici 3.45. Kod toga su praćeni horizontalni pomak vrha donje etaže, horizontalni pomak vrha gornje etaže, horizontalno ubrzanje vrha donje etaže, horizontalno ubrzanje vrha gornje etaže, deformacije u armaturi pri dnu stupa gornje etaže (točka A), deformacije u armaturi pri dnu stupa donje etaže (točke B i C), deformacije u betonu pri dnu stupa donje etaže (točke D i F), deformacije u betonu pri dnu stupa gornje etaže (točke E i G), te stanje pukotina u ispuni i okviru tijekom vremena. Pri tome se napominje kako su prikazane vrijednosti pomaka i ubrzanja okvira relativne u odnosu na njegovu bazu (platformu).

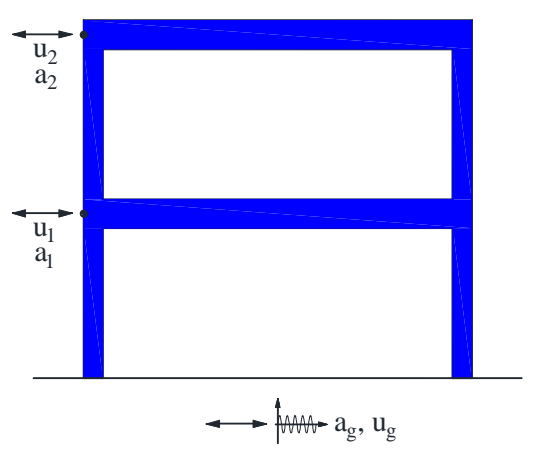

(i) Pomaci i ubrzanja

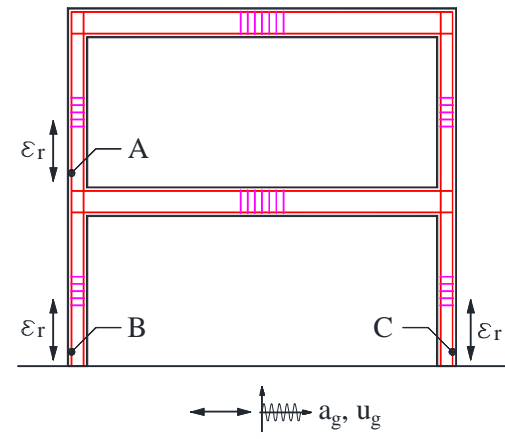

(ii) Deformacije armature

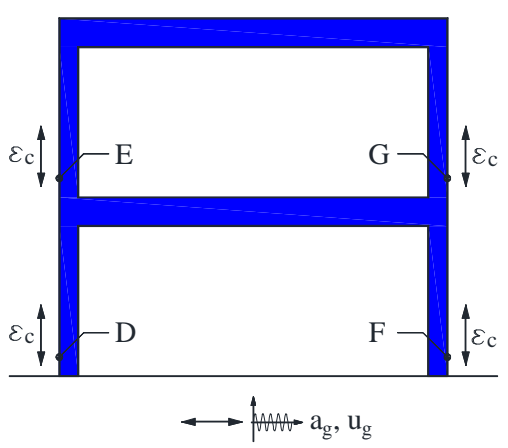

(iii)Deformacije betona

Slika 3.45. Prikaz mjernih mjesta i mjerenih veličina

\subsubsection{Rezultati ispitivanja}

U nastavku su odvojeno prikazani rezultati za umjetni akcelerogram AA1 i umjetni akcelerogram AA2. Istovremeno su prikazani rezultati za sve ispitane okvire, u ovisnosti o apliciranoj pobudi. Pri valorizaciji ovih rezultata treba također imati na umu da je kod nekih uzoraka došlo do trajnih (nepovratnih) pomaka i deformacija uslijed djelovanja prethodno apliciranih pobuda. 


\subsubsection{Rezultati za umjetni akcelerogram AA1}

Horizontalni pomaci vrha gornje etaže okvira $\left(\mathrm{u}_{2}\right)$ u vremenu prikazani su na Slikama 3.46 i 3.47. Može se primijetiti da okviri BF, FF1 i FF2 imaju značajno veće pomake u odnosu na okvire PF2, PF1 i IF. Pri djelovanju umjetnog akcelerograma s maksimalnim ubrzanjem $\mathrm{a}_{\mathrm{g}, \max }=0.8 \mathrm{~g}$, najveći pomaci za okvire BF, FF1 i FF2 iznosili su 16.5, 11.2 i 5 mm. Pri djelovanju istog akcelerograma, najveći pomaci kod okvira PF2, PF1 i IF iznosili su 2.8, 2.3 i $1.6 \mathrm{~mm}$. Usporedbom vrijednosti pomaka na prikazanim dijagramima, može se primijetiti da najveće pomake ima okvir bez ispune BF, dok okvir s fleksibilnim prizemljem FF1 ima nešto manje pomake. Kod okvira s fleksibilnim katom FF2, vrijednosti pomaka vrha gornje etaže su oko 3 puta manje nego kod okvira bez ispune BF. Kod okvira PF2, PF1 i IF, vidljiv je utjecaj otvora $u$ ispuni na veličinu pomaka. Najveće pomake imao je okvir sa širim otvorom u ispuni PF2, dok je najmanje pomake imao potpuno ispunjeni okvir IF.

Horizontalni pomaci vrha donje etaže okvira $\left(\mathrm{u}_{1}\right) \mathrm{u}$ vremenu prikazani su na Slikama 3.48 i 3.49. Može se primijetiti da najveće pomake ima okvir s fleksibilnim prizemljem FF1, dok okvir bez ispune BF ima nešto manje pomake. Okvir s fleksibilnim katom FF2 ima značajno manje pomake u odnosu na okvire BF i FF1. Pri djelovanju umjetnog akcelerograma $\mathrm{s}$ maksimalnim ubrzanjem $\mathrm{a}_{\mathrm{g}, \max }=0.8 \mathrm{~g}$, najveći pomaci za okvire BF, FF1 i FF2 iznosili su 9.8, 11.4 i $2.2 \mathrm{~mm}$. Kod okvira PF2, PF1 i IF, pomaci vrha donje etaže su podjednaki, te se kreću oko $2 \mathrm{~mm}$.

Usporedbom dijagrama na Slikama 3.46-3.49 može se primijetiti da su pomaci vrha gornje etaže okvira veći u odnosu na pomake vrha donje etaže okvira. Kod okvira s fleksibilnim prizemljem FF1, pomaci vrha gornje i donje etaže su podjednaki. Ovaj efekt je rezultat položaja ispune na njegovoj gornjoj etaži koja ukrućuje okvir na tom mjestu, te se cijela etaža giba kao kruto tijelo. Kod okvira s fleksibilnim katom FF2, pomaci vrha donje etaže su značajno manji u odnosu na pomake vrha gornje etaže. Manji pomaci su posljedica položaja ispune na donjoj etaži (u prizemlju). Kod okvira PF2, PF1 i IF ovaj efekt nije značajno izražen zbog velike krutosti konstrukcije.

Usporedbom dijagrama na Slikama 3.46-3.49, može se primijetiti da su pomaci etaža kod okvira PF2, PF1 i IF značajno manji nego kod okvira BF, FF1 i FF2. Vidljivo je da ispuna doprinosi okviru povećanjem krutosti i nosivosti sustava. Ovo rezultira povoljnijim naponsko-deformacijskim stanjem okvira koji imaju ispunu na svim etažama (bez i s otvorima u ispuni) nego kod okvira bez ispune i okvira s fleksibilnim etažama. 
Horizontalna ubrzanja vrhova etaža prikazana su na Slikama 3.50-3.53. Može se primijetiti da su ubrzanja podjednaka kod svih ispitanih uzoraka.

Deformacije armature pri dnu stupa gornje etaže (točka A) u vremenu prikazane su na Slikama 3.54 i 3.55. One su najveće za okvir s fleksibilnim katom FF2. Pri djelovanju akcelerograma s maksimalnim ubrzanjem $\mathrm{a}_{\mathrm{g}, \max }=0.8 \mathrm{~g}$, najveće deformacije armature $\mathrm{za}$ okvire BF, FF1 i FF2 iznosile su 1.4, 0.9 i 1.2 \%o. Okviri PF2, PF1 i IF imaju značajno manje deformacije armature.

Deformacije armature pri dnu stupa donje etaže (točka B) u vremenu prikazane su na Slikama 3.56 i 3.57. Najveće deformacije imao je okvir s fleksibilnim prizemljem FF1. Pri djelovanju akcelerograma s maksimalnim ubrzanjem $\mathrm{a}_{\mathrm{g}, \max }=0.8 \mathrm{~g}$, one se kreću i do $2.5 \%$. Obzirom da je granica tečenja čelika $\pm 2.5 \%$, očito je da dolazi do pojave tečenja u armaturi. Okvir bez ispune BF ima nešto manje deformacije u odnosu na okvir FF1. Okvir s fleksibilnim katom FF2 ima značajno manje deformacije armature, zbog utjecaja ispune na donjoj etaži. Kod okvira PF2, PF1 i IF, one su također male. Pri tome su najveće kod okvira sa širim otvorom u ispuni PF2, a najmanje kod potpuno ispunjenog okvira IF. Deformacije armature pri dnu stupa donje etaže (točka C) u vremenu prikazane su na Slikama 3.58 i 3.59. One su kompatibilne s deformacijama prikazanim na Slikama 3.56 i 3.57. Pri djelovanju akcelerograma s maksimalnim ubrzanjem $\mathrm{a}_{\mathrm{g}, \max }=0.8 \mathrm{~g}$, deformacije dostižu i vrijednost od 3 \%o za slučaj okvira s fleksibilnim prizemljem FF1. Deformacije armature u točki C su nešto veće od onih u točki B, što je posljedica karaktera pobude.

Deformacije betona pri dnu stupa donje etaže (točka D) u vremenu prikazane su na Slikama 3.60 i 3.61. One su kompatibilne s deformacijama armature pri dnu stupa donje etaže u točki B. Najveće deformacije betona pokazivao je okvir s fleksibilnim prizemljem FF1, dok je okvir bez ispune BF imao nešto manje deformacije. Okvir s fleksibilnim katom FF2 imao je značajno manje deformacije betona. Pri djelovanju umjetnog akcelerograma s maksimalnim ubrzanjem $\mathrm{a}_{\mathrm{g} \text {,max }}=0.8 \mathrm{~g}$, najveće deformacije betona za okvire BF, FF1 i FF2 iznosile su -1.1, -1.3 i $0.1 \%$. Kod okvira BF i FF1, one su pretežito tlačne. Okviri PF2, PF1 i IF imali su vrlo male, podjednake deformacije, do $0.08 \%$.

Deformacije betona pri dnu stupa gornje etaže (točka E) u vremenu prikazane su na Slikama 3.62 i 3.63. One su kompatibilne s deformacijama armature pri dnu stupa gornje etaže u točki A. Najveće deformacije betona pokazivao je okvir s fleksibilnim katom FF2, dok su okviri BF i FF1 imali značajno manje deformacije. Pri djelovanju umjetnog akcelerograma $\mathrm{s}$ maksimalnim ubrzanjem $\mathrm{a}_{\mathrm{g}, \max }=0.8 \mathrm{~g}$, najveće deformacije betona za okvire BF, FF1 i FF2 iznosile su -0.3, 0.2 i $-1.2 \%$ o.Okviri PF2, PF1 i IF imali su značajno manje deformacije. 
Najveće deformacije imao je okvir s širim otvorom u ispuni PF2, do -0.16 \%o. Analogno deformacijama u točki D, deformacije armature u točki E su pretežito tlačne, što je posljedica karaktera pobude.

Deformacije betona pri dnu stupa donje etaže (točka F) u vremenu prikazane su na Slikama 3.64 i 3.65. One su kompatibilne s deformacijama betona pri dnu stupa donje etaže u točki D. Njihove vrijednosti su nešto manje od onih u točki D. Najveće deformacije su pokazivali okviri BF i FF1. Pri djelovanju umjetnog akcelerograma s maksimalnim ubrzanjem $\mathrm{a}_{\mathrm{g}, \max }=0.8 \mathrm{~g}$, najveće deformacije betona za okvire BF i FF1 iznosile su -1.0 i -0.86\%o. Kod okvira FF2, te okvira PF2, PF1 i IF, deformacije betona u točki F su bile značajno manje. Pri djelovanju umjetnog akcelerograma s maksimalnim ubrzanjem $\mathrm{a}_{\mathrm{g}, \max }=0.8 \mathrm{~g}$, one su dostizale vrijednost $\pm 0.06 \%$.

Deformacije betona pri dnu stupa gornje etaže (točka $G$ ) u vremenu prikazane su na Slikama 3.66 i 3.67. One su također kompatibilne s deformacijama betona pri dnu stupa gornje etaže u točki E. Njihove vrijednosti su nešto manje od onih u točki E. Dakle, najveće deformacije imao je okvir s fleksibilnim katom FF2. Nešto manje deformacije imali su okviri BF i FF1, dok su okviri PF2, PF1 i IF imali značajno manje deformacije. Pri djelovanju umjetnog akcelerograma s maksimalnim ubrzanjem $\mathrm{a}_{\mathrm{g}, \max }=0.8 \mathrm{~g}$, najveće deformacije betona za okvire BF, FF1 i FF2 iznosile su $-0.23,-0.23$ i $0.55 \%$, dok su za okvire PF2, PF1 i IF bile ispod $0.05 \%$.

Usporedbom vrijednosti pomaka, ubrzanja i deformacija na Slikama 3.46-3.67, može se primijetiti da povećanjem maksimalnog ubrzanja podloge $a_{g, m a x}$ dolazi do povećanja pomaka $\mathrm{i}$ ubrzanja vrhova etaža okvira, te povećanja deformacija armature i betona pri dnu stupova okvira. Ovaj efekt je više izražen za slučajeve okvira bez ispune BF i okvira s fleksibilnim etažama FF1 i FF2, a manje za potpuno ispunjene okvire IF i okvire s otvorima u ispuni PF1 i PF2. 

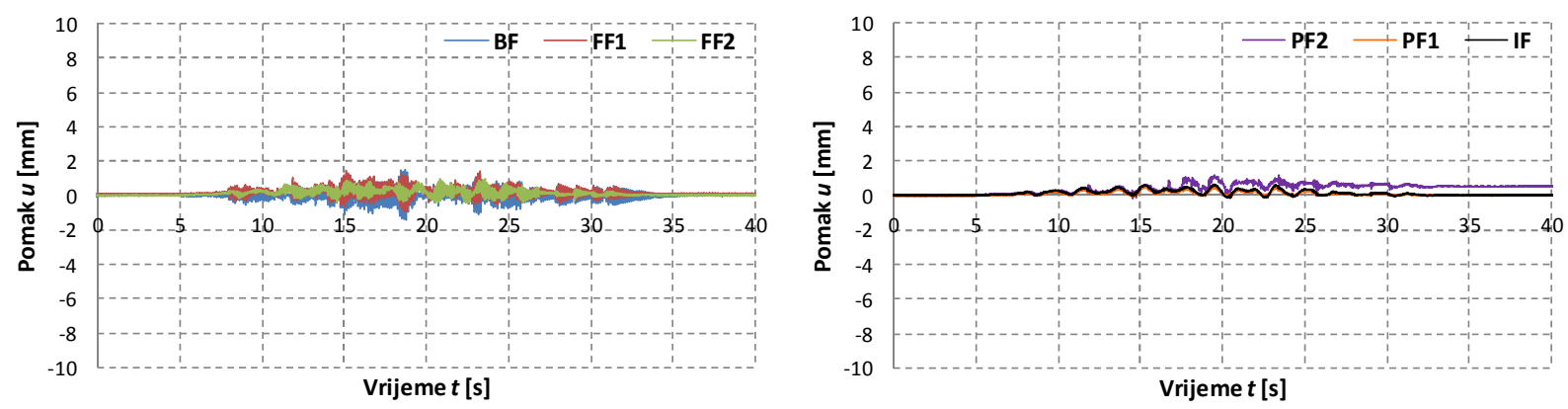

a) $\mathrm{a}_{\mathrm{g}, \max }=0.1 \mathrm{~g}$
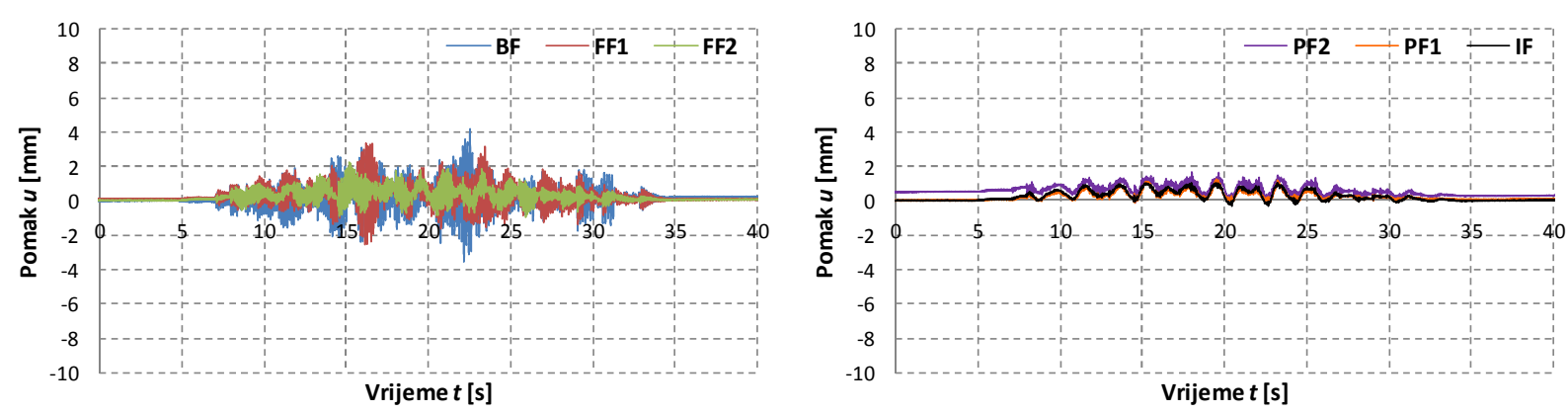

b) $\mathrm{a}_{\mathrm{g}, \max }=0.2 \mathrm{~g}$
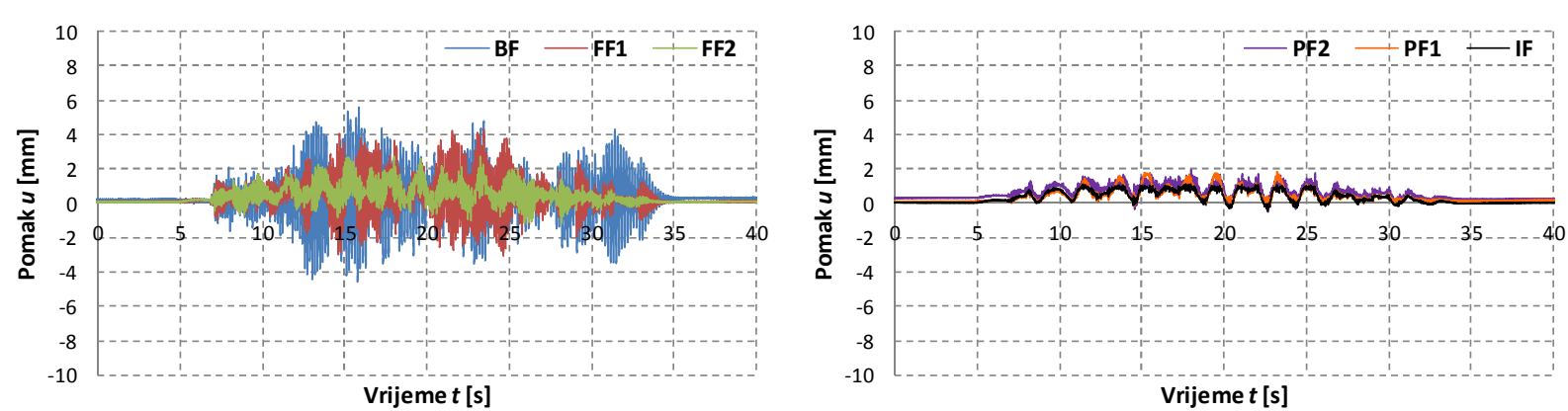

c) $\mathrm{a}_{\mathrm{g}, \max }=0.3 \mathrm{~g}$
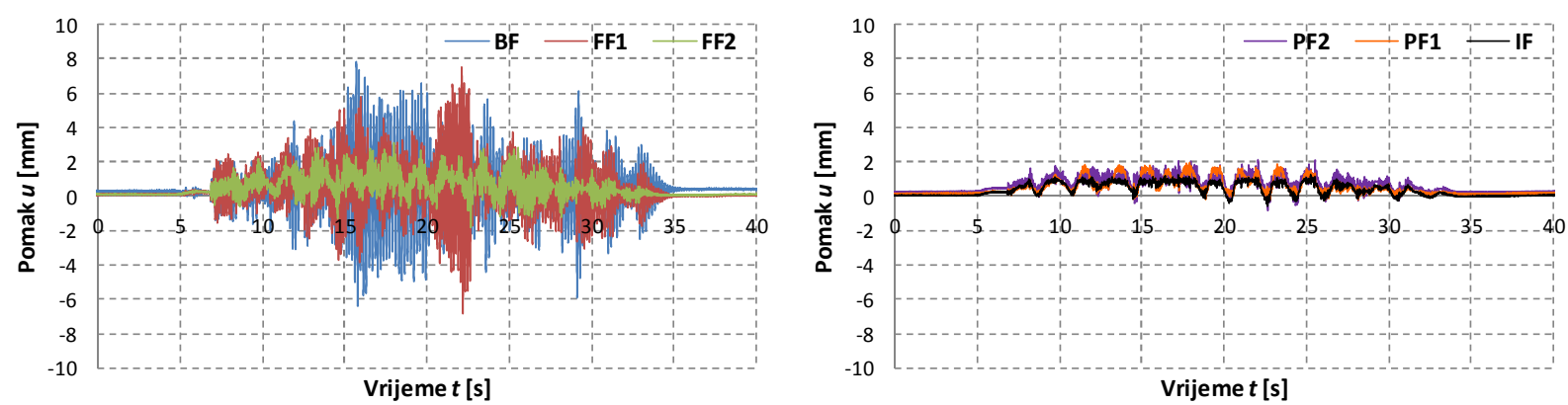

d) $\mathrm{a}_{\mathrm{g}, \max }=0.4 \mathrm{~g}$

Slika 3.46. Horizontalni pomak vrha gornje etaže okvira $\left(u_{2}\right)$ u vremenu za umjetni akcelerogram AA1 s maksimalnim ubrzanjem $\mathrm{a}_{\mathrm{g}, \max }=0.1,0.2,0.3 \mathrm{i} 0.4 \mathrm{~g}$ 

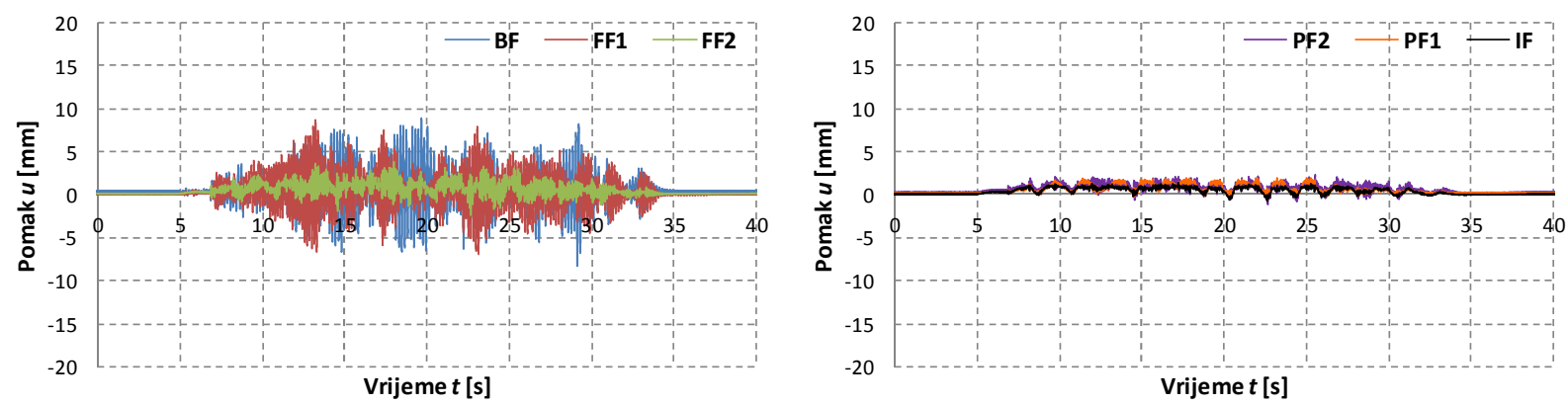

a) $a_{g, \max }=0.5 \mathrm{~g}$
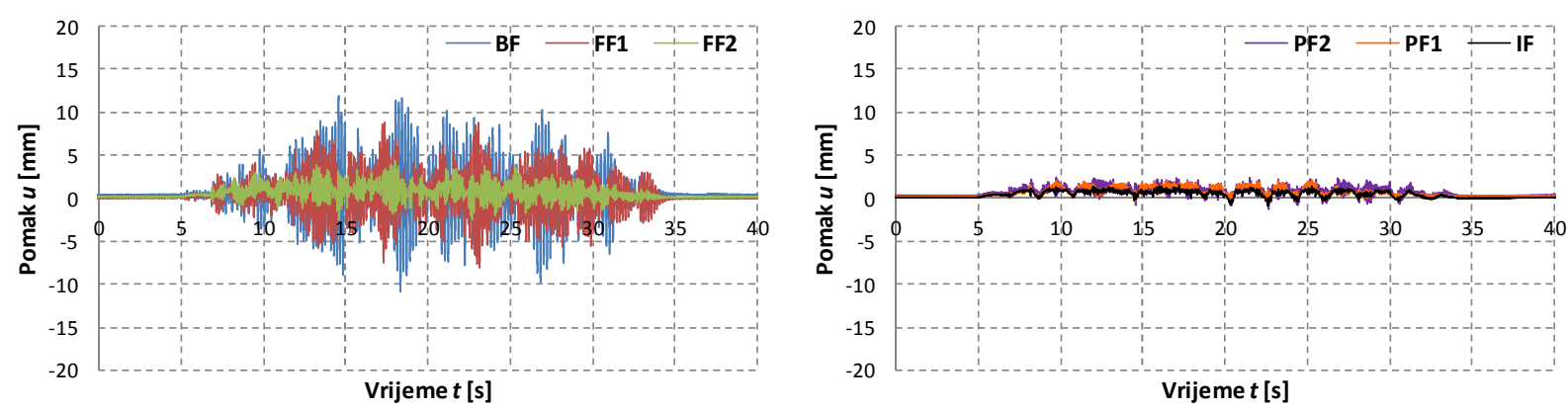

b) $\mathrm{a}_{\mathrm{g}, \max }=0.6 \mathrm{~g}$
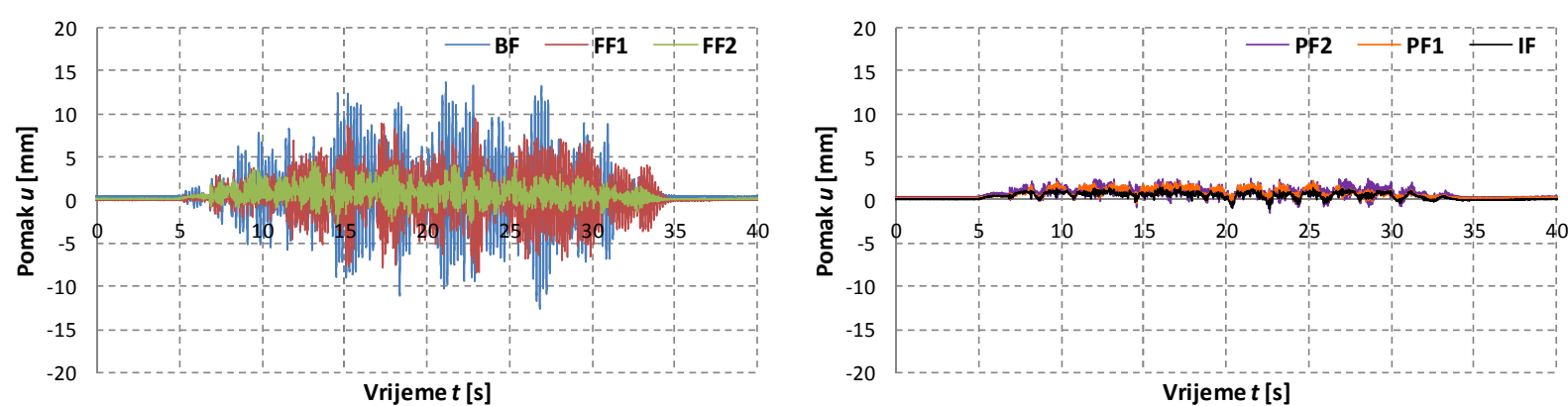

c) $\mathrm{a}_{\mathrm{g}, \max }=0.7 \mathrm{~g}$
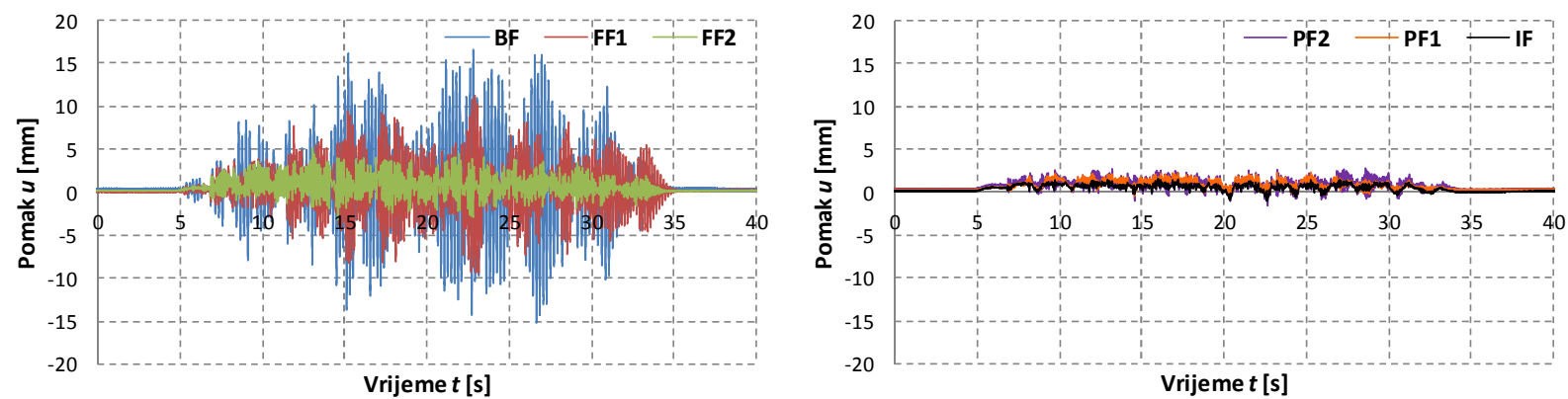

d) $\mathrm{a}_{\mathrm{g}, \max }=0.8 \mathrm{~g}$

Slika 3.47. Horizontalni pomak vrha gornje etaže okvira $\left(u_{2}\right)$ u vremenu za umjetni akcelerogram AA1 s maksimalnim ubrzanjem $\mathrm{a}_{\mathrm{g}, \max }=0.5,0.6,0.7 \mathrm{i} 0.8 \mathrm{~g}$ 

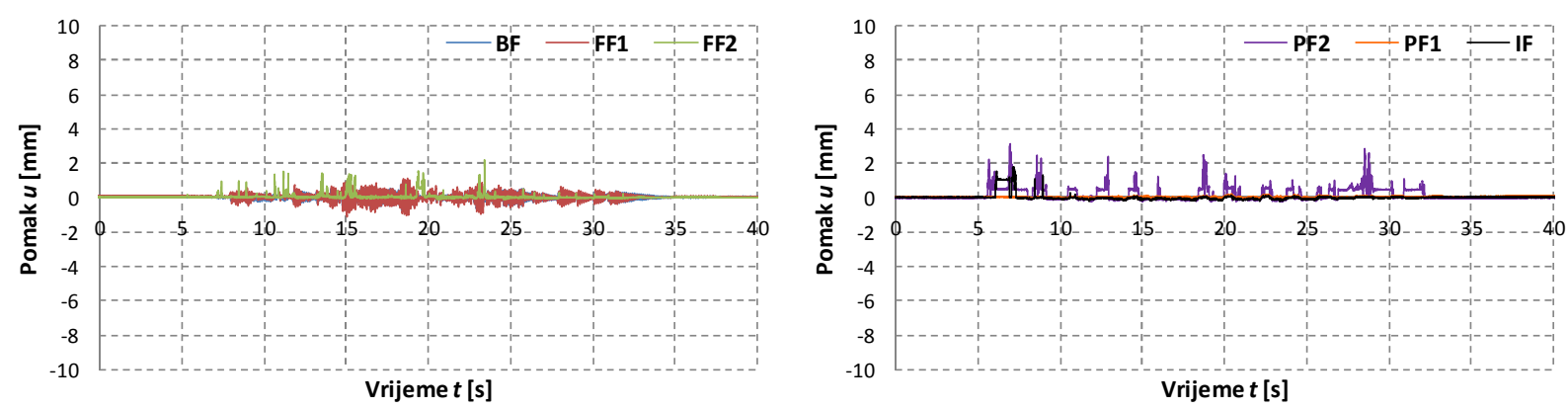

a) $\mathrm{a}_{\mathrm{g}, \max }=0.1 \mathrm{~g}$
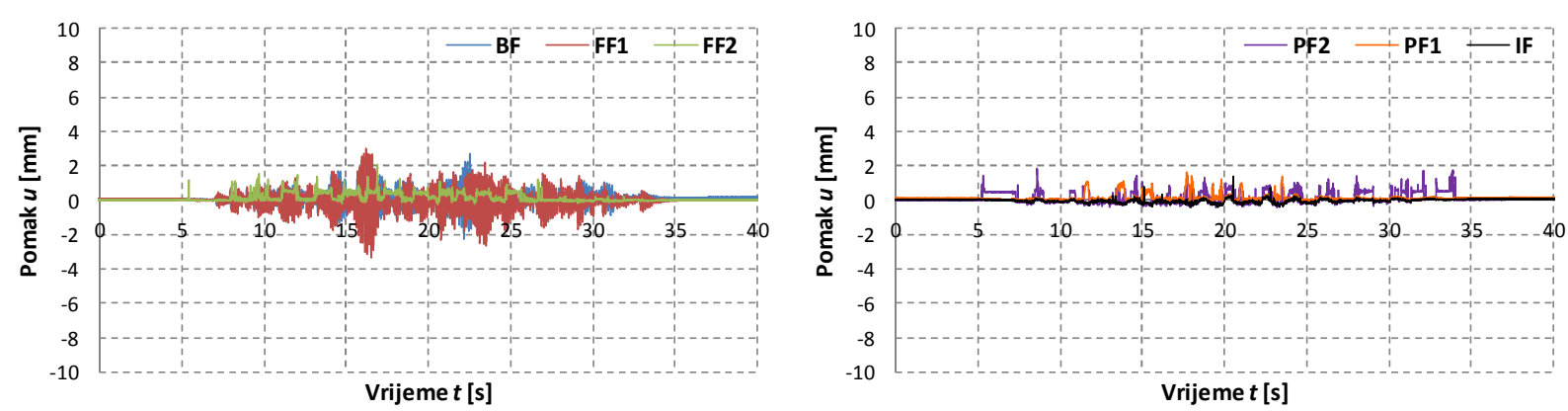

b) $\mathrm{a}_{\mathrm{g}, \max }=0.2 \mathrm{~g}$
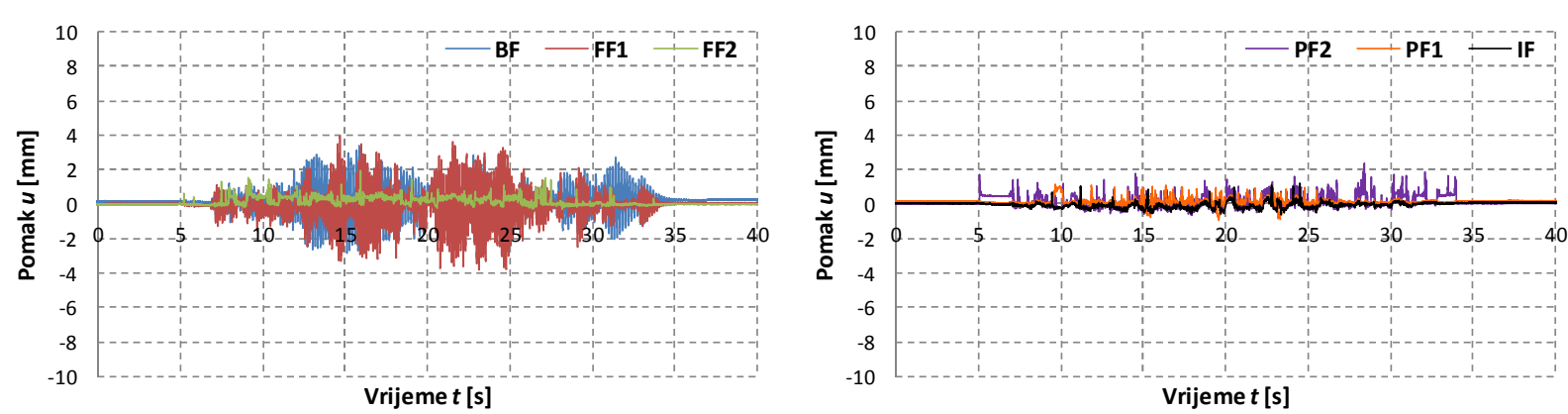

c) $\mathrm{a}_{\mathrm{g}, \max }=0.3 \mathrm{~g}$
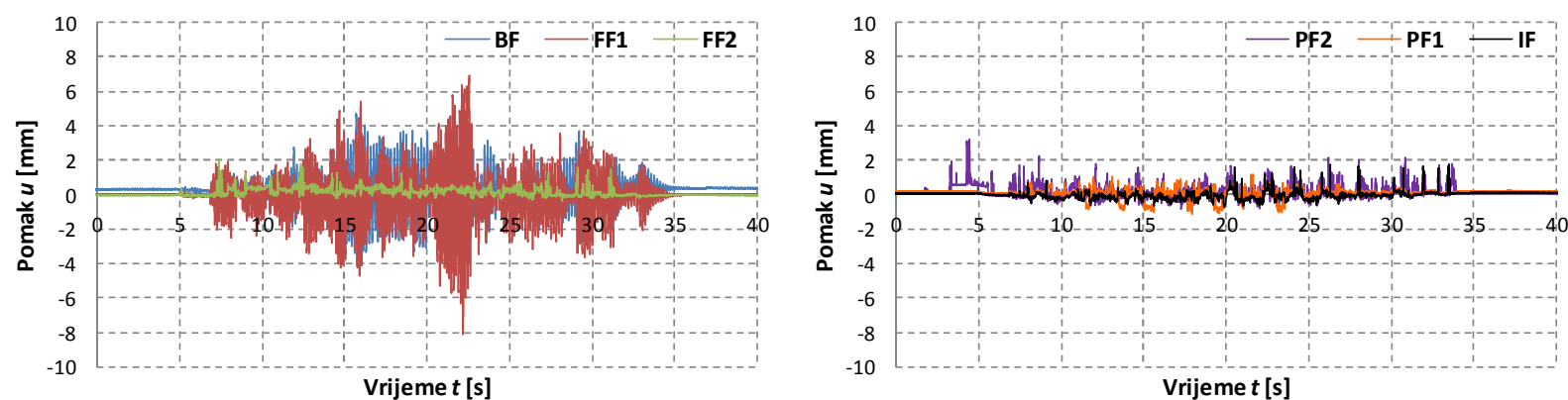

d) $\mathrm{a}_{\mathrm{g}, \max }=0.4 \mathrm{~g}$

Slika 3.48. Horizontalni pomak vrha donje etaže okvira $\left(u_{1}\right)$ u vremenu za umjetni akcelerogram AA1 s maksimalnim ubrzanjem $a_{g, \max }=0.1,0.2,0.3$ i $0.4 \mathrm{~g}$ 

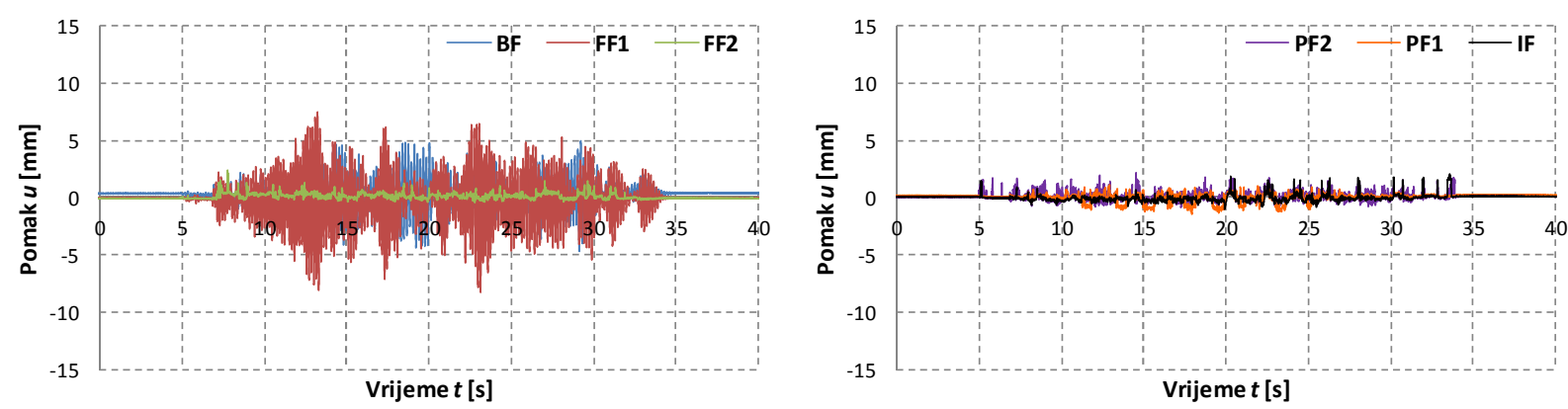

a) $\mathrm{a}_{\mathrm{g}, \max }=0.5 \mathrm{~g}$
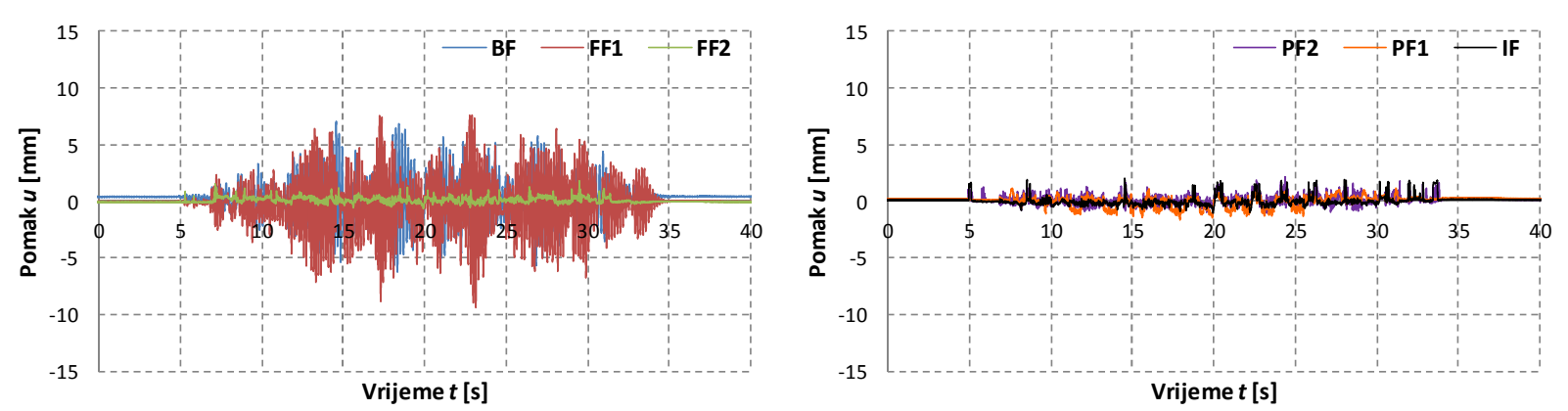

b) $\mathrm{a}_{\mathrm{g}, \max }=0.6 \mathrm{~g}$
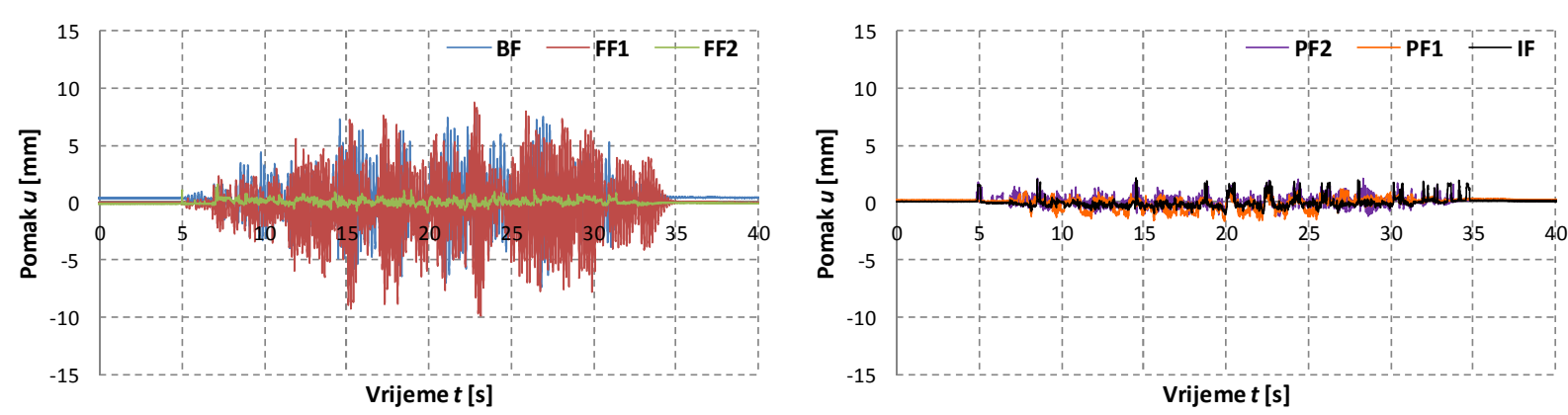

c) $\mathrm{a}_{\mathrm{g}, \max }=0.7 \mathrm{~g}$
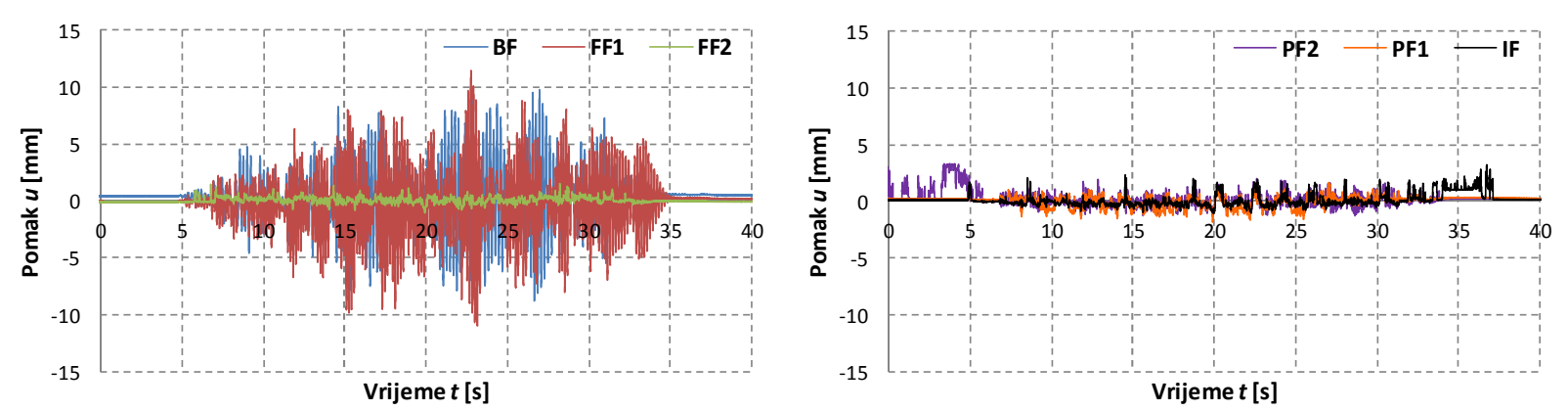

d) $\mathrm{a}_{\mathrm{g}, \max }=0.8 \mathrm{~g}$

Slika 3.49. Horizontalni pomak vrha donje etaže okvira $\left(u_{1}\right)$ u vremenu za umjetni akcelerogram AA1 s maksimalnim ubrzanjem $\mathrm{a}_{\mathrm{g}, \max }=0.5,0.6,0.7 \mathrm{i} 0.8 \mathrm{~g}$ 

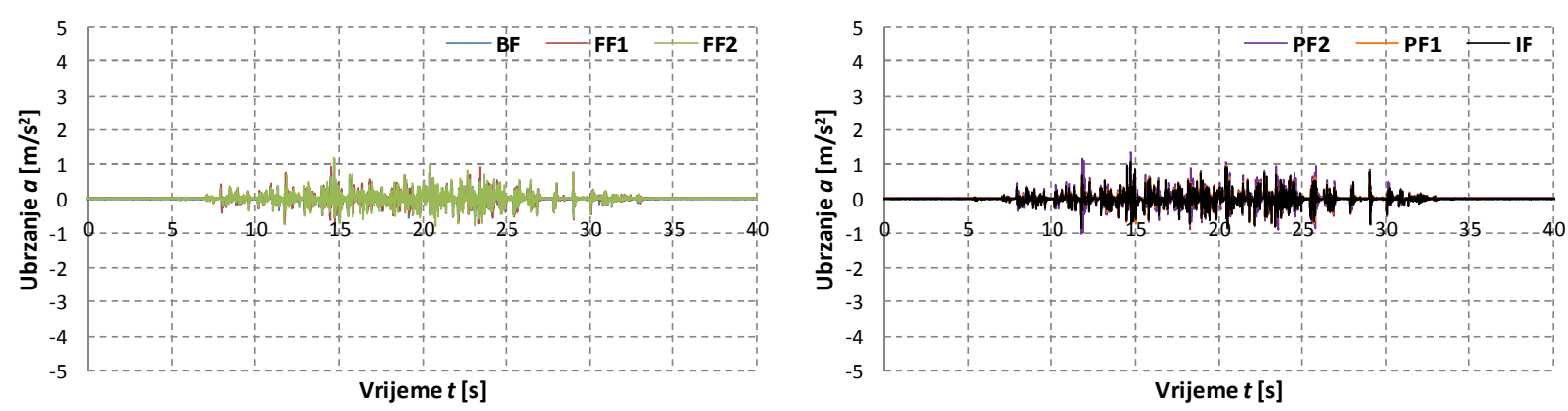

a) $\mathrm{a}_{\mathrm{g}, \max }=0.1 \mathrm{~g}$
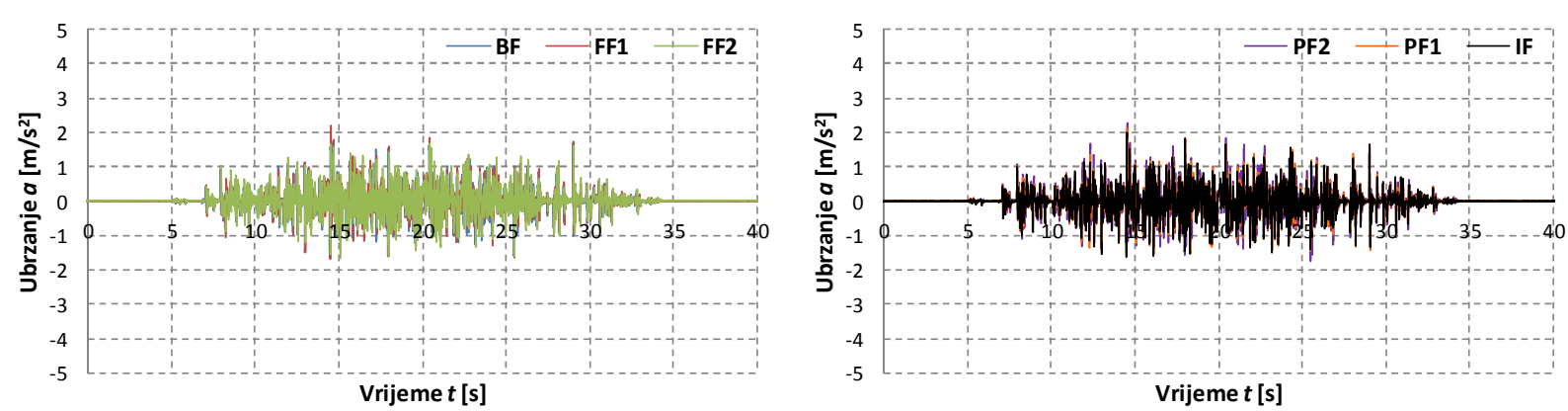

b) $\mathrm{a}_{\mathrm{g}, \max }=0.2 \mathrm{~g}$
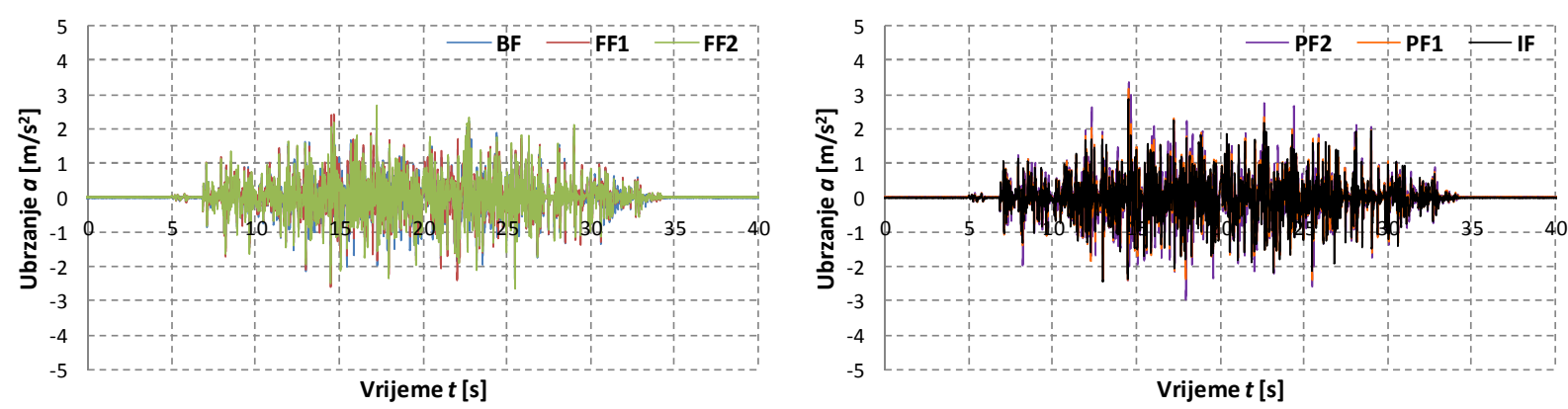

c) $\mathrm{a}_{\mathrm{g}, \max }=0.3 \mathrm{~g}$
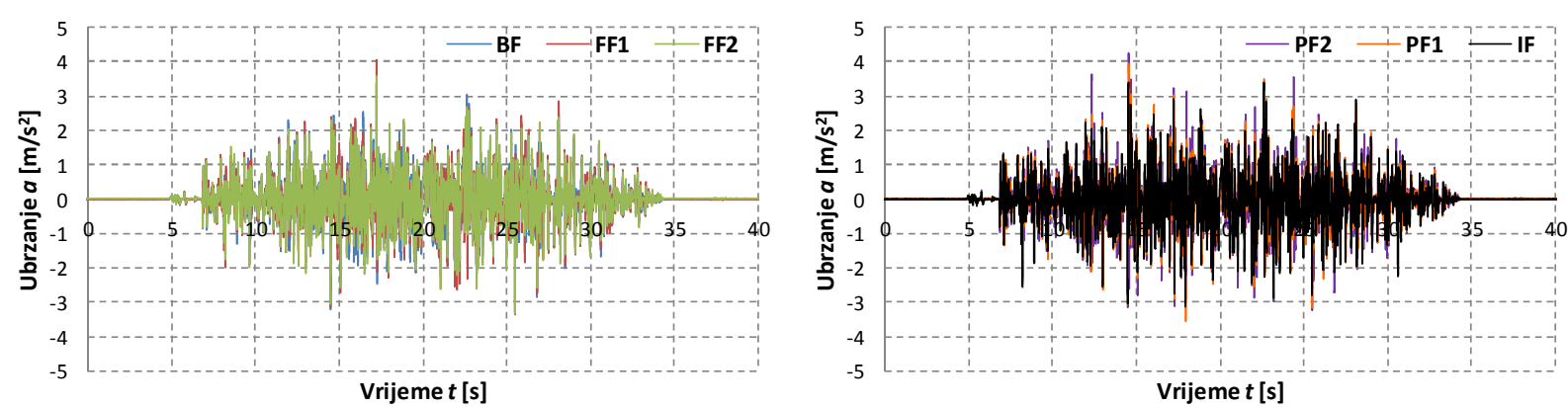

d) $\mathrm{a}_{\mathrm{g}, \max }=0.4 \mathrm{~g}$

Slika 3.50. Horizontalno ubrzanje vrha gornje etaže okvira $\left(a_{2}\right)$ u vremenu za umjetni akcelerogram AA1 s maksimalnim ubrzanjem $a_{\mathrm{g}, \max }=0.1,0.2,0.3 \mathrm{i} 0.4 \mathrm{~g}$ 

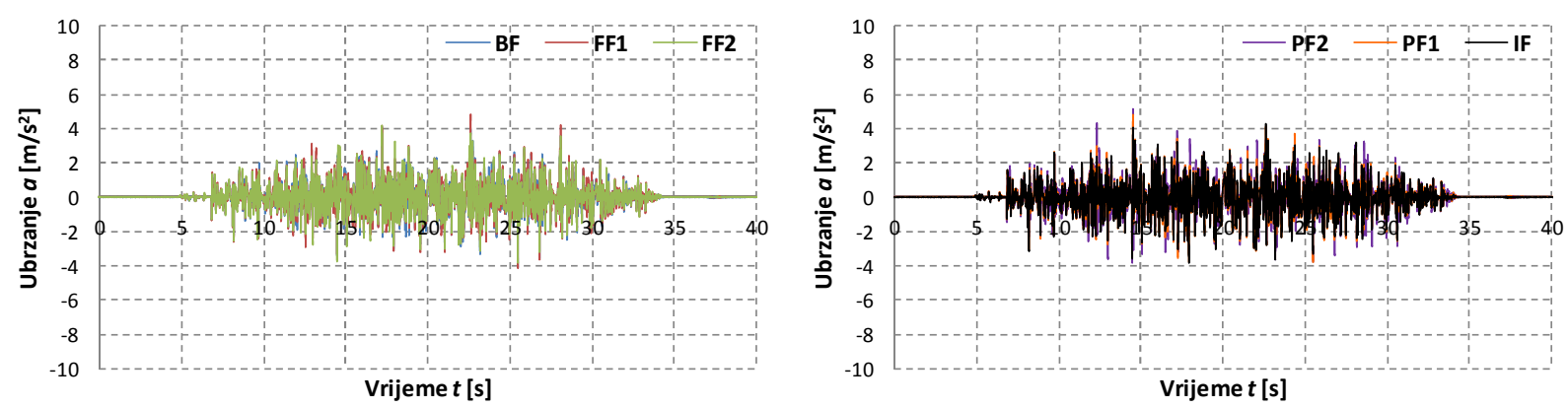

a) $\mathrm{a}_{\mathrm{g}, \max }=0.5 \mathrm{~g}$
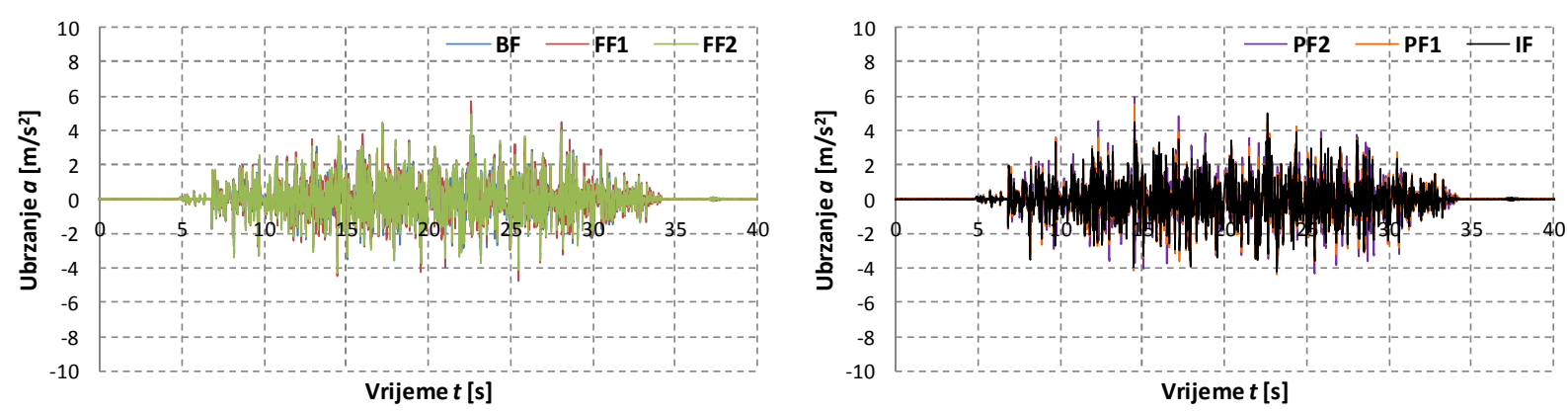

b) $\mathrm{a}_{\mathrm{g}, \max }=0.6 \mathrm{~g}$
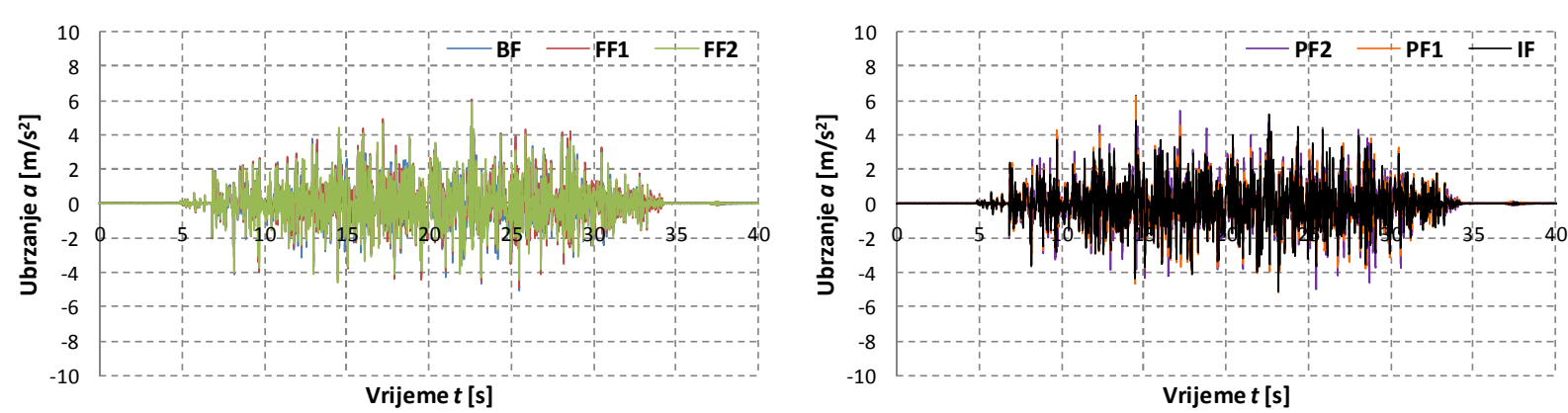

c) $\mathrm{a}_{\mathrm{g}, \max }=0.7 \mathrm{~g}$
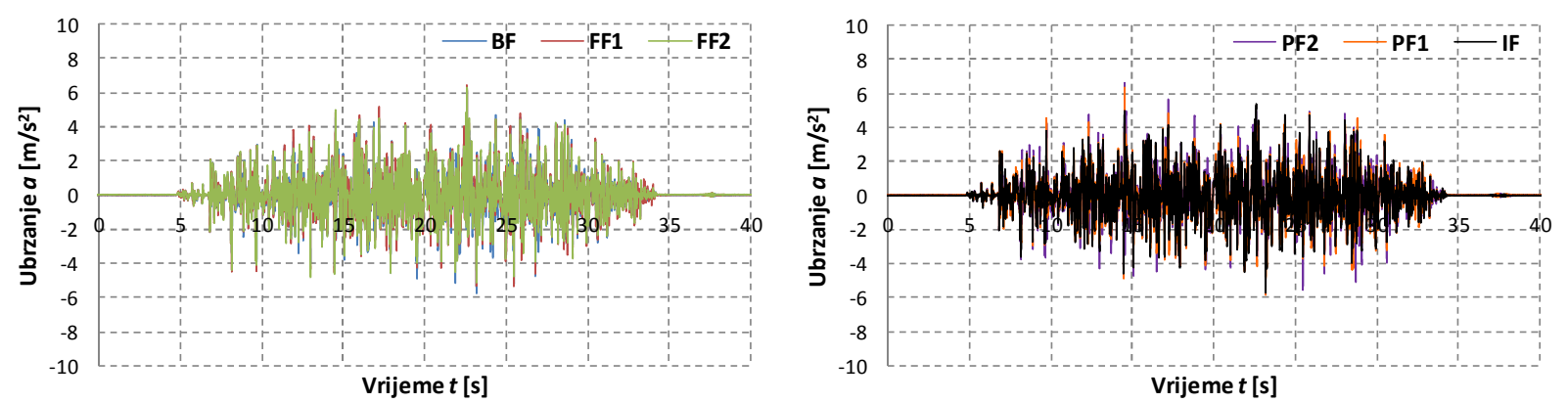

d) $\mathrm{a}_{\mathrm{g}, \max }=0.8 \mathrm{~g}$

Slika 3.51. Horizontalno ubrzanje vrha gornje etaže okvira $\left(a_{2}\right)$ u vremenu za umjetni akcelerogram AA1 s maksimalnim ubrzanjem $\mathrm{a}_{\mathrm{g}, \max }=0.5,0.6,0.7 \mathrm{i} 0.8 \mathrm{~g}$ 

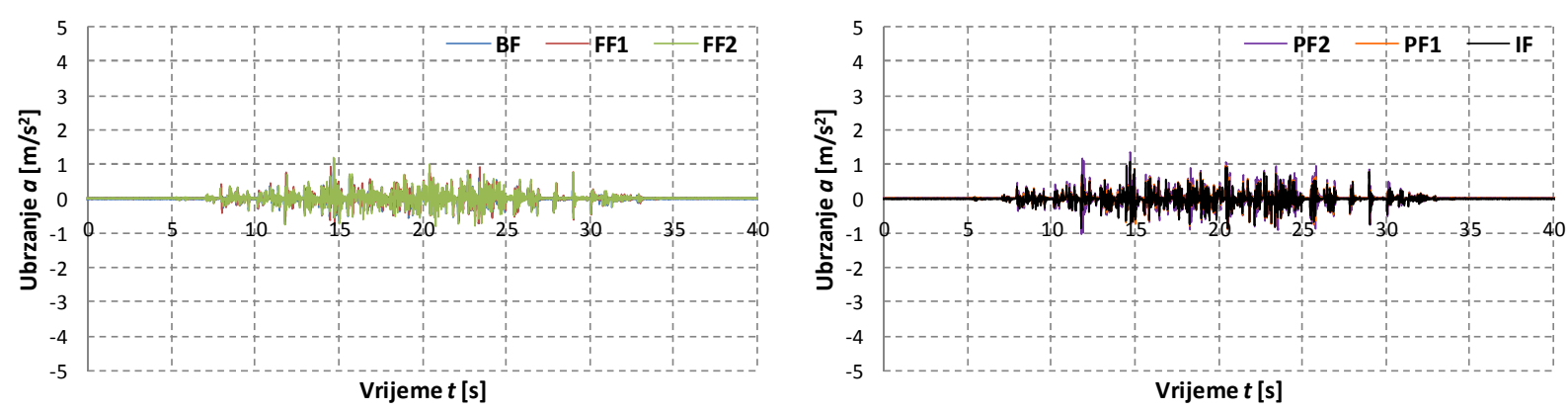

a) $\mathrm{a}_{\mathrm{g}, \max }=0.1 \mathrm{~g}$
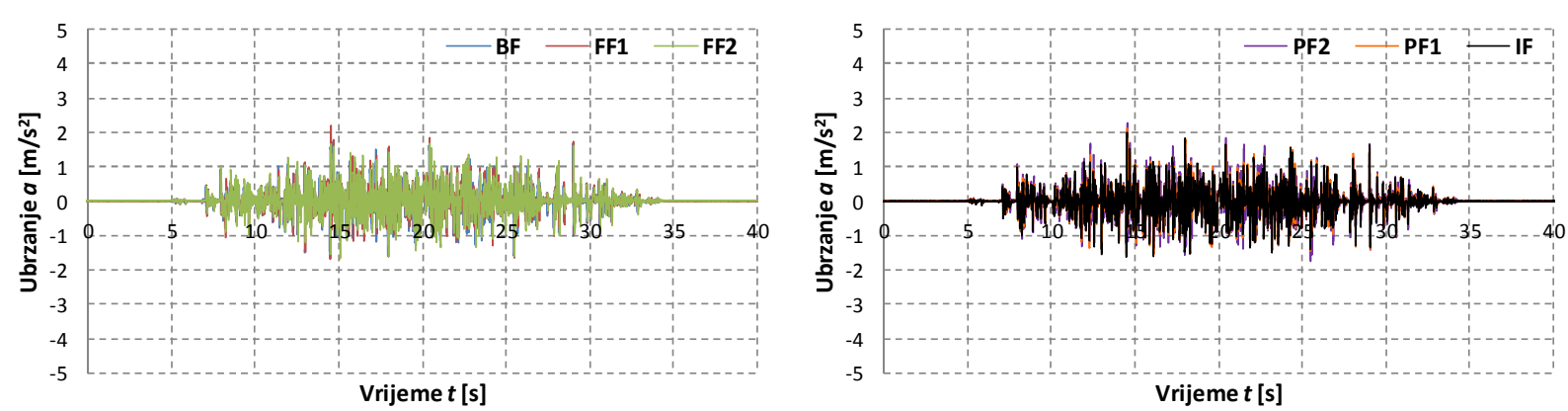

b) $\mathrm{a}_{\mathrm{g}, \max }=0.2 \mathrm{~g}$
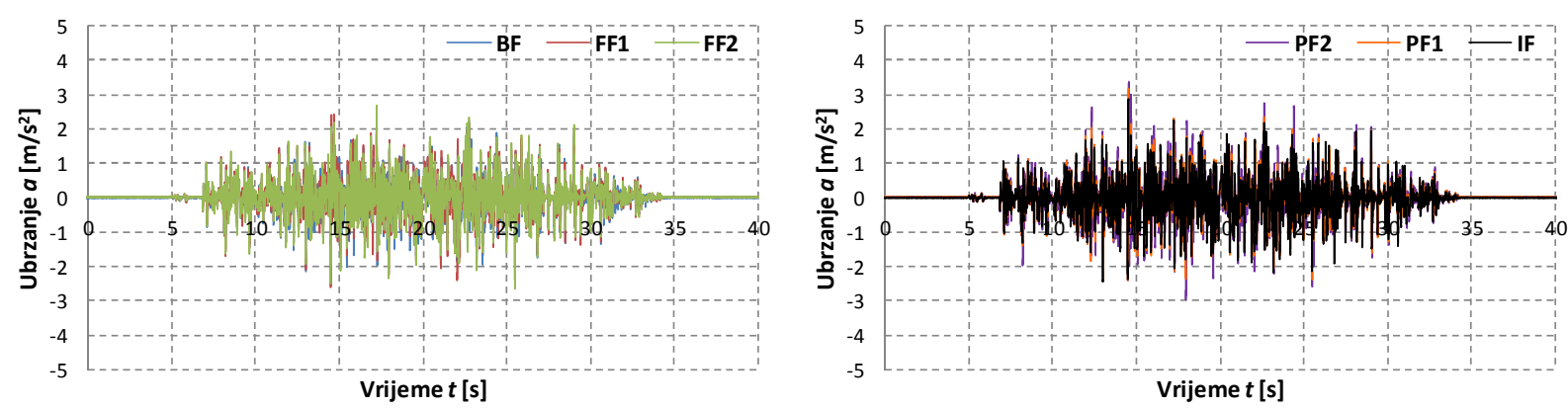

c) $\mathrm{a}_{\mathrm{g}, \max }=0.3 \mathrm{~g}$
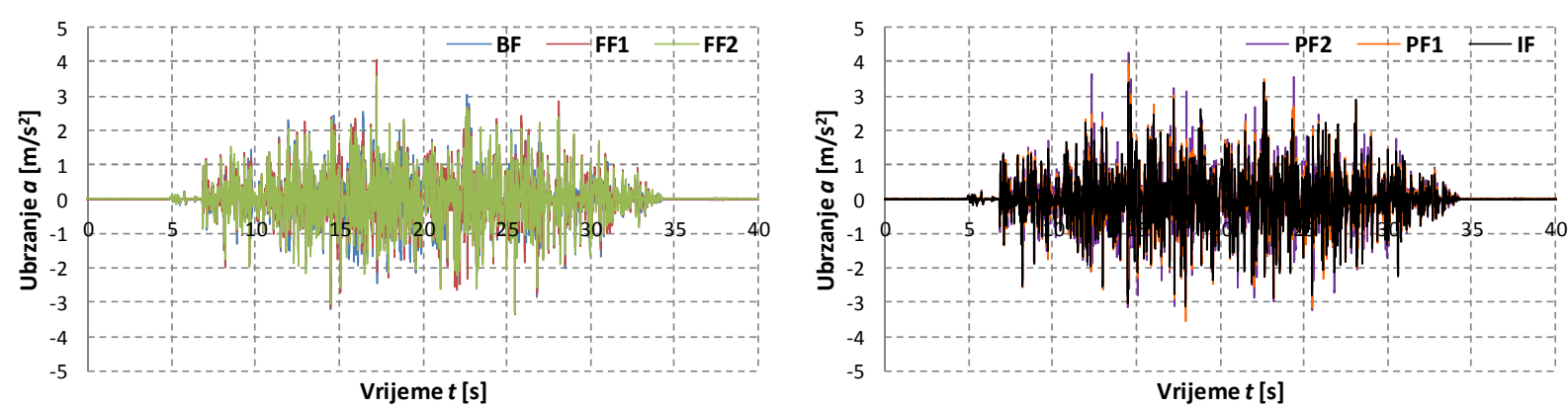

d) $\mathrm{a}_{\mathrm{g}, \max }=0.4 \mathrm{~g}$

Slika 3.52. Horizontalno ubrzanje vrha donje etaže okvira $\left(a_{1}\right)$ u vremenu za umjetni akcelerogram AA1 s maksimalnim ubrzanjem $\mathrm{a}_{\mathrm{g}, \max }=0.1,0.2,0.3 \mathrm{i} 0.4 \mathrm{~g}$ 

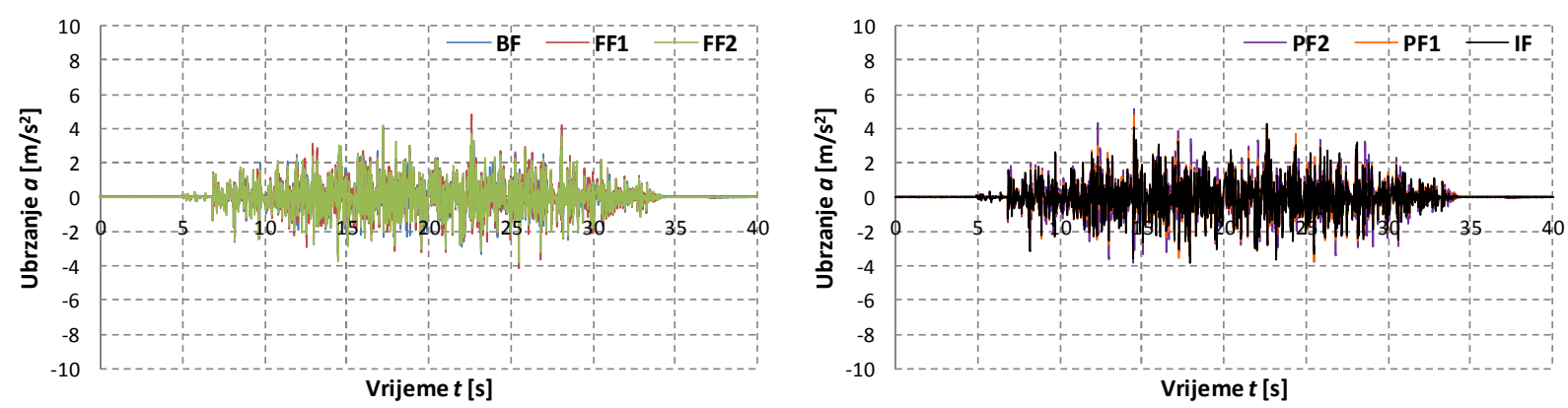

a) $\mathrm{a}_{\mathrm{g}, \max }=0.5 \mathrm{~g}$
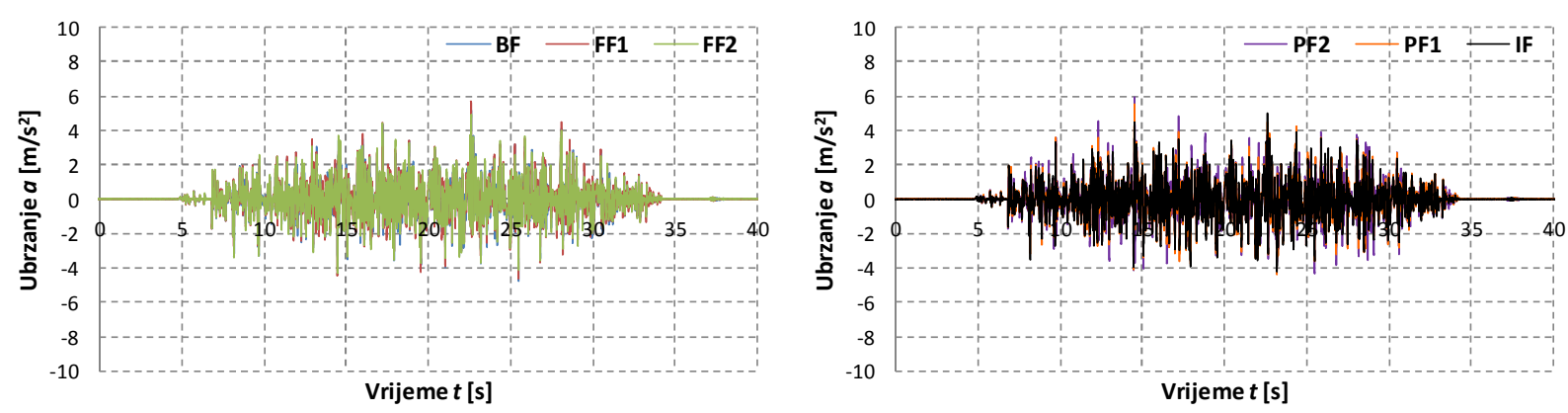

b) $\mathrm{a}_{\mathrm{g}, \max }=0.6 \mathrm{~g}$
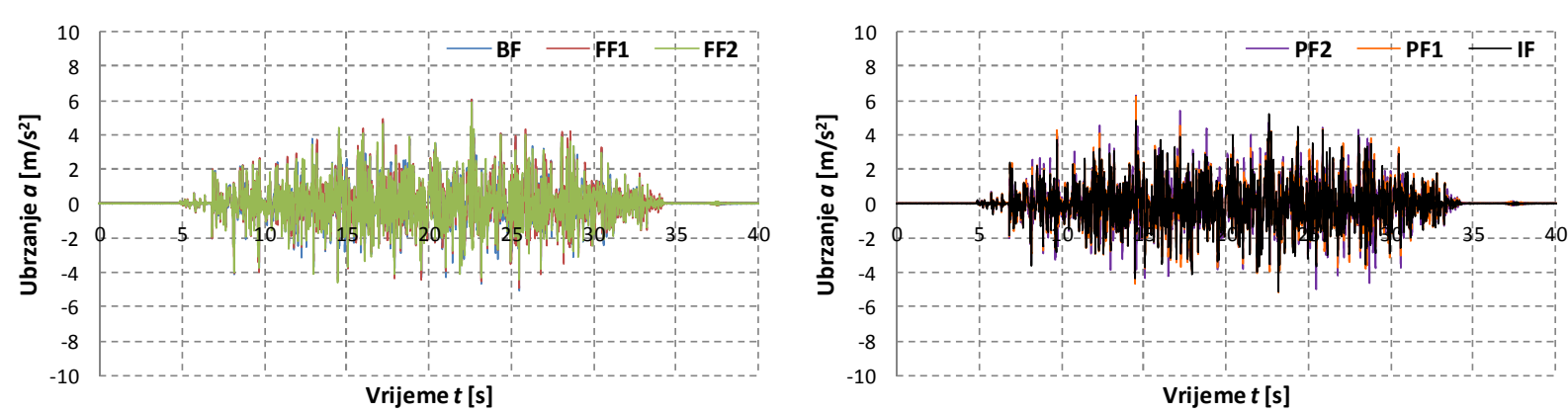

c) $\mathrm{a}_{\mathrm{g}, \max }=0.7 \mathrm{~g}$
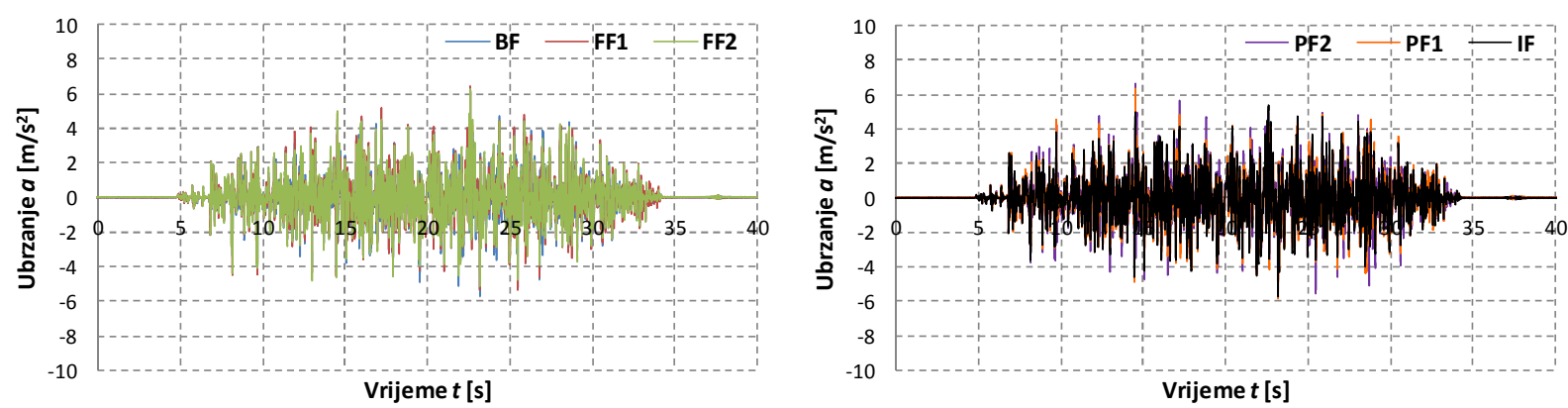

d) $\mathrm{a}_{\mathrm{g}, \max }=0.8 \mathrm{~g}$

Slika 3.53. Horizontalno ubrzanje vrha donje etaže okvira $\left(a_{1}\right)$ u vremenu za umjetni akcelerogram AA1 s maksimalnim ubrzanjem $\mathrm{a}_{\mathrm{g}, \max }=0.5,0.6,0.7 \mathrm{i} 0.8 \mathrm{~g}$ 

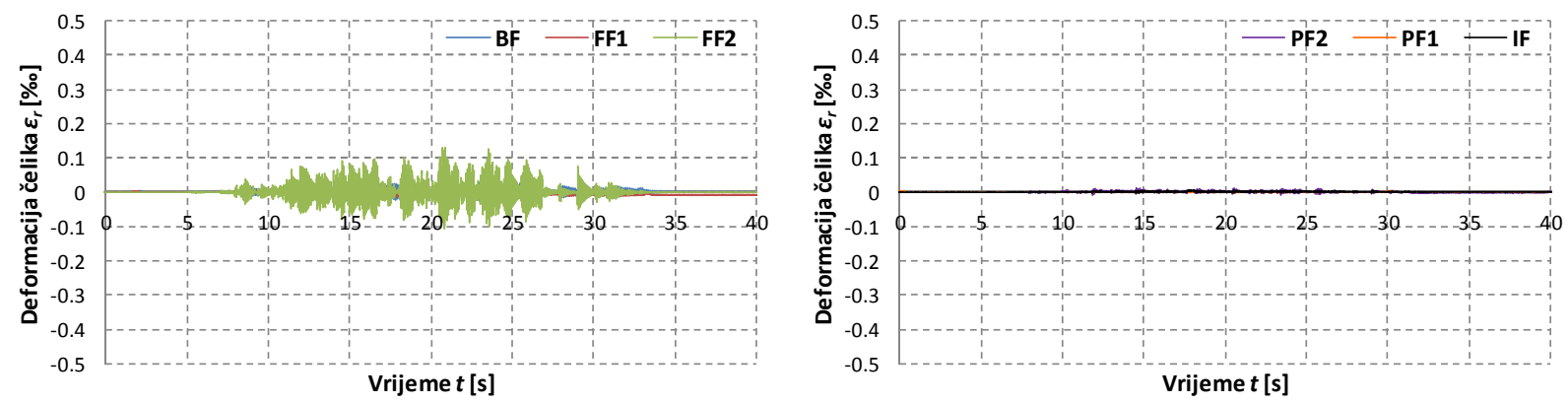

a) $\mathrm{a}_{\mathrm{g}, \max }=0.1 \mathrm{~g}$
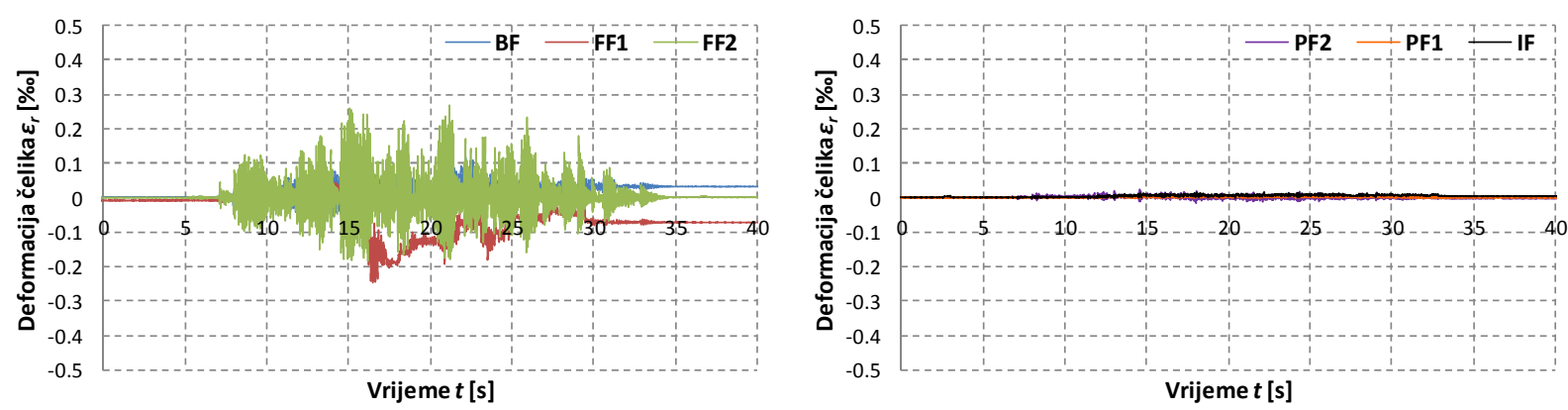

b) $\mathrm{a}_{\mathrm{g}, \max }=0.2 \mathrm{~g}$
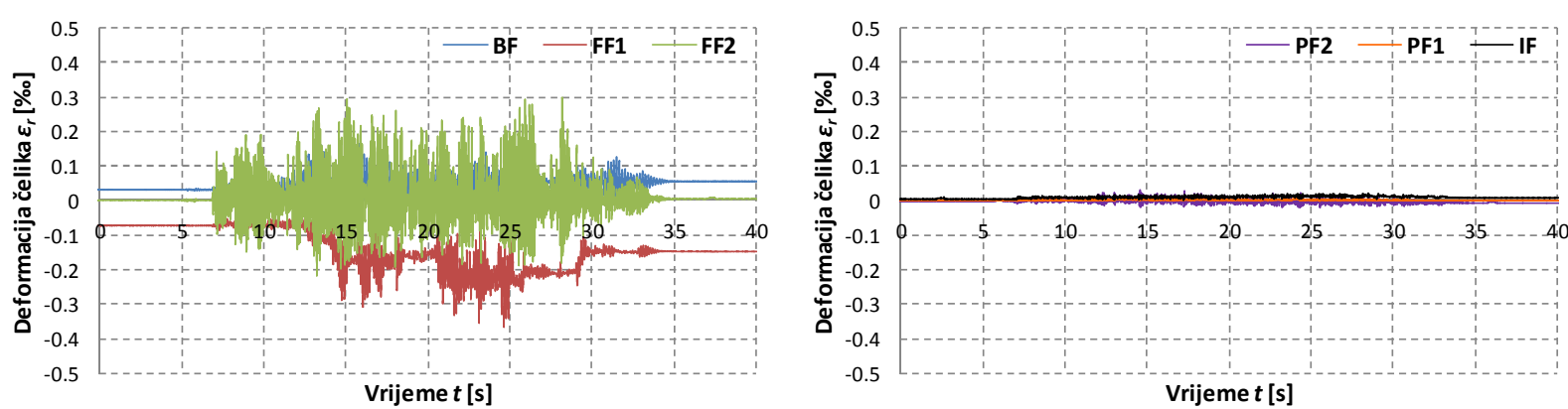

c) $\mathrm{a}_{\mathrm{g}, \max }=0.3 \mathrm{~g}$
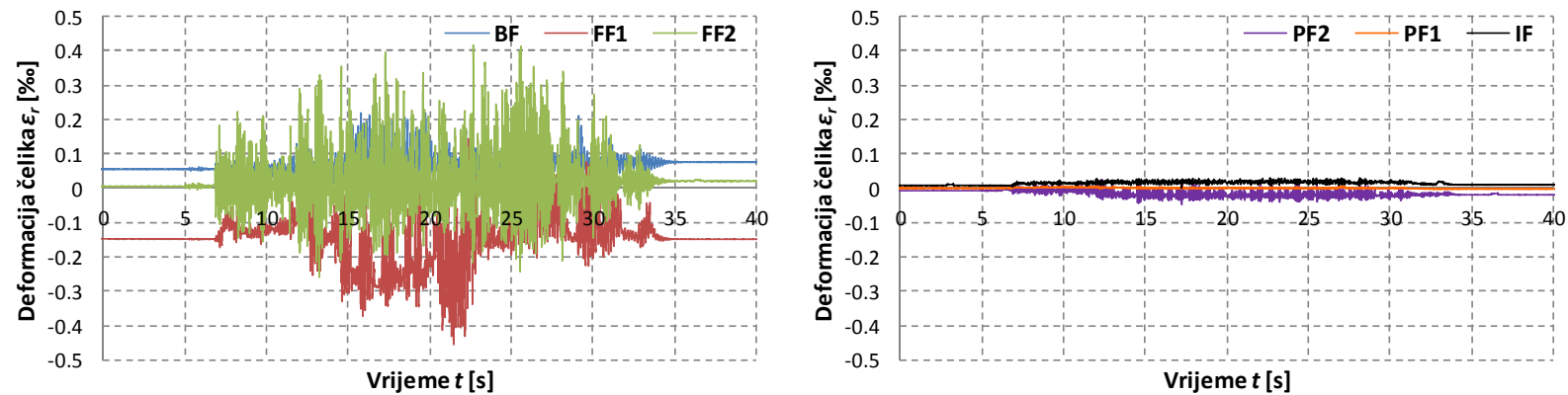

d) $\mathrm{a}_{\mathrm{g}, \max }=0.4 \mathrm{~g}$

Slika 3.54. Deformacija armature pri dnu stupa gornje etaže okvira (točka A) u vremenu za umjetni akcelerogram AA1 s maksimalnim ubrzanjem $\mathrm{a}_{\mathrm{g}, \max }=0.1,0.2,0.3 \mathrm{i} 0.4 \mathrm{~g}$ 

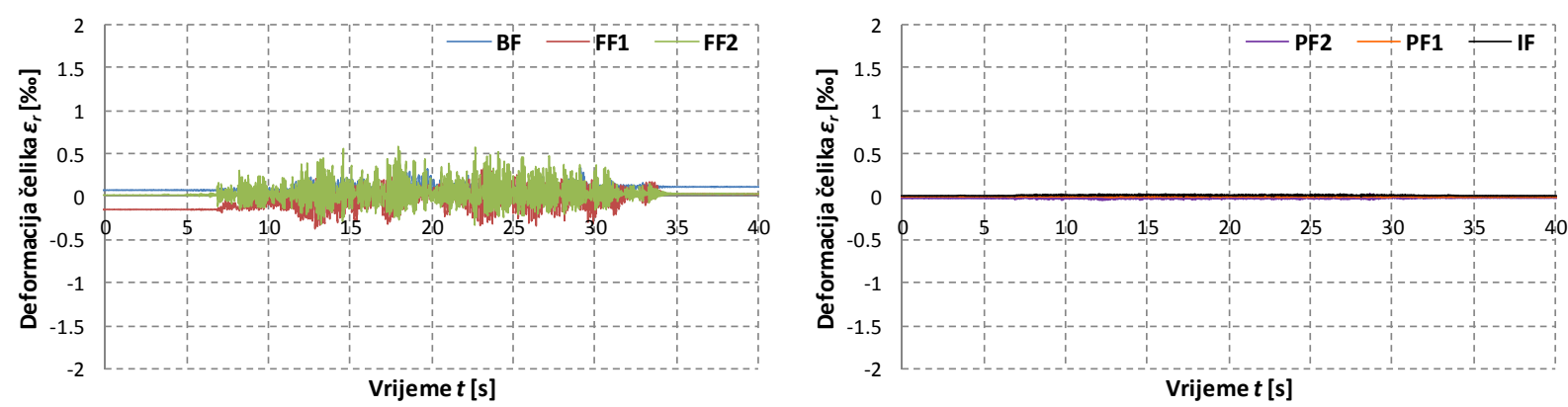

a) $\mathrm{a}_{\mathrm{g}, \max }=0.5 \mathrm{~g}$
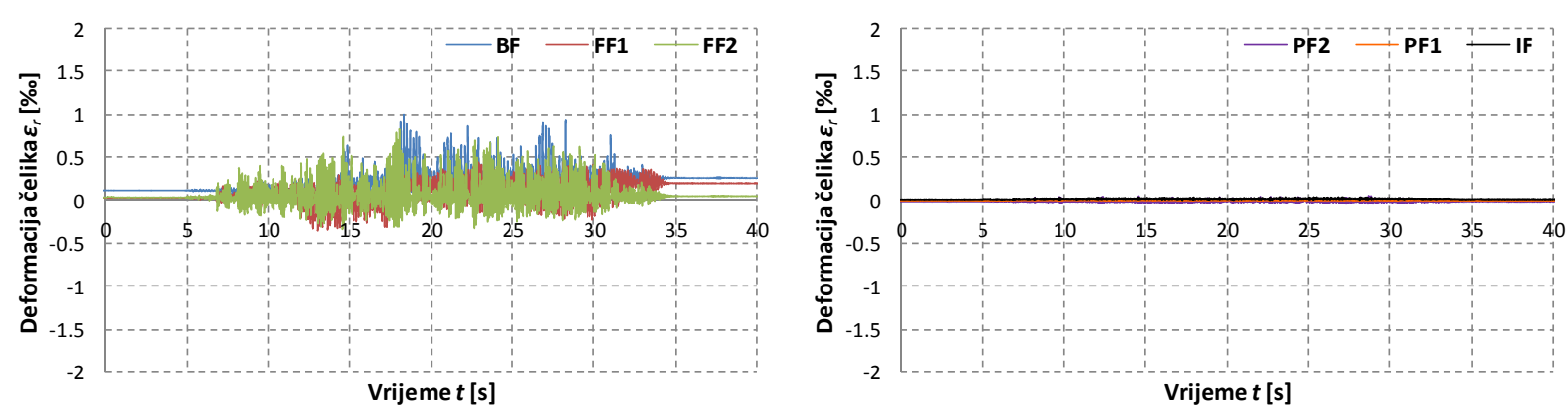

b) $\mathrm{a}_{\mathrm{g}, \max }=0.6 \mathrm{~g}$
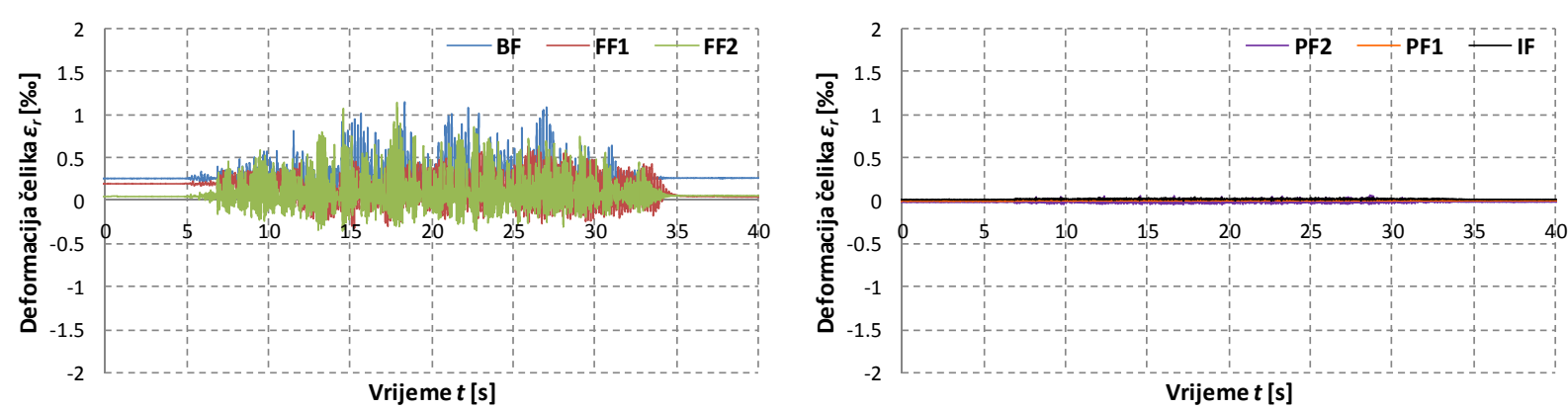

c) $\mathrm{a}_{\mathrm{g}, \max }=0.7 \mathrm{~g}$
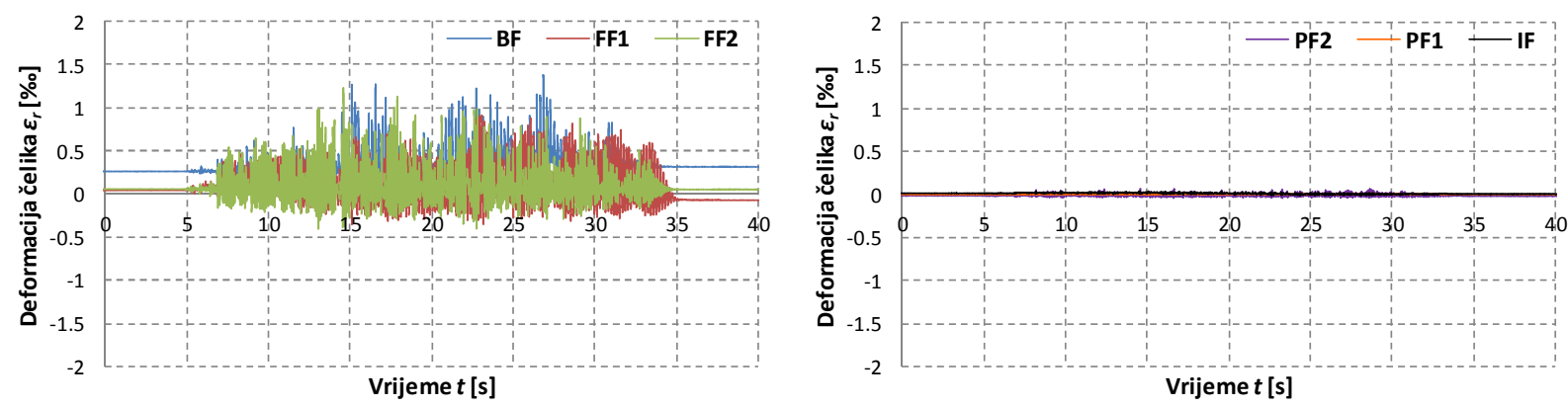

d) $\mathrm{a}_{\mathrm{g}, \max }=0.8 \mathrm{~g}$

Slika 3.55. Deformacija armature pri dnu stupa gornje etaže okvira (točka A) u vremenu za umjetni akcelerogram AA1 s maksimalnim ubrzanjem $\mathrm{a}_{\mathrm{g}, \max }=0.5,0.6,0.7$ i $0.8 \mathrm{~g}$ 

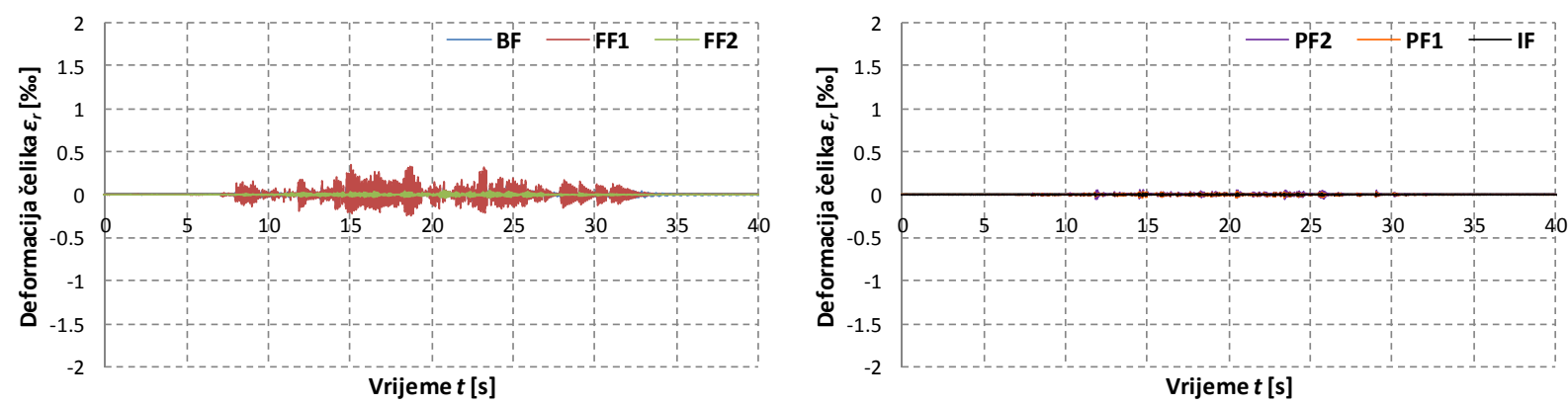

a) $\mathrm{a}_{\mathrm{g}, \max }=0.1 \mathrm{~g}$
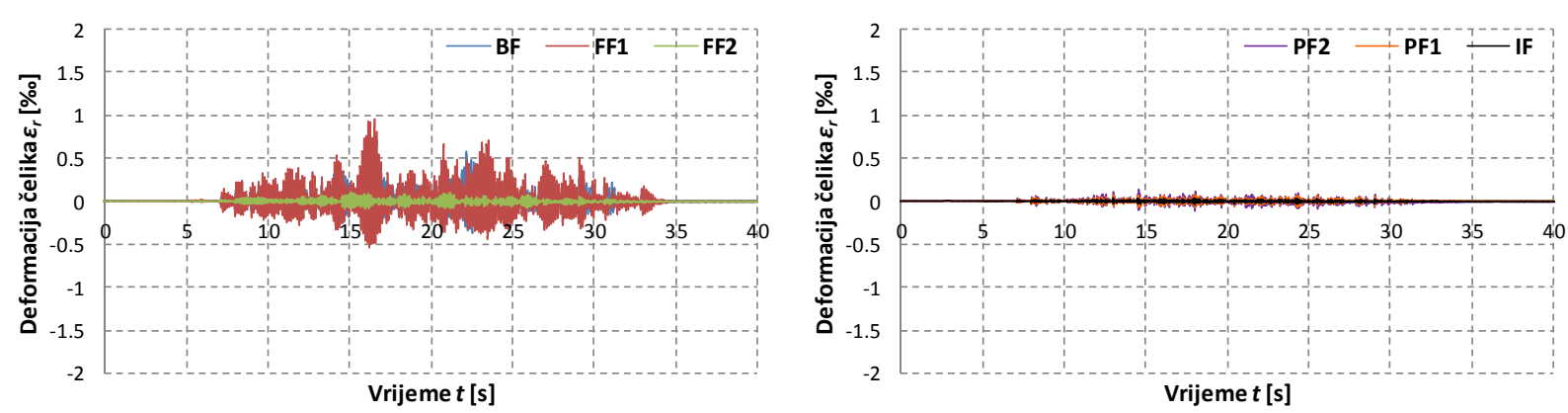

b) $\mathrm{a}_{\mathrm{g}, \max }=0.2 \mathrm{~g}$
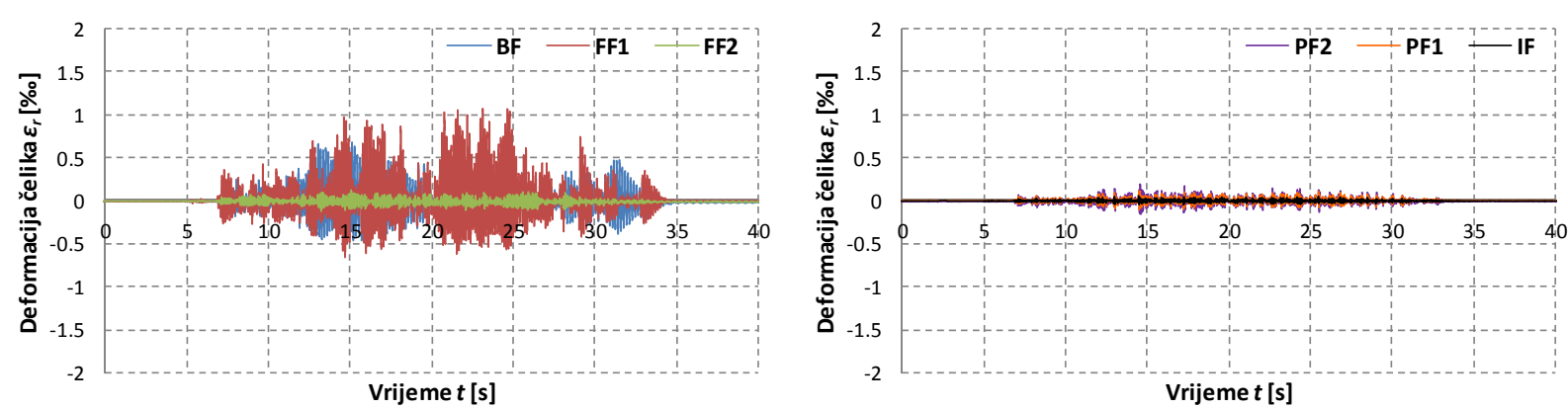

c) $\mathrm{a}_{\mathrm{g}, \max }=0.3 \mathrm{~g}$
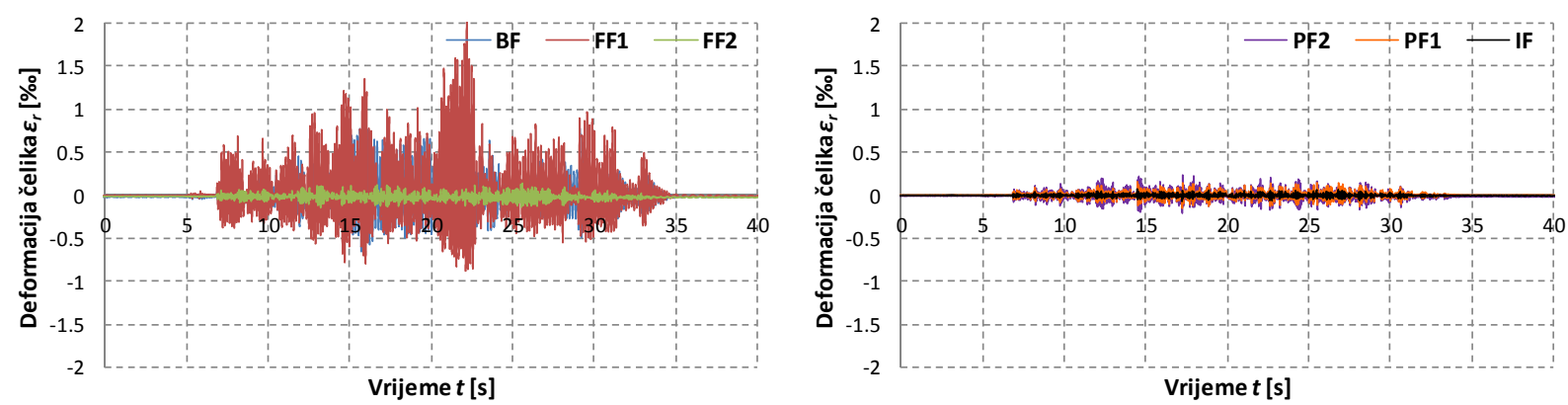

d) $\mathrm{a}_{\mathrm{g}, \max }=0.4 \mathrm{~g}$

Slika 3.56. Deformacija armature pri dnu stupa donje etaže okvira (točka B) u vremenu za umjetni akcelerogram AA1 s maksimalnim ubrzanjem $\mathrm{a}_{\mathrm{g}, \max }=0.1,0.2,0.3 \mathrm{i} 0.4 \mathrm{~g}$ 

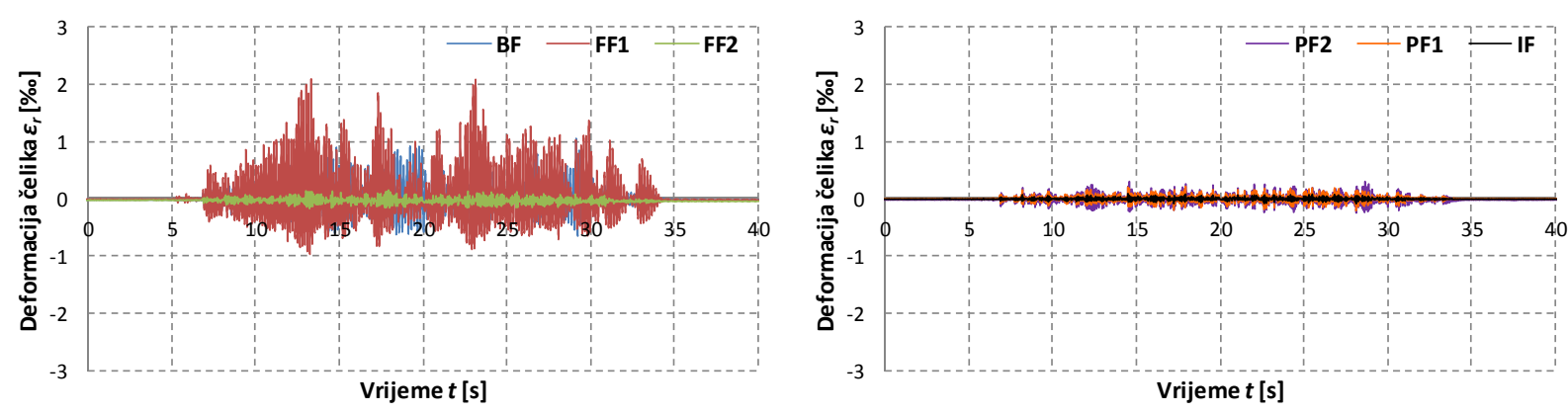

a) $a_{g, \max }=0.5 \mathrm{~g}$
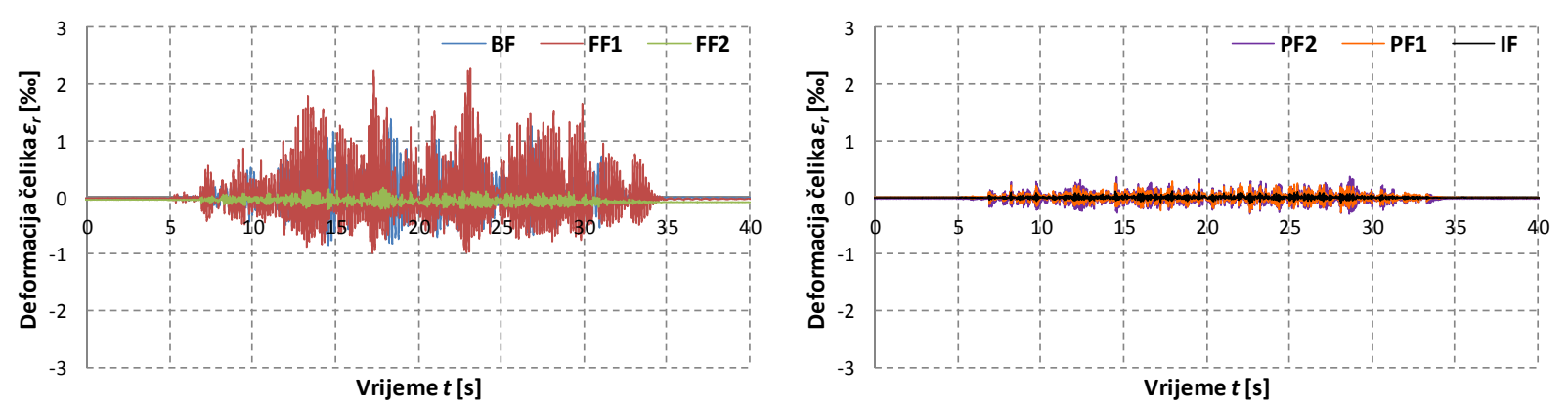

b) $\mathrm{a}_{\mathrm{g}, \max }=0.6 \mathrm{~g}$
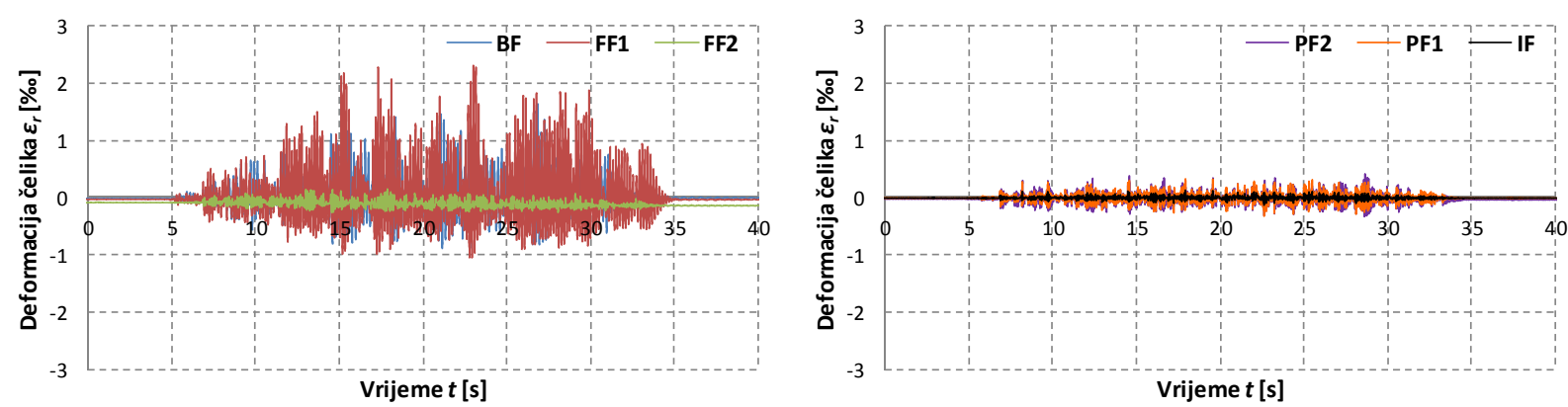

c) $\mathrm{a}_{\mathrm{g}, \max }=0.7 \mathrm{~g}$
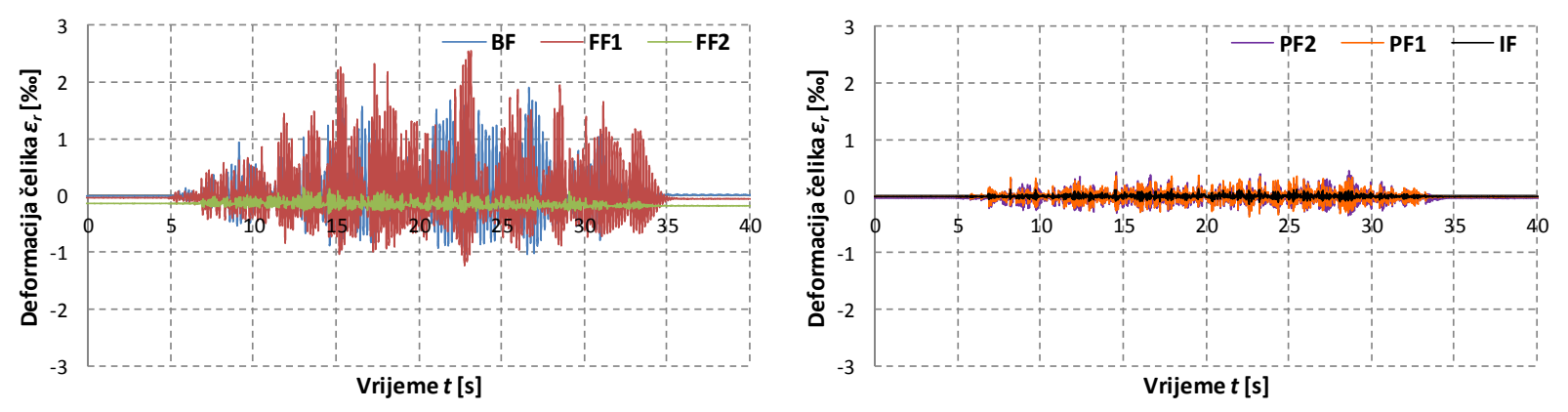

d) $\mathrm{a}_{\mathrm{g}, \max }=0.8 \mathrm{~g}$

Slika 3.57. Deformacija armature pri dnu stupa donje etaže okvira (točka B) u vremenu za umjetni akcelerogram AA1 s maksimalnim ubrzanjem $\mathrm{a}_{\mathrm{g}, \max }=0.5,0.6,0.7 \mathrm{i} 0.8 \mathrm{~g}$ 

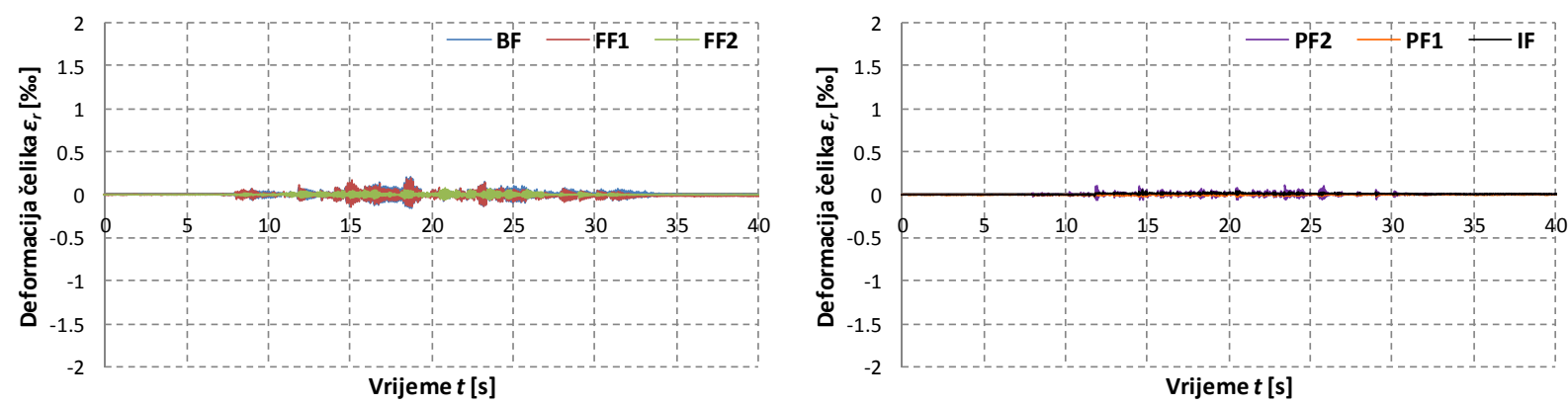

a) $\mathrm{a}_{\mathrm{g}, \max }=0.1 \mathrm{~g}$
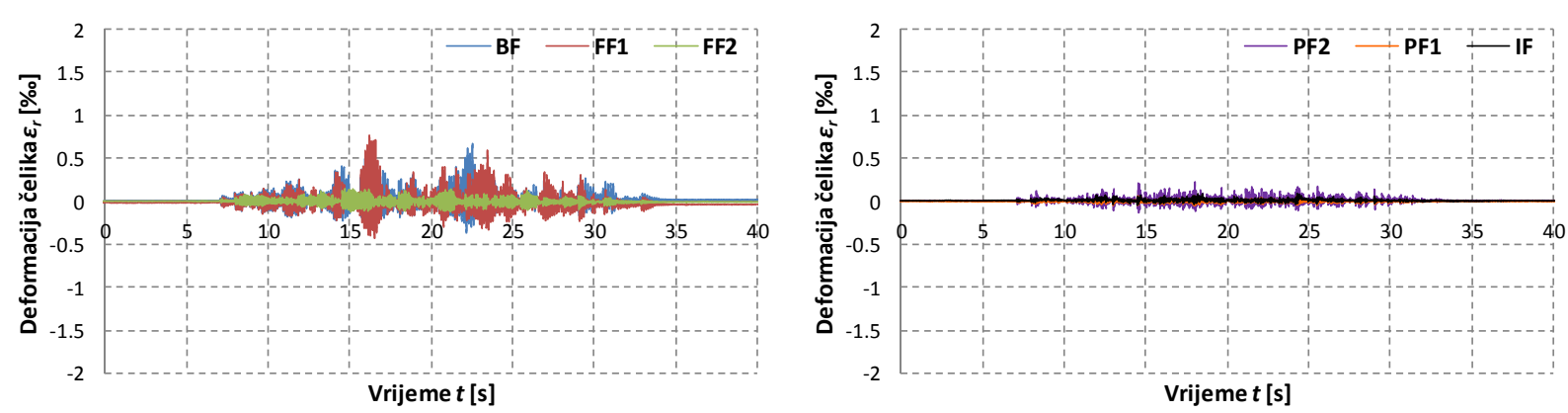

b) $\mathrm{a}_{\mathrm{g}, \max }=0.2 \mathrm{~g}$
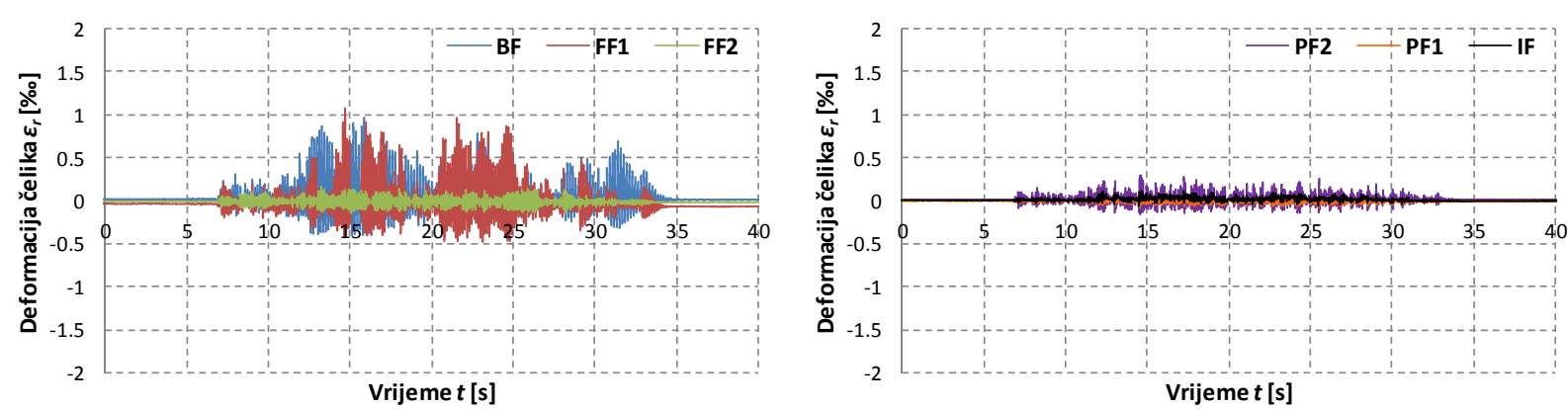

c) $\mathrm{a}_{\mathrm{g}, \max }=0.3 \mathrm{~g}$
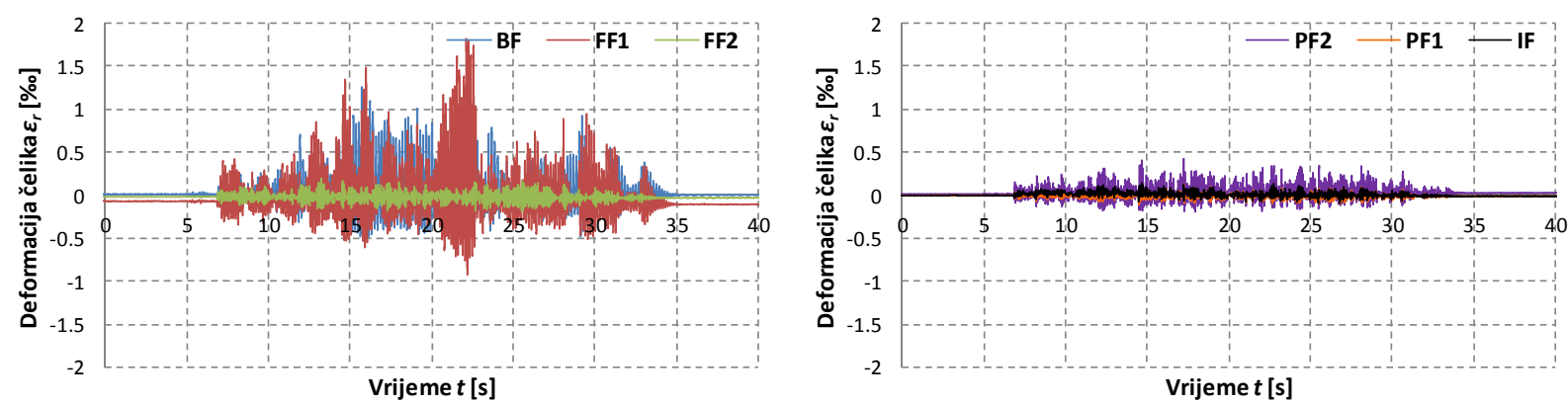

d) $\mathrm{a}_{\mathrm{g}, \max }=0.4 \mathrm{~g}$

Slika 3.58. Deformacija armature pri dnu stupa donje etaže okvira (točka C) u vremenu za umjetni akcelerogram AA1 s maksimalnim ubrzanjem $\mathrm{a}_{\mathrm{g}, \max }=0.1,0.2,0.3 \mathrm{i} 0.4 \mathrm{~g}$ 

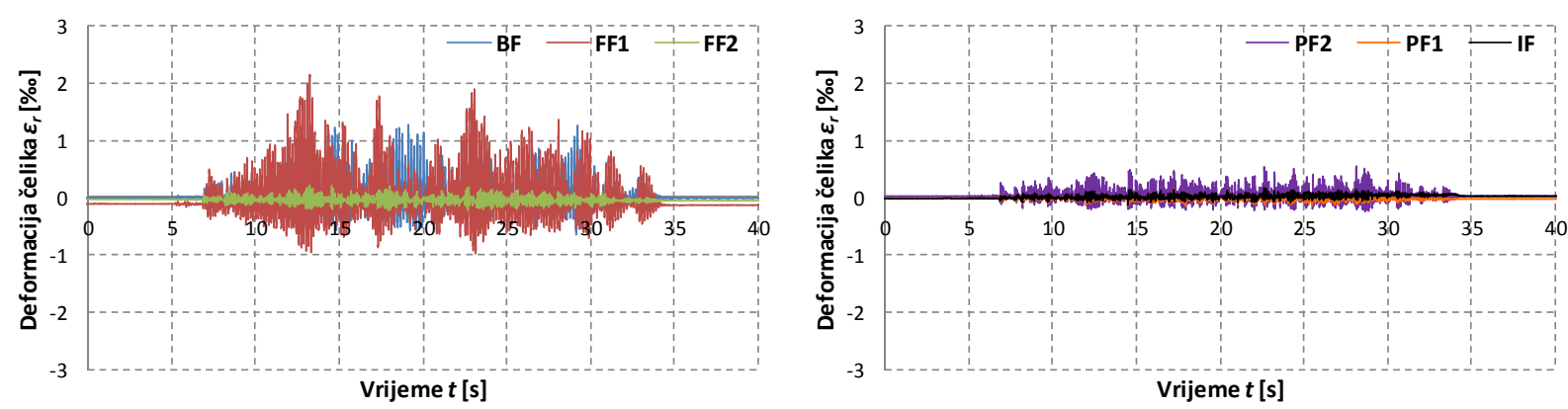

a) $a_{g, \max }=0.5 \mathrm{~g}$
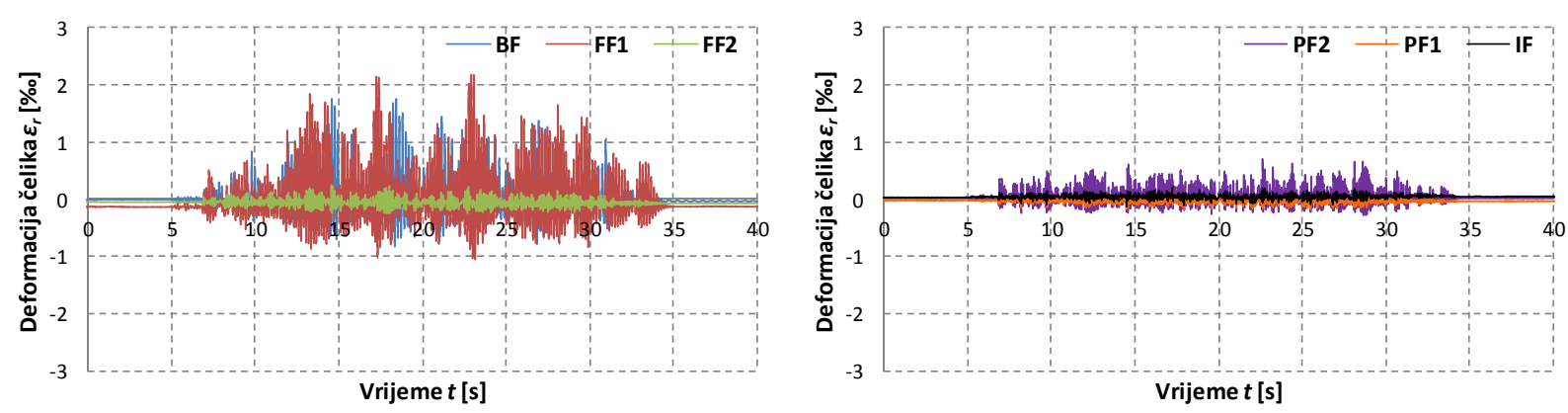

b) $\mathrm{a}_{\mathrm{g}, \max }=0.6 \mathrm{~g}$
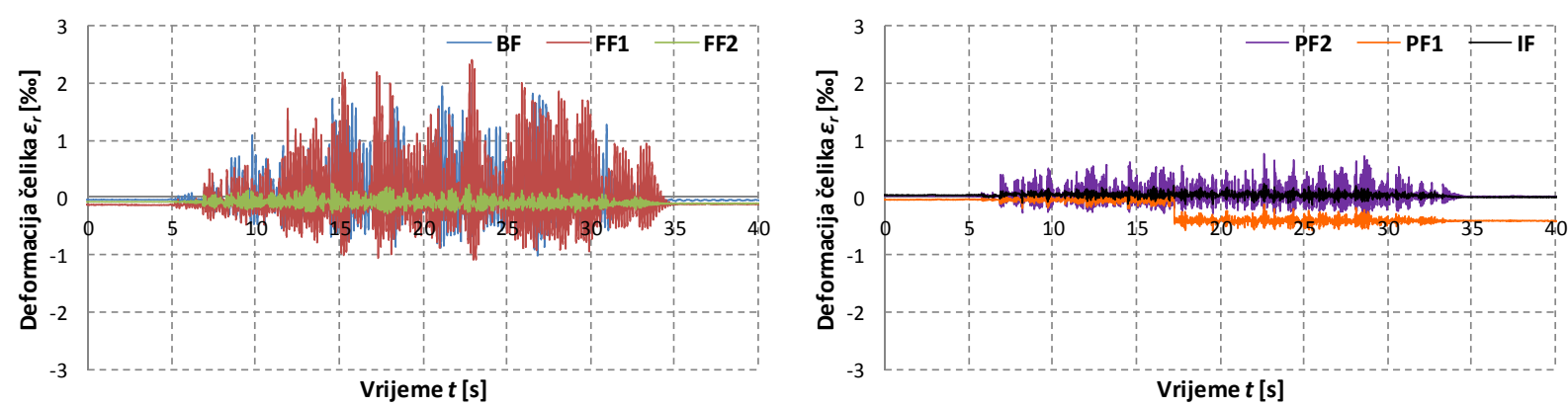

c) $\mathrm{a}_{\mathrm{g}, \max }=0.7 \mathrm{~g}$
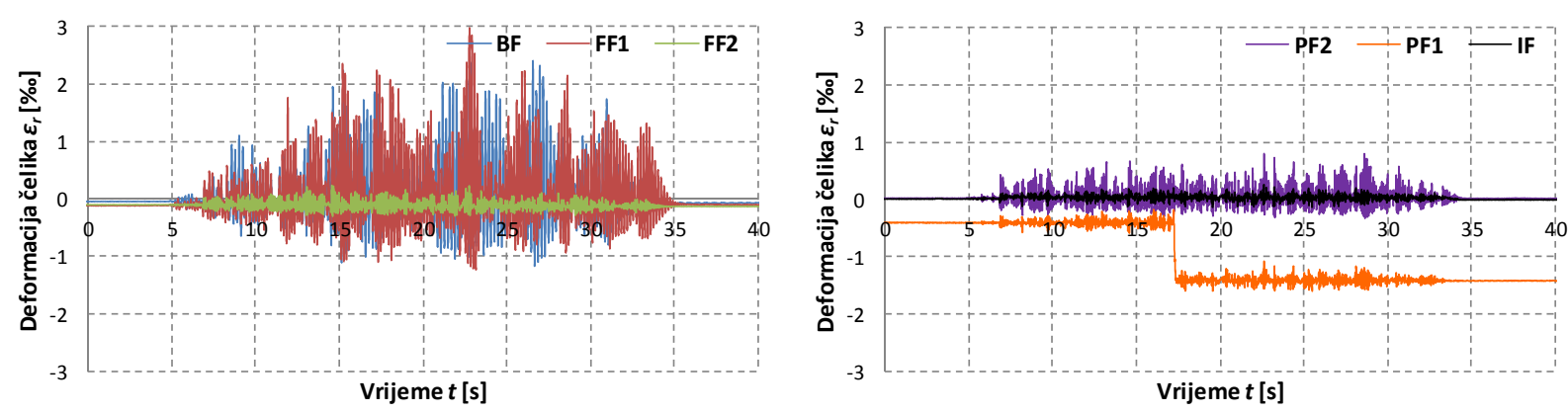

d) $\mathrm{a}_{\mathrm{g}, \max }=0.8 \mathrm{~g}$

Slika 3.59. Deformacija armature pri dnu stupa donje etaže okvira (točka C) u vremenu za umjetni akcelerogram AA1 s maksimalnim ubrzanjem $\mathrm{a}_{\mathrm{g}, \max }=0.5,0.6,0.7 \mathrm{i} 0.8 \mathrm{~g}$ 

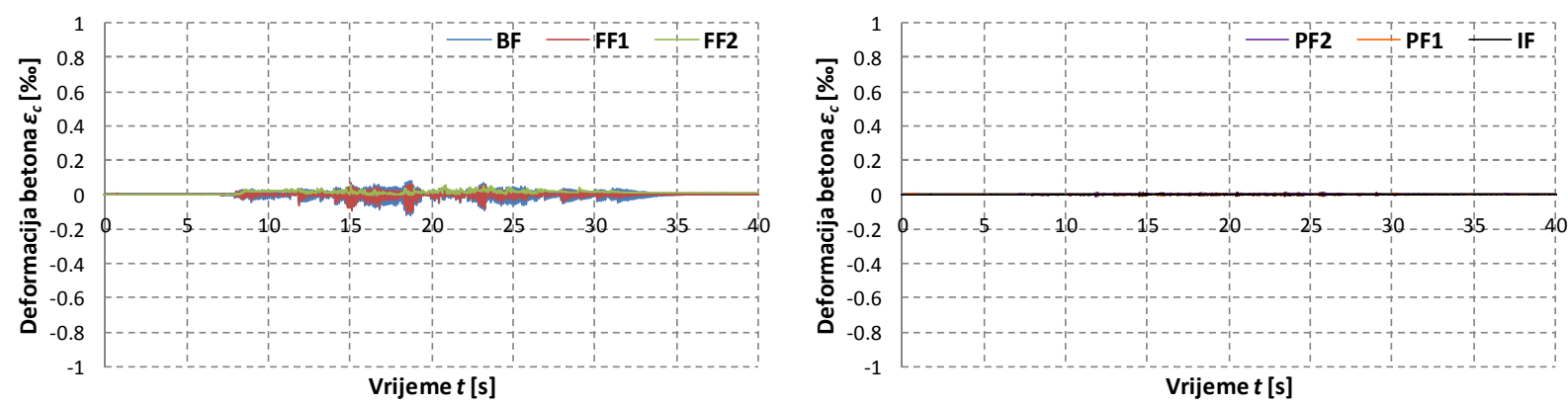

a) $\mathrm{a}_{\mathrm{g}, \max }=0.1 \mathrm{~g}$

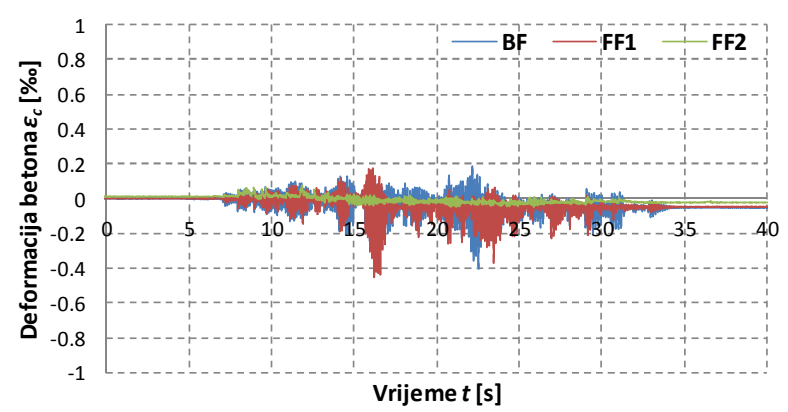

b) $\mathrm{a}_{\mathrm{g}, \max }=0.2 \mathrm{~g}$
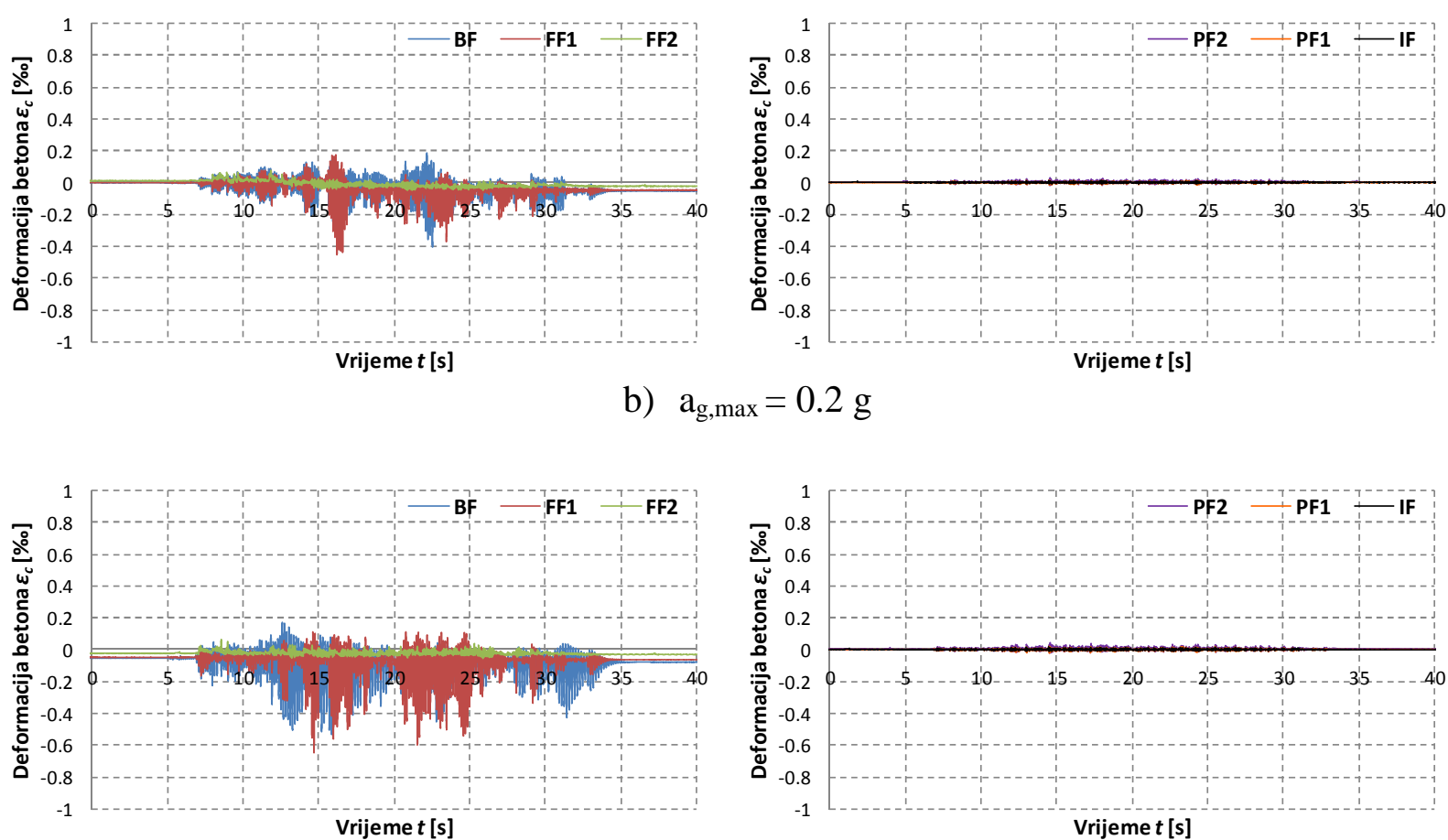

c) $\mathrm{a}_{\mathrm{g}, \max }=0.3 \mathrm{~g}$
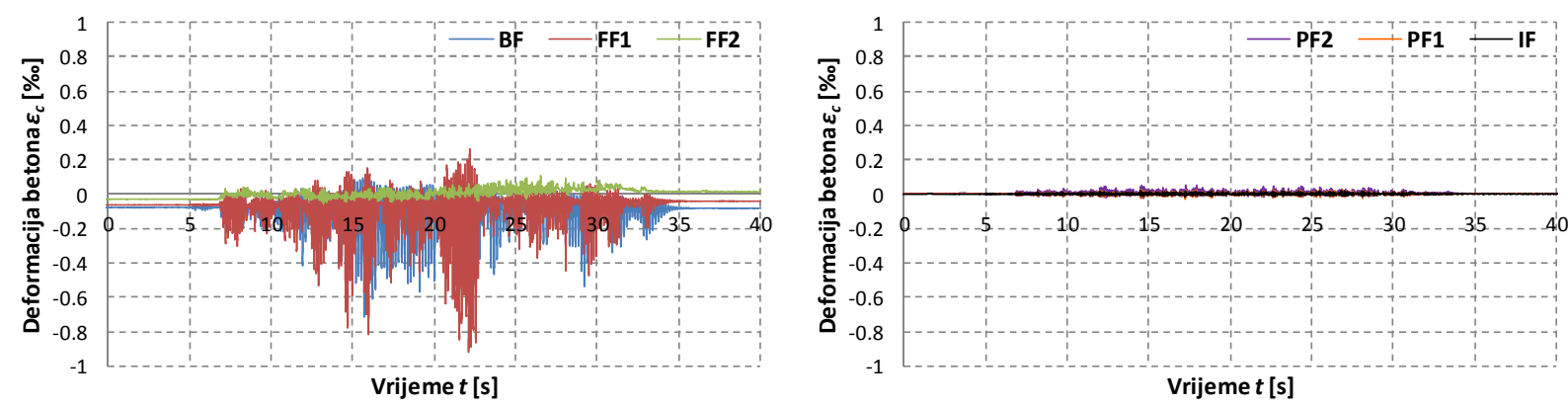

d) $\mathrm{a}_{\mathrm{g}, \max }=0.4 \mathrm{~g}$

Slika 3.60. Deformacija betona pri dnu stupa donje etaže okvira (točka D) u vremenu za umjetni akcelerogram AA1 s maksimalnim ubrzanjem $\mathrm{a}_{\mathrm{g}, \max }=0.1,0.2,0.3$ i $0.4 \mathrm{~g}$ 

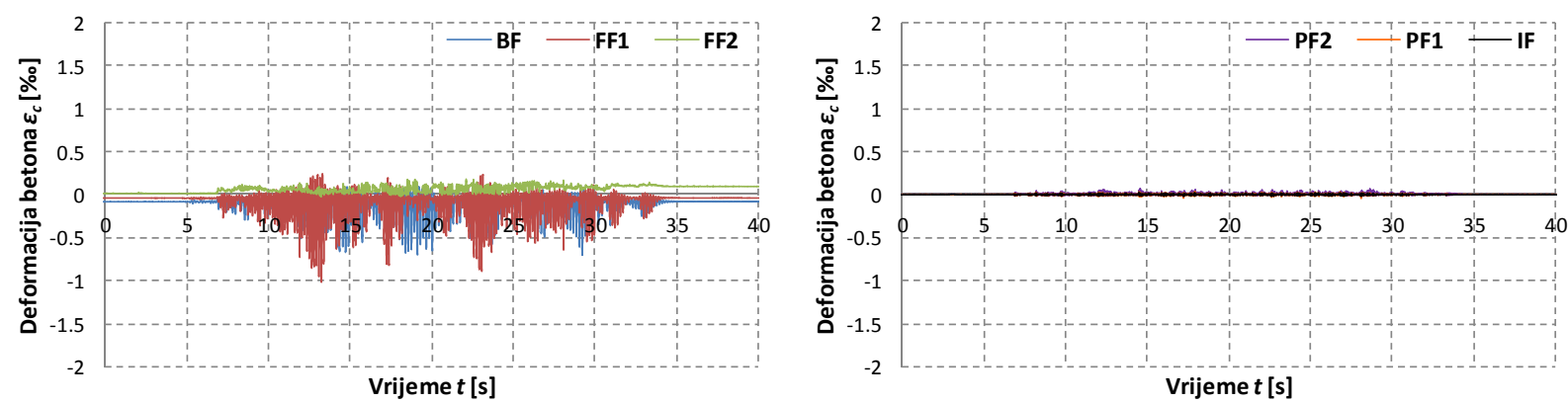

a) $\mathrm{a}_{\mathrm{g}, \max }=0.5 \mathrm{~g}$
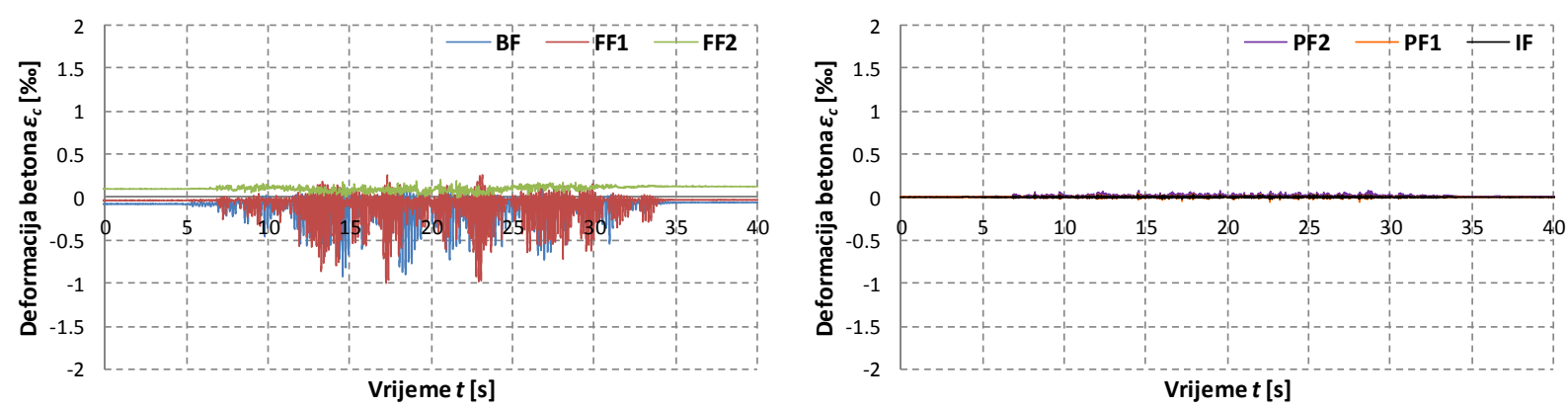

b) $\mathrm{a}_{\mathrm{g}, \max }=0.6 \mathrm{~g}$
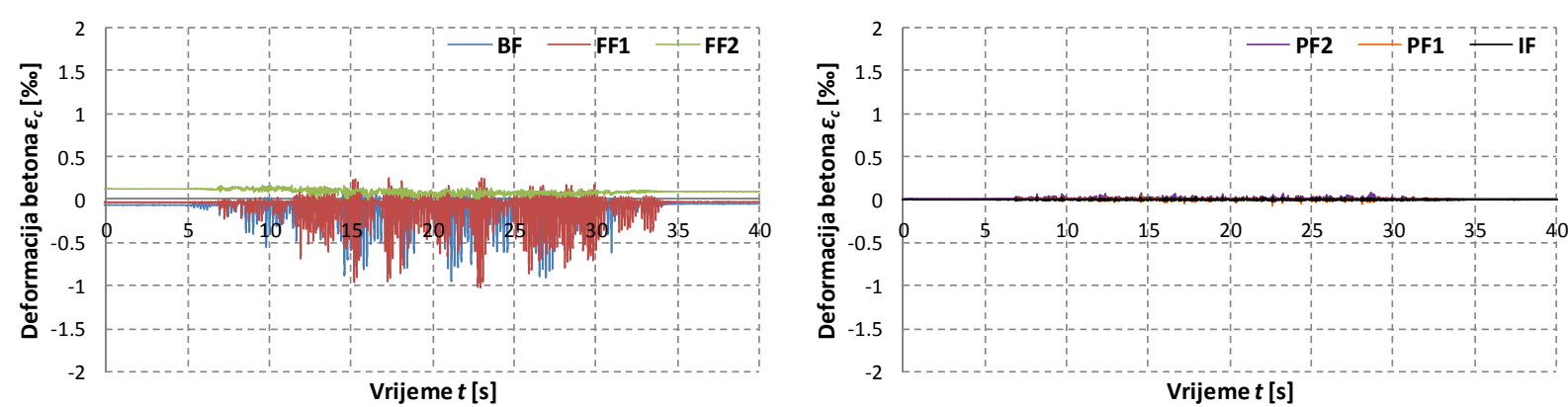

c) $\mathrm{a}_{\mathrm{g}, \max }=0.7 \mathrm{~g}$
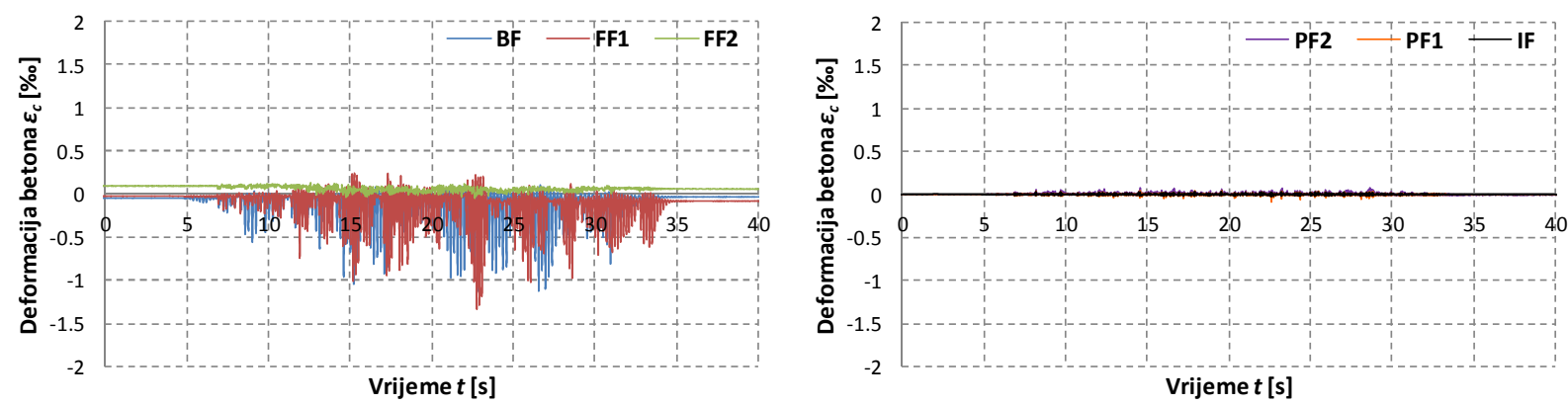

d) $\mathrm{a}_{\mathrm{g}, \max }=0.8 \mathrm{~g}$

Slika 3.61. Deformacija betona pri dnu stupa donje etaže okvira (točka D) u vremenu za umjetni akcelerogram AA1 s maksimalnim ubrzanjem $\mathrm{a}_{\mathrm{g}, \max }=0.5,0.6,0.7 \mathrm{i} 0.8 \mathrm{~g}$ 

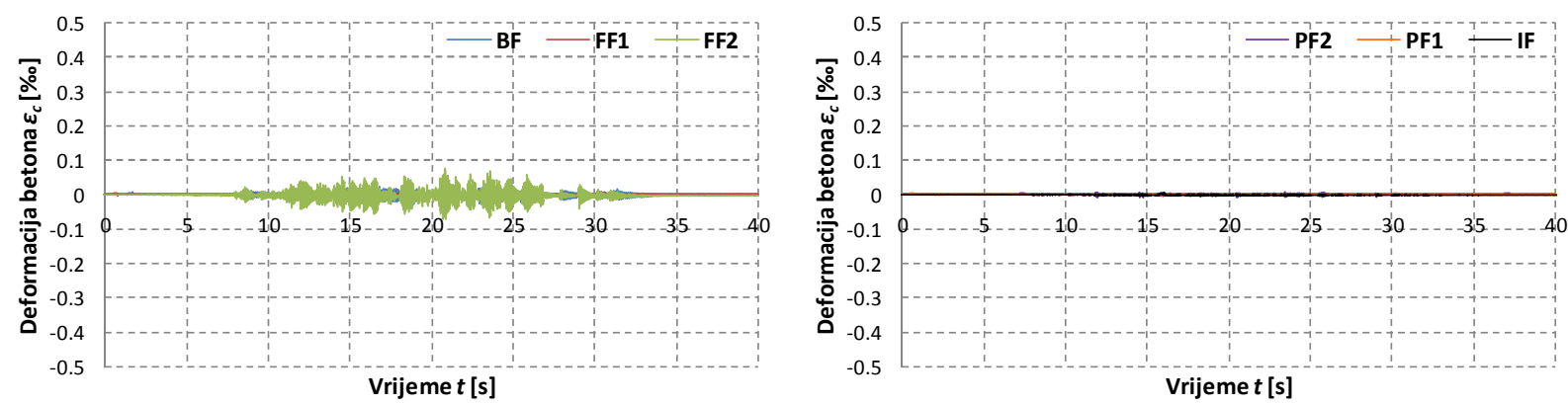

a) $\mathrm{a}_{\mathrm{g}, \max }=0.1 \mathrm{~g}$

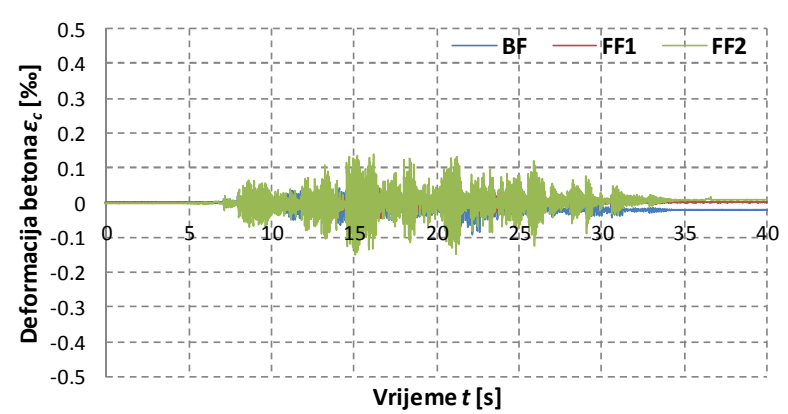

b) $\mathrm{a}_{\mathrm{g}, \max }=0.2 \mathrm{~g}$
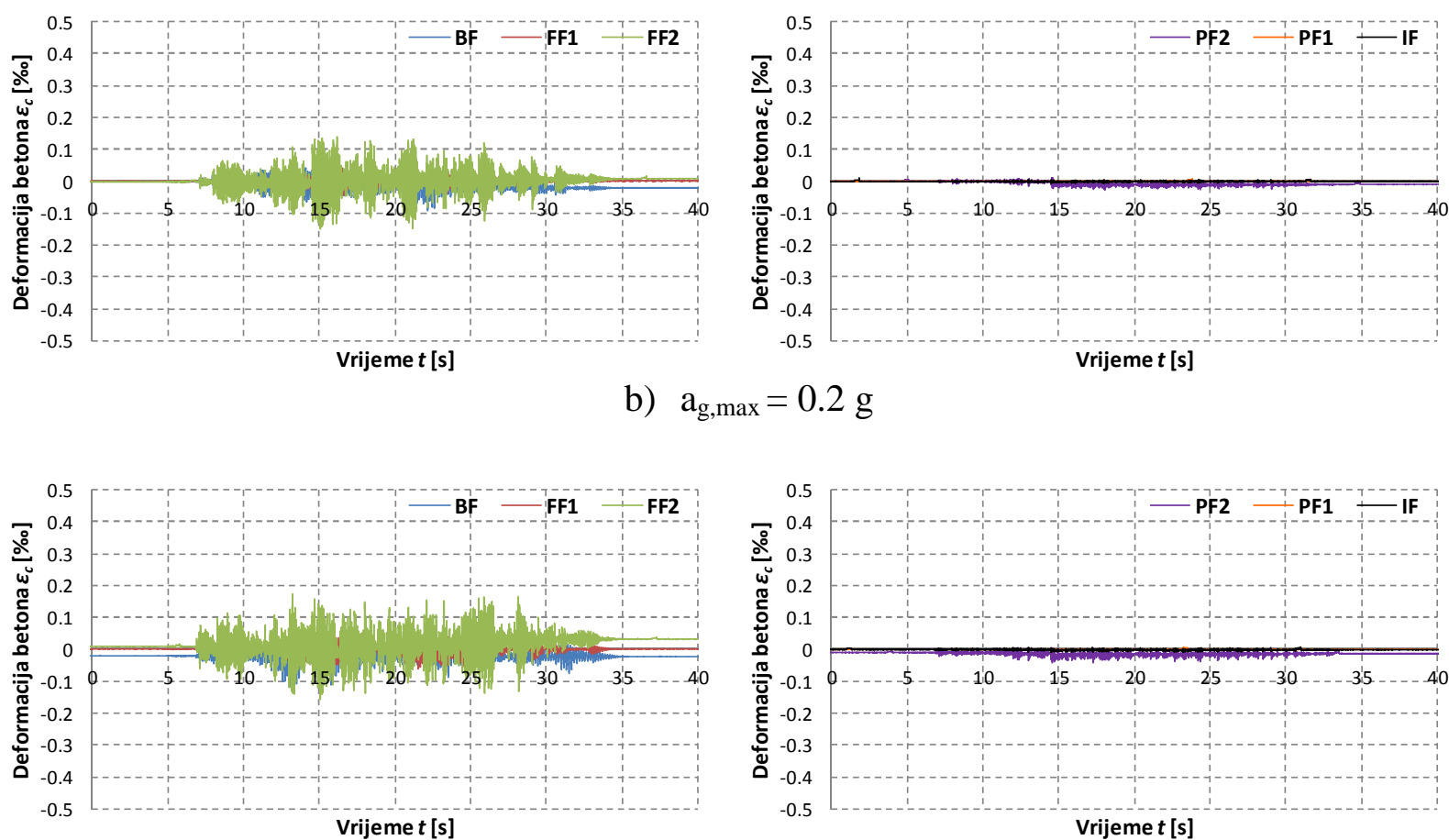

c) $\mathrm{a}_{\mathrm{g}, \max }=0.3 \mathrm{~g}$
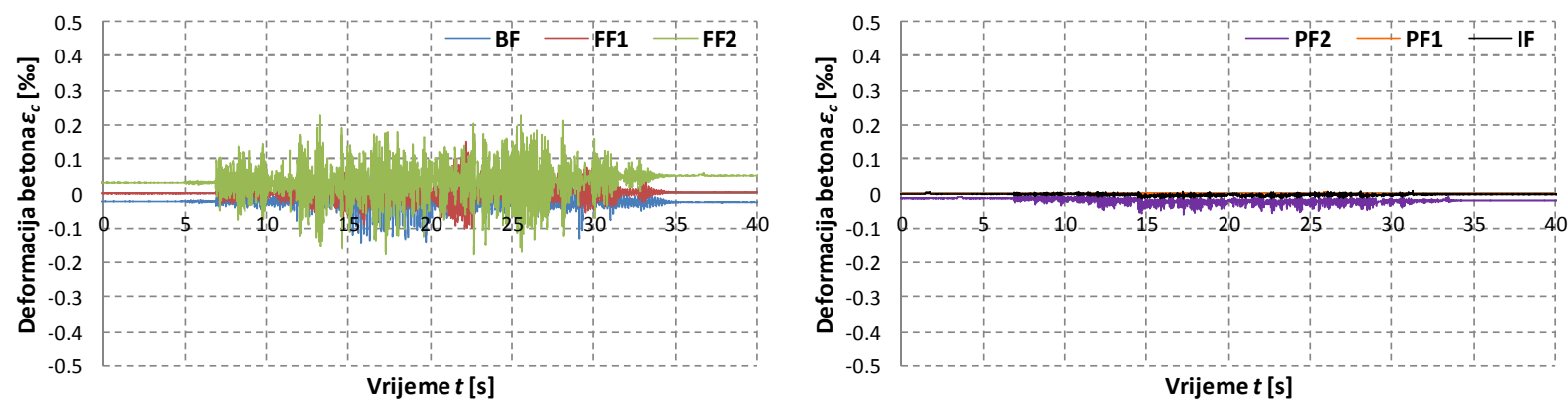

d) $a_{g, \text { max }}=0.4 \mathrm{~g}$

Slika 3.62. Deformacija betona pri dnu stupa gornje etaže okvira (točka E) u vremenu za umjetni akcelerogram AA1 s maksimalnim ubrzanjem $\mathrm{a}_{\mathrm{g}, \max }=0.1,0.2,0.3$ i $0.4 \mathrm{~g}$ 

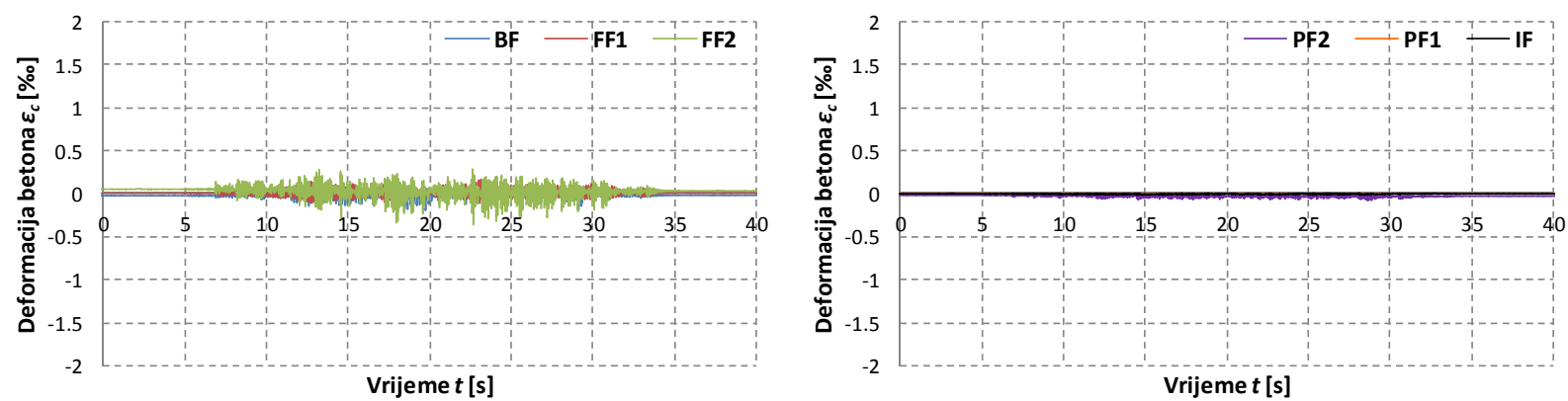

a) $\mathrm{a}_{\mathrm{g}, \max }=0.5 \mathrm{~g}$
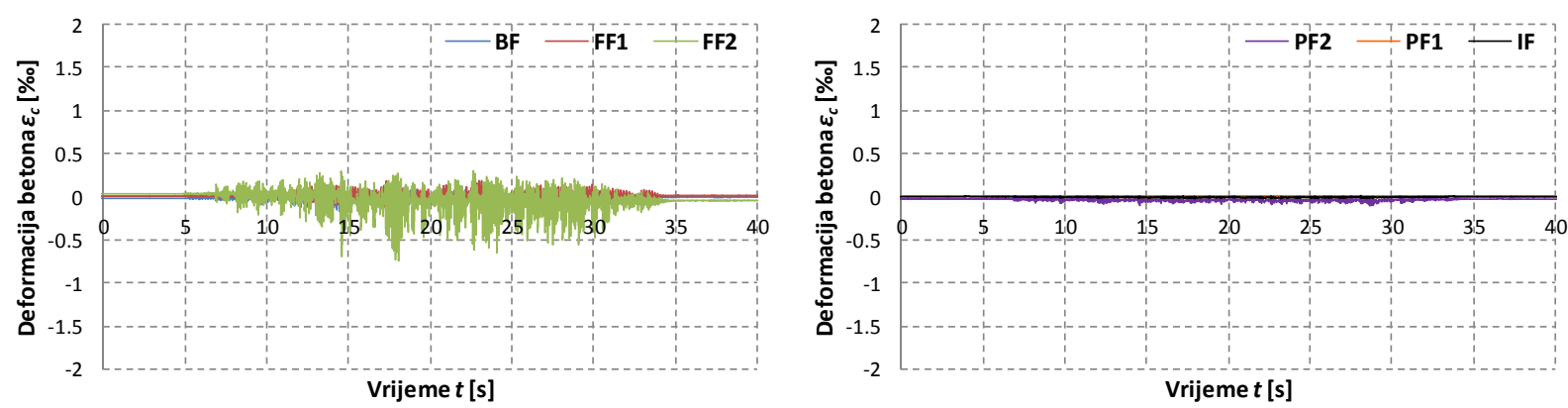

b) $\mathrm{a}_{\mathrm{g}, \max }=0.6 \mathrm{~g}$
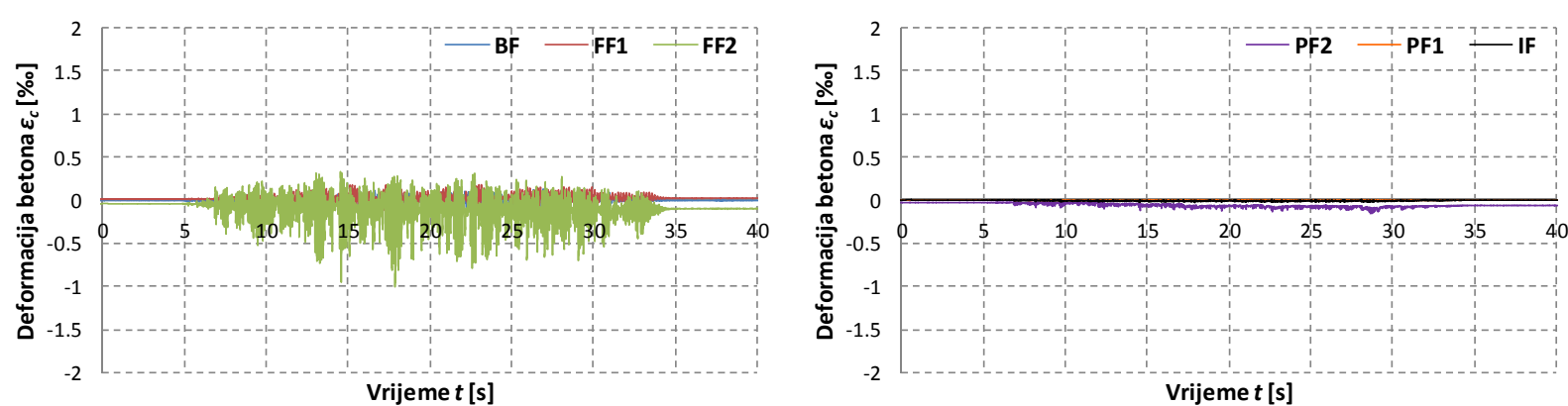

c) $\mathrm{a}_{\mathrm{g}, \max }=0.7 \mathrm{~g}$
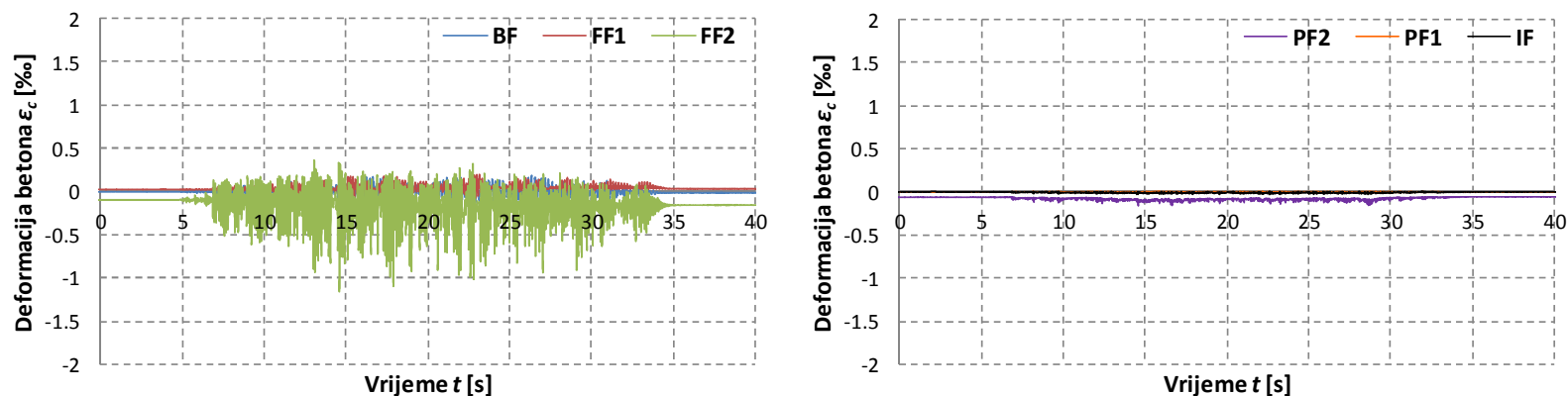

d) $\mathrm{a}_{\mathrm{g}, \max }=0.8 \mathrm{~g}$

Slika 3.63. Deformacija betona pri dnu stupa gornje etaže okvira (točka E) u vremenu za umjetni akcelerogram AA1 s maksimalnim ubrzanjem $\mathrm{a}_{\mathrm{g}, \max }=0.5,0.6,0.7 \mathrm{i} 0.8 \mathrm{~g}$ 

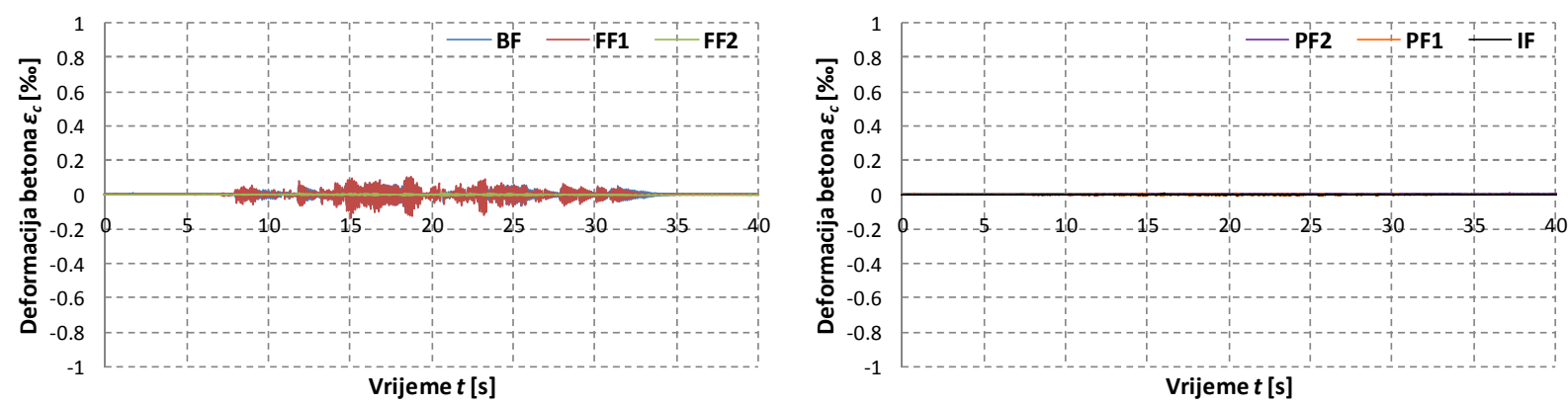

a) $\mathrm{a}_{\mathrm{g}, \max }=0.1 \mathrm{~g}$

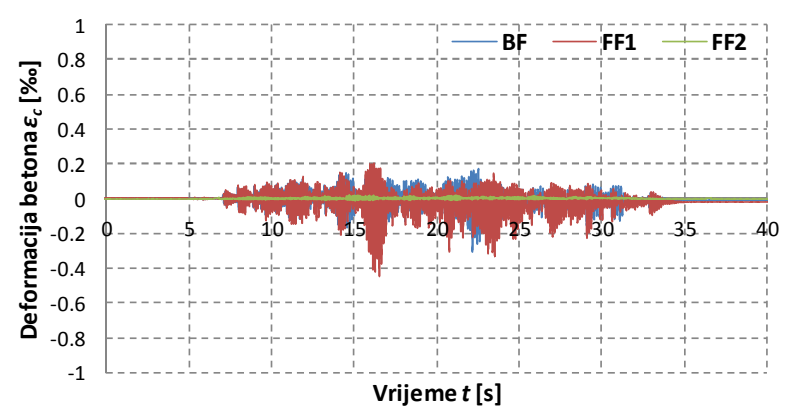

b) $\mathrm{a}_{\mathrm{g}, \max }=0.2 \mathrm{~g}$
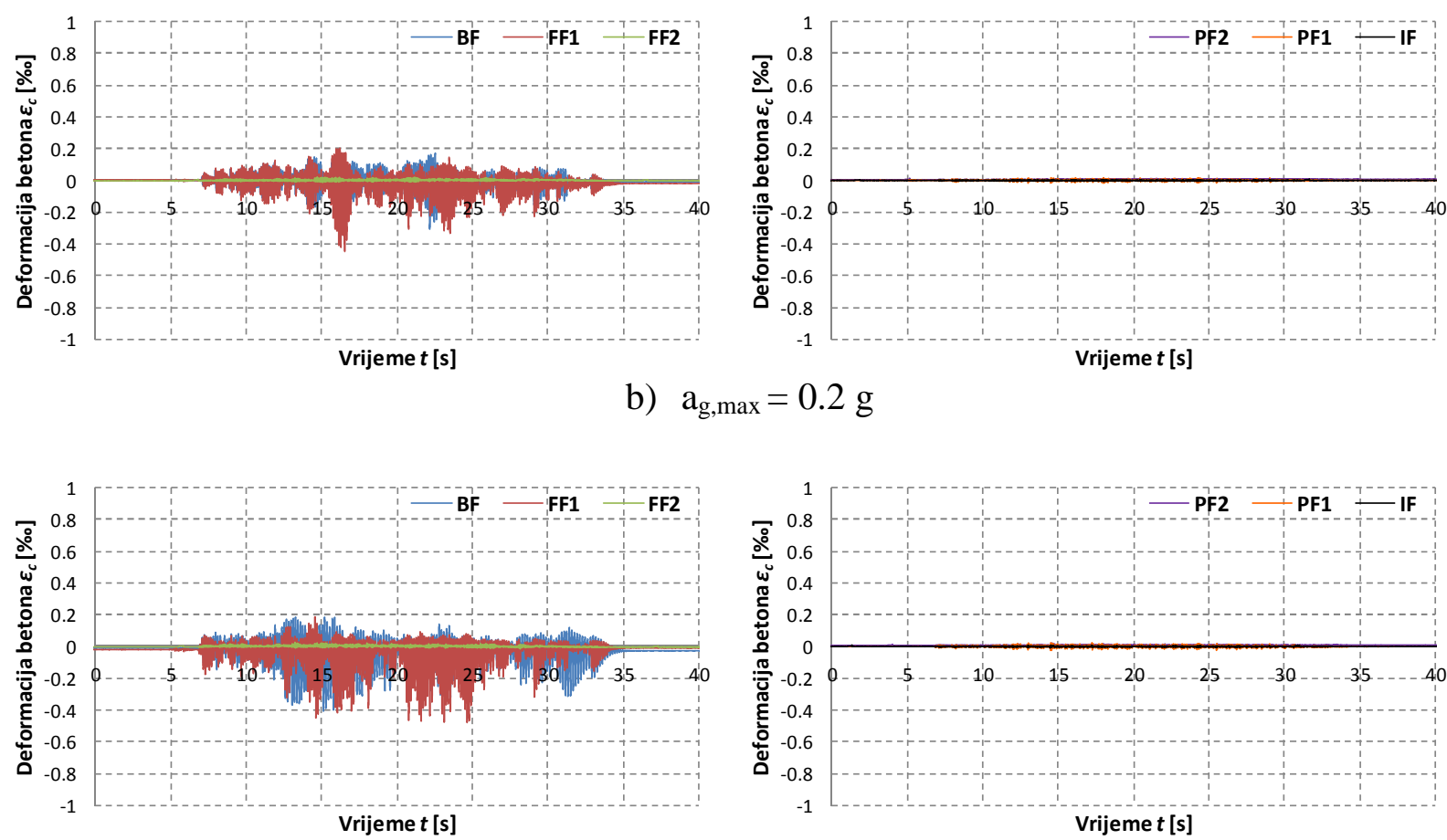

c) $\mathrm{a}_{\mathrm{g}, \max }=0.3 \mathrm{~g}$
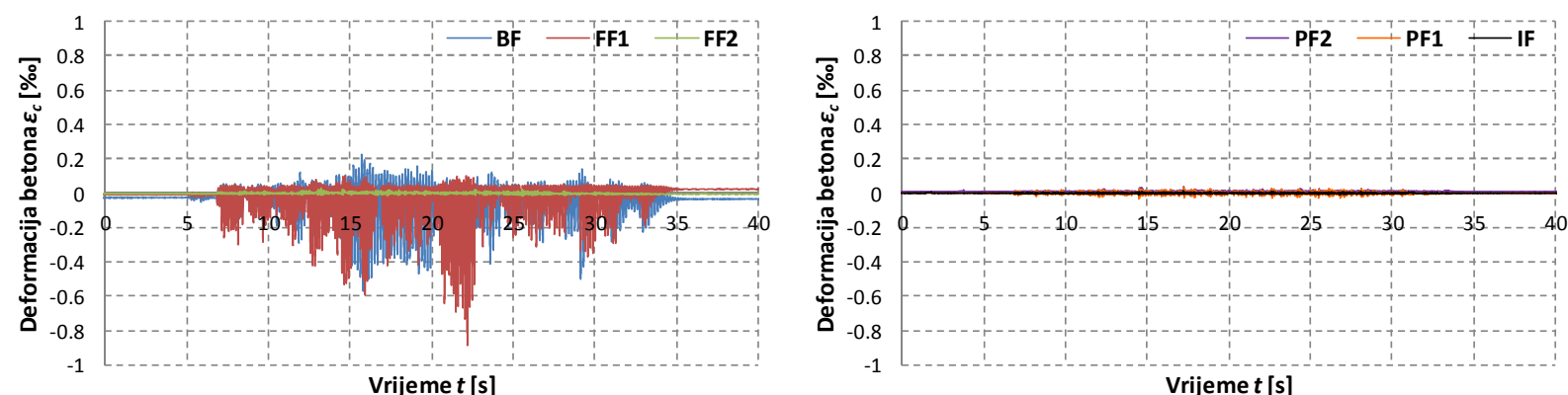

d) $\mathrm{a}_{\mathrm{g}, \max }=0.4 \mathrm{~g}$

Slika 3.64. Deformacija betona pri dnu stupa donje etaže okvira (točka F) u vremenu za umjetni akcelerogram AA1 s maksimalnim ubrzanjem $\mathrm{a}_{\mathrm{g}, \max }=0.1,0.2,0.3$ i $0.4 \mathrm{~g}$ 

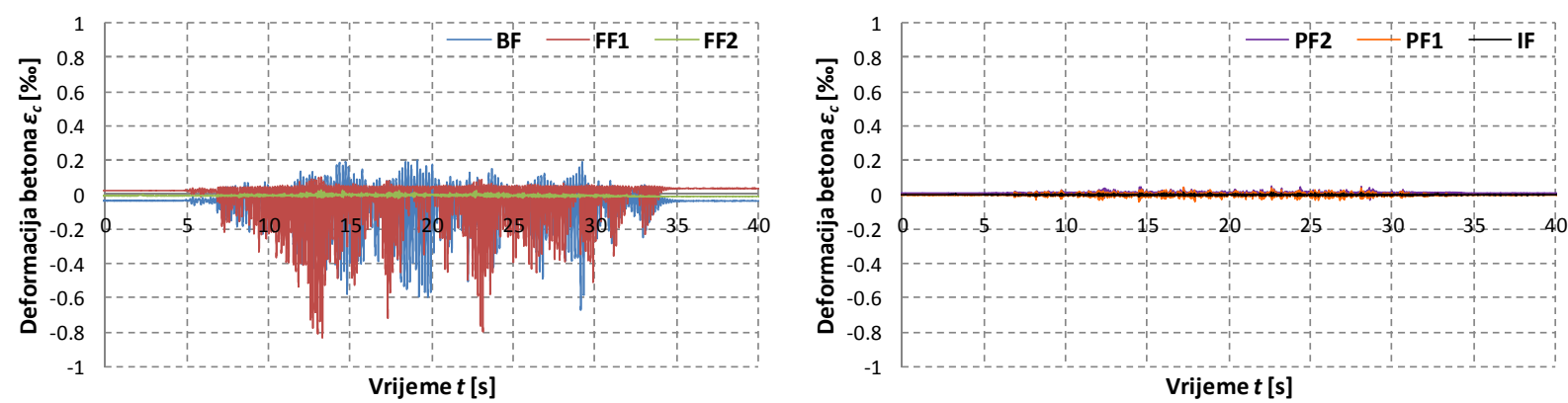

a) $a_{g, \text { max }}=0.5 \mathrm{~g}$

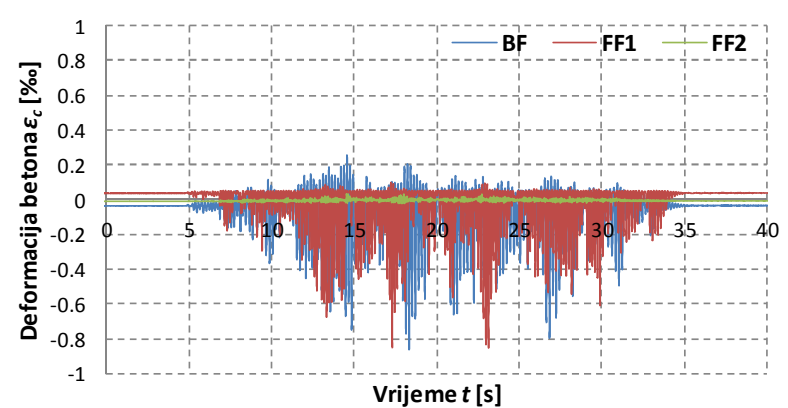

b) $\mathrm{a}_{\mathrm{g}, \max }=0.6 \mathrm{~g}$
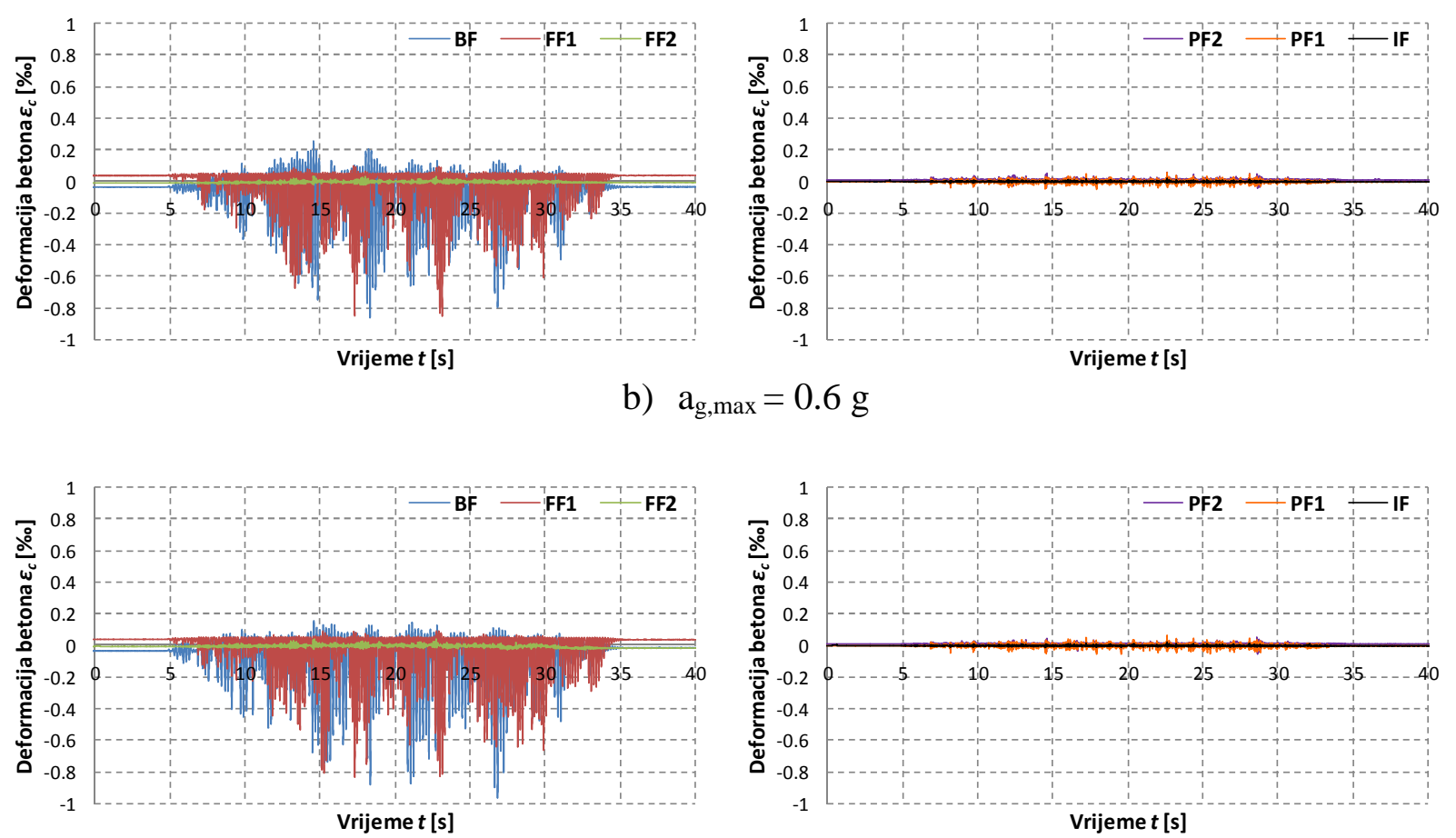

c) $\mathrm{a}_{\mathrm{g}, \max }=0.7 \mathrm{~g}$
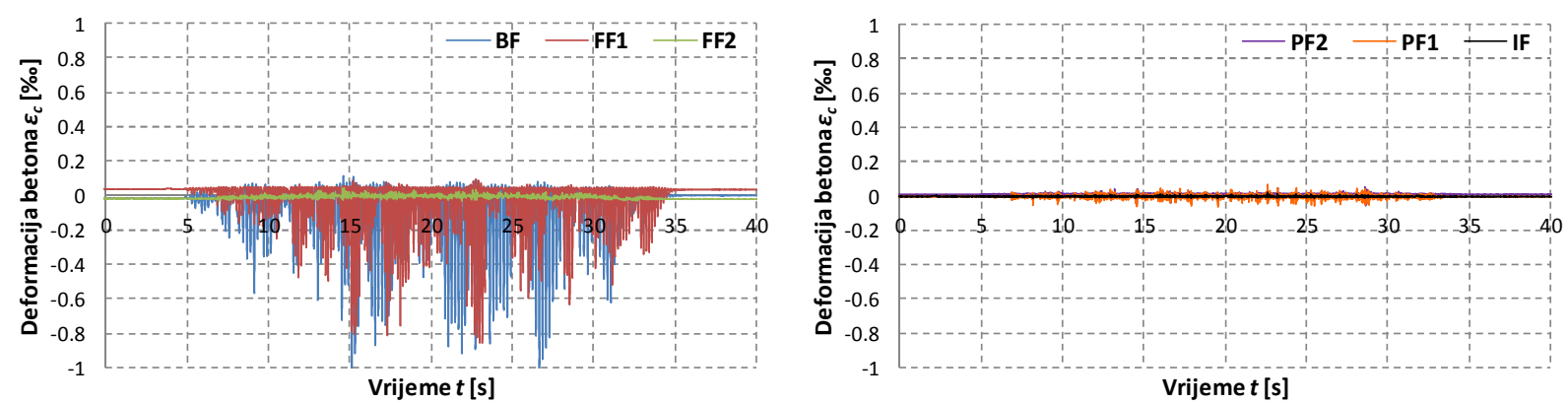

d) $\mathrm{a}_{\mathrm{g}, \max }=0.8 \mathrm{~g}$

Slika 3.65. Deformacija betona pri dnu stupa donje etaže okvira (točka F) u vremenu za umjetni akcelerogram AA1 s maksimalnim ubrzanjem $\mathrm{a}_{\mathrm{g}, \max }=0.5,0.6,0.7 \mathrm{i} 0.8 \mathrm{~g}$ 

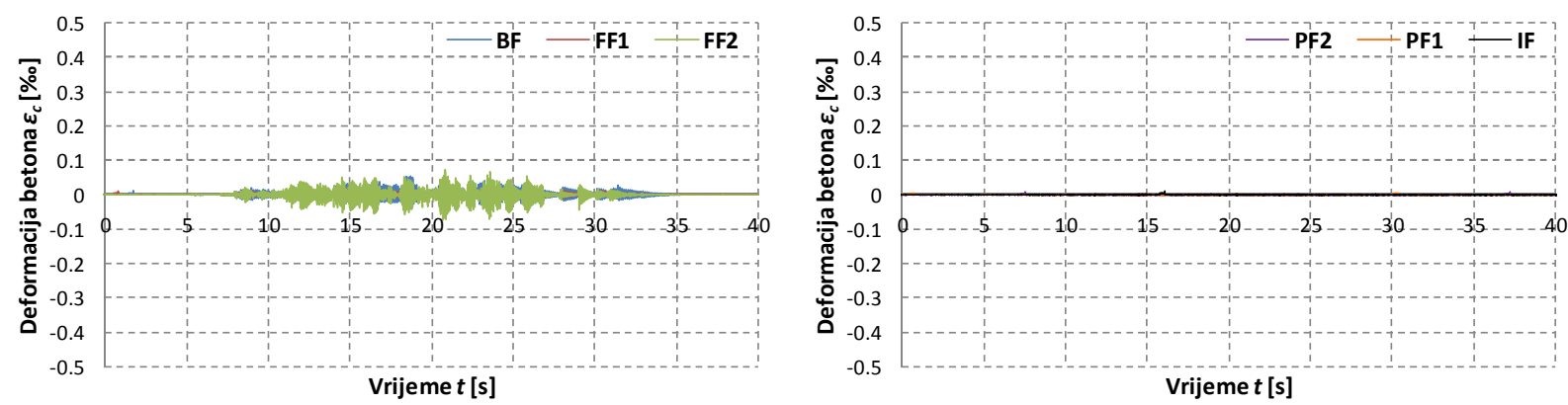

a) $\mathrm{a}_{\mathrm{g}, \max }=0.1 \mathrm{~g}$

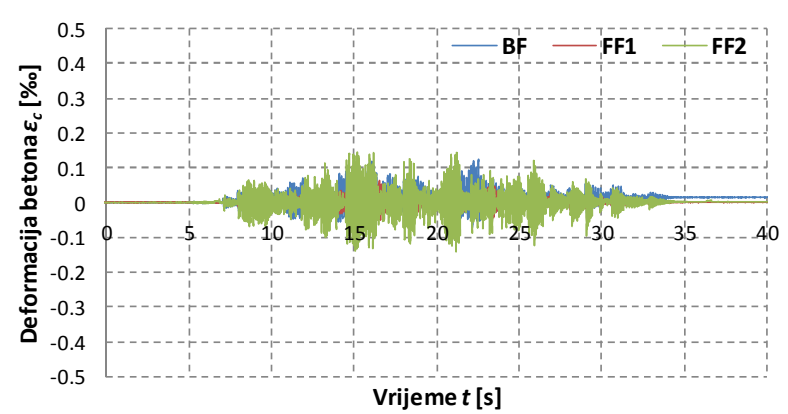

b) $\mathrm{a}_{\mathrm{g}, \max }=0.2 \mathrm{~g}$
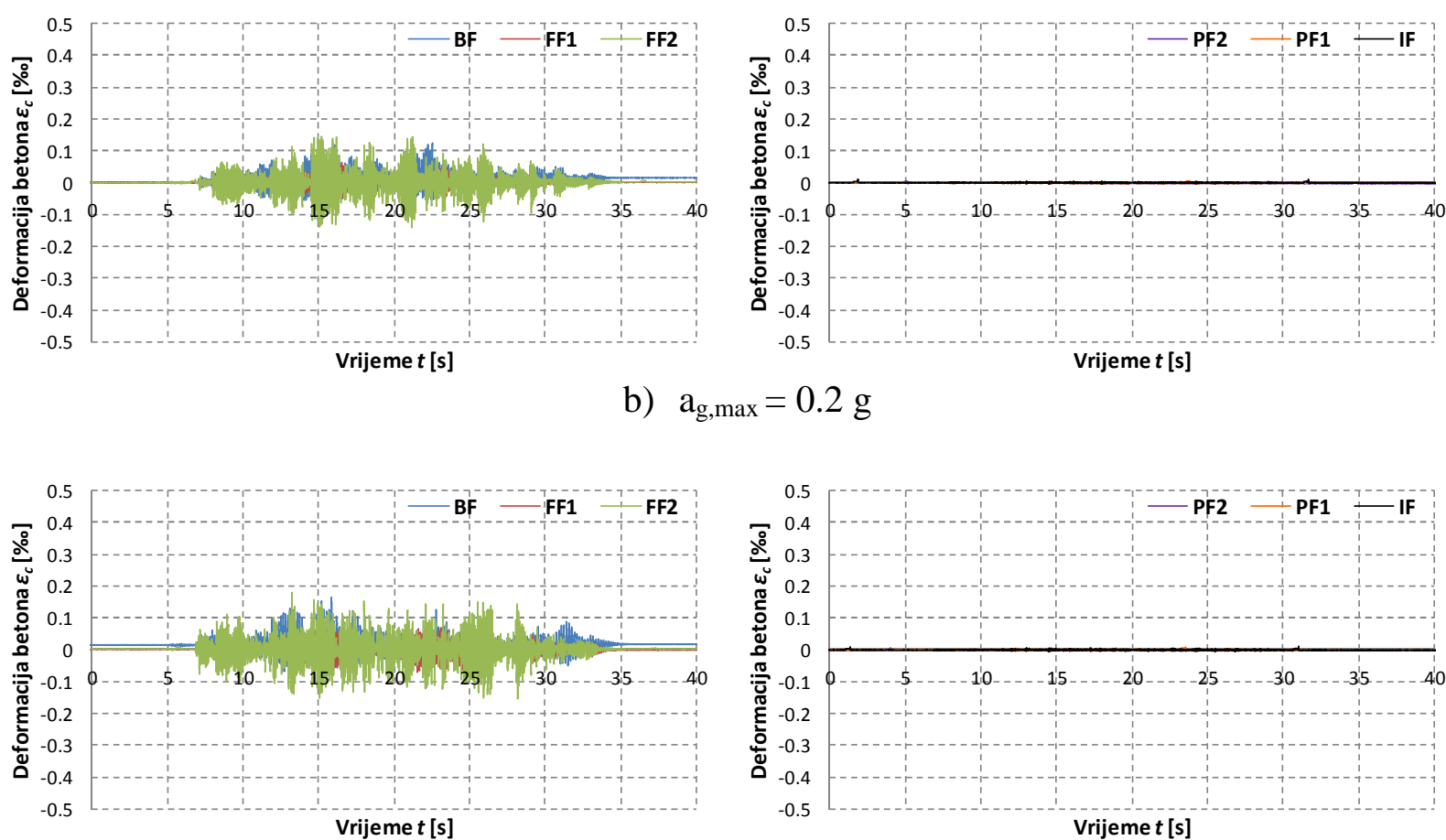

c) $\mathrm{a}_{\mathrm{g}, \max }=0.3 \mathrm{~g}$
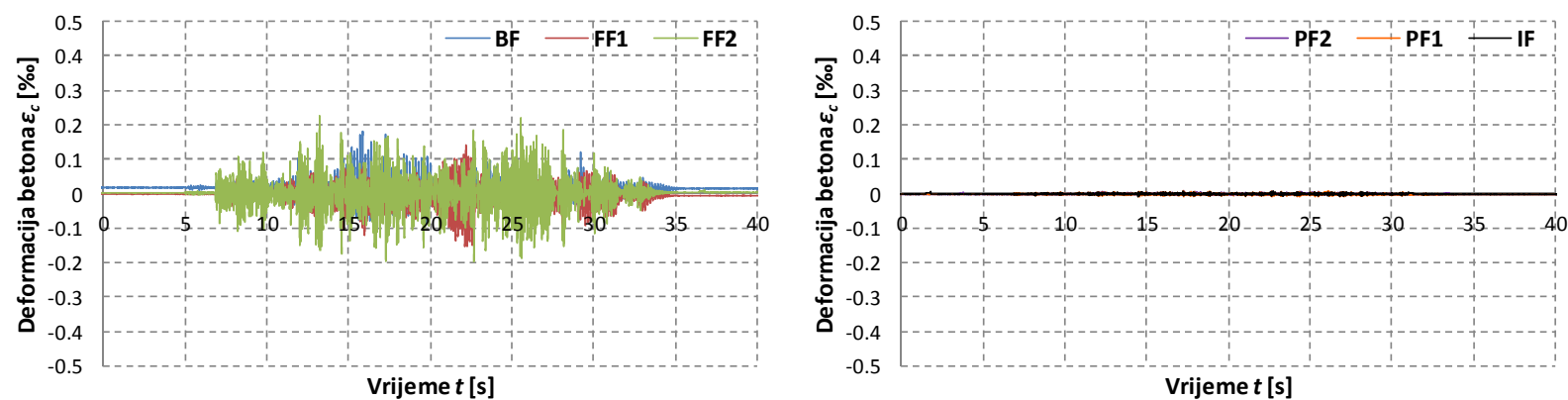

d) $a_{g, \text { max }}=0.4 \mathrm{~g}$

Slika 3.66. Deformacija betona pri dnu stupa gornje etaže okvira (točka G) u vremenu za umjetni akcelerogram AA1 s maksimalnim ubrzanjem $\mathrm{a}_{\mathrm{g}, \max }=0.1,0.2,0.3 \mathrm{i} 0.4 \mathrm{~g}$ 

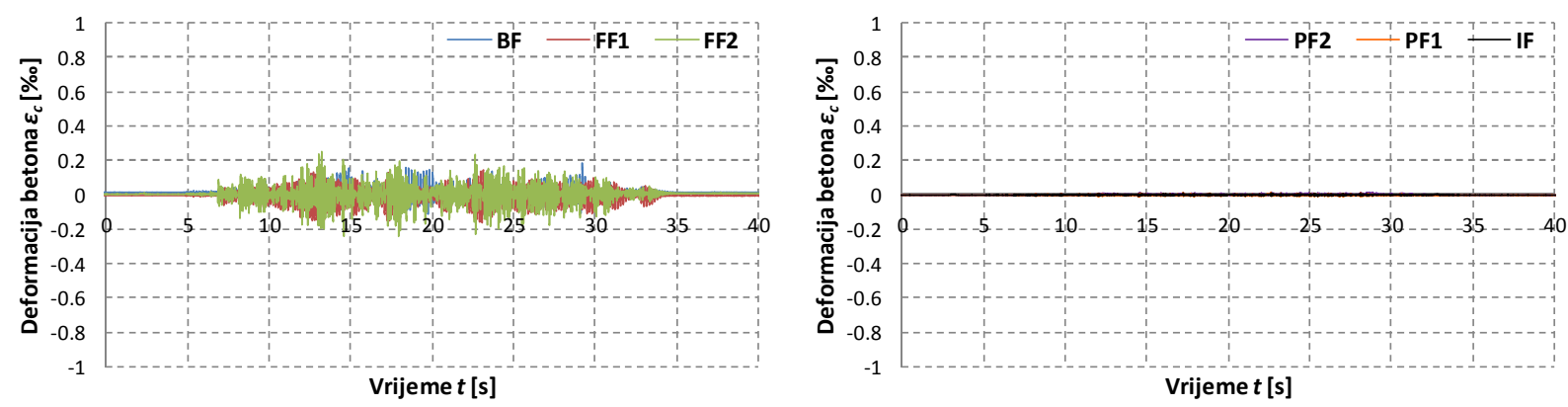

a) $\mathrm{a}_{\mathrm{g}, \max }=0.5 \mathrm{~g}$

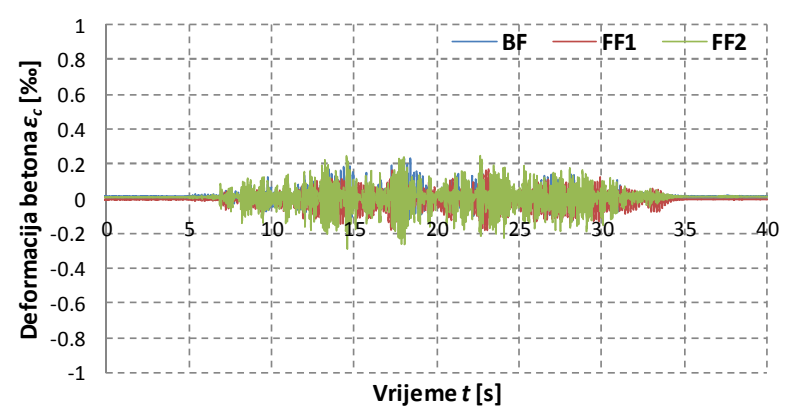

b) $\mathrm{a}_{\mathrm{g}, \max }=0.6 \mathrm{~g}$
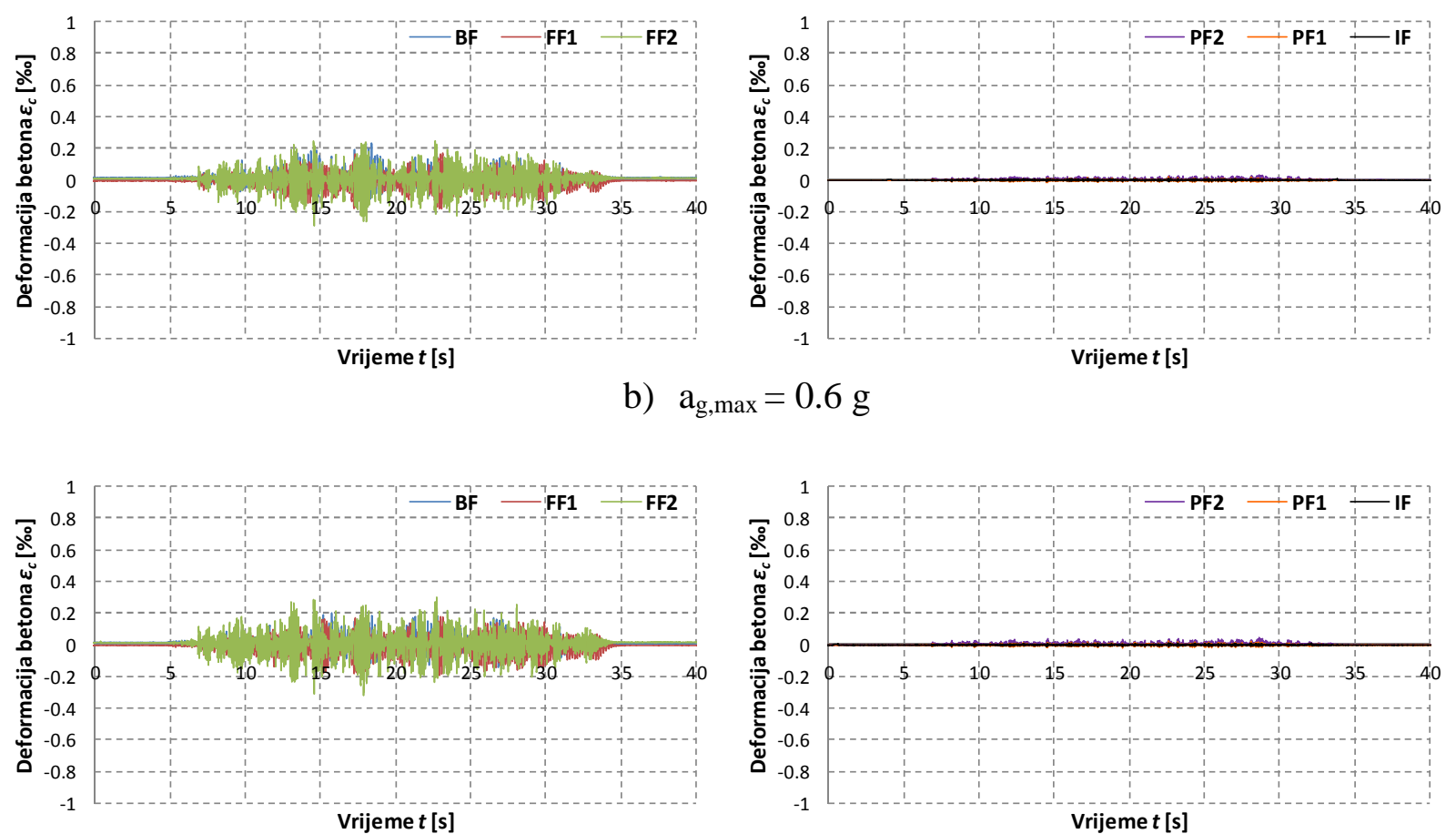

c) $\mathrm{a}_{\mathrm{g}, \max }=0.7 \mathrm{~g}$

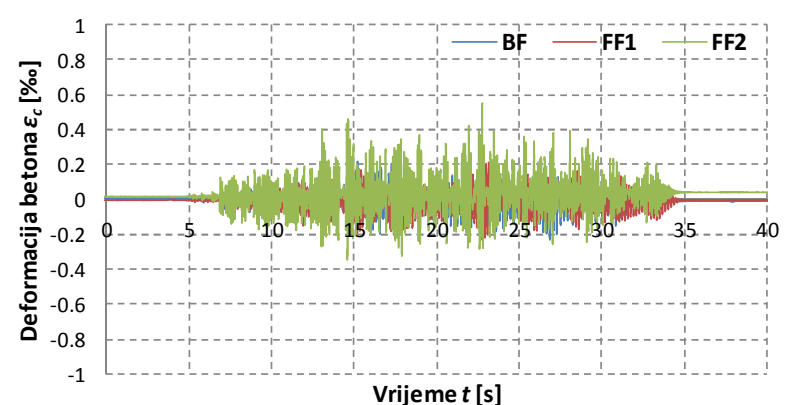

d) $\mathrm{a}_{\mathrm{g}, \max }=0.8 \mathrm{~g}$

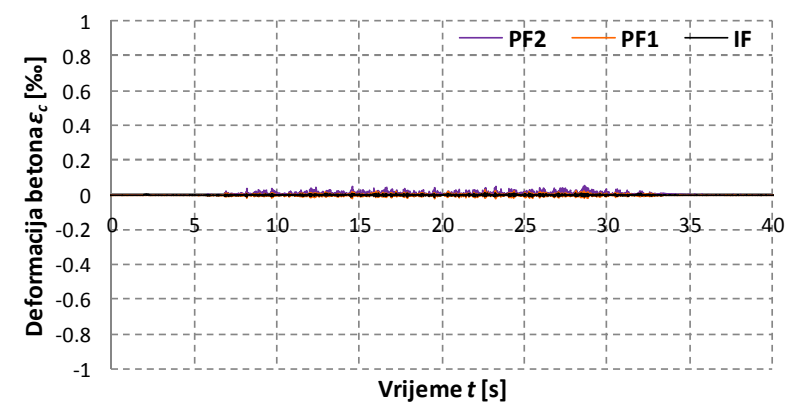

Slika 3.67. Deformacija betona pri dnu stupa gornje etaže okvira (točka $\mathrm{G}$ ) u vremenu za umjetni akcelerogram AA1 s maksimalnim ubrzanjem $\mathrm{a}_{\mathrm{g}, \max }=0.5,0.6,0.7 \mathrm{i} 0.8 \mathrm{~g}$ 


\subsubsection{Rezultati za umjetni akcelerogram AA2}

Nakon izlaganja okvira nizu umjetnih akcelerograma AA1, svi okviri su izloženi nizu umjetnih akcelerograma AA2. Pri tome su amplitude akcelerograma također postupno povećavane, tako da je maksimalna amplituda iznosila $\mathrm{a}_{\mathrm{g}, \max }=0.1,0.2,0.3 \mathrm{i} 0.4 \mathrm{~g}$. Horizontalni pomaci vrha gornje etaže okvira $\left(\mathrm{u}_{2}\right)$ u vremenu prikazani su na Slici 3.68. Horizontalni pomaci vrha donje etaže okvira $\left(\mathrm{u}_{1}\right) \mathrm{u}$ vremenu prikazani su na Slici 3.69. Horizontalna ubrzanja vrha gornje etaže okvira $\left(a_{2}\right)$ u vremenu prikazani su na Slici 3.70 . Horizontalna ubrzanja vrha donje etaže okvira $\left(a_{1}\right)$ u vremenu prikazani su na Slici 3.71 . Deformacije armature pri dnu stupa gornje etaže (točka A) u vremenu prikazane su na Slici 3.72. Deformacije armature pri dnu stupa donje etaže (točka B) u vremenu prikazane su na Slici 3.73. Deformacije armature pri dnu stupa donje etaže (točka C) u vremenu prikazane su na Slici 3.74. Deformacije betona pri dnu stupa donje etaže (točka D) u vremenu prikazane su na Slici 3.75. Deformacije betona pri dnu stupa gornje etaže (točka E) u vremenu prikazane su na Slici 3.76. Deformacije betona pri dnu stupa donje etaže (točka F) u vremenu prikazane su na Slici 3.77. Deformacije betona pri dnu stupa gornje etaže (točka G) u vremenu prikazane su na Slici 3.78.

Usporedbom izmjerenih vrijednosti odgovarajući veličina, može se zaključiti da su rezultati umjetnog akcelerograma AA1 kompatibilni s rezultatima umjetnog akcelerograma AA2. Pri tome treba imati na umu da su ispitni uzorci već bili prethodno oštećeni uslijed djelovanja umjetnog akcelerograma AA1, te da je kod nekih uzoraka došlo do zaostalih (nepovratnih) deformacija u okviru i ispuni. 

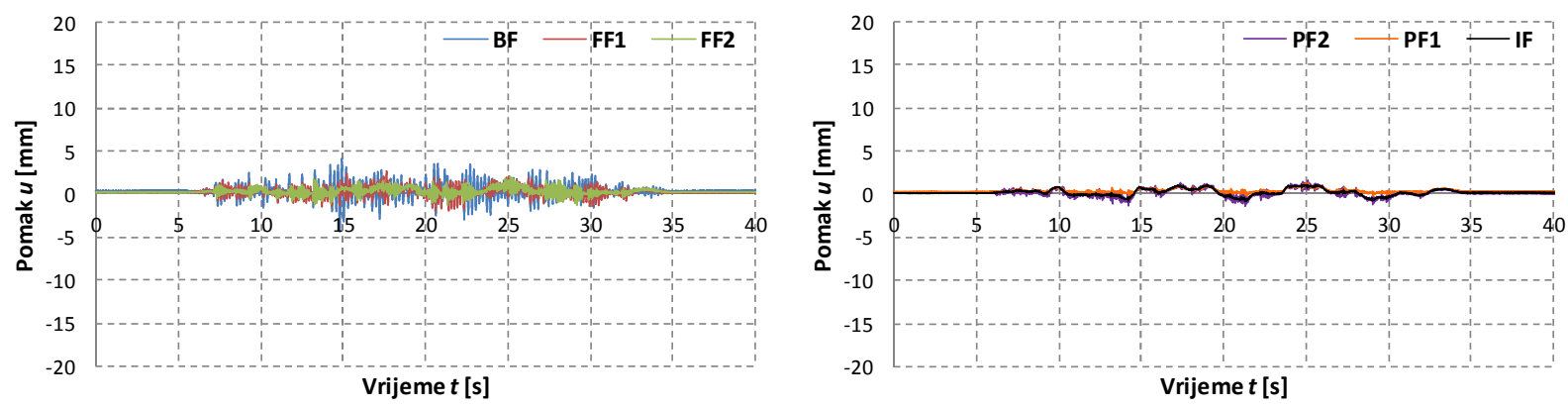

a) $\mathrm{a}_{\mathrm{g}, \max }=0.1 \mathrm{~g}$
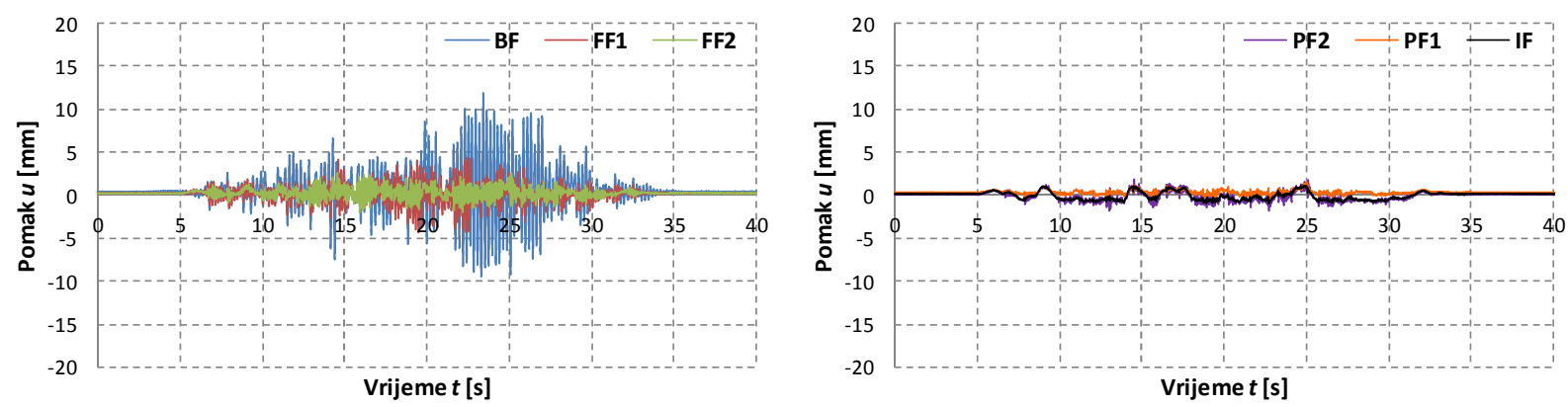

b) $\mathrm{a}_{\mathrm{g}, \max }=0.2 \mathrm{~g}$
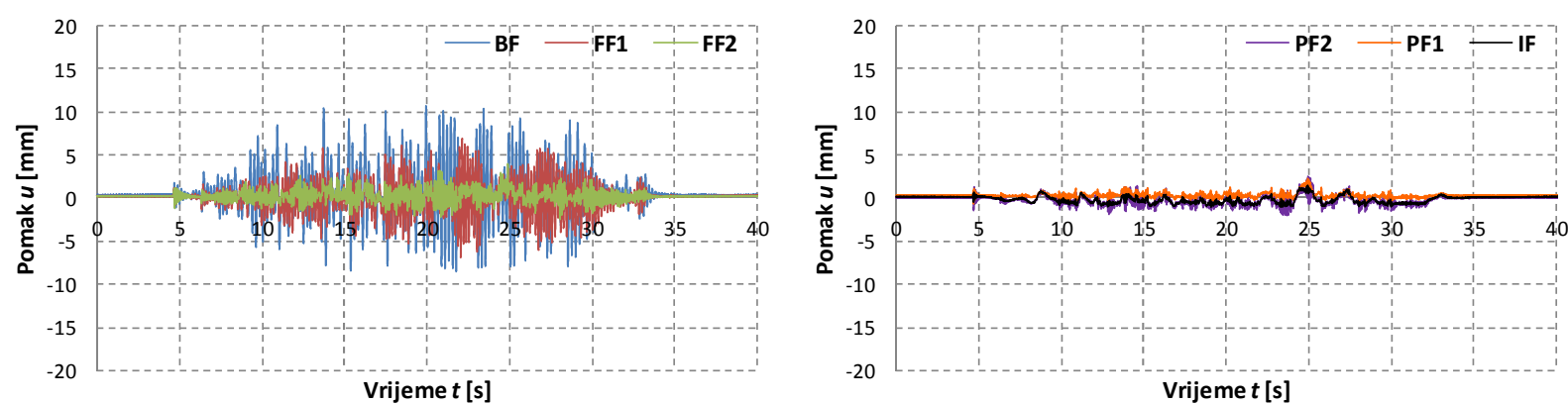

c) $\mathrm{a}_{\mathrm{g}, \max }=0.3 \mathrm{~g}$
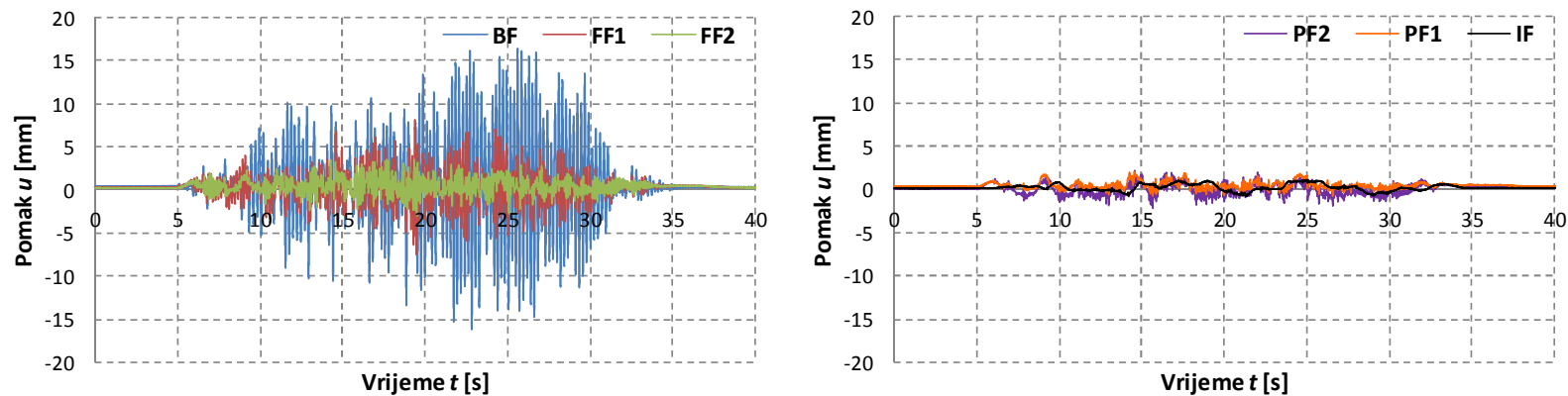

d) $\mathrm{a}_{\mathrm{g}, \max }=0.4 \mathrm{~g}$

Slika 3.68. Horizontalni pomak vrha gornje etaže okvira $\left(u_{2}\right)$ u vremenu za umjetni akcelerogram AA2 s maksimalnim ubrzanjem $\mathrm{a}_{\mathrm{g}, \max }=0.1,0.2,0.3 \mathrm{i} 0.4 \mathrm{~g}$ 

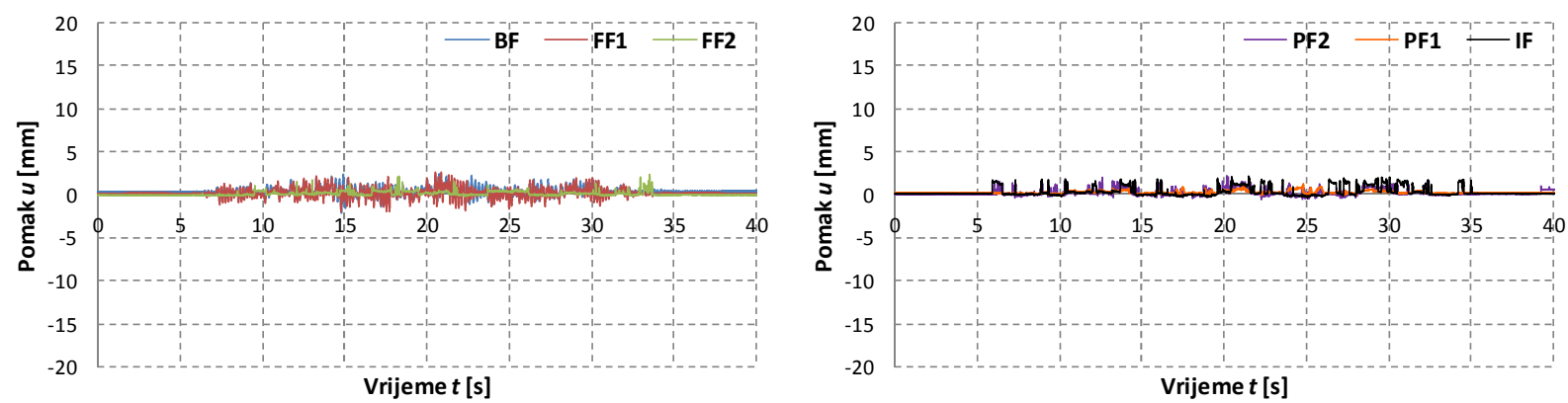

a) $\mathrm{a}_{\mathrm{g}, \max }=0.1 \mathrm{~g}$
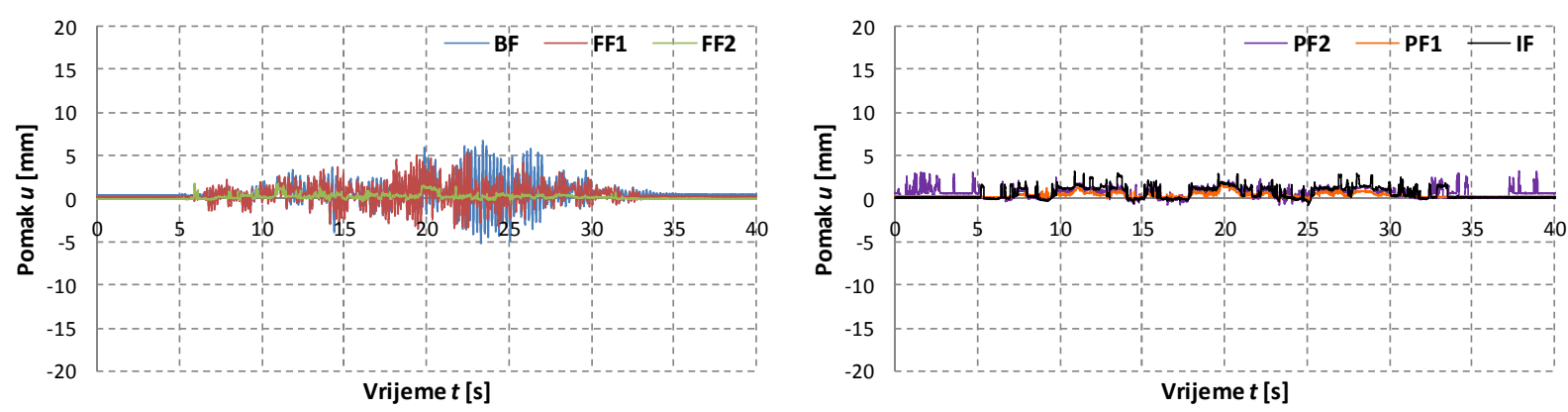

b) $\mathrm{a}_{\mathrm{g}, \max }=0.2 \mathrm{~g}$
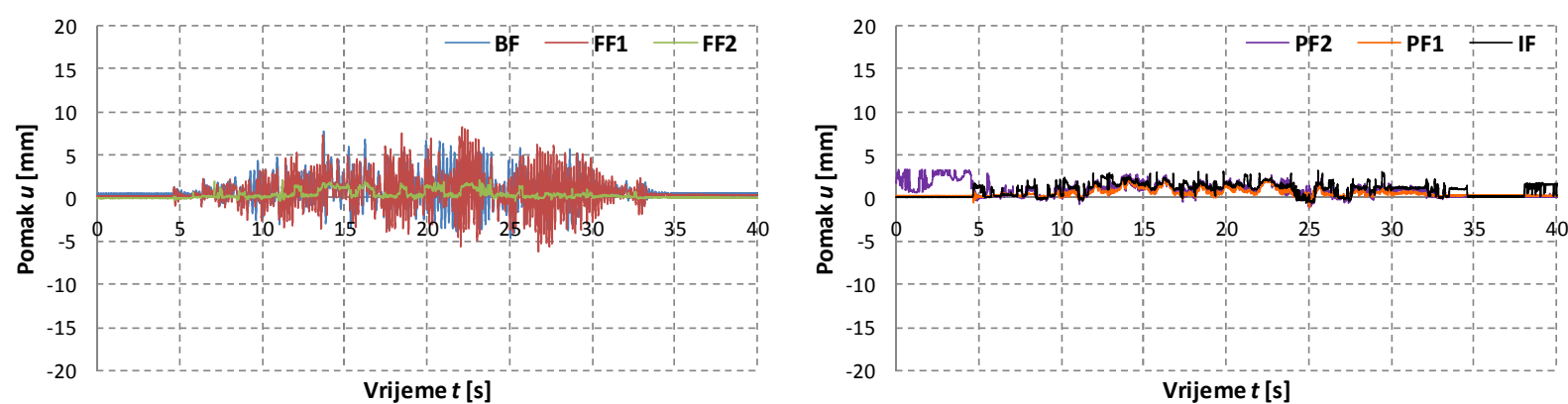

c) $\mathrm{a}_{\mathrm{g}, \max }=0.3 \mathrm{~g}$
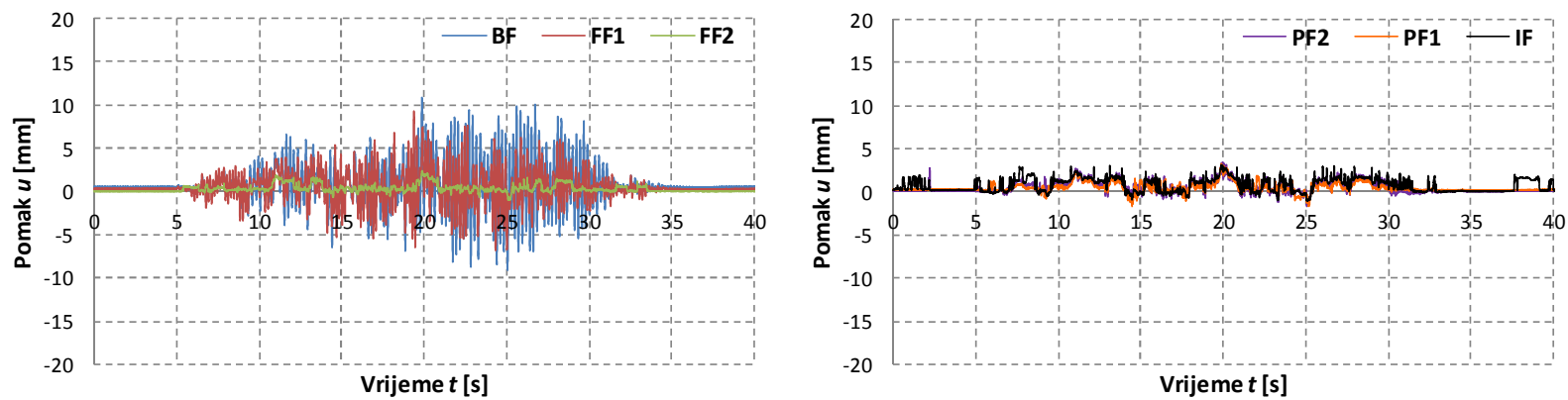

d) $\mathrm{a}_{\mathrm{g}, \max }=0.4 \mathrm{~g}$

Slika 3.69. Horizontalni pomak vrha donje etaže okvira $\left(u_{1}\right)$ u vremenu za umjetni akcelerogram AA2 s maksimalnim ubrzanjem $\mathrm{a}_{\mathrm{g}, \max }=0.1,0.2,0.3 \mathrm{i} 0.4 \mathrm{~g}$ 

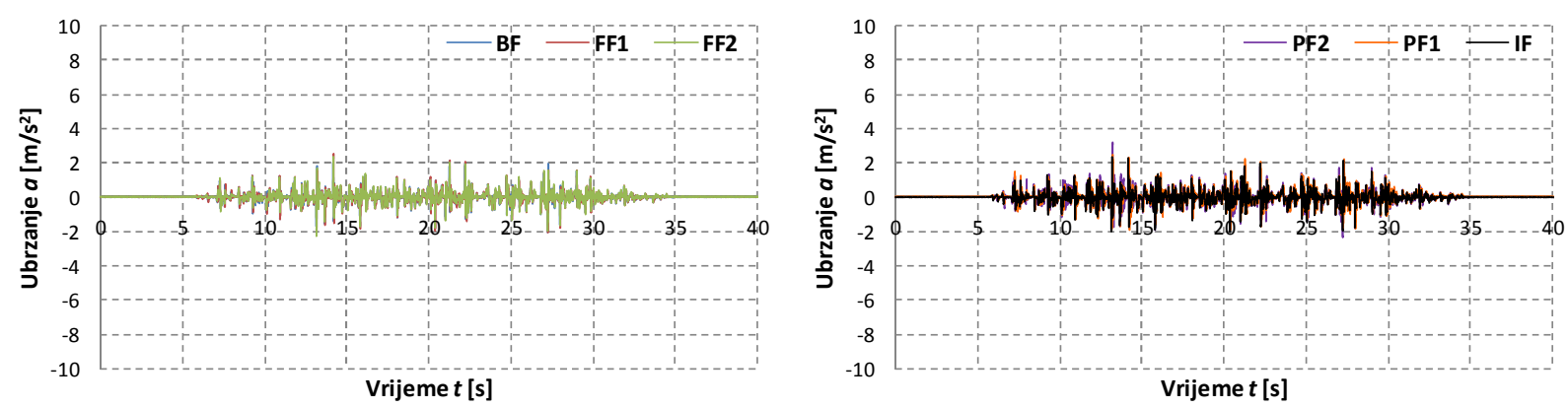

a) $\mathrm{a}_{\mathrm{g}, \max }=0.1 \mathrm{~g}$
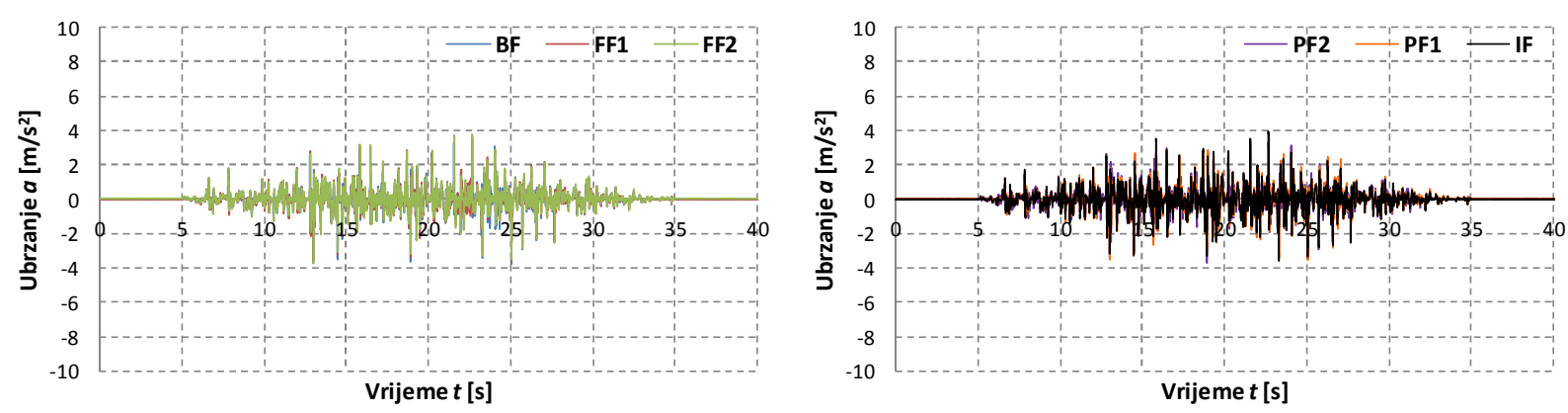

b) $\mathrm{a}_{\mathrm{g}, \max }=0.2 \mathrm{~g}$
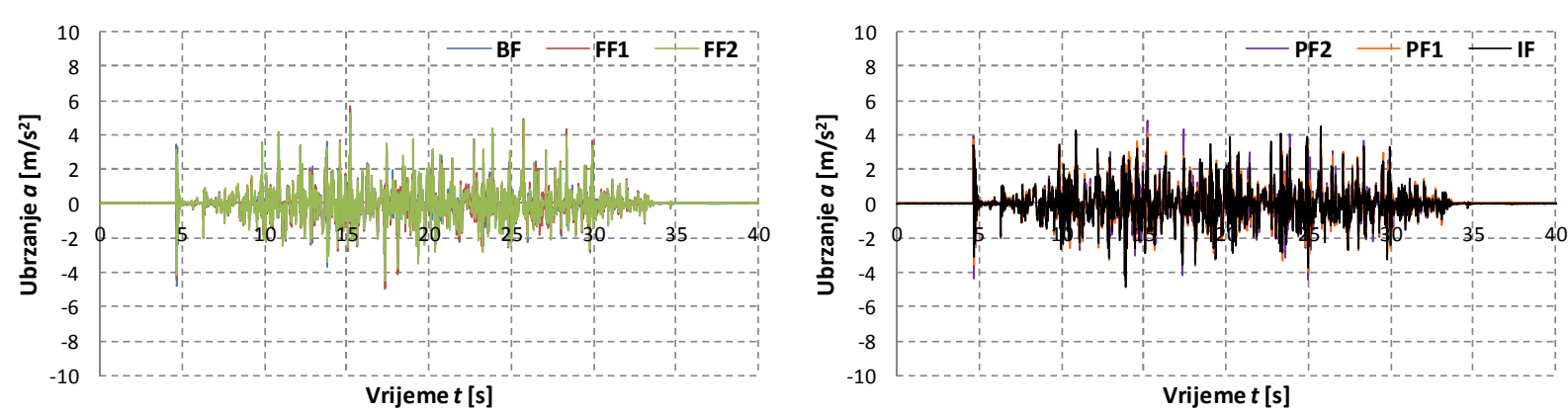

c) $\mathrm{a}_{\mathrm{g}, \max }=0.3 \mathrm{~g}$
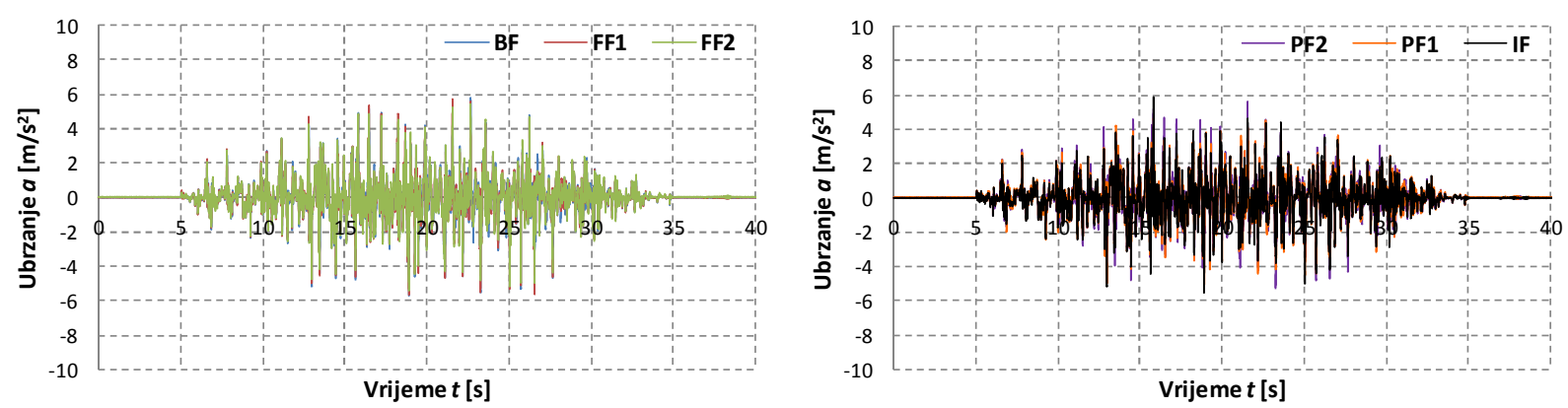

d) $\mathrm{a}_{\mathrm{g}, \max }=0.4 \mathrm{~g}$

Slika 3.70. Horizontalno ubrzanje vrha gornje etaže okvira $\left(a_{2}\right)$ u vremenu za umjetni akcelerogram AA2 s maksimalnim ubrzanjem $\mathrm{a}_{\mathrm{g}, \max }=0.1,0.2,0.3 \mathrm{i} 0.4 \mathrm{~g}$ 

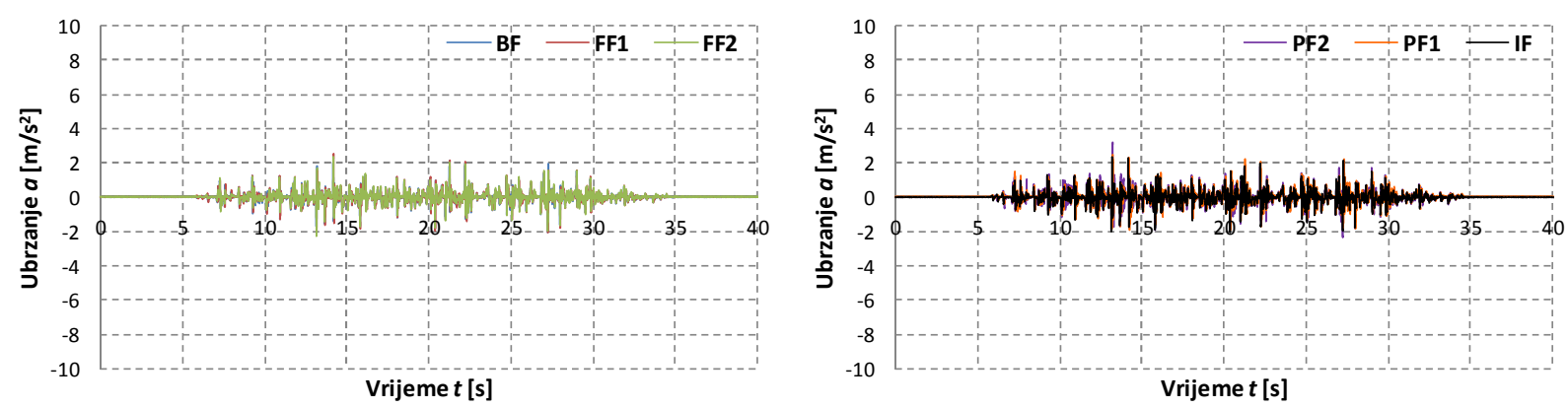

a) $\mathrm{a}_{\mathrm{g}, \max }=0.1 \mathrm{~g}$
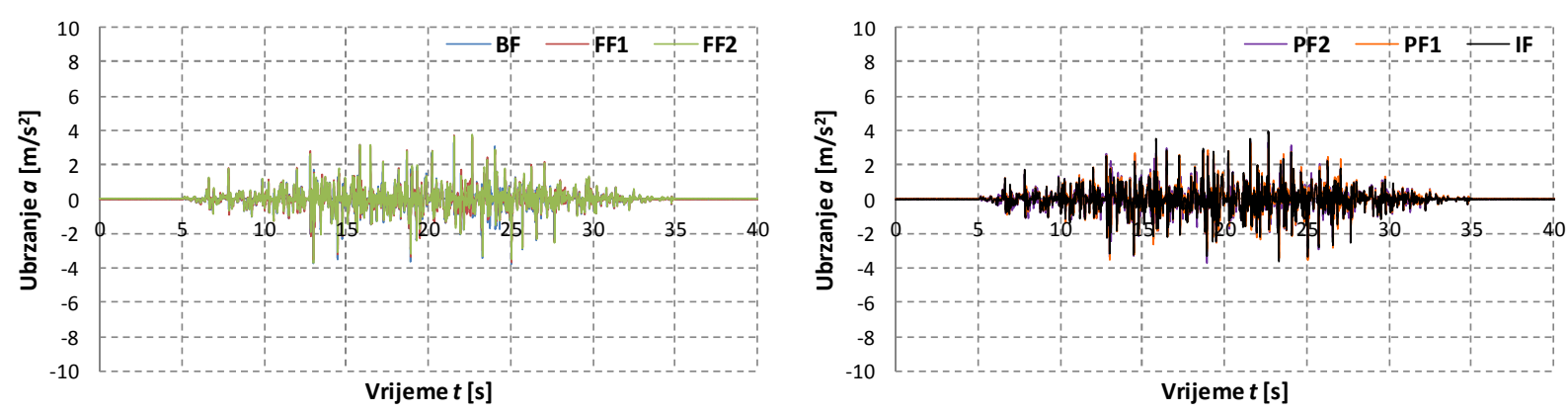

b) $\mathrm{a}_{\mathrm{g}, \max }=0.2 \mathrm{~g}$
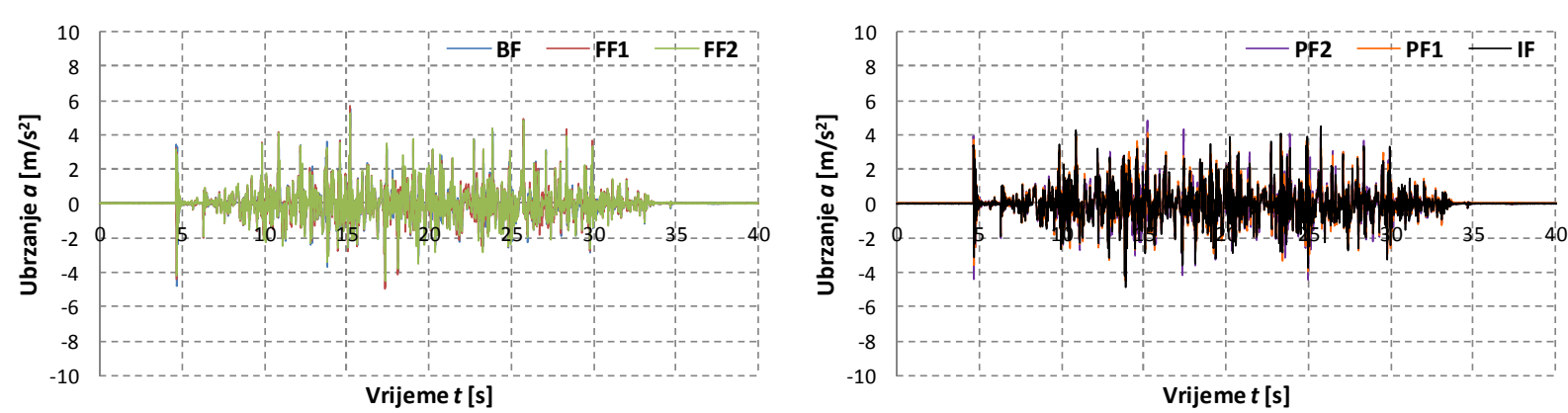

c) $\mathrm{a}_{\mathrm{g}, \max }=0.3 \mathrm{~g}$
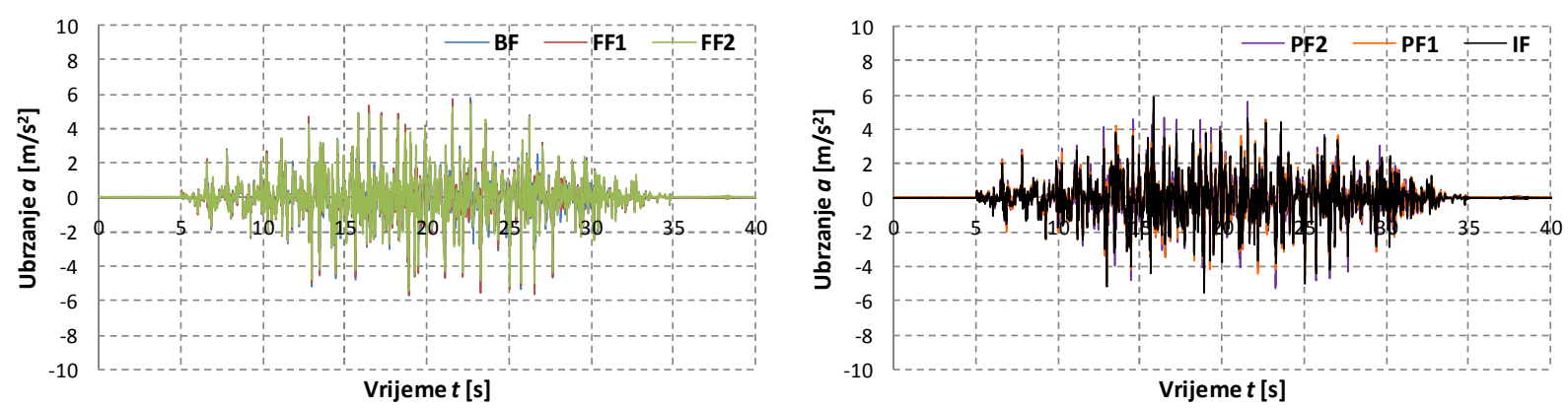

d) $\mathrm{a}_{\mathrm{g}, \max }=0.4 \mathrm{~g}$

Slika 3.71. Horizontalno ubrzanje vrha donje etaže okvira $\left(a_{1}\right)$ u vremenu za umjetni akcelerogram AA2 s maksimalnim ubrzanjem $\mathrm{a}_{\mathrm{g}, \max }=0.1,0.2,0.3 \mathrm{i} 0.4 \mathrm{~g}$ 

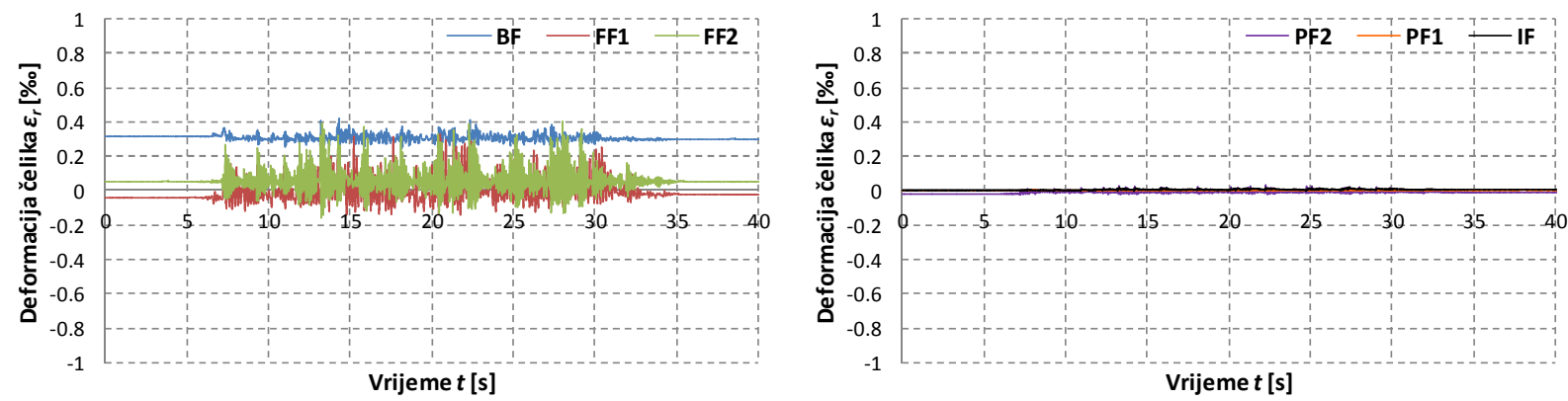

a) $\mathrm{a}_{\mathrm{g}, \max }=0.1 \mathrm{~g}$

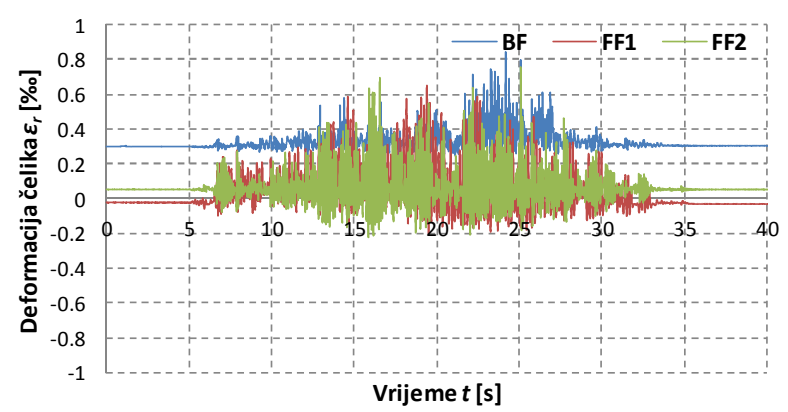

b) $\mathrm{a}_{\mathrm{g}, \max }=0.2 \mathrm{~g}$
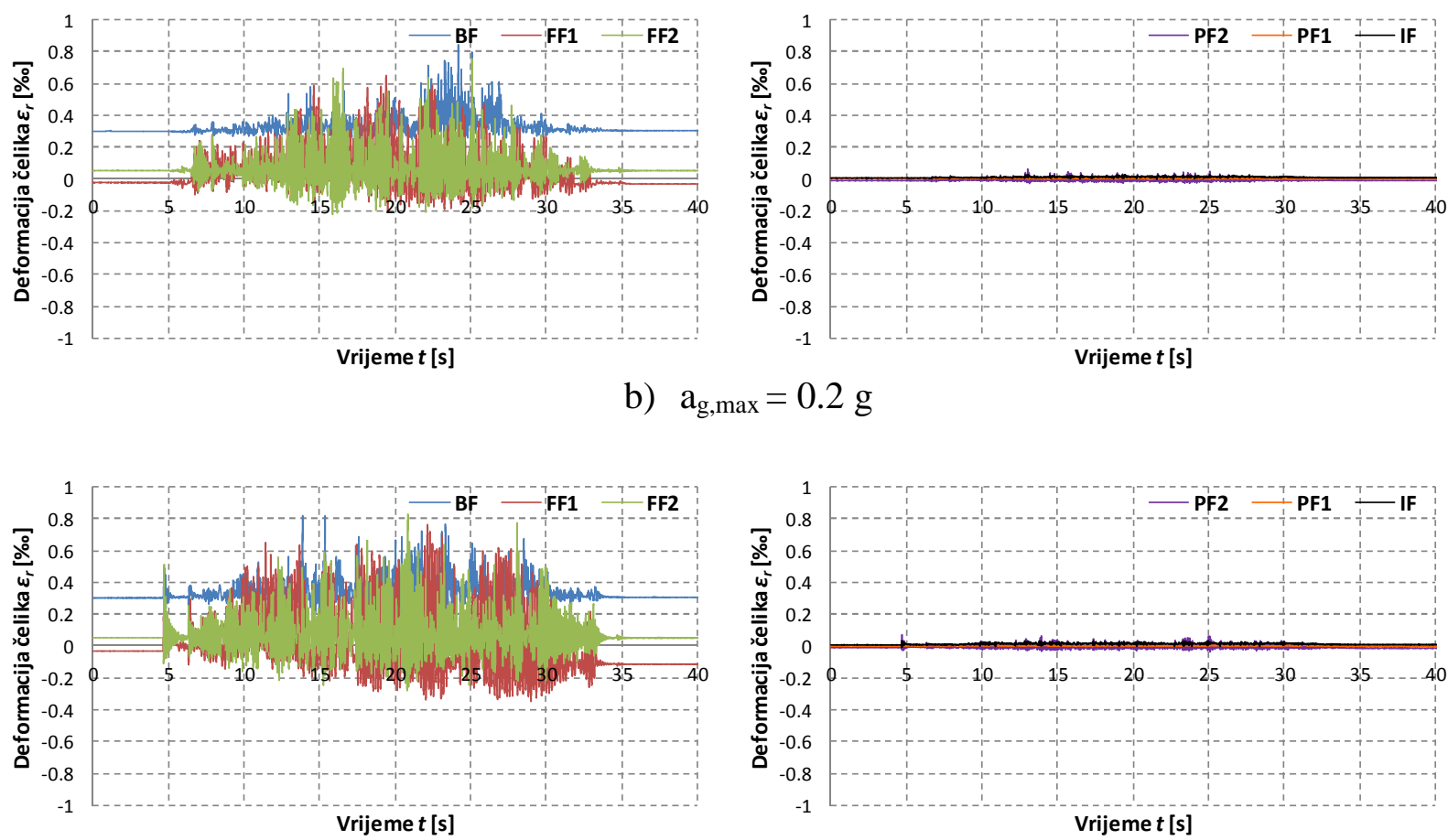

c) $\mathrm{a}_{\mathrm{g}, \max }=0.3 \mathrm{~g}$
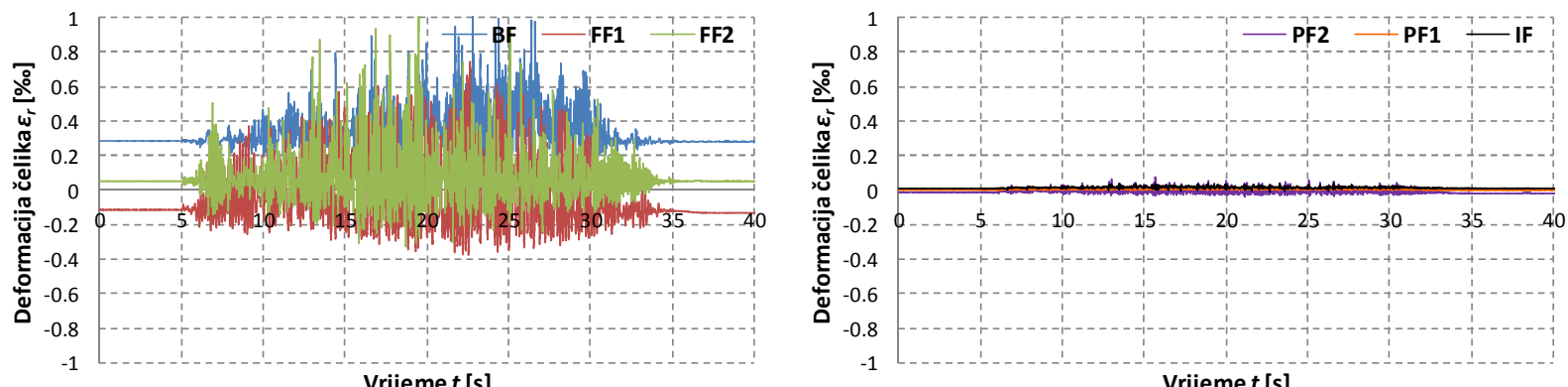

d) $\mathrm{a}_{\mathrm{g}, \max }=0.4 \mathrm{~g}$

Slika 3.72. Deformacija armature pri dnu stupa gornje etaže okvira (točka A) u vremenu za umjetni akcelerogram AA2 s maksimalnim ubrzanjem $\mathrm{a}_{\mathrm{g}, \max }=0.1,0.2,0.3 \mathrm{i} 0.4 \mathrm{~g}$ 

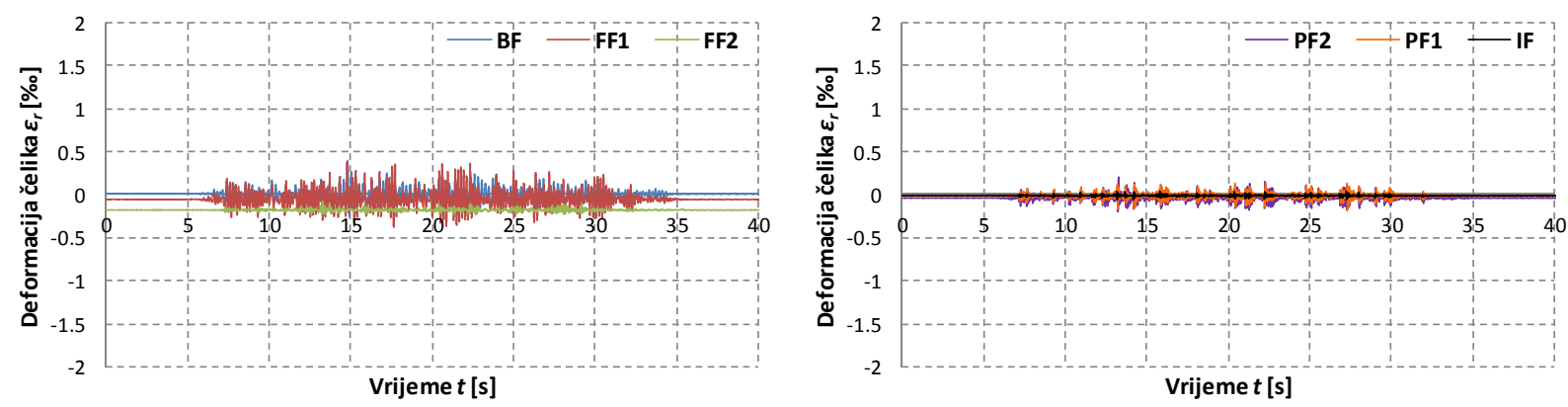

a) $\mathrm{a}_{\mathrm{g}, \max }=0.1 \mathrm{~g}$
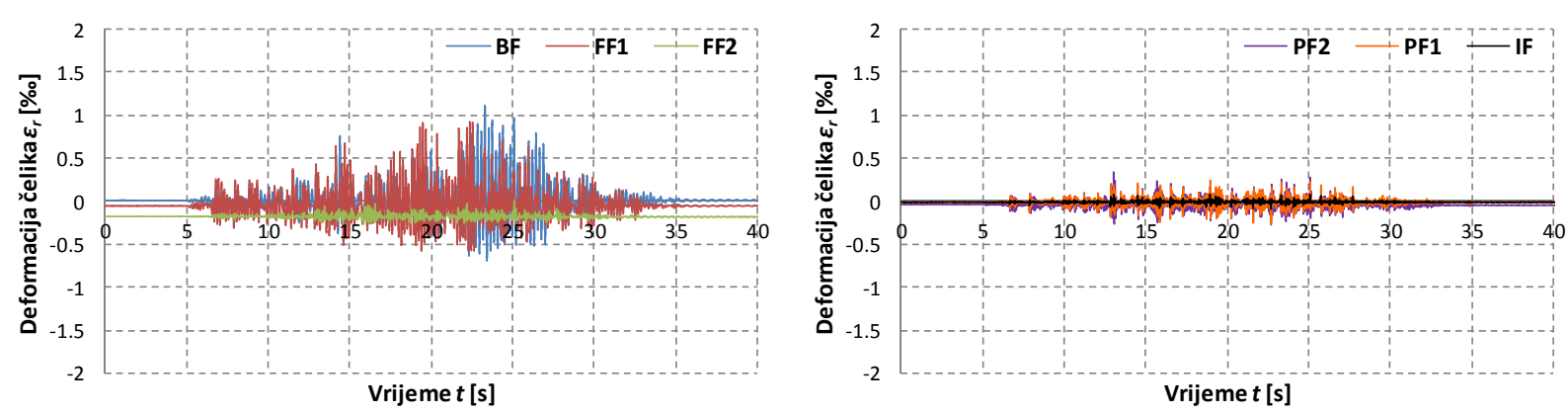

b) $\mathrm{a}_{\mathrm{g}, \max }=0.2 \mathrm{~g}$
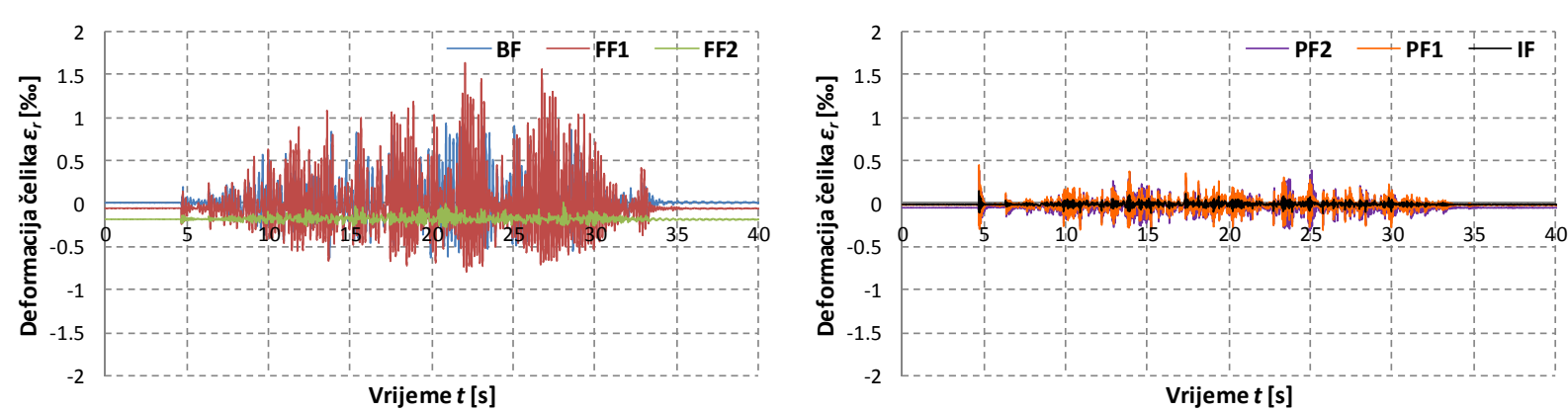

c) $\mathrm{a}_{\mathrm{g}, \max }=0.3 \mathrm{~g}$
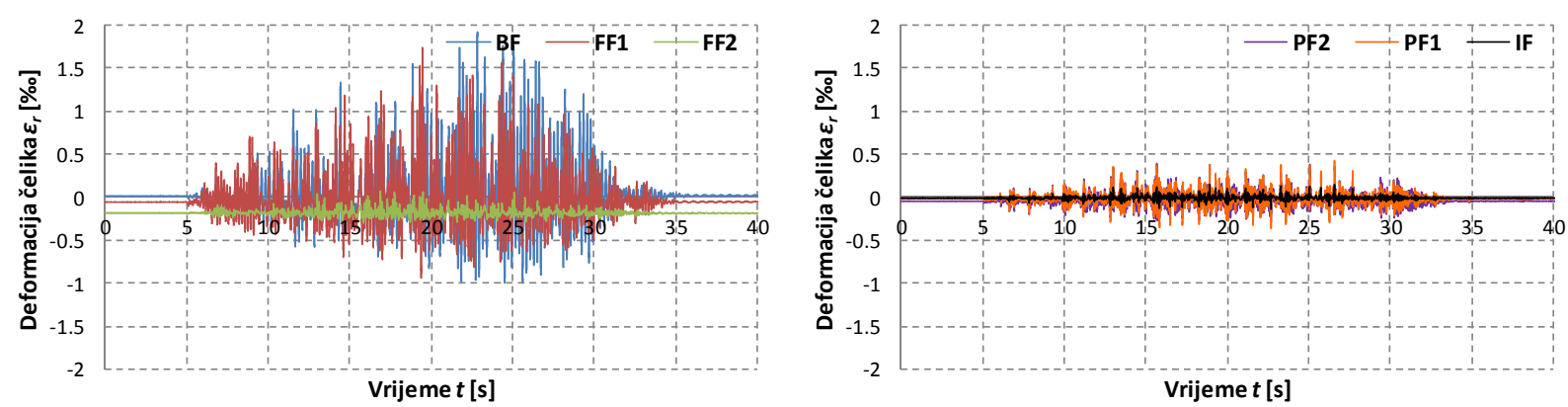

d) $\mathrm{a}_{\mathrm{g}, \max }=0.4 \mathrm{~g}$

Slika 3.73. Deformacija armature pri dnu stupa donje etaže okvira (točka B) u vremenu za umjetni akcelerogram AA2 s maksimalnim ubrzanjem $\mathrm{a}_{\mathrm{g}, \max }=0.1,0.2,0.3$ i $0.4 \mathrm{~g}$ 

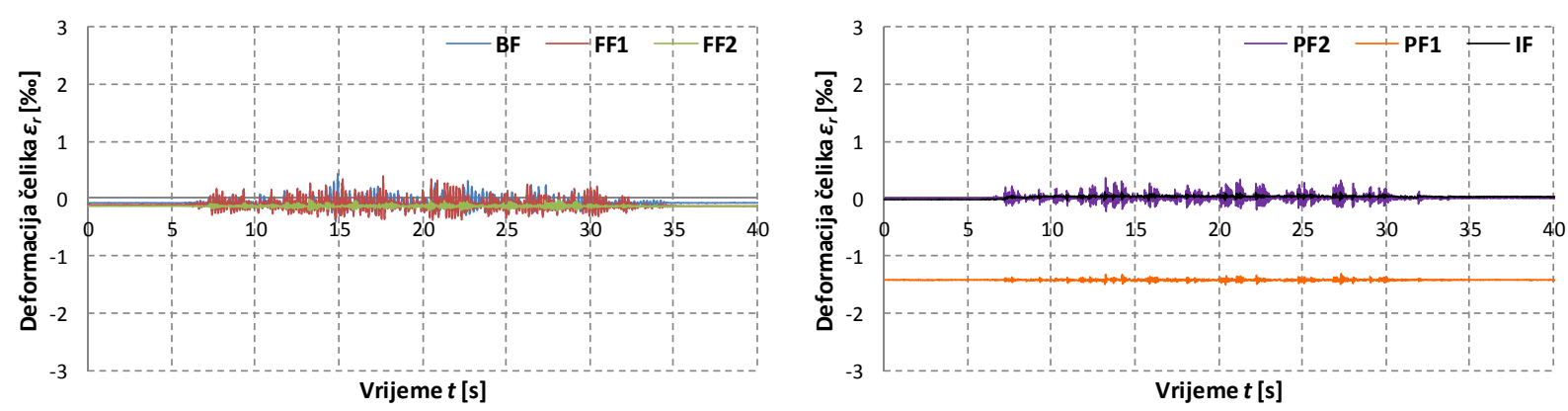

a) $\mathrm{a}_{\mathrm{g}, \max }=0.1 \mathrm{~g}$
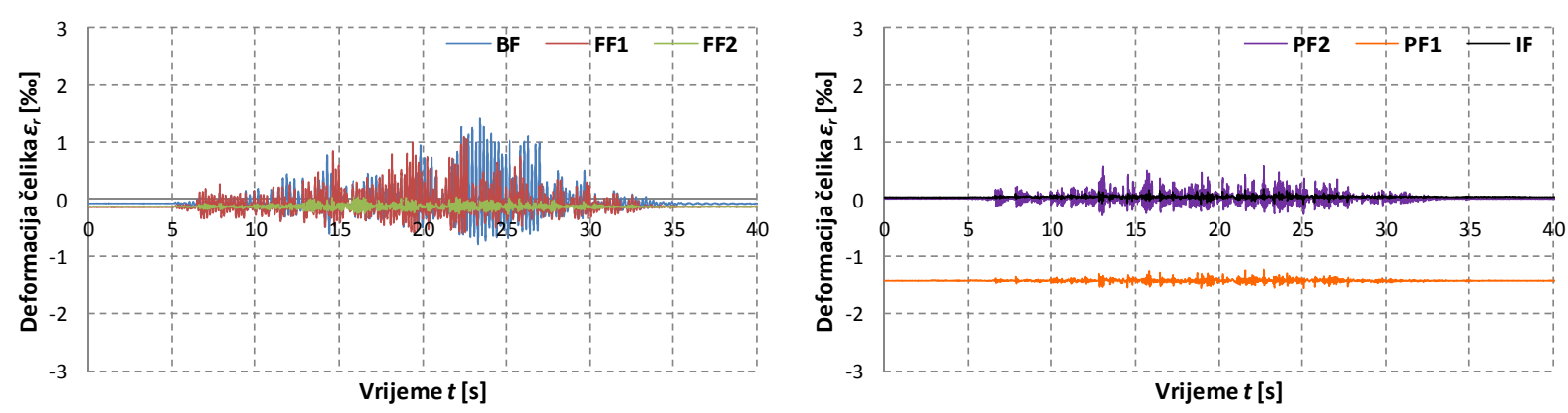

b) $\mathrm{a}_{\mathrm{g}, \max }=0.2 \mathrm{~g}$
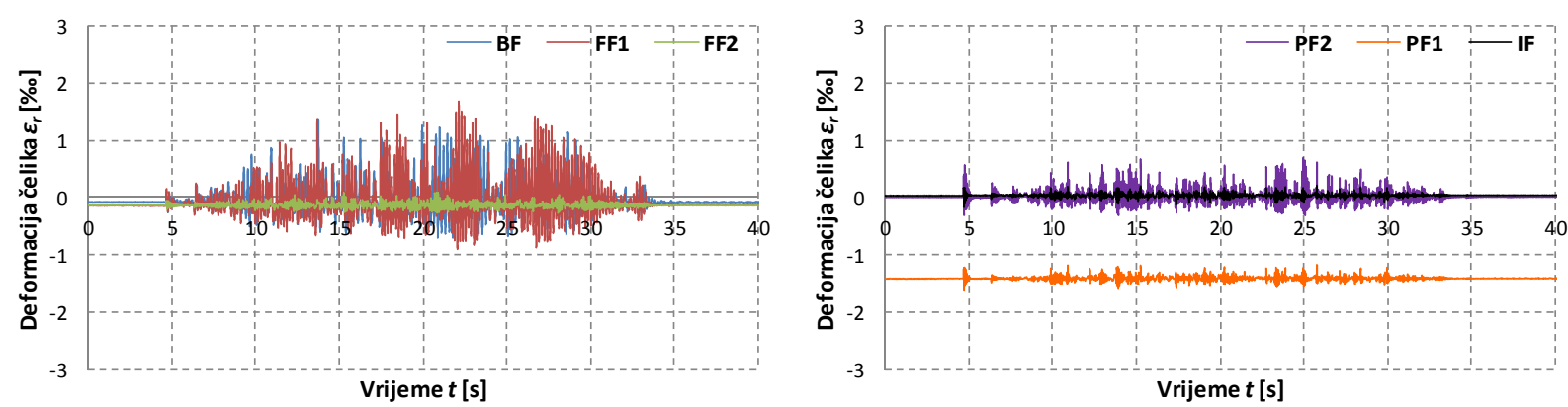

c) $\mathrm{a}_{\mathrm{g}, \max }=0.3 \mathrm{~g}$
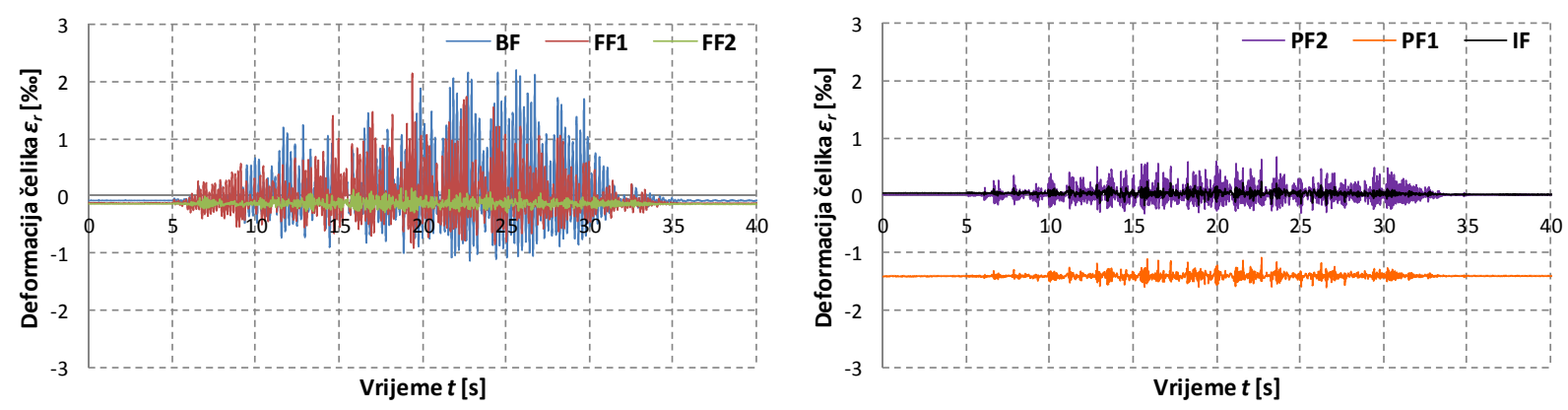

d) $\mathrm{a}_{\mathrm{g}, \max }=0.4 \mathrm{~g}$

Slika 3.74. Deformacija armature pri dnu stupa donje etaže okvira (točka C) u vremenu za umjetni akcelerogram AA2 s maksimalnim ubrzanjem $\mathrm{a}_{\mathrm{g}, \max }=0.1,0.2,0.3 \mathrm{i} 0.4 \mathrm{~g}$ 

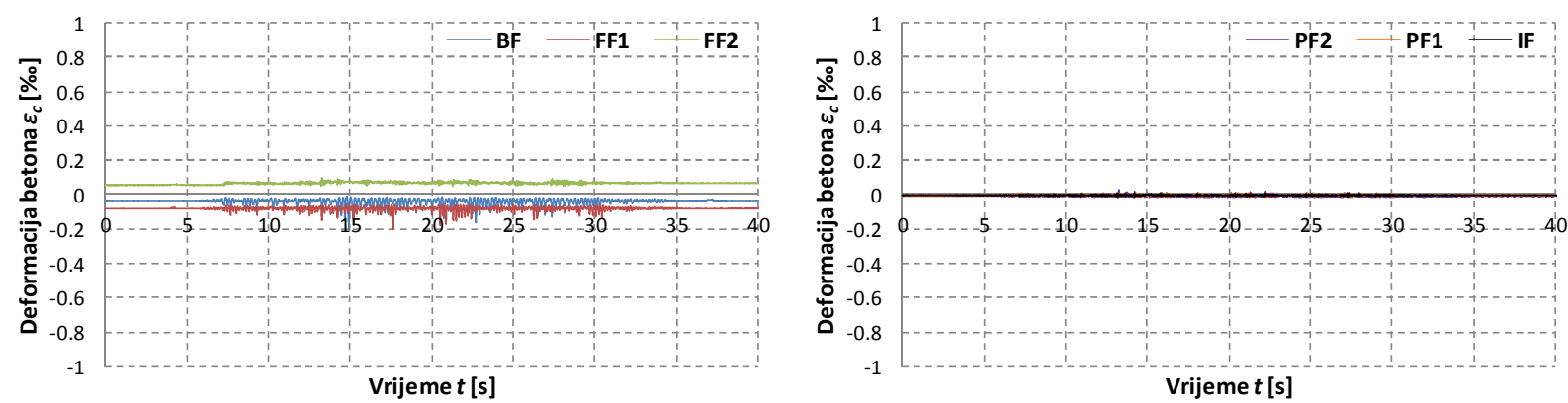

a) $a_{g, \max }=0.1 \mathrm{~g}$

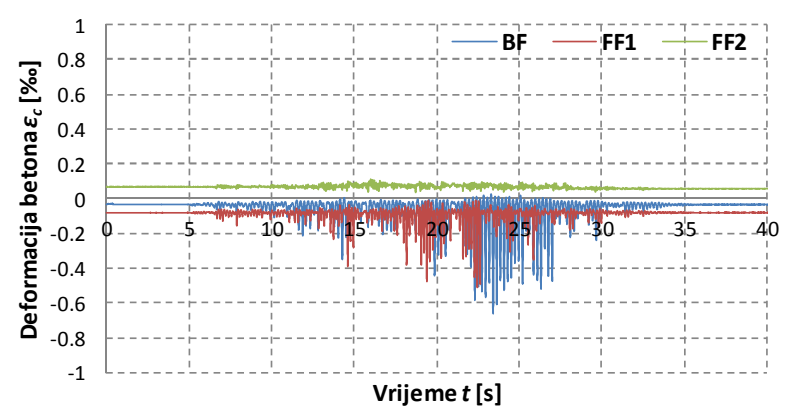

b) $\mathrm{a}_{\mathrm{g}, \max }=0.2 \mathrm{~g}$
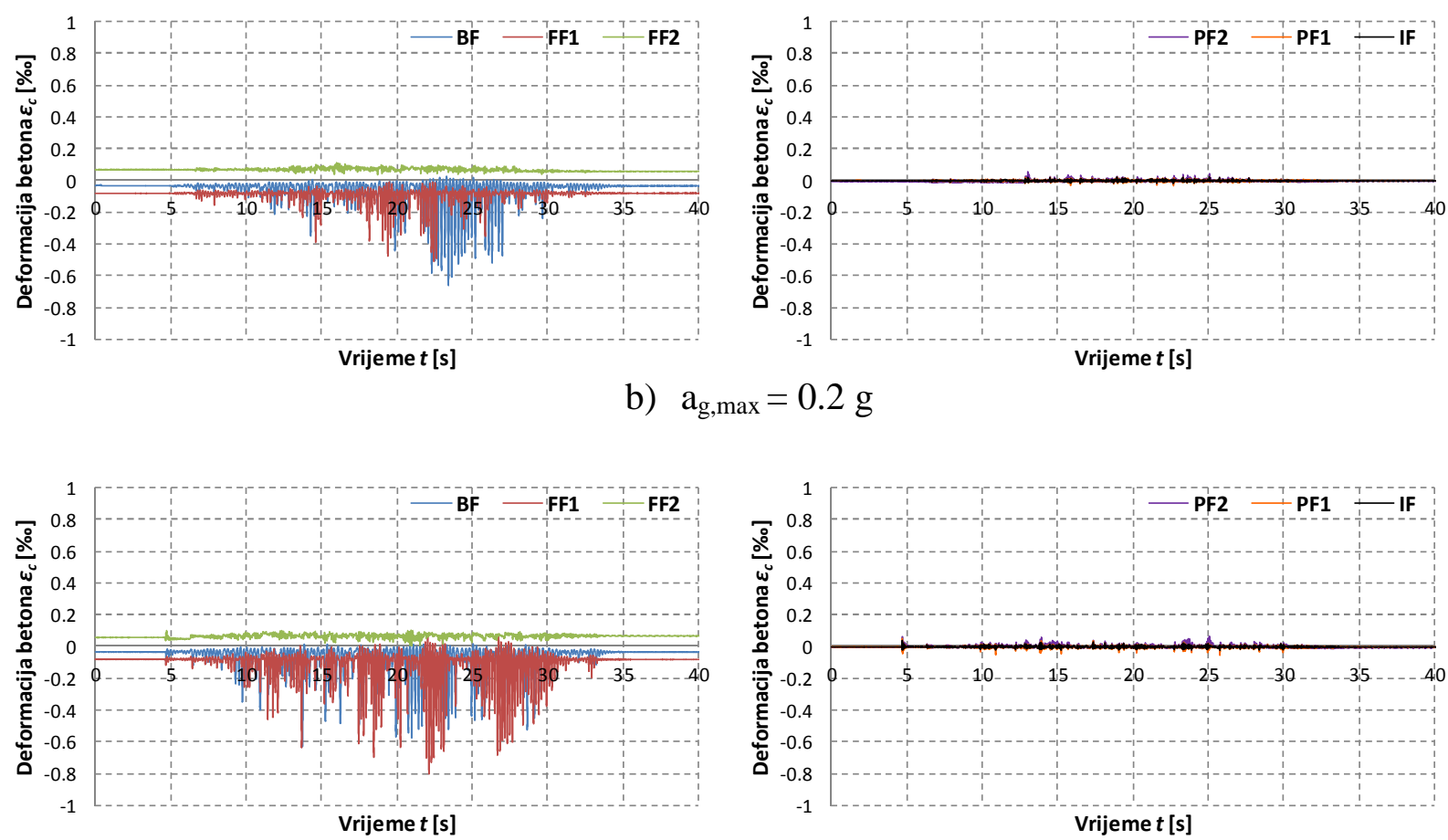

c) $\mathrm{a}_{\mathrm{g}, \max }=0.3 \mathrm{~g}$
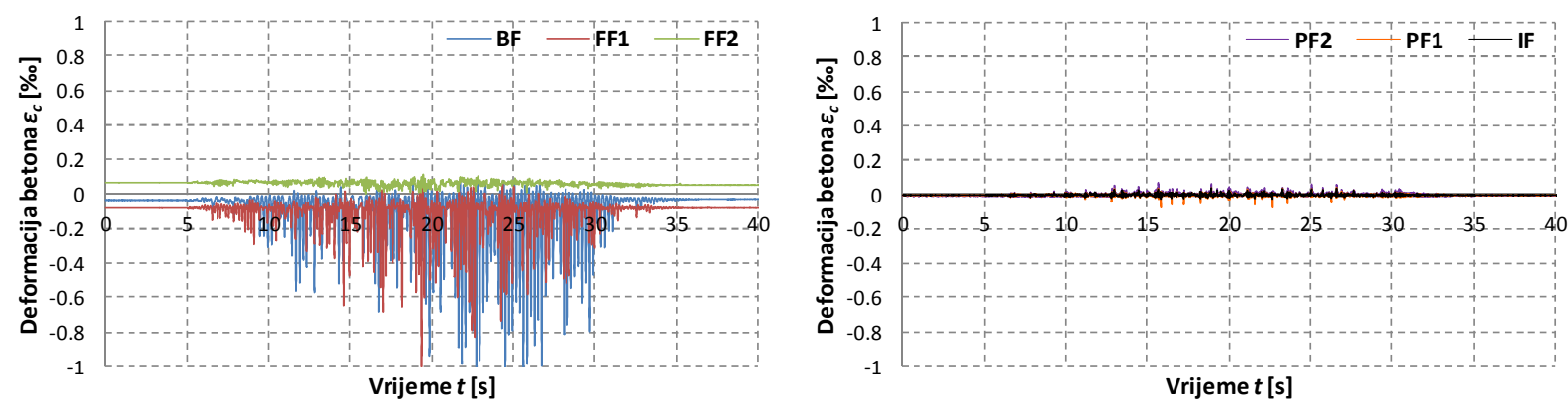

d) $\mathrm{a}_{\mathrm{g}, \max }=0.4 \mathrm{~g}$

Slika 3.75. Deformacija betona pri dnu stupa donje etaže okvira (točka D) u vremenu za umjetni akcelerogram AA2 s maksimalnim ubrzanjem $\mathrm{a}_{\mathrm{g}, \max }=0.1,0.2,0.3 \mathrm{i} 0.4 \mathrm{~g}$ 

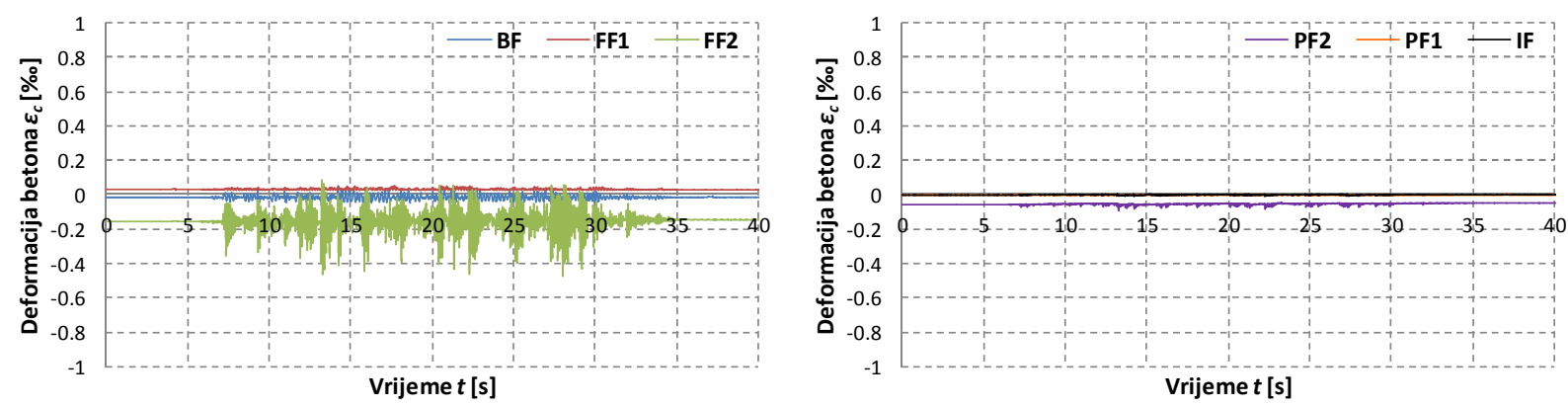

a) $\mathrm{a}_{\mathrm{g}, \max }=0.1 \mathrm{~g}$

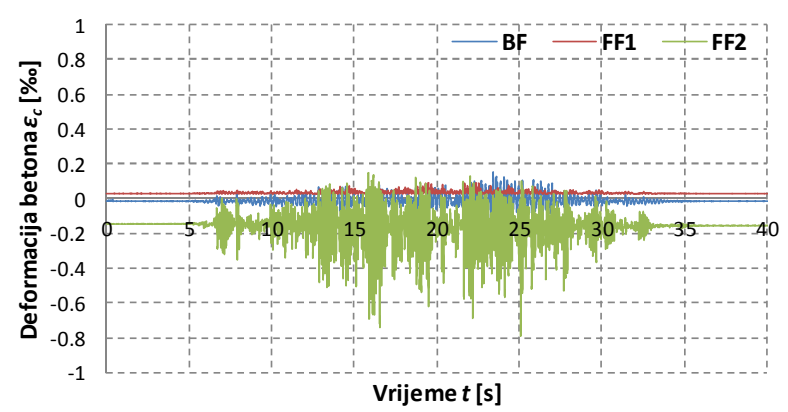

b) $\mathrm{a}_{\mathrm{g}, \max }=0.2 \mathrm{~g}$
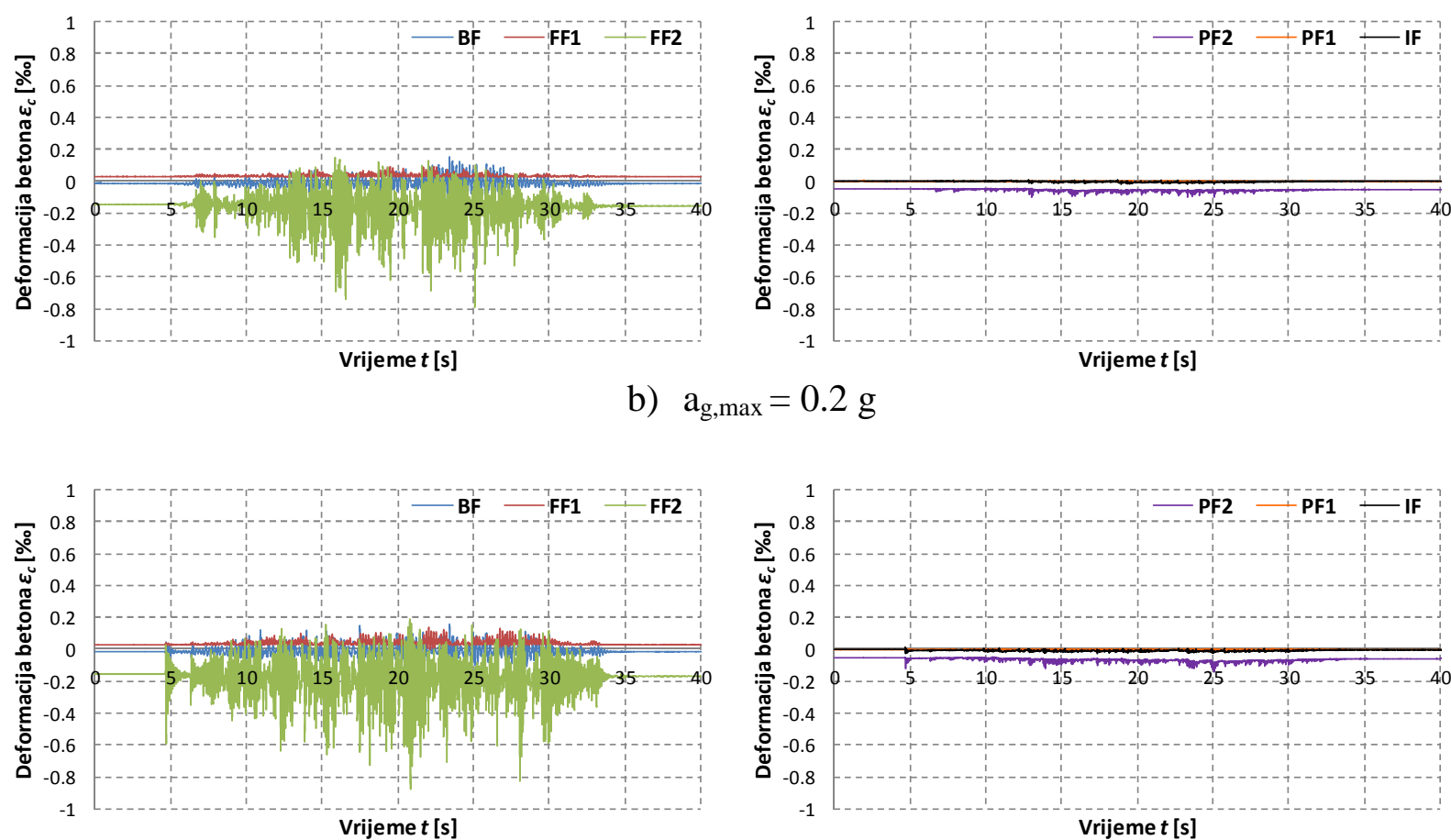

c) $\mathrm{a}_{\mathrm{g}, \max }=0.3 \mathrm{~g}$
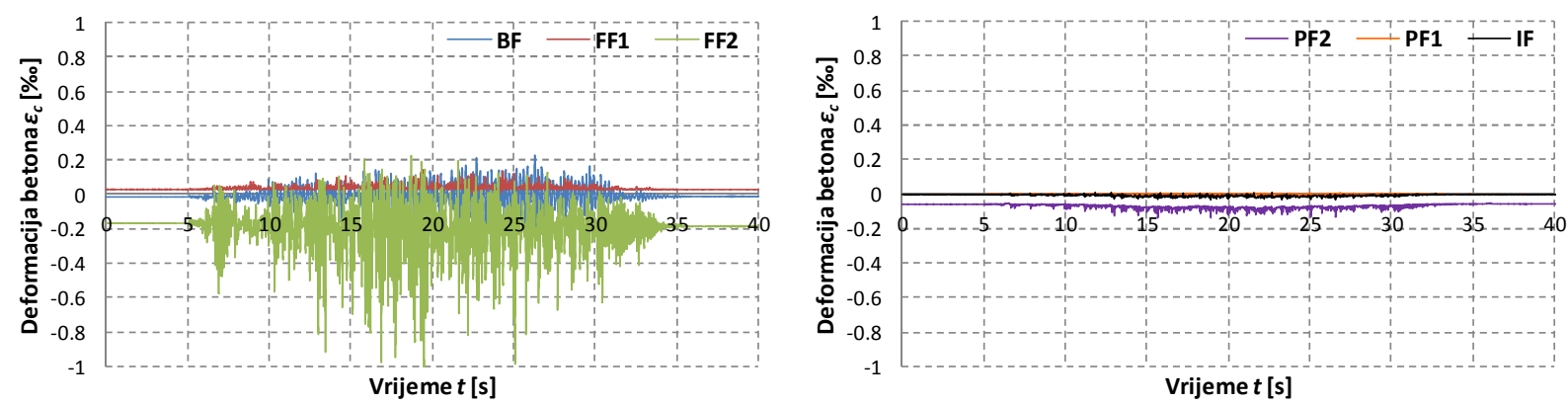

d) $\mathrm{a}_{\mathrm{g}, \max }=0.4 \mathrm{~g}$

Slika 3.76. Deformacija betona pri dnu stupa gornje etaže okvira (točka E) u vremenu za umjetni akcelerogram AA2 s maksimalnim ubrzanjem $\mathrm{a}_{\mathrm{g}, \max }=0.1,0.2,0.3 \mathrm{i} 0.4 \mathrm{~g}$ 

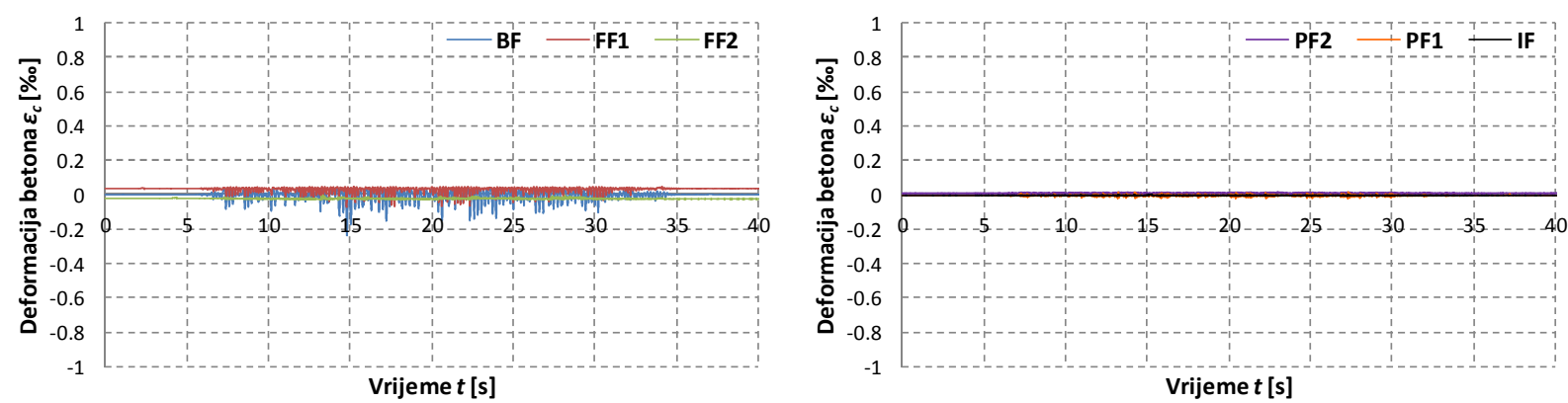

a) $\mathrm{a}_{\mathrm{g}, \max }=0.1 \mathrm{~g}$

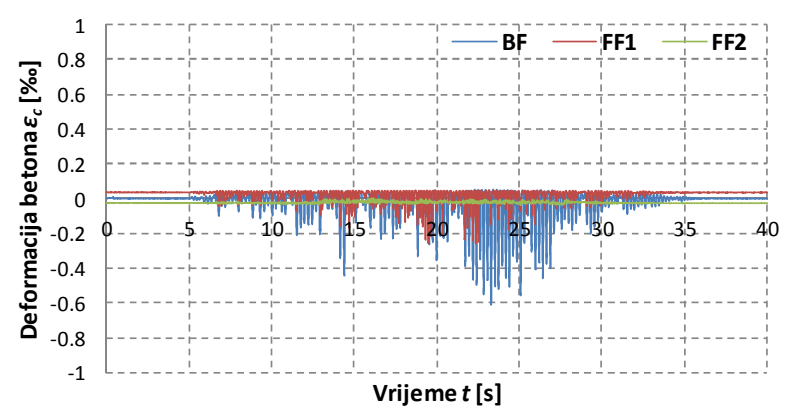

b) $\mathrm{a}_{\mathrm{g}, \max }=0.2 \mathrm{~g}$
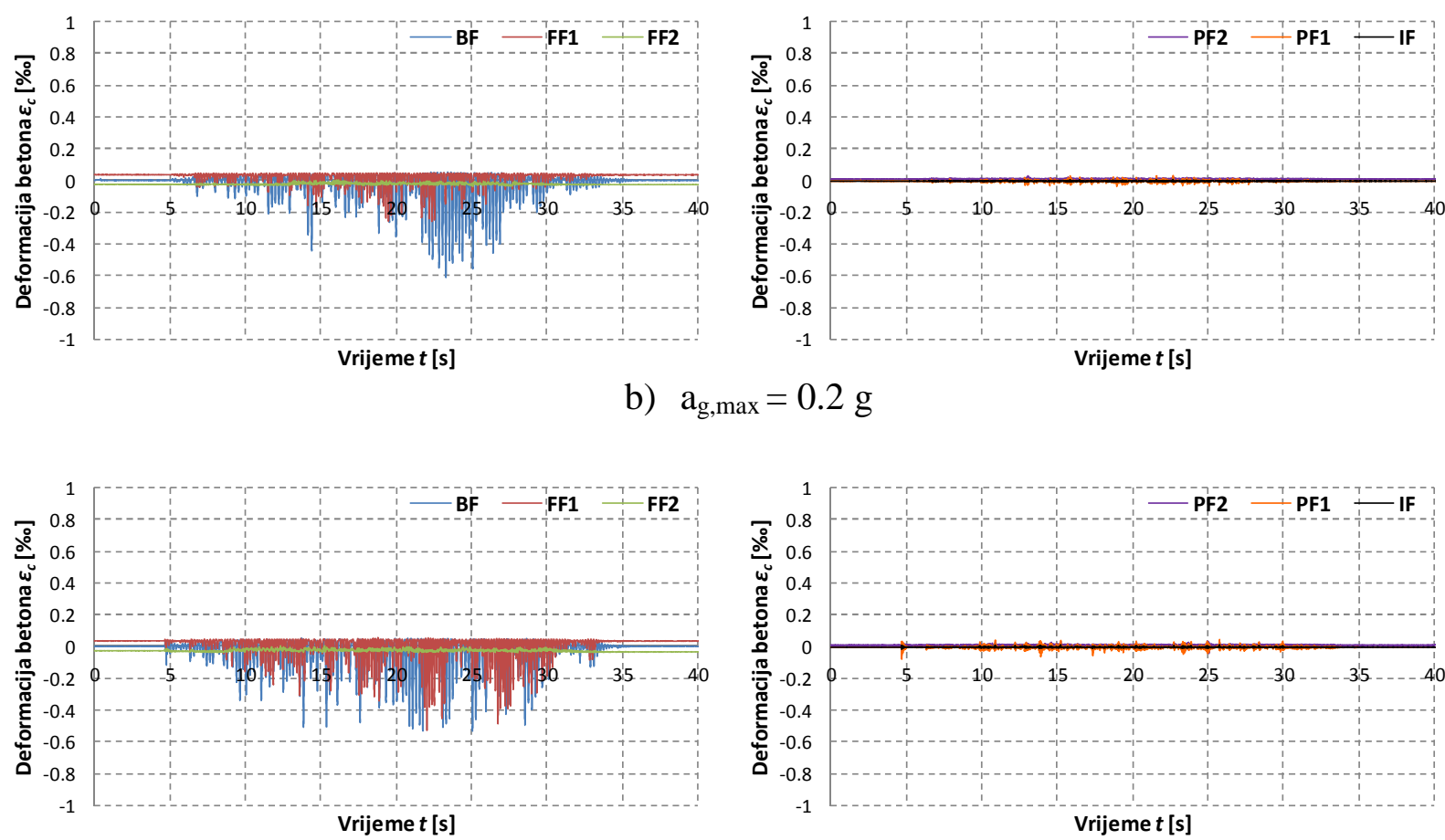

c) $\mathrm{a}_{\mathrm{g}, \max }=0.3 \mathrm{~g}$

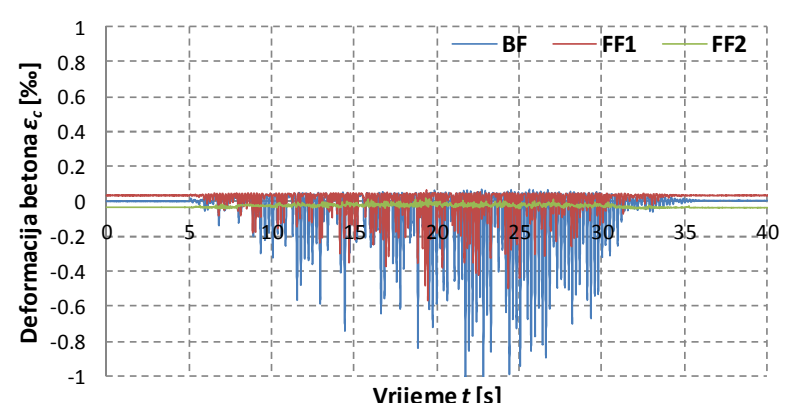

d) $\mathrm{a}_{\mathrm{g}, \max }=0.4 \mathrm{~g}$

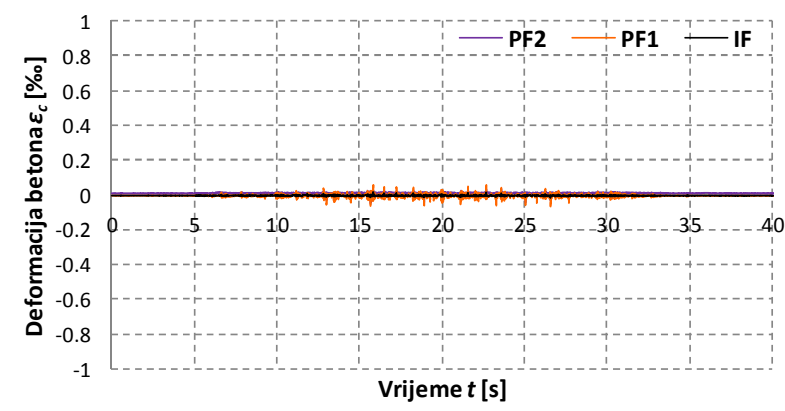

Slika 3.77. Deformacija betona pri dnu stupa donje etaže okvira (točka F) u vremenu za umjetni akcelerogram AA2 s maksimalnim ubrzanjem $\mathrm{a}_{\mathrm{g}, \max }=0.1,0.2,0.3 \mathrm{i} 0.4 \mathrm{~g}$ 

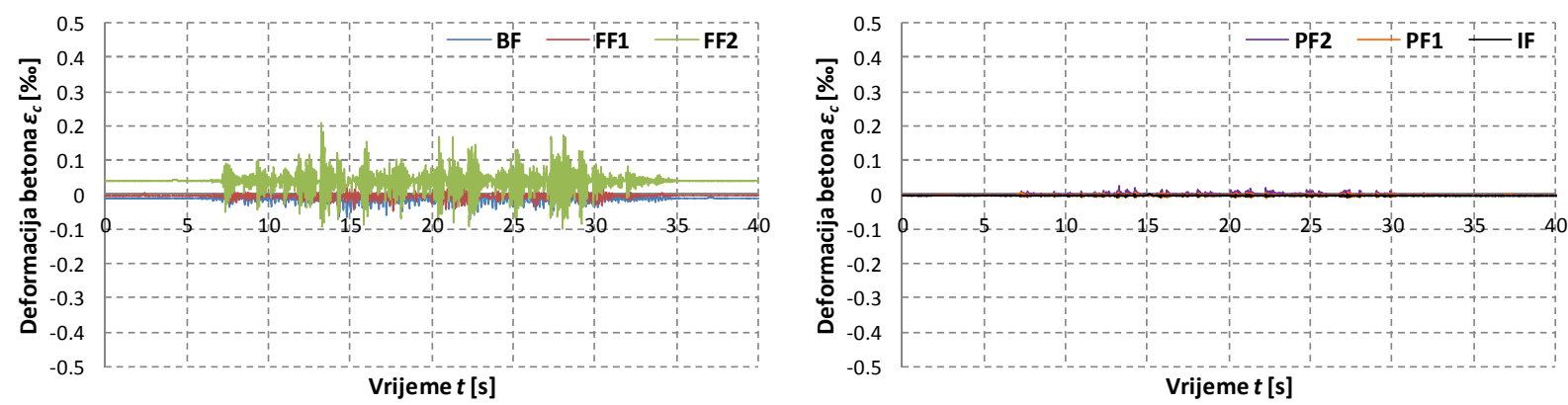

a) $\mathrm{a}_{\mathrm{g}, \max }=0.1 \mathrm{~g}$

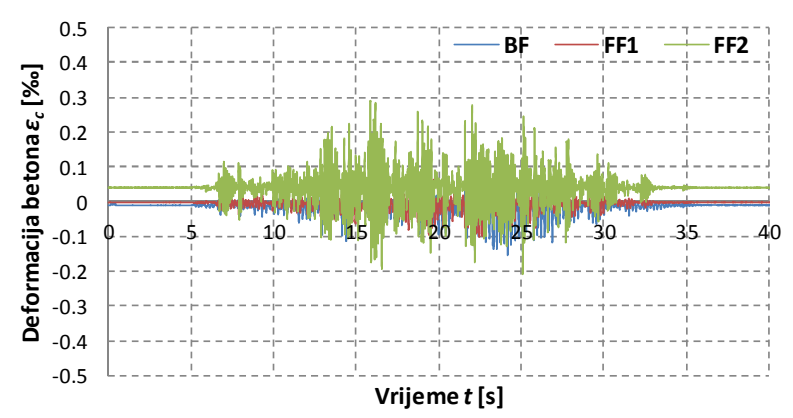

b) $\mathrm{a}_{\mathrm{g}, \max }=0.2 \mathrm{~g}$
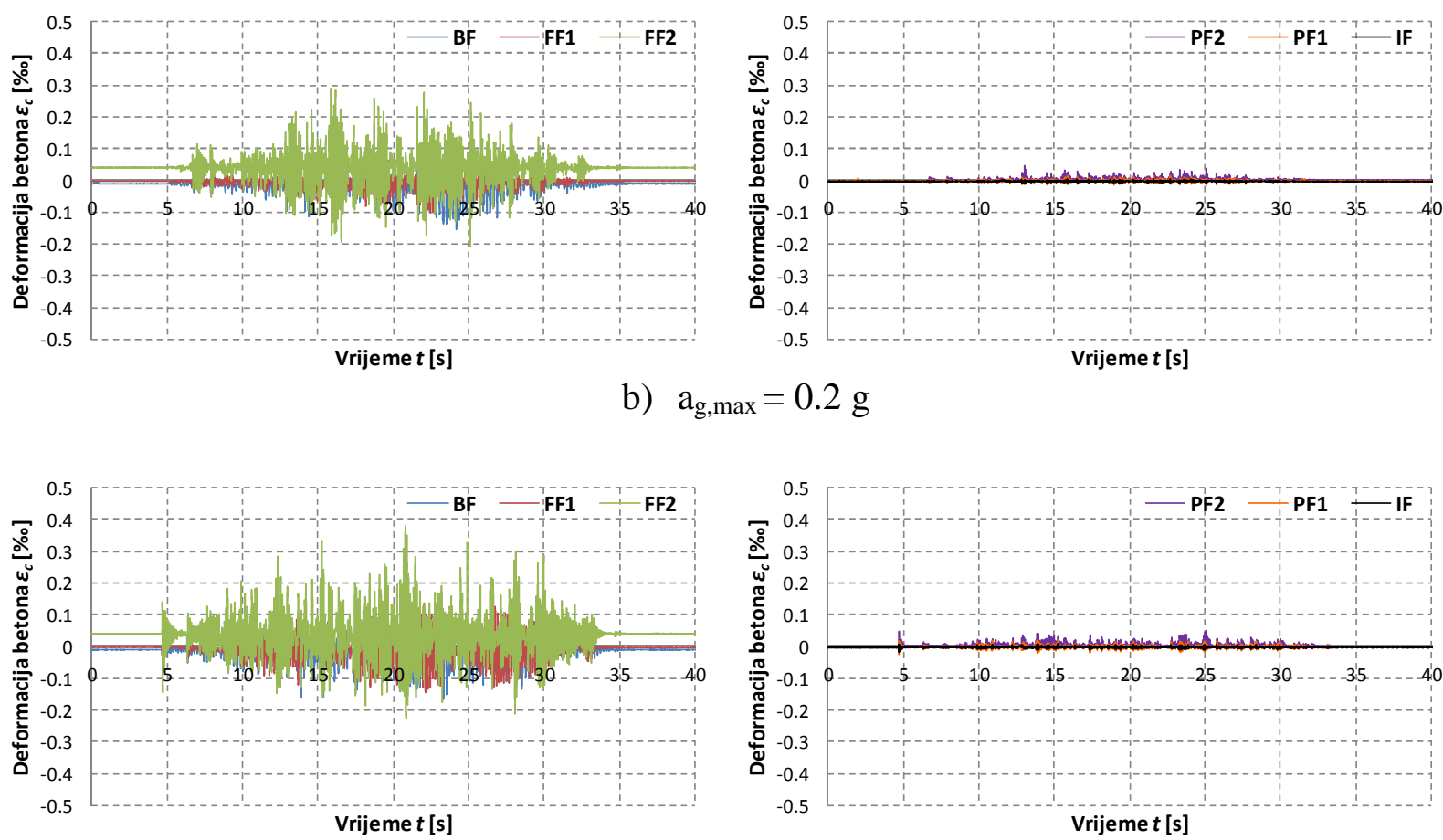

c) $\mathrm{a}_{\mathrm{g}, \max }=0.3 \mathrm{~g}$
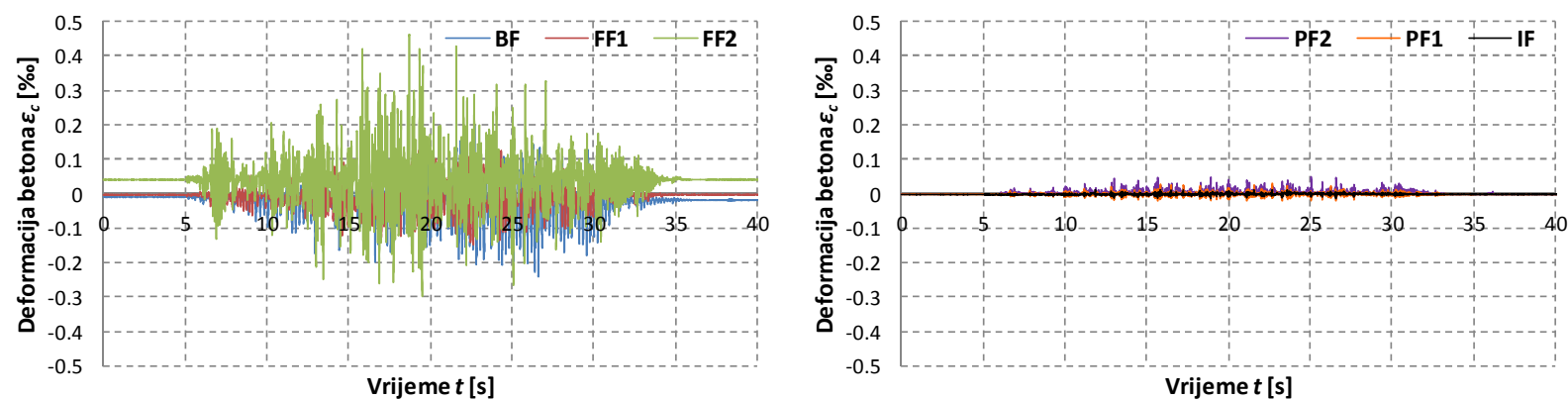

d) $\mathrm{a}_{\mathrm{g}, \max }=0.4 \mathrm{~g}$

Slika 3.78. Deformacija betona pri dnu stupa gornje etaže okvira (točka G) u vremenu za umjetni akcelerogram AA2 s maksimalnim ubrzanjem $\mathrm{a}_{\mathrm{g}, \max }=0.1,0.2,0.3 \mathrm{i} 0.4 \mathrm{~g}$ 
Shematski prikaz konačnog stanja pukotina u okviru i ziđu prikazano je na Slici 3.79. Kod okvira bez ispune BF i okvira s fleksibilnim prizemljem FF1 došlo je do formiranja pukotina na spoju donje grede i stupa okvira. Kod okvira s otvorima PF2 i PF1 došlo je do formiranja pukotina na spoju ispune i platforme, odnosno došlo je do odvajanja ispune na tom mjestu. Okvir s fleksibilnim katom FF2 i potpuno ispunjeni okvir IF nisu imali vidljivih pukotina. Fotografije stanja pukotina nakon završetka svih ispitivanja prikazane su na Slici 3.80 .

BF

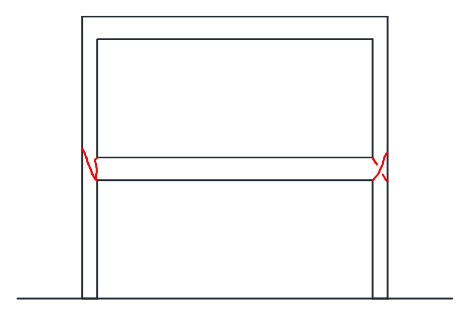

PF2

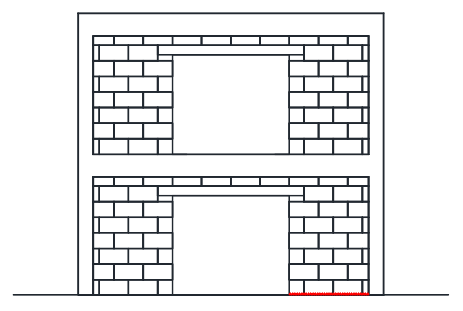

FF1

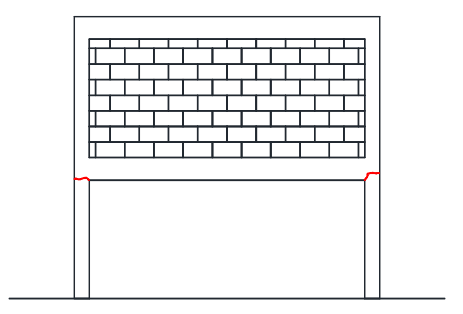

PF1

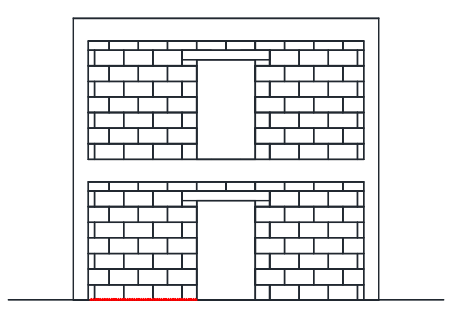

Slika 3.79. Shematski prikaz konačnog stanja pukotina u okviru i ispuni nakon završetka svih ispitivanja

Utvrđene vlastite frekvencije sustava za sve ispitane uzorke prikazane su u Tablici 3.3. Vlastite frekvencije sustava mjerene su prije početka ispitivanja, te nakon izlaganja uzorka nizu umjetnih akcelerograma AA1 i AA2. Odgovarajući vlastiti periodi sustava, dobiveni kao recipročna vrijednost vlastitih frekvencija, dani su u Tablici 3.4. Grafički prikaz vlastitih perioda za pojedini uzorak prikazan je na Slici 3.81 . 

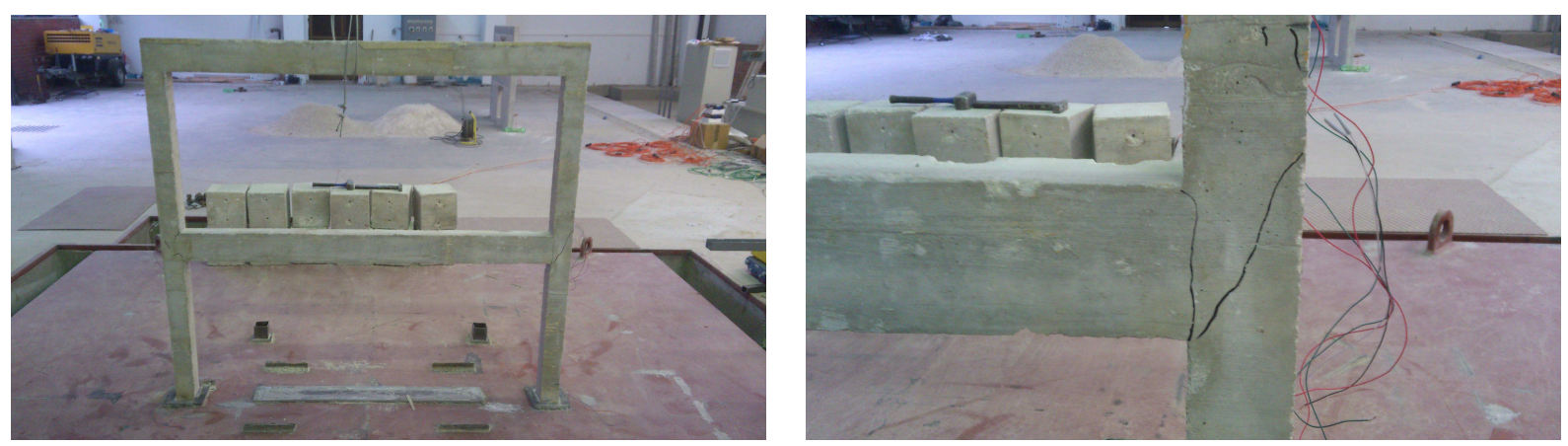

a) $\mathrm{BF}$
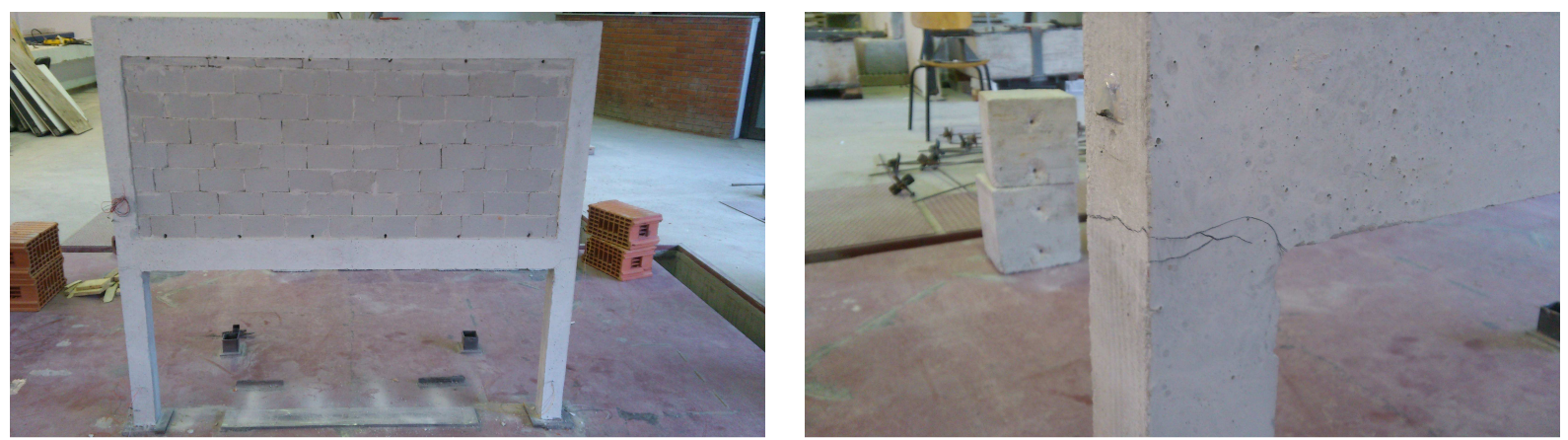

b) FF1
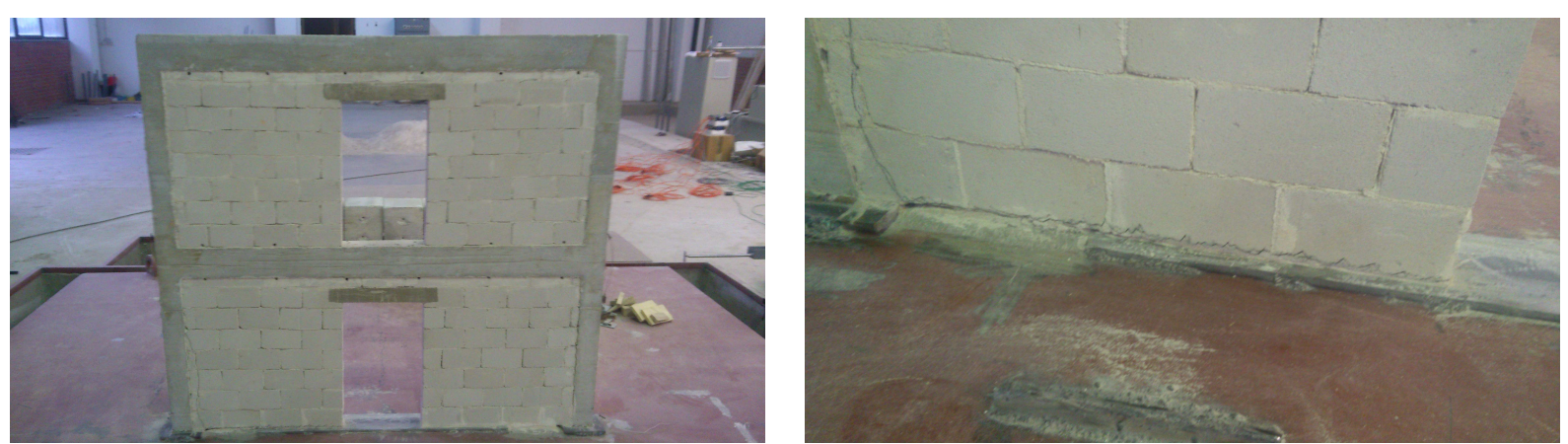

c) PF1
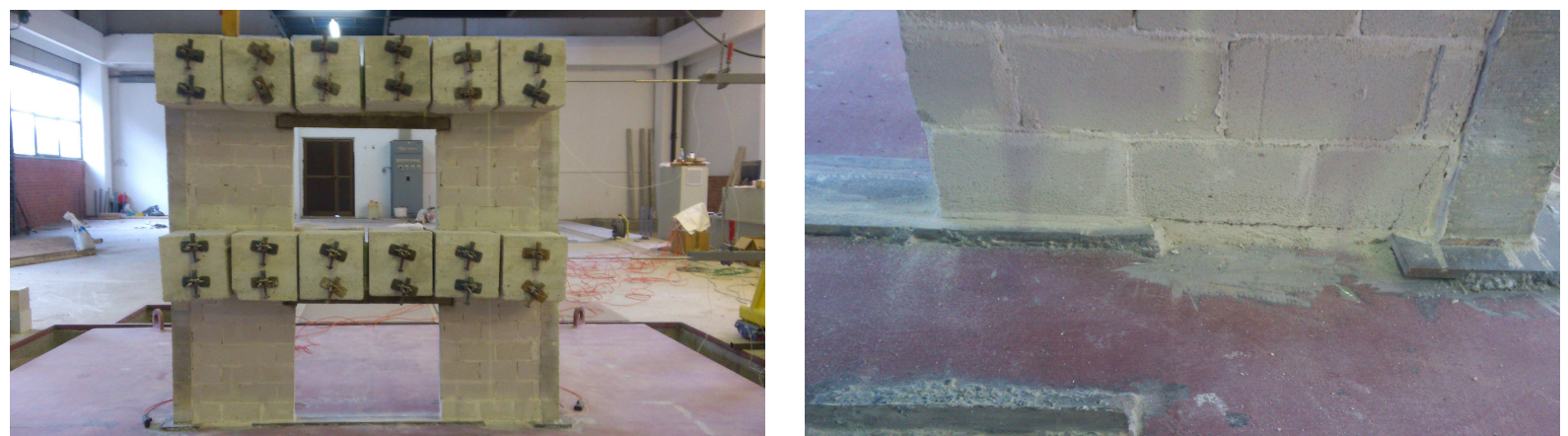

d) PF2

Slika 3.80. Fotografije konačnog stanja deformacija i pukotina u ispitanim betonskim okvirima sa zidanom ispunom 
Tablica 3.3. Izmjerene vlastite frekvencije sustava

\begin{tabular}{lllllll}
\hline Frekvencija $(\mathrm{Hz})$ & \multicolumn{7}{l}{ Uzorak } & & & & \\
\cline { 2 - 7 } & BF & FF1 & FF2 & PF2 & PF1 & IF \\
\hline početni & 8.40 & 8.30 & 13.50 & 9.45 & 9.55 & 9.75 \\
nakon "AA1" & 4.70 & 6.80 & 10.90 & 9.17 & 9.50 & 9.56 \\
nakon "AA2" & 4.60 & 6.50 & 10.60 & 9.10 & 9.45 & 9.56 \\
\hline
\end{tabular}

Tablica 3.4. Odgovarajući prvi periodi sustava

\begin{tabular}{lllllll}
\hline Period (s) & Uzorak & & & & & \\
\cline { 2 - 7 } & BF & FF1 & FF2 & PF2 & PF1 & IF \\
\hline početni & 0.12 & 0.12 & 0.07 & 0.11 & 0.10 & 0.10 \\
nakon "AA1" & 0.21 & 0.15 & 0.09 & 0.11 & 0.11 & 0.10 \\
nakon "AA2" & 0.22 & 0.15 & 0.09 & 0.11 & 0.11 & 0.10 \\
\hline
\end{tabular}
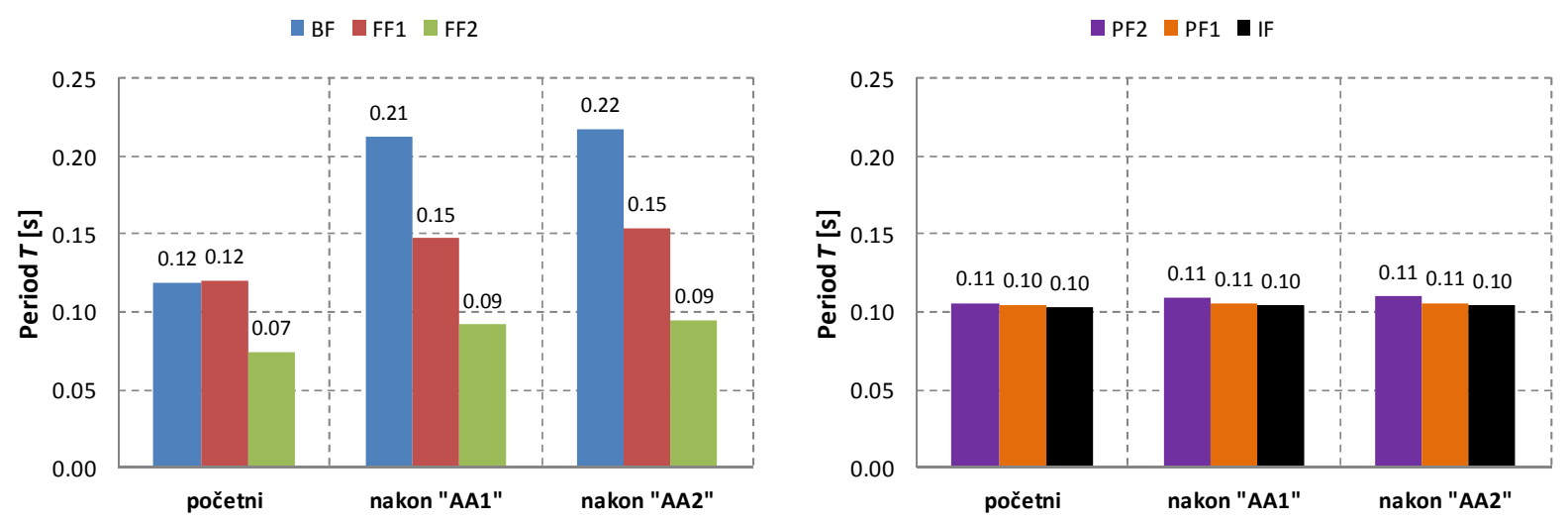

Slika 3.81. Grafički prikaz vlastitih perioda sustava za ispitane betonske okvire sa zidanom ispunom

Može se primijetiti kako su početni periodi okvira bez ispune BF i okvira s fleksibilnim prizemljem FF1 podjednaki, dok okvir s fleksibilnim katom FF2 ima manji početni period zbog veće krutosti u prizemlju. Nakon izlaganja uzorka nizu umjetnih akcelerograma AA1, dolazi do značajnog povećanja perioda kod okvira BF i FF1. Prethodno navedeno u skladu je sa stanjem pukotina prikazanim na Slici 3.79. Kod okvira FF2, povećanje perioda je manje izraženo. Vlastiti period sustava za okvire PF2, PF1 i IF se praktički ne mijenja, odnosno njegovo povećanje je neznatno. 


\subsection{Zaključak}

Napravljena su opsežna eksperimentalna ispitivanja umanjenih modela čeličnih i betonskih okvira sa zidanom ispunom. Ispitivanja su vršena u Laboratoriju za potresna ispitivanja u Žrnovnici pokraj Splita, pri Fakultetu građevinarstva, arhitekture i geodezije, Sveučilišta u Splitu. Pri tome je korištena suvremena oprema za mjerenje i obradu podataka. Kod čeličnih okvira vršena su statička ispitivanja pod horizontalnom silom do sloma, te dinamička ispitivanja pomoću potresne platforme. Razmatrani su okviri s većom i manjom savojnom krutosti, od kojih je svaki tip razmatran $\mathrm{s}$ tri varijante ispune (bez žbuke, $\mathrm{s}$ nearmiranom žbukom i s armiranom žbukom). Kod betonskih okvira vršena su dinamička ispitivanja pomoću potresne platforme. Ispitani su okviri bez ispune, potpuno ispunjeni okvir, okviri s fleksibilnim etažama te okviri s otvorima u ispuni. Kod dinamičkih ispitivanja čeličnih i betonskih okvira, aplicirani su umjetni akcelerogrami kompatibilni s elastičnim spektrima odgovora, te akcelerogram jednog realnog potresa.

Temeljem provedenih statičkih ispitivanja čeličnih okvira sa zidanom ispunom izneseni su sljedeći najvažniji zaključci:

- Žbuka može značajno doprinijeti čvrstoći i nosivosti ziđa, a samim time čvrstoći i nosivosti okvira sa zidanom ispunom.

- Intenzitet relativnog doprinosa žbuke ukupnoj nosivosti i čvrstoći ovakvih sustava ovisi o nekoliko faktora: debljini i kvaliteti žbuke, debljini i kvaliteti ziđa, krutosti okvira, odnosu krutosti okvira $\mathrm{i}$ ispune, itd.

- Armirana žbuka povećava duktilnost ziđa i smanjuje širinu pukotina u njemu.

- Može se očekivati da bi žbuka armirana s mrežom veće površine poprečnog presjeka značajno povećala nosivost i duktilnost ziđa, odnosno okvira sa zidanom ispunom.

Temeljem provedenih dinamičkih ispitivanja čeličnih okvira sa zidanom ispunom izneseni su sljedeći najvažniji zaključci:

- Ponašanje čeličnih okvira sa zidanom ispunom pri potresu značajno ovisi o krutosti okvira. Kruti okviri imaju manje pomake nego meki okviri, što smanjuje deformacije ispune i sprječava njezino oštećenje. U odnosu na meke okvire, kruti okviri generiraju veće seizmičke (inercijalne) sile, ali i posjeduju veću mehaničku otpornost. Meki okviri imaju veće pomake nego kruti okviri. Ovo rezultira većim deformacijama ispune, tj. njezinim mogućim oštećenjem i većim odvajanjem (pukotinom) na spoju s okvirom. 
- Krutost ziđa doprinosi sveukupnoj krutosti čeličnog okvira s ispunom. Kruća ispuna povećava inercijalne sile, ali ima i veću mehaničku otpornost od meke ispune. U provedenim ispitivanja, kruća ispuna pokazala je povoljnije ponašanje u odnosu na meku ispunu. Naime, u odnosu na neožbukano ziđe, ziđe s obostranom žbukom osiguralo je veću otpornost i manju deformabilnost sustava, te smanjilo zone pukotina u ziđu. Doprinos usvojene staklene mreže unutar žbuke nije bio očit za ispitane uzorke, što je vjerojatno posljedica relativno male površine poprečnog presjeka vlakana u mreži.

- Analogno kao i kod statičkih ispitivanja, može se očekivati da bi žbuka armirana s mrežom veće površine poprečnog presjeka značajno povećala nosivost i duktilnost ziđa, odnosno okvira sa zidanom ispunom.

- Povećanjem maksimalnog ubrzanja podloge dolazi i do povećanja pomaka, ubrzanja i deformacija kod čeličnih okvira sa zidanom ispunom.

Temeljem provedenih dinamičkih ispitivanja armiranobetonskih okvira sa zidanom ispunom izneseni su sljedeći najvažniji zaključci:

- Armiranobetonski okviri s različitim položajima ispune i otvorima u ispuni imaju i različito ponašanje pri potresu.

- Umetanje ispune na sve etaže okvira rezultira povoljnijim naponsko-deformacijskim stanjem novonastalog sustava u odnosu na okvir bez ispune. Može se očekivati da će takva konstrukcija imati manje pomake i deformacije (naprezanja) u okviru i ispuni pri potresu.

- Otvori u ispuni smanjuju njezinu krutost, a samim time krutost i nosivost okvira sa zidanom ispunom. Može se očekivati da će takva konstrukcija imati veće pomake i deformacije pri potresu. Povećanje veličine otvora $u$ ispuni povećava pomake i deformacije okvira s ispunom, te smanjuje njegovu mehaničku otpornost.

- Armiranobetonski okviri s fleksibilnim prizemljem (ispuna samo na gornjim etažama) pokazuju nepovoljnije ponašanje pri potresu od istih konstrukcija s ispunom na svim etažama. Naime, krući nosivi sustavi na gornjim etažama generiraju i veće inercijalne sile, koje se moraju prenijeti na fleksibilne nosive sustave u prizemlju, što rezultira njihovom smanjenom potresnom otpornošću. Ovakve konstrukcije imaju veće pomake i deformacije sustava pri potresu. Za očekivati je da bi povećanje broja etaža okvira s fleksibilnim prizemljem rezultiralo nepovoljnijim ponašanjem pri potresu, što nije ispitivano u ovom radu. 
- Okviri s fleksibilnom etažom pokazuju nešto povoljnije ponašanje od okvira s fleksibilnim prizemljem. Naime, ispuna u prizemlju ukrućuje konstrukciju pri dnu, što rezultira manjim pomacima i deformacijama na donjoj etaži. Međutim, na etažama gdje nema ispune povećavaju se pomaci i deformacije u okviru i armaturi. Za očekivati je da bi ovaj efekti bio izraženiji s većim brojem ispunjenih etaža iznad fleksibilne.

- Povećanjem maksimalnog ubrzanja podloge dolazi i do povećanja pomaka, ubrzanja i deformacija kod armiranobetonskih okvira sa zidanom ispunom.

Provedena eksperimentalna ispitivanja u ovom radu omogućuju stjecanje spoznaja o stvarnom ponašanju čeličnih i armiranobetonskih okvira sa zidanom ispunom pri statičkom i potresnom opterećenju. 


\section{NUMERIČKI MODEL ZA STATIČKU I DINAMIČKU ANALIZU OKVIRA SA ZIDANOM ISPUNOM}

\subsection{Općenito}

U ovom je poglavlju prikazan prethodno razvijeni i provjereni 2D numerički model za statičku i dinamičku analizu ravninskih konstrukcija od betona (okviri, zidovi), čelika (okviri) i ziđa [1-5]. Pri tome ove konstrukcije mogu biti samostalne ili povezane (primjerice betonski ili čelični okviri sa zidanom ispunom). Razvijeni model može simulirati najvažnije nelinearne efekte sustava okvir-ziđe-temelj-tlo, kao što su: materijalna nelinearnost (nelinearno ponašanje betona, čelika, ziđa, tla), geometrijska nelinearnost (veliki pomaci), nelinearno ponašanje na spoju dvaju različitih materijala (odvajanje, utiskivanje, klizanje) itd.

Za diskretizaciju analizirane konstrukcije koristi se metoda konačnih elemenata, a za vremensku diskretizaciju jednadžbe gibanja metoda konačnih diferencija. Može se koristiti implicitni i eksplicitni Newmarkov vremenski algoritam. Koriste se 8-čvorni osnovni konačni elementi, odnosno 6-čvorni ravninski i 2-čvorni štapni elementi kao kontaktni elementi.

$\mathrm{U}$ ovom je radu numerički model poboljšan s adekvatnom simulacijom faznog nastajanja okvira s ispunom (u praksi se prvo izvodi okvir, uz aktiviranje dijela gravitacijskog opterećenja, a potom ispuna), te adekvatnom simulacijom nearmirane i armirane žbuke na vanjskim plohama ziđa (ziđe je često ožbukano). 
Faznost građenja će se modelirati s pomoću sukcesivno aktivne mreže konačnih elemenata, tj. sukcesivno aktivne krutosti sustava. Pri tome će se pamtiti povijest deformacija (naprezanja) i oštećenja (pukotine) svih gradiva tijekom vremena.

Žbuka će se modelirati dopunskim konačnim elementima, ,preklopljenim“ s elementima ziđa. Pretpostavlja se puna kompatibilnost pomaka žbuke i ziđa, tj. nema proklizavanja između žbuke i ziđa. Žbuka će se modelirati analogno betonu (sa simulacijom popuštanja u tlaku, razvojem pukotina u vlaku, vlačnom i posmičnom krutosti ispucane žbuke i sl.). Armatura žbuke će se modelirati adekvatno armaturi u betonu.

$\mathrm{Na}$ temelju izloženog modela razvijen je proračunski program za statičku i dinamički analizu ravninskih armiranobetonskih i čeličnih okvira sa zidanom ispunom. Primjenom ovog numeričkog modela, numerički je istražen utjecaj više parametara na ponašanje okvira s ispunom. Također, numerički model je verificiran pomoću rezultata dobivenih eksperimentalnim ispitivanjem. Više o tome je prikazano u Poglavlju 5 i 6.

\subsection{Jednadžba ravnoteže i diskretizacija konstrukcije}

\subsubsection{Prostorna diskretizacija}

Prostornom diskretizacijom i primjenom metode konačnih elemenata, jednadžba dinamičke ravnoteže zidane konstrukcije može se napisati u obliku:

$$
\mathbf{M} \ddot{\mathbf{u}}+\mathbf{C} \dot{\mathbf{u}}+\mathbf{R}(\mathbf{u}) \mathbf{u}=\mathbf{f}
$$

gdje su u nepoznati čvorni pomaci, $\dot{\mathbf{u}}$ brzine i üubrzanja; $\mathbf{M}$ je matrica masa, $\mathbf{C}$ matrica prigušenja i R(u) vektor unutrašnjih čvornih sila; f je vektor vanjskih čvornih sila, koji može biti primjerice generiran od djelovanja vjetra, stroja i sl. $(\mathbf{f}=\mathbf{F}(\mathrm{t}))$ ili od djelovanja potresa $\left(\mathbf{f}=\mathbf{M} \ddot{\mathbf{d}}_{\mathbf{0}}(\mathrm{t})\right.$ ), vidjeti Sliku 4.1. Kod toga je $\ddot{\mathbf{d}}_{\mathbf{0}}$ vektor ubrzanja podloge, a t vrijeme. Matrica krutosti R(u), koja ovisi o trenutnim pomacima, može se napisati kao:

$$
\mathbf{R}(\mathbf{u}) \mathbf{u}=\mathbf{K u} \quad ; \quad \mathbf{K}=\partial \mathbf{R} / \partial \mathbf{u}
$$

gdje je K matrica krutosti konstrukcije. 


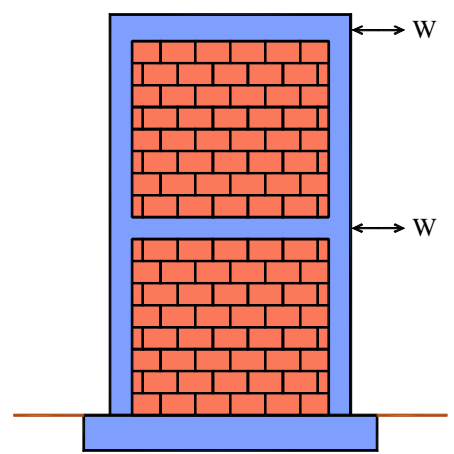

(i) Vanjska sila (vjetar i sl.)

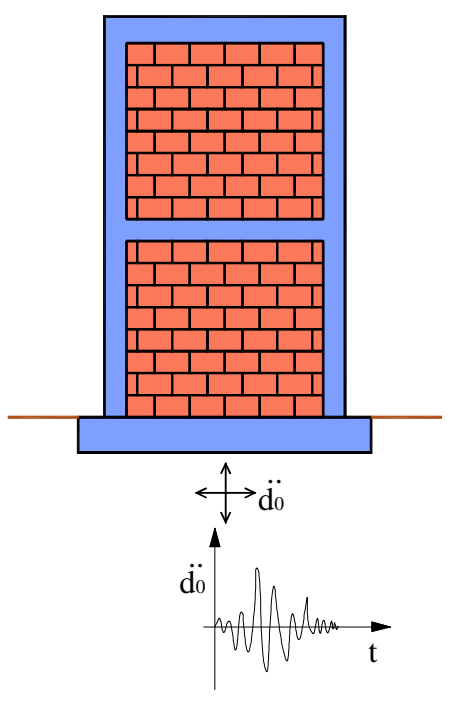

(ii) Ubrzanje podloge (potres)

Slika 4.1. Dinamička "opterećenja" zidanog zida

Za realne konstrukcije, veza deformacija-pomak je općenito nelinearna, $\mathrm{tj}$.:

$$
\boldsymbol{\varepsilon}=\mathbf{B} \mathbf{u} \quad ; \quad \mathbf{B}=\mathbf{B}(\mathbf{u})
$$

što predstavlja tzv. geometrijsku nelinearnost. Naime, zbog promjene geometrije, matrica $\mathbf{B}$ nije linearna već ovisi o pomacima sustava. Veza $\varepsilon$-u poznata je i pod nazivom model geometrije.

Veza naprezanje-deformacija $\sigma-\varepsilon$, je također općenito nelinearna i predstavlja tzv. materijalnu nelinearnost. Veza $\sigma-\varepsilon$ se može napisati i u obliku:

$$
\boldsymbol{\sigma}=\mathbf{D} \varepsilon \quad ; \quad \mathbf{D}=\mathbf{D}(\mathbf{u})
$$

gdje je D matrica veze naprezanje-deformacija i u slučaju elastičnog materijala predstavlja dobro poznatu matricu elastičnih konstanti. Veza $\sigma-\varepsilon$ poznata je pod nazivom konstitutivni zakon ili model materijala.

Za statičke probleme, (4.1) se svodi na:

$$
\mathbf{R}(\mathbf{u}) \mathbf{u}=\mathbf{K u}=\mathbf{f}
$$

gdje je $\mathbf{f}$ vanjsko statičko (mirno) opterećenje.

Za rješenje svojstvene zadaće problema, koja je nužna za provedbu dinamičke analize (određivanje duljine vremenskog inkrementa kod vremenske integracije jednadžbe gibanja), jednadžba (4.1) se svodi na:

$$
\mathbf{K x}=\lambda \mathbf{M x} \quad ; \quad(\mathbf{K}-\lambda \mathbf{M}) \mathbf{x}=0
$$

gdje je K matrica krutosti sustava, $\mathbf{M}$ matrica masa sustava, $\mathbf{x}$ svojstveni vektor i $\lambda$ svojstvena vrijednost. Svojstvena zadaća je ovdje riješena WYD metodom [127]. 
Za prostornu diskretizaciju konstrukcije, koja se ovdje aproksimira stanjem ravninskog naprezanja, koriste se 8-čvorni (eng. "serendipity") elementi (Slika 4.2i). Pod konstrukcijom se podrazumijeva područje konstrukcije izvedeno od nearmiranog ili armiranog betona, nearmiranog ili armiranog ziđa, čelika te tlo ispod temelja. Armatura unutar 2D elementa simulirana je s pomoću 1D šipkastog elementa, koji doprinosi ukupnoj krutosti 2D elementa. Pretpostavlja se da nema proklizavanja armaturnih šipki.

Za modeliranje spoja između tla i temelja ili između morta i ziđa, koriste se dodirni (kontaktni) elementi (Slika 4.2ii). Mogu se koristiti 2D (plošni) šestočvorni dodirni elementi konačno male debljine w (Slika 4.2ii) za simulaciju kontinuiranog spoja između "osnovnih" 8-čvornih elemenata, ili 1D (štapni) dvočvorni dodirni elementi (Slika 4.2ii) za simulaciju diskretnog (točkastog) spoja između ravninskih elemenata (primjerice za armaturu koja prolazi preko spojne plohe). 2D dodirni elementi mogu simulirati klizanje, odvajanje i utiskivanje na plohi spoja, a na temelju usvojenog modela ponašanja gradiva dodirnog elementa. 1D dodirni elementi mogu preuzeti uzdužne sile i posmik, prema usvojenom modelu ponašanja materijala. Zglobno su vezani na krajevima, s dva stupnja slobode (pomaka) u čvornim točkama.

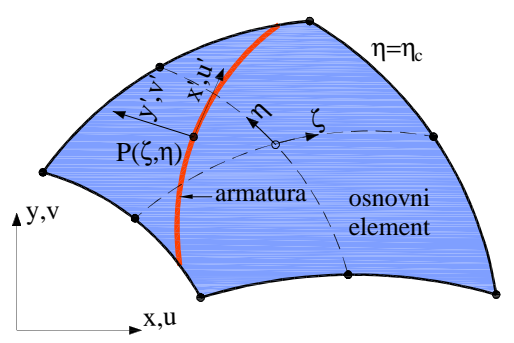

(i) Osnovni 2D osmočvorni (eng "serendipity") element za armirani beton, ziđe i tlo

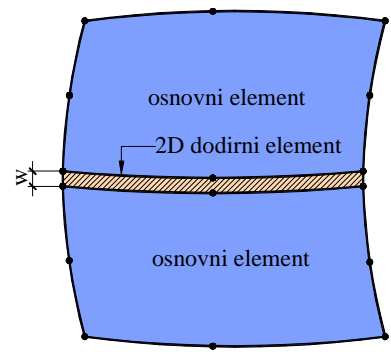

$2 D$ dodirni šestočvorni element

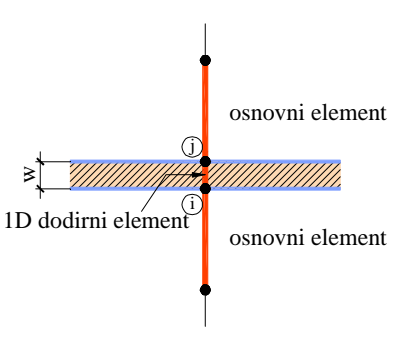

$1 D$ dodirni dvočvorni element

(ii) Dodirni 2D (kontaktni) elementi na spoju temelja i tla ili između morta i ziđa.

Slika 4.2. Konačni elementi za zidanu konstrukciju 


\subsubsection{Vremenska diskretizacija}

Za rješenje jednadžbe (4.1) koristi se implicitni, eksplicitni ili implicitno-eksplicitni Newmarkov iterativni algoritam kojeg je razvio Hughes [128] i koji je implementiran u [1].

Kod implicitnog algoritma, jednadžba ravnoteže (4.1) je zadovoljena u vremenu $\mathrm{t}_{\mathrm{n}+1}=\mathrm{t}_{\mathrm{n}}+\Delta \mathrm{t}$, odnosno $\mathrm{u}(\mathrm{n}+1)$ vremenskom inkrementu:

$$
\mathbf{M} \ddot{\mathbf{u}}_{\mathrm{n}+1}+\mathbf{R}\left(\mathbf{u}_{\mathrm{n}+1}, \dot{\mathbf{u}}_{\mathrm{n}+1}\right)=\mathbf{f}_{\mathrm{n}+1}
$$

pri čemu su:

$$
\begin{aligned}
& \mathbf{u}_{\mathrm{n}+1}=\overline{\mathbf{u}}_{\mathrm{n}+1}+\beta \Delta t^{2} \ddot{\mathbf{u}}_{\mathrm{n}} \\
& \dot{\mathbf{u}}_{\mathrm{n}+1}=\overline{\dot{\mathbf{u}}}_{\mathrm{n}+1}+\gamma \Delta t \ddot{\mathbf{u}}_{\mathrm{n}} \\
& \overline{\mathbf{u}}_{\mathrm{n}+1}=\mathbf{u}_{\mathrm{n}}+\Delta t \dot{\mathbf{u}}_{\mathrm{n}}+0,5(1-2 \beta) \Delta t^{2} \ddot{\mathbf{u}}_{\mathrm{n}} \\
& \dot{\mathbf{u}}_{\mathrm{n}+1}=\dot{\mathbf{u}}_{\mathrm{n}}+(1-\gamma) \Delta t \ddot{\mathbf{u}}_{\mathrm{n}}
\end{aligned}
$$

U gornjim izrazima $\Delta$ t je vremenski korak, a n je vremenski inkrement; $\overline{\mathbf{u}}_{n+1}$ i $\overline{\dot{\mathbf{u}}}_{\mathrm{n}+1}$ su pretpostavljene, a $\mathbf{u}_{n+1}$ i $\dot{\mathbf{u}}_{n+1}$ su korigirane vrijednosti pomaka i brzina; $\beta$ i $\gamma$ su parametri koji određuju stabilnost i točnost metode [129].

Uvrštavanjem (4.8) i (4.9) u (4.7), te uvođenjem inkrementalno-iterativnog postupka rješavanja općeg nelinearnog problema, dobiva se tzv. efektivni statički problem:

$$
\mathbf{K}_{\tau}^{*} \Delta \mathbf{u}=\left(\mathbf{f}^{*}\right)^{\mathrm{i}}
$$

gdje se matrica efektivne tangentne krutosti $\mathbf{K}_{\tau}^{*}$ računa u vremenu $\tau$ s pomoću:

$$
\mathbf{K}_{\tau}^{*}=\frac{\mathbf{M}}{\beta \Delta \mathrm{t}^{2}}+\gamma \frac{\mathbf{C}_{\tau}}{\beta \Delta \mathrm{t}}+\mathbf{K}_{\tau}
$$

a vektor efektivnog opterećenja $\mathbf{f}^{*}$ s pomoću:

$$
\mathbf{f}^{*}=\mathbf{f}_{\mathrm{n}+1}-\mathbf{M} \ddot{\mathbf{u}}_{\mathrm{n}+1}^{\mathrm{i}}-\mathbf{R}\left(\mathbf{u}_{\mathrm{n}+1}^{\mathrm{i}}, \dot{\mathbf{u}}_{\mathrm{n}+1}^{\mathrm{i}}\right)
$$

U gornjim izrazima n označava vremenski korak, a i iteracijski korak; $\Delta \mathbf{u}$ je vektor prirasta pomaka. Newmarkov implicitni algoritam iterativnog rješenja problema prikazan je u Tablici $4.1[1]$.

Newmarkov eksplicitni algoritam iterativnog rješenja problema može se napisati u obliku:

$$
\mathbf{M} \ddot{\mathbf{u}}_{\mathrm{n}+1}+\mathbf{R}\left(\overline{\mathbf{u}}_{\mathrm{n}+1}+\overline{\mathbf{u}}_{\mathrm{n}+1}\right)=\mathbf{f}_{\mathrm{n}+1}
$$

Ovaj je algoritam prikazan u Tablici 4.2 [1]. Kod eksplicitnih metoda jednadžba dinamičke ravnoteže je zadovoljena $u$ vremenu $t_{n}$, a nepoznate varijable se računaju $u$ vremenu 
$\mathrm{t}_{\mathrm{n}+1}=\mathrm{t}_{\mathrm{n}}+\Delta \mathrm{t}$. Osnovna prednost ovih metoda je mali broj i jednostavnost računskih operacija unutar svakog vremenskog koraka. Njihov glavni nedostatak je da nisu bezuvjetno stabilne. S toga se proračunska prednost eksplicitnih metoda često kompenzira činjenicom da su neophodni mali vremenski inkrementi kada su u sustavu prisutni kruti (mali) elementi. Ove metode često nisu efikasne kod uporabe krutih dodirnih elemenata.

Tablica 4.1. Newmark-ov implicitni algoritam iterativnog rješenja problema

\begin{tabular}{|c|c|}
\hline (1) & Za vremenski korak $(n+1)$, staviti iteracijski korak $\mathrm{i}=1$ \\
\hline (2) & 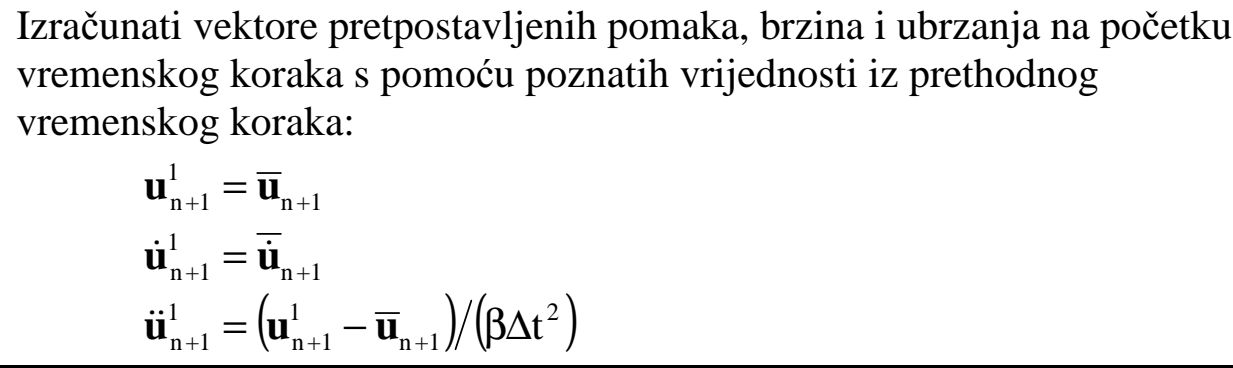 \\
\hline (3) & $\begin{array}{l}\text { Izračunati efektivne rezidualne sile }\left(\mathbf{f}^{*}\right)^{\mathrm{i}} \text { : } \\
\qquad\left(\mathbf{f}^{*}\right)^{\mathrm{i}}=\mathbf{f}_{\mathrm{n}+1}-\mathbf{M} \ddot{\mathbf{u}}_{\mathrm{n}+1}^{\mathrm{i}}-\mathbf{R}\left(\mathbf{u}_{\mathrm{n}+1}^{\mathrm{i}}, \dot{\mathbf{u}}_{\mathrm{n}+1}^{\mathrm{i}}\right)\end{array}$ \\
\hline (4) & $\begin{array}{l}\text { Izračunati matricu efektivne krutosti } \mathbf{K}_{\tau}^{*} \text { (ako je potrebno): } \\
\qquad \mathbf{K}_{\tau}^{*}=\frac{\mathbf{M}}{\beta \Delta \mathrm{t}^{2}}+\gamma \frac{\mathbf{C}_{\tau}}{\beta \Delta \mathrm{t}}+\mathbf{K}_{\tau}\end{array}$ \\
\hline (5) & $\begin{array}{l}\text { Izračunati vektor prirasta pomaka } \Delta \mathbf{u}^{\mathrm{i}} \text { : } \\
\qquad \mathbf{K}_{\tau}^{*} \Delta \mathbf{u}^{\mathrm{i}}=\left(\mathbf{f}^{*}\right)^{\mathrm{i}}\end{array}$ \\
\hline (6) & $\begin{array}{l}\text { Korigirati pretpostavljene vrijednosti pomaka, brzina i ubrzanja: } \\
\qquad \begin{aligned} \mathbf{u}_{\mathrm{n}+1}^{\mathrm{i}+1} & =\mathbf{u}_{\mathrm{n}+1}^{\mathrm{i}}+\Delta \mathbf{u}_{\mathrm{n}+1}^{\mathrm{i}} \\
\ddot{\mathbf{u}}_{\mathrm{n}+1}^{\mathrm{i}+1} & =\left(\mathbf{u}_{\mathrm{n}+1}^{i+1}-\overline{\mathbf{u}}_{\mathrm{n}+1}\right) /\left(\beta \Delta \mathrm{t}^{2}\right) \\
\dot{\mathbf{u}}_{\mathrm{n}+1}^{\mathrm{i}+1} & =\dot{\mathbf{u}}_{\mathrm{n}+1}^{\mathrm{i}}+(\gamma \Delta \mathrm{t}) \ddot{\mathbf{u}}_{\mathrm{n}+1}^{\mathrm{i}+1}\end{aligned}\end{array}$ \\
\hline
\end{tabular}

Kontrolirati konvergenciju postupka:

- Ako $\Delta \mathbf{u}^{\mathrm{i}}$ zadovoljava kriterij konvergencije:

$$
\left\|\Delta \mathbf{u}^{\mathrm{i}}\right\| /\left\|\mathbf{u}_{\mathrm{n}+1}^{\mathrm{i}+1}\right\| \leq \varepsilon_{\mathrm{n}}
$$

prelazi se na sljedeći vremenski korak (zamijeni se "n" s "n+1" i ide na korak rješenja (1)). Rješenje $u$ vremenu $t_{n+1}$ je:

$$
\begin{aligned}
\mathbf{u}_{\mathrm{n}+1} & =\mathbf{u}_{\mathrm{n}+1}^{\mathrm{i}+1} \\
\dot{\mathbf{u}}_{\mathrm{n}+1} & =\dot{\mathbf{u}}_{\mathrm{n}+1}^{\mathrm{i}+1} \\
\ddot{\mathbf{u}}_{\mathrm{n}+1} & =\ddot{\mathbf{u}}_{\mathrm{n}+1}^{\mathrm{i}+1}
\end{aligned}
$$

- Ako kriterij konvergencije nije zadovoljen, iteracijski postupak s korekcijom pomaka, brzina i ubrzanja se nastavlja (zamijeni se "i" s "i+1", te ide na korak rješenja (3)). 
Moguća je istovremena uporaba implicitnog i eksplicitnog Newmarkovog algoritma [1]. Naime, područje konstrukcije s krućim elementima efikasno je integrirati s implicitnim, a područje konstrukcije s mekšim elementima s eksplicitnim algoritmom.

Tablica 4.2. Newmark-ov eksplicitni algoritam iterativnog rješenja problema

\begin{tabular}{|c|c|}
\hline (1) & Za vremenski korak $(n+1)$, staviti iteracijski korak $i=1$ \\
\hline$(2)$ & 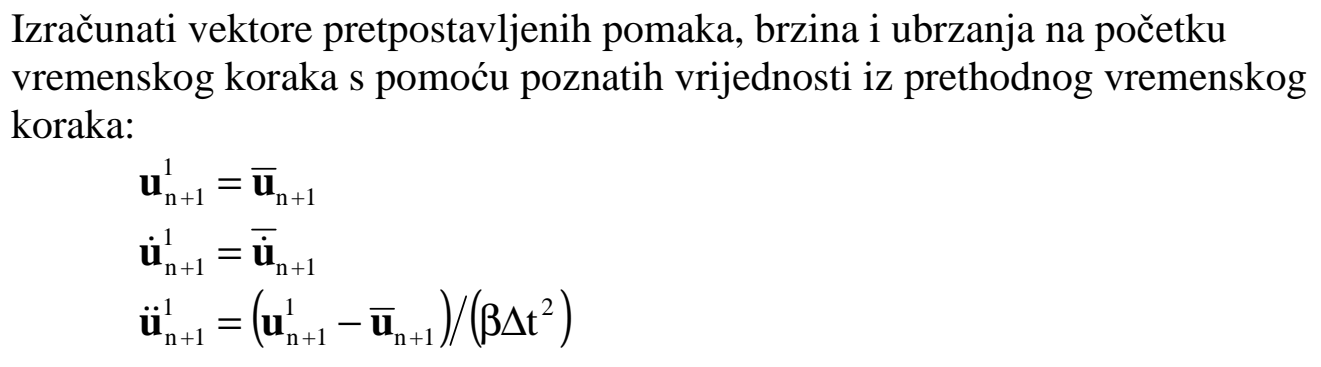 \\
\hline (3) & $\begin{array}{l}\text { Izračunati efektivne rezidualne sile }\left(\mathbf{f}^{*}\right)^{\mathrm{i}} \text { : } \\
\qquad\left(\mathbf{f}^{*}\right)^{\mathrm{i}}=\mathbf{f}_{\mathrm{n}+1}-\mathbf{R}\left(\mathbf{u}_{\mathrm{n}+1}^{\mathrm{i}}, \dot{\mathbf{u}}_{\mathrm{n}+1}^{\mathrm{i}}\right)\end{array}$ \\
\hline (4) & $\begin{array}{l}\text { Izračunati matricu efektivne krutosti } \mathbf{K}^{*} \text { (ako je potrebno): } \\
\qquad \mathbf{K}^{*}=\frac{\mathbf{M}}{\beta \Delta \mathrm{t}^{2}} \\
\text { Napomena: Budući da je matrica masa } \mathbf{M} \text { konstantna, matricu efektivne } \\
\text { krutosti } \mathbf{K}^{*} \text { dovoljno je izračunati samo jednom na početku postupka rješenja. } \\
\text { Također je vidljivo da treba biti } \beta>0 \text {. }\end{array}$ \\
\hline$(5)$ & $\begin{array}{l}\text { Izračunati vektor prirasta pomaka } \Delta \mathbf{u}^{\mathrm{i}} \text { : } \\
\qquad \mathbf{K}^{*} \Delta \mathbf{u}^{\mathrm{i}}=\left(\mathbf{f}^{*}\right)^{\mathrm{i}}\end{array}$ \\
\hline (6) & $\begin{array}{l}\text { Korigirati pretpostavljene vrijednosti pomaka, brzina i ubrzanja: } \\
\qquad \begin{aligned} & \mathbf{u}_{n+1}^{i+1}=\mathbf{u}_{\mathrm{n}+1}^{i}+\Delta \mathbf{u}_{\mathrm{n}+1}^{i} \\
& \ddot{\mathbf{u}}_{\mathrm{n}+1}^{i+1}=\left(\mathbf{u}_{\mathrm{n}+1}^{i+1}-\overline{\mathbf{u}}_{\mathrm{n}+1}\right) /\left(\beta \Delta t^{2}\right) \\
& \dot{\mathbf{u}}_{\mathrm{n}+1}^{i+1}=\dot{\mathbf{u}}_{\mathrm{n}+1}^{i}+(\gamma \Delta t) \ddot{\mathbf{u}}_{\mathrm{n}+1}^{i+1}\end{aligned}\end{array}$ \\
\hline (7) & $\begin{array}{l}\text { Kontrolirati konvergenciju postupka. } \\
\text { Kod eksplicitnog postupka s jednokratnom korekcijom rezultata kontrola } \\
\text { konvergencije nije potrebna, već se direktno prelazi na sljedeći vremenski } \\
\text { korak. } \\
\text { Kod višekratne korekcije rezultata, potrebno je kontrolirati konvergenciju } \\
\text { postupka kako je to opisano u Tablici } 4.1 \text {. }\end{array}$ \\
\hline
\end{tabular}




\subsubsection{Konstrukcijsko prigušenje}

U metodi direktne integracije jednadžbi gibanja, koja je i ovdje korištena, redovito se koristi Rayleigh-ovo viskozno prigušenje, kod kojeg se matrica prigušenja $\mathbf{C}$ izražava kao linearna kombinacija matrica $\mathbf{M}$ i $\mathbf{K}$ prema:

$$
\mathbf{C}=\alpha_{\mathrm{d}} \mathbf{M}+\beta_{\mathrm{d}} \mathbf{K}
$$

U gornjem izrazu $\alpha_{d}$ i $\beta_{d}$ su konstante koje se određuju na osnovu koeficijenta prigušenja $\xi_{\mathrm{i}}$ za bilo koja dva nezavisna moda. Koeficijent prigušenja $\xi_{\mathrm{i}}$ za pojedine modove vibracija određuje se eksperimentalno (na osnovu mjerenja amplituda prigušenja slobodnih oscilacija ili mjerenja energije disipacije). Konstante $\alpha_{\mathrm{d}}$ i $\beta_{\mathrm{d}}$ su vezane izrazom:

$$
\alpha_{\mathrm{d}}+\beta_{\mathrm{d}} \omega_{\mathrm{i}}^{2}=2 \omega_{\mathrm{i}} \xi_{\mathrm{i}}
$$

gdje je $\omega_{1}$ kružna frekvencija (rad/s) promatranog moda neprigušenog sustava. Ako se uzmu dva uzastopna moda slobodnih oscilacija s odgovarajućim frekvencijama $\omega_{1}$ i $\omega_{2}$, te prigušenjima $\xi_{1}$ i $\xi_{2}$, ove se konstante mogu izračunati prema:

$$
\begin{aligned}
& \alpha_{d}=2 \omega_{1} \omega_{2}\left(\omega_{2} \xi_{1}-\omega_{1} \xi_{2}\right) /\left(\omega_{2}^{2}-\omega_{1}^{2}\right) \\
& \beta_{d}=2\left(\omega_{2} \xi_{2}-\omega_{1} \xi_{1}\right) /\left(\omega_{2}^{2}-\omega_{1}^{2}\right)
\end{aligned}
$$

Matrica prigušenja $\mathbf{C}$ uvedena je u kontekstu primjene linearnih elastičnih analiza. Kod provedbe nelinearnih dinamičkih analiza, s modelima materijala koji uključuju unutrašnju disipaciju energije, matrica prigušenja $\mathbf{C}$ trebala bi obuhvatiti samo onaj dio disipacije energije koji nije obuhvaćen modelima materijala. Ostaje otvoreno pitanje u kojem iznosu treba uključiti viskozno Rayleigh-ovo prigušenje pri uključenju nelinearnih modela materijala i geometrije.

\subsubsection{Metoda rješenja nelinearnog problema}

Može se reći da ne postoji metoda rješenja sustava nelinearnih jednadžbi koja bi bila potpuno efikasna za sve nelinearne probleme. Neke metode mogu biti vrlo efikasne za određene tipove problema, dok kod drugih mogu biti potpuno neefikasne. Kod problema s izraženijom nelinearnošću, potrebno je koristiti manje inkremente opterećenja. Kod rješavanja problema stabilnosti, odnosno u slučajevima postojanja tzv. točke bifurkacije (razdvajanja), neke metode mogu biti potpuno neupotrebljive [130]. Izbor metode nelinearnog rješenja obično je zasnovan na iskustvu. Neke metode nelinearnih rješenja mogu se naći u [129-135]. 
U ovom je radu korištena metoda Newton-Raphsona, koja je jedna od najčešće korištenih metoda, a koja se ukratko prikazuje u nastavku.

Jednadžba dinamičke ravnoteže može se skraćeno napisati u obliku:

$$
\mathbf{f}^{*}(\mathbf{u}, \dot{\mathbf{u}}, \ddot{\mathbf{u}})=0=\mathbf{f}-\mathbf{R}(\mathbf{u}, \dot{\mathbf{u}})-\mathbf{M} \ddot{\mathbf{u}}
$$

Prema metodi Newton-Raphsona (NR), rješenje problema u inkrementalno-iterativnom obliku dano je s:

$$
\begin{aligned}
& \Delta \mathbf{u}^{\mathrm{i}}=-\left[\mathrm{J}\left(\mathbf{u}^{\mathrm{i}}, \dot{\mathbf{u}}^{\mathrm{i}}, \ddot{\mathbf{u}}^{\mathrm{i}}\right)\right]\left(\mathbf{f}^{*}\right)^{\mathrm{i}} \\
& \mathbf{u}^{\mathrm{i}+\mathbf{1}}=\mathbf{u}^{\mathrm{i}}+\Delta \mathbf{u}^{\mathrm{i}}
\end{aligned}
$$

$\mathrm{U}(4.18)\left[\mathrm{J}\left(\mathbf{u}^{\mathrm{i}}, \dot{\mathbf{u}}^{\mathrm{i}}, \ddot{\mathbf{u}}^{\mathrm{i}}\right)\right]$ označava Jacobi-jevu matricu, koja je definirana s:

$$
\left[\mathrm{J}\left(\mathbf{u}^{\mathrm{i}}, \dot{\mathbf{u}}^{\mathrm{i}}, \ddot{\mathbf{u}}^{\mathrm{i}}\right)\right]=\frac{\partial\left(\mathbf{f}^{*}\right)^{\mathrm{i}}}{\partial \mathbf{u}^{\mathrm{i}}}
$$

a na temelju (4.17) slijedi:

$$
\frac{\partial\left(\mathbf{f}^{*}\right)^{i}}{\partial \mathbf{u}^{i}}=\frac{\partial \mathbf{R}^{i}}{\partial \mathbf{u}^{i}}+\frac{\partial \mathbf{R}^{i}}{\partial \dot{\mathbf{u}}^{i}} \frac{\partial \dot{\mathbf{u}}^{i}}{\partial \mathbf{u}^{i}}+\mathbf{M} \frac{\partial \ddot{\mathbf{u}}^{\mathrm{i}}}{\partial \mathbf{u}^{i}}=\left(\mathbf{K}^{*}\right)^{\mathrm{i}}
$$

Korištenjem Newmark-ove diskretizacije, (4.20) odgovara (4.12), tj.:

$$
\left(\mathbf{K}_{\tau}^{*}\right)^{\mathrm{i}}=\frac{\mathbf{M}}{\beta \Delta \mathrm{t}^{2}}+\gamma \frac{\mathbf{C}_{\tau}^{\mathrm{i}}}{\beta \Delta \mathrm{t}}+\mathbf{K}_{\tau}^{\mathrm{i}}
$$

gdje $\mathbf{K}_{\tau}^{\mathrm{i}}=\partial \mathbf{R}^{\mathrm{i}} / \partial \mathbf{u}^{\mathrm{i}}$ označava matricu tangentne krutosti, a $\mathbf{C}_{\tau}^{\mathrm{i}}=\partial \mathbf{R}^{\mathrm{i}} / \partial \dot{\mathbf{u}}^{\mathrm{i}}$ matricu tangentnog prigušenja.

Za statičke probleme, (4.17) se svodi na:

$$
\mathbf{f}^{*}(\mathrm{u})=0=\mathbf{f}-\mathbf{R}(\mathrm{u})
$$

a (4.20) na:

$$
\left(\mathbf{K}^{*}\right)^{\mathrm{i}}=\mathbf{K}_{\tau}^{\mathrm{i}}
$$

Iteracijski postupak rješenja problema se nastavlja sve dok nije zadovoljen kriterij konvergencije. Metoda NR ima kvadratnu brzinu konvergencije. Ažuriranje (popravljanje) matrice $\mathbf{K}^{*}$ u svakoj iteraciji svakog inkrementa iziskuje dosta proračunskog vremena, pa je kod problema s ograničenom nelinearnošću efikasnije koristiti MNR metode.

Kod MNR metoda, Jacobi-jeva matrica se ne popravlja u svakom vremenskom koraku. Jedna varijanta je da se matrica $\mathbf{K}^{*}$ izračuna samo na početku svakog inkrementa vremena/opterećenja, a dalje se zadržava konstantnom. Također je moguće $\mathbf{K}^{*}$ izračunati samo jednom na početku postupka rješenja i zadržati je konstantnom kroz sve inkremente i 
iteracije. Koriste se i druge mogućnosti, npr. da se $\mathbf{K}^{*}$ popravlja samo u nekoliko prvih iteracija, a dalje drži konstantnom. Shematski prikaz ovih metoda, prema [135], dan je na Slici 4.3.

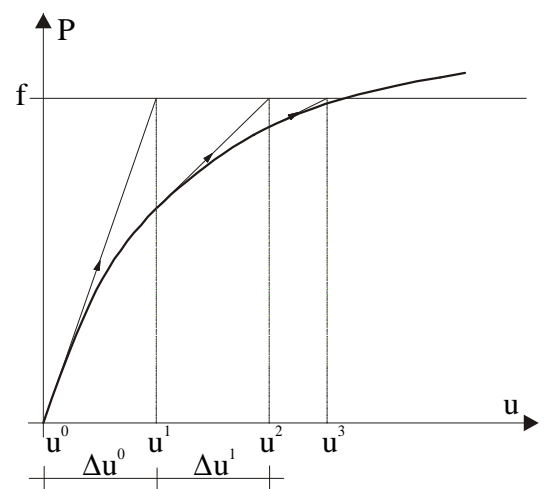

(i) NR metoda

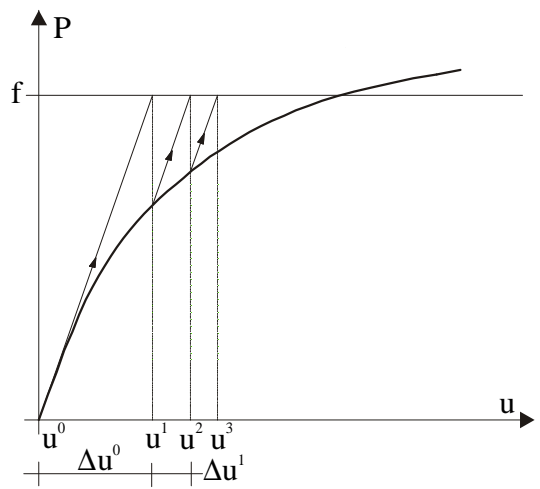

(ii) MNR metoda

Slika 4.3. Shematski prikaz metoda NR i MNR

Metode MNR imaju sporiju konvergenciju, ali prema utrošku vremena računanja često mogu biti brže i efikasnije od metode NR. Može se reći da su metode NR i MNR općenito najčešće korištene budući da su dobro testirane, jednostavno ih je implementirati i vrlo su efikasne. To je glavni razlog njihove primjene i u ovom radu.

\subsubsection{Kriterij konvergencije}

Za kontrolu toka nelinearnog numeričkog postupka, obično se koriste dva kriterija konvergencije: kriterij konvergencije baziran na rezidualnim (neuravnoteženim) silama ili kriterij konvergencije baziran na pomacima.

U analizama armirano betonskih konstrukcija obično se koristi kriterij konvergencije preko prirasta pomaka, jer rezidualne sile mogu formirati "ravnotežne grupe" [136], koje nemaju značajan utjecaj na ukupni odgovor konstrukcije. Kod toga je prikladno odvojeno kontrolirati priraste translacija od prirasta rotacija.

Broj iteracija dominantno ovisi o odabranoj veličini dopustive tolerancije, odnosno o zahtijevanoj točnosti rješenja. Stoga, odabiru dopustive tolerancije treba posvetiti naročitu pažnju, jer nekad blaža tolerancija može bitno smanjiti vrijeme trajanja proračuna bez značajne razlike u rezultatima. Ovo osobito vrijedi za probleme s velikim brojem nepoznanica i izrazitim nelinearnim ponašanjem. U uobičajenim slučajevima, dopustiva tolerancija od 0.001 do 0.01 trebala bi biti dovoljna za postizanje dostatne točnosti rješenja i relativno mali 
utrošak proračunskog vremena. Ipak, u većini praktičnih slučajeva zadovoljavajuće točni rezultati mogu se postići i s tolerancijom od 0.01-0.03. Blaže kriterije konvergencije koji, kako je istaknuto, ne moraju značajnije utjecati na točnost dobivenih rezultata, treba koristiti kod problema s velikim brojem čvorova/nepoznanica i s izrazitim nelinearnim ponašanjem.

Prosječno, ukupni broj iteracija između 10-15 za svaki vremenski korak, uz dopustivu toleranciju od oko 0.005, može se smatrati zadovoljavajućim.

\subsection{Modeli materijala}

Od primarnog je značaja primjena što adekvatnijih modela materijala za što realističniju simulaciju ponašanja zidanih zidova pod statičkim i dinamičkim opterećenjem, odnosno za uključivanje dominantnih nelinearnih efekata ponašanja zidanih konstrukcija. Ovdje su prikazani primijenjeni modeli materijala za pojedine dijelove zidane građevine (armirani beton, ziđe, tlo).

Nelinearnost ponašanja gradiva može se razmatrati na makro i mikro razini, pa su s tim povezani i njihovi odgovarajući modeli. Prednost se daje tzv. makromodelima jer su jednostavni, skraćuju trajanje analize i mogu obuhvatiti najvažnije nelinearne efekte ponašanja materijala.

U osnovi, svi se modeli mogu grupirati u one temeljene na mehanici kontinuuma ili $u$ one koji uzimaju u obzir pojavu diskontinuiteta nakon pojave pukotina (modeli temeljeni na mehanici loma ili na diskretnim elementima).

U nastavku su prikazani opći elastični i elasto-plastični modeli materijala, te posebni modeli za simulaciju ponašanja armiranog betona, ziđa i tla.

\subsubsection{Linearno - elastični model materijala}

Veza naprezanje $(\sigma)$ - deformacija $(\varepsilon)$ izražava se s pomoću:

$$
\sigma=\mathbf{D \varepsilon}
$$

gdje je D matrica elastičnih konstanti gradiva. Za probleme ravninskog naprezanja, ona je oblika:

$$
\mathbf{D}=\frac{E}{1-v^{2}}\left[\begin{array}{ccc}
1 & v & 0 \\
v & 1-v & 0 \\
0 & 0 & \frac{1-v}{2}
\end{array}\right]
$$


a za probleme ravninske deformacije oblika:

$$
\mathbf{D}=\frac{E}{(1+v)(1-v)}\left[\begin{array}{ccc}
1-v & v & 0 \\
v & 1-v & 0 \\
0 & 0 & \frac{1-2 v}{2}
\end{array}\right]
$$

U gornjim je izrazima E modul elastičnosti gradiva, a $v$ Poisson-ov koeficijent. U slučaju primjene inkrementalno-iteracijskog postupka, E označava tangentni (tekući) modul elastičnosti za promatranu razinu naprezanja (deformacija).

\subsubsection{Elasto-plastični model materijala}

Plastično ponašanje materijala je karakterizirano nepovratnom plastičnom deformacijom. Plastična deformacija u ovom modelu nastaje trenutačno, kada stanje naprezanja dosegne određenu razinu. Ovo stanje naprezanja je definirano s tzv. uvjetom plastičnosti. Sve dok nije zadovoljen uvjet plastičnosti, koristi se linearno-elastični model materijala. Potom se pretpostavlja plastično ponašanje.

Uvjet plastičnosti se najčešće izražava s pomoću:

$$
\mathrm{F}\left(\boldsymbol{\sigma}, \mathrm{k}_{\mathrm{h}}\right)=0
$$

gdje je $k_{h}$ parametar ojačanja (eng. "hardening parametar") i definira pomicanje plohe plastičnog tečenja za daljnja opterećenja. Modeliranje ojačanja materijala može biti bazirano na plastičnoj deformaciji $\varepsilon_{\mathrm{p}}$, kod čega je:

$$
\mathrm{dk}_{\mathrm{h}}=\mathrm{d} \varepsilon_{\mathrm{p}}
$$

ili pak na plastičnom radu, kod čega je:

$$
\mathrm{dk}_{\mathrm{h}}=\boldsymbol{\sigma}^{\mathrm{T}} \mathrm{d} \boldsymbol{\varepsilon}_{\mathrm{p}}
$$

Teorije ojačanja pretpostavljaju da se funkcija popuštanja (uvjet plastičnosti) mijenja za naredna opterećenja. One uzimaju utjecaj povijesti naprezanja (deformacija) za definiranje narednih ploha popuštanja. Naime, ove teorije pokušavaju modelirati eksperimentalno utvrđene promjene u ponašanju gradiva za vrijeme plastičnog deformiranja. U numeričkim su analizama korištena različita pravila ojačanja. U slučaju potpuno (idealno) plastičnog ponašanja, ploha popuštanja ostaje fiksna u prostoru glavnih naprezanja. U tom se slučaju uvjet plastičnosti može izraziti s pomoću:

$$
\mathrm{F}(\boldsymbol{\sigma})-\mathrm{F}_{0}=0
$$


gdje je $\mathrm{F}_{0}$ efektivno jednoosno naprezanje pri popuštanju, koje ostaje nepromijenjeno za vrijeme plastičnog deformiranja. U slučaju najjednostavnijeg izotropnog pravila ojačanja (eng. "isotropic hardening flow rule"), uvjet plastičnosti se može izraziti s pomoću:

$$
\mathrm{F}(\boldsymbol{\sigma})-\mathrm{F}_{0}\left(\mathrm{k}_{\mathrm{h}}\right)=0
$$

gdje efektivno jednoosno naprezanje $F_{0}$ zavisi o skalarnom parametru $k_{h}$. Najčešće korišteni uvjeti plastičnosti su: Tresca, Von Mises, Mohr-Coulomb i Drucker-Prager.

Nakon pojave plastičnog ponašanja, potrebno je definirati pravilo popuštanja. Ono definira veličinu i smjer prirasta plastične deformacije. Naime, u području plastičnog deformiranja, prirast ukupne deformacije $d \varepsilon$ može se rastaviti na prirast elastične $d \varepsilon_{\mathrm{e}} \mathrm{i}$ prirast plastične d $\varepsilon_{\mathrm{p}}$ deformacije, tj.:

$$
\mathrm{d} \varepsilon=\mathrm{d} \varepsilon_{\mathrm{e}}+\mathrm{d} \varepsilon_{\mathrm{p}}
$$

Prirast elastične deformacije može se dobiti s pomoću:

$$
\mathrm{d} \varepsilon_{\mathrm{e}}=\mathbf{D}^{-1} \mathrm{~d} \sigma
$$

Prirast plastične deformacije može se izraziti kao:

$$
\mathrm{d} \varepsilon_{\mathrm{p}}=\mathrm{d} \bar{\lambda}(\partial \mathrm{Q} / \partial \sigma)
$$

gdje je $\mathrm{d} \bar{\lambda}$ konstanta proporcionalnosti, a Q plastični potencijal. Prema izrazu (4.34), koji se naziva pravilo popuštanja, prirast plastične deformacije je proporcionalan gradijentu naprezanja plastičnog potencijala. $U$ slučaju $\mathrm{Q} \equiv \mathrm{F}$ (plastični potencijal je identičan plohi popuštanja), pravilo popuštanja se naziva pridruženo pravilo popuštanja (eng. "associated flow rule") ili princip normalnosti (eng. "normality principle"), a u slučaju $Q \neq F$ nepridruženo pravilo popuštanja (eng. "non associated flow rule").

Konstitutivni zakon u području plastičnog ponašanja definiran je s pomoću:

$$
\mathrm{d} \sigma=\mathbf{D}_{\mathrm{ep}} \mathrm{d} \varepsilon
$$

Elasto-plastična konstitutivna matrica $\mathbf{D}_{\mathrm{ep}}$ definirana je s pomoću:

$$
\mathbf{D}_{\mathrm{ep}}=\mathbf{D}-\frac{\overline{\mathbf{d}} \overline{\mathbf{d}}^{\mathrm{T}}}{\mathrm{A}_{\mathrm{S}}+\overline{\mathbf{d}}^{\mathrm{T}}}
$$

gdje je za pridruženo pravilo popuštanja:

$$
\begin{aligned}
& \mathbf{a}^{\mathrm{T}}=\partial \mathrm{F} / \partial \sigma \\
& \overline{\mathbf{d}}=\mathbf{D a}
\end{aligned}
$$

U gornjim je izrazima D matrica elastičnih konstanti gradiva, a $A_{S}$ nagib krivulje naprezanje plastična deformacija za jednoosno naponsko stanje. Detaljniji teorijski opis ovog modela može se primjerice naći u [137, 138], a njegova numerička primjena u [139, 140]. 


\subsubsection{Model ponašanja armiranog betona}

Prikazani model se koristi za simulaciju ponašanja dijelova zidane građevine koji su izgrađeni iz betona ili armiranog betona (serklaži, temelji, stupovi, nadvoji, grede i sl.) Taj je model prethodno razvijen za statičku i dinamičku analizu klasičnih armiranobetonskih konstrukcija [1] i ovdje će se samo ukratko opisati.

\subsubsection{Model ponašanja betona}

Grafički prikaz usvojenog modela ponašanja betona u polju glavnih naprezanja prikazan je na Slici 4.4ii, a njegov jednodimenzionalni prikaz (analogija $\mathrm{s}$ jednoosnim stanjem naprezanja) na Slici 4.4i. Usvojen je prilično jednostavan model ponašanja, koji se temelji na osnovnim parametrima betona, za simulaciju problema kod kojih nelinearnosti prvenstveno nastaju zbog pucanja betona u vlaku i popuštanja betona u tlaku. Na Slici 2.4 oznake imaju sljedeće značenje: $f_{c, c}$ i $f_{c, t}$ su jednoosna tlačna i jednoosna vlačna računska čvrstoća betona; $\varepsilon_{c, c}$ i $\varepsilon_{c, t}$ su jednoosna tlačna i jednoosna vlačna lomna računska deformacija betona; $E_{c}$ je računski modul elastičnosti betona i $\alpha$ koeficijent $\leq 1$.

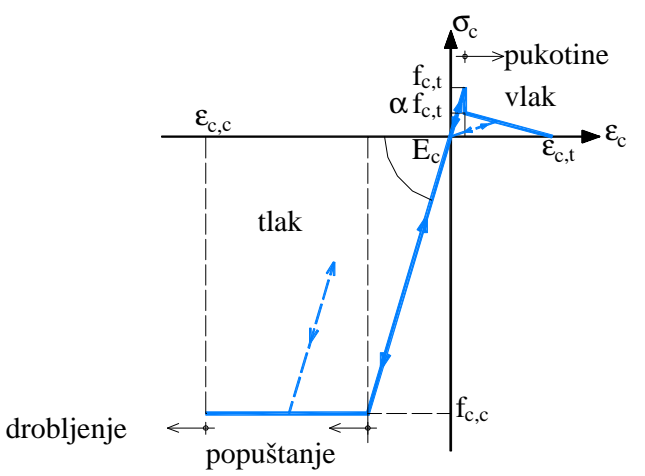

(i) jednodimenzionalni prikaz

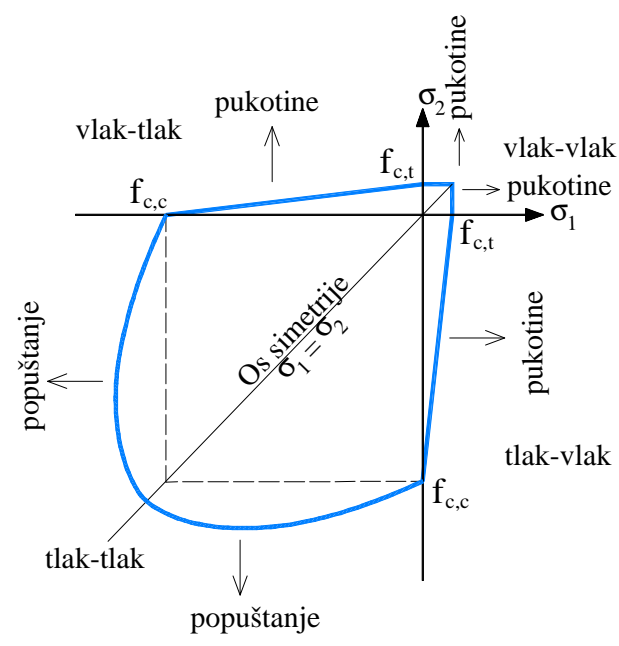

(ii) 2D prikaz u polju glavnih naprezanja

Slika 4.4. Grafički prikaz usvojenog modela ponašanja betona

\subsubsection{Modeliranje betona u dvoosnom tlaku}

Pretpostavljeno je da je beton pri malom naprezanju homogen i izotropan, te da je veza naprezanje - deformacija linearno-elastična. Veza prirasta naprezanja $\Delta \boldsymbol{\sigma}_{\mathrm{c}}$ i prirasta deformacije $\Delta \boldsymbol{\varepsilon}_{\mathrm{c}}$ dana je s pomoću: 


$$
\Delta \boldsymbol{\sigma}_{\mathrm{c}}=\mathbf{D}_{\mathrm{c}} \Delta \boldsymbol{\varepsilon}_{\mathrm{c}}
$$

gdje je $\mathbf{D}_{\mathbf{c}}$ matrica elastičnih konstanti betona. Veza (4.39) vrijedi u opterećenju i u rasterećenju.

Linearno-elastično ponašanje vrijedi sve dok stanje naprezanja ne zadovolji uvjet popuštanja (plastičnosti). Zbog jednostavnosti i zadovoljavajuće točnosti, primjenjuje se Von Misesov uvjet popuštanja izražen preko komponenti naprezanja:

$$
\mathrm{F}\left(\boldsymbol{\sigma}_{\mathrm{c}}\right)=\left(\sigma_{\mathrm{x}}^{2}+\sigma_{\mathrm{y}}^{2}-\sigma_{\mathrm{x}} \sigma_{\mathrm{y}}+3 \tau_{\mathrm{xy}}^{2}\right)^{1 / 2}-\mathrm{f}_{\mathrm{c}, \mathrm{c}}=0
$$

gdje je $f_{c, c}$ ekvivalentna jednoosna tlačna čvrstoća betona. Nakon što je zadovoljen uvjet popuštanja (4.40), pretpostavlja se potpuno plastično ponašanje betona.

Uvjet drobljenja betona definiran je u funkciji komponenti deformacija, preko:

$$
\mathrm{F}_{\varepsilon}\left(\boldsymbol{\varepsilon}_{\mathrm{c}}\right)=\left(\varepsilon_{\mathrm{x}}^{2}+\varepsilon_{\mathrm{y}}^{2}-\varepsilon_{\mathrm{x}} \varepsilon_{\mathrm{y}}+0.75 \gamma_{\mathrm{xy}}^{2}\right)^{1 / 2}-\varepsilon_{\mathrm{c}, \mathrm{t}}=0
$$

gdje je $\varepsilon_{c, t}$ granična tlačna deformacija dobivena jednoosnim testom. Kod toga se $\varepsilon_{c, t}$ obično uzima između 0.003 i 0.005 .

Kad je uvjet drobljenja zadovoljen $\left(\mathrm{F}\left(\varepsilon_{\mathrm{c}}\right) \geq 0\right)$, pretpostavlja se da beton nema nikakve krutosti pa su i naprezanja u njemu jednaka nuli. Kod toga treba imati na umu da se u rješenju s pomoću MKE promatra stanje naprezanja u tzv. integracijskim točkama. Ukupna krutost elementa određuje se na osnovu doprinosa svake integracijske točke. Stoga drobljenje betona u nekoj točki elementa ne znači da cijeli element nema nikakvu krutost. Isto tako, slom betona u jednoj ili više integracijskih točaka ne znači ujedno i slom konstrukcije.

\subsubsection{Modeliranje betona u vlaku}

Pretpostavljeno je linearno-elastično ponašanje betona sve dok nije zadovoljen uvjet sloma (pojave pukotina), te ponovno vrijedi izraz (4.39).

U području vlak-vlak, pretpostavljeno je da se pukotine javljaju u ravnini okomitoj na pravac maksimalnog glavnog vlačnog naprezanja ako ovo naprezanje prekorači jednoosnu vlačnu čvrstoću betona $\mathrm{f}_{\mathrm{c}, \mathrm{t}}$. Dakle, pukotine nastaju kada je:

$$
\sigma_{1} \geq \mathrm{f}_{\mathrm{c}, \mathrm{t}} \quad \mathrm{i} / \mathrm{ili} \quad \sigma_{2} \geq \mathrm{f}_{\mathrm{c}, \mathrm{t}}
$$

gdje $\sigma_{1}$ i $\sigma_{2}$ predstavljaju glavna vlačna naprezanja. Ukoliko $\sigma_{1}$ i $\sigma_{2}$ prekorače vlačnu čvrstoću betona $\mathrm{f}_{\mathrm{c}, \mathrm{t}}$, pukotine se javljaju istovremeno i međusobno su okomite.

U području vlak-tlak, prema Slici 4.5ii, pretpostavljeno je da pukotine nastaju kada je:

$$
\left(f_{c, t}-\sigma_{1}\right) / f_{c, t} \geq \sigma_{2} / f_{c, c} \quad \text { i/ili } \quad \sigma_{1} f_{c, c}+\sigma_{2} f_{c, t} \leq f_{c, c} f_{c, t}
$$


Pretpostavljeno je da se pukotine javljaju u ravnini okomitoj na pravac glavnog vlačnog naprezanja $\sigma_{1}\left(\operatorname{kod}\right.$ čega je $\left.\sigma_{1}>\sigma_{2}\right)$. Ako glavno tlačno naprezanje $\sigma_{2}$ prekorači tlačnu čvrstoću $\mathrm{f}_{\mathrm{c}, \mathrm{t}}$, pretpostavljeno je potpuno plastično ponašanje betona. Drobljenje betona se javlja ukoliko glavna tlačna deformacija $\varepsilon_{2}$ prekorači jednoosnu tlačnu deformaciju betona $\varepsilon_{\mathrm{c}, \mathrm{c}}$.

Stanja naprezanja u točkama prije pojave mogućih pukotina prikazana su na Slici 4.5i. Glavna naprezanja $\sigma_{1}$ i $\sigma_{2}\left(\right.$ gdje je $\left.\sigma_{1}>\sigma_{2}\right)$ mogu se izračunati prema izrazu:

$$
\sigma_{1,2}=0.5\left(\sigma_{x}+\sigma_{y}\right) \pm \sqrt{0.25\left(\sigma_{x}-\sigma_{y}\right)^{2}+\tau_{x y}^{2}}
$$

Pukotina nastaje u ravnini okomitoj na pravac glavnog vlačnog naprezanja $\sigma_{1}$ (Slika 4.5i), koji je definiran s pomoću:

$$
\alpha_{\text {cr }}=0.5 \operatorname{arctg}\left[2 \tau_{\mathrm{xy}} /\left(\sigma_{\mathrm{x}}-\sigma_{\mathrm{y}}\right)\right]
$$

Pravac ravnine pukotine definiran je s pomoću:

$$
\alpha_{\mathrm{cr}}^{*}=\alpha_{\mathrm{cr}}+\pi / 2
$$

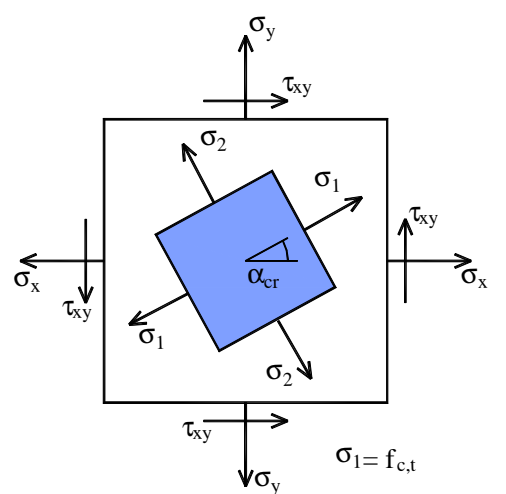

(i) Formiranje pukotine

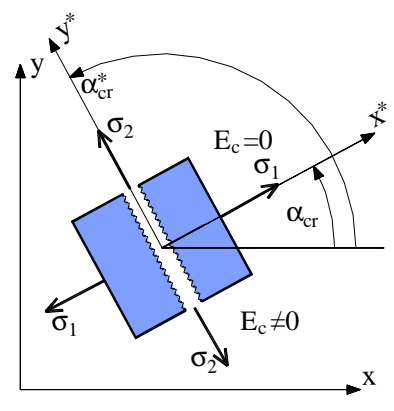

(ii) Prikaz pukotine

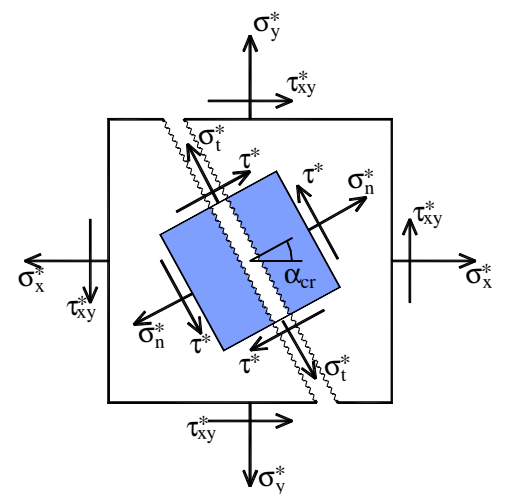

(iii) Naprezanja nakon pucanja

Slika 4.5. Model pukotina

U inkrementalno-iteracijskom postupku rješenja, unutar jednog inkrementa (prirasta) opterećenja moguće je otvaranje više pukotina čim su u određenim integracijskim točkama zadovoljeni uvjeti (4.42), odnosno (4.43). Kod toga glavna vlačna naprezanja mogu značajno premašiti vlačnu čvrstoću, pa dobiveni broj i nagib pukotina neće odgovarati stvarnosti. Pri tome sve pukotine koje su nastale u prvoj iteraciji promatranog prirasta opterećenja ostaju trajno zabilježene. Očito je da veličina prirasta opterećenja značajno utječe na dobivene rezultate.

Pukotine su modelirane kao raspodijeljene, odnosno "razmazane" (eng. "smeared cracks"). Pristup raspodijeljenih pukotina zanemaruje stvarni diskontinuitet pomaka. Naime, pukotine su uključene na indirektan način pretpostavljajući da beton ostaje kontinuum. S 
proračunske točke gledanja, ovaj je pristup daleko pogodniji od modela diskretnih pukotina budući da topologija idealizirane konstrukcije ostaje nepromijenjena; lokalni diskontinuitet zbog pucanja modeliran je kao kontinuirani. Naime, ovaj je pristup sukladan pretpostavkama MKE i mehanike kontinuuma. Nedostatak ovog pristupa je taj što nije moguće izračunati relativne pomake zbog pucanja betona, te stvarni položaj i širinu pukotina. Nakon otvaranja pukotine, pretpostavljeno je da njen položaj (kut $\left.\alpha_{c r}^{*}\right)$ ostaje nepromijenjen za naredna opterećenja. Na taj način je definiran i položaj ostalih pukotina koje eventualno mogu nastati (leže u okomitim ravnima). Nakon pojave pukotine beton postaje anizotropan, a smjer pukotine određuje glavne smjerove anizotropije. Modelirano je djelomično i potpuno zatvaranje otvorenih pukotina, kao i ponovno otvaranje ranije zatvorenih pukotina. Nakon potpunog zatvaranja pukotine, prijenos tlačnog naprezanja simuliran je kao u slučaju neispucanog (homogenog) betona. Nakon ponovnog otvaranja pukotine, ne računa se s vlačnom krutošću puknutog betona.

Pretpostavljeno ponašanje betona $\mathrm{u}$ vlaku nakon pojave pukotina pobliže je opisano kako niže slijedi.

\section{A. Veza naprezanje-deformacija nakon pucanja betona}

Nakon pojave pukotine, beton postaje ortotropan. Uvodi se novi zakon ponašanja materijala, definiran u lokalnom koordinatnom sustavu $\mathrm{x}^{*}-\mathrm{y}^{*}$ (Slika 4.5ii). Veza naprezanjedeformacija puknutog betona može se napisati u obliku:

$$
\boldsymbol{\sigma}_{\mathrm{c}}^{*}=\mathbf{D}_{\mathrm{c}}^{*} \boldsymbol{\varepsilon}_{\mathrm{c}}^{*}
$$

gdje $\mathbf{D}_{\mathrm{c}}^{*}$ označava matricu "elastičnih" konstanti puknutog betona. Vektori naprezanja $\sigma_{\mathrm{c}}^{*}=\left[\sigma_{\mathrm{n}}^{*}, \sigma_{\mathrm{t}}^{*}, \tau_{\mathrm{nt}}^{*}\right]^{\mathrm{T}}$ i deformacija $\varepsilon_{\mathrm{c}}^{*}=\left[\varepsilon_{\mathrm{n}}^{*}, \varepsilon_{\mathrm{t}}^{*}, \varepsilon_{\mathrm{nt}}^{*}\right]^{\mathrm{T}}$ imaju komponente u skladu s lokalnim koordinatnim sustavom (Slika 4.5iii).

Vlačno naprezanje okomito na ravninu pukotine $\sigma_{\mathrm{n}}^{*}$ je jednako nuli. Međutim, ovo se naprezanje postupno reducira na nulu, a u skladu s usvojenim modelom vlačne krutosti puknutog betona (Slika 4.6). Koeficijent posmika $G_{c}^{*} u$ matrici $\mathbf{D}_{c}^{*}$ definiran je preko usvojenog modela posmične krutosti puknutog betona (Slika 2.7). Posmično naprezanje u ravnini pukotine $\tau_{\mathrm{nt}}^{*}$ definirano je kao:

$$
\tau_{\mathrm{nt}}^{*}=\mathrm{G}_{\mathrm{c}}^{*} \gamma_{\mathrm{nt}}^{*}
$$


Oblik konstitutivne veze puknutog betona za slučaj ravninskog naprezanja i ravninske deformacije dan je u nastavku.

Za ravninsko stanje naprezanja, veza naprezanje-deformacija za beton koji ima jednu pukotinu u smjeru osi $y^{*}$ definirana je s pomoću:

$$
\left[\begin{array}{c}
\sigma_{\mathrm{n}}^{*} \\
\sigma_{\mathrm{t}}^{*} \\
\tau_{\mathrm{nt}}^{*}
\end{array}\right]=\left[\begin{array}{ccc}
0 & 0 & 0 \\
0 & \mathrm{E}_{\mathrm{c}} & 0 \\
0 & 0 & \mathrm{G}_{\mathrm{c}}^{*}
\end{array}\right]\left[\begin{array}{c}
\varepsilon_{\mathrm{n}}^{*} \\
\varepsilon_{\mathrm{t}}^{*} \\
\gamma_{\mathrm{nt}}^{*}
\end{array}\right]
$$

U skladu sa stanjem ravninske deformacije, komponenta deformacije okomite na ravninu pukotine definirana je s pomoću:

$$
\varepsilon_{\mathrm{t}}^{*}=-v_{\mathrm{c}}\left(\sigma_{\mathrm{n}}^{*}+\sigma_{\mathrm{t}}^{*}\right) / \mathrm{E}_{\mathrm{c}}
$$

gdje je $v_{\mathrm{c}}$ Poisson-ov koeficijent za beton.

U slučaju dviju pukotina, matrica $\mathbf{D}_{\mathrm{c}}^{*}$ ima oblik:

$$
\mathbf{D}_{\mathrm{c}}^{*}=\left[\begin{array}{ccc}
0 & 0 & 0 \\
0 & 0 & 0 \\
0 & 0 & \mathrm{G}_{\mathrm{c}}^{*}
\end{array}\right]
$$

Treba napomenuti da je u slučaju neispucanog (homogenog) betona uvjet nastanka pukotina dan sa $\sigma_{1}, \sigma_{2}>f_{c, t}$, dok je u slučaju betona s jednom pukotinom uvjet nastanka druge pukotine definiran sa $\varepsilon_{\mathrm{t}}^{*}>\varepsilon_{\mathrm{cr}}\left(\mathrm{gdje} \mathrm{je} \varepsilon_{\mathrm{cr}}=\mathrm{f}_{\mathrm{c}, \mathrm{t}} / \mathrm{E}_{\mathrm{c}}\right)$.

Za ravninsko stanje deformacije, veza naprezanje-deformacija za beton koji ima jednu pukotinu u smjeru osi $\mathrm{y}^{*}$ dana je s pomoću:

$$
\left[\begin{array}{c}
\sigma_{\mathrm{n}}^{*} \\
\sigma_{\mathrm{t}}^{*} \\
\tau_{\mathrm{nt}}^{*}
\end{array}\right]=\left[\begin{array}{ccc}
0 & 0 & 0 \\
0 & \mathrm{E}_{\mathrm{c}} /\left(1-v^{2}\right) & 0 \\
0 & 0 & \mathrm{G}_{\mathrm{c}}^{*}
\end{array}\right]\left[\begin{array}{c}
\varepsilon_{\mathrm{n}}^{*} \\
\varepsilon_{\mathrm{t}}^{*} \\
\gamma_{\mathrm{nt}}^{*}
\end{array}\right]
$$

Naprezanje okomito na ravninu pukotine definirano je s pomoću:

$$
\sigma_{\mathrm{z}}^{*}=v_{\mathrm{c}}\left(\sigma_{\mathrm{t}}^{*}+\sigma_{\mathrm{n}}^{*}\right)
$$

U slučaju dviju pukotina, matrica $\mathbf{D}_{c}^{*}$ je definirana s pomoću (4.51). U svim se slučajevima posmični modul $\mathrm{G}_{\mathrm{c}}^{*}$ postupno reducira na nulu, sukladno modelu posmične krutosti puknutog betona. Također, vlačno naprezanje okomito na ravninu pukotine se ažurira u skladu s usvojenim modelom vlačne krutosti puknutog betona. 


\section{B. Modeliranje vlačne krutosti betona s pukotinama}

Utjecaj vlačne krutosti puknutog betona simuliran je postupnim smanjenjem komponente vlačnog naprezanja okomito na ravninu pukotine, sukladno dijagramu naprezanje-deformacija za jednoosno naponsko stanje. Usvojeni dijagram naprezanjedeformacija prikazan je na Slici 4.6.

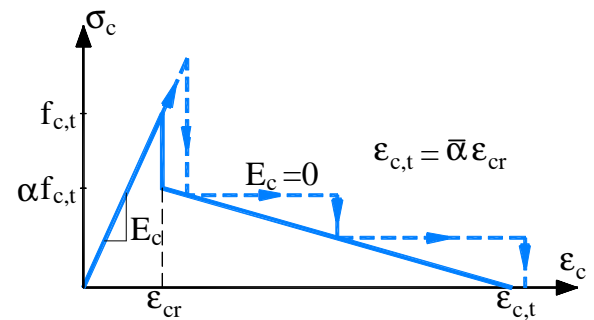

(i) Otvaranje pukotine

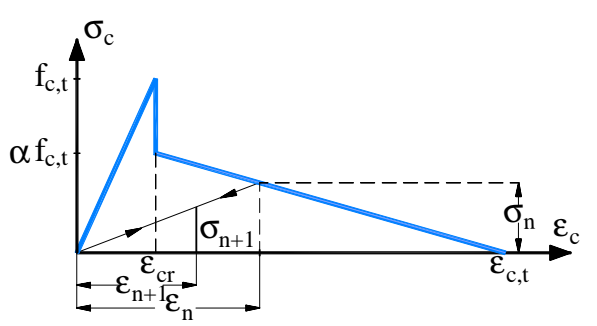

(ii) Djelomično zatvaranje pukotina

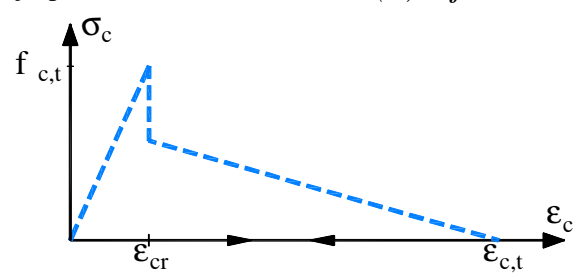

(iii) Ponovno otvaranje pukotine

Slika 4.6. Veza naprezanje-deformacija za beton nakon pojave pukotine

$\mathrm{U}$ trenutku pojave pukotine (Slika 4.6i), čemu odgovara $\sigma_{1}=\mathrm{f}_{\mathrm{c}, \mathrm{t}}=\mathrm{E}_{\mathrm{c}} \varepsilon_{\mathrm{cr}}$, normalno naprezanje okomito na ravninu pukotine je smanjeno na $\sigma_{n}^{*}=\alpha f_{c, t}$. Ukoliko deformacija okomito na ravninu pukotine prekorači vrijednost granične deformacije $\varepsilon_{c, t}$, usvojeno je $\sigma_{\mathrm{n}}^{*}=0$. Granična se deformacija može izraziti u obliku:

$$
\varepsilon_{\mathrm{c}, \mathrm{t}}=\bar{\alpha} \varepsilon_{\mathrm{cr}}
$$

gdje je $\varepsilon_{\text {cr }}$ deformacija kod pojave pukotine, a $\bar{\alpha}$ odabrani koeficijent. U slučaju rasterećenja, veza naprezanje-deformacija prikazana je na Slici 4.6ii. Nakon potpunog zatvaranja pukotine, mogućnost prijenosa tlačnog naprezanja preko ravnine pukotine modelirana je kao i u slučaju homogenog betona. Nakon ponovnog otvaranja pukotine (Slika 4.6iii), nije računato s nikakvom vlačnom krutošću ispucanog betona, tj. $\sigma_{n}^{*}=0$. Nakon ponovnog potpunog zatvaranja pukotine, opet je omogućen prijenos tlačnog naprezanja.

U numeričkim su analizama korištene različite vrijednosti koeficijenta $\bar{\alpha}$. Budući da ne postoje putovi njegovog točnog definiranja, ostaje jedina mogućnost da se $\bar{\alpha}$ odredi na osnovu testova ili iskustva. Čini se da odabrana veća vrijednost $\bar{\alpha}$ adekvatnije simulira 
konstrukcije koje su pretežno opterećene na savijanje, a manja vrijednost $\bar{\alpha}$ konstrukcije pretežno opterećene na posmik. Preporuča se da se za $\bar{\alpha}$ odabere vrijednost [141]:

$$
\begin{aligned}
& \bar{\alpha}=5-15 \quad \text { za pojavu pukotina zbog savijanja } \\
& \bar{\alpha}=15-25 \quad \text { za pojavu pukotina zbog posmika }
\end{aligned}
$$

\section{Modeliranje posmične krutosti betona s pukotinama}

U modelu raspodijeljenih pukotina, posmična krutost puknutog betona najčešće je modelirana redukcijom vrijednosti modula posmika. Takav je pristup i ovdje korišten. Pretpostavljeno je da je modul posmika puknutog betona $G_{c}^{*}$ linearno zavisan od veličine vlačne deformacije okomito na ravninu pukotine. Naime, $G_{c}^{*}$ je definiran s pomoću:

$$
\mathrm{G}_{\mathrm{c}}^{*}=\bar{\beta} \mathrm{G}_{\mathrm{c}}
$$

gdje je $G_{c}$ modul posmika homogenog betona, a $\bar{\beta}$ koeficijent prikazan na Slici 2.7 , odnosno definiran s pomoću:

$$
\begin{array}{ll}
\bar{\beta}=1-\varepsilon_{\mathrm{n}}^{*} / \varepsilon_{\mathrm{c}, \mathrm{p}} & \text { za } \varepsilon_{\mathrm{n}}^{*} \leq \varepsilon_{\mathrm{c}, \mathrm{p}} \\
\bar{\beta}=0 & \text { za } \varepsilon_{\mathrm{n}}^{*}<\varepsilon_{\mathrm{c}, \mathrm{p}}
\end{array}
$$

U gornjim izrazima, $\varepsilon_{\mathrm{n}}^{*}$ je tekuća vrijednost deformacije okomito na ravninu pukotine, a $\varepsilon_{\mathrm{c}, \mathrm{p}}$ granična vrijednost deformacije iznad koje nema posmičnog prijenosa u ravnini pukotine. Ova fiktivna deformacija odgovara širini pukotine kod koje nema zahvaćanja agregata u posmiku i trenja između ravnina pukotine, te utjecaja zaklinjenja armature. Ova se deformacija može napisati u obliku:

$$
\varepsilon_{\mathrm{c}, \mathrm{p}}=\bar{\gamma} \varepsilon_{\mathrm{cr}}
$$

gdje je $\bar{\gamma}$ empirijski koeficijent, čija vrijednost uglavnom zavisi od tipa sloma.

Ukoliko slom konstrukcije nastaje zbog posmika, numerički rezultati će bitno zavisiti od veličine $\varepsilon_{\mathrm{c}, \mathrm{p}}$. U tom slučaju se predlaže da se za $\bar{\gamma}$ usvoji vrijednost [141]:

$$
\bar{\gamma}=10-15
$$

što daje manju vrijednost granične deformacije $\varepsilon_{\mathrm{c}, \mathrm{p}}$ od one najčešće korištene u literaturi $\varepsilon_{\mathrm{c}, \mathrm{p}}$ $=0.001-0.0025)$. 
Za konstrukcije kod kojih slom nastaje zbog savijanja, numerički rezultati su manje osjetljivi o veličini $\varepsilon_{\mathrm{c}, \mathrm{p}}$. U tom se slučaju preporuča vrijednost $\varepsilon_{\mathrm{c}, \mathrm{p}}=0.004$, čemu odgovara:

$$
\bar{\gamma}=20-35
$$

Treba naglasiti da izrazi (4.59) i (4.60) za određivanje granične vlačne deformacije $\varepsilon_{c, p}$ nemaju izravnu eksperimentalnu ni teorijsku podlogu, već su određeni na temelju numeričke simulacije rezultata nekih eksperimenata, pa kod njihove primjene treba biti obazriv.

Kod rasterećenja i ponovnog opterećenja, pretpostavljena je ista veza modula posmika i vlačne deformacije okomito na ravninu pukotine (Slika 4.7). Ovo podrazumijeva idealno zatvaranje pukotine.

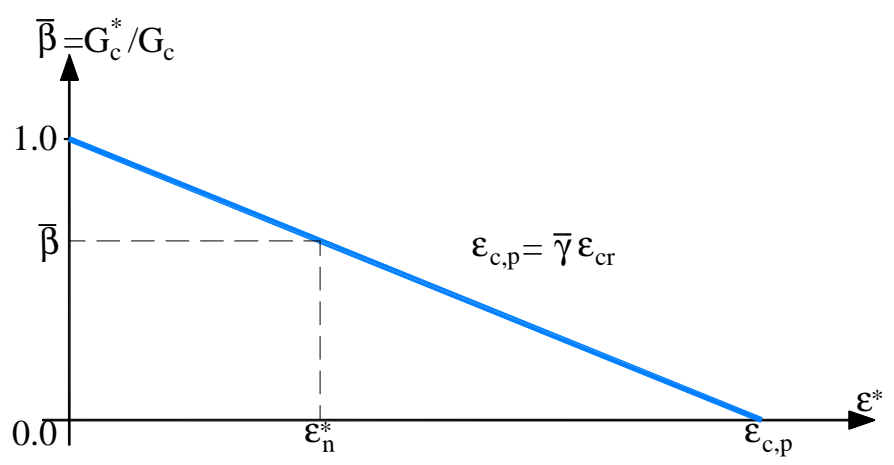

Slika 4.7. Model posmične krutosti betona s pukotinama

U slučaju betona s dvije pukotine, modul posmika puknutog betona $G_{c}^{*}$ određuje se na isti način, kod čega se između tekućih deformacija $\varepsilon_{\mathrm{n}}^{*}$ i $\varepsilon_{\mathrm{t}}^{*} \quad$ (okomitih na ravninu pukotine) uzima ona koja ima veću vrijednost.

\section{Zatvaranje pukotina}

U prikazanom je modelu simulirano zatvaranje i ponovno otvaranje pukotina. Shematski prikaz mogućih stanja pukotina prikazan je na Slici 4.8 . 


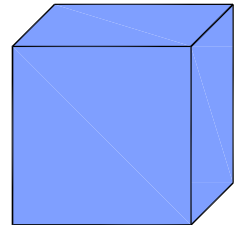

Bez pukotina

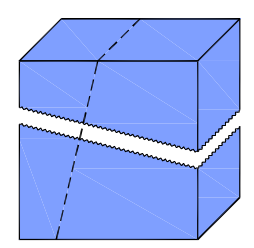

Prva pukotina zatvorena druga pukotina otvorena

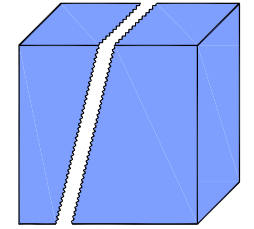

Otvorena prva pukotina

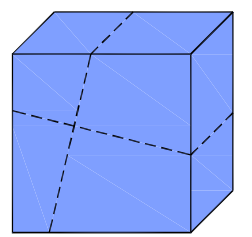

Obje pukotine zatvorene

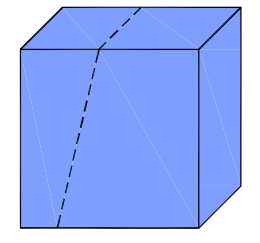

Prva pukotina zatvorena

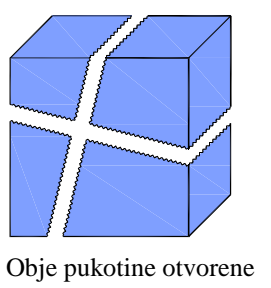

Slika 4.8. Moguća stanja pukotina u betonu

Za određivanje stanja pukotine, promatrana je deformacija okomito na ravninu pukotine. Usvojeno je da je pukotina potpuno zatvorena ako je:

$$
\varepsilon_{\mathrm{n}}^{*}<0 \quad \text { i/ili } \quad \varepsilon_{\mathrm{t}}^{*}<0
$$

Ako je tekuća deformacija okomito na ravninu pukotine smanjena, ali je još uvijek pozitivna, pretpostavljeno je djelomično zatvaranje pukotine. Ovaj slučaj se javlja kada je tekuća deformacija $\varepsilon_{n+1}\left(u n+1\right.$ prirastu opterećenja) manja od prethodne deformacije $\varepsilon_{n}$ (Slika 4.5ii). Tekuće vlačno naprezanje okomito na ravninu pukotine $\sigma_{n+1}$ izračunava se $s$ pomoću:

$$
\sigma_{\mathrm{n}+1}=\sigma_{\mathrm{n}} \varepsilon_{\mathrm{n}} / \varepsilon_{\mathrm{n}+1}
$$

Ponovno otvaranje prethodno zatvorene pukotine kontrolirano je također praćenjem vlačne deformacije okomito na ravninu pukotine. Ukoliko dolazi do ponovnog otvaranja pukotine, tj. ako je:

$$
\varepsilon_{\mathrm{n}}^{*}>0 \quad \mathrm{i} / \mathrm{ili} \quad \varepsilon_{\mathrm{t}}^{*}>0
$$

ne računa se s nikakvom vlačnom krutošću betona, dok je omogućen prijenos posmičnog naprezanja. 


\subsubsection{Model ponašanja armature}

Armatura se simulira zasebnim štapnim elementima u okviru osnovnog elementa betona (Slika 4.2i). Matrica krutosti cijelog elementa dobiva se zbrajanjem doprinosa krutosti svih šipki armature i krutosti osnovnog betonskog elementa.

Usvojena veza naprezanje-deformacija za betonski čelik prikazana je na Slici 4.9. Na njoj $\mathrm{f}_{\mathrm{r}, \mathrm{c}}$ i $\mathrm{f}_{\mathrm{r}, \mathrm{t}}$ su jednoosna tlačna i jednoosna vlačna čvrstoća čelika; $\varepsilon_{\mathrm{r}, \mathrm{c}}$ i $\varepsilon_{\mathrm{r}, \mathrm{t}}$ su jednoosna tlačna i jednoosna vlačna računska lomna deformacija čelika; $E_{r}$ i $E_{r}^{\prime}$ su računski moduli elastičnosti armature. Dakle, usvojena je klasična bi-linearna veza, s linearnim ponašanjem u rasterećenju.

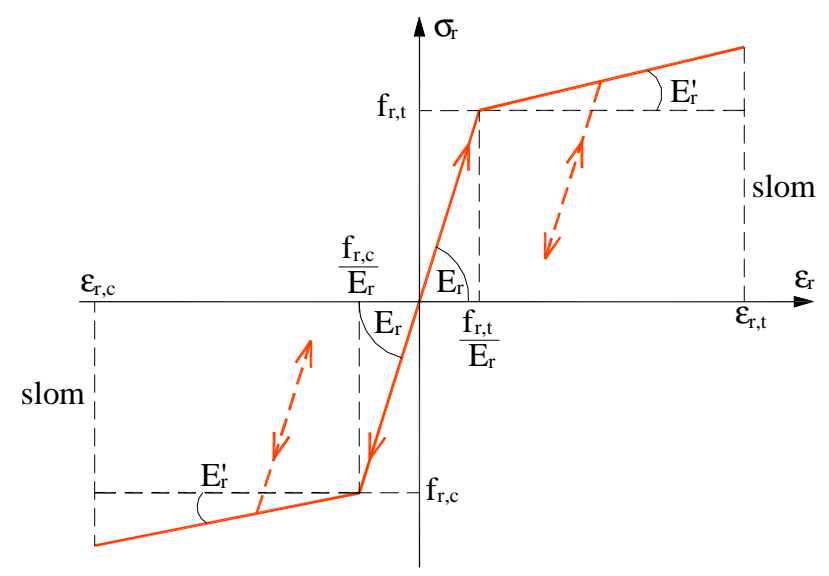

Slika 4.9. Veza naprezanje-deformacija za betonski čelik (armaturu)

\subsubsection{Modeli ponašanja ziđa}

U cilju što adekvatnijeg simuliranja ziđa, korisno je još jednom napomenut da je ono na makrorazini različitih fizikalno-mehaničkih svojstava, nehomogeno i anizotropno. Zidni elementi u pravilu imaju različite čvrstoće i krutosti u vertikalnom i horizontalnom smjeru. Mort često ima bitno različita svojstva u odnosu na zidne elemente. Horizontalne sljubnice često nisu ravnomjerno i potpuno ispunjene mortom, dok su vertikalne sljubnice obično samo djelomično ispunjene mortom ili su kod manje važnih gradnji čak i "prazne". Osim kvalitete morta u sljubnici, važna je kvaliteta veze (prionjivost) morta i zidnog elementa. Kvaliteta izvedbe obično nije podjednaka na čitavoj plohi zida. Stoga i kvaliteta ziđa, koji uključuje sve svoje sastavne dijelove, njihove spojeve (sljubnice) i različita gradiva, nije ujednačena. 
U okviru statičkih i dinamičkih analiza zidanih konstrukcija, najčešće se koriste dva globalna numerička modela ziđa: makromodel i mikromodel (Slika 4.10).

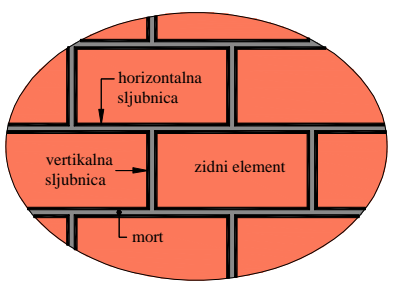

(i) Fragment ziđa

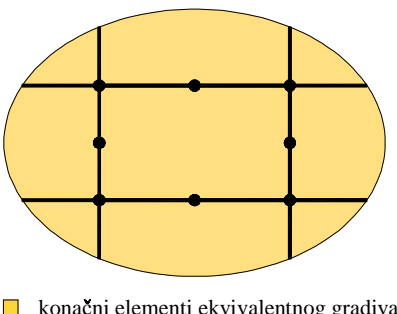

(ii) Makromodel ziđa

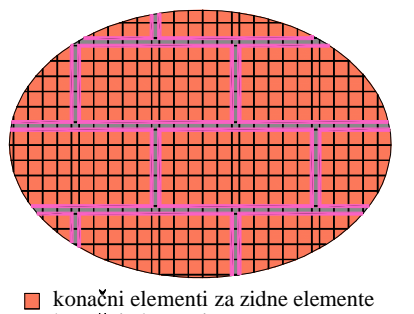

- konačni elementi za mort

- dodirni elementi između zidnih elemenata i morta Mikromodel ziđa 1

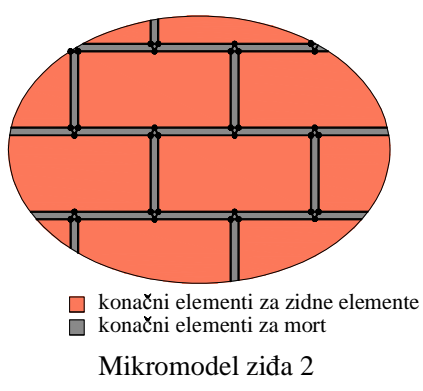

(iii) Mikromodeli ziđa

Slika 4.10. Neki modeli ziđa

(i) Makromodel ziđa (Slika 4.10ii) - kod kojeg se složena struktura, kvaliteta i izvedba ziđa od različitih gradiva na makro (globalnoj) razini aproksimira reprezentativnim (zamjenjujućim) gradivom, takvih fizikalno-mehaničkih svojstava da što bolje opiše graničnu nosivost, sigurnost, deformabilnost i oštećenja stvarnog složenog ziđa. Takvim se pristupom omogućavaju veći konačni elementi (grublja diskretizacija) i smanjuje broj nepoznanica u sustavu, odnosno značajno ubrzava proračun konstrukcije.

(ii) Mikromodel ziđa (Slika 4.10iii) - kod kojeg se prostorna diskretizacija ziđa obavlja na razini zidnog elementa i morta (sljubnice), ili kod nekih drugih analiza simulira se spoj morta i zidnog elementa dodirnim elementima. Moguće je koristiti različite mikromodele ziđa, različite preciznosti, složenosti i trajanja analize. U odnosu na makromodel ziđa, mikromodeli ziđa daju preciznije rezultate i precizniju lokaciju pojave popuštanja i oštećenja u ziđu, ali uz znatno složenije i dugotrajnije proračune. Kako obično nisu poznata stvarna svojstva morta te spoja morta i zidnih blokova na čitavoj površini konstrukcije, a osobito zbog realne prostorne veličine problema i dugotrajne vremenske analize, mikromodeli ziđa se rjeđe primjenjuju. Oni se koriste 
uglavnom za manje prostorne probleme, te za simulaciju statičkih i dinamičkih eksperimentalnih ispitivanja zidova.

U nastavku su prikazana dva makromodela za analizu ravninskih zidanih konstrukcija. Prvi model za ziđe (Makromodel ziđa 1) je pojednostavljeni izvorni model koji kriterij čvrstoće i sloma ziđa razmatra preko normalnih naprezanja u smjeru sljubnica i odgovarajućih posmičnih naprezanja. Drugi model za ziđe (Makromodel ziđa 2) je poboljšani Makromodel ziđa 1, kod kojeg su kriterij čvrstoće ziđa i kriterij sloma ziđa odvojeno razmatrani u tri različita koordinatna sustava, tj. u tri različita smjera naprezanja. Naime, odvojeno su analizirana:

(i) normalna naprezanja u smjeru sljubnica zida i odgovarajuća posmična naprezanja,

(ii) glavna normalna naprezanja i

(iii) najveće posmično naprezanje i odgovarajuće normalno naprezanje.

\subsubsection{Makromodel ziđa 1}

Kao što je prethodno navedeno, Makromodel ziđa 1 je pojednostavljeni model. U ovom modelu posebnu pažnju treba posvetiti definiranju adekvatnih fizikalno-mehaničkih parametara zamjenjujućeg idealiziranog gradiva ziđa, koje reprezentira svojstva zidnih blokova, morta u horizontalnim i vertikalnim sljubnicama, te karakteristike spoja između morta i zidnih elemenata. Predloženi model uključuje anizotropna svojstva ziđa, s različitim vrijednostima modula elastičnosti $E_{m}$, čvrstoća (tlačna $f_{m, c}$, vlačna $f_{m, t}$, posmična $f_{m, p}$ ) $i$ lomnih deformacija (tlačna $\varepsilon_{\mathrm{m}, \mathrm{c}}$, vlačna $\varepsilon_{\mathrm{m}, \mathrm{t}}$ ) za horizontalni (h) i vertikalni (v) smjer (Slika 4.11). Naime, pretpostavljaju se problemi kod kojih su glavni smjerovi anizotropije horizontalni i vertikalni, u što spada najveći broj realnog ziđa. Prethodno navedeni parametri za zamjenjujuće gradivo određuju se na temelju analize odgovarajućih parametara zidnih elemenata, morta te veze morta i zidnih elemenata. 


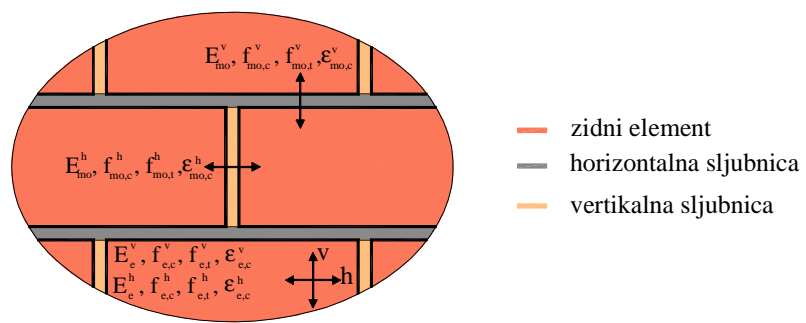

(i) Fragment realnog ziđa s parametrima za zidne elemente $i$ mort
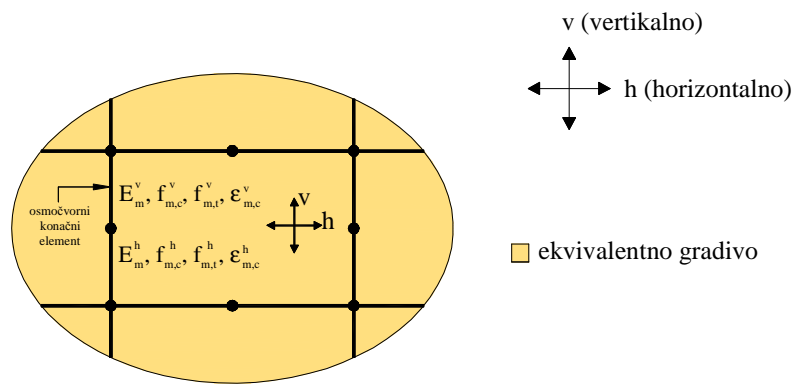

(ii) Makromodel ziđa s parametrima ekvivalentnog gradiva

Slika 4.11. Grafički prikaz anizotropnog makromodela ziđa

\section{$\underline{\text { A. Modeliranje ponašanja ziđa u tlaku i vlaku }}$}

Grafički prikaz usvojenog ortotropnog modela ponašanja idealiziranog ziđa u tlaku i vlaku dan je na Slici 4.12, na kojoj oznake imaju slijedeće značenje: $\sigma_{m}^{\mathrm{h}}$ i $\sigma_{m}^{\mathrm{v}}$ su normalna naprezanja ziđa $\mathrm{u}$ horizontalnom $\mathrm{i}$ vertikalnom smjeru; $\mathrm{f}_{\mathrm{m}, \mathrm{c}}^{\mathrm{h}} \mathrm{i} \mathrm{f}_{\mathrm{m}, \mathrm{c}}^{\mathrm{v}} \mathrm{su}$ računska tlačna čvrstoća ziđa u horizontalnom i vertikalnom smjeru; $\mathrm{f}_{\mathrm{m}, \mathrm{t}}^{\mathrm{h}} \mathrm{i} \mathrm{f}_{\mathrm{m}, \mathrm{t}}^{\mathrm{v}}$ su računska vlačna čvrstoća ziđa $\mathrm{u}$ horizontalnom i vertikalnom smjeru; $\mathrm{E}_{\mathrm{m}}^{\mathrm{h}}$ i $\mathrm{E}_{\mathrm{m}}^{\mathrm{v}}$ su moduli elastičnosti ziđa u horizontalnom i vertikalnom smjeru; $\varepsilon_{\mathrm{m}, \mathrm{c}}^{\mathrm{h}} \mathrm{i} \quad \varepsilon_{\mathrm{m}, \mathrm{c}}^{\mathrm{v}}$ su granične tlačne deformacije ziđa $\mathrm{u}$ horizontalnom $\mathrm{i}$ vertikalnom smjeru. 


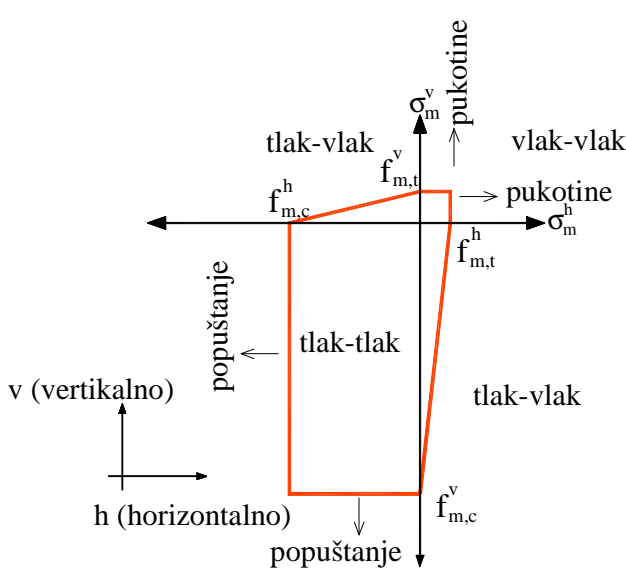

(i) 2 D prikaz

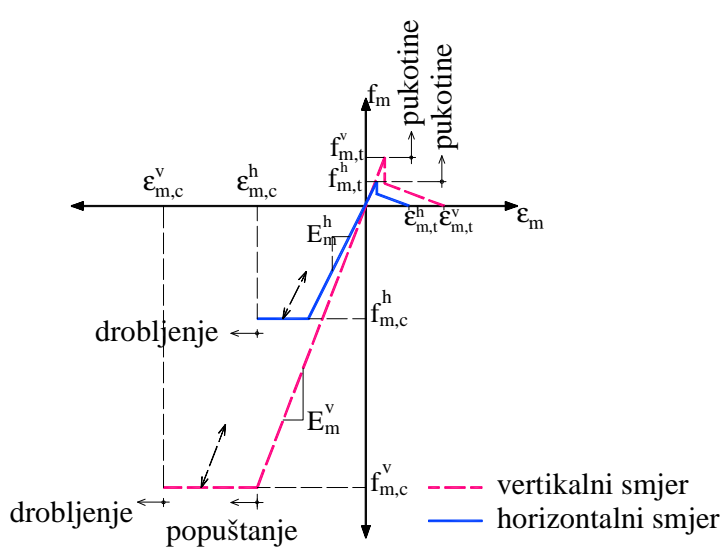

(ii) Jednodimenzionalni prikaz

Slika 4.12. Grafički prikaz ortotropnog modela ponašanja idealiziranog ziđa u tlaku i vlaku

Kao što je vidljivo sa slike 4.12, zanemaren je utjecaj dvoosnog stanja naprezanja na graničnu tlačnu nosivost ziđa, što je na strani veće sigurnosti. Dakle, osnovni parametri ziđa su njegova tlačna i vlačna čvrstoća, modul elastičnosti, te granične tlačne deformacije u horizontalnom i vertikalnom smjeru. U realnim konstrukcijama, temeljni parametri ziđa $u$ vertikalnom smjeru imaju veće vrijednosti nego u horizontalnom smjeru.

Za referentnu računsku vrijednost tlačne čvrstoće ziđa u vertikalnom i horizontalnom smjeru uzima se manja vrijednost od pojedinačnih čvrstoća zidnog elementa ili morta u tim smjerovima. Za referentnu računsku vrijednost vlačne čvrstoće ziđa u vertikalnom i horizontalnom smjeru uzima se čvrstoća prionjivosti između morta i zidnog elementa $u$ vertikalnoj i horizontalnoj sljubnici. Referentni modul elastičnosti ziđa u vertikalnom i horizontalnom smjeru dobiva se na temelju modula elastičnosti zidnih blokova i sljubnica $u$ tim smjerovima, uzimajući u obzir dimenzije blokova i sljubnica u ravnini zida u tim smjerovima.

Ponašanje ziđa u vlaku nakon pojave pukotina modelira se kao u betonu (Slika 4.5). Moguće je uključiti i doprinos vlačne krutosti puknutog ziđa. Vrijednost parametra $\bar{\alpha}$ za ziđe, kojim se određuje maksimalna vlačna deformacija okomito na sljubnicu iznad koje nema vlačne krutosti ziđa, potrebno je utvrditi eksperimentalno.

Ponovo se naglašava da su čvrstoća i krutost ziđa u vertikalnom smjeru redovito znatno veće od istih u horizontalnom smjeru. Na sreću, realna vertikalna normalna naprezanja u ziđu su redovito značajno veća od horizontalnih. 
Modeliranje otvaranja i zatvaranja pukotina u ziđu analogno je onome u betonu, samo što su pukotine u ziđu prema usvojenoj pretpostavci horizontalne i/ili vertikalne (Slika 4.13). Pukotine se mogu djelomično otvarati i zatvarati (analogno Slici 4.5). Preko zatvorene pukotine tlak se prenosi kao i kod homogenog ziđa. Nakon ponovnog otvaranja prethodno potpuno zatvorene pukotine, ne računa se s nikakvom krutošću ziđa. Nakon pojave tečenja u tlaku i nakon pojave pukotina, uzima se da ziđe nema krutost.

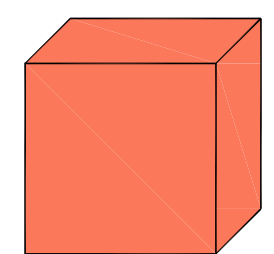

Bez pukotina

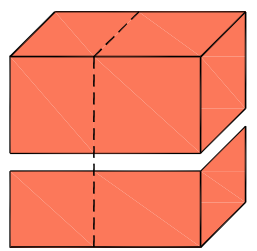

Prva pukotina zatvorena, druga pukotina otvorena

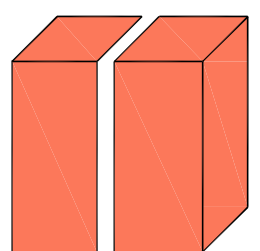

Otvorena prva pukotina

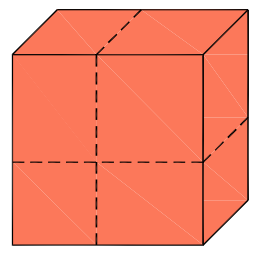

Obje pukotine zatvorene

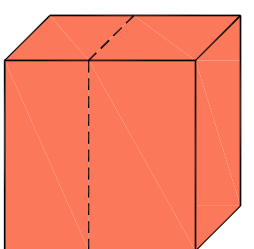

Prva pukotina zatvorena

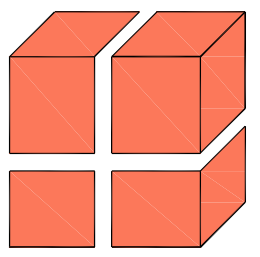

Obje pukotine otvorene

Slika 4.13. Moguća stanja pukotina u ziđu

1. Modeliranje ziđa u područje tlak-tlak $\left(\sigma_{\mathrm{m}}^{\mathrm{v}}<0, \sigma_{\mathrm{m}}^{\mathrm{h}}<0\right)$

(i) Ako je $\sigma_{m}^{v} \geq f_{c, m}^{v}, \sigma_{m}^{h} \geq f_{c, m}^{h} \rightarrow$ elastično ponašanje. Ova naprezanja su konačna. Nema modifikacije krutosti $\left(E_{m}^{v}, E_{m}^{\mathrm{h}}\right)$.

(ii) Ako je $\sigma_{\mathrm{m}}^{\mathrm{v}}<-\mathrm{f}_{\mathrm{c}, \mathrm{m}}^{\mathrm{v}} \quad \rightarrow$ tečenje u smjeru (v)

- ako je $\varepsilon_{\mathrm{m}}^{\mathrm{v}} \geq \varepsilon_{\mathrm{c}, \mathrm{m}}^{\mathrm{v}}$ nema sloma $\sigma_{\mathrm{m}}^{\mathrm{v}}=-\mathrm{f}_{\mathrm{c}, \mathrm{m}}^{\mathrm{v}}$

- ako je $\varepsilon_{\mathrm{m}}^{\mathrm{v}}<\varepsilon_{\mathrm{c}, \mathrm{m}}^{\mathrm{v}}$ slom ziđa $\left(\sigma_{\mathrm{m}}^{\mathrm{v}}=0, \mathrm{E}_{\mathrm{m}}^{\mathrm{v}}=0\right)$

(iii)Ako je $\sigma_{\mathrm{m}}^{\mathrm{h}}<-\mathrm{f}_{\mathrm{c}, \mathrm{m}}^{\mathrm{h}} \quad \rightarrow$ tečenje $\mathrm{u}$ smjeru ( $\mathrm{h}$ )

- ako je $\varepsilon_{\mathrm{m}}^{\mathrm{v}} \geq \varepsilon_{\mathrm{c}, \mathrm{m}}^{\mathrm{v}}$ nema sloma $\sigma_{\mathrm{m}}^{\mathrm{v}}=-\mathrm{f}_{\mathrm{c}, \mathrm{m}}^{\mathrm{v}}$

- ako je $\varepsilon_{\mathrm{m}}^{\mathrm{h}} \geq \varepsilon_{\mathrm{c}, \mathrm{m}}^{\mathrm{h}}$ nema sloma $\sigma_{\mathrm{m}}^{\mathrm{h}}=-\mathrm{f}_{\mathrm{c}, \mathrm{m}}^{\mathrm{h}}$

- ako je $\varepsilon_{\mathrm{m}}^{\mathrm{h}}<\varepsilon_{\mathrm{c}, \mathrm{m}}^{\mathrm{h}}$ slom ziđa $\left(\sigma_{\mathrm{m}}^{\mathrm{h}}=0, \mathrm{E}=0\right)$ 
2. Modeliranje ziđa u području vlak-vlak $\left(\sigma_{\mathrm{m}}^{\mathrm{v}}>0, \sigma_{\mathrm{m}}^{\mathrm{h}}>0\right)$

(i) Ako je $\sigma_{\mathrm{m}}^{\mathrm{v}} \leq \mathrm{f}_{\mathrm{t}, \mathrm{m}}^{\mathrm{v}}, \sigma_{\mathrm{m}}^{\mathrm{h}} \leq \mathrm{f}_{\mathrm{t}, \mathrm{m}}^{\mathrm{h}} \rightarrow$ elastično ponašanje. Ova naprezanja su konačna. Nema modifikacije krutosti $\left(E_{m}^{v}, E_{m}^{\mathrm{h}}\right)$.

(ii) Ako je $\sigma_{\mathrm{m}}^{\mathrm{v}}>\mathrm{f}_{\mathrm{t}, \mathrm{m}}^{\mathrm{v}} \quad \rightarrow$ pojava pukotina, modifikacija vlačne krutosti. Sve analogno onome za izotropni beton (uključujući otvaranje i zatvaranje pukotina) za $\quad \varepsilon_{\mathrm{m}}^{\mathrm{v}} \geq \varepsilon_{\mathrm{t}, \mathrm{m}}^{\mathrm{v}} \rightarrow \sigma_{\mathrm{m}}^{\mathrm{v}}=0, \mathrm{E}_{\mathrm{m}}^{\mathrm{v}}=0$

(iii)Ako je $\sigma_{\mathrm{m}}^{\mathrm{h}}>-\mathrm{f}_{\mathrm{t}, \mathrm{m}}^{\mathrm{h}} \quad \rightarrow$ analogno točki (ii)

3. Modeliranje ziđa u područje tlak-vlak $\left(\sigma_{\mathrm{m}}^{\mathrm{v}}<0, \sigma_{\mathrm{m}}^{\mathrm{h}} \geq 0\right)$

Sve analogno točkama 1 i 2.

\section{B. 1. Modeliranje posmičnog sloma ziđa}

Osim preko vlaka (pukotine) i/ili preko tlaka (drobljenje), slom ziđa može biti i preko posmika u horizontalnoj ravnini (horizontalnoj sljubnici). Posmični slom u vertikalnoj sljubnici nije modeliran. Kriterij sloma ziđa na posmik u horizontalnoj ravnini definiran je prema Slici 4.14, odnosno kao:

$$
\tau_{\mathrm{xy}} \leq \tau_{\mathrm{m}}^{\mathrm{h}}
$$

gdje je $\tau_{x y}$ računsko posmično naprezanje iz numeričkog proračuna, a $\tau_{\mathrm{m}}^{\mathrm{h}}$ računska posmična nosivost ziđa u horizontalnoj sljubnici definirana sa (tlačno naprezanje ima negativan predznak):

(i) $\sigma_{\mathrm{v}} \leq 0 \quad$ (tlak)

$$
\begin{aligned}
& \tau_{\mathrm{m}}^{\mathrm{h}}=\tau_{\mathrm{m}, 0}^{\mathrm{h}}-0,4 \sigma_{\mathrm{m}}^{\mathrm{v}} \\
& \tau_{\mathrm{m}, \mathrm{g}}^{\mathrm{h}}=\tau_{\mathrm{m}, 0}^{\mathrm{h}}-0,4 \mathrm{f}_{\mathrm{m}, \mathrm{c}}^{\mathrm{t}}
\end{aligned}
$$

(ii) $\quad \sigma_{\mathrm{v}}>0 \quad$ (vlak)

$$
\tau_{\mathrm{m}}^{\mathrm{h}}=\tau_{\mathrm{m}, 0}^{\mathrm{h}}\left(1-\frac{\sigma_{\mathrm{m}}^{\mathrm{v}}}{\mathrm{f}_{\mathrm{m}, \mathrm{t}}^{\mathrm{v}}}\right) \geq 0
$$




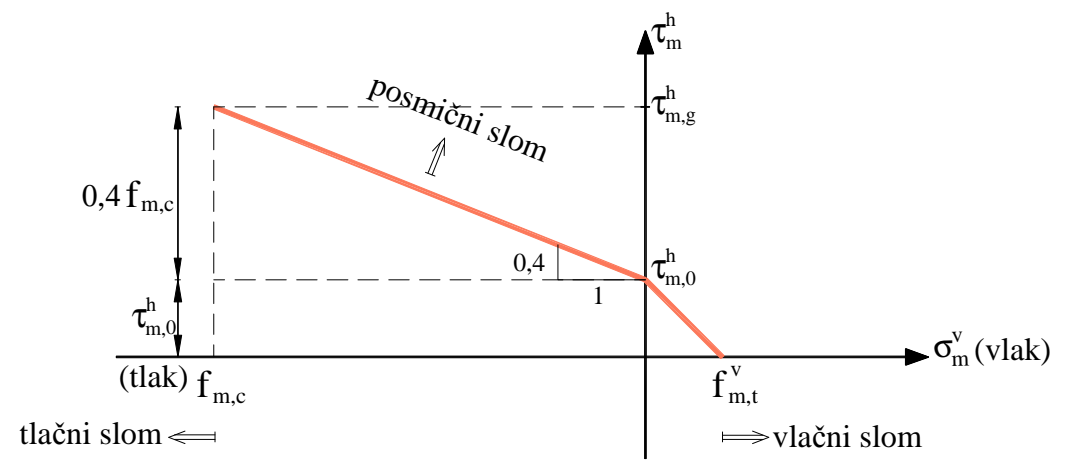

Slika 4.14. Grafički prikaz posmične nosivosti ziđa u horizontalnoj ravnini

$\mathrm{U}$ prethodnim izrazima $\tau_{\mathrm{m}, 0}^{\mathrm{h}}$ označava računsku nosivost ziđa $\mathrm{u}$ horizontalnoj sljubnici za slučaj čistog posmika (bez normalnih tlačnih naprezanja poprečno na sljubnicu), a $\sigma_{m}^{v}$ vertikalno naprezanje. Prema [142], ziđe koje je u vlaku ne može nositi posmična naprezanja u ravnini vlaka. Ako se rabi takav pristup, u predloženom modelu u području vlaka treba uzeti $\mathrm{f}_{\mathrm{m}, \mathrm{t}}^{\mathrm{v}}=0$.

Posmična krutost ispucalog ziđa simulirana je slično kao posmična krutost ispucalog betona. Naime, uz pretpostavku da nakon pojave pukotina ziđe ostaje kontinuum, reducira se početni modul posmika ziđa $G_{m}$ sukladno veličini vlačne deformacije okomito na ravninu pukotine $\varepsilon_{\mathrm{n}, \mathrm{m}}^{*}$ prema (Slika 4.15):

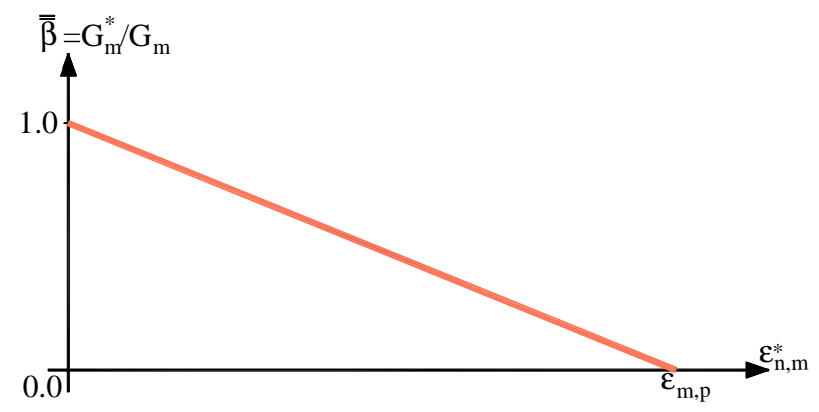

Slika 4.15. Grafički prikaz simuliranja posmične krutosti ziđa s pukotinama

$$
\mathrm{G}_{\mathrm{m}}^{*}=\stackrel{\bar{\beta}}{\bar{\beta}} \mathrm{G}_{\mathrm{m}}
$$

gdje je $\mathrm{G}_{\mathrm{m}}^{*}$ modul posmika ziđa koje ima pukotine, a $\overline{\bar{\beta}}$ koeficijent definiran sa: 


$$
\begin{array}{ll}
\overline{\bar{\beta}}=1-\frac{\varepsilon_{\mathrm{n}, \mathrm{m}}^{*}}{\varepsilon_{\mathrm{m}, \mathrm{p}}} \text { za } & \varepsilon_{\mathrm{n}, \mathrm{m}}^{*} \leq \varepsilon_{\mathrm{m}, \mathrm{p}} \\
\overline{\bar{\beta}}=0 \quad \text { za } & \varepsilon_{\mathrm{n}, \mathrm{m}}^{*}>\varepsilon_{\mathrm{m}, \mathrm{p}}
\end{array}
$$

kod čega je $\varepsilon_{\mathrm{m}, \mathrm{p}}$ granična deformacija okomito na ravninu pukotine kod koje nema prijenosa posmika. Ona se može napisati u obliku:

$$
\varepsilon_{\mathrm{m}, \mathrm{p}}=\bar{\gamma} / \varepsilon_{\mathrm{mr}}
$$

Koeficijent $\stackrel{\bar{\gamma}}{\gamma}$ treba eksperimentalno utvrditi za različite vrste ziđa i uvjete opterećenja. U slučaju posmičnog sloma ziđa u određenoj integracijskoj točki, tj. kada je $\tau_{x, y}>\tau_{m, g}^{\mathrm{h}}$, uzima se $\mathrm{G}_{\mathrm{m}}=0$.

\section{B. 2. Modeliranje posmičnog sloma ziđa}

Do posmičnog sloma dolazi ako je zadovoljen jedan od niže navedenih kriterija za vertikalni i horizontalni smjer. Ako je zadovoljen kriterij sloma, uzima se da je $\mathrm{G}=0$.

\section{Kriterij $\tau=\tau\left(\sigma_{y}\right)$}

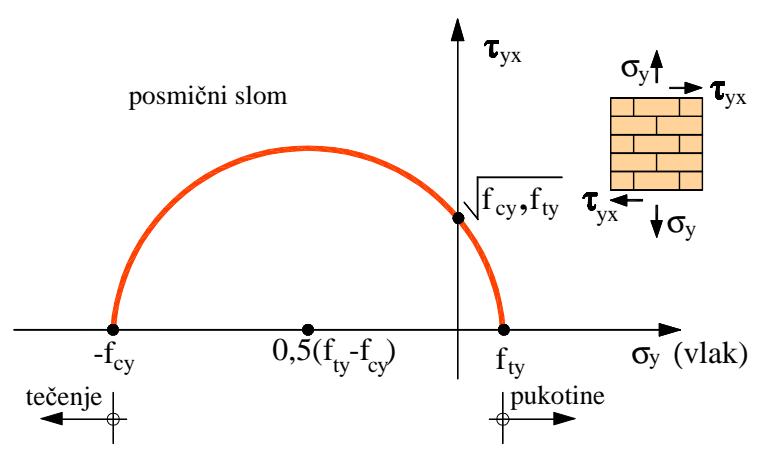

Slika 4.16. Grafički prikaz posmične nosivosti ziđa u smjeru y

Posmično naprezanje u y smjeru $\tau_{\mathrm{yx}}$ definirano je s pomoću:

$$
\begin{aligned}
& {\left[\sigma_{y}-0,5\left(f_{t y}-f_{t y}\right)\right]^{2}+\tau^{2}=0,25\left(f_{c y}-f_{t y}\right)^{2}} \\
& \tau \leq \sqrt{0,25\left(f_{\text {cy }}-f_{\text {ty }}\right)^{2}\left[\sigma_{y}-0,5\left(f_{t y}-f_{t y}\right)\right]^{2}}
\end{aligned}
$$


2. Kriterij $\tau=\tau\left(\sigma_{x}\right)$

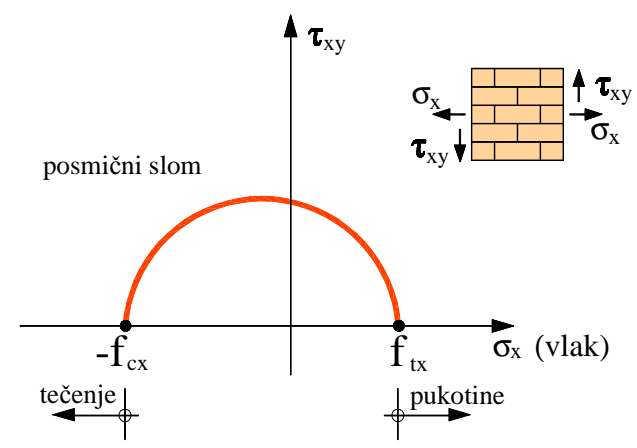

Slika 4.17. Grafički prikaz posmične nosivosti ziđa u smjeru y

Posmično naprezanje u x smjeru $\tau_{\mathrm{xy}}$ definirano je s pomoću:

$$
\begin{aligned}
& {\left[\sigma_{x}-0,5\left(f_{t x}-f_{t x}\right)\right]^{2}+\tau^{2}=0,25\left(f_{c x}-f_{t x}\right)^{2}} \\
& \tau \leq \sqrt{0,25\left(f_{c x}-f_{t x}\right)^{2}\left[\sigma_{x}-0,5\left(f_{t x}-f_{t x}\right)\right]^{2}}
\end{aligned}
$$

\subsubsection{Mikromodel ziđa}

Primjenom mikromodela ziđa može se preciznije i pouzdanije modelirati stvarno ponašanje ziđa nego primjenom makromodela, a osobito pojasniti „slika“ ponašanja ziđa na mikro razini. Moguća je uporaba različitih mikromodela (vidjeti primjerice Sliku 4.10), s različitim razinama točnosti i pouzdanosti, ali i s različitim trajanjem i složenosti analize. Poznato je da se finijom diskretizacijom, odnosno s povećanim brojem nepoznanica, a osobito pri primjeni nelinearnog modela materijala i geometrije te kod dinamičkih analiza, produljuje trajanje analize.

Ako se želi precizan proračun, s opisom ponašanja ziđa na mikrorazini, moguća je primjerice primjena Mikromodela 1 na Slici 4.10. Naime, u tom su modelu zidni elementi i sljubnice (mort) diskretizirani 8-čvornim elementima, dok su na spoju morta i zidnih elemenata uzeti tanki 6-čvorni dodirni elementi. Svi elementi imaju takve modele materijala, koji su prethodno opisani, da mogu dobro opisati stvarno ponašanje svih gradiva i spojnih ploha u tlaku, vlaku i posmiku. Kod toga je moguća simulacija ortotropnih svojstava zidnih blokova i morta (sljubnica) u horizontalnom i vertikalnom smjeru.

U Mikromodelu 2 na Slici 4.10, zidni elementi su diskretizirani 8-čvornim elementima, a vertikalne i horizontalne sljubnice sa 6-čvornim dodirnim elementima debljine koja 
odgovara stvarnoj debljini sljubnica. Mogući su i drugačiji mikromodeli, tj. drugačije diskretizacije ziđa.

\subsubsection{Model ponašanja konstrukcijskog čelika}

Modelirano je popuštanje i slom čelika preko glavnih normalnih naprezanja (deformacija), bez uključenja utjecaja posmika [5]. Korišten je klasični elasto-plastični model ponašanja čelika, jednak u tlaku i vlaku (Slika 4.18).

Jednodimenzionalni prikaz modela ponašanja čelika prikazan je na Slici 4.18a, na kojoj $\sigma_{\mathrm{s}}$ označava jednoosno normalno naprezanje čelika, $\varepsilon_{\mathrm{s}}$ jednoosnu normalnu deformaciju čelika, $\mathrm{f}_{\mathrm{s} 0}$ označava jednoosnu vlačnu čvrstoću čelika, $\mathrm{E}_{\mathrm{s}}$ ishodišni modul elastičnosti čelika pri jednoosnom vlačnom testu, $\varepsilon_{\mathrm{s} 0}$ graničnu deformaciju čelika pri jednoosnom vlačnom testu i $\varepsilon_{\mathrm{sy}}=\mathrm{f}_{\mathrm{s} 0} / \mathrm{E}_{\mathrm{s}}$ deformaciju čelika pri pojavi tečenja. Dakle, pretpostavlja se elastična veza između naprezanja $\left(\sigma_{\mathrm{s}}\right)$ i deformacije $\left(\varepsilon_{\mathrm{s}}\right)$ čelika sve do dostizanja jednoosne čvrstoće čelika. Nakon toga se pretpostavlja potpuno plastično ponašanje čelika, s lomom kad se prekorači granična jednoosna deformacija čelika. U rasterećenju se pretpostavlja linearno elastično ponašanje, bez uključenja Bauschinger-ova efekta.

Dvodimenzionalni prikaz modela ponašanja čelika u polju glavnih naprezanja prikazan je na Slici 4.18b. Dakle, koristi se elastični model ponašanja u opterećenju i rasterećenju, sve dok nije zadovoljen Von Misesov kriterij tečenja. Nakon toga se pretpostavlja potpuno plastično ponašanje sve dok nije zadovoljen kriterij sloma čelika. Von Misesov kriterij tečenja definiran je sa:

$$
\left(\sigma_{1}^{2}+\sigma_{2}^{2}-\sigma_{1} \sigma_{2}\right)^{1 / 2}-f_{s 0}=0
$$

gdje su $\sigma_{1}, \sigma_{2}$ glavna naprezanja i $\mathrm{f}_{\mathrm{s} 0}$ jednoosna vlačna čvrstoća čelika.

Kriterij sloma čelika definiran je u funkciji glavnih deformacija. Kod toga se ponovo koristi Von Misesov kriterij, izražen s pomoću:

$$
\left(\varepsilon_{1}^{2}+\varepsilon_{2}^{2}-\varepsilon_{1} \varepsilon_{2}\right)^{1 / 2}-\varepsilon_{s 0}=0
$$

gdje su $\varepsilon_{1}, \varepsilon_{2}$ glavne deformacije i $\varepsilon_{\mathrm{s} 0}$ granična deformacija čelika iz jednoosnog testa.

Model uključenja posmičnih naprezanja na slom čelika definiran je sa:

$$
\sigma_{\max }^{2}+\left(\tau_{x y}-\frac{\tau_{s 0}^{2}-f_{s 0}^{2}}{2 \tau_{s 0}}\right)^{2}=f_{s 0}^{2}+\left(\tau_{x y}-\frac{\tau_{s 0}^{2}-f_{s 0}^{2}}{2 \tau_{s 0}}\right)^{2}
$$


gdje $\sigma_{\max }$ označava najveću apsolutnu vrijednost glavnih naprezanja $\sigma_{\max }=\max \left(\sigma_{1}, \sigma_{2}\right), \tau_{\mathrm{xy}}=$ $\tau_{\mathrm{yx}}$ označava tekuće posmično naprezanje $\mathrm{i} \tau_{\mathrm{s} 0}$ označava posmičnu čvrstoću čelika bez normalnih naprezanja, tj. pri čistom posmiku $\left(\tau_{\mathrm{S} 0} \approx 0.55 f_{\mathrm{S} 0}\right)$.

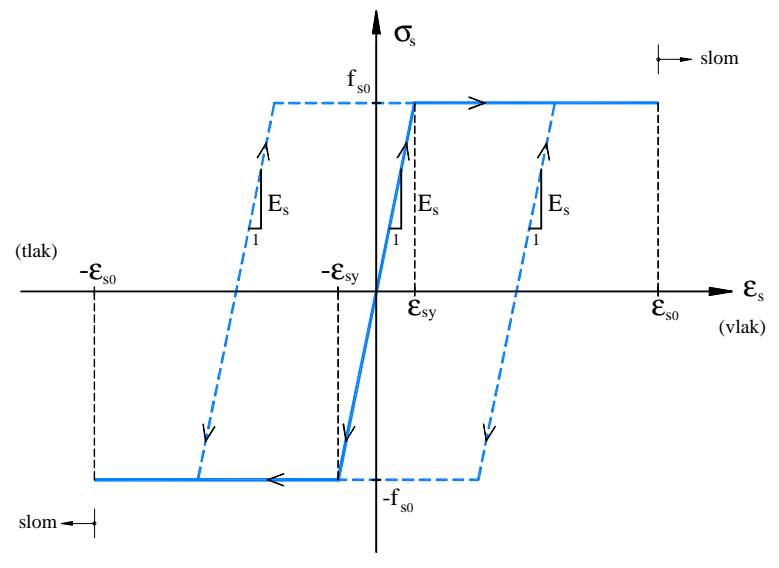

a) $1 \mathrm{D}$ prikaz

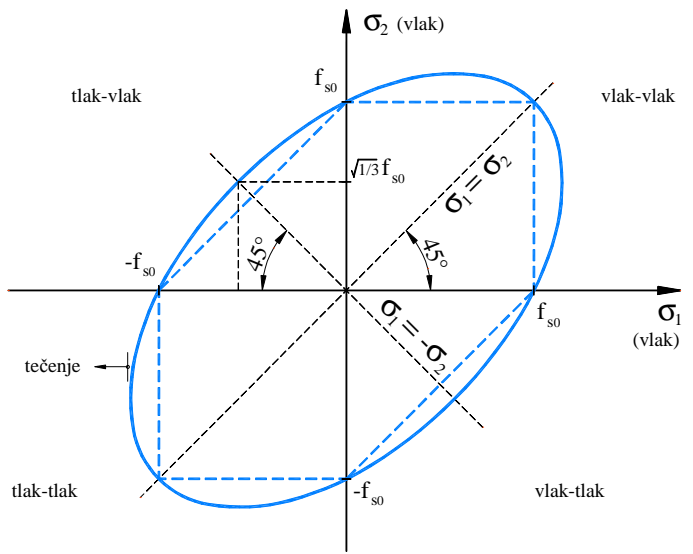

b) $2 \mathrm{D}$ prikaz

Slika 4.18. Model čelika

\subsubsection{Model za simulaciju kontakta}

\subsubsection{2D kontaktni elementi}

2D kontaktni (dodirni) elementi prenose normalno naprezanje $\sigma_{\mathrm{n}}$ na kontaktu prema Slici 4.19, što omogućava simulaciju klizanja, odvajanja i utiskivanja na kontaktu između temelja i tla, ili između morta (sljubnice) i zidnog elementa. Moguće je zadati različite oblike veze $\sigma_{n}-\varepsilon_{n}$, gdje je $\sigma_{n}$ naprezanje i $\varepsilon_{n}$ deformacija okomito na spojnu plohu. Treba odabrati takav dijagram naprezanje-deformacija koji će najbolje opisati stvarno ponašanje na kontaktu.

U tlačnom području $\sigma_{\mathrm{k}, \mathrm{c}}$ označava računsku tlačnu čvrstoću na kontaktu kod koje dolazi do popuštanja, $\varepsilon_{\mathrm{k}, \mathrm{c}}$ graničnu tlačnu deformaciju kod sloma, $\mathrm{E}_{\mathrm{k}}$ modul elastičnosti okomito na spojnu plohu i $\mathrm{E}_{1}$ modul elastičnosti za ponašanje s ojačanjem.

$\mathrm{U}$ vlačnom području $\sigma_{\mathrm{k}, \mathrm{t}}$ označava računsku vlačnu čvrstoću iznad koje nastaju pukotine, $\mathrm{E}_{2}$ modul elastičnosti za ponašanje s ojačanjem, $\varepsilon_{\mathrm{k}, \mathrm{t}}$ vlačnu deformaciju okomito na 
spojnu plohu kod pojave pukotine i $\varepsilon_{\mathrm{k}, \mathrm{g}}$ maksimalnu vlačnu deformaciju okomito na spojnu plohu iznad koje nema nikakve vlačne krutosti za odabrano gradivo. Model vlačne krutosti i ostale karakteristike dijagrama na Slici 4.19 slični su onima za beton, s dopunskim mogućnostima modeliranja u tlaku i vlaku (elasto-plastično ponašanje i ojačanje).

Ovisno o svojstvima kontakta (beton-tlo ili mort-zidni element), odabire se takav oblik dijagrama na Slici 4.19, s odgovarajućim parametrima gradiva, koji će najrealističnije opisati stvarno ponašanje na kontaktu. Kod toga se za parametre materijala dodirnih elemenata uzimaju niže vrijednosti od odgovarajućih parametara susjednih gradiva na kontaktu, odnosno prionjivost na dodirnoj plohi za vlačno područje dijagrama.

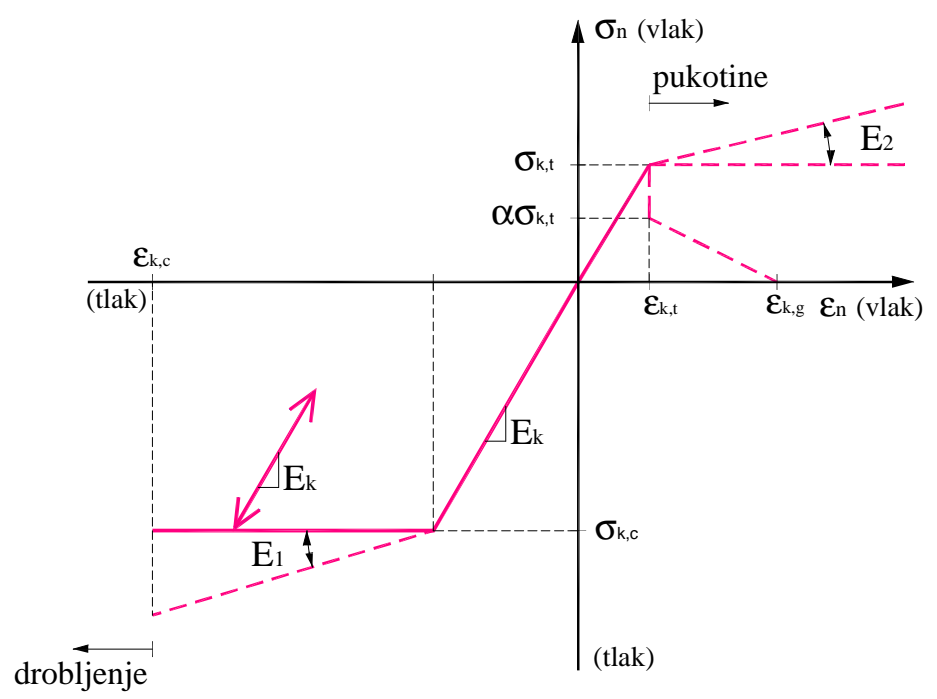

Slika 4.19. Modeliranje prijenosa normalnog naprezanja 2D dodirnog elementa

2D dodirni element prenosi posmik na spojnoj plohi, tj. omogućava simulaciju klizanja i posmičnog sloma spoja. Grafički prikaz posmične nosivost na spoju dan je na Slici 4.20. Modeliranje posmičnog sloma slično je onome kod ziđa, $\mathrm{tj}$.:

$$
\tau_{\mathrm{s}} \leq \tau_{\mathrm{k}}
$$

gdje je $\tau_{\mathrm{s}}$ posmično naprezanje $\mathrm{u}$ dodirnom elementu i $\tau_{\mathrm{k}}$ računska posmična čvrstoća $u$ smjeru kontakta, definirana sa:

(i) u tlaku $\left(\sigma_{\mathrm{n}} \leq 0\right)$

$$
\tau_{\mathrm{k}}=\tau_{\mathrm{k}, 0}+0.4 \sigma_{\mathrm{n}} \leq \tau_{\mathrm{k}, 0}+0.4 \mathrm{f}_{\mathrm{k}, \mathrm{c}}
$$




$$
\begin{aligned}
& \text { u vlaku }\left(\sigma_{\mathrm{n}}>0\right) \\
& \tau_{\mathrm{k}}=\tau_{\mathrm{k}, 0}\left(1-\frac{\mathrm{f}_{\mathrm{k}, \mathrm{t}}}{\tau_{\mathrm{k}, 0}}\right) \geq 0
\end{aligned}
$$

gdje $\tau_{\mathrm{k}, 0}$ označava računsku posmičnu čvrstoću spoja izloženog čistom posmiku (bez tlaka), a $\sigma_{\mathrm{n}}$ je normalno naprezanje na spojnoj plohi. Prema [142], ziđe koje ima vlačna naprezanja okomito na spojnu plohu ne može preuzeti posmik u toj ravnini.

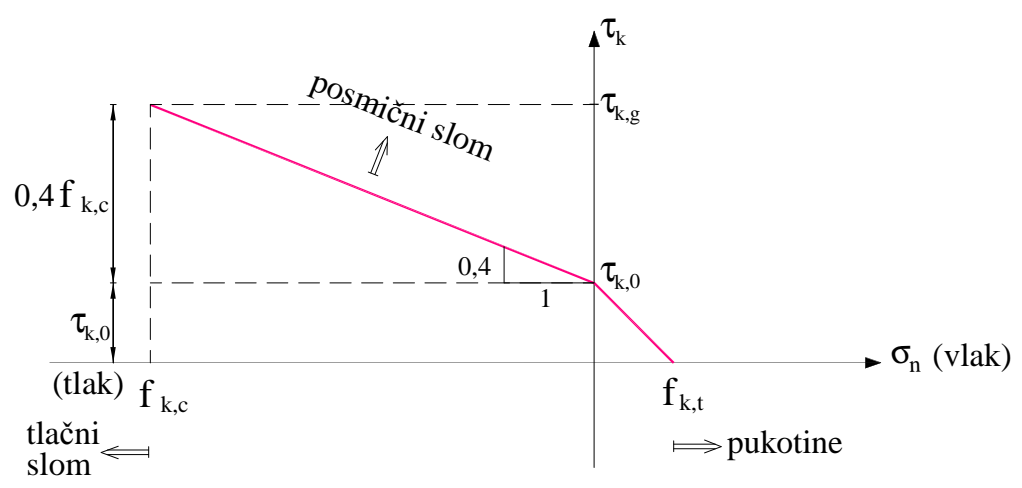

Slika 4.20. Grafički prikaz posmične nosivosti 2D dodirnog elementa

Posmična krutost dodirnog elementa koji ima pukotine simulira se na sličan način kao kod betona i ziđa. Naime, modul posmika dodirnog elementa koji ima pukotine $G_{k}^{*}$ uzima se tako da se početni modul posmika $G_{k}$ pomnoži s koeficijentom $\overline{\bar{\beta}}(\leq 1)$, koji se određuje na analogan način kao za ziđe i beton:

$$
\mathrm{G}_{\mathrm{k}}^{*}=\overline{\bar{\beta}} \mathrm{G}_{\mathrm{k}}
$$

\subsubsection{1D kontaktni elementi}

1D kontaktni (dodirni) elementi služe za simulaciju armaturnih šipki koje prolaze kroz 2D dodirne elemente. Oni, kao i svaka šipka, prenose normalna i posmična naprezanja.

Normalna naprezanja u smjeru elementa (šipke) prenose se sukladno usvojenom dijagramu naprezanje-deformacija za čelik. U tom kontekstu, može se primjerice koristiti dijagram prema Slici 4.19, ili je moguće u računalnom programu zadati bilo koji poligonalni oblik veze naprezanje-deformacija. Kada je "linija“ na dijagramu $\sigma-\varepsilon$ silazna ili su prekoračene lomne deformacije, uzima se modul elastičnosti čelika $\mathrm{E}_{\mathrm{a}}=0$. 
Posmična naprezanja koja šipka ("moždanik") može preuzeti, definirana su površinom šipke $A_{a}$ i modulom posmika šipke $G_{a}$. Nije modeliran posmični slom $1 D$ elementa, već samo tlačni i vlačni slom. Uzima se da je $\mathrm{G}_{\mathrm{a}}=0$ kada je $\mathrm{i} \mathrm{E}_{\mathrm{a}}=0$.

\subsubsection{Model ponašanja tla}

Za modeliranje ponašanja tla za sada nije predviđen poseban model, već se koristi model ponašanja betona opisan u točki 4.3.3. ili makro model ponašanja ziđa opisan u točki 4.3.5. Koji je model ponašanja pouzdaniji, ovisi o karakteristikama tla. Naime, tla mogu biti iz nekoherentnih materijala, koherentnih materijala, stjenovita i sl. Kod toga je važno ispravno definirati parametre modela na temelju raspoloživih parametara tla. Prikazani modeli mogu simulirati ponašanje tla u tlaku, pojavu i razvoj pukotina u tlu u vlaku, anizotropna svojstva tla i niz drugih nelinearnih efekata prema točki 4.3.3 i 4.3.5.

\subsubsection{Model za simulaciju žbuke}

U ovom je radu nadograđen prethodno razvijeni numerički model za simulaciju žbuke [125]. Korišten je jednostavan pristup pomoću kojeg se konačni elementi žbuke preklapaju s elementima ispune, pri čemu se osigurava potpuna kompatibilnost pomaka u zajedničkim čvorovima elemenata (Slika 4.21). Pretpostavlja se da nema proklizavanja između žbuke i ispune.

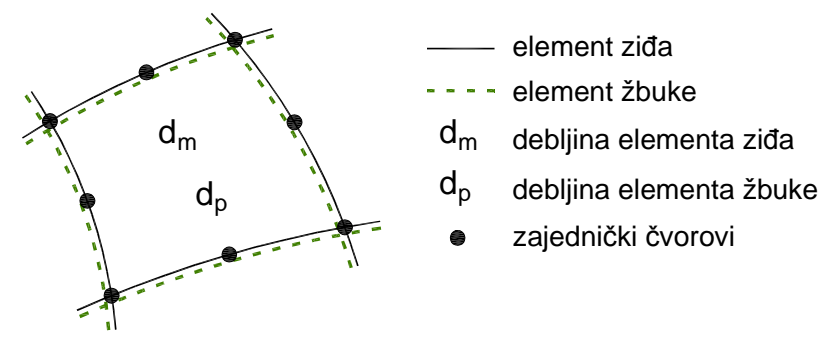

Slika 4.21. Prostorna diskretizacija ziđa i žbuke

Kod toga, ziđe i žbuka imaju različita materijalna svojstva i debljinu elemenata (debljina elementa ziđa odgovara debljini zidnog elementa, dok debljina elementa žbuke odgovara ukupnoj debljini žbuke na ziđu). Kod modela žbuke koristi se isti materijalni model kao i za 
beton (sa simulacijom popuštanja u tlaku, razvojem pukotina u vlaku, vlačnom i posmičnom krutosti ispucane žbuke i sl.). Stoga, ukupna nosivost i krutost ožbukanog ziđa modelira se odvojenim istovremenim doprinosima ziđa i žbuke.

Utjecaj disperziranih vlakana unutar žbuke simulira se pomoću odgovarajućeg naponsko-deformacijskog dijagrama za mikroarmiranu žbuku (Slika 4.22.), koju bi trebalo eksperimentalno utvrditi.

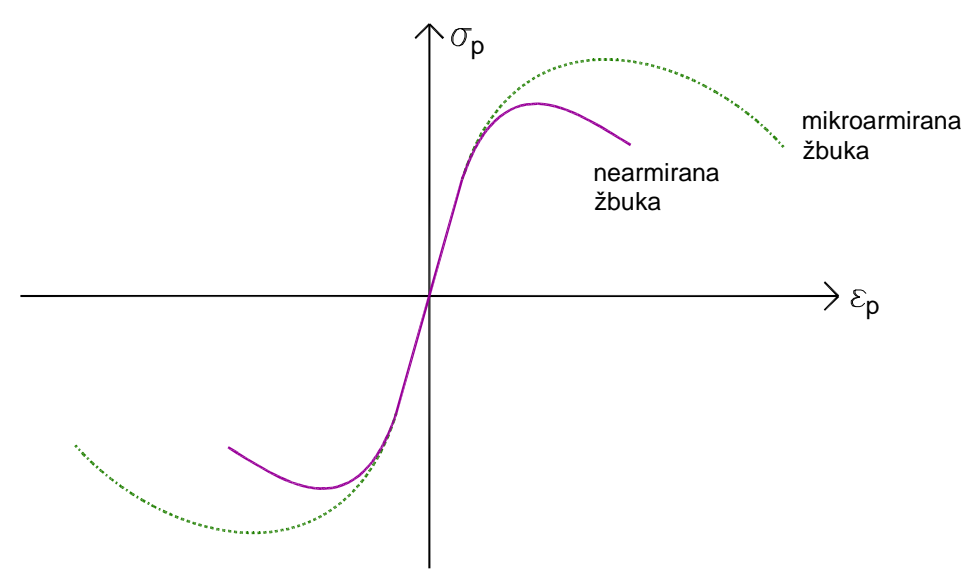

Slika 4.22. Grafički prikaz modela mikroarmirane žbuke

Modeliranje mrežaste armature u žbuci je isto kao i kod armiranog betona. Također se pretpostavlja da nema proklizavanja između armature i žbuke. Armatura u žbuci se modelira pomoću jednodimenzionalnih elemenata, koji imaju samo vlačnu čvrstoću u smjeru vlakana (Slika 4.23).

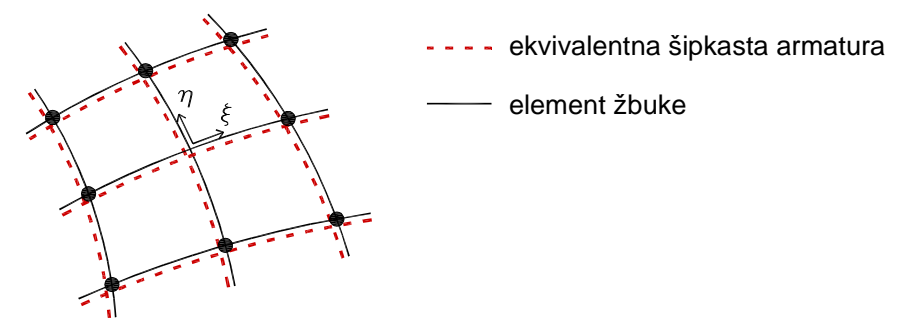

Slika 4.23. Modeliranje mrežaste armature u žbuci 


\subsubsection{Model za simulaciju faznog nastajanja}

$\mathrm{U}$ ovom je radu prethodno razvijeni numerički model poboljšan s adekvatnom simulacijom faznog nastajanja okvira s ispunom (u praksi se prvo izvodi okvir, uz aktiviranje dijela gravitacijskog opterećenja, a potom ispuna) - vidjeti Sliku 4.24).
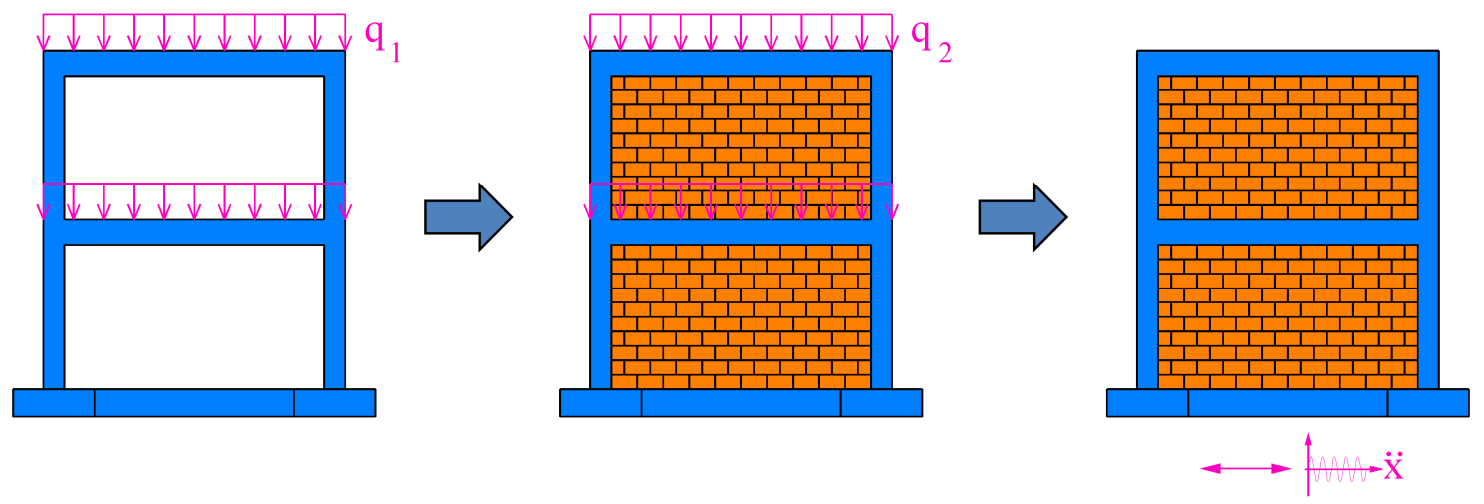

Slika 4.24. Faznost nastajanja i opterećenja konstrukcije

Faznost građenja je modelirana s pomoću sukcesivno aktivne mreže konačnih elemenata, tj. sukcesivno aktivne krutosti sustava (Slika 4.25). Pri tome se pamti povijest deformacija (naprezanja) i oštećenja (pukotine) svih gradiva tijekom vremena.

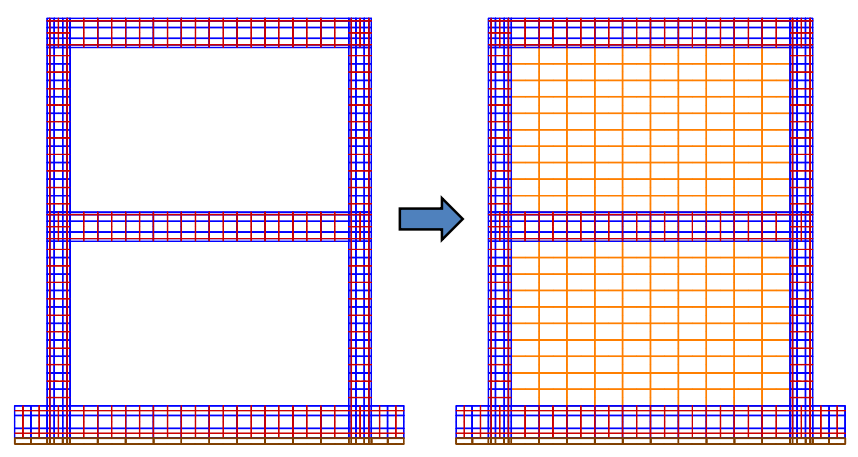

Slika 4.25. Sukcesivno aktivna mreža konačnih elemenata 


\subsection{Zaključak}

Prikazan je razvijeni 2D numerički model za statičku i dinamičku analizu ravninskih armiranobetonskih i čeličnih okvira sa zidanom ispunom Razvijeni model može simulirati najvažnije nelinearne efekte sustava okvir-ziđe-temelj-tlo, kao što su: materijalna nelinearnost (nelinearno ponašanje betona, čelika, ziđa, tla), geometrijska nelinearnost (veliki pomaci), nelinearno ponašanje na spoju dvaju različitih materijala (odvajanje, utiskivanje, klizanje) itd.

$\mathrm{U}$ ovom je radu numerički model poboljšan s adekvatnom simulacijom faznog nastajanja okvira s ispunom, te adekvatnom simulacijom nearmirane i armirane žbuke na vanjskim plohama ziđa. U daljnjem tekstu prikazana je provjera numeričkog modela na temelju rezultata prethodno provedenih eksperimentalnih ispitivanja, te je numerički istražen utjecaj više parametara na ponašanje jednog realnog okvira sa zidanom ispunom pri djelovanju potresa. 


\section{VERIFIKACIJA RAZVIJENOG NUMERIČKOG MODELA}

\subsection{Općenito}

U ovom je Poglavlju prikazana verifikacija razvijenog numeričkog modela pomoću prethodno provedenih eksperimenata i eksperimenata drugih autora. Kod toga treba napomenuti da je polazni model, koji je ovdje dograđen, prethodno provjeren na velikom broju eksperimentalnih testova i numeričkih modela iz literature [1-7, 143-146]. 


\subsection{Statička analiza}

\subsubsection{Simulacija statičkih ispitivanja čeličnih okvira sa zidanom ispunom}

Analizirani su uzorci čeličnih okvira sa zidanom ispunom prikazanih u Poglavlju 3. Uzorci su opterećeni vertikalnim stalnim opterećenjem iznosa $5 \mathrm{kN} / \mathrm{m}^{1}$, te monotono rastućom horizontalnom silom pri vrhu okvira. Usvojena prostorna diskretizacija ispitanih okvira prikazana je na Slici 5.1. Usvojeni osnovni parametri gradiva za numeričku analizu prikazani su u Tablici 5.1. Korišten je relativno mali prirast horizontalne sile kako bi se bolje opisalo stvarno ponašanje konstrukcije.

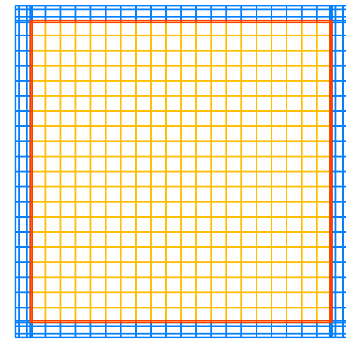

$\mathrm{SF}-1$

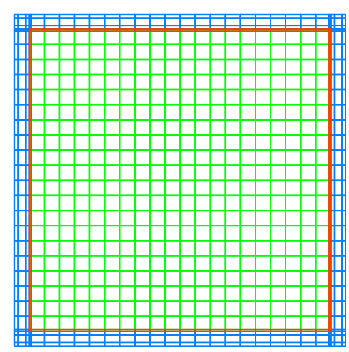

SF-2, SF-3

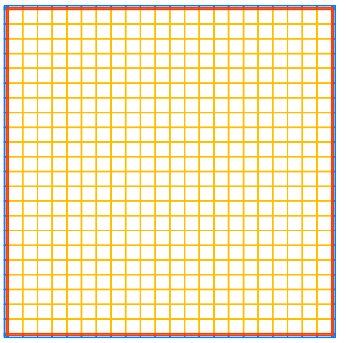

WF-1

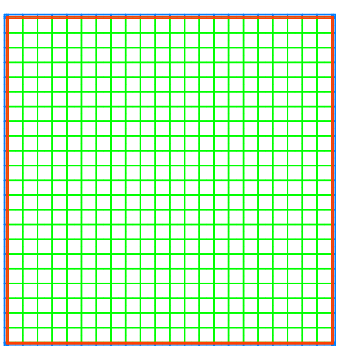

WF-2, WF-3

Slika 5.1. Usvojena prostorna diskretizacija za statičku analizu razmatranih čeličnih okvira sa zidanom ispunom

Tablica 5.1. Usvojeni parametri gradiva za numeričku analizu

\begin{tabular}{lllllll}
\hline Varijabla & \multirow{2}{*}{ Jedinica } & \multicolumn{2}{l}{ Materijal } & & & \\
\cline { 3 - 7 } & & Čelik & Ziđe & Žbuka & Stak mreža & Kontakt \\
\hline Modul elastičnosti & $\mathrm{MPa}$ & 200000 & 1020 & 3500 & 1231 & 1020 \\
Poissonov koeficijent & - & 0.30 & 0.1 & 0.15 & - & - \\
Modul posmika & $\mathrm{MPa}$ & 76923 & 464 & 1522 & - & 464 \\
Tlačna čvrstoća & $\mathrm{MPa}$ & 360.0 & 2.2 & 3.0 & - & 2.2 \\
Vlačna čvrstoća & $\mathrm{MPa}$ & 360.0 & 0.2 & 1.0 & 42.8 & 0.0 \\
Granična tlačna deformacija & - & 0.0500 & 0.0035 & 0.0035 & - & 0.0035 \\
Granična vlačna deformacija & - & 0.0500 & 0.0029 & 0.0029 & 0.0348 & 0.0000 \\
\hline
\end{tabular}


Usporedba eksperimentalno utvrđenih i numerički dobivenih $H$ - $u$ veza za sve ispitane uzorke prikazana je na Slici 5.2. Može se primijetiti dobro slaganje rezultata do $80 \%$ vrijednosti granične sile $H$. Pri maksimalnoj sili $H$, a naročito nakon, postoji prilična razlika u eksperimentalno utvrđenim i numerički dobivenim rezultatima. Kod toga treba imati na umu da u ovom području model ne posjeduje odgovarajuću točnost obzirom da koristi elastoplastični materijalni model za čelik, ziđe i žbuku u tlaku, kao i Newtonov algoritam za rješenje nelinearnih jednadžbi. Također dolazi i do različitih lokalnih nelinearnih efekata neposredno pred slom konstrukcije, koji se ne mogu adekvatno simulirati s ovim modelom.

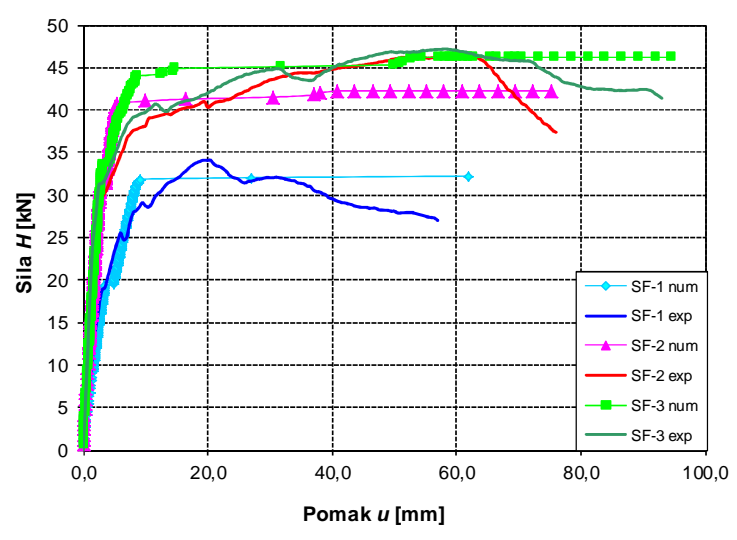

a) Kruti okvir (SF)

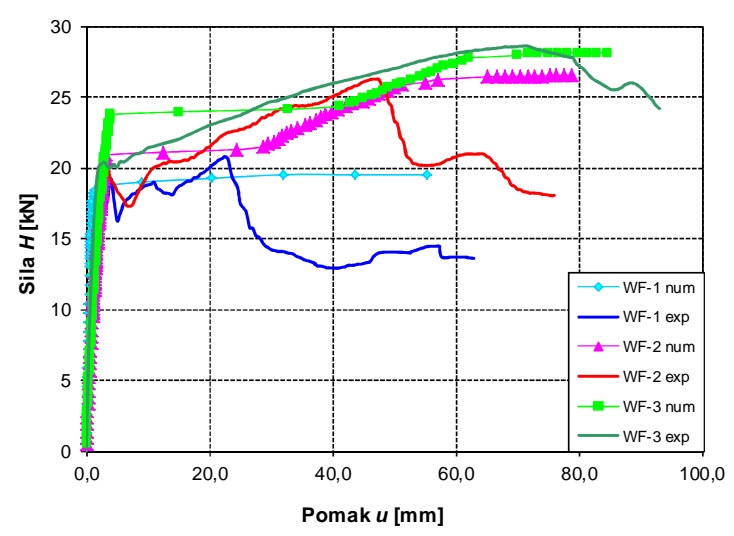

b) Meki okvir (WF)

Slika 5.2. Usporedba eksperimentalno utvrđenih i numerički dobivenih $H$ - $u$ veza

Usporedba eksperimentalno utvrđenih i numerički dobivenih $H-\varepsilon_{\mathrm{s}}$ veza za sve ispitane uzorke prikazana je na Slici 5.3, što potvrđuje njihovo prilično dobro poklapanje (analogno vezi $(H-u)$.

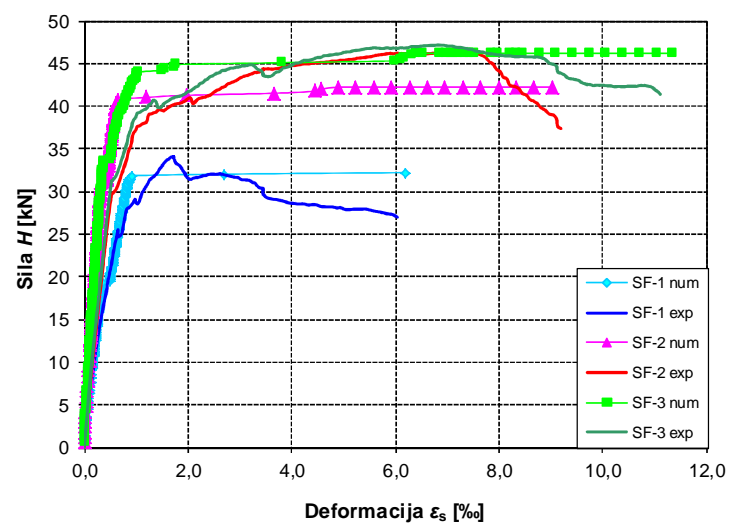

a) Kruti okvir (SF)

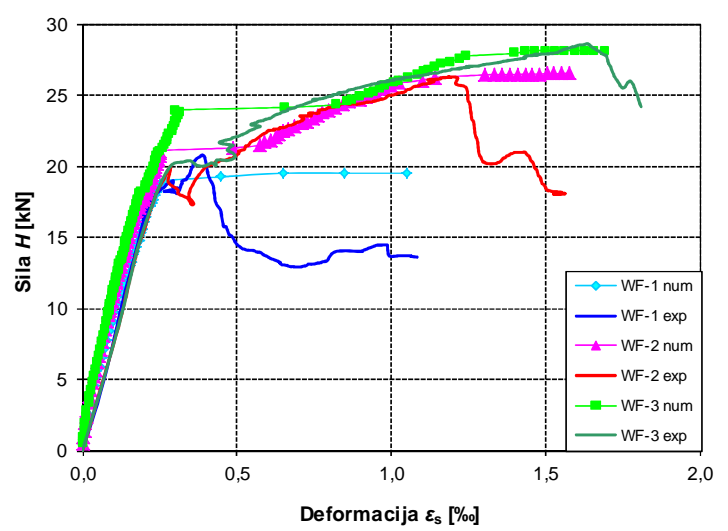

b) Meki okvir (WF)

Slika 5.3. Usporedba eksperimentalno utvrđenih i numerički dobivenih $H$ - $\varepsilon_{\mathrm{s}}$ veza 
Numerički dobivene deformacije okvira i stanja pukotina u ziđu su prikazane na Slici 5.4. Usporedbom s fotografijama eksperimentalno ispitanih uzoraka na Slici 3.19, može se primijetiti njihovo dobro podudaranje.

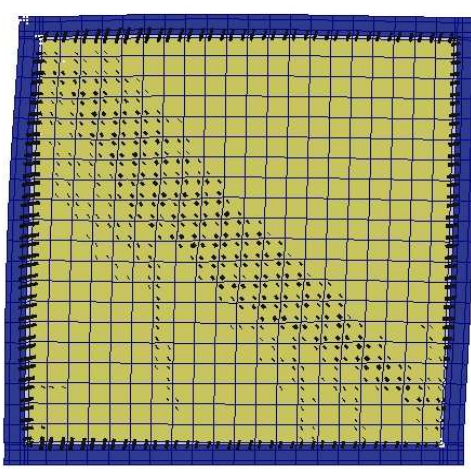

SF-1

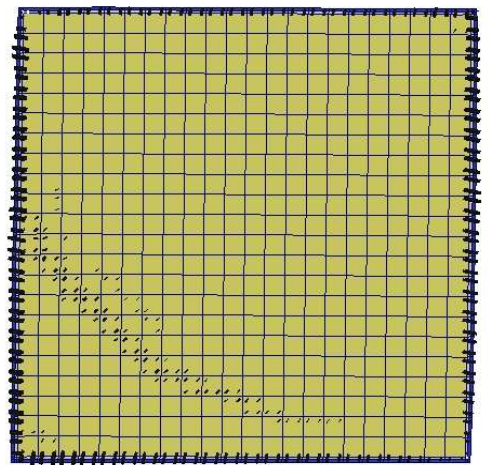

WF-1

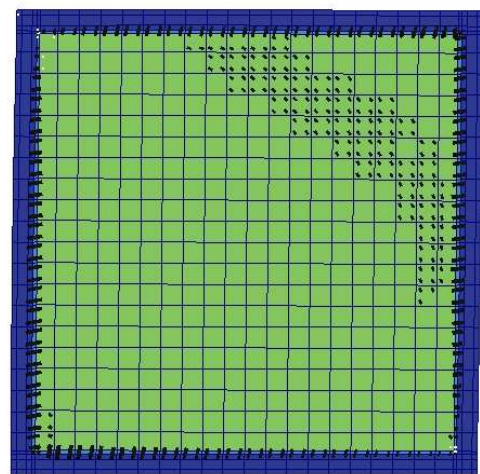

SF-2

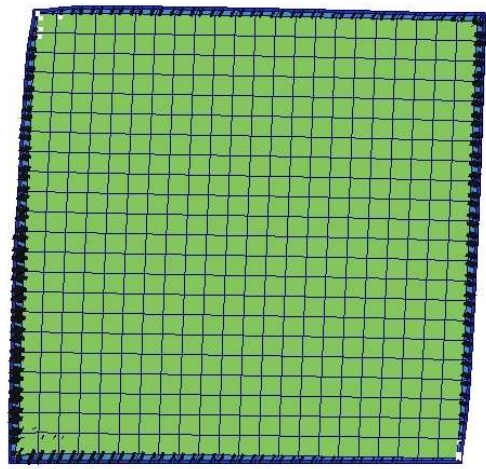

WF-2

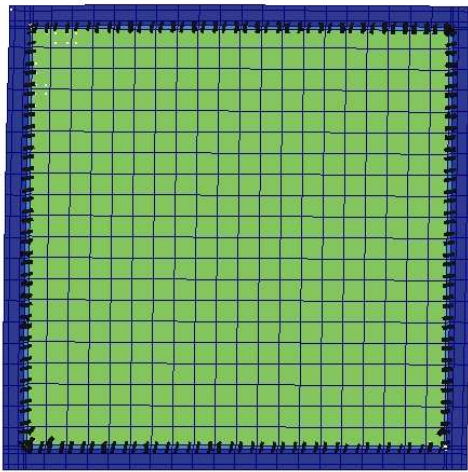

SF-3

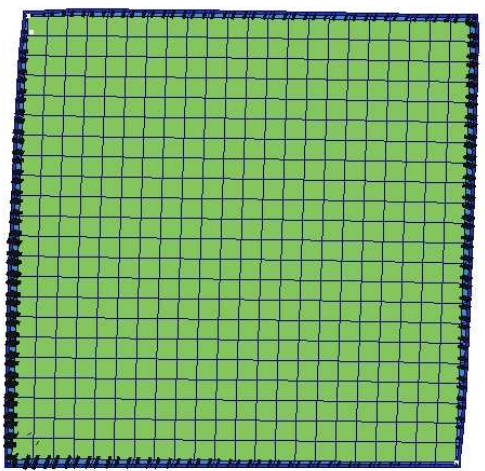

WF-3

Slika 5.4. Konačno stanje deformacija i pukotina u ziđu kod okvira sa zidanom ispunom numerička analiza

\subsubsection{Cikličko opterećenje}

Analiziran je jednoetažni jednopoljni čelični okvir ispunjen ziđem (Slika 5.5a), kojeg su eksperimentalno ispitali A.A. Tasnimi i A. Mohebkhah [41]. Vrh okvira je podvrgnut cikličkom horizontalnom pomaku prema Slici 5.6, odnosno horizontalnoj statičkoj sili na tom mjestu. Kod toga je najprije ispitan čisti okvir bez zidane ispune, a potom isti okvir sa zidanom ispunom. Pobliži opis geometrije konstrukcije, svojstava gradiva i sl. dan je u [41]. 
Usvojena prostorna diskretizacija konstrukcije prikaza je na Slici 5.5b, a usvojeni osnovni parametri gradiva u Tablici 5.2. Nažalost, neki parametri materijala su pretpostavljeni jer nisu opisani u lit. [41]. Korišten je makromodel ziđa, s izotropnim svojstvima ziđa.

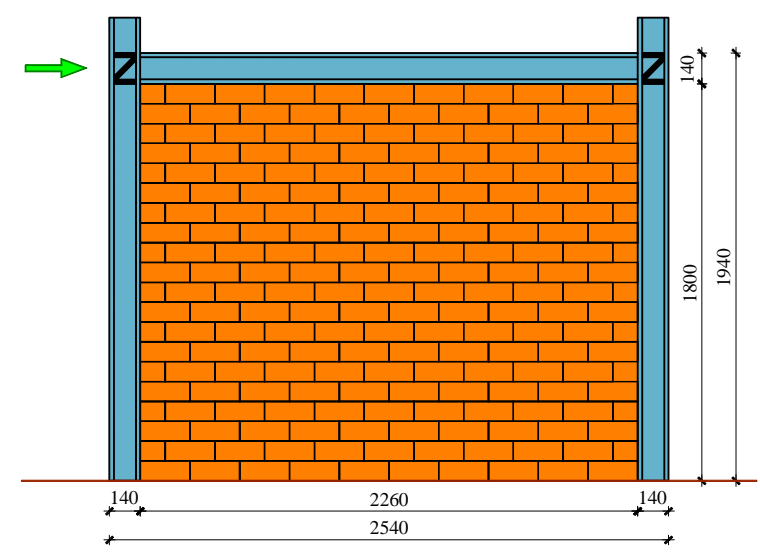

a) Geometrijski podaci

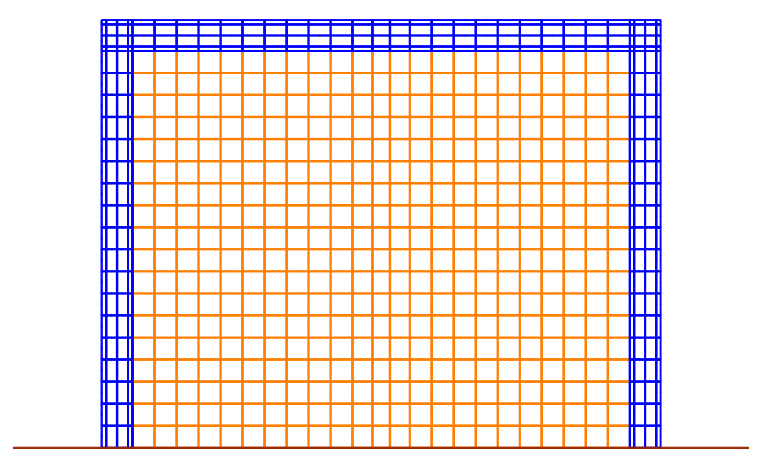

b) Prostorna diskretizacija

Slika 5.5. Geometrijski podaci i usvojena prostorna diskretizacija razmatranog čeličnog okvira sa zidanom ispunom

Tablica 5.2. Usvojeni parametri materijala za numeričku analizu

\begin{tabular}{lllll}
\hline Varijabla & \multirow{2}{*}{ Jedinica } & Materijal & & Kontakt \\
\cline { 3 - 5 } & & Čelik & Ziđe & 300 \\
\hline Modul elastičnosti & $\mathrm{MPa}$ & 200000 & 300 & 0.15 \\
Poissonov koeficijent & - & 0.30 & 0.15 & 130 \\
Modul posmika & $\mathrm{MPa}$ & 80700 & 130 & 7,63 \\
Tlačna čvrstoća & $\mathrm{MPa}$ & 280.0 & 7,63 & 0,00 \\
Vlačna čvrstoća & $\mathrm{MPa}$ & 280.0 & 0,30 & 0,060 \\
Granična tlačna deformacija & - & 0.060 & 0,060 & 0.000 \\
Granična vlačna deformacija & - & 0.060 & 0.010 & \\
\hline
\end{tabular}

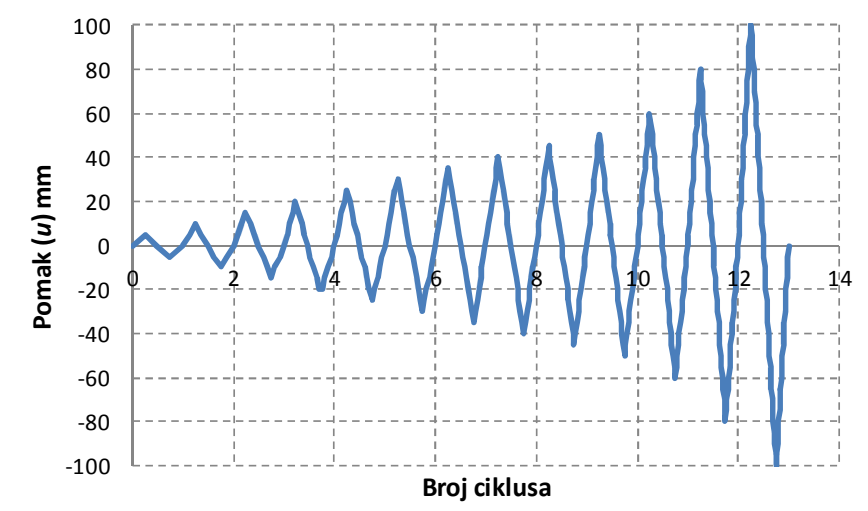

Slika 5.6. Aplicirani horizontalni pomak $(u)$ vrha okvira 
Za slučaj čistog okvira bez ispune, veza opterećenje (horizontalna sila u vrhu okvira) horizontalni pomak vrha okvira prikazana je na Slici 5.7. Može se reći da se eksperimentalni i numerički rezultati dobro podudaraju. Razlike u rezultatima vjerojatno su vezane za nepoznavanje stvarnih naponsko-deformacijskih svojstava čelika, ali vjerojatno i zbog manjkavosti numeričkog modela. Računsko vertikalno naprezanje s vanjske strane baze stupa prikazano je na Slici 5.8 .

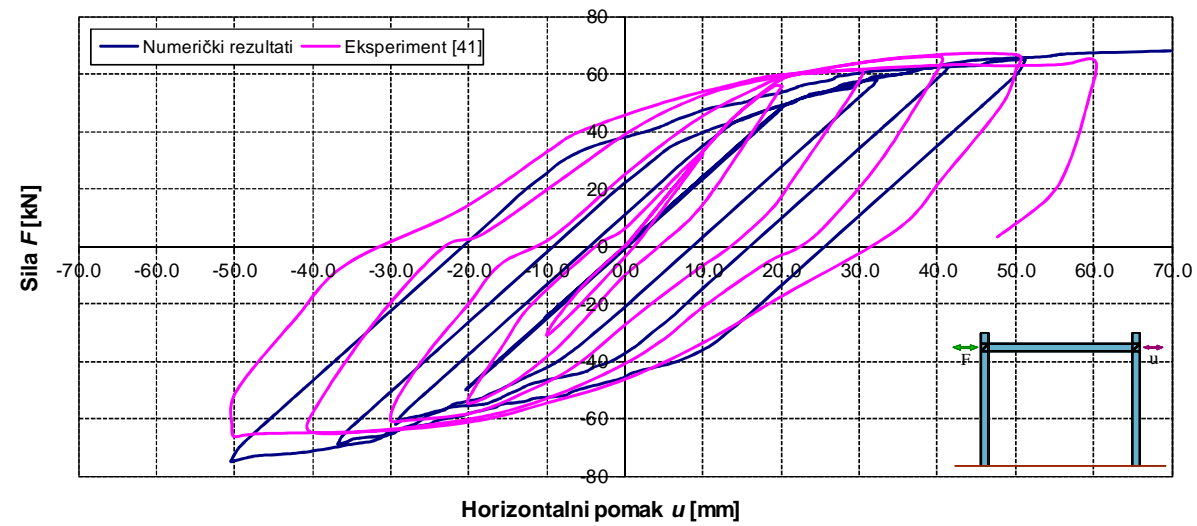

Slika 5.7. Horizontalni pomak $(u)$ vrha čistog okvira

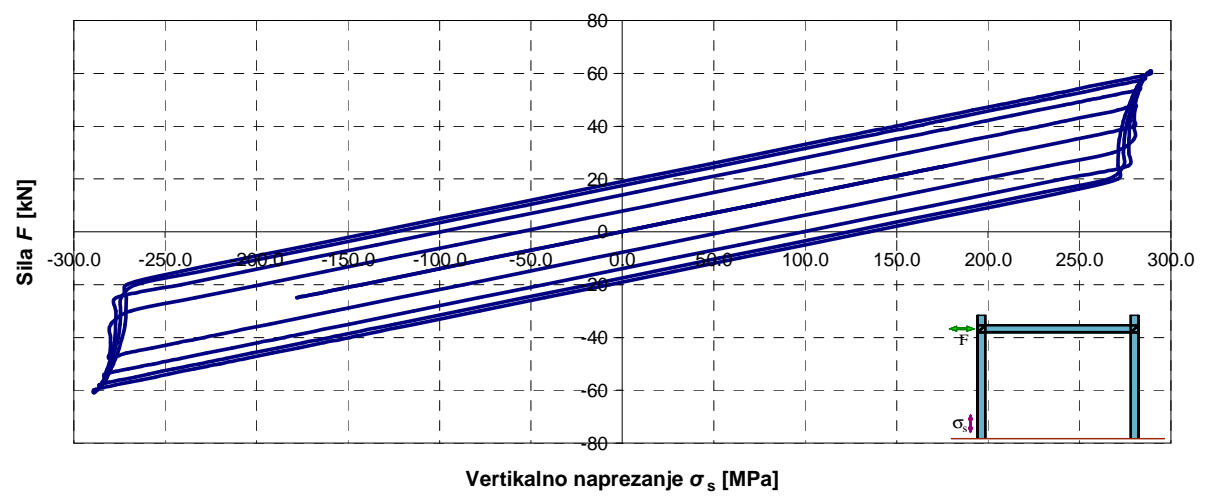

Slika 5.8. Računsko vertikalno naprezanje $\left(\sigma_{\mathrm{s}}\right)$ pri dnu stupa s vanjske strane čistog okvira

Za slučaj okvira sa zidanom ispunom, veza opterećenje (horizontalna sila u vrhu okvira) - horizontalni pomak vrha okvira prikazana je na Slici 5.9. Računsko vertikalno naprezanje pri dnu stupa s vanjske strane prikazano je na Slici 5.10. Konačno stanje pukotina u ziđu prikazano je na Slici 5.11. Također se može konstatirati dobro podudaranje eksperimentalnih i numeričkih rezultata. Razlika u rezultatima ovdje je dijelom i posljedica nepreciznog poznavanja krutosti i naponsko-deformacijskih svojstava ziđa. 


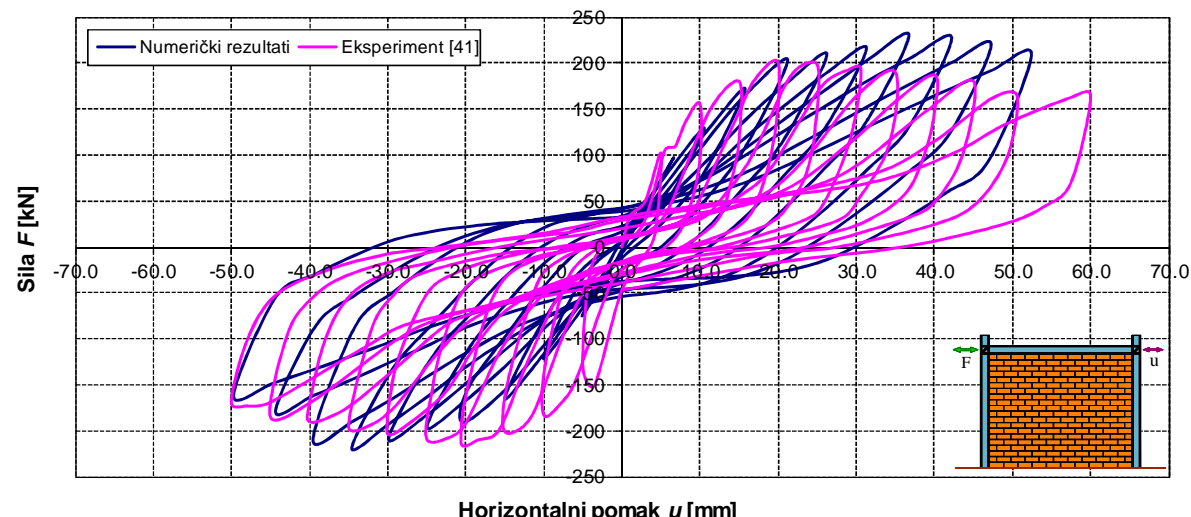

Slika 5.9. Horizontalni pomak $(u)$ vrha okvira sa zidanom ispunom

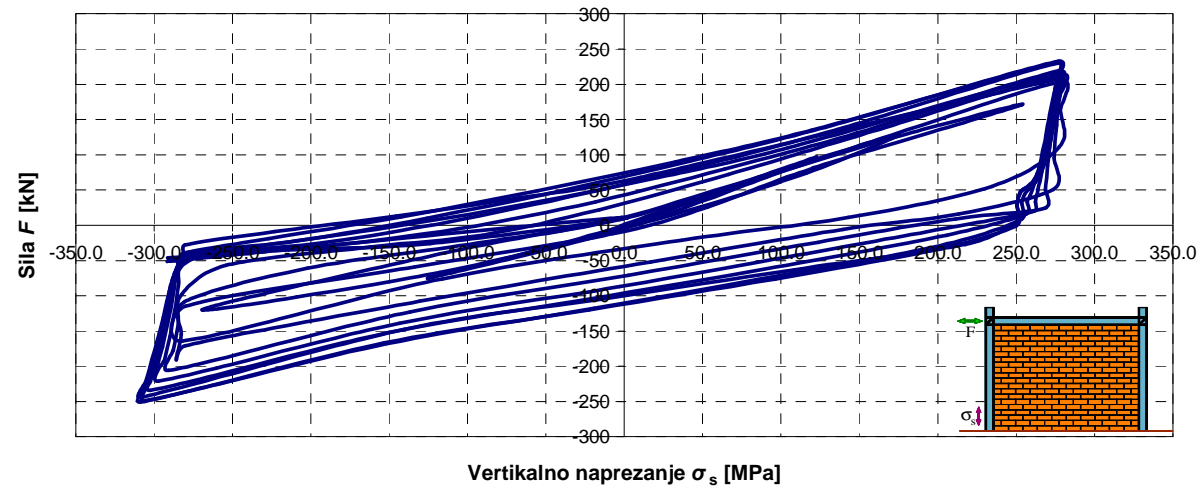

Slika 5.10. Računsko vertikalno naprezanje $\left(\sigma_{\mathrm{s}}\right)$ pri dnu stupa s vanjske strane okvira sa zidanom ispunom

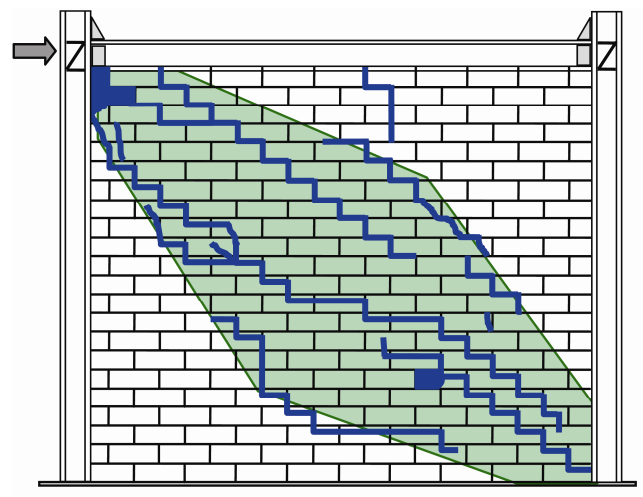

a) Eksperiment [41]

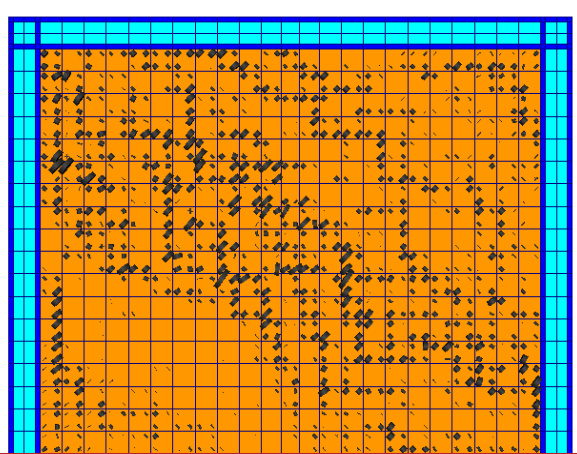

b) Numerički rezultati

Slika 5.11. Konačno stanje pukotina u ziđu 


\subsection{Dinamička analiza}

\subsubsection{Simulacija dinamičkih ispitivanja čeličnih okvira sa zidanom ispunom}

Analizirani su uzorci čeličnih okvira sa zidanom ispunom prikazanih u Poglavlju 3. Uzorci su opterećeni vertikalnim stalnim opterećenjem iznosa $30 \mathrm{kN}$, te izloženi horizontalnoj komponenti ubrzanja podloge. Usvojena prostorna diskretizacija ispitanih okvira prikazana je na Slici 5.12. Korištena je jednaka prostorna diskretizacija konstrukcije kao i kod statičke analize, uz dodatnu prostornu diskretizaciju betonskog bloka za simulaciju vertikalnog djelovanja. Korišteni su osnovni 2D elementi za simulaciju konstrukcijskog čelika, ziđa i betonskog bloka, te 2D kontaktni elementi za simulaciju mogućeg odvajanja okvira i ispune. Ziđe je modelirano s izotropnim makromodelom materijala. Usvojeni osnovni parametri gradiva za numeričku analizu prikazani su u Tablici 5.1.

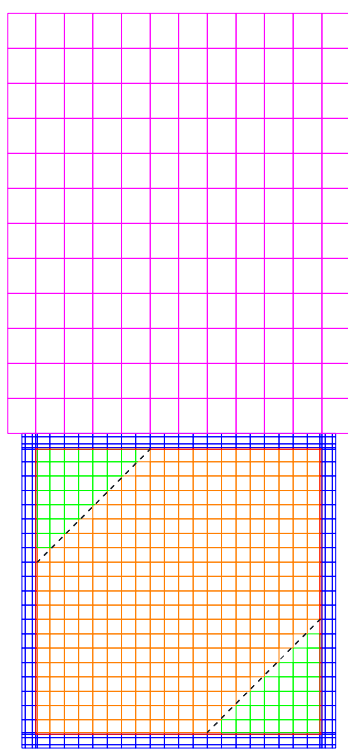

$\mathrm{SF}$

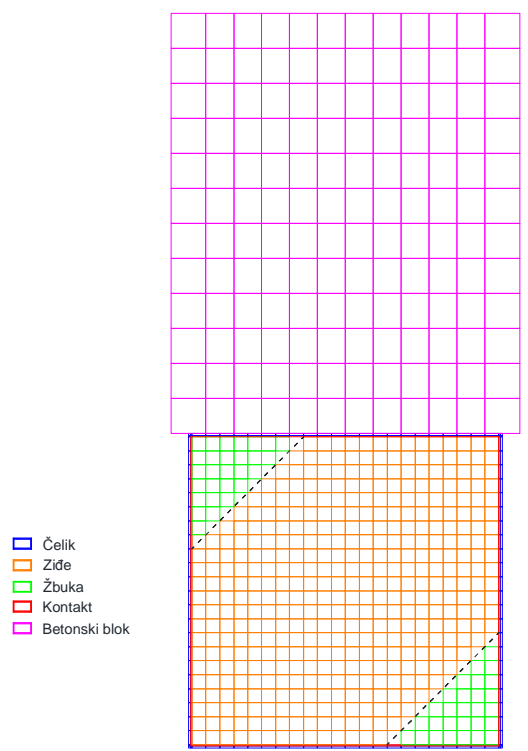

WF

Slika 5.12. Usvojena prostorna diskretizacija za dinamičku analizu razmatranih čeličnih okvira sa zidanom ispunom

Za provedbu numeričke analize korišteni su vremenski zapisi ostvarenih ubrzanja i pomaka platforme prilikom provedenih ispitivanja. Izmjerena ubrzanja i pomaci platforme vrlo se dobro slažu sa zadanim vrijednostima, što upućuje na njenu visoku preciznost i 
pouzdanost. Pobude su nanošene u skladu s procedurom opisanoj u Poglavlju 3. Apliciran je niz umjetnih akcelerograma AA1 i niz akcelerograma potresa Petrovac sa sukcesivno povećavanim amplitudama od $0.1 \mathrm{~g}$. Kod umjetnog akceleorograma AA1, maksimalna ubrzanja se povećavaju od 0.1 do $0.8 \mathrm{~g}$, a kod potresa Petrovac od 0.1 do $0.45 \mathrm{~g}$.

Ubrzanje je aplicirano na donjem rubu konstrukcije (na mjestu pridržanja). Korištena je implicitna vremenska integracija $\mathrm{s}$ vremenskim inkrementom duljine približno 1/100 osnovnog perioda slobodnih vibracija razmatranih okvira. Pretpostavljeno je viskozno konstrukcijsko prigušenje u iznosu od $2 \%$. Za kriterij konvergencije iterativnog postupka, usvojena je norma prirasta pomaka od $0.1 \%$ u odnosu na normu tekućih ukupnih pomaka.

Za svaki aplicirani akcelerogram praćene su karakteristične vrijednosti pomaka, ubrzanja i deformacija, te stanja deformacija i pukotina u ziđu kao i kod provedenog eksperimenta. Svi rezultati su prezentirani grafički, te uspoređeni s utvrđenim eksperimentalnim rezultatima. U nastavku su prikazani samo neki dijagrami s usporedbom eksperimentalno utvrđenih i numerički dobivenih rezultata (vidjeti Slike 5.13-5.26). 


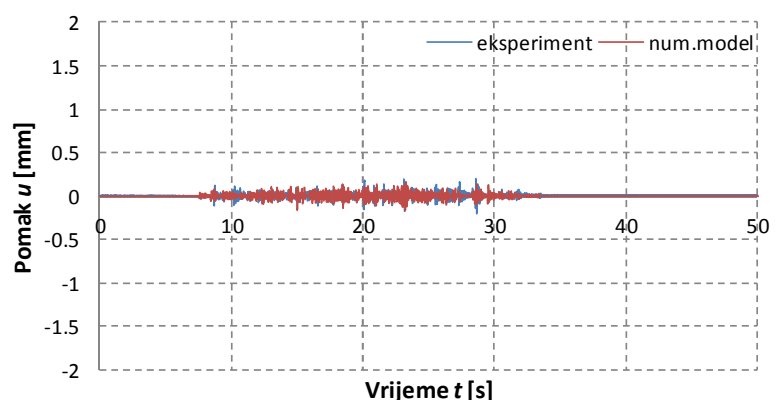

a) $\mathrm{a}_{\mathrm{g}, \max }=0.2 \mathrm{~g}$

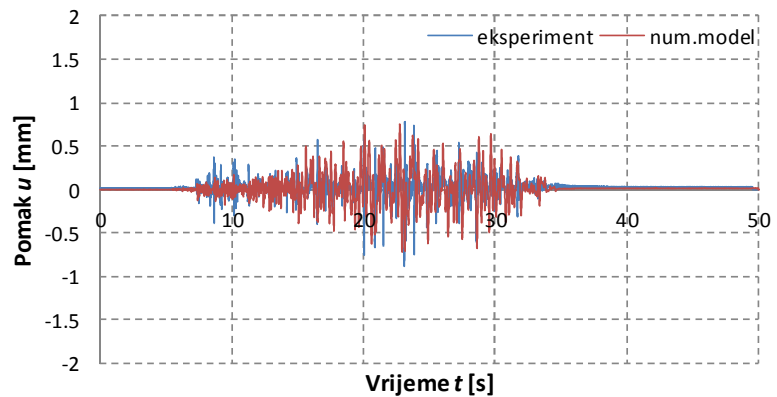

c) $\mathrm{a}_{\mathrm{g}, \max }=0.6 \mathrm{~g}$

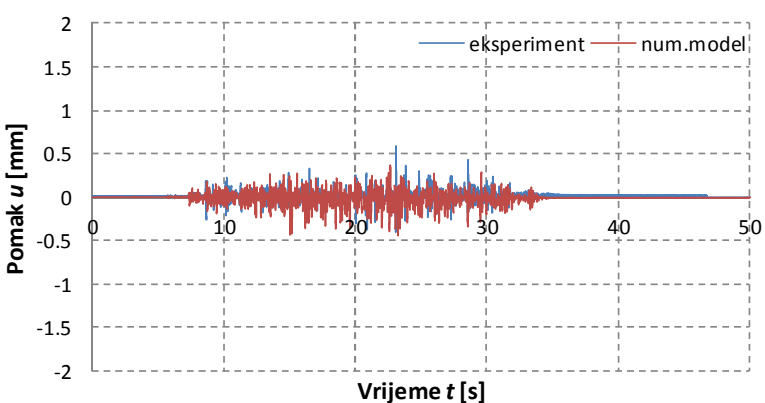

b) $\mathrm{a}_{\mathrm{g}, \max }=0.4 \mathrm{~g}$

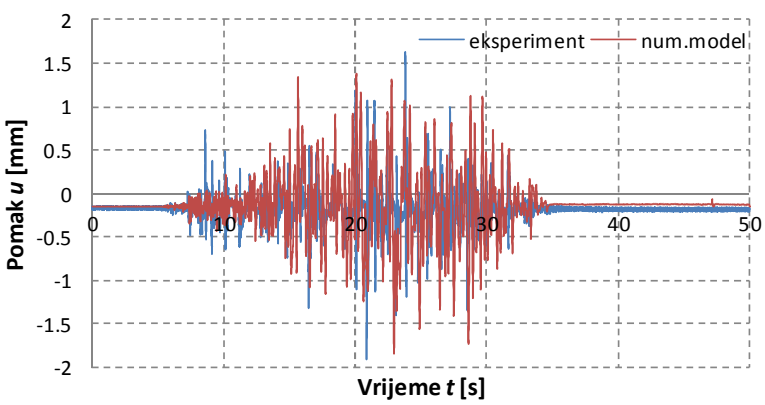

d) $\mathrm{a}_{\mathrm{g}, \text { max }}=0.8 \mathrm{~g}$

Slika 5.13. Usporedba pomaka vrha okvira SF-1 za umjetni akcelerogram AA1

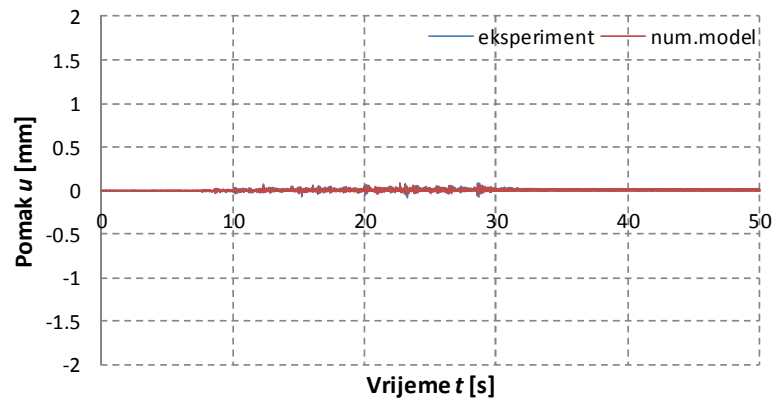

a) $\mathrm{a}_{\mathrm{g}, \max }=0.1 \mathrm{~g}$

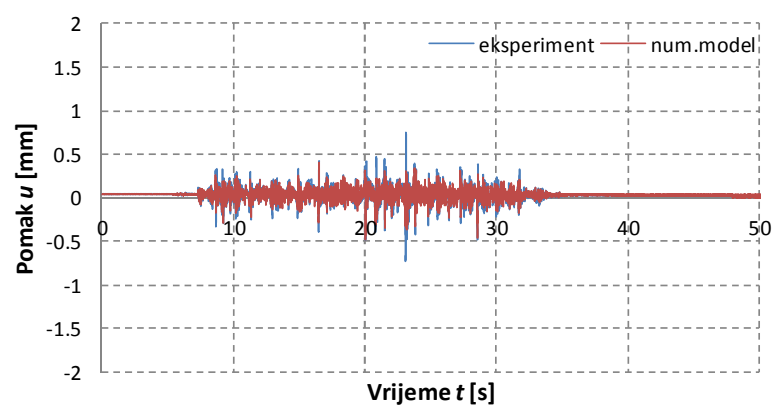

c) $\mathrm{a}_{\mathrm{g}, \max }=0.5 \mathrm{~g}$

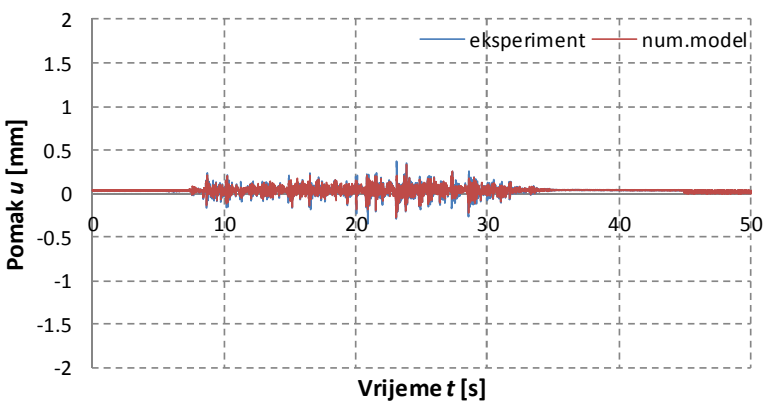

b) $\mathrm{a}_{\mathrm{g}, \max }=0.3 \mathrm{~g}$

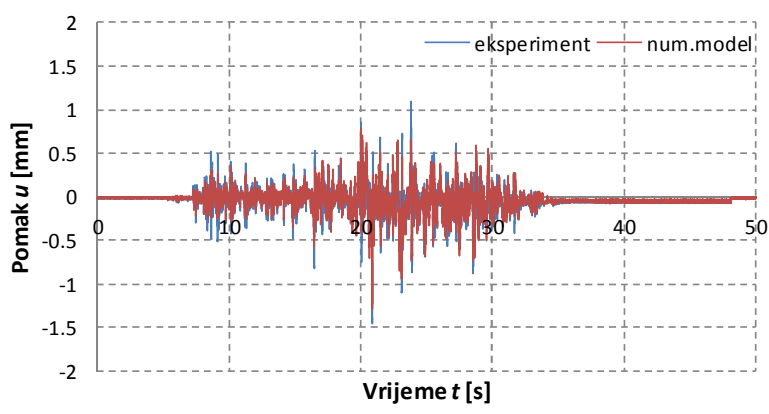

d) $\mathrm{a}_{\mathrm{g}, \max }=0.7 \mathrm{~g}$

Slika 5.14. Usporedba pomaka vrha okvira SF-3 za umjetni akcelerogram AA1 


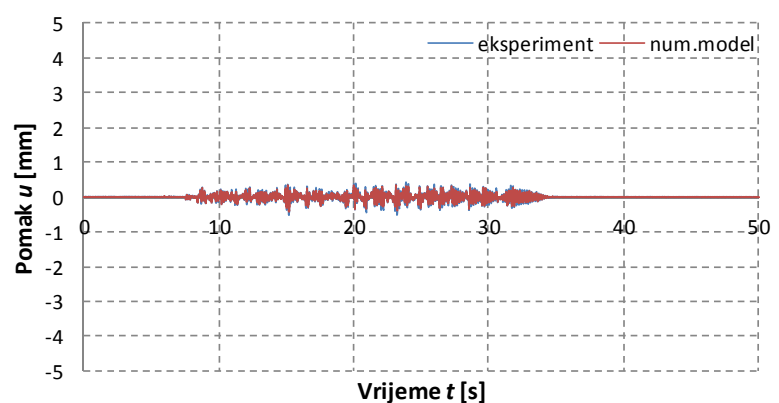

a) $\mathrm{a}_{\mathrm{g}, \max }=0.2 \mathrm{~g}$

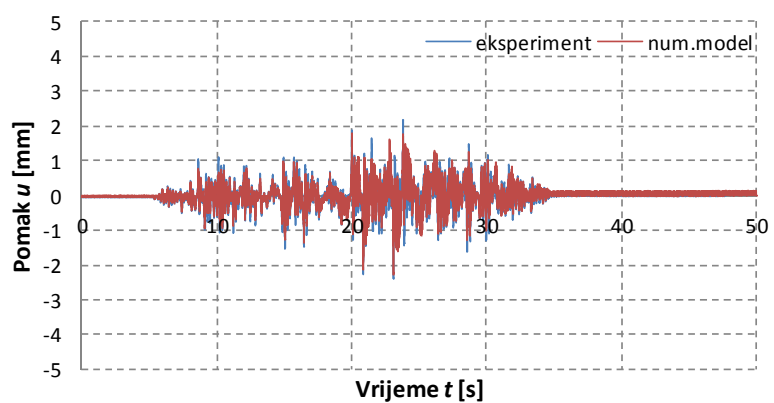

c) $\mathrm{a}_{\mathrm{g}, \max }=0.6 \mathrm{~g}$

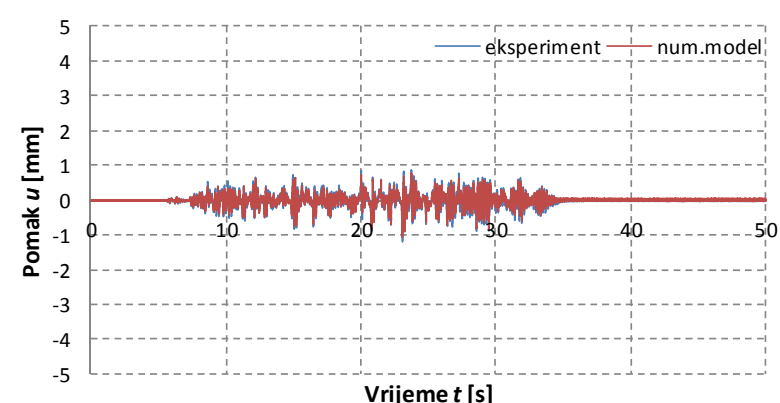

b) $\mathrm{a}_{\mathrm{g}, \max }=0.4 \mathrm{~g}$

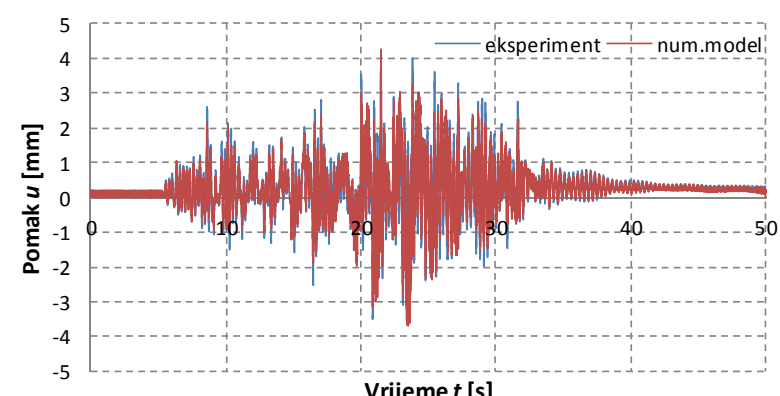

d) $\mathrm{a}_{\mathrm{g}, \max }=0.8 \mathrm{~g}$

Slika 5.15. Usporedba pomaka vrha okvira WF-1 za umjetni akcelerogram AA1

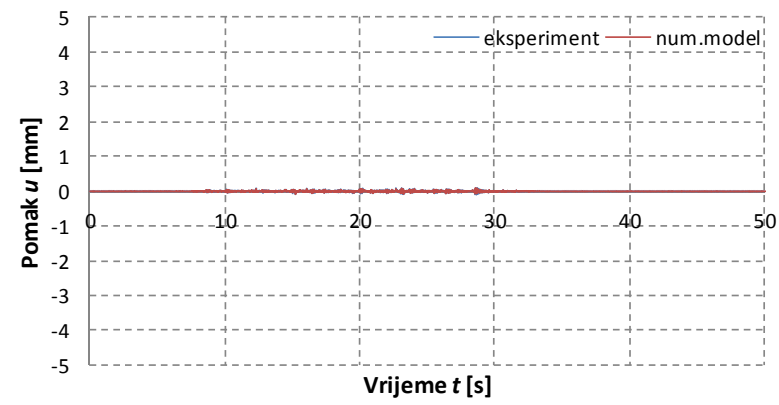

a) $\mathrm{a}_{\mathrm{g}, \max }=0.1 \mathrm{~g}$

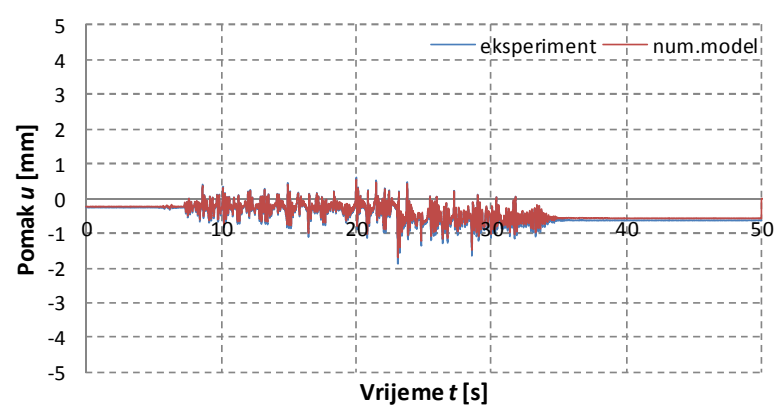

c) $\mathrm{a}_{\mathrm{g}, \max }=0.5 \mathrm{~g}$

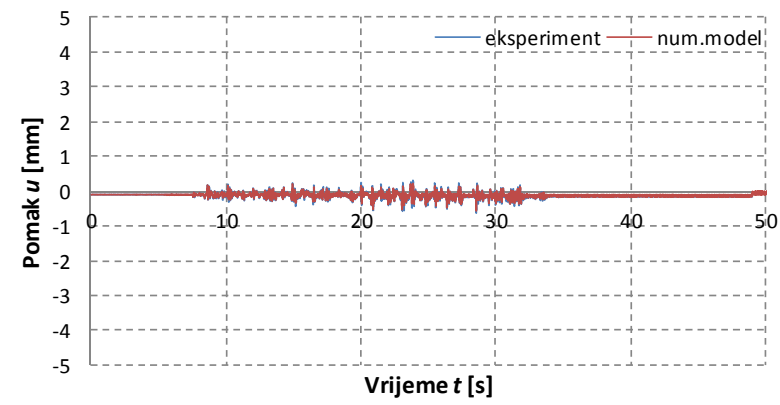

b) $\mathrm{a}_{\mathrm{g}, \max }=0.3 \mathrm{~g}$

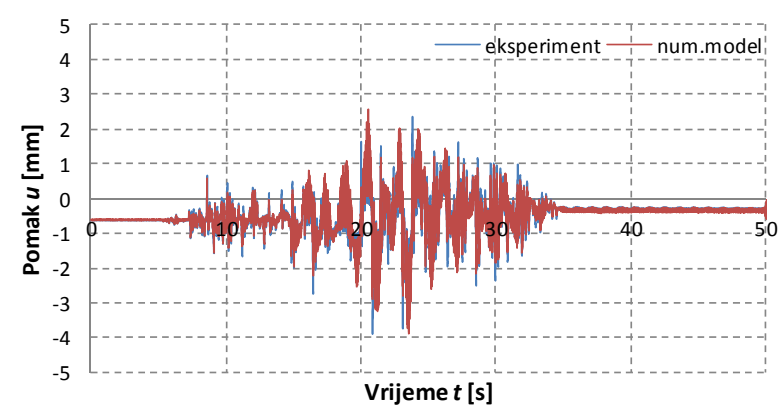

d) $\mathrm{a}_{\mathrm{g}, \max }=0.7 \mathrm{~g}$

Slika 5.16. Usporedba pomaka vrha okvira WF-3 za umjetni akcelerogram AA1 


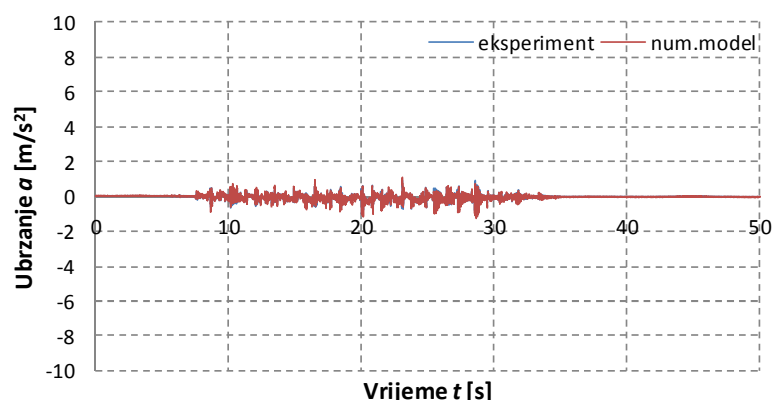

a) $\mathrm{a}_{\mathrm{g}, \max }=0.2 \mathrm{~g}$

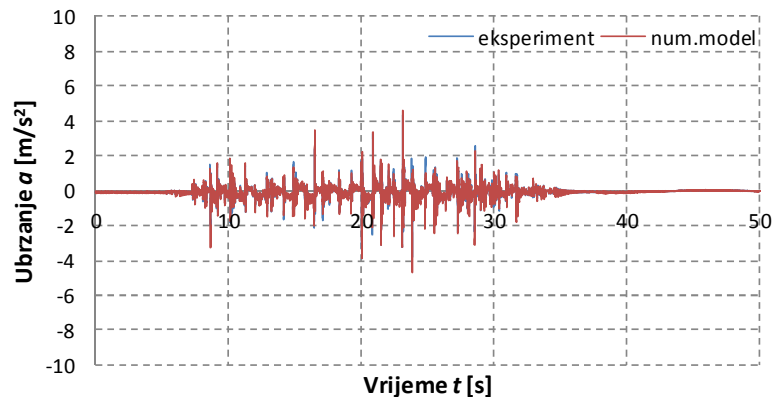

c) $\mathrm{a}_{\mathrm{g}, \max }=0.6 \mathrm{~g}$

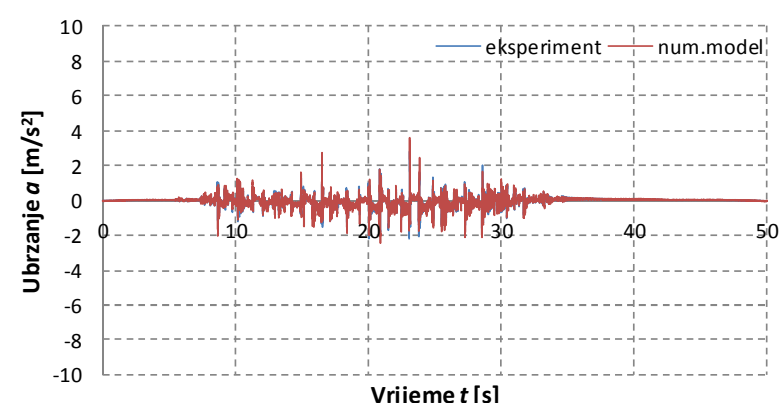

b) $\mathrm{a}_{\mathrm{g}, \max }=0.4 \mathrm{~g}$

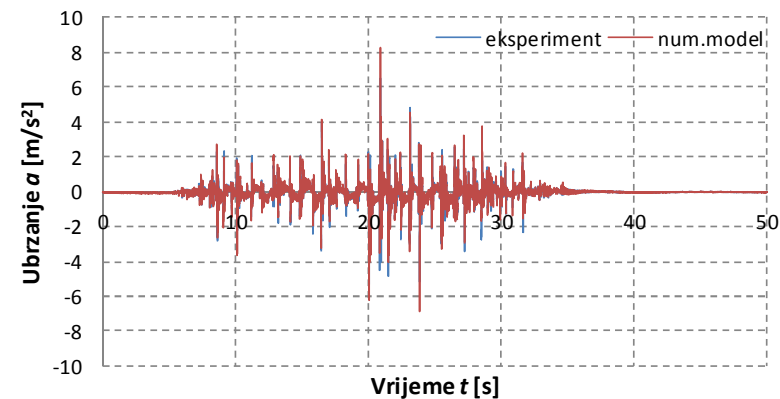

d) $\mathrm{a}_{\mathrm{g}, \max }=0.8 \mathrm{~g}$

Slika 5.17. Usporedba ubrzanja vrha okvira SF-2 za umjetni akcelerogram AA1

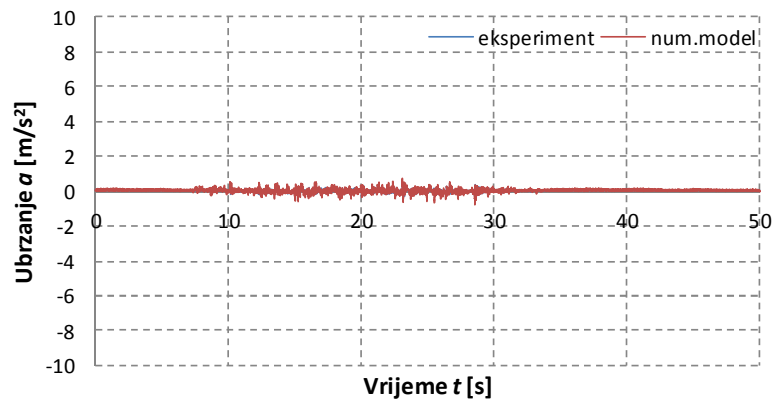

a) $\mathrm{a}_{\mathrm{g}, \max }=0.1 \mathrm{~g}$

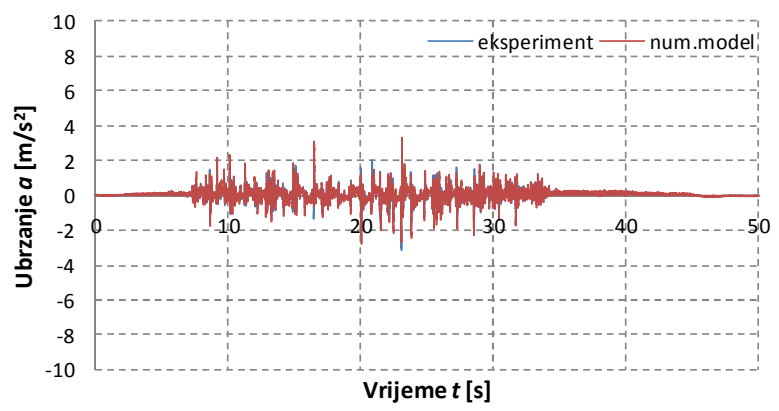

c) $\mathrm{a}_{\mathrm{g}, \max }=0.5 \mathrm{~g}$

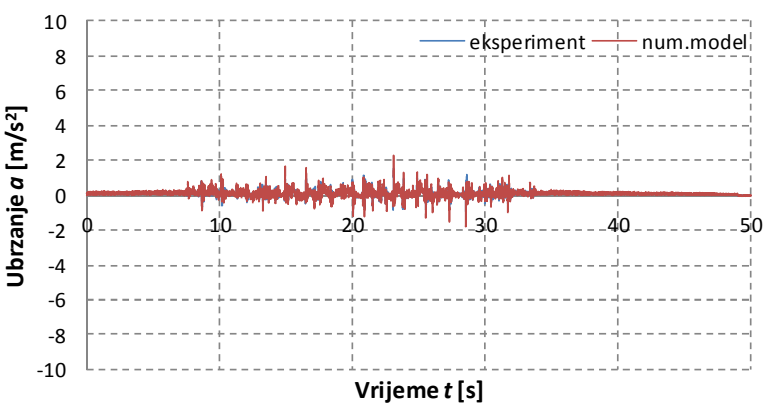

b) $\mathrm{a}_{\mathrm{g}, \max }=0.3 \mathrm{~g}$

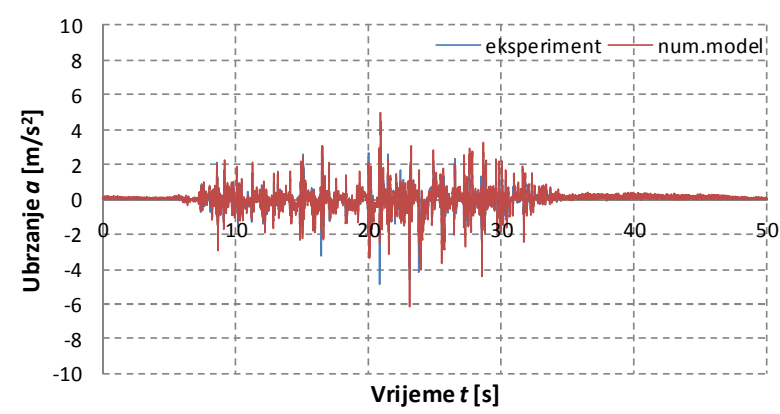

d) $\mathrm{a}_{\mathrm{g}, \max }=0.7 \mathrm{~g}$

Slika 5.18. Usporedba ubrzanja vrha okvira WF-2 za umjetni akcelerogram AA1 


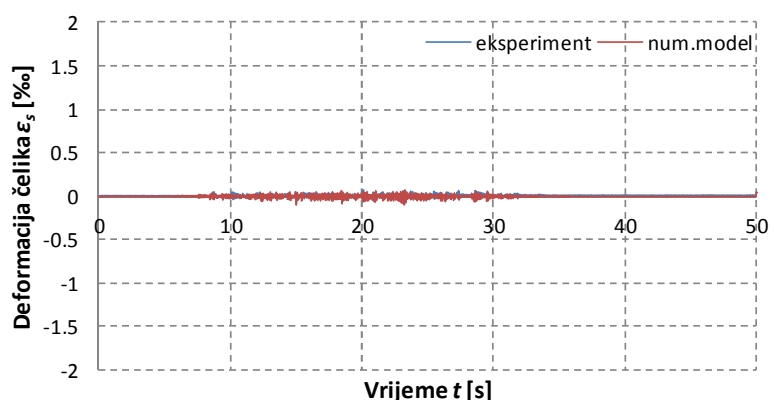

a) $\mathrm{a}_{\mathrm{g}, \max }=0.2 \mathrm{~g}$

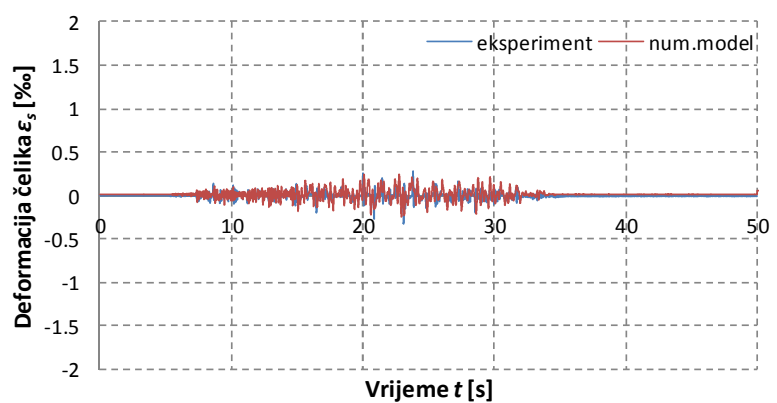

c) $\mathrm{a}_{\mathrm{g}, \max }=0.6 \mathrm{~g}$

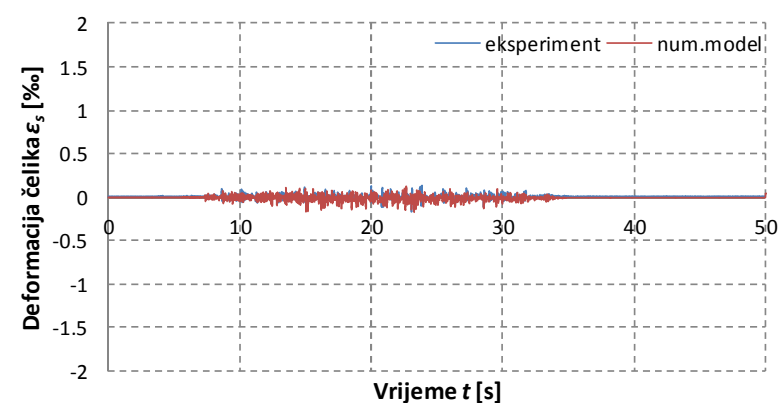

b) $\mathrm{a}_{\mathrm{g}, \max }=0.4 \mathrm{~g}$

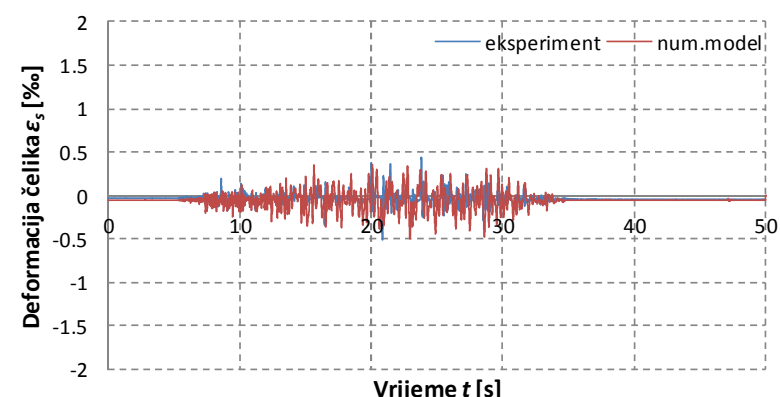

d) $\mathrm{a}_{\mathrm{g}, \max }=0.8 \mathrm{~g}$

Slika 5.19. Usporedba deformacija čelika pri dnu stupa (točka A) okvira SF-1 za umjetni akcelerogram AA1

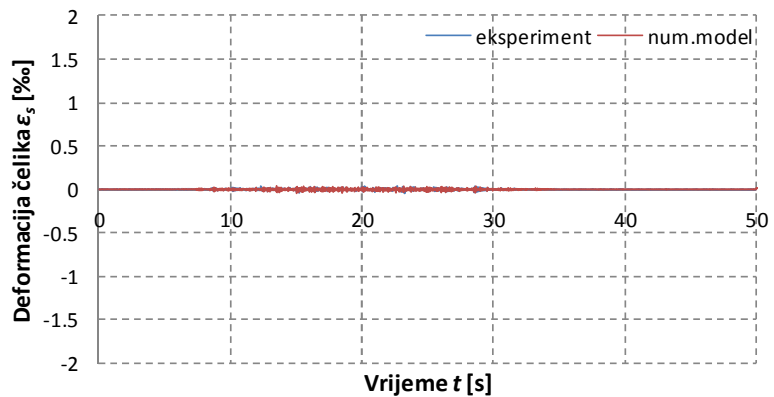

a) $\mathrm{a}_{\mathrm{g}, \max }=0.1 \mathrm{~g}$

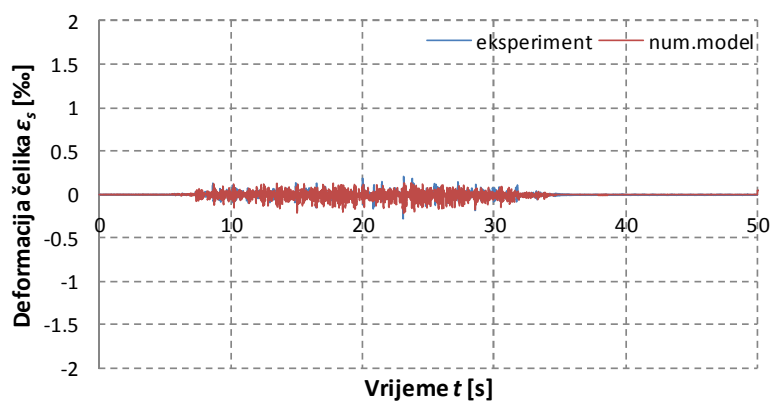

c) $\mathrm{a}_{\mathrm{g}, \max }=0.5 \mathrm{~g}$

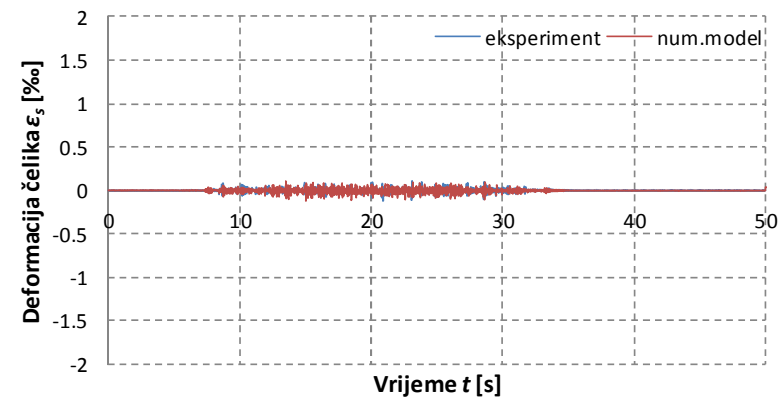

b) $\mathrm{a}_{\mathrm{g}, \max }=0.3 \mathrm{~g}$

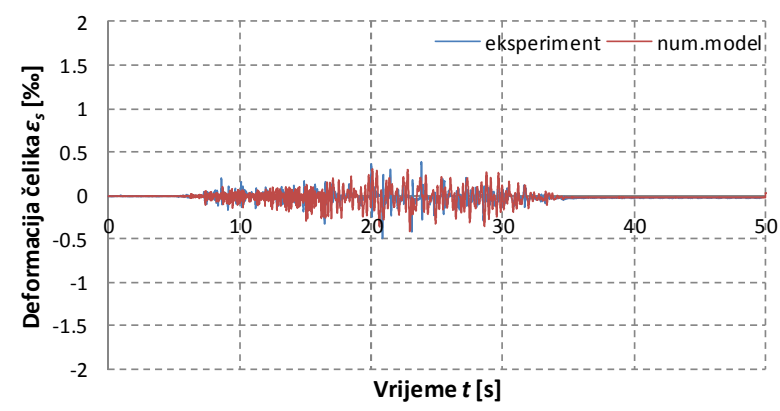

d) $\mathrm{a}_{\mathrm{g}, \max }=0.7 \mathrm{~g}$

Slika 5.20. Usporedba deformacija čelika pri dnu stupa (točka A) okvira SF-2 za umjetni akcelerogram AA1 


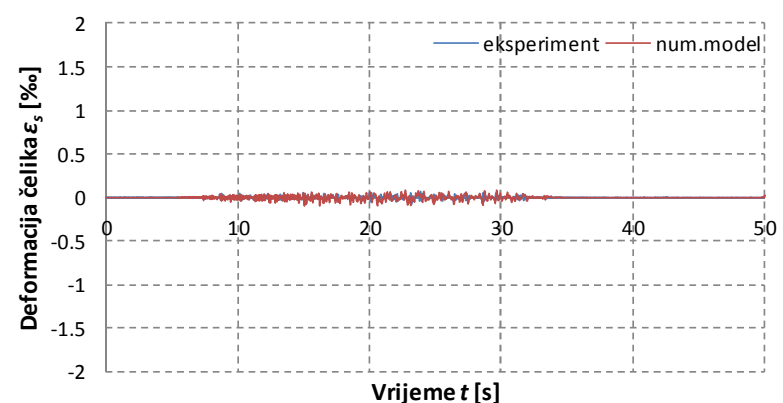

a) $\mathrm{a}_{\mathrm{g}, \max }=0.2 \mathrm{~g}$

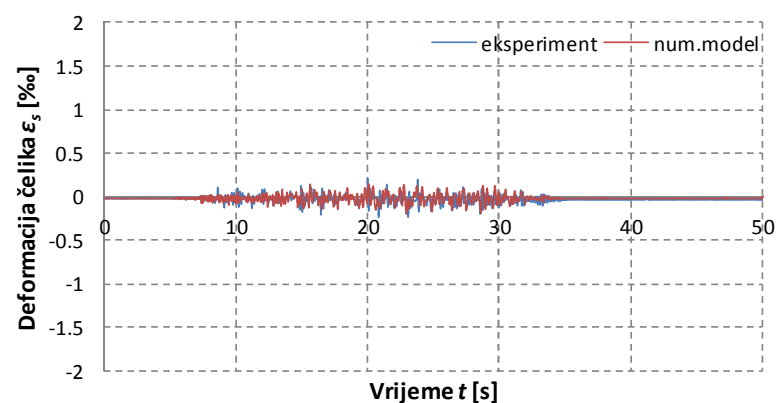

c) $\mathrm{a}_{\mathrm{g}, \max }=0.6 \mathrm{~g}$

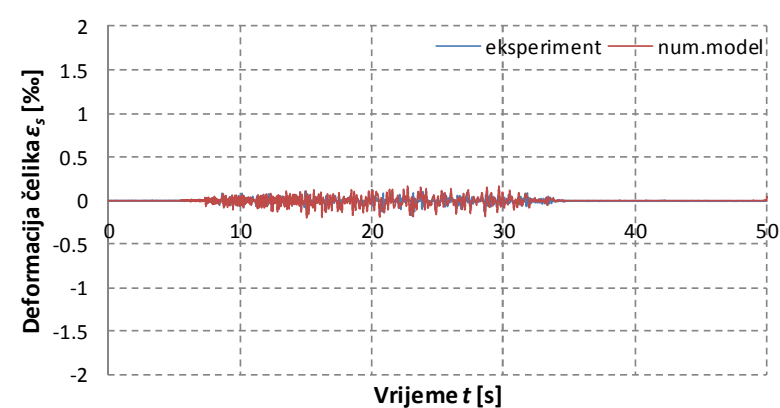

b) $\mathrm{a}_{\mathrm{g}, \max }=0.4 \mathrm{~g}$

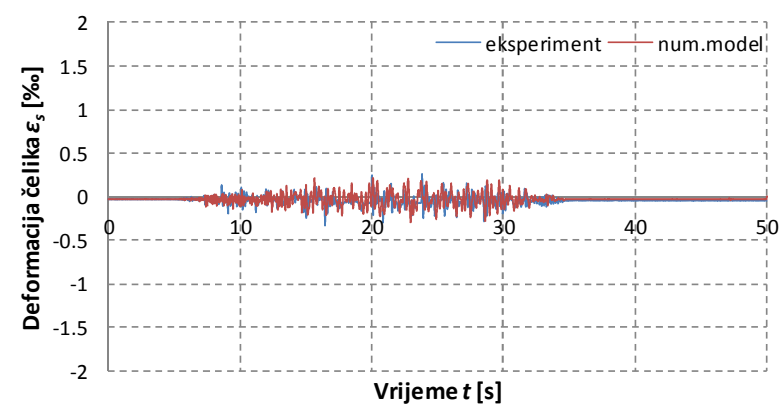

d) $\mathrm{a}_{\mathrm{g}, \max }=0.8 \mathrm{~g}$

Slika 5.21. Usporedba deformacija čelika pri dnu stupa (točka A) okvira WF-3 za umjetni akcelerogram AA1

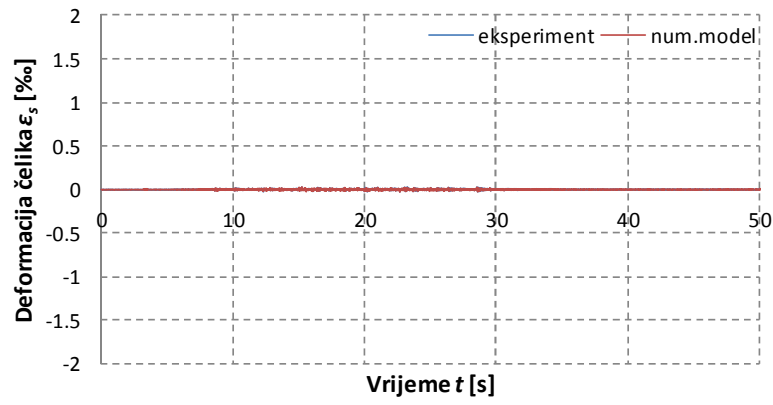

a) $\mathrm{a}_{\mathrm{g}, \max }=0.1 \mathrm{~g}$

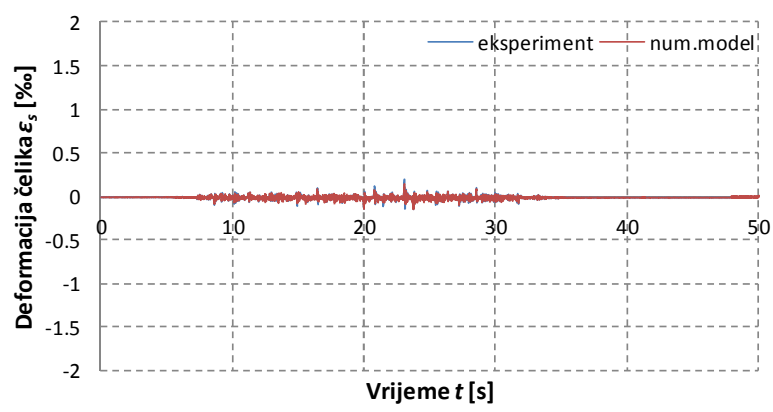

c) $\mathrm{a}_{\mathrm{g}, \max }=0.5 \mathrm{~g}$

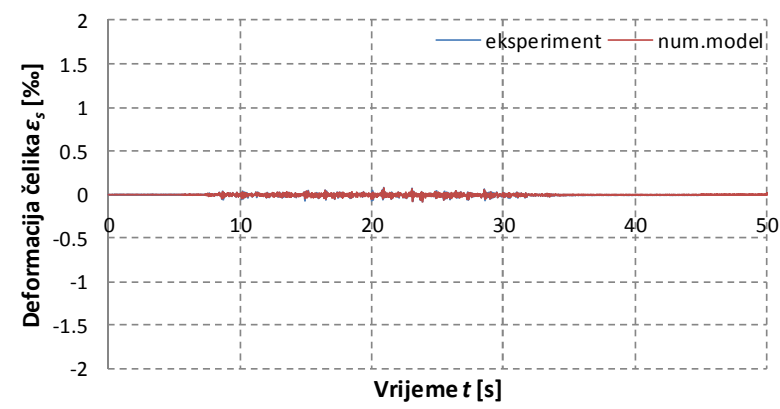

b) $\mathrm{a}_{\mathrm{g}, \max }=0.3 \mathrm{~g}$

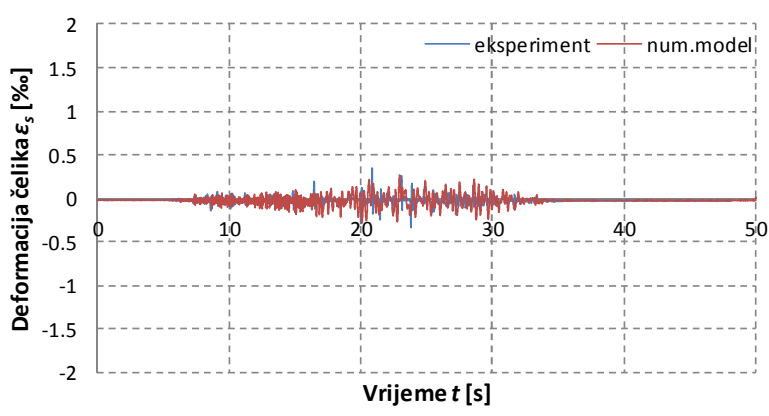

d) $\mathrm{a}_{\mathrm{g}, \max }=0.7 \mathrm{~g}$

Slika 5.22. Usporedba deformacija čelika pri dnu stupa (točka B) okvira SF-3 za umjetni akcelerogram AA1 


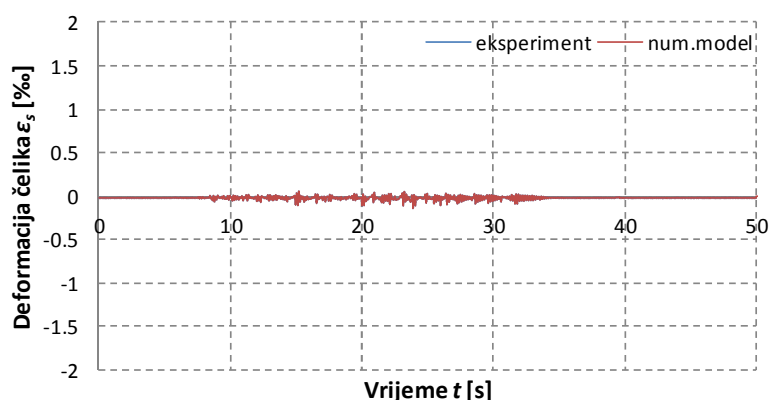

a) $\mathrm{a}_{\mathrm{g}, \max }=0.2 \mathrm{~g}$

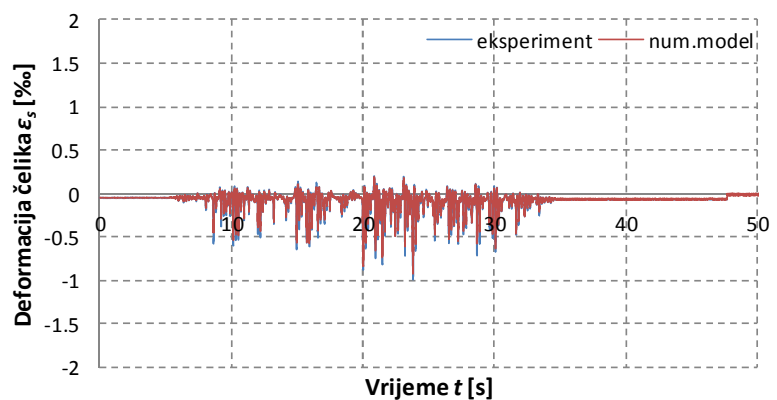

c) $\mathrm{a}_{\mathrm{g}, \max }=0.6 \mathrm{~g}$

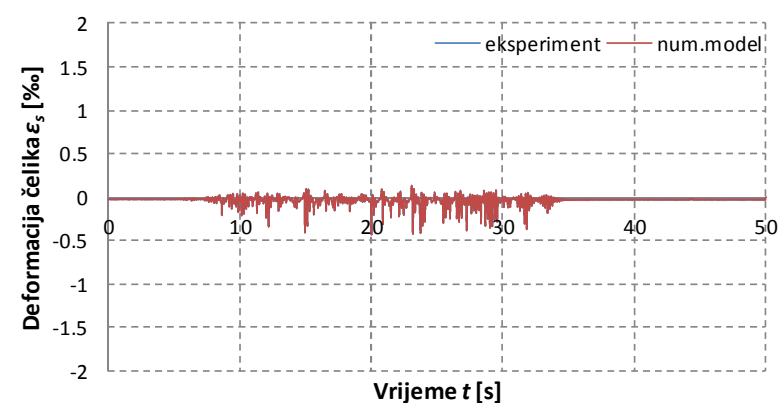

b) $\mathrm{a}_{\mathrm{g}, \max }=0.4 \mathrm{~g}$

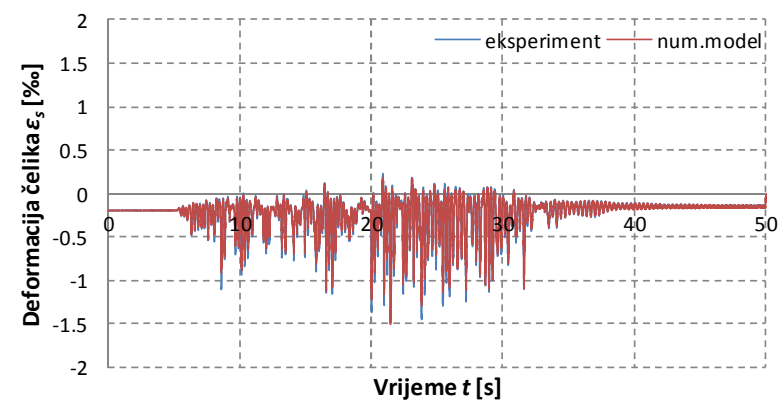

d) $\mathrm{a}_{\mathrm{g}, \max }=0.8 \mathrm{~g}$

Slika 5.23. Usporedba deformacija čelika pri dnu stupa (točka B) okvira WF-1 za umjetni akcelerogram AA1

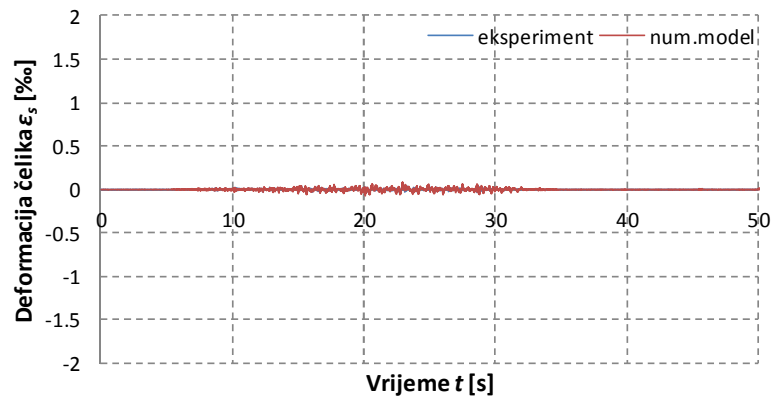

a) $\mathrm{a}_{\mathrm{g}, \max }=0.1 \mathrm{~g}$

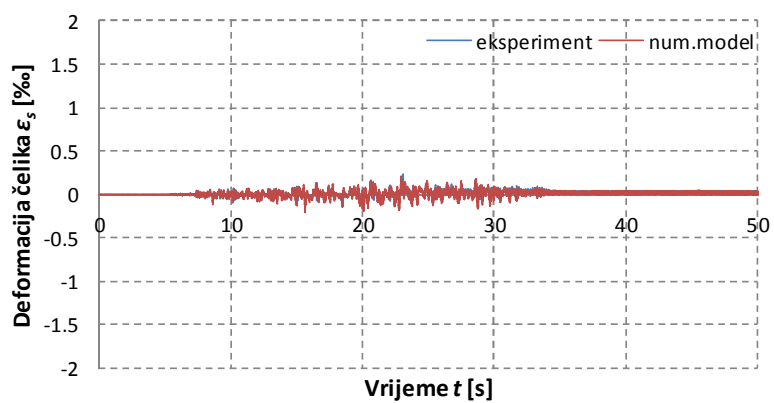

c) $\mathrm{a}_{\mathrm{g}, \max }=0.5 \mathrm{~g}$

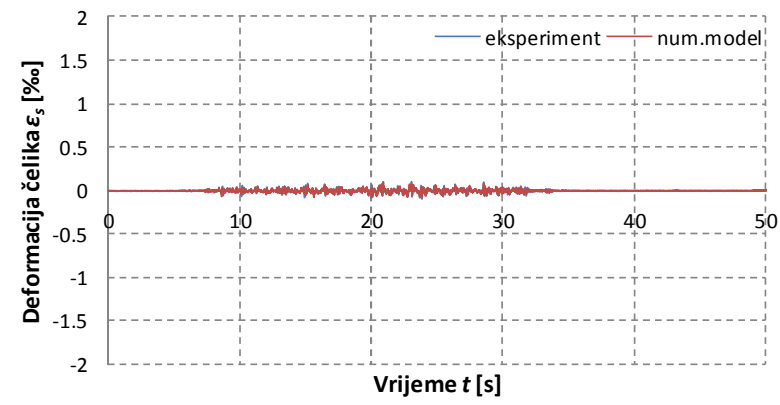

b) $\mathrm{a}_{\mathrm{g}, \max }=0.3 \mathrm{~g}$

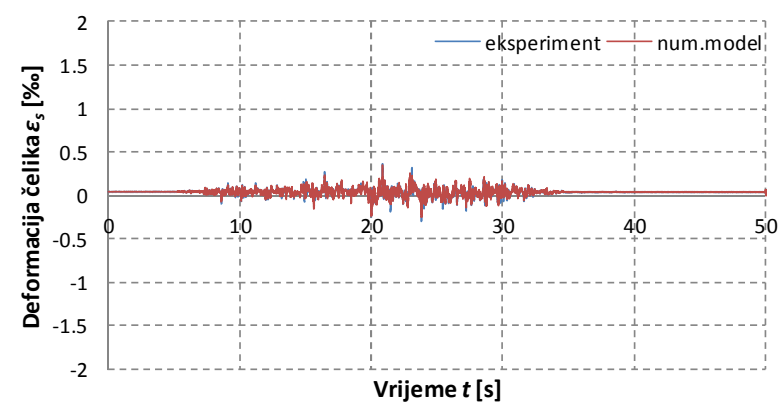

d) $\mathrm{a}_{\mathrm{g}, \max }=0.7 \mathrm{~g}$

Slika 5.24. Usporedba deformacija čelika pri dnu stupa (točka B) okvira WF-2 za umjetni akcelerogram AA1 


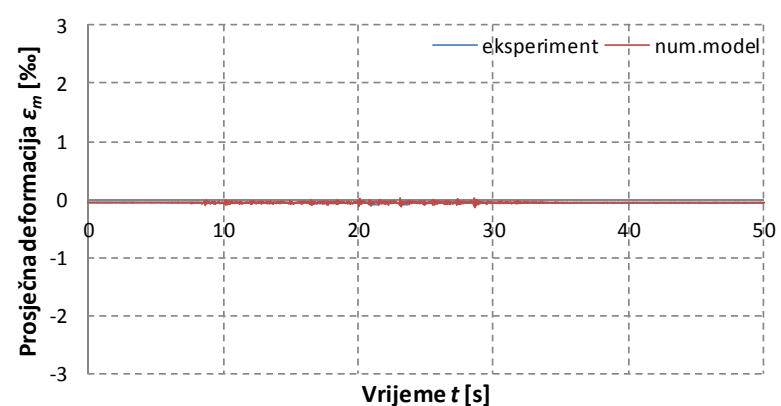

a) $\mathrm{a}_{\mathrm{g}, \max }=0.2 \mathrm{~g}$

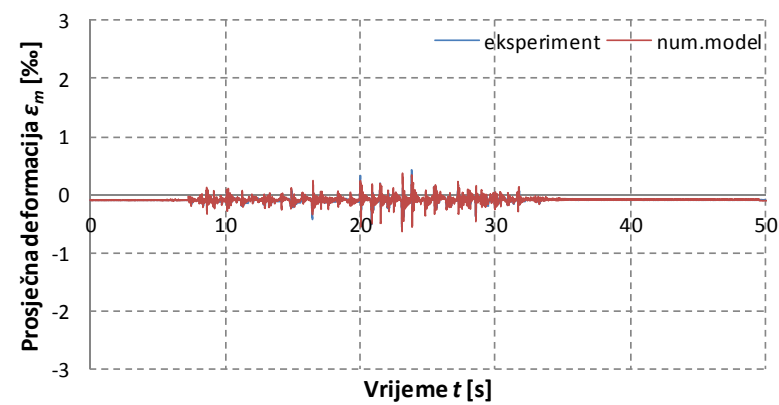

c) $\mathrm{a}_{\mathrm{g}, \max }=0.6 \mathrm{~g}$

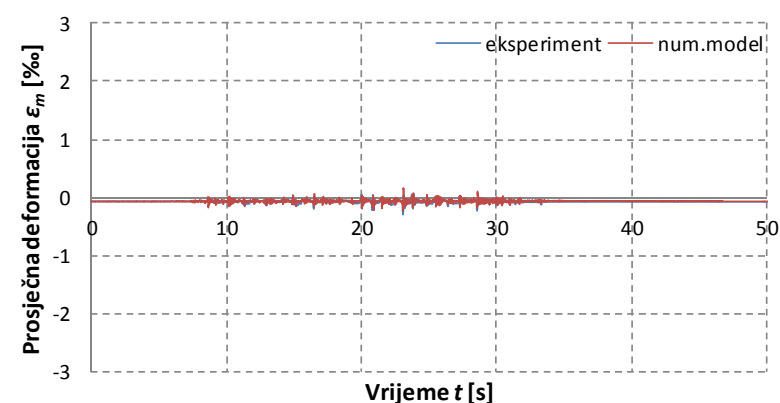

b) $\mathrm{a}_{\mathrm{g}, \max }=0.4 \mathrm{~g}$

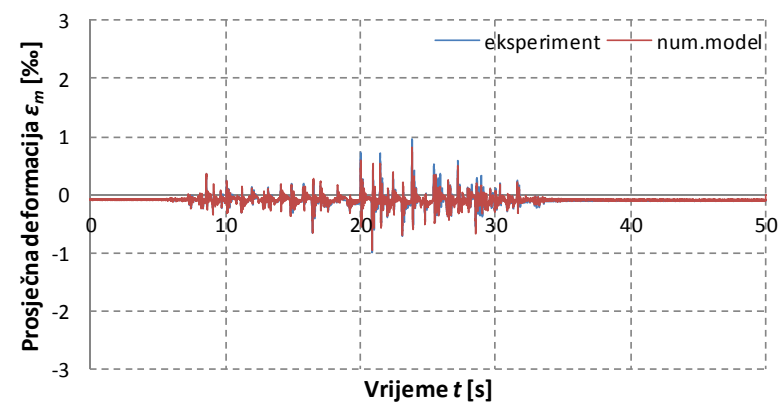

d) $\mathrm{a}_{\mathrm{g}, \max }=0.8 \mathrm{~g}$

Slika 5.25. Usporedba prosječnih deformacija ziđa u smjeru dijagonale D1 okvira SF-1 za umjetni akcelerogram AA1

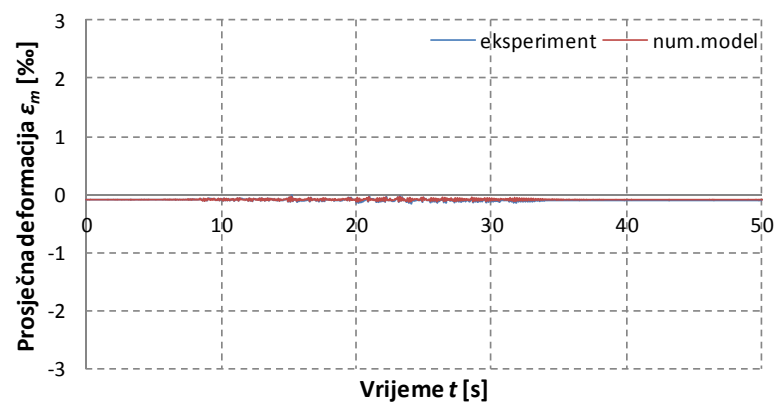

a) $\mathrm{ag}_{\mathrm{g}, \max }=0.1 \mathrm{~g}$

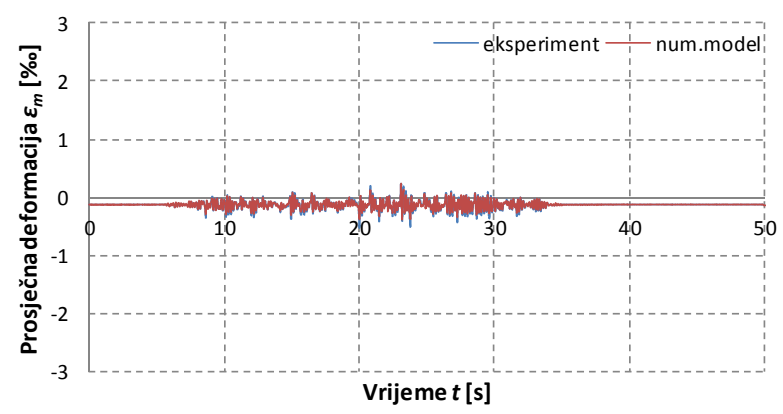

c) $\mathrm{a}_{\mathrm{g}, \max }=0.5 \mathrm{~g}$

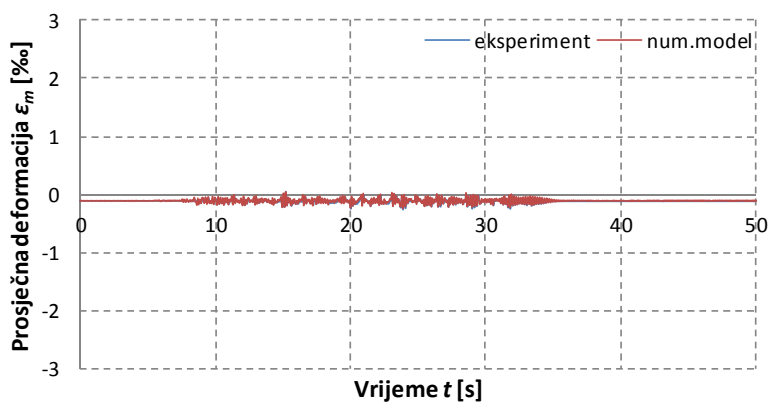

b) $\mathrm{a}_{\mathrm{g}, \max }=0.3 \mathrm{~g}$

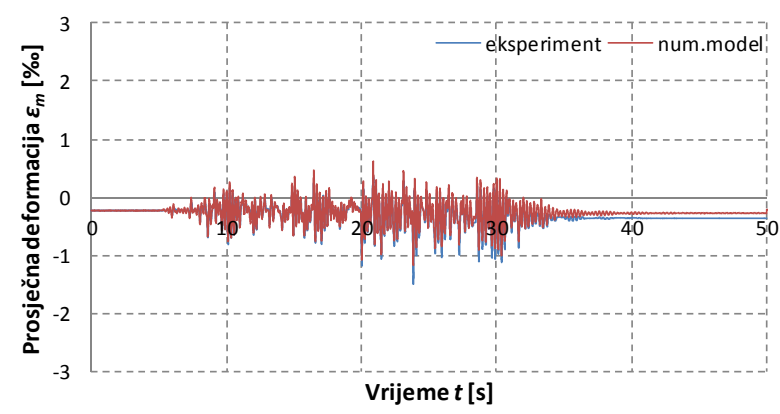

d) $\mathrm{a}_{\mathrm{g}, \max }=0.7 \mathrm{~g}$

Slika 5.26. Usporedba prosječnih deformacija ziđa u smjeru dijagonale D2 okvira WF-1 za umjetni akcelerogram AA1 
Usporedbom eksperimentalno utvrđenih i numerički dobivenih rezultata, može se primijetiti njihovo dobro podudaranje. Naravno, kod nekih krivulja postoje odstupanja. Kod toga treba imati na umu da numerički model koristi elasto-plastični materijalni model za čelik, ziđe i žbuku u tlaku, kao i Newtonov algoritam za rješenje nelinearnih jednadžbi, što može imati utjecaja na rezultate numeričke analize. Također dolazi i do različitih lokalnih nelinearnih efekata uslijed oštećenja konstrukcije, koji se ne mogu adekvatno simulirati s ovim modelom.

Konačno stanje deformacija i pukotina u ziđu dobiveno pomoću numeričke dinamičke analize čeličnih okvira sa zidanom ispunom prikazano je na Slici 5.27. Usporedbom s fotografijama uzoraka nakon završetka ispitivanja (vidjeti Sliku 3.41), može se primijetiti njihovo dobro podudaranje.

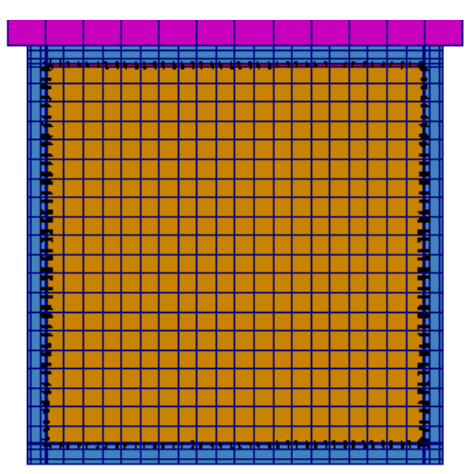

SF-1

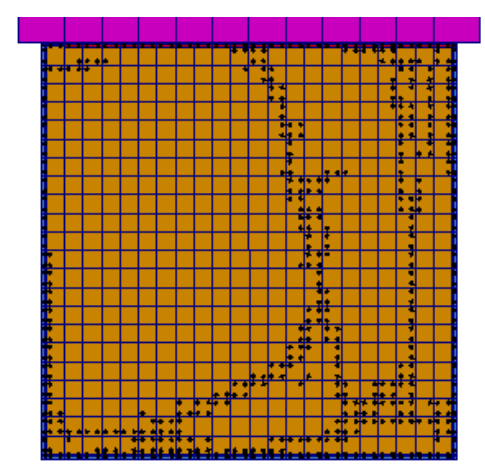

WF-1

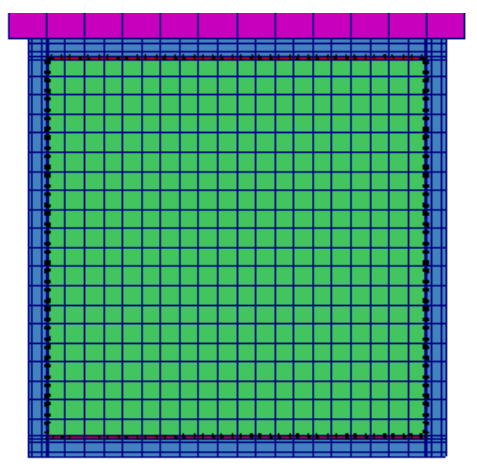

SF-2

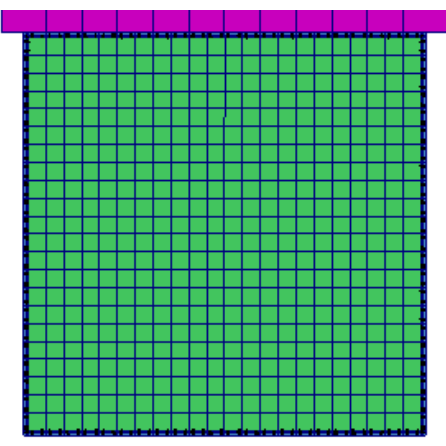

WF-2

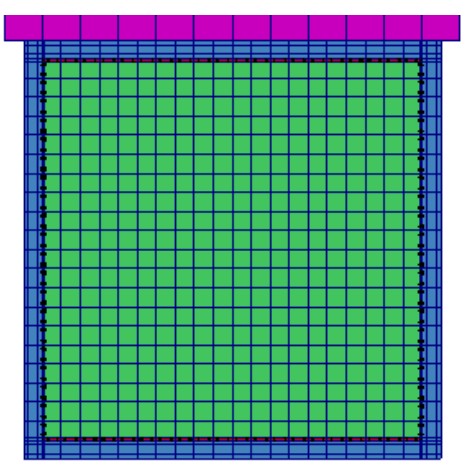

$\mathrm{SF}-3$

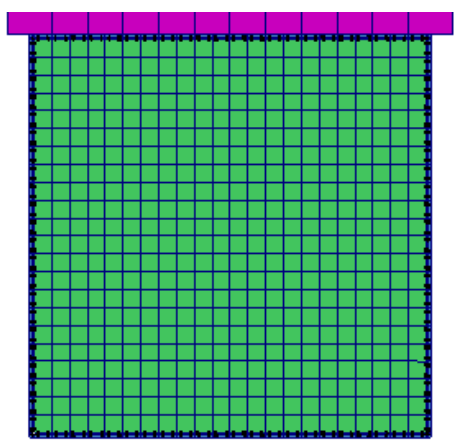

WF-3

Slika 5.27. Konačno stanje deformacija i pukotina u ziđu kod čeličnog okvira sa zidanom ispunom - numerička dinamička analiza 


\subsubsection{Simulacija dinamičkih ispitivanja betonskih okvira sa zidanom ispunom}

Provedena je numerička simulacija ponašanja uzoraka betonskih okvira sa zidanom ispunom na potresnoj platformi. Geometrijske karakteristike uzoraka, materijalna svojstva, opterećenje i rezultati ispitivanja opisani su detaljno u Poglavlju 3. Usvojena prostorna diskretizacija ispitanih okvira sa zidanom ispunom prikazana je na Slici 5.28. Korišteni su osnovni 2D elementi za simulaciju betona i ziđa, 1D štapni elementi unutar osnovnih 2D elemenata za simulaciju armature okvira, te 2D kontaktni elementi za simulaciju mogućeg odvajanja okvira $\mathrm{i}$ ispune. Istovremeno je modelirana uzdužna i poprečna armatura u okviru. Za simulaciju ziđa korišten je izotropni makromodel materijala. Usvojeni materijalni parametri za numeričku analizu prikazani su u Tablici 5.3.
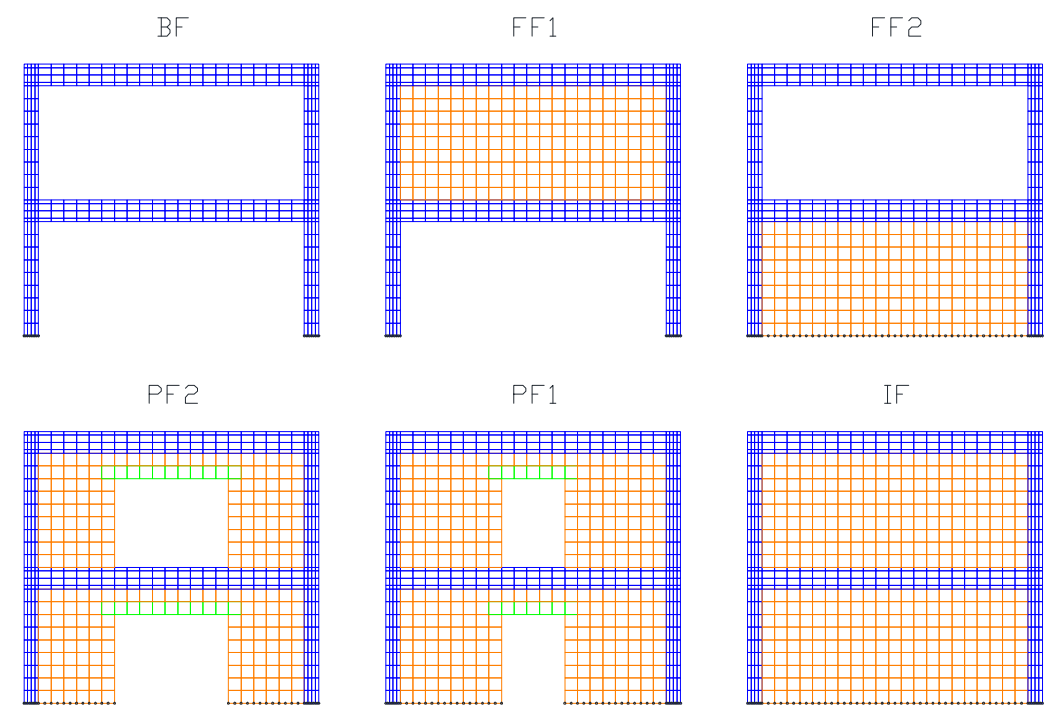

Slika 5.28. Usvojena prostorna diskretizacija razmatranih betonskih okvira sa zidanom ispunom

Tablica 5.3. Usvojeni parametri gradiva za numeričku analizu

\begin{tabular}{llllll}
\hline Varijabla & Jedinica & Materijal & & & \\
\cline { 3 - 6 } & & Beton & Ziđe & Armatura & Kontakt \\
\hline Modul elastičnosti & $\mathrm{MPa}$ & 30000 & 1020 & 200000 & 1020 \\
Poissonov koeficijent & - & 0.15 & 0.1 & - & - \\
Modul posmika & $\mathrm{MPa}$ & 13000 & 464 & - & 464 \\
Tlačna čvrstoća & $\mathrm{MPa}$ & 37.0 & 2.2 & 500.0 & 2.2 \\
Vlačna čvrstoća & $\mathrm{MPa}$ & 3.0 & 0.2 & 500.0 & 0.0 \\
Granična tlačna deformacija & - & 0.0035 & 0.0035 & 0.0100 & 0.0035 \\
Granična vlačna deformacija & - & 0.0010 & 0.0029 & 0.0100 & 0.0000 \\
\hline
\end{tabular}


Analizirani okviri su opterećeni vertikalnim stalnim opterećenjem od $3.0 \mathrm{kN} / \mathrm{m}^{1}$ na svakoj etaži, te izloženi horizontalnoj komponenti ubrzanja podloge. Pri tome su korišteni vremenski zapisi ostvarenih ubrzanja i pomaka platforme prilikom provedenih ispitivanja. Izmjerena ubrzanja i pomaci platforme vrlo se dobro slažu sa zadanim vrijednostima, što upućuje na njenu visoku preciznost i pouzdanost. Pobude su nanošene sukcesivno, analogno proceduri opisanoj u Poglavlju 3. Dakle, najprije su aplicirani umjetni akcelerogrami AA1 s maksimalnim ubrzanjima od 0.1 do $0.8 \mathrm{~g}$, a potom umjetni akcelerogrami AA2 s maksimalnim ubrzanjima od 0.1 do $0.4 \mathrm{~g}$.

Ubrzanje je aplicirano na donjem rubu konstrukcije (na mjestu pridržanja). Korištena je implicitna vremenska integracija s vremenskim inkrementom duljine približno 1/100 osnovnog perioda slobodnih vibracija razmatranih okvira. Pretpostavljeno je viskozno konstrukcijsko prigušenje u iznosu od $2 \%$. Za kriterij konvergencije iterativnog postupka, usvojena je norma prirasta pomaka od $0.1 \%$ u odnosu na normu tekućih ukupnih pomaka.

Za svaki aplicirani akcelerogram praćene su karakteristične vrijednosti pomaka, ubrzanja i deformacija, te stanja deformacija i pukotina u ziđu i betonu kao i kod provedenog eksperimenta. Svi rezultati su prezentirani grafički, te uspoređeni $\mathrm{s}$ utvrđenim eksperimentalnim rezultatima. U nastavku su prikazani samo neki dijagrami s usporedbom eksperimentalno utvrđenih i numerički dobivenih rezultata (vidjeti Slike 5.29-5.44). 


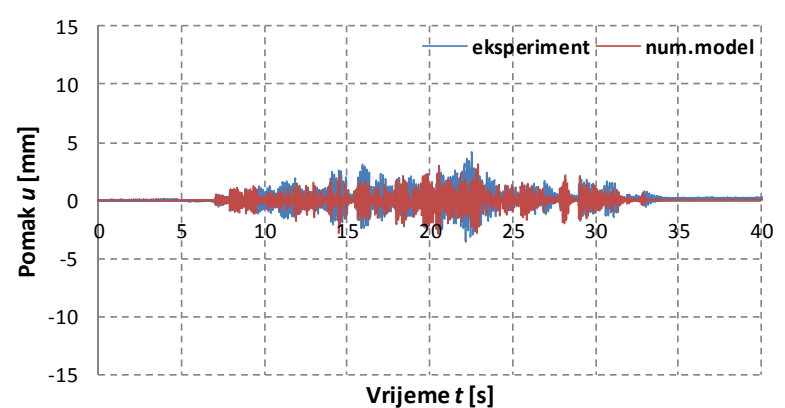

a) $\mathrm{a}_{\mathrm{g}, \max }=0.2 \mathrm{~g}$

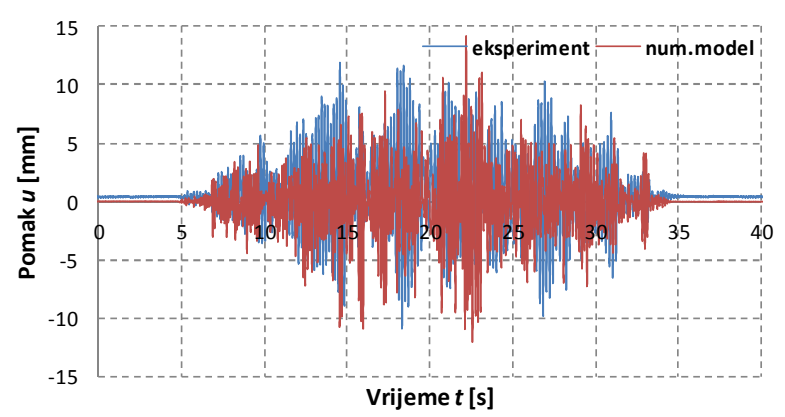

c) $\mathrm{a}_{\mathrm{g}, \max }=0.6 \mathrm{~g}$

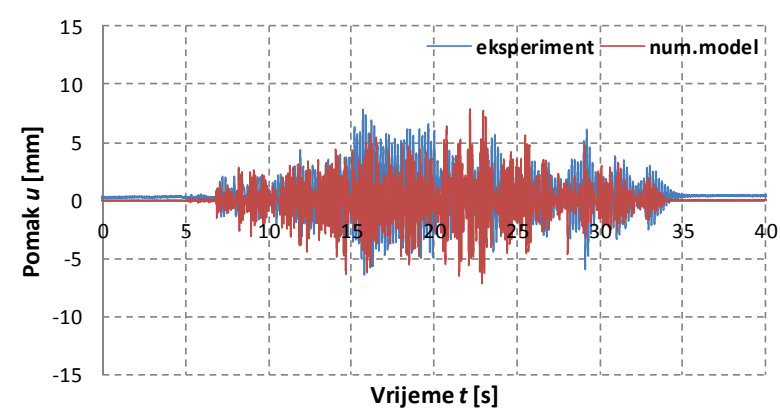

b) $\mathrm{a}_{\mathrm{g}, \max }=0.4 \mathrm{~g}$

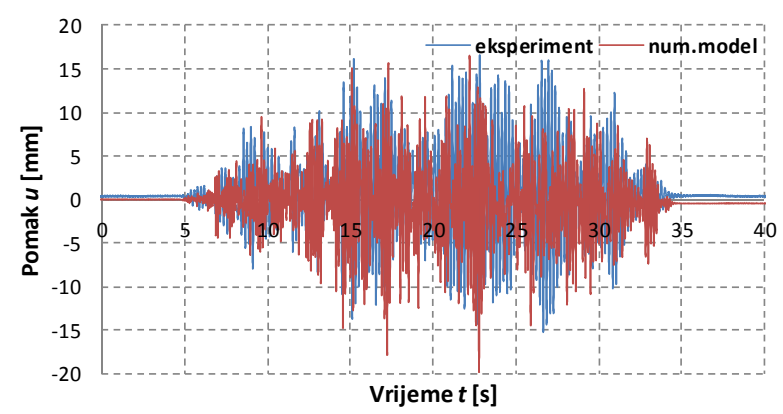

d) $\mathrm{a}_{\mathrm{g}, \max }=0.8 \mathrm{~g}$

Slika 5.29. Usporedba pomaka vrha gornje etaže okvira za uzorak BF

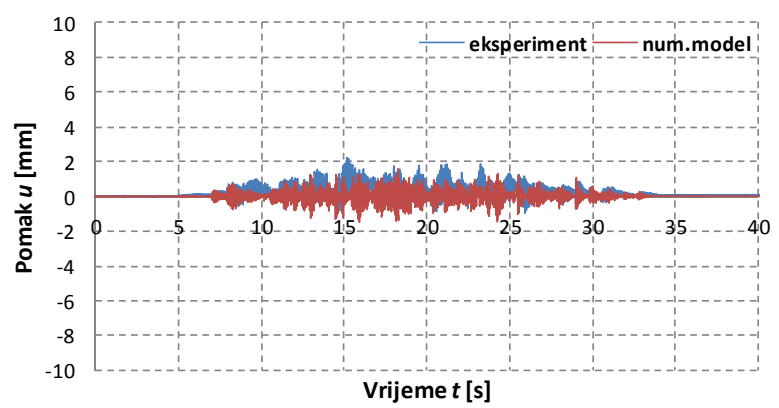

a) $\mathrm{a}_{\mathrm{g}, \max }=0.2 \mathrm{~g}$

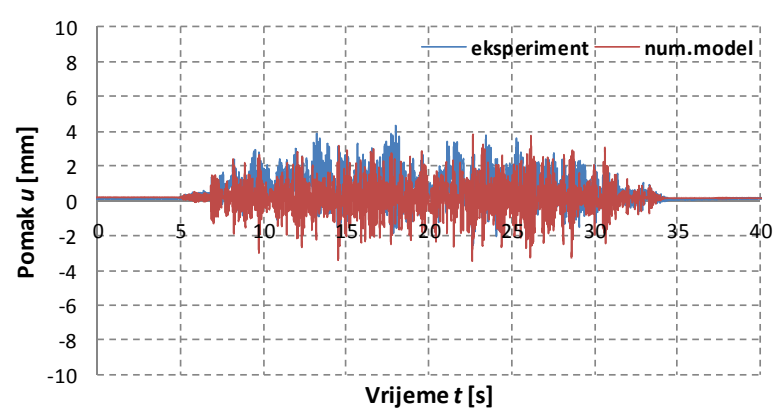

c) $\mathrm{a}_{\mathrm{g}, \max }=0.6 \mathrm{~g}$

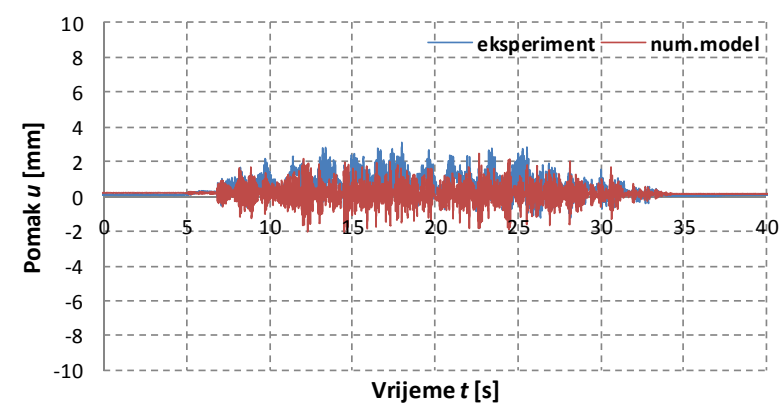

b) $\mathrm{a}_{\mathrm{g}, \max }=0.4 \mathrm{~g}$

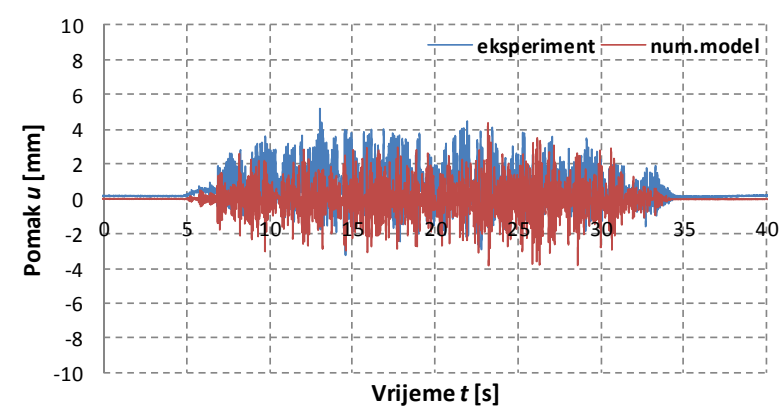

d) $\mathrm{a}_{\mathrm{g}, \max }=0.8 \mathrm{~g}$

Slika 5.30. Usporedba pomaka vrha gornje etaže okvira za uzorak FF2 


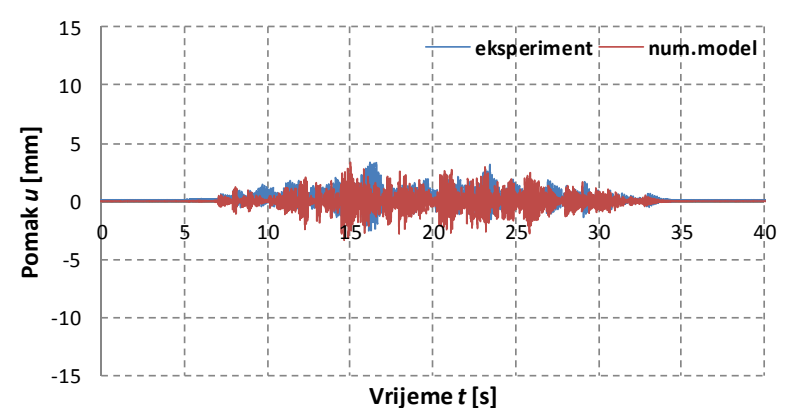

a) $\mathrm{a}_{\mathrm{g}, \text { max }}=0.2 \mathrm{~g}$

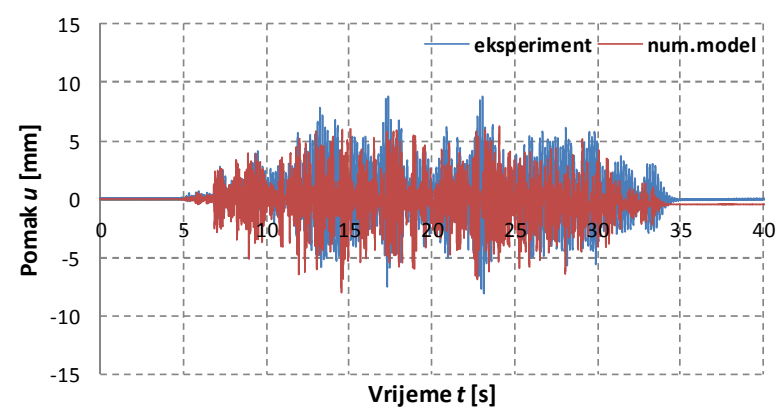

c) $\mathrm{a}_{\mathrm{g}, \text { max }}=0.6 \mathrm{~g}$

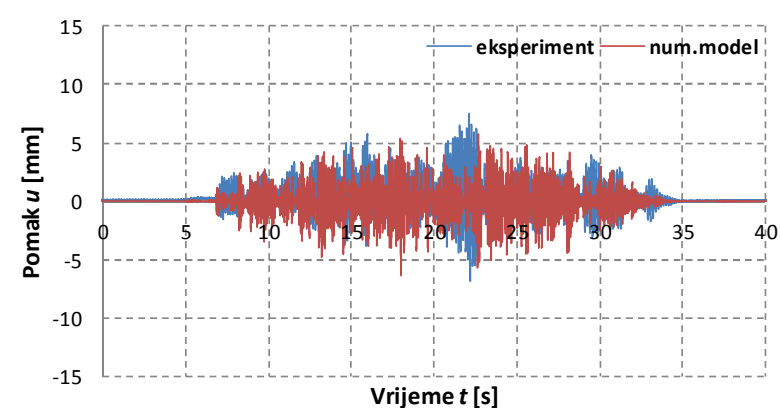

b) $\mathrm{a}_{\mathrm{g}, \max }=0.4 \mathrm{~g}$

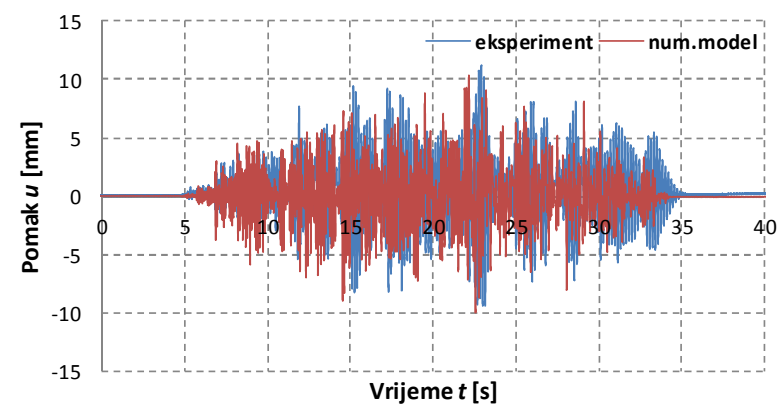

d) $\mathrm{a}_{\mathrm{g}, \max }=0.8 \mathrm{~g}$

Slika 5.31. Usporedba pomaka vrha gornje etaže okvira za uzorak FF1

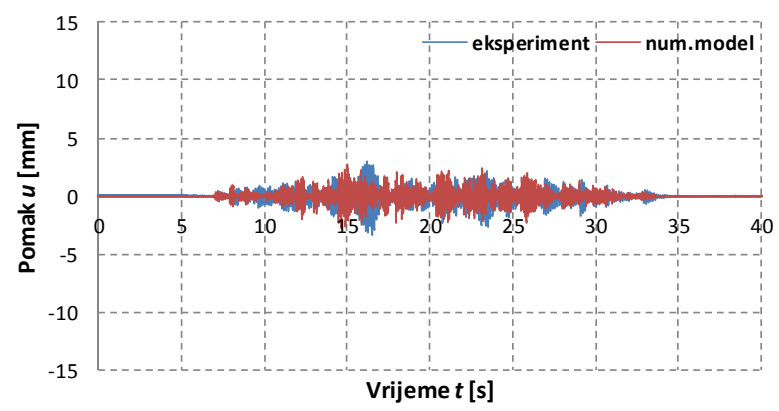

a) $\mathrm{a}_{\mathrm{g}, \max }=0.2 \mathrm{~g}$

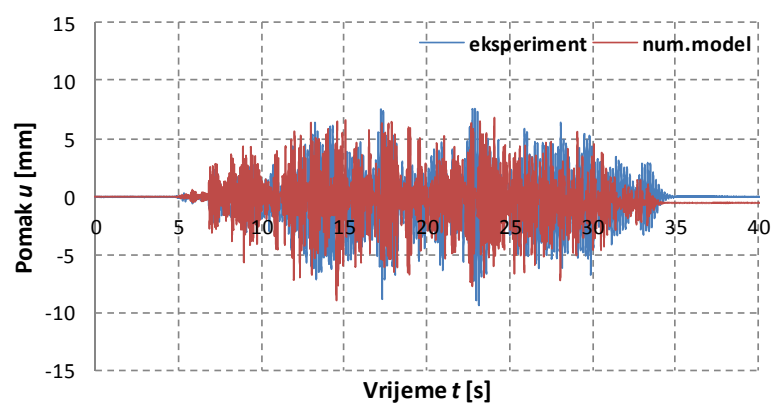

c) $\mathrm{a}_{\mathrm{g}, \max }=0.6 \mathrm{~g}$

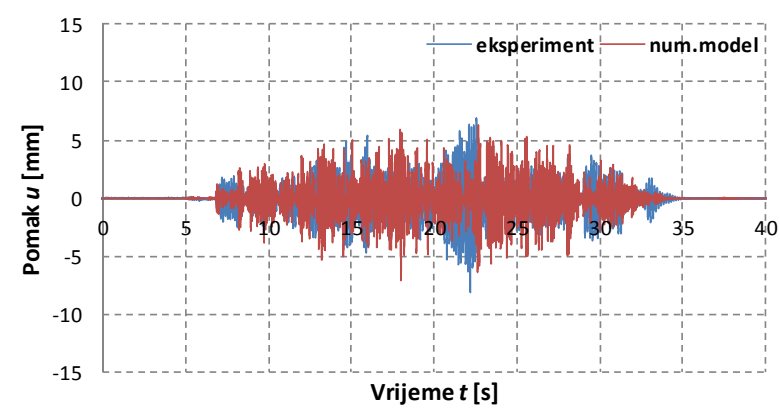

b) $\mathrm{a}_{\mathrm{g}, \max }=0.4 \mathrm{~g}$

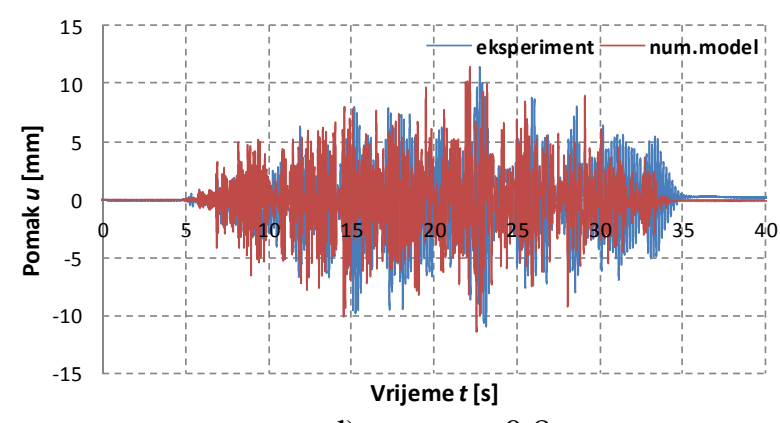

d) $\mathrm{a}_{\mathrm{g}, \max }=0.8 \mathrm{~g}$

Slika 5.32. Usporedba pomaka vrha donje etaže okvira za uzorak FF1 


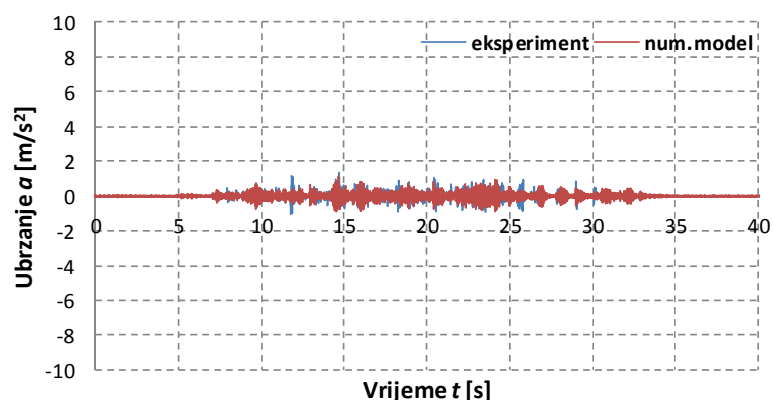

a) $\mathrm{a}_{\mathrm{g}, \max }=0.1 \mathrm{~g}$

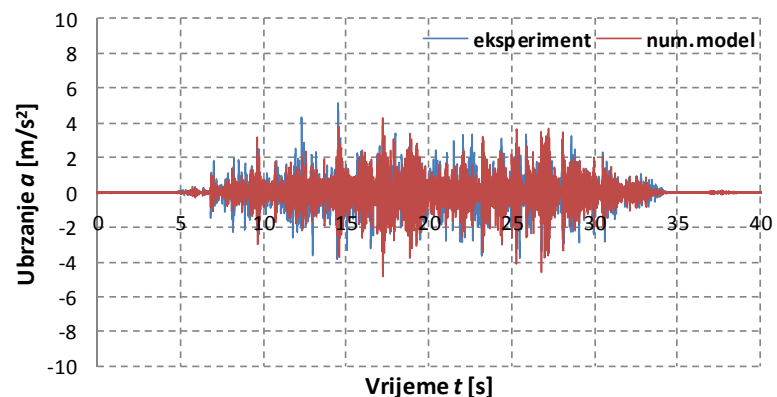

c) $\mathrm{a}_{\mathrm{g}, \max }=0.5 \mathrm{~g}$

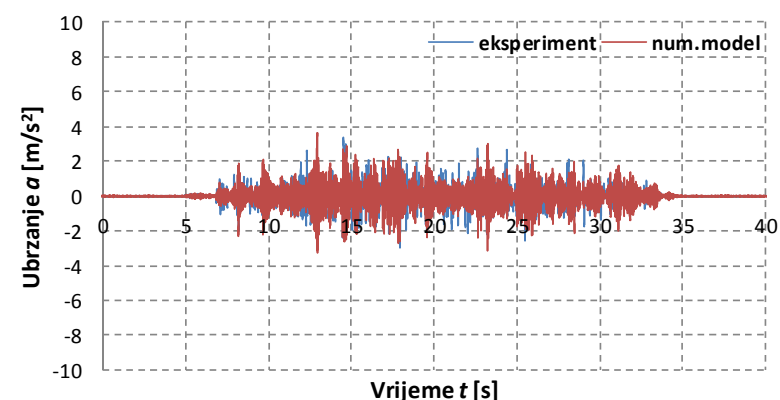

b) $\mathrm{a}_{\mathrm{g}, \max }=0.3 \mathrm{~g}$

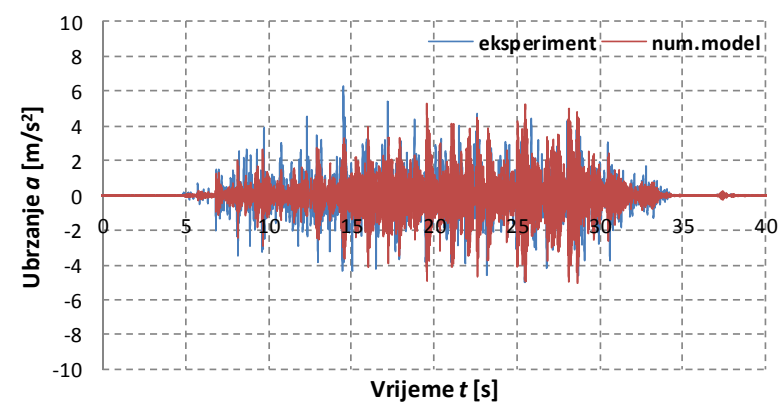

d) $\mathrm{a}_{\mathrm{g}, \max }=0.7 \mathrm{~g}$

Slika 5.33. Usporedba ubrzanja vrha gornje etaže okvira za uzorak PF2

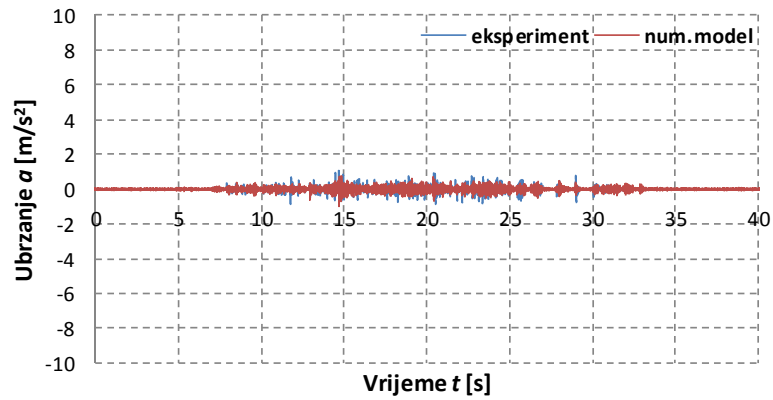

a) $\mathrm{a}_{\mathrm{g}, \max }=0.1 \mathrm{~g}$

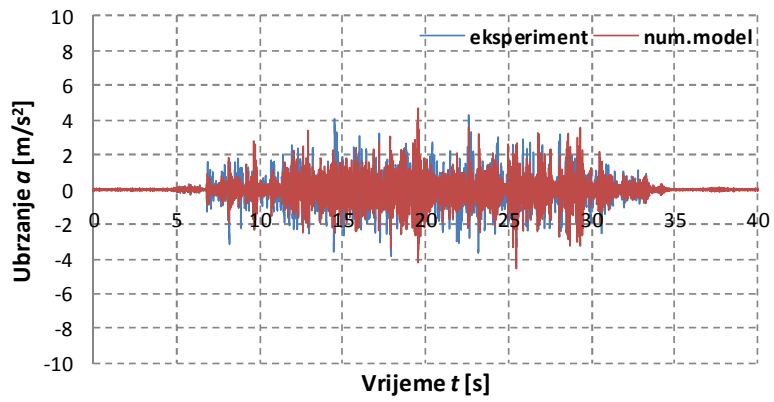

c) $\mathrm{a}_{\mathrm{g}, \max }=0.5 \mathrm{~g}$

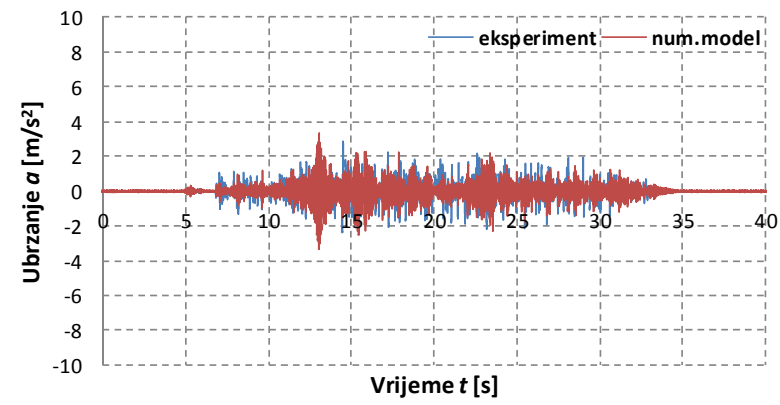

b) $\mathrm{a}_{\mathrm{g}, \max }=0.3 \mathrm{~g}$

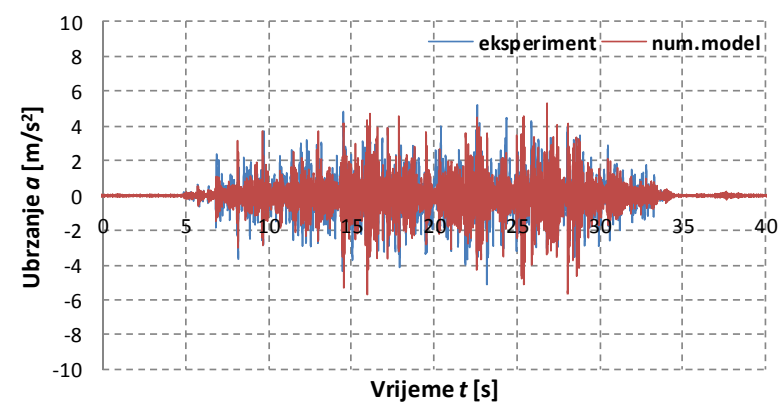

d) $\mathrm{a}_{\mathrm{g}, \max }=0.7 \mathrm{~g}$

Slika 5.34. Usporedba ubrzanja vrha gornje etaže okvira za uzorak IF 


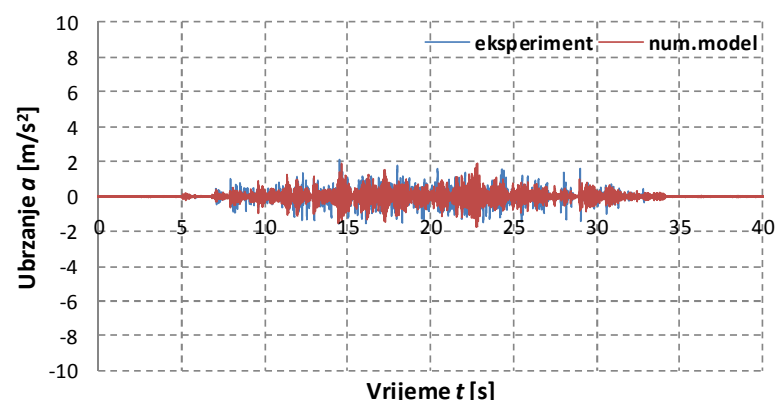

a) $\mathrm{a}_{\mathrm{g}, \max }=0.2 \mathrm{~g}$

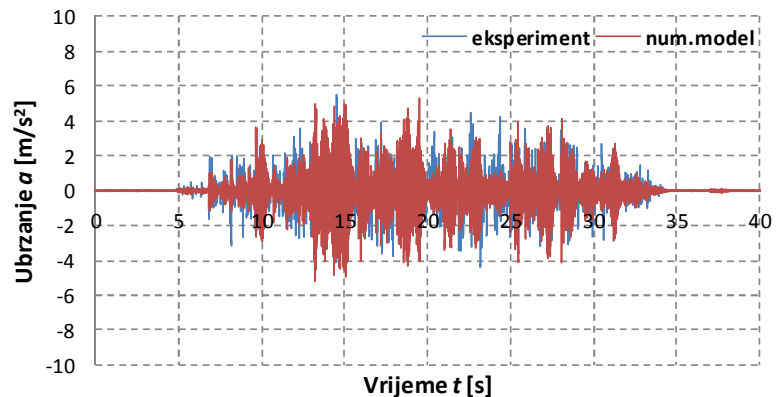

c) $\mathrm{a}_{\mathrm{g}, \text { max }}=0.6 \mathrm{~g}$

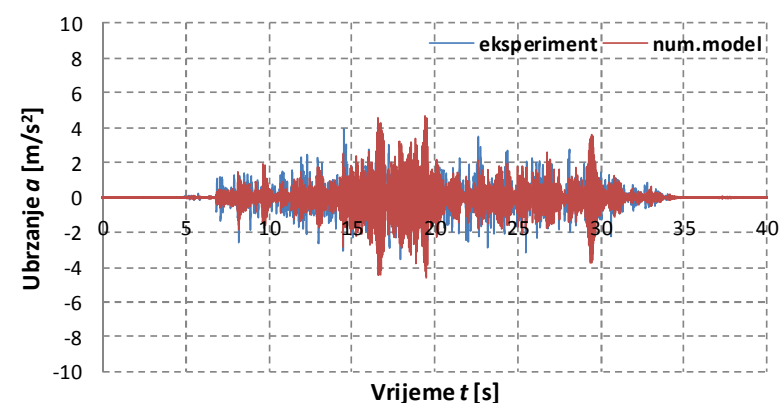

b) $\mathrm{a}_{\mathrm{g}, \max }=0.4 \mathrm{~g}$

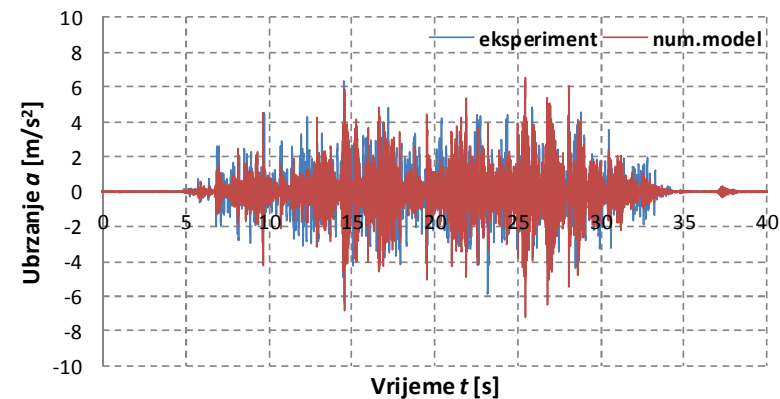

d) $\mathrm{a}_{\mathrm{g}, \max }=0.8 \mathrm{~g}$

Slika 5.35. Usporedba ubrzanja vrha donje etaže okvira za uzorak PF1

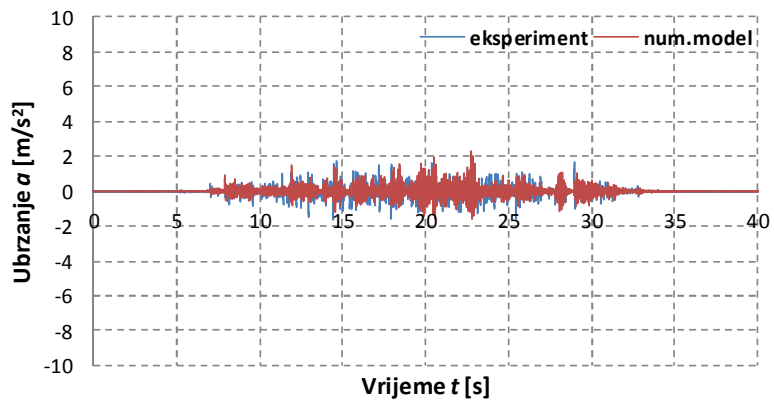

a) $\mathrm{a}_{\mathrm{g}, \max }=0.2 \mathrm{~g}$

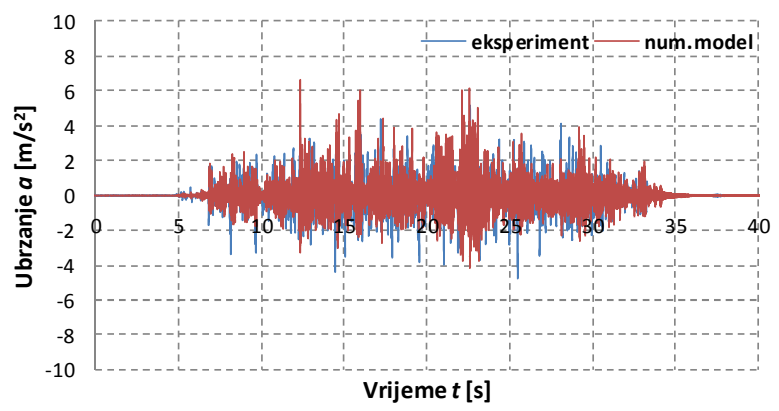

c) $\mathrm{a}_{\mathrm{g}, \max }=0.6 \mathrm{~g}$

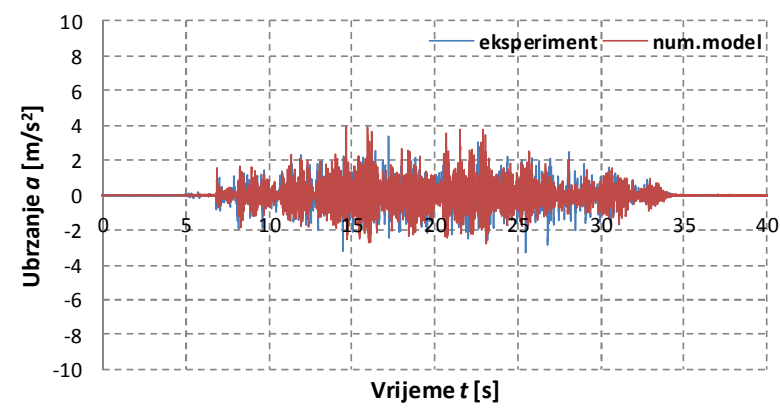

b) $\mathrm{a}_{\mathrm{g}, \max }=0.4 \mathrm{~g}$

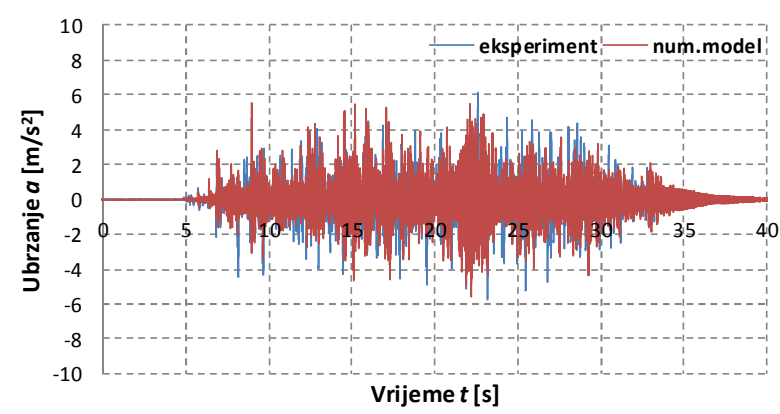

d) $\mathrm{a}_{\mathrm{g}, \max }=0.8 \mathrm{~g}$

Slika 5.36. Usporedba ubrzanja vrha donje etaže okvira za uzorak BF 


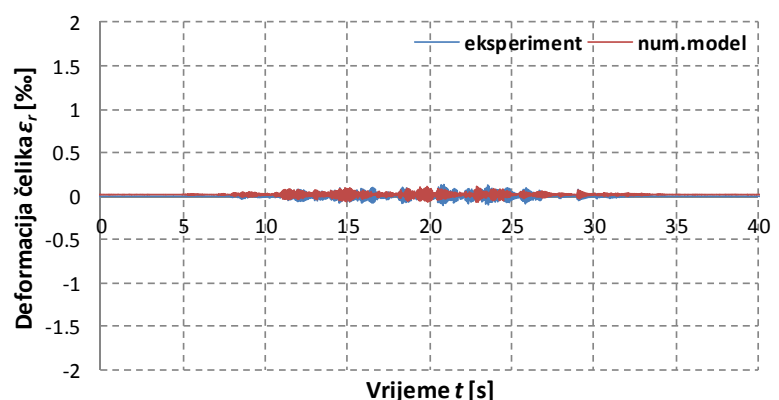

a) $\mathrm{a}_{\mathrm{g}, \max }=0.1 \mathrm{~g}$

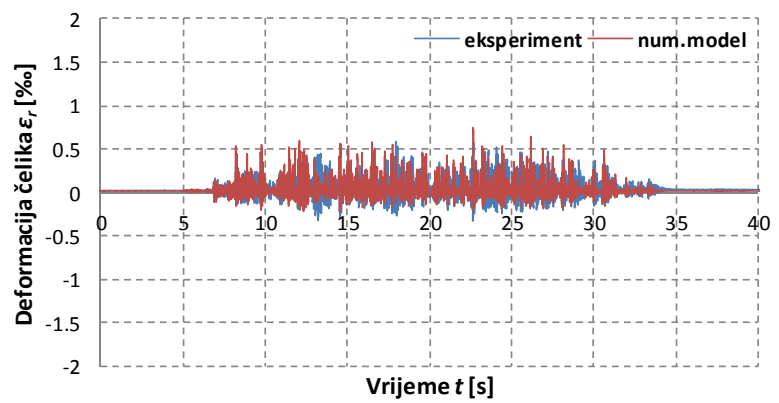

c) $\mathrm{a}_{\mathrm{g}, \max }=0.5 \mathrm{~g}$

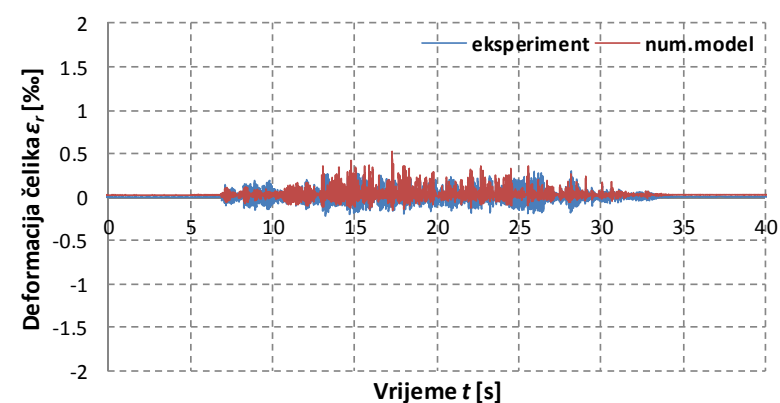

b) $\mathrm{a}_{\mathrm{g}, \max }=0.3 \mathrm{~g}$

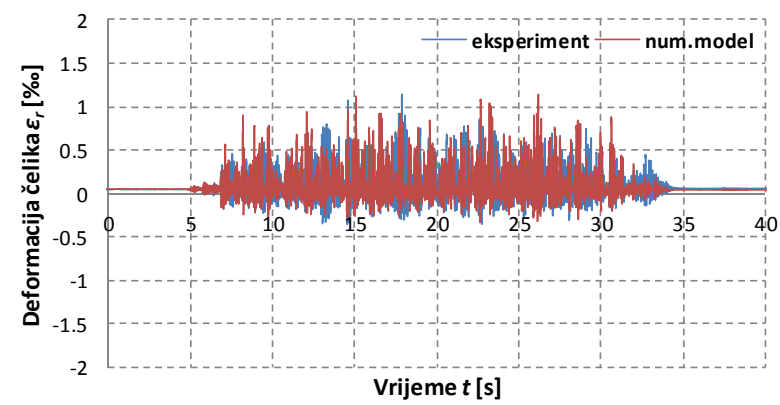

d) $\mathrm{a}_{\mathrm{g}, \max }=0.7 \mathrm{~g}$

Slika 5.37. Usporedba deformacija armature pri dnu stupa gornje etaže okvira (točka A) za uzorak FF2

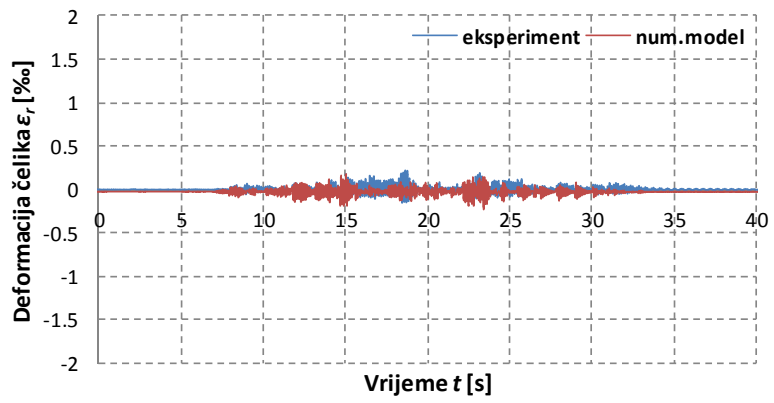

a) $\mathrm{a}_{\mathrm{g}, \max }=0.1 \mathrm{~g}$

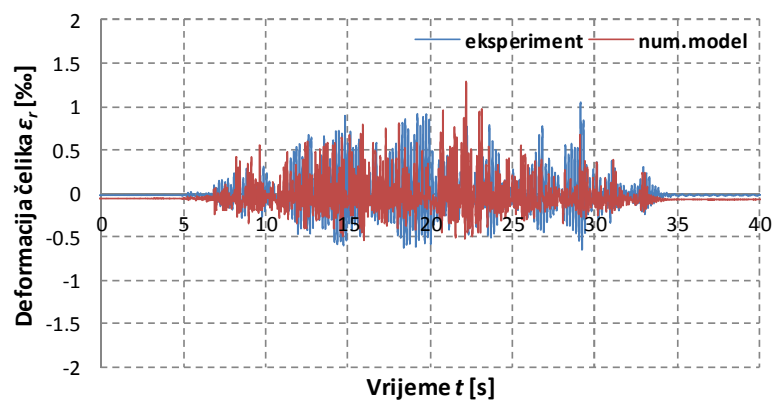

c) $\mathrm{a}_{\mathrm{g}, \max }=0.5 \mathrm{~g}$

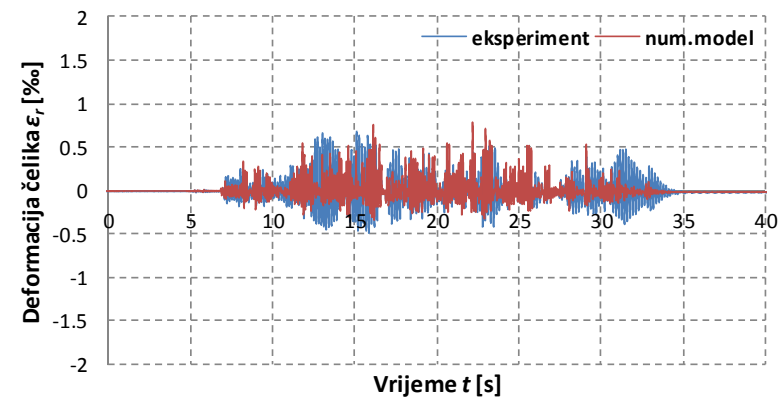

b) $\mathrm{a}_{\mathrm{g}, \max }=0.3 \mathrm{~g}$

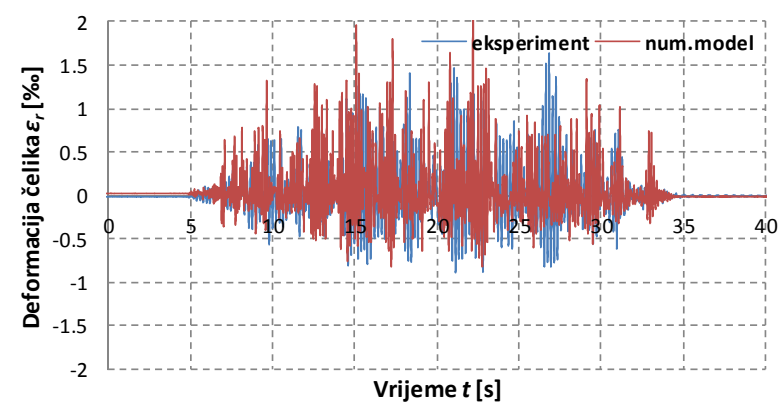

d) $\mathrm{a}_{\mathrm{g}, \max }=0.7 \mathrm{~g}$

Slika 5.38. Usporedba deformacija armature pri dnu stupa donje etaže okvira (točka B) za uzorak BF 


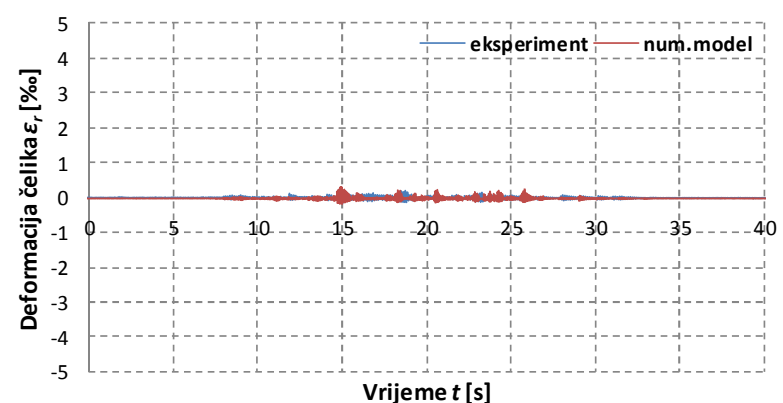

a) $\mathrm{a}_{\mathrm{g}, \max }=0.1 \mathrm{~g}$

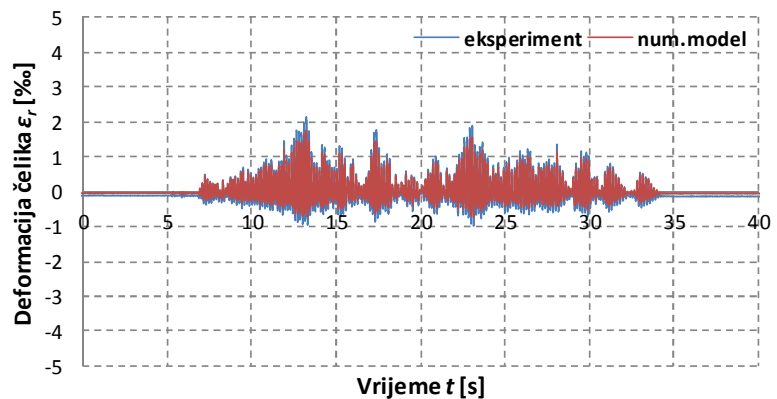

c) $\mathrm{a}_{\mathrm{g}, \max }=0.5 \mathrm{~g}$

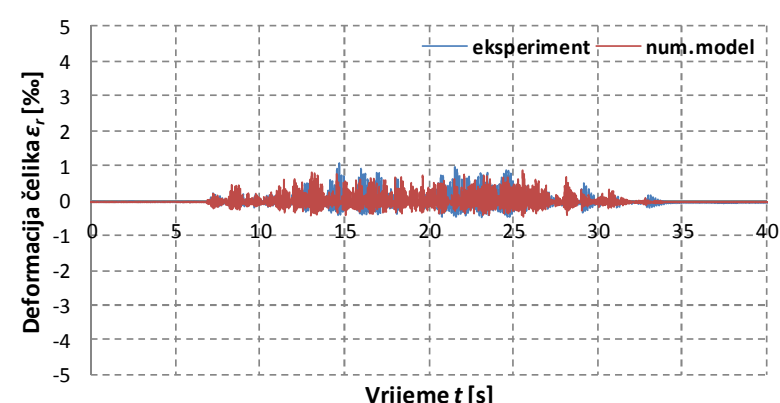

b) $\mathrm{a}_{\mathrm{g}, \max }=0.3 \mathrm{~g}$

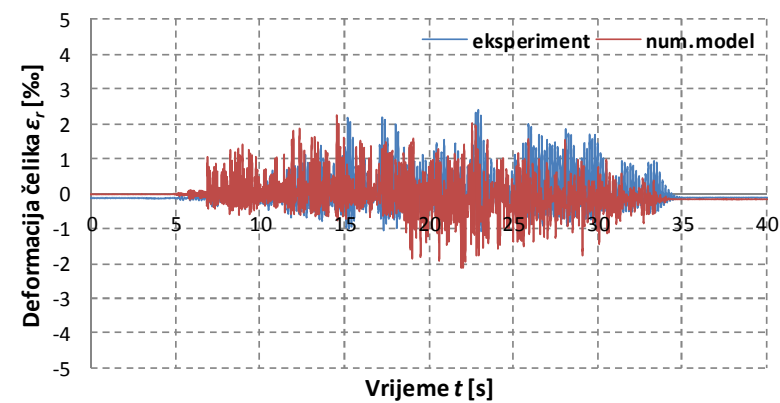

d) $\mathrm{a}_{\mathrm{g}, \max }=0.7 \mathrm{~g}$

Slika 5.39. Usporedba deformacija armature pri dnu stupa donje etaže okvira (točka C) za uzorak FF1

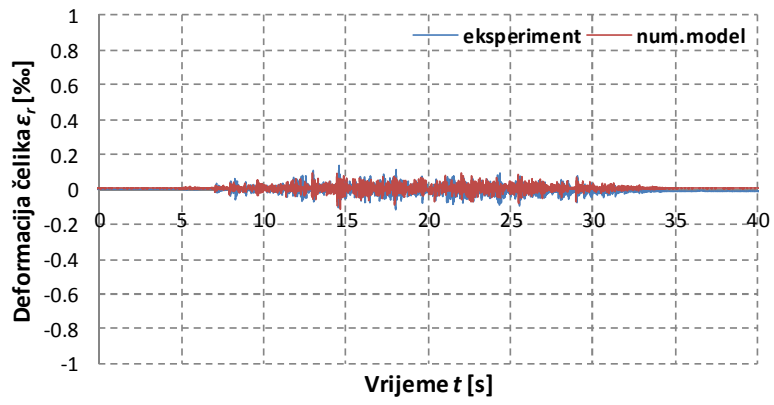

a) $\mathrm{a}_{\mathrm{g}, \max }=0.2 \mathrm{~g}$

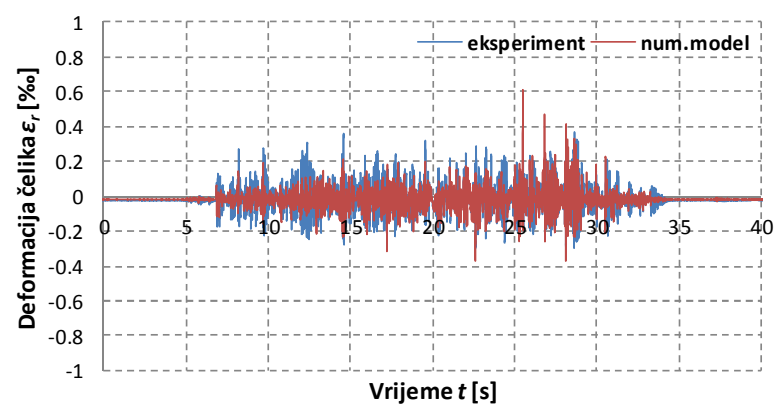

c) $\mathrm{a}_{\mathrm{g}, \max }=0.6 \mathrm{~g}$

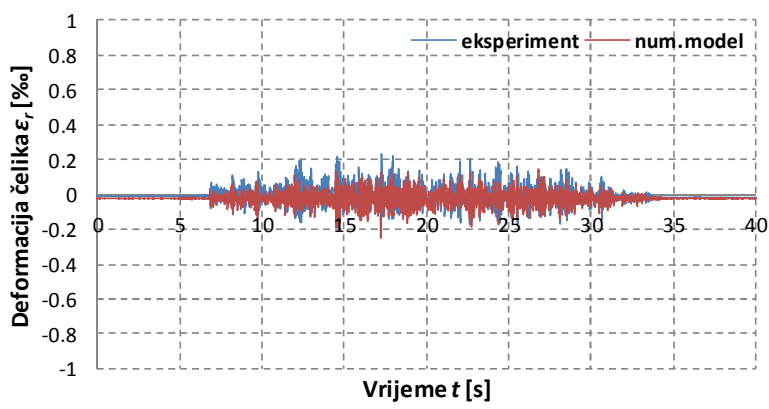

b) $\mathrm{a}_{\mathrm{g}, \max }=0.4 \mathrm{~g}$

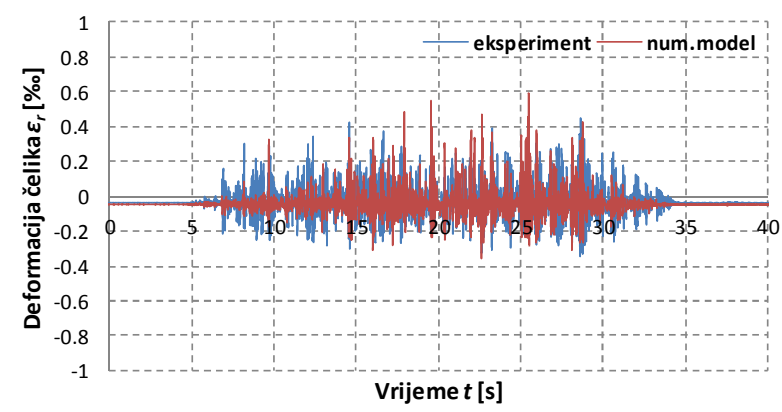

d) $\mathrm{a}_{\mathrm{g}, \max }=0.8 \mathrm{~g}$

Slika 5.40. Usporedba deformacija armature pri dnu stupa donje etaže okvira (točka B) za uzorak PF2 


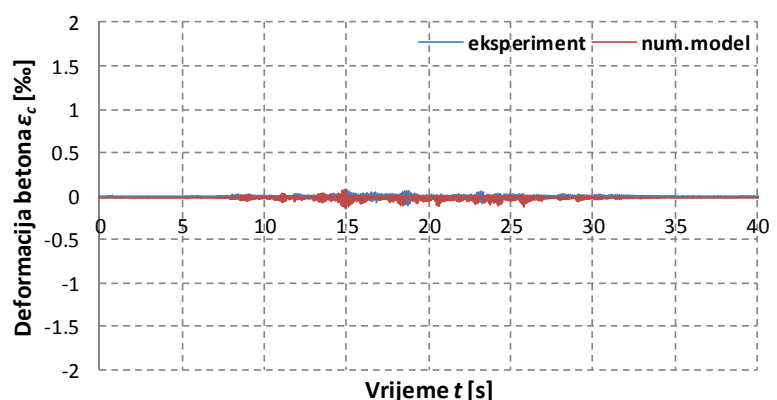

a) $\mathrm{a}_{\mathrm{g}, \max }=0.1 \mathrm{~g}$

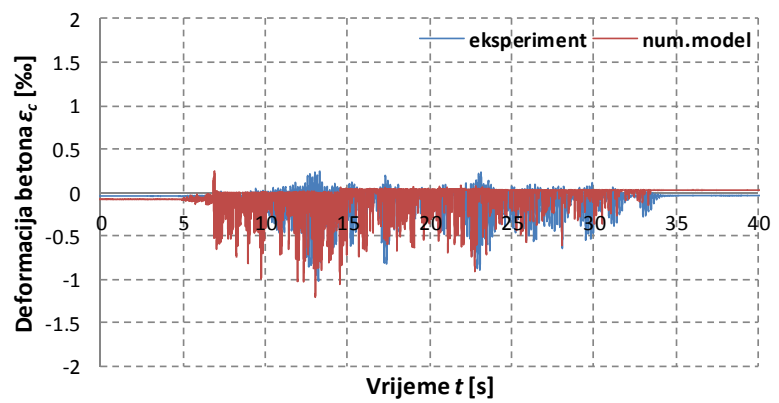

c) $\mathrm{a}_{\mathrm{g}, \max }=0.5 \mathrm{~g}$

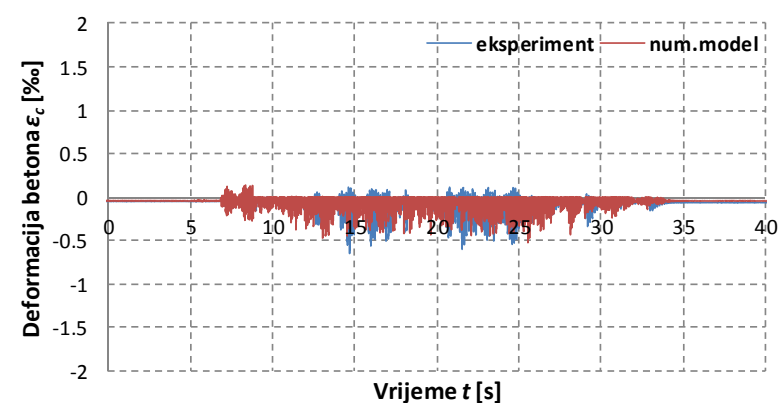

b) $\mathrm{a}_{\mathrm{g}, \max }=0.3 \mathrm{~g}$

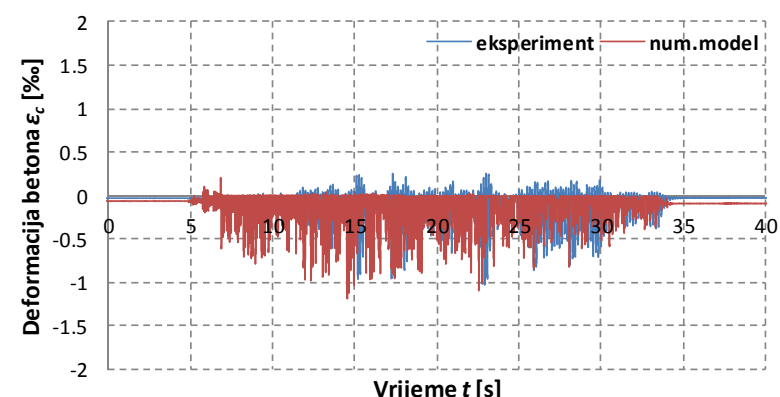

d) $\mathrm{a}_{\mathrm{g}, \max }=0.7 \mathrm{~g}$

Slika 5.41. Usporedba deformacija betona pri dnu stupa donje etaže okvira (točka D) za uzorak FF1

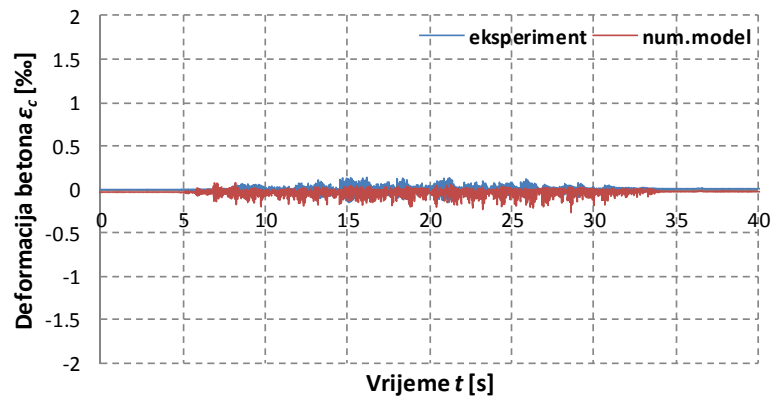

a) $\mathrm{a}_{\mathrm{g}, \max }=0.2 \mathrm{~g}$

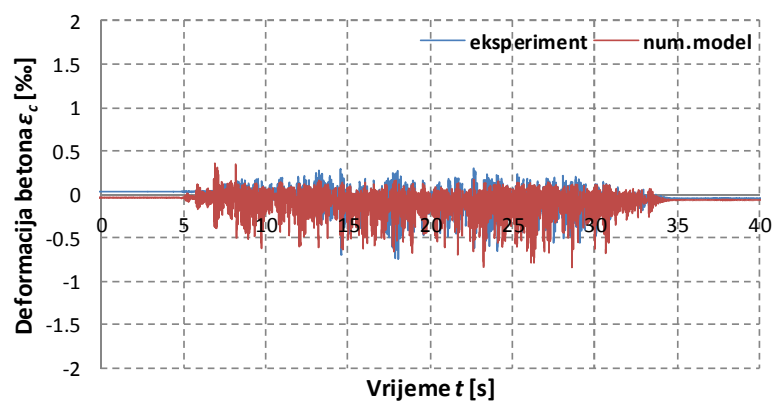

c) $\mathrm{a}_{\mathrm{g}, \max }=0.6 \mathrm{~g}$

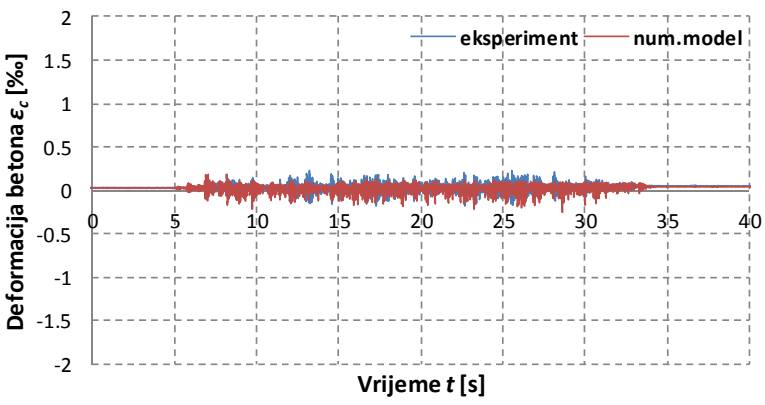

b) $\mathrm{a}_{\mathrm{g}, \max }=0.4 \mathrm{~g}$

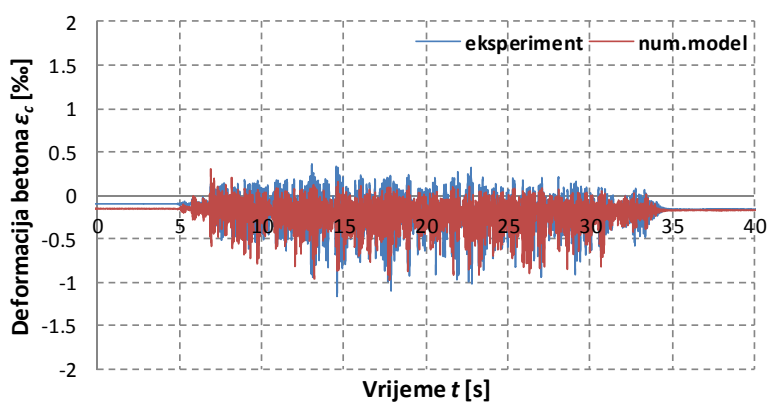

d) $\mathrm{a}_{\mathrm{g}, \max }=0.8 \mathrm{~g}$

Slika 5.42. Usporedba deformacija betona pri dnu stupa gornje etaže okvira (točka E) za uzorak FF2 


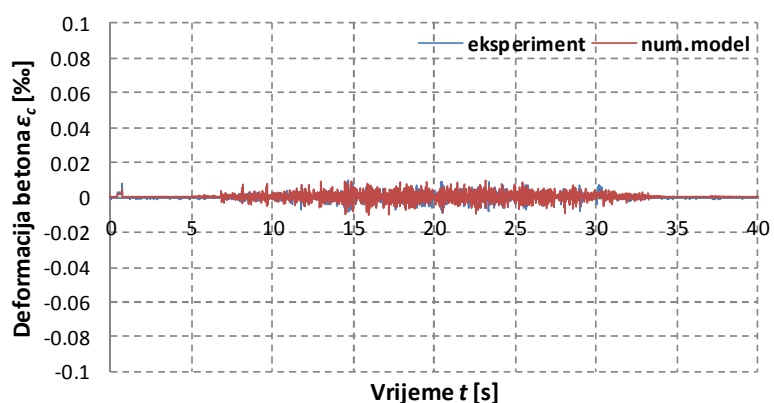

a) $\mathrm{a}_{\mathrm{g}, \max }=0.1 \mathrm{~g}$

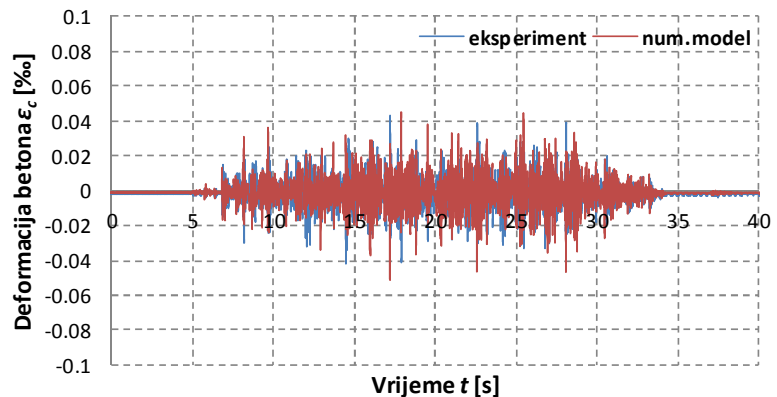

c) $\mathrm{a}_{\mathrm{g}, \max }=0.5 \mathrm{~g}$

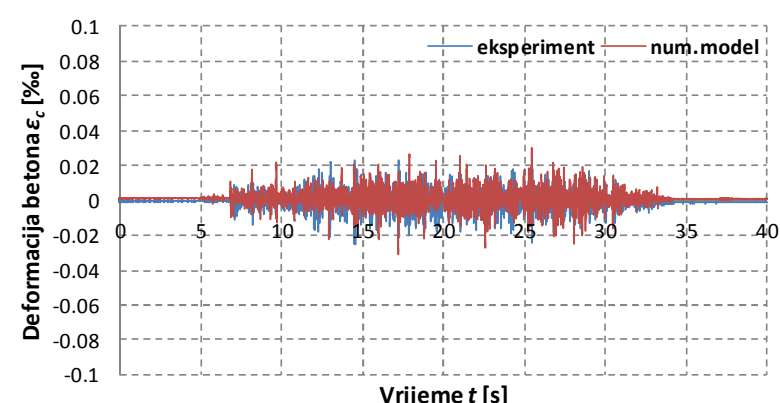

b) $\mathrm{a}_{\mathrm{g}, \max }=0.3 \mathrm{~g}$

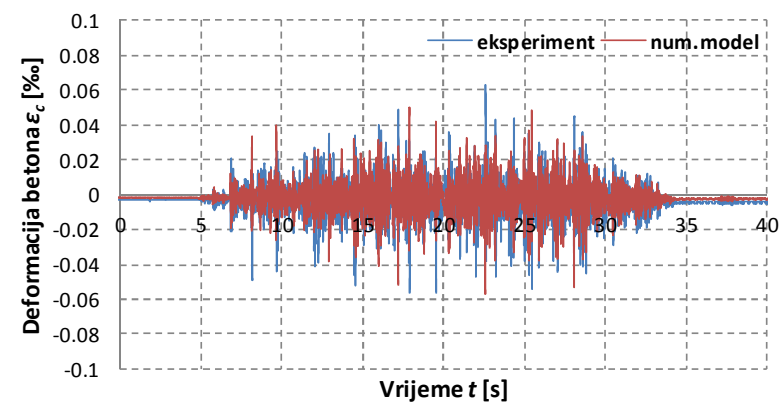

d) $\mathrm{a}_{\mathrm{g}, \max }=0.7 \mathrm{~g}$

Slika 5.43. Usporedba deformacija betona pri dnu stupa donje etaže okvira (točka F) za uzorak PF1

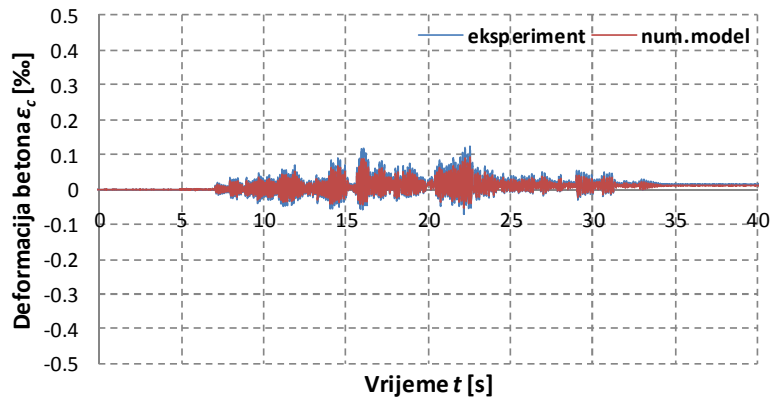

a) $\mathrm{a}_{\mathrm{g}, \max }=0.2 \mathrm{~g}$

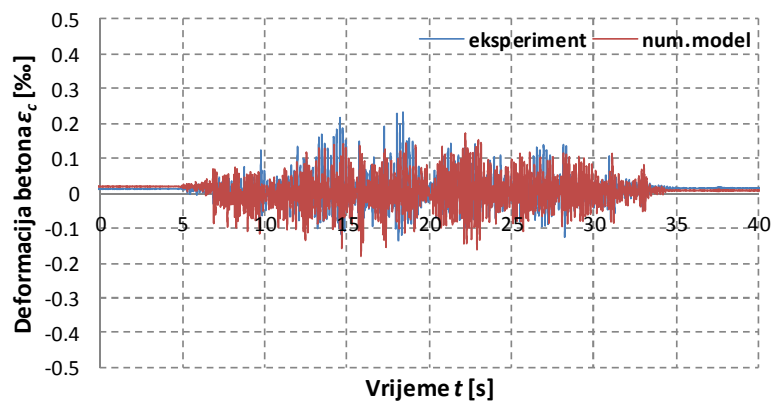

c) $\mathrm{a}_{\mathrm{g}, \max }=0.6 \mathrm{~g}$

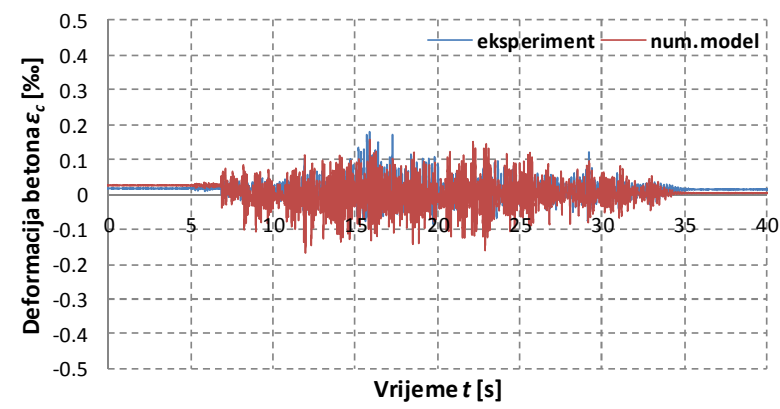

b) $\mathrm{a}_{\mathrm{g}, \max }=0.4 \mathrm{~g}$

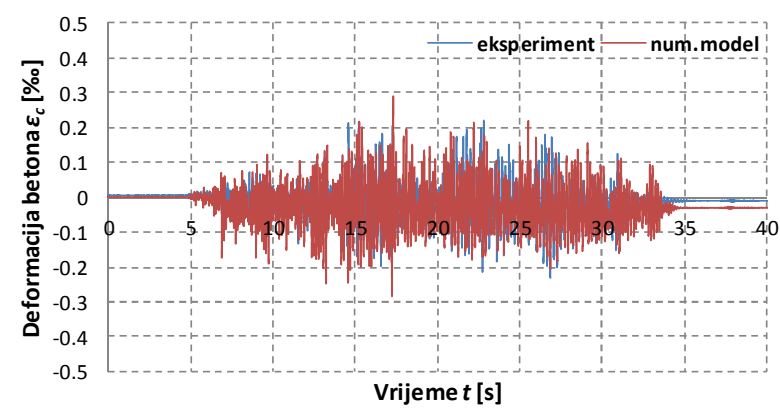

d) $\mathrm{a}_{\mathrm{g}, \max }=0.8 \mathrm{~g}$

Slika 5.44. Usporedba deformacija betona pri dnu stupa gornje etaže okvira (točka G) za uzorak BF 
Usporedbom eksperimentalno utvrđenih i numerički dobivenih rezultata, može se primijetiti njihovo dobro podudaranje. Naravno, i ovdje kod nekih krivulja postoje odstupanja, što je u prethodnom potpoglavlju već objašnjeno.

Konačno stanje deformacija i pukotina u betonu i ziđu dobiveno pomoću numeričke dinamičke analize armiranobetonskih okvira sa zidanom ispunom prikazano je na Slici 5.45. Usporedbom s fotografijama uzoraka nakon završetka ispitivanja (vidjeti Sliku 3.80), može se primijetiti njihovo dobro podudaranje.

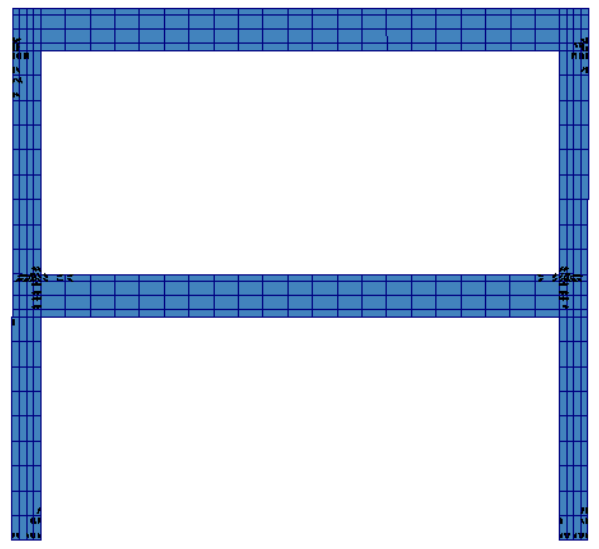

a) $\mathrm{BF}$

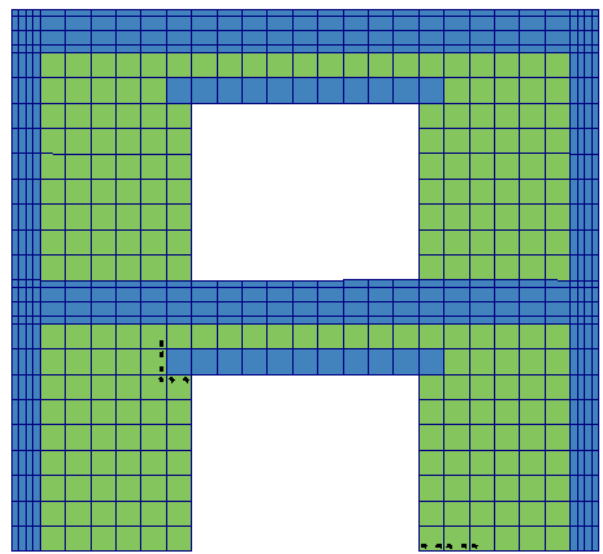

c) PF2

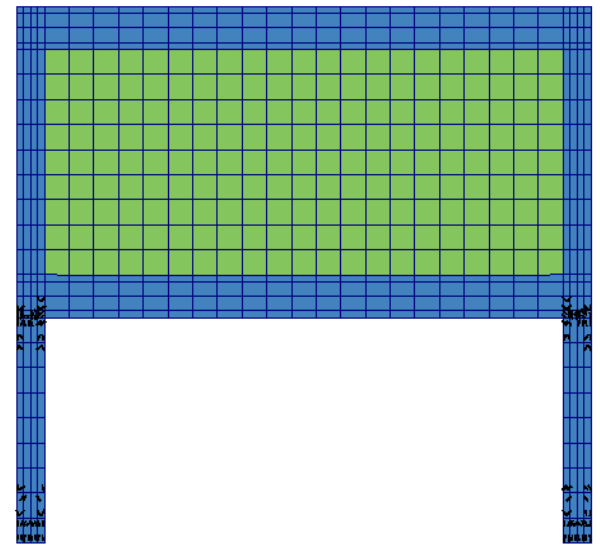

b) FF1

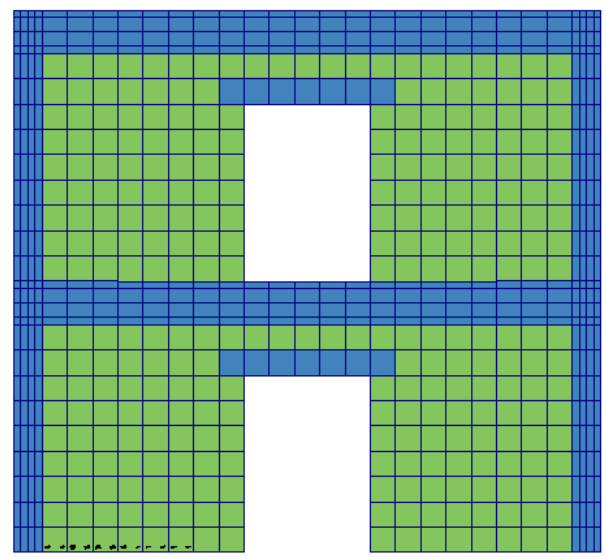

d) PF1

Slika 5.45. Konačno stanje deformacija i pukotina u betonskim okvirima sa zidanom ispunom - numerička dinamička analiza 


\subsection{Zaključak}

Pomoću prethodno provedenih eksperimenata i eksperimenata drugih autora izvršena je verifikacija razvijenog numeričkog modela za statičku i dinamičku analizu ravninskih armiranobetonskih i čeličnih okvira sa zidanom ispunom. Dobiveni rezultati pomoću numeričke analize dobro se slažu s eksperimentalno utvrđenim rezultatima. Ovo upućuje na pouzdanost razvijenog numeričkog modela koji može korisno poslužiti u analizi praktičnih armiranobetonskih i čeličnih okvira s ispunom. Naravno, svaka daljnja provjera razvijenog modela pomoću rezultata eksperimentalnih ispitivanja složenih inženjerskih konstrukcija je svakako dobrodošla. 


\section{PARAMETARSKE NUMERIČKE ANALIZE}

\subsection{Općenito}

U ovom je Poglavlju prikazana provedena numerička dinamička analiza troetažnog okvira sa zidanom ispunom pri potresu, kako bi se ilustrirala moguća primjena razvijenog numeričkog modela i istražili neki utjecajni faktori takvih konstrukcija. Analizirano je pet tipova okvira, s različitim položajem i krutosti ispune. Okvir je proračunat u skladu s važećim propisima. Aplicirano je pet različitih potresa, skaliranih na maksimalno ubrzanje od $0.3 \mathrm{~g}$. Karakteristične veličine (pomaci, ubrzanja, naprezanja i sl.) dobivene pomoću numeričke analize prikazani su grafički. Na ovaj način, numerički je istražen utjecaj više parametara na ponašanje okvira sa zidanom ispunom pri djelovanju potresa. Na kraju su dani najvažniji zaključci istraživanja. Primjeri nekih numeričkih analiza pomoću razvijenog numeričkog modela mogu se naći u $[3,6,7]$. 


\subsection{Primjer numeričke analize troetažnog okvira}

\subsubsection{Geometrija}

Osnovni podaci analiziranih troetažnih jednopoljnih armiranobetonskih okvira sa zidanom ispunom prikazani su na Slici 6.1. Razmatrani su slučajevi čistog okvira (bez ispune), okvira s ispunom na svim etažama te okvira s fleksibilnim prizemljem (ispuna samo na gornjim etažama). Varirana su dva tipa ispune, tj. razmatrano je ziđe bolje kvalitete (kruto ziđe) i lošije kvalitete (meko ziđe). Koriste se sljedeće oznake za analizirane konstrukcije:

F čisti armiranobetonski okvir

$\mathrm{IF}_{\mathrm{rs}} \quad$ armiranobetonski okvir s krutim ziđem na svim etažama

$\mathrm{IF}_{\mathrm{rw}} \quad$ armiranobetonski okvir s mekim ziđem na svim etažama

$\mathrm{IF}_{\mathrm{fs}} \quad$ armiranobetonski okvir s fleksibilnim prizemljem i krutim ziđem na gornjim etažama

$\mathrm{IF}_{\mathrm{fw}}$ armiranobetonski okvir s fleksibilnim prizemljem i mekim ziđem na gornjim etažama

Konstrukcije su prethodno dimenzionirane prema Hrvatskim normama [115], koje su u skladu s Europskim normama [147]. Korišteno je proračunsko ubrzanje tla iznosa 0.3 g. Usvojen je faktor ponašanja $q=3.6$. Pri dimenzioniranju i numeričkoj analizi kod čistog okvira F, krutost i čvrstoća ispune ne doprinose ukupnoj nosivosti konstrukcije. Usvojena armatura prikazana je na Slici 6.1. Istovremeno se modelira uzdužna i poprečna armatura. Pretpostavlja se da su razmatrane konstrukcije oslonjene na krutu podlogu, s mogućnošću odizanja temelja. Prostorna diskretizacija razmatranih okvira prikazana je na Slici 6.2.
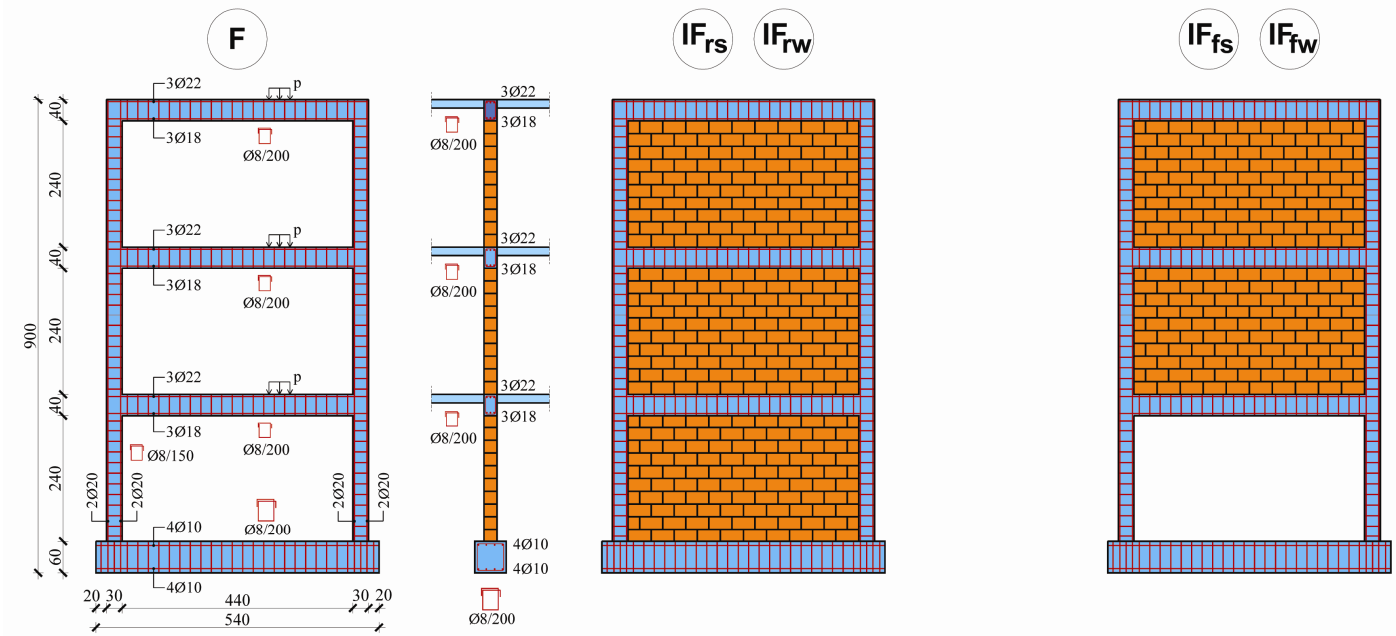

Slika 6.1. Analizirani troetažni okviri 

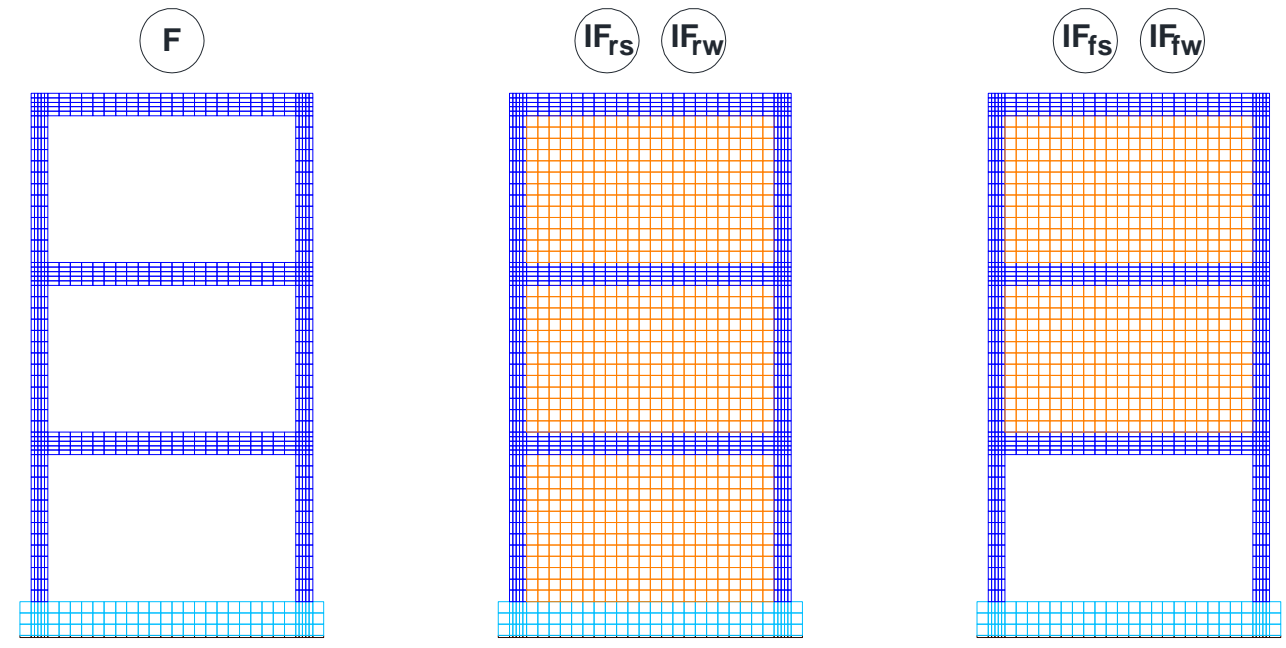

Slika 6.2. Prostorna diskretizacija analiziranog okvira

\subsubsection{Opterećenje}

Sve konstrukcije su prethodno analizirane za gravitacijska opterećenja, uzimajući u obzir izgradnju okvira sa zidanom ispunom u različitim fazama. Konstrukcije su opterećene vlastitom težinom i dodatnim stalnim opterećenjem iznosa $p=35 \mathrm{kN} / \mathrm{m}$ na svakoj etaži. Pri tome se napominje kako zidana ispuna ne doprinosi krutosti i otpornosti čitave konstrukcije za slučaj čistog okvira F, već služi samo kao masa.

Nakon toga je provedena dinamička analiza uzimajući u obzir početna naponskodeformacijska stanja svake analizirane konstrukcije. Konstrukcije su izložene horizontalnoj komponenti ubrzanja podloge, s maksimalnim ubrzanjem $0.3 \mathrm{~g}$ (prema proračunskom ubrzanju podloge). Korišteni su skalirani akcelerogrami prikazani na Slici 6.3, s odgovarajućim Fourierovim transformacijama. Izabrano je pet različitih potresa koji uzrokuju visoke nelinearnosti u konstrukciji.

Proračunati prvi vlastiti periodi i frekvencije analiziranih konstrukcija dani su u Tablici 6.1, gdje M predstavlja ukupnu težinu konstrukcije (uključujući temelj).

Tablica 6.1. Prvi periodi, vlastite frekvencije i ukupna težina analiziranih konstrukcija

\begin{tabular}{lllllll}
\hline Varijabla & \multirow{2}{*}{ Jedinica } & \multicolumn{2}{l}{ Oznaka } & & & \\
\cline { 3 - 7 } & & $\mathrm{F}$ & $\mathrm{IF}_{\mathrm{rs}}$ & $\mathrm{IF}_{\mathrm{rw}}$ & $\mathrm{IF}_{\mathrm{fs}}$ & $\mathrm{IF}_{\mathrm{fw}}$ \\
\hline $\mathrm{T}_{1}$ & $\mathrm{~s}$ & 0.44 & 0.11 & 0.19 & 0.30 & 0.33 \\
$\omega_{1}$ & $\mathrm{~Hz}$ & 14.24 & 58.01 & 33.79 & 20.79 & 19.32 \\
$\mathrm{M}$ & $\mathrm{kN}$ & 622 & 622 & 622 & 596 & 596 \\
\hline
\end{tabular}



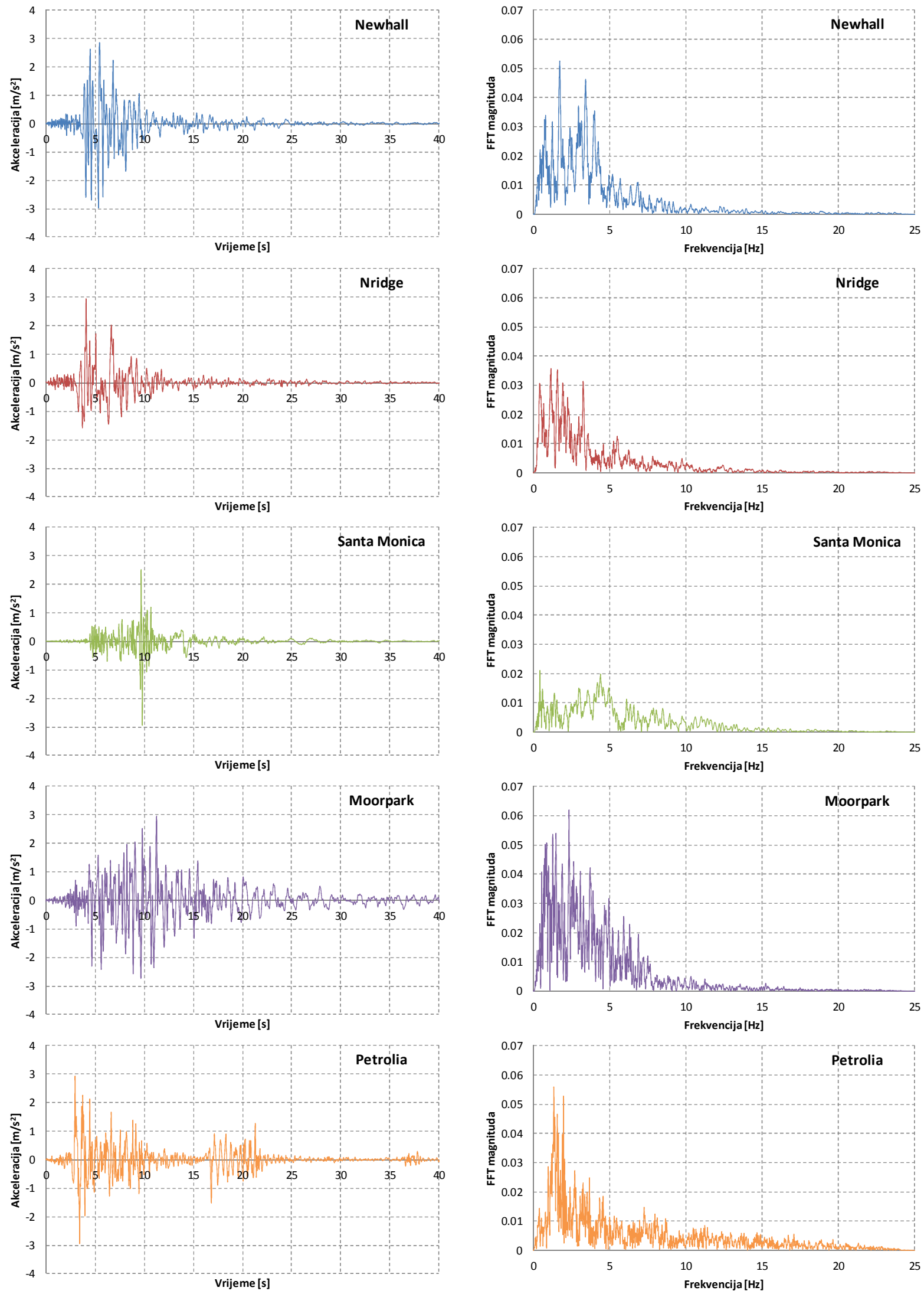

a) Akcelerogram potresa

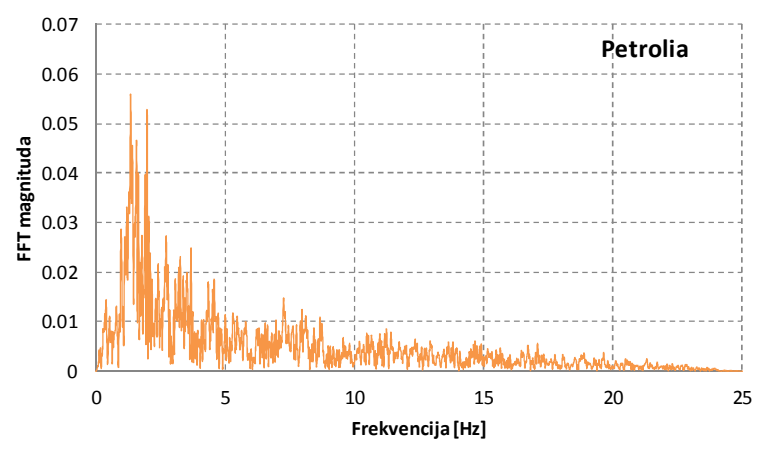

b) Fourierova transformacija (FFT)

Slika 6.3. Skalirane horizontalne komponente akcelerograma potresa s odgovarajućim Fourierovim transformacijama 


\subsubsection{Svojstva materijala}

Usvojeni parametri materijala u numeričkoj analizi prikazani su u Tablici 6.2. Koristi se izotropni makromodel materijala za simulaciju ziđa. Napominje se kako su prema normama [115] usvojena maksimalna naprezanja za beton $\sigma_{\mathrm{c}}=23 \mathrm{MPa}$ i armaturu $\sigma_{\mathrm{s}}=500 \mathrm{MPa}$, dok u numeričkom modelu naprezanja mogu dosegnuti stvarne čvrstoće materijala $\left(\sigma_{\mathrm{s}} \leq 600 \mathrm{MPa}\right.$, $\sigma_{\mathrm{c}} \leq 30 \mathrm{MPa}$ ). U ovom radu, kruto ziđe predstavlja ziđe s većom tlačnom, vlačnom i posmičnom čvrstoćom, te s većim modulima elastičnosti i posmika. Ista analogija vrijedi i za meko ziđe. Usvojeno je da kruto ziđe ima pet puta veće parametre krutosti i čvrstoća u odnosu na meko ziđe.

Tablica 6.2. Usvojeni parametri materijala za numeričku analizu

\begin{tabular}{lllllll}
\hline Varijabla & \multirow{2}{*}{ Jedinica } & \multicolumn{2}{l}{ Materijal } & & & \\
\cline { 3 - 7 } & & Beton & Čelik & $\begin{array}{l}\text { Kruto } \\
\text { ziđe }\end{array}$ & $\begin{array}{l}\text { Meko } \\
\text { ziđe }\end{array}$ & Kontakt \\
\hline Modul elastičnosti & $\mathrm{MPa}$ & 30000 & 200000 & 5000 & 1000 & 30000 \\
Poissonov koeficijent & - & 0.2 & - & 0.1 & 0.1 & - \\
Modul posmika & $\mathrm{MPa}$ & 12500 & - & 1000 & 200 & 12500 \\
Tlačna čvrstoća & $\mathrm{MPa}$ & 30 & 600 & 5 & 1 & 30 \\
Vlačna čvrstoća & $\mathrm{MPa}$ & 3 & 600 & 0.15 & 0.03 & 0 \\
Granična tlačna deformacija & - & -0.0035 & -0.02 & -0.01 & -0.01 & -0.0035 \\
Granična vlačna deformacija & - & 0.001 & 0.02 & 0.0003 & 0.0003 & 0 \\
\hline
\end{tabular}

\subsubsection{Neki aspekti numeričke analize}

Korišteni su osnovni 2D elementi za simulaciju tla, temelja, okvira i ispune, te 2D kontaktni elementi na spoju temelja s tlom. Pri tome je korištena $2 \times 2$ Gauss-ova integracija. Armatura je modelirana 1D štapnim elementima unutar osnovnih elemenata. Ubrzanje je aplicirano na donjem rubu ispod tla (na mjestu pridržanja). Korištena je implicitna vremenska integracija s vremenskim inkrementom duljine približno 1/100 osnovnog perioda slobodnih vibracija razmatranih okvira. Za kriterij konvergencije iterativnog postupka, usvojena je norma prirasta pomaka od $0.1 \%$ u odnosu na normu tekućih ukupnih pomaka. Usvojeno je viskozno konstrukcijsko prigušenje u iznosu od $2 \%$. Za svaki vremenski inkrement praćene su karakteristične vrijednosti pomaka, ubrzanja i deformacija armature i betona, ukupna inercijalna sila na konstruckiju, te stanje pukotina u okviru i ispuni. 


\subsubsection{Rezultati analize}

Horizontalni pomak vrha razmatranih okvira prikazan je na Slici 6.4. Može se primijetiti kako svaka konstrukcija ima različit odgovor ovisno o apliciranoj pobudi. Ovdje dolazi do kolapsa okvira s fleksibilnim prizemljem $\mathrm{IF}_{\mathrm{fs}}$ i $\mathrm{IF}_{\mathrm{fw}}$ uslijed djelovanja nekih potresa. Stoga ove konstrukcije ne posjeduju dovoljnu sigurnost, iako su proračunate u skladu s postojećim propisima [115]. Čisti okvir F ima veće pomake obzirom da je mekša konstrukcija. Krute konstrukcije $\mathrm{IF}_{\mathrm{rs}}$ i $\mathrm{IF}_{\mathrm{rw}}$, koje imaju podjednaku krutost, imaju podjednake manje pomake.

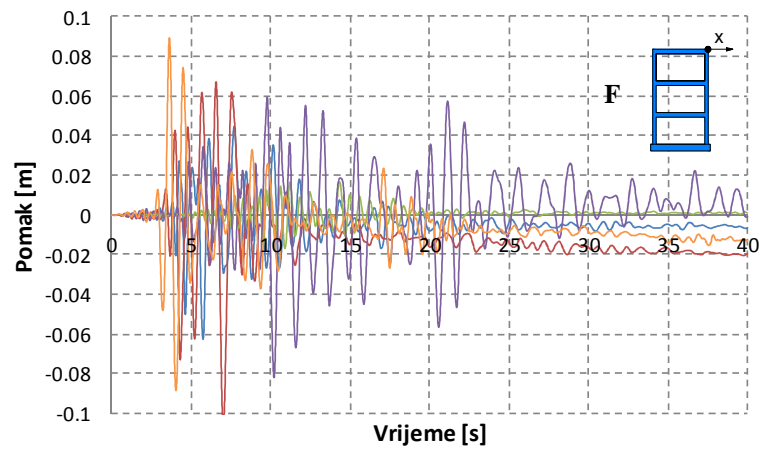

Legenda:
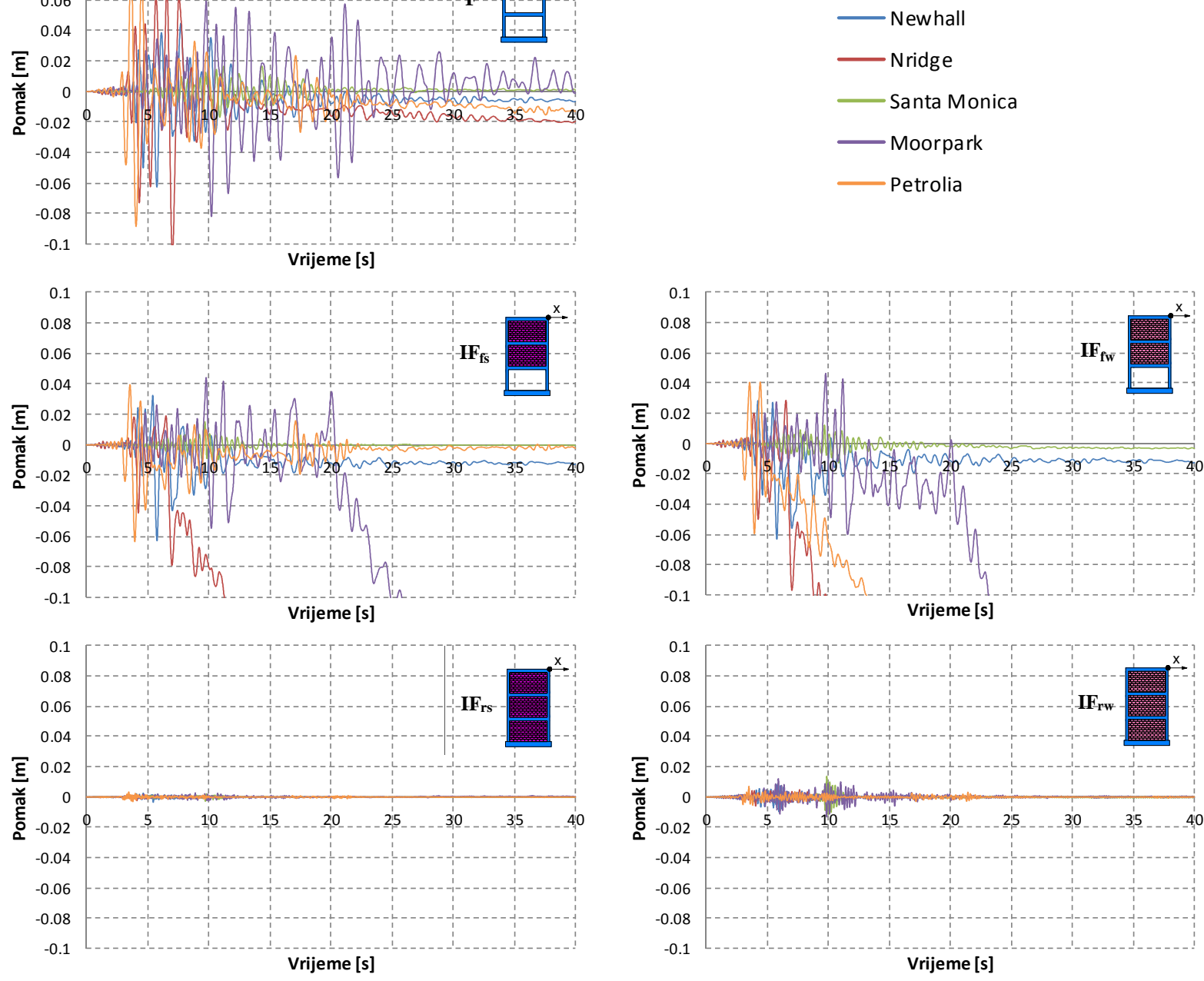

Slika 6.4. Horizontalni pomak vrha razmatranih okvira u vremenu 
Horizontalno ubrzanje (relativno u odnosu na bazu) vrha razmatranih okvira prikazano je na Slici 6.5.

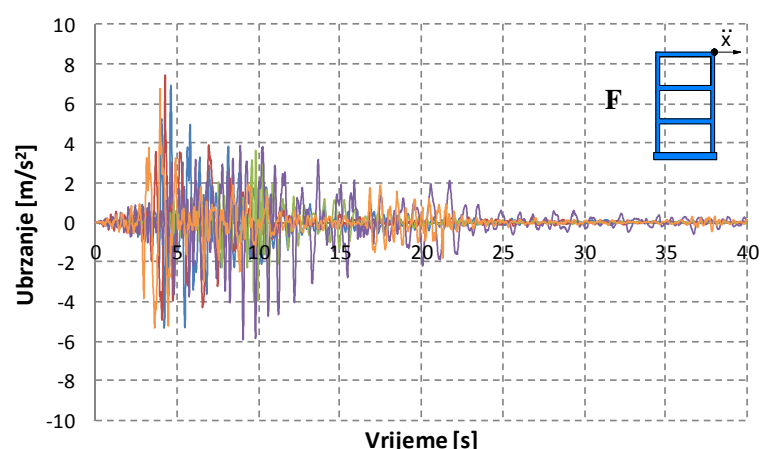

\section{Legenda:}

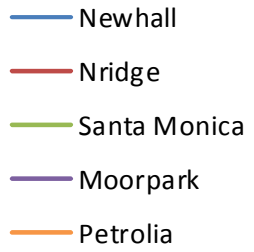

Vrijeme [s]
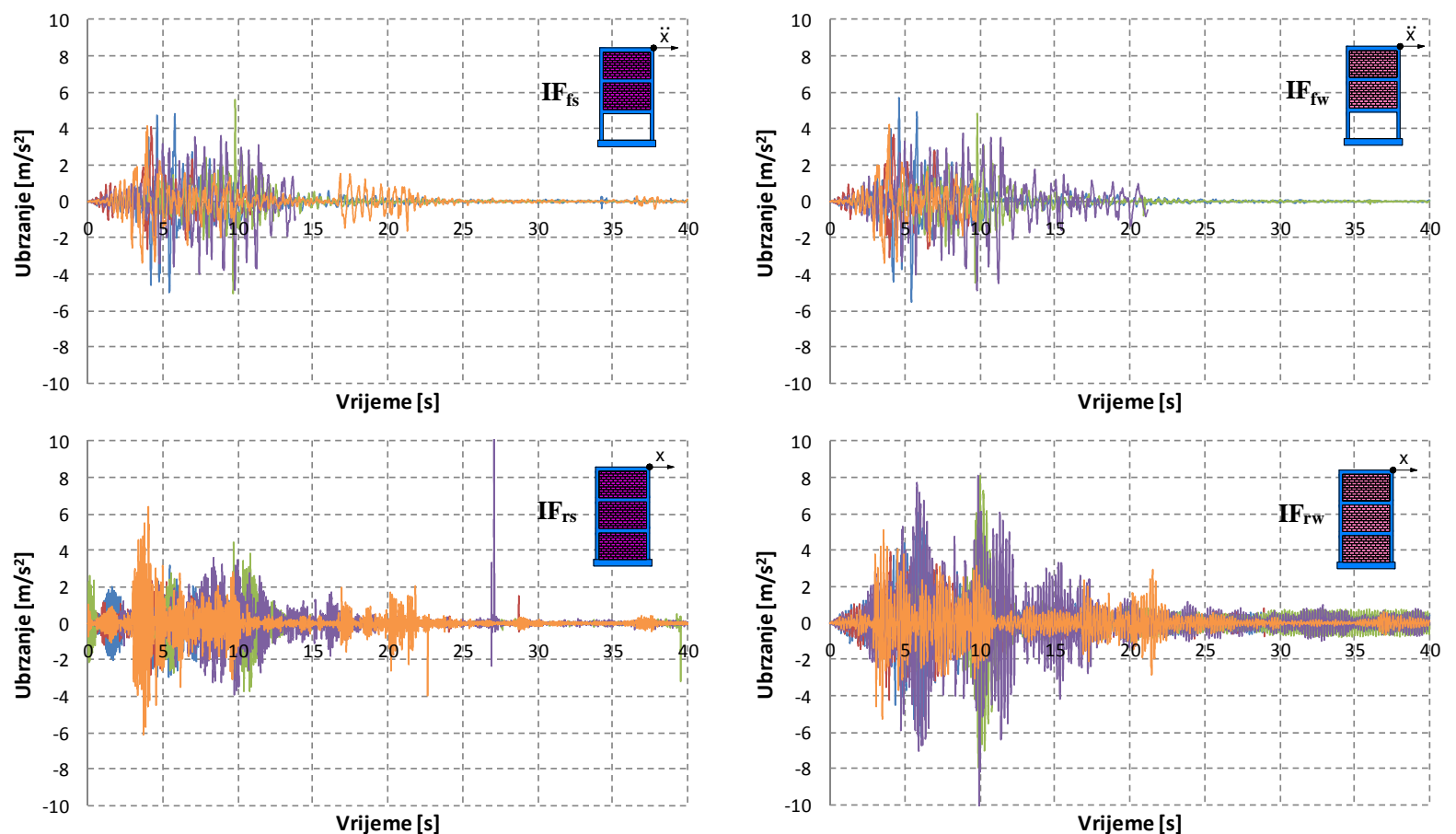

Slika 6.5. Horizontalno ubrzanje vrha razmatranih okvira u vremenu 
Ukupna inercijalna sila na razmatrane okvire (koja uključuje ukupno ubrzanje konstrukcije) generirana uslijed djelovanja potresa prikazana je na Slici 6.6. Kao što je i očekivano, može se primijetiti da kruće konstrukcije imaju značajno veće inercijalne sile u odnosu na mekše konstrukcije. Najmanja inercijalna sila je generirana kod čistog okvira F. Krute konstrukcije s fleksibilnim prizemljem imaju nešto manje inercijalne sile u odnosu na odgovarajuće konstrukcije s jednakim krutostima po etažama. Također, ispuna u okvirima značajno povećava inercijalne sile u odnosu na čiste okvire.

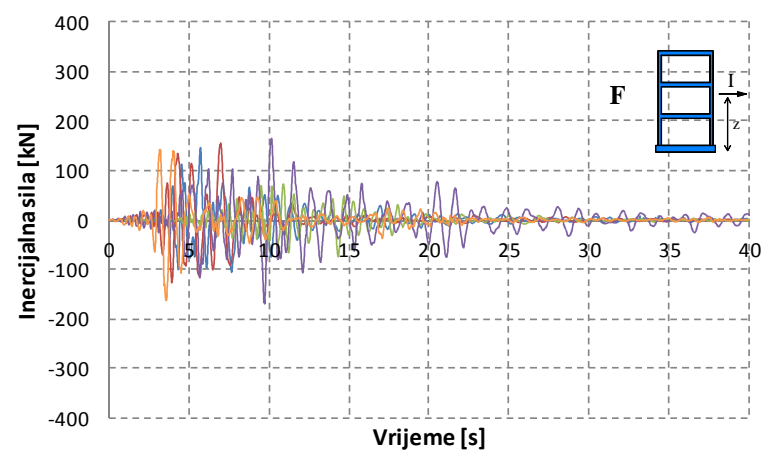

Legenda:
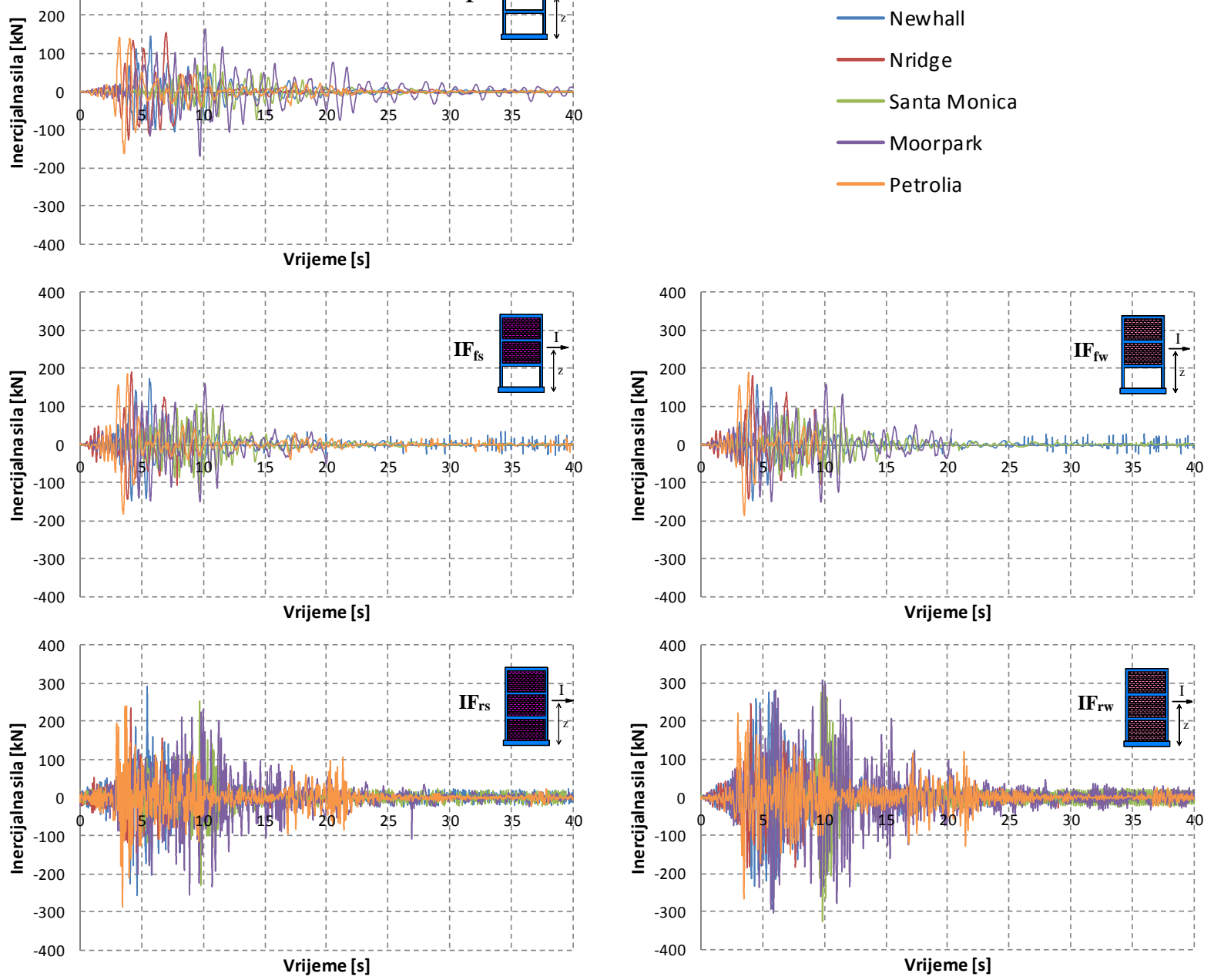

Slika 6.6. Ukupna horizontalna inercijalna sila na razmatranim okvirima u vremenu 
Naprezanja u vertikalnoj armaturi pri dnu stupa razmatranih okvira prikazana su na Slici 6.7. Krute konstrukcije $\mathrm{IF}_{\mathrm{rs}}, \mathrm{IF}_{\mathrm{rw}}$ imaju najmanja naprezanja u armaturi. Može se primijetiti da su naprezanja u armaturi kod čistog okvira iznad $500 \mathrm{MPa}$, tj. iznad maksimalno dopuštenih vrijednosti prema normama [115]. Dakle, ove konstrukcije ne posjeduju dovoljnu sigurnosti te stoga niža vrijednost faktora ponašanja $q$ treba biti korištena $\mathrm{u}$ njihovom proračunu. Prethodno je navedeno da konstrukcije $\mathrm{IF}_{\mathrm{fs}}, \mathrm{IF}_{\mathrm{fw}}$ ne mogu podnijeti nepovoljnije potrese. Dakle, potrebno ih je proračunati s nižim faktorom ponašanja $q$.

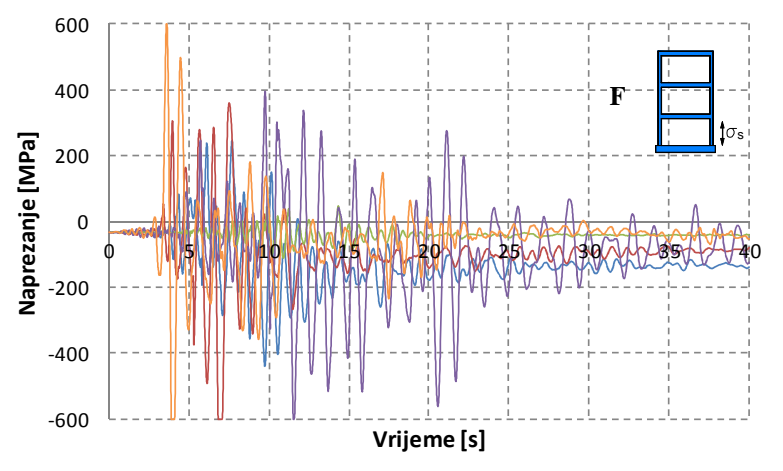

Legenda:
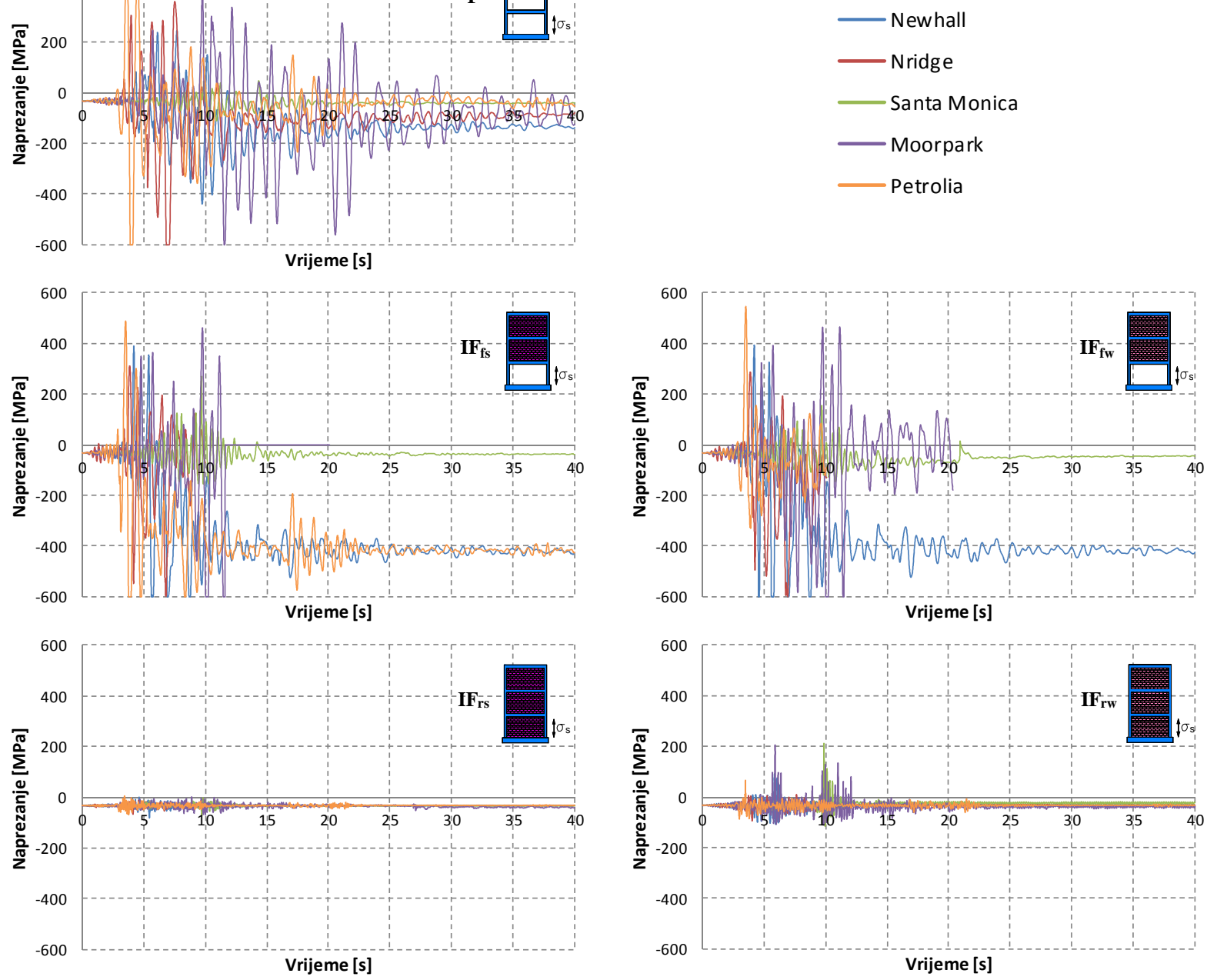

Slika 6.7. Naprezanje u vertikalnoj armaturi pri dnu stupa razmatranih okvira u vremenu 
Naprezanja u sponi pri dnu stupa razmatranih okvira (pri temelju) prikazana su na Slici 6.8. Može se primijetiti da su naprezanja niža kod krutih konstrukcija $\mathrm{IF}_{\mathrm{rs}}, \mathrm{IF}_{\mathrm{rw}}$. Kod čistog okvira ona dostižu oko $400 \mathrm{MPa}$. Kod fleksibilnih okvira s ispunom $\mathrm{IF}_{\mathrm{fs}}, \mathrm{IF}_{\mathrm{fw}}$, naprezanja $\mathrm{u}$ sponama dostižu graničnu čvrstoću od $600 \mathrm{MPa}$.

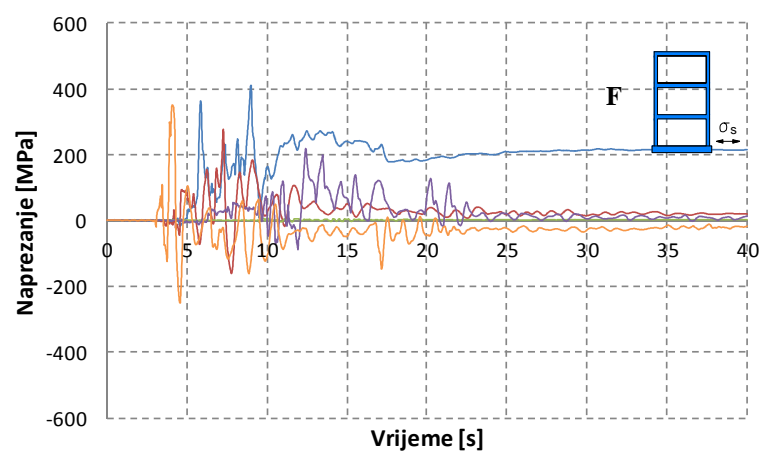

Legenda:
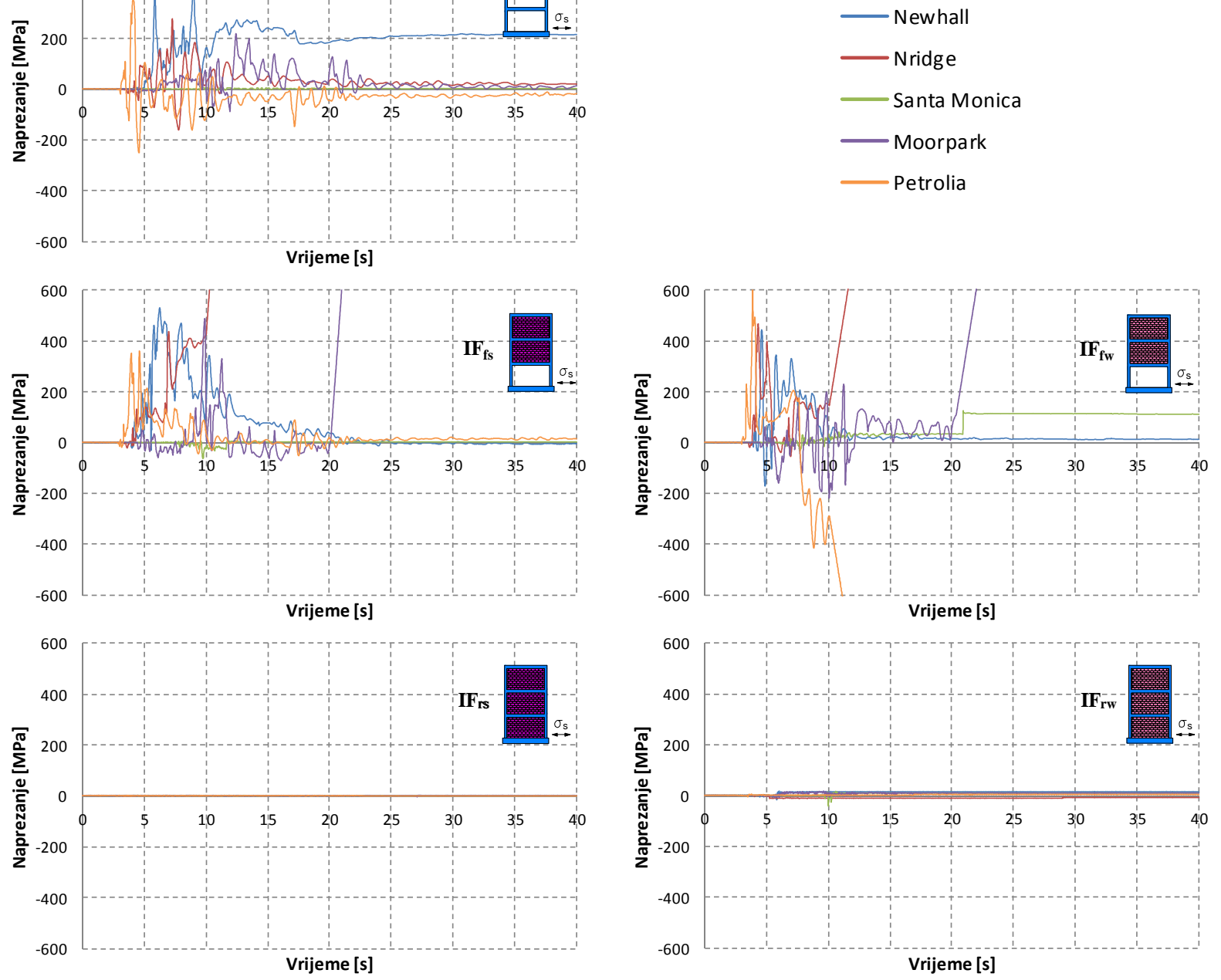

Slika 6.8. Naprezanje u sponi pri dnu stupa razmatranih konstrukcija u vremenu 
Naprezanja u betonu pri dnu stupa razmatranih okvira (s vanjske strane) prikazana su na Slici 6.9. Tlačna naprezanja u betonu su mala. Kod svih konstrukcija za sve pobude ona ne prelaze trećinu jednoosne tlačne čvrstoće betona.

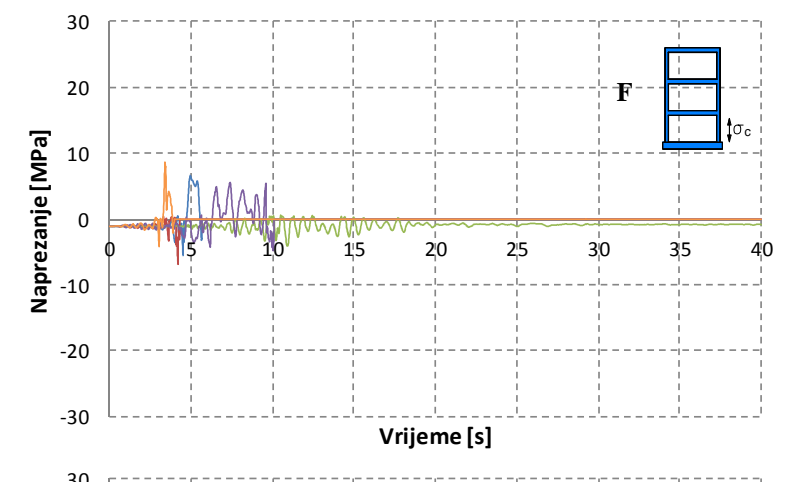

Legenda:
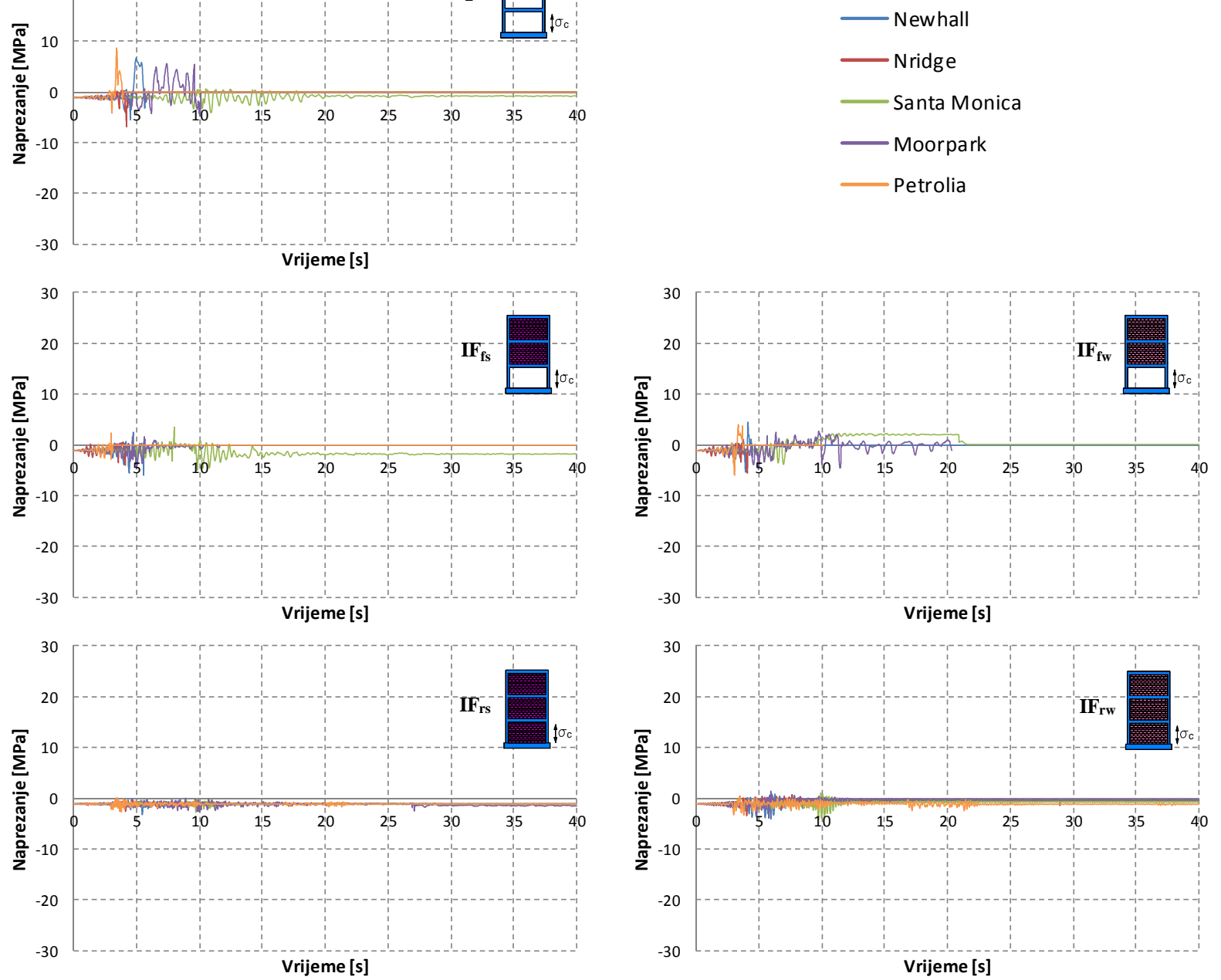

Slika 6.9. Vertikalno naprezanje u betonu pri dnu stupa razmatranih konstrukcija u vremenu

Konačna stanja deformacija i pukotina za neke konstrukcije nakon djelovanja potresa Santa Monica prikazana su na Slici 6.10. Stanja deformacija i pukotina neposredno prije loma nekih konstrukcija prikazana su na Slici 6.11.

Općenito, može se zaključiti da su rezultati numeričkih analiza u ovom primjeru analogni rezultatima provedenih eksperimentalnih testova betonskih okvira sa zidanom ispunom u Točki 3. 


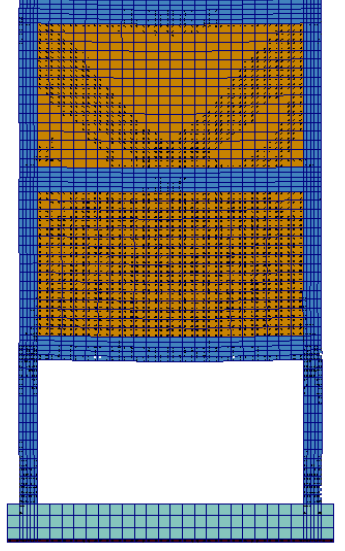

a) $\mathrm{IF}_{\mathrm{fs}}$

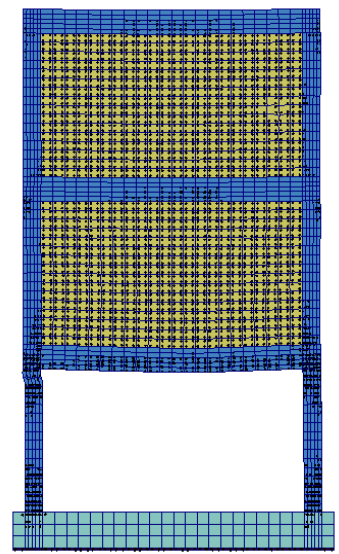

b) $\mathrm{IF}_{\mathrm{fs}}$

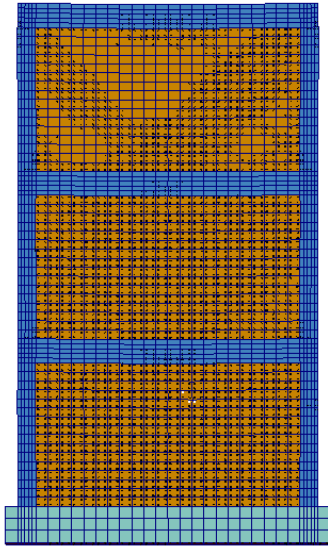

c) $\mathrm{IF}_{\mathrm{rs}}$

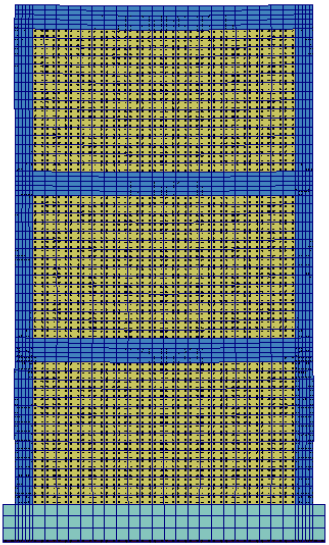

d) $\mathrm{IF}_{\mathrm{rw}}$

Slika 6.10. Konačno stanje deformacija i pukotina nakon djelovanja potresa Santa Monica

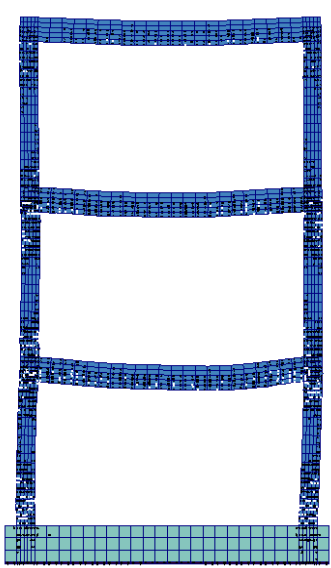

a1) $\mathrm{F}$

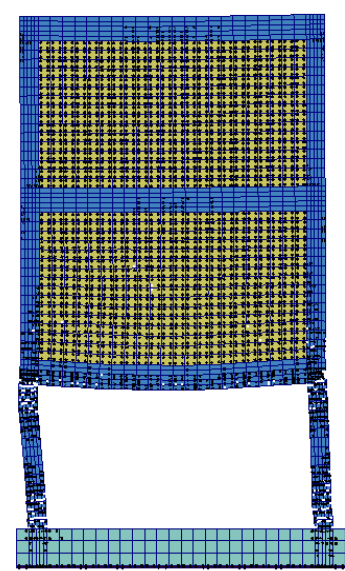

a2) $\mathrm{IF}_{\mathrm{fw}}$

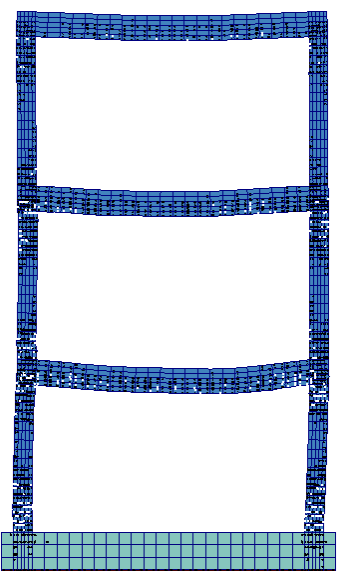

b1) F

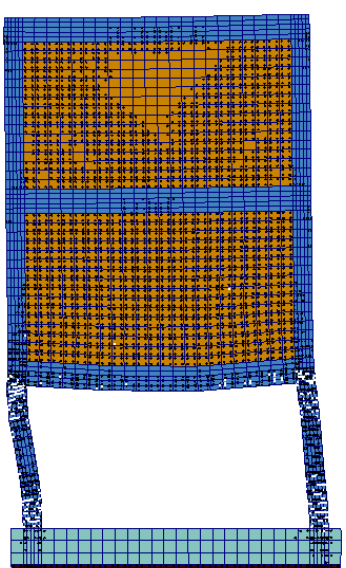

b2) $\mathrm{IF}_{\mathrm{fs}}$

a) Newhall

b) Petrolia

Slika 6.11. Stanje deformacija i pukotina konstrukcije neposredno pred lom

\subsection{Zaključak}

Radi ilustracije primjene razvijenog numeričkog modela i numeričke analize nekih utjecajnih parametara, analiziran je troetažni okvir sa zidanom ispunom pri djelovanju potresa. Razmatrani su slučajevi čistog okvira (bez ispune), okvira s ispunom na svim etažama te okvira s fleksibilnim prizemljem (ispuna samo na gornjim etažama), s varijacijom kvalitete ispune. U nastavku su dani najvažniji zaključci provedene dinamičke analize.

Inercijalne sile na analiziranim konstrukcijama pri potresu su značajno veće od sila dobivenih ekvivalentnom statičkom analizom prema važećim normama. Ovo je posebno 
važno pri proračunu mehaničke otpornosti stupova na horizontalne poprečne sile, tj. pri proračunu njihove odgovarajuće horizontalne armature. Provedene numeričke analize pokazuju veće razine naprezanja u sponama pri dnu stupova.

Okviri s fleksibilnim prizemljem su pokazali nepovoljnije ponašanje pri potresu u odnosu na iste konstrukcije s jednakom krutosti po etažama. Takve konstrukcije treba izbjegavati, a ako se koriste, treba koristiti adekvatni proračun. Naime, pri proračunu ovih konstrukcija prema važećim Europskim normama [147] trebaju se usvojiti adekvatni faktori ponašanja (manje vrijednosti). Također, spone u stupovima trebaju biti pravilno proračunate.

Ako pri proračunu armiranobetonskih okvira sa zidanom ispunom koji su fleksibilni u prizemlju ispuna ne doprinosi nosivosti okvira, već služi samo kao masa, postiže se povoljnije stanje u prizemlju u odnosu na realno stanje. Naime, stvarne seizmičke sile u stupovima prizemlja ovih okvira su veće od proračunskih sila prema prethodno spomenutom pristupu. Pri proračunu seizmičkih sila koje djeluju na ove konstrukcije potrebno je uključiti ispunu na gornjim etažama korištenjem gornjih vrijednosti očekivanih parametara njene krutosti, dok se mehanička otpornost ispune treba provjeriti korištenjem nižih vrijednosti njene očekivane čvrstoće. Prethodno navedeno ne odnosi se samo na okvire koji nemaju ispune u prizemlju, već i na okvire koji imaju široke otvore u ispuni u prizemlju koji značajno smanjuju njihovu krutost.

Kod okvira s ispunom na svim etažama, krutost ispune ne utječe značajno na globalnu sigurnost okvira. Kod ovih konstrukcija, mekša ispuna generira niže seizmičke sile u odnosu na kruće ispune, ali i posjeduje i manju mehaničku otpornost. U odnosu na okvire s jednakom krutosti po etažama, okviri s fleksibilnim prizemljem imaju nešto manje inercijalne sile.

Treba naglasiti da su prethodno navedeni zaključci u skladu s rezultatima provedenih eksperimentalnih testova dvoetažnih betonskih okvira s ispunom prikazanim u Točki 3.

Temeljem provedene numeričke analize potvrđeno je da razvijeni numerički model može uspješno poslužiti za analizu ravninskih okvirnih konstrukcija sa zidanom ispunom u praksi. 


\section{ZAKLJUČAK I PRAVCI DALJNJIH ISTRAŽIVANJA}

\subsection{Zaključak}

Ponašanje okvira sa zidanom ispunom pod statičkim, i naročito dinamičkim (potresnim) opterećenjem još uvijek predstavlja predmet velikog broja istraživanja. Njihovo ponašanje je vrlo složeno, osobito pri potresu, te ovisi o više faktora: svojstvima okvira, svojstvima ispune, vezi između okvira i ispune, veličini otvora u ispuni, broju etaža okvira, broju polja okvira, stalnom opterećenju (masi) itd. Temeljem provedenih eksperimentalnih i numeričkih ispitivanja, te dobivenih rezultata, mogu se iznijeti najvažniji zaključci o ponašanju ovakvih konstrukcija pod statičkim i potresnim opterećenjem, te dati praktični savjeti i preporuke za njihov pouzdani proračun.

Krutost okvira igra značajnu ulogu u ponašanju okvira sa zidanom ispunom pri potresu. Kruti okviri imaju manje pomake nego meki okviri, što smanjuje deformacije ispune i sprječava njezino oštećenje. U odnosu na meke okvire, kruti okviri generiraju veće seizmičke (inercijalne) sile, ali i posjeduju veću mehaničku otpornost. Meki okviri imaju veće pomake nego kruti okviri. Ovo rezultira većim deformacijama ispune, tj. njezinim mogućim oštećenjem i većim odvajanjem (pukotinom) na spoju s okvirom. 
Krutost ziđa doprinosi sveukupnoj krutosti okvira s ispunom. Kruća ispuna povećava inercijalne sile, ali ima i veću mehaničku otpornost od meke ispune. U provedenim ispitivanjima, kruća ispuna pokazala je povoljnije ponašanje u odnosu na meku ispunu.

Žbuka može značajno doprinijeti čvrstoći i nosivosti ziđa, a samim time čvrstoći i nosivosti okvira sa zidanom ispunom. Intenzitet relativnog doprinosa žbuke ukupnoj nosivosti i čvrstoći ovakvih sustava ovisi o nekoliko faktora: debljini i kvaliteti žbuke, debljini i kvaliteti ziđa, krutosti okvira, odnosu krutosti okvira $\mathrm{i}$ ispune, itd. U provedenim ispitivanjima, ziđe s obostranom žbukom osiguralo je veću otpornost i manju deformabilnost sustava nego neožbukano ziđe, te smanjilo zone pukotina u njemu.

Armirana žbuka povećava duktilnost ziđa i smanjuje širinu pukotina u njemu. U provedenim ispitivanjima, doprinos usvojene staklene mreže unutar žbuke nije bio očit za ispitane uzorke, što je vjerojatno posljedica relativno male površine poprečnog presjeka vlakana u mreži. Može se očekivati da bi žbuka armirana s mrežom veće površine poprečnog presjeka značajno povećala nosivost i duktilnost ziđa, odnosno okvira sa zidanom ispunom.

Položaj ispune na etažama okvira, kao i veličina otvora u ispuni, imaju velik utjecaj na ponašanje ovakvih konstrukcija pri potresu.

Kod okvira s ispunom na svim etažama postiže se povoljnije naponsko-deformacijsko stanje sustava u odnosu na okvir bez ispune. Može se očekivati da će takva konstrukcija imati manje pomake i deformacije (naprezanja) u okviru i ispuni pri potresu.

Otvori $\mathrm{u}$ ispuni smanjuju njezinu krutost, a samim time krutost i nosivost okvira sa zidanom ispunom. Može se očekivati da će takva konstrukcija imati veće pomake i deformacije pri potresu. Povećanje veličine otvora u ispuni povećava pomake i deformacije okvira s ispunom, te smanjuje njegovu mehaničku otpornost.

Okviri s fleksibilnim prizemljem (ispuna samo na gornjim etažama) pokazuju nepovoljnije ponašanje pri potresu od istih konstrukcija s ispunom na svim etažama. Naime, krući nosivi sustavi na gornjim etažama generiraju i veće inercijalne sile, koje se moraju prenijeti na fleksibilne nosive sustave u prizemlju. Ovo rezultira njihovom smanjenom potresnom otpornošću, te većim pomacima i deformacijama sustava. Takve konstrukcije treba izbjegavati, a ako se koriste, treba koristiti adekvatni proračun. Naime, pri proračunu ovih konstrukcija prema važećim Hrvatskim i Europskim normama [115, 147] trebaju se usvojiti adekvatni faktori ponašanja (manje vrijednosti). Također, spone u stupovima trebaju biti pravilno proračunate.

Ako pri proračunu armiranobetonskih okvira sa zidanom ispunom koji su fleksibilni u prizemlju ispuna ne doprinosi nosivosti okvira, već služi samo kao masa, postiže se povoljnije 
stanje u prizemlju u odnosu na realno stanje. Naime, stvarne seizmičke sile u stupovima prizemlja ovih okvira su veće od proračunskih sila prema prethodno spomenutom pristupu. Pri proračunu seizmičkih sila koje djeluju na ove konstrukcije potrebno je uključiti ispunu na gornjim etažama korištenjem gornjih vrijednosti očekivanih parametara njene krutosti, dok se mehanička otpornost ispune treba provjeriti korištenjem nižih vrijednosti njene očekivane čvrstoće. Prethodno navedeno ne odnosi se samo na okvire koji nemaju ispune u prizemlju, već i na okvire koji imaju široke otvore u ispuni u prizemlju koji značajno smanjuju njihovu krutost.

Okviri s fleksibilnom etažom pokazuju nešto povoljnije ponašanje od okvira s fleksibilnim prizemljem. Naime, ispuna u prizemlju ukrućuje konstrukciju pri dnu, što rezultira manjim pomacima i deformacijama na donjoj etaži. Međutim, na etažama gdje nema ispune povećavaju se pomaci i deformacije u okviru i armaturi.

Povećanjem maksimalnog ubrzanja podloge povećavaju se pomaci, ubrzanja i deformacije okvira sa zidanom ispunom.

Razvijen je 2D numerički model za statičku i dinamičku analizu ravninskih armiranobetonskih i čeličnih okvira sa zidanom ispunom koji može simulirati najvažnije nelinearne efekte sustava okvir-ziđe-temelj-tlo. U ovom radu, numerički model je poboljšan s adekvatnom simulacijom faznog nastajanja okvira s ispunom, te adekvatnom simulacijom nearmirane i armirane žbuke na vanjskim plohama ziđa. Verifikacija modela je provedena pomoću rezultata prethodno izvršenih eksperimentalnih ispitivanja.

Primjenom ovog numeričkog modela, numerički je istražen utjecaj više parametara na ponašanje okvira s ispunom. Ovo potvrđuje da razvijeni numerički model može uspješno poslužiti za analizu ravninskih okvirnih konstrukcija sa zidanom ispunom u praksi. Naime, daljnja provjera razvijenog numeričkog modela pomoću eksperimentalnih ispitivanja složenih inženjerskih konstrukcija bila bi od velike koristi.

\subsection{Pravci daljnjih istraživanja}

Ponašanje okvirnih konstrukcija sa zidanom ispunom pri statičkom i naročito potresnom opterećenju je vrlo složeno i zahtjeva veliku pozornost pri njihovom projektiranju. Područje istraživanja ponašanja ovih konstrukcija je vrlo široko, te su potrebna daljnja eksperimentalna i numerička istraživanja kako bi se moglo preciznije predvidjeti ponašanje takvih konstrukcija 
pri potresu, te dati praktični savjeti i preporuke za njihov pouzdani proračun. U nastavku su ukratko navedeni neki mogući pravci daljnjih istraživanja.

Eksperimentalnim ispitivanjem postiže se najbolji uvid u stvarno ponašanje konstrukcija, naročito s pomoću dinamičke platforme koja može najtočnije opisati njihovo stvarno ponašanje pri potresu. Takva ispitivanja još uvijek su rijetka, prvenstveno zbog malog broja ove skupe i sofisticirane opreme u svijetu, te velikih troškova provedbe takvih ispitivanja. Nužna su daljnja istraživanja ovih nosivih sustava s pomoću dinamičkih platformi. Pri tome su ispitivanja konstrukcija u realnom mjerilu najvjerodostojnija. Ispitivanja na realnim modelima su relativno složena i skupa, a često i nemoguća. Međutim, parametarske analize na modelima konstrukcija u manjem mjerilu mogu biti od velike koristi. U daljnjem znanstveno-istraživačkom radu planira se ispitati utjecaj više parametara na ponašanje okvira sa zidanom ispunom pri potresu, poput:

- utjecaj broja etaža i polja okvira,

- sanacija oštećenih okvira s ispunom uslijed prethodno apliciranih potresa,

- utjecaj temeljnog tla,

- varijacija u svojstvima materijala,

- aseizmička izolacija s tlom ispod temelja,

- ojačanje ziđa (ispune okvira) nenapetim i napetim trakama,

- utjecaj anizotropije ispune, itd.

Iako su razvijeni brojni numerički modeli za statičku i dinamičku analizu čeličnih i betonskih okvira sa zidanom ispunom, koji se značajno razlikuju glede njihove složenosti i točnosti, još uvijek nema takvog numeričkog modela koji bi bio dostatno jednostavan za praktičnu uporabu i koji bi modelirao sve najvažnije nelinearne efekte ponašanja ovih konstrukcija. Planirana su daljnja poboljšanja postojećeg numeričkom modela kako bi se njime moglo pouzdano analizirati složene inženjerske konstrukcije. Poželjno je raspolagati s većim brojem rezultata eksperimentalnih ispitivanja kako bi se razvijeni numerički model mogao provjeriti, te po potrebi unaprijediti. Planiraju se poboljšati sljedeća rješenja:

- modeliranje brzine deformacije na ponašanje betona, čelika, ziđa i armature,

- adekvatnije modeliranje nastajanja konstrukcije u fazama,

- modeliranje posmičnog sloma betona,

- adekvatnije modeliranje popuštanja i tečenja materijala u tlaku,

- modeliranje aseizmičke izolacije betonskih okvira,

- adekvatnije modeliranje proklizavanja na spoju okvira i ispune, i sl. 


\section{LITERATURA}

U nastavku je dan pregled korištene literature. 
(1) Radnic, J. Damjanic, F., Numerical model for static and dynamic analysis of RC structures, Izgradnja (in Croatian), 10, pp. 5-14, 1989.

(2) Radnic, J., Modelling of the strain rate effects in dynamic analysis of R/C structures, Engineering modeling, 3(1-2), pp. 13-20, 1990.

(3) Radnic, J., Harapin, A. Matesan, D., Trogrlic, B., Smilovic, M., Grgic, N., Baloevic, G., Numerical Model for Analysis of Masonry Structure, Građevinar, 63, pp. 529-546, 2011.

(4) Radnic, J., Harapin, A. Matesan, D., Smilovic, M., Grgic, N., Numerical Model for Static and Dynamic Analysis of Masonry Structure, 5th International Conference on Advanced Computational Engineering and Experimenting ACEX-2011, 2011.

(5) Radnic, J., Baloevic, G., Matesan, D., Smilovic, M., On a numerical model for static and dynamic analysis of in-plane masonry infilled steel frames, Materialwissenschaft und Werkstofftechnik, 44 (5), pp. 423-430, 2013.

(6) Baloevic, G., Radnic, J., Harapin, A., Numerical dynamic tests of masonry-infilled RC frames, Engineering Structures, 50, pp. 43-55, 2013.

(7) Radnic, J., Baloevic, G., Grgic, N., Harapin, A., Buzov, A. The effect of flexibility in ground storey of concrete wall and infilled frame on their seismic response, Materialwissenschaft und Werkstofftechnik (prihvaćeno za objavu).

(8) Polyakov, S. V., On the interaction between masonry filler walls and enclosing frame when loading in the plane of the wall, Translation in earthquake engineering, Earthquake Engineering Research Institute (EERI), San Francisco, pp. 36-42, 1960.

(9) Holmes, M., Steel frames with brickwork and concrete infilling, ICE Proc., 19(4), pp. 473-478, 1961.

(10) Smith, B. S., Lateral stiffness of infilled frames, J. Struct. Div., 88(6), pp. 183-199, 1962.

(11) Mainstone, R. J., On the stiffnesses and strengths of infilled frames, Proc., ICE Suppl., Vol. 4, Building Research Station, Garston, UK, pp. 57-90, 1971.

(12) Wood, R. H., Plasticity, composite action and collapse design of unreinforced shear wall panels in frames, ICE Proc., 65, pp. 381-411, 1978.

(13) Liauw, T. C., Kwan, K. H., Nonlinear behaviour of nonintegral infilled frames, Comput. Struct., 18, pp. 551-560, 1984.

(14) Žarnić, R., Inelastic model of R/C frame with masonry infill - analytical approach, International Journal for Engineering Modelling, 7 (1-2), pp. 47-54, 1994. 
(15) Chrysostomou, C. Z., Gergely, P., and Abel, J. F., A six-strut model for nonlinear dynamic analysis of steel infilled frames, Int. J. Struct. Stab. Dyn., 2(3), pp. 335-353, 2002.

(16) Saneinejad, A., Hobbs, B., Inelastic design of infilled frames, Journal of structural engineering New York, N.Y., 121 (4), pp. 634-649, 1995.

(17) El-Dakhakhni, W.W., Elgaaly, M., Hamid, A.A., Finite element modeling of concrete masonry-infilled steel frame, 9th Canadian Masonry Symp., National Research Council (NRC), Ottawa, Canada, 2001.

(18) El-Dakhakhni, W.W., Elgaaly, M., Hamid, A.A., Three-strut model for concrete masonry-infilled steel frames, Journal of Structural Engineering, 129 (2), pp. 177-185, 2003.

(19) Crisafulli, F.J., Carr, A.J., Proposed macro-model for the analysis of infilled frame structures, Bulletin of the New Zealand Society for Earthquake Engineering, 40 (2), pp. 69-77., 2007.

(20) Al-Chaar, G., Issa, M., Sweeney, S., Behavior of masonry-infilled nonductile reinforced concrete frames, Journal of Structural Engineering, 128 (8), pp. 1055-1063, 2002.

(21) Dymiotis, C., Kappos, A.J., Chryssanthopoulos, M.K., Seismic reliability of masonryinfilled RC frames, Journal of structural engineering New York, N.Y., 127 (3), pp. 296305,2001

(22) Kappos, A.J., Stylianidis, K.C., Michailidis, C.N., Analytical models for brick masonry infilled R/C frames under lateral loading, Journal of Earthquake Engineering, 2 (1), pp. 59-87, 1998.

(23) Kaushik, H.B., Rai, D.C., Jain, S.K., Code approaches to seismic design of masonryinfilled reinforced concrete frames: A state-of-the-art review, Earthquake Spectra, 22 (4), pp. 961-983, 2006.

(24) Lagaros, N.D., Life-cycle cost analysis of design practices for RC framed structures, Bulletin of Earthquake Engineering, 5 (3), pp. 425-442, 2007.

(25) Lu, Y., Comparative study of seismic behavior of multistory reinforced concrete framed structures, Journal of Structural Engineering, 128 (2), pp. 169-178, 2002.

(26) Masi, A., Seismic vulnerability assessment of gravity load designed R/C frames, Bulletin of Earthquake Engineering, 1 (3), pp. 371-395, 2003.

(27) Mucciarelli, M., Contri, P., Monachesi, G., Calvano, G., Gallipoli, M., An empirical method to assess the seismic vulnerability of existing buildings using the HVSR technique, Pure and Applied Geophysics, 158 (12), pp. 2635-2647, 2001. 
(28) Mallick, D.V., Severn, R.T., The behaviour of infilled frames under static loading, ICE Proc., 38(4), pp. 639-656, 1967.

(29) Dhanasekar, M., Page, A.W. Influence of brick masonry infill properties on the behaviour of infilled frames, ICE Proc., 81(4), pp. 593-605, 1986.

(30) Liauw, T.C., Lo, C.Q., Multibay infilled frames without shear connectors, ACI Struct. J., July-Aug., pp. 423-428, 1988.

(31) Schmidt, T., An approach of modelling masonry infilled frames by the F.E. method and a modified equivalent strut method, Darmstadt Concrete, Annu. J. on Concrete and Concrete Struct., pp. 185-194, 1989.

(32) Mehrabi, A.B., Shing, P.B., Finite element modeling of masonry-infilled RC frames, Journal of Structural Engineering, 123 (5), pp. 604-613, 1997.

(33) Ghosh, A.K., Amde, A.M., Finite element analysis of infilled frames, Journal of Structural Engineering, 128 (7), pp. 881-889, 2002.

(34) Chiou, Y.-J., Tzeng, J.-C., Liou, Y.-W., Experimental and analytical study of masonry infilled frames, Journal of Structural Engineering, 125 (10), pp. 1109-1117, 1999.

(35) Stavridis, A., Shing, P.B., Finite-element modeling of nonlinear behavior of masonryinfilled RC frames, Journal of Structural Engineering, 136 (3), pp. 285-296, 2010.

(36) Koutromanos, I., Stavridis, A., Shing, P.B., Willam, K., Numerical modeling of masonry-infilled RC frames subjected to seismic loads, Computers and Structures, 89 (11-12), pp. 1026-1037, 2011.

(37) Asteris, P.G., Antoniou, S.T., Sophianopoulos, D.S., Chrysostomou, C.Z., Mathematical macromodeling of infilled frames: State of the art, Journal of Structural Engineering, 137 (12), pp. 1508-1517, 2011.

(38) Asteris, P.G., Cotsovos, D.M., Numerical investigation of the effect of infill walls on the structural response of rc frames, Open Construction and Building Technology Journal, 6 (SPEC. ISS. 1), pp. 164-1812, 2012.

(39) Asteris, P.G., Finite element micro-modeling of infilled frames, Electronic Journal of Structural Engineering, 8, pp. 1-11, 2008.

(40) Asteris, P.G., Lateral stiffness of brick masonry infilled plane frames, Journal of Structural Engineering, 129 (8), pp. 1071-1079, 2003.

(41) Mohebkhah, A., Tasnimi, A.A., Moghadam, H.A., Nonlinear analysis of masonryinfilled steel frames with openings using discrete element method, Journal of Constructional Steel Research, 64 (12), pp. 1463-1472, 2008. 
(42) Al-Chaar, G., Mehrabi, A. B., Manzouri, T., Finite element interface modeling and experimental verification of masonry-infilled R/C frames, Masonry Soc. J., 26 (1), pp. 47-65, 2008.

(43) Aliaari, M., Memari, A.M., Analysis of masonry infilled steel frames with seismic isolator subframes, Engineering Structures, 27 (4), pp. 487-500, 2005.

(44) Celarec, D., Ricci, P., Dolšek, M., The sensitivity of seismic response parameters to the uncertain modelling variables of masonry-infilled reinforced concrete frames, Engineering Structures, 35, pp. 165-177, 2012.

(45) Chaker, A.A., Cherifati, A., Influence of masonry infill panels on the vibration and stiffness characteristics of R/C frame buildings, Earthquake Engineering and Structural Dynamics, 28 (9), pp. 1061-1065, 1999.

(46) Combescure, D., Pegon, P., Application of the local-to-global approach to the study of infilled frame structures under seismic loading, Nuclear Engineering and Design, 196 (1), pp. 17-40, 2000.

(47) Dawe, J.L., Liu, Y., Seah, C.K., A parametric study of masonry infilled steel frames, Canadian Journal of Civil Engineering, 28 (SUPPL. 1), pp. 149-157, 2001.

(48) Dawe, J.L., Seah, C.K., Liu, Y., A computer model for predicting infilled frame behaviour, Canadian Journal of Civil Engineering, 28 (SUPPL. 1), pp. 133-148, 2001.

(49) Dolšek, M., Fajfar, P., Soft storey effects in uniformly infilled reinforced concrete frames, Journal of Earthquake Engineering, 5 (1), pp. 1-12, 2001.

(50) Dolšek, M., Fajfar, P., The effect of masonry infills on the seismic response of a four storey reinforced concrete frame-a probabilistic assessment, Engineering Structures, 30 (11), pp. 3186-3192, 2008.

(51) Dolšek, M., Fajfar, P., The effect of masonry infills on the seismic response of a fourstorey reinforced concrete frame - a deterministic assessment, Engineering Structures, 30 (7), pp. 1991-2001, 2008.

(52) El Haddad, M.H., Finite element analysis of infilled frames considering cracking and separation phenomena, Computers and Structures, 41 (3), pp. 439-447, 1991.

(53) Fardis, M.N., Panagiotakos, T.B., Seismic design and response of bare and masonryinfilled reinforced concrete buildings. Part II: Infilled structures, Journal of Earthquake Engineering, 1 (3), pp. 475-503, 1997.

(54) Fardis, M.N., Seismic design and response of bare and masonry-infilled reinforced concrete buildings. Part I: Bare structures, Journal of Earthquake Engineering, 1 (1), pp. 219-256, 1997. 
(55) Hao, H., Ma, G.-W., Lu, Y., Damage assessment of masonry infilled RC frames subjected to blasting induced ground excitations, Engineering Structures, 24 (6), pp. 799-809, 2002.

(56) Koutromanos, I., Stavridis, A., Shing, P.B., Willam, K., Numerical modeling of masonry-infilled RC frames subjected to seismic loads, Computers and Structures, 89 (11-12), pp. 1026-1037, 2011.

(57) Lee, H.-S., Woo, S.-., Effect of masonry infills on seismic performance of a 3-storey $\mathrm{R} / \mathrm{C}$ frame with non-seismic detailing, Earthquake Engineering and Structural Dynamics, 31 (2), pp. 353-378, 2002.

(58) Madan, A., Reinhorn, A.M., Mander, J.B., Valles, R.E., Modeling of masonry infill panels for structural analysis, Journal of Structural Engineering, 123 (10), pp. 12951302, 1997.

(59) Puglisi, M., Uzcategui, M., Flórez-López, J., Modeling of masonry of infilled frames, Part I: The plastic concentrator, Engineering Structures, 31 (1), pp. 113-118, 2009.

(60) Puglisi, M., Uzcategui, M., Flórez-López, J., Modeling of masonry of infilled frames, Part II: Cracking and damage, Engineering Structures, 31 (1), pp. 119-124, 2009.

(61) Singh, H., Paul, D.K., Sastry, V.V., Inelastic dynamic response of reinforced concrete infilled frames, Computers and Structures, 69 (6), pp. 685-693, 1998.

(62) Uva, G., Porco, F., Fiore, A., Appraisal of masonry infill walls effect in the seismic response of RC framed buildings: A case study, Engineering Structures, 34, pp. 514526, 2012.

(63) Uva, G., Raffaele, D., Porco, F., Fiore, A., On the role of equivalent strut models in the seismic assessment of infilled RC buildings, Engineering Structures, 42, pp. 83-94, 2012.

(64) Wu, C., Hao, H., Lu, Y., Dynamic response and damage analysis of masonry structures and masonry infilled RC frames to blast ground motion, Engineering Structures, 27 (3), pp. 323-333, 2005.

(65) Wu, C., Hao, H., Numerical simulation of structural response and damage to simultaneous ground shock and airblast loads, International Journal of Impact Engineering, 34 (3), pp. 556-572, 2007.

(66) Klingner, R. E., Bertero, V. V., Infilled frames in earthquake resistant construction, Rep. EERC 76-32, Univ. of California, Berkeley, Calif., 1976.

(67) Bertero V.V., Brokken S., Infills in seismic resistant building, Journal of Structural Engineering ASCE, 109(6), pp.1337-1361, 1983. 
(68) Dawe, J.L., Schriver, A.B., Sofocleous, C., Masonry infilled steel frames subjected to dynamic load, Canadian journal of civil engineering, 16 (6), pp. 877-885, 1989.

(69) Dawe, J.L., Seah, C.K., Behaviour of masonry infilled steel frames, Canadian journal of civil engineering, 16 (6), pp. 865-876, 1989.

(70) Dawe, J.L., Seah, C.K., Out-of-plane resistance of concrete masonry infilled panels, Canadian journal of civil engineering, 16 (6), pp. 854-864, 1989.

(71) El-Dakhakhni, W.W., Hamid, A.A., Hakam, Z.H.R., Elgaaly, M., Hazard mitigation and strengthening of unreinforced masonry walls using composites, Composite Structures, 73 (4), pp. 458-477, 2006.

(72) Mander, J.B., Nair, B., Seismic Resistance of Brick-Infilled Steel Frames With and Without Retrofit, The Masonry Society Journal, 12(2), pp. 24-37, 1993.

(73) Mehrabi, A.B., Shing, P.B., Schuller, M.P., Noland, J.L. Experimental evaluation of masonry-infilled RC frames, Journal of Structural Engineering, 122 (3), pp. 228-237, 1996.

(74) Kakaletsis, D., Karayannis, C., Experimental investigation of infilled r/c frames with eccentric openings, Structural Engineering and Mechanics, 26 (3), pp. 231-250, 2007.

(75) Kakaletsis, D.J., David, K.N., Karayannis, C.G., Effectiveness of some conventional seismic retrofitting techniques for bare and infilled R/C frames, Structural Engineering and Mechanics, 39 (4), pp. 499-520, 2011.

(76) Kakaletsis, D.J., Influence of masonry strength and rectangular spiral shear reinforcement on infilled RC frames under cyclic loading, WIT Transactions on Modelling and Simulation, 46, pp. 643-653, 2007.

(77) Kakaletsis, D.J., Karayannis, C.G., Experimental investigation of infilled reinforced concrete frames with openings, ACI Structural Journal, 106 (2), pp. 132-141, 2009.

(78) Kakaletsis, D.J., Karayannis, C.G., Influence of masonry strength and openings on infilled R/C frames under cycling loading, Journal of Earthquake Engineering, 12 (2), pp. 197-221, 2008.

(79) Tasnimi, A.A., Mohebkhah, A., Investigation on the behavior of brick-infilled steel frames with openings, experimental and analytical approaches, Engineering Structures, 33 (3), pp. 968-980, 2011.

(80) Mosalam, K.M., White, R.N., Gergely, P., Static response of infilled frames using quasi-static experimentation, Journal of Structural Engineering, 123 (11), pp. 14621469, 1997. 
(81) Altin, S., Anil, O., Kara, M.E., Kaya, M., An experimental study on strengthening of masonry infilled RC frames using diagonal CFRP strips, Composites Part B: Engineering, 39 (4), pp. 680-693, 2008.

(82) Blackard, B., Willam, K., Mettupalayam, S., Experimental observations of masonry infilled reinforced concrete frames with openings, American Concrete Institute, ACI Special Publication, (265 SP), pp. 199-221, 2009.

(83) Mosalam, K.M., White, R.N., Ayala, G., Response of infilled frames using pseudodynamic experimentation, Earthquake Engineering and Structural Dynamics, 27 (6), pp. 589-608, 1998.

(84) Buonopane, S.G., White, R.N., Pseudodynamic testing of masonry infilled reinforced concrete frame, Journal of Structural Engineering, 125 (6), pp. 578-589, 1999.

(85) Colangelo, F., Pseudo-dynamic seismic response of reinforced concrete frames infilled with non-structural brick masonry, Earthquake Engineering and Structural Dynamics, 34 (10), pp. 1219-1241, 2005.

(86) Negro, P., Colombo, A., Irregularities induced by nonstructural masonry panels in framed buildings, Engineering Structures, 19 (7), pp. 576-585, 1997.

(87) Negro, P., Verzeletti, G., Effect of infills on the global behaviour of R/C frames: Energy considerations from pseudodynamic tests, Earthquake Engineering and Structural Dynamics, 25 (8), pp. 753-773, 1996.

(88) Klinger, R.E, Rubiano, N.R, Bhashandy S.C., Evaluation and analytical verification of shaking table data from infilled frames, Masonry Society Journal, The Masonry Society, USA, 15(2), pp. 33-41, 1997.

(89) Fardis, M.N., Bousias, S.N., Franchioni, G., Panagiotakos, T.B., Seismic response and design of RC structures with plan-eccentric masonry infills, Earthquake Engineering and Structural Dynamics, 28 (2), pp. 173-191, 1999.

(90) Žarnić, R., Gostič, S., Crewe, A.J., Taylor, C.A., Shaking table tests of 1:4 reducedscale models of masonry infilled reinforced concrete frame buildings, Earthquake Engineering and Structural Dynamics, 30 (6), pp. 819-834, 2001.

(91) Lee, H.-S., Woo S.-W., Seismic performance of a 3-story RC frame in a low-seismicity region, Engineering Structures, 24 (6), pp. 719-734, 2002.

(92) Dolce, M., Cardone, D., Ponzo, F.C., Valente, C., Shaking table tests on reinforced concrete frames without and with passive control systems, Earthquake Engineering and Structural Dynamics, 34 (14), pp. 1687-1717, 2005. 
(93) Hashemi, A., Mosalam, K.M., Shake-table experiment on reinforced concrete structure containing masonry infill wall, Earthquake Engineering and Structural Dynamics, 35 (14), pp. 1827-1852, 2006.

(94) Stavridis, A., Koutromanos, I., Shing, P.B., Shake-table tests of a three-story reinforced concrete frame with masonry infill walls, Earthquake Engineering and Structural Dynamics, 41 (6), pp. 1089-1108, 2012.

(95) Koutromanos, I., Kyriakides, M., Stavridis, A., Billington, S., Shing, P.B., Shake-table tests of a 3-story masonry-infilled RC frame retrofitted with composite materials, Journal of Structural Engineering (United States), 139 (8), pp. 1340-1351, 2013.

(96) Calvi, G.M., Bolognini, D., Seismic response of reinforced concrete frames infilled with weakly reinforced masonry panels, Journal of Earthquake Engineering, 5 (2), pp. 153$185,2001$.

(97) Dolšek, M., Fajfar, P., Mathematical modelling of an infilled RC frame structure based on the results of pseudo-dynamic tests, Earthquake Engineering and Structural Dynamics, 31 (6), pp. 1215-1230, 2002.

(98) Flanagan, R.D., Bennett, R.M., Bidirectional behavior of structural clay tile infilled frames, Journal of Structural Engineering, 125 (3), pp. 236-244, 1999.

(99) Kwan, A.K.H., Xia, J.Q., Shake-table tests of large-scale shear wall and infilled frame models, Proceedings of the Institution of Civil Engineers: Structures and Buildings, 110 (1), pp. 66-77, 1995.

(100) Liu, Y., Soon, S., Experimental study of concrete masonry infills bounded by steel frames, Canadian Journal of Civil Engineering, 39 (2), pp. 180-190, 2012.

(101) Markulak, D., Radić, I., Sigmund, V., Cyclic testing of single bay steel frames with various types of masonry infill, Engineering Structures, 51, pp. 267-277, 2013.

(102) Moghadam, H.A., Mohammadi, M.Gh., Ghaemian, M., Experimental and analytical investigation into crack strength determination of infilled steel frames, Journal of Constructional Steel Research, 62 (12), pp. 1341-1352, 2006.

(103) Perera, R., Performance evaluation of masonry-infilled RC frames under cyclic loading based on damage mechanics, Engineering Structures, 27 (8), pp. 1278-1288, 2005.

(104) Riddington, J.R., Influence of initial gaps on infilled frame behaviour, Proceedings of the Institution of Civil Engineers (London), 77 (pt 2), pp. 295-310, 1984.

(105) Sahota, M.K., Riddington, J.R., Experimental investigation into using lead to reduce vertical load transfer in infilled frames, Engineering Structures, 23 (1), pp. 94-101, 2001. 
(106) Shing, P.B., Mehrabi, A.B., Schuller, M., Noland, J.L., Experimental evaluation and finite element analysis of masonry-infilled R/C frames, Analysis and Computation, pp. 84-93, 1994.

(107) Shing, P.B., Stavridis, A., Koutromanos, I., Willam, K., Blackard, B., Kyriakides, M.A., Billington, S.L., Arnold, S., Seismic performance of non-ductile RC frames with brick infill, Improving the Seismic Performance of Existing Buildings and Other Structures Proc. 2009 ATC and SEI Conference on Improving the Seismic Performance of Existing Buildings and Other Structures, pp. 1117-1128, 2009.

(108) Zovkic, J., Sigmund, V., Guljas, I., Cyclic testing of a single bay reinforced concrete frames with various types of masonry infill, Earthquake Engineering and Structural Dynamics, 42 (8), pp. 1131-1149, 2013.

(109) Chopra, A.K., Dynamics of Structures: Theory and Applications to Earthquake Engineering, Prentice Hall, Upper Saddle River, New Jersey, 2007.

(110) The European Strong-motion Database, http://www.isesd.hi.is/ESD_Local/

(111) INGV real time Strong Motion Data, http://ismd.mi.ingv.it/

(112) Fahjan Y., Ozdemir, Z., Scaling of earthquake accelerograms for non-linear dynamic analyses to match the earthquake design spectra, The 14th World Conference on Earthquake Engineering (14WCEE), Beijing, China, October 12-17, 2008.

(113) Masi, A., Vona, M., Mucciarelli, M., Selection of natural and synthetic accelerograms for seismic vulnerability studies on reinforced concrete frames, Journal of Structural Engineering, 137 (3), pp. 367-378, 2011.

(114) SIMQKE (software), Conditioned Earthquake Ground Motion Simulator, Department of Civil Engineering and Operations Research, Princeton University, 1997, http://nisee.berkeley.edu/elibrary/

(115) Eurokod 8: Projektiranje potresne otpornosti konstrukcija - 1. dio: Opća pravila, potresna djelovanja i pravila za zgrade (EN 1998-1:2004+AC:2009).

(116) SeismoSignal (software), SeismoSoft, http://www.seismosoft.com/

(117) HRN EN 1052-1:2004, Metode ispitivanja ziđa - 1. dio: Određivanje tlačne čvrstoće (EN 1052-1:1998).

(118) HRN EN 1052-3:2004, Metode ispitivanja ziđa - 3. dio: Određivanje početne posmične čvrstoće (prEN 1052-3:2001).

(119) HRN EN 1015-11:2000, Metode ispitivanja mortova za ziđe - 11. dio: Određivanje čvrstoće pri savijanju i tlačne čvrstoće očvrslog morta (EN 1015-11:1999). 
(120) HRN EN 13496:2004, Toplinsko-izolacijski proizvodi za primjenu u zgradarstvu Određivanje mehaničkih svojstava mrežice od staklenih vlakanaca (EN 13496:2002)

(121) HRN EN 12390-3:2009, Ispitivanje očvrsnuloga betona - 3. dio: Tlačna čvrstoća ispitnih uzoraka (EN 12390-3:2009).

(122) HRN EN 12390-6:2010, Ispitivanje očvrsloga betona - 6. dio: Vlačna čvrstoća cijepanjem ispitnih uzoraka (EN 12390-6:2009).

(123) HRN EN 12390-13:2013, Ispitivanje očvrsloga betona - 13. dio: Određivanje sekantnog modula elastičnosti pri tlaku (EN 12390-13:2013).

(124) HRN EN 10002-1:2008, Metalni materijali - Vlačno ispitivanje - 1. dio: Metoda ispitivanja pri sobnoj temperaturi (EN 10002-1:2001).

(125) Radnic, J., Baloevic, G., Grgic, N., Matesan, D., The effects of plaster on the behavior of masonry-infilled steel frames under in-plane horizontal loading, 1st International Conference on Mechanics of Composites (MECHCOMP2014), Stony Brook, USA, 812 June 2014.

(126) Radnic, J., Baloevic, G., Grgic, N., Matesan, D., Shaking table study of the effects of a plaster on the behavior of masonry-infilled steel frames, 8th International Conference on Advanced Computational Engineering and Experimenting (ACE-X 2014), Paris, France, 30 June - 3 July 2014.

(127) Harapin, A., Radnić, J., Brzović, D., WYD method for an eigen solution of coupled problems, Int. Jnl. of Multiphysics, 3(2), pp. 167-176, 2009.

(128) Hughes, T.J.R., Pister K.S., Taylor R.L.:"Implicit-explicit finite elements in nonlinear transient analysis", Comp. Meth. Apl. Mech. Engng., 17(18), pp. 159-182, 1979.

(129) Bathe, K.J., Cimento A.: "Some practical procedures for the solution of nonlinear finite elemet equations", 5th Int. Conf. SMiRT, Berlin, 1979.

(130) Bathe, K.J., Cimento A.: "Some practical procedures for the solution of nonlinear finite elemet equations", 5th Int. Conf. SMiRT, Berlin, 1979.

(131) Crisfield, M.A.: "A faster modified Newton-Raphson iteration", Comp. Meth. in Appl. Mech. and Engng., 20, pp. 267-278, 1979.

(132) Geradin, M., Hogge, M.A.: "Quasi Newton iteration in nonlinear structural dynamics“, 5th Int. Conf. SMiRT, Berlin, 1979.

(133) Matthies, H., Strang, G.: "The solution of nonlinear finite element equations", Int. J. Num. Meth. Eng., 14, pp. 1613-1626, 1979.

(134) Mihanović, A.: "Dinamika konstrukcija", Građevinski fakultet Sveučilišta u Splitu, Split, 1995. 
(135) Mihanović, A., Marović, P., Dvornik, J.: "Nelinearni proračuni armirano betonskih konstrukcija", Društvo hrvatskih građevinskih konstruktora, serija Priručnici, knjiga 7 , Zagreb, 1993.

(136) Bergan, P.G., Holand I.: "Nonlinear finite element analysis of concrete structures", Comp. Meth. in Appl. Mech. and Engng., 17(18), pp. 443-467, 1979.

(137) Hill, R.: "The mathematical Theory of Plasticity", Oxford University Press, 1950.

(138) Prager, W.: "An introduction to plasticity", Addison-Wesley, Amsterdam \& London, 1959.

(139) Owen, D. R. J., Hinton, E.: "Finite elements in plasticity", Pineridge Press, Swansea, UK, 1980.

(140) Zienkiewiez, O. C., and Taylor, R. L.: "The finite element method", 4th ed., Vol. 1, McGraw-Hill, New York, 1989.

(141) Damjanić, F. B.: "Reinforced concrete failure under both static and transient conditions", Ph. D. Thesis, C/Ph/71/83, University of Wales, Swansea, 1983.

(142) HRN ENV 1996-1-1: 2007, Eurokod 6: Projektiranje zidanih konstrukcija

(143) Radnić, J., Harapin, A., Ćubela, D., Spregnute konstrukcije: numerički model za analizu pod kratkotrajnim mirnim opterećenjem, Građevinsko-arhitektonski fakultet Sveučilišta u Splitu, Split, 2005.

(144) Harapin, A., Radnić, J., Ćubela, D., Numerical model for composite structures with experimental confirmation, Materials Science and Engineering Technology, 39 (2), pp.143-156, 2008.

(145) Smilović, M., Ćubela, D., Radnić, J., Harapin, A., Experimental testing of woodconcrete and steel- concrete composite elements in comparison with numerical testing, Materials Science and Engineering Technology, 44 (6), pp.562-570, 2013.

(146) Radnić, J., Harapin, A., Smilović, M., Grgić, N., Glibić, M., Statička i dinamička analiza starog kamenog mosta u Mostaru, Gradevinar, 64, pp. 655-665, 2012.

(147) Eurocode 8: Design of structures for earthquake resistance — part 1: General rules, seismic actions and rules for buildings ENV 1998-1-1/2/3. Brussels: European Committee for Standardization, 2004. 


\section{Životopis}

Goran Baloević, dipl.ing.građ. rođen je 26. lipnja 1985.godine u Splitu. Osnovnu školu završio je u Splitu, te nakon nje pohađa Prirodoslovno matematičku gimnaziju u Splitu. Upisao sveučilišni dodiplomski studij građevinarstva akademske godine 2004/05 na Građevinsko-arhitektonskom Fakultetu, Sveučilišta u Splitu. Tijekom studija dobio više nagrada od strane Fakulteta i nekoliko tvrtki kao student s najboljim prosjekom ocjena u generaciji. Kao jedan od dobitnika natječaja Cemex Student iz 2008.g., obavljao stručnu praksu u Globalnom centru za istraživanje i razvoj tvrtke Cemex u Švicarskoj. Diplomirao 2009.g. kod doc.dr.sc Sandre Juradin s temom „Samozbijajući beton“ i stekao stručni naziv diplomirani inženjer građevinarstva.

Od 1.travnja 2009.g. zaposlen na Građevinsko-arhitektonskom Fakultetu, Sveučilišta u Splitu u svojstvu asistenta. Odmah upisao poslijediplomski doktorski studij na Građevinskoarhitektonskom Fakultetu, znanstveno područje Tehničke znanosti, znanstveno polje Građevinarstvo, grana Nosive konstrukcije. Od početka rada na Fakultetu uključen u nastavnu djelatnost pri Katedri za građevinske materijale i pri Katedri za betonske konstrukcije i mostove. Održavao vježbe iz predmeta Građevinski materijali 1, Građevinski materijali 2, Zidane konstrukcije, Osnove betonskih konstrukcija, Trajnost konstrukcija, Numeričko modeliranje betonskih konstrukcija.

U periodu od 2009.g. do 2015.g. suradnik je na istraživačkom projektu pod nazivom ',Eksperimentalna i numerička istraživanja potresne otpornosti građevina", pod vodstvom prof. dr. sc. Jure Radnića. Sudjelovao u projektiranju različitih inženjerskih objekata, te u laboratorijskim ispitivanjima raznih građevinskih materijala, ponajviše betona. Koautor je na sedam izvornih znanstvenih i preglednih radova u CC časopisima, tri znanstvena rada u drugim časopisima, devet znanstvenih radova objavljenih $\mathrm{u}$ zbornicima skupova $\mathrm{s}$ međunarodnim recenzijama, tri rada druge vrste u zbornicima skupova s recenzijom i sedam sažetaka u zbornicima skupova.

Aktivno se služi engleskim i talijanskim jezikom. 